\title{
Islamic divorces in Europe : bridging the gap between European and Islamic legal orders
}

Citation for published version (APA):

Kruiniger, P. (2014). Islamic divorces in Europe : bridging the gap between European and Islamic legal orders. [Doctoral Thesis, Maastricht University]. Boom Juridisch. https://doi.org/10.26481/dis.20141217pk

Document status and date:

Published: 01/01/2014

DOI:

10.26481/dis.20141217pk

Document Version:

Publisher's PDF, also known as Version of record

\section{Please check the document version of this publication:}

- A submitted manuscript is the version of the article upon submission and before peer-review. There can be important differences between the submitted version and the official published version of record.

People interested in the research are advised to contact the author for the final version of the publication, or visit the DOI to the publisher's website.

- The final author version and the galley proof are versions of the publication after peer review.

- The final published version features the final layout of the paper including the volume, issue and page numbers.

Link to publication

\footnotetext{
General rights rights.

- You may freely distribute the URL identifying the publication in the public portal. please follow below link for the End User Agreement:

www.umlib.nl/taverne-license

Take down policy

If you believe that this document breaches copyright please contact us at:

repository@maastrichtuniversity.nl

providing details and we will investigate your claim.
}

Copyright and moral rights for the publications made accessible in the public portal are retained by the authors and/or other copyright owners and it is a condition of accessing publications that users recognise and abide by the legal requirements associated with these

- Users may download and print one copy of any publication from the public portal for the purpose of private study or research.

- You may not further distribute the material or use it for any profit-making activity or commercial gain

If the publication is distributed under the terms of Article $25 \mathrm{fa}$ of the Dutch Copyright Act, indicated by the "Taverne" license above, 
Islamic Divorces in Europe 
The commercial edition of this book is published by Eleven International Publishing

ISBN 978-94-6236-501-8

ISBN 978-94-6274-192-8 (E-book)

(c) 2015 Pauline Kruiniger | Eleven International Publishing

Cover photo: 'Tomb of Moulay Ismail' (Meknes, Morocco) by tunart.

Published, sold and distributed by Eleven International Publishing

P.O. Box 85576

2508 CG The Hague

The Netherlands

Tel.: +31703307033

Fax: +31703307030

e-mail: sales@budh.nl

www.elevenpub.com

Sold and distributed in USA and Canada

International Specialized Book Services

920 NE 58th Avenue, Suite 300

Portland, OR 97213-3786, USA

Tel.: 1-800-944-6190 (toll-free)

Fax: +1-503-280-8832

orders@isbs.com

www.isbs.com

Eleven International Publishing is an imprint of Boom uitgevers Den Haag.

This publication is protected by international copyright law.

All rights reserved. No part of this publication may be reproduced, stored in a retrieval system, or transmitted in any form or by any means, electronic, mechanical, photocopying, recording or otherwise, without the prior permission of the publisher.

Printed in The Netherlands 


\title{
Islamic Divorces in Europe
}

Bridging the Gap between European and Islamic Legal Orders

\author{
DISSERTATION
}

to obtain the degree of Doctor at the Maastricht University, on the authority of the Rector Magnificus Prof. dr. L.L.G. Soete in accordance with the decision of the Board of Deans to be defended in public

on Wednesday 17 December 2014, at 14.00 hours

by

Pauline Maria Kruiniger 


\section{Supervisor}

Prof. dr. G.-R. de Groot

\section{Co-supervisor}

Dr. S.W.E. Rutten

\section{Assessment Committee}

Prof. dr. C. Flinterman (voorzitter)

Prof. dr. L.P.H.M. Buskens (Universiteit Leiden)

Prof. dr. V. van den Eeckhout (Universiteit van Antwerpen/Universiteit Leiden)

Prof. dr. F.J.A. van der Velden (Vrije Universiteit Amsterdam)

The Netherlands Organisation for Scientific Research (NWO) has funded this research by a grant in December 2008 (Open MaGW Program/Social Sciences). 


\section{Table of Contents}

Note on Transliteration $\quad$ xv

List of Frequently Used Arabic Terms $\quad$ xvii

1 Introduction 1

1.1 Islamic Divorces in Europe 1

1.1.1 Cultural Diversity in Law 2

1.1.2 Bridging Gaps in Legal Diversity: Private International Law 4

1.2 Formulation of Two Problems 5

$\begin{array}{lll}1.3 & \text { Research Questions } & 7\end{array}$

1.4 Approach and Methodology 8

1.4.1 Three-Tier Approach 8

1.4.1.1 Identifying the Diversity of Islamic Divorces 8

1.4.1.2 Exploring the Diversity of European Recognition Policies 9

1.4.1.3 How to Manage the Legal Diversity Adequately? 11

$\begin{array}{lll}1.4 .2 & \text { Methodology } & 11\end{array}$

1.4.2.1 Part I: Islamic Divorces in Classical Islamic and Contemporary Law

1.4.2.1.1 Functional Classification of Islamic Divorces 12

$\begin{array}{lll}\text { 1.4.2.1.2 Focus on the Status of Women } & 13\end{array}$

1.4.2.1.3 Islamic Divorce: Private or Public Act or Judgment? 14

1.4.2.2 Part II: Fourfold Analysis of National Recognition Policies in Europe $\begin{array}{ll}\text { in a Comparative Perspective } & 15\end{array}$

1.4.2.2.1 Identification of the Framework for Assessment of the Recognition 15

1.4.2.2.2 Attention to the Correct Legal Nature of an Islamic Divorce? 15

1.4.2.2.3 Assessment of the Degree of 'Openness' towards Islamic Divorces $\quad 15$

$\begin{array}{ll}\text { 1.4.2.2.4 Attention to Limping Legal Relationships? } & 16\end{array}$

1.4.2.3 Part III: How to Identify Adequate Legal Instruments 16

$\begin{array}{lll}1.5 & \text { Sources } & 17\end{array}$

$\begin{array}{lll}1.6 & \text { Account for Selection } & 18\end{array}$

1.7 Societal and Academic Relevance 20

2 Context 23

2.1 Divorce in Europe 23 
2.2 Women's Rights upon Divorce 25

2.2.1 Introduction 25

2.2.2 Article 16 Women's Convention 27

2.2.2.1 Context 27

2.2.2.1.1 'Specialized' Sequel to Other Human Rights Instruments 27

2.2.2.1.2 Discrimination and Gender Equality: Its Core Notions 27

2.2.2.1.3 Its Relation to Other Articles within the Women's Convention 28

2.2.2.1.4 The Women's Convention's Monitoring Mechanisms 29

2.2.2.2 Nature of Article $16 \quad 30$

2.2.2.3 Declarations and Reservations $\quad 33$

2.2.3 Closing Remarks 36

\section{Part I Islamic Divorce Laws and Practices}

3 Introduction $\quad 41$

3.1 Islamic versus Occidental Notion of Divorce 41

3.2 Divorce in Islam: The Prerogative of the Husband 41

3.3 'Islamic Divorce' Further Explained 42

3.4 Structure of Part I 44

$4 \quad$ Context: Islamic Law in a Nutshell $\quad 47$

$4.1 \quad$ Islamic or Shari'a Law?

4.2 Sources 48

4.3 Schools of Jurisprudence 51

$4.4 \quad$ Some Characteristic Features 52

$\begin{array}{lll}4.5 & \text { Shari } a \text { Law Today } & 54\end{array}$

$5 \quad$ Divorce in Shari'a Law $\quad 57$

$\begin{array}{lll}5.1 & \text { Introduction } & 57\end{array}$

5.2 Marriage in Islam and Shari $a$ Law 58

5.2.1 Definition, Characteristics, Purposes, and Types of Marriage 58

$\begin{array}{ll}\text { 5.2.2 Categories of (In-)Validity of Marriage } & 60\end{array}$

$\begin{array}{lll}\text { 5.2.2.1 The Valid Marriage } & 61\end{array}$

$\begin{array}{lll}\text { 5.2.2.2 The Irregular Marriage } & 63\end{array}$

$\begin{array}{lll}\text { 5.2.2.3 The Invalid Marriage } & 65\end{array}$

5.3 Dissolution of Marriage: Talaq versus Faskh 68

$\begin{array}{lll}\text { 5.3.1 Distinctive Criterion } & 69\end{array}$

5.3.2 Distinctive Legal Effects $\quad 69$

5.4 Divorce by the Husband: The Repudiation 71 
5.4.1 Nature and Legal, Moral, and Religious Characteristics 71

$\begin{array}{lll}\text { 5.4.2 Requirements of Validity } & 72\end{array}$

5.4.2.1 Substantive Requirements of Validity Related to the Divorcer 72

5.4.2.1.1 Legal Capacity 72

5.4.2.1.2 Intention to Repudiate $\quad 72$

$\begin{array}{ll}\text { 5.4.2.1.3 Being a Muslim } & 74\end{array}$

5.4.2.2 Substantive Requirements of Validity Related to the Divorcee 74

5.4.2.2.1 Specific Status of the Divorcee 74

5.4.2.2.2 During Her Period of Purity?

5.4.2.2.3 Indication of the Divorcee 75

5.4.2.3 Substantive Requirement of Validity Related to the Moment of Repu$\begin{array}{ll}\text { diation } & 75\end{array}$

5.4.2.4 Formal Requirements of Validity $\quad 76$

5.4.2.4.1 Expression of the Repudiation $\quad 76$

$\begin{array}{lll}\text { 5.4.2.4.2 Witnesses } & 78\end{array}$

$\begin{array}{lll}\text { 5.4.2.4.3 Mandate, Authorization, or Agreement } & 78\end{array}$

$\begin{array}{lll}\text { 5.4.3 } & \text { Forms of Talaq } & 78\end{array}$

$\begin{array}{lll}\text { 5.4.3.1 The Single Repudiation } & 78\end{array}$

$\begin{array}{lll}\text { 5.4.3.2 The Triple Repudiation } & 79\end{array}$

$\begin{array}{lll}\text { 5.4.4 Regulations of Talaq } & 79\end{array}$

$\begin{array}{lll}\text { 5.4.4.1 Talaq Al-Sunna } & 79\end{array}$

5.4.4.2 Talaq Al-Bid'a $\quad 81$

5.5 Dissolution of Marriage Initiated by the Wife: Judicial Divorce or

5.5.1 The Maliki System: Judicial Repudiation 83

5.5.2 The Shafi $i$-Hanbali System: Judicial Annulment 84

5.6 Divorce Based on Agreement between the Spouses 84

5.6.1 The Negotiated Repudiation, Khul $^{\circ} \quad 85$

$\begin{array}{lll}\text { 5.6.1.1 Nature and Characteristics } & 87\end{array}$

$\begin{array}{lll}\text { 5.6.1.2 Requirements of Validity } & 90\end{array}$

5.6.1.2.1 Substantive Requirements of Validity 90

5.6.1.2.2 Formal Requirements of Validity 91

5.6.1.3 Nature and Proportions of the Compensation 91

5.6.2 The Repudiation by Agreement, Mubara'a 93

5.6.3 The Repudiation by Mandate or Authorization, Talaq Al-Tawkil or

5.6.3.1 Tawkil: The Mandate to Repudiate 93

5.6.3.2 Tafwid: The Authorization to Repudiate 94

5.6.3.3 The Self-Repudiation Further Explained 94 
5.7 After Divorce 96

5.7.1 Revocability or Irrevocability of the Divorce 97

5.7.1.1 The Revocable Repudiation-Based Divorce 97

5.7.1.1.1 The Revocation 98

5.7.1.1.2 Requirements to the Revocation 98

5.7.1.2 The Irrevocable Repudiation-Based Divorce 100

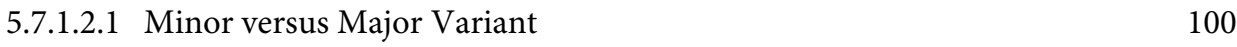

5.7.1.2.2 Tahlil Procedure 101

$\begin{array}{lll}\text { 5.7.2 Waiting Period } & 102\end{array}$

$\begin{array}{lll}\text { 5.7.2.1 Purposes } & 102\end{array}$

5.7.2.2 Duration 103

5.7.2.3 Rights and Duties of the Wife 103

$\begin{array}{lll}\text { 5.7.3 Maintenance } & 104\end{array}$

5.7.3.1 Nafaqa versus Alimony 104

5.7.3.2 The Wife's Entitlements to Maintenance 104

5.7.3.3 Child(-ren)'s Entitlements to Maintenance 104

5.7.3.4 Maintenance versus Remunerations for Nursing or Custody 105

$\begin{array}{lll}\text { 5.7.4 Dower } & 105\end{array}$

$\begin{array}{lll}\text { 5.7.4.1 Definition and Characteristics } & 105\end{array}$

$\begin{array}{lll}\text { 5.7.4.2 Types of Dower } & 106\end{array}$

5.7.4.3 The Wife's Entitlement to the Dower 107

$\begin{array}{lll}\text { 5.7.4.4 Dower as Tool of Bargaining Power } & 108\end{array}$

$\begin{array}{ll}\text { 5.7.5 Consolation Gift } & 109\end{array}$

5.7.6 Parental Authority: Custody and Legal Guardianship 109

$\begin{array}{lll}\text { 5.7.6.1 Distinction } & 109\end{array}$

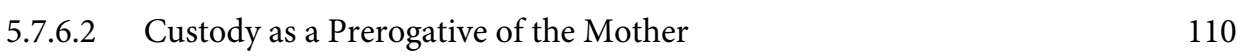

$\begin{array}{lll}\text { 5.7.6.3 Requirements to the Custodian } & 110\end{array}$

$\begin{array}{lll}\text { 5.7.6.4 Terms of Custody } & 111\end{array}$

$\begin{array}{lll}\text { 5.7.7 Inheritance Rights } & 112\end{array}$

6 Divorce in Egypt 113

$\begin{array}{lll}6.1 & \text { Introduction } & 113\end{array}$

6.1.1 Islamic Family Law before the Arab Spring 114

6.1.2 Islamic Family Law since the Arab Spring 116

$\begin{array}{lll}6.2 & \text { Divorce } & 121\end{array}$

6.2.1 Divorce on the Initiative of the Husband 121

6.2.2 Divorce on the Initiative of the Wife 123

6.2.3 Divorce through the Involvement of Both Spouses 126

$\begin{array}{lll}6.3 & \text { After Divorce } & 127\end{array}$ 
6.3.1 Waiting Period 129

6.3.2 Maintenance 129

$\begin{array}{lll}\text { 6.3.3 Dower } & 129\end{array}$

$\begin{array}{lll}\text { 6.3.4 Remuneration } & 130\end{array}$

$\begin{array}{ll}\text { 6.3.5 Provisions for Children } & 130\end{array}$

$\begin{array}{lll}\text { 6.3.5.1 Legal Guardianship } & 130\end{array}$

$\begin{array}{lll}\text { 6.3.5.2 Custody } & 130\end{array}$

$\begin{array}{lll}\text { 6.3.5.3 Maintenance } & 131\end{array}$

6.4 Assessment 132

$7 \quad$ Divorce in Iran 135

$\begin{array}{lll}7.1 & 135\end{array}$

7.1.1 Family Law in Pre-Revolutionary Iran 135

7.1.2 The Post-Revolutionary Islamic State and Its Actors 139

7.1.3 Family Law in Post-Revolutionary Iran 140

7.1.4 Features of Contemporary Iranian (Family) Law 144

$\begin{array}{lll}7.2 & \text { Divorce } & 146\end{array}$

7.2.1 Judicial Intervention and Registration of the Divorce 147

$\begin{array}{lll}\text { 7.2.1.1 Procedure until } 2013 & 147\end{array}$

$\begin{array}{lll}\text { 7.2.1.2 Procedure since } 2013 & 149\end{array}$

7.2.2 Divorce by the Husband 151

7.2.3 Divorce by the Wife 152

$\begin{array}{lll}\text { 7.2.4 Divorce by Agreement } & 156\end{array}$

$\begin{array}{lll}7.3 & \text { After Divorce } & 157\end{array}$

$\begin{array}{lll}\text { 7.3.1 Waiting Period } & 158\end{array}$

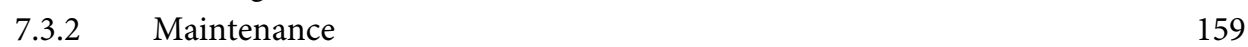

$\begin{array}{lll}7.3 .3 & \text { Dower } & 160\end{array}$

$\begin{array}{lll}\text { 7.3.4 Remuneration } & 164\end{array}$

7.3.5 Provisions for Children 166

$\begin{array}{lll}\text { 7.3.5.1 Custody } & 166\end{array}$

$\begin{array}{lll}\text { 7.3.5.2 Guardianship } & 167\end{array}$

$\begin{array}{lll}\text { 7.3.5.3 Maintenance } & 168\end{array}$

$\begin{array}{lll}7.4 & 168\end{array}$

8 Divorce in Morocco $\quad 171$

$\begin{array}{lll}8.1 & \text { Introduction } & 171\end{array}$

$\begin{array}{lll}8.2 & \text { Divorce } & 176\end{array}$

8.2.1 Divorce on the Initiative of the Husband 179

8.2.2 Divorce on the Initiative of the Wife 180 
8.2.3 Divorce through the Involvement of Both Spouses 183

$\begin{array}{lll}8.3 & \text { After Divorce } & 187\end{array}$

$\begin{array}{lll}\text { 8.3.1 Waiting Period } & 188\end{array}$

$\begin{array}{ll}\text { 8.3.2 Maintenance } & 189\end{array}$

$\begin{array}{lll}\text { 8.3.3 Dower } & 189\end{array}$

$\begin{array}{lll}\text { 8.3.4 Consolation Gift }\left(M^{\prime} t^{\prime} a\right) & 190\end{array}$

$\begin{array}{lll}\text { 8.3.5 Indemnification } & 190\end{array}$

$\begin{array}{lll}\text { 8.3.6 Provisions for Children } & 191\end{array}$

$\begin{array}{lll}\text { 8.3.6.1 Custody } & 192\end{array}$

$\begin{array}{lll}\text { 8.3.6.2 Guardianship } & 193\end{array}$

$\begin{array}{lll}\text { 8.3.6.3 Maintenance } & 193\end{array}$

$\begin{array}{lll}8.4 & \text { Assessment } & 194\end{array}$

9 Divorce in Pakistan 199

$\begin{array}{lll}9.1 & \text { Introduction } & 199\end{array}$

9.2 Divorce 202

9.2.1 Divorce on the Initiative of the Husband 203

9.2.2 Divorce on the Initiative of the Wife 204

9.2.3 Divorce through Involvement of Both Spouses 206

$\begin{array}{ll}9.3 & \text { After Divorce } \\ 9.3 .1 & 207\end{array}$

9.3.1 Waiting Period 208

$\begin{array}{ll}\text { 9.3.2 Maintenance } & 208\end{array}$

$\begin{array}{lll}9.3 .3 & \text { Dower } & 209\end{array}$

$\begin{array}{lll}\text { 9.3.4 Remuneration } & 210\end{array}$

$\begin{array}{ll}\text { 9.3.5 Provisions for Children } & 210\end{array}$

$\begin{array}{lll}9.4 & \text { Assessment } & 210\end{array}$

10 Conclusion: An Unbridgeable Incompatibility? 215

Part II Recognition of Islamic Divorces in Europe

$\begin{array}{llr}11 & \text { Introduction } & 219\end{array}$

12 Context: Migration 221

13 The Netherlands $\quad 223$

13.1 General Legal Framework 223

13.2 Articles 10:57, 10:58, and 10:59 BW: A General Overview 226

13.3 Recognition of Divorce Decisions: Article 10:57 BW 229 
13.4 Article 10:57 BW: Broadening the Scope

13.5 Recognition of Divorce Exclusively by Unilateral Declaration of Either Spouse: Article 10:58 BW

13.6 Public Policy Exception

13.7 Recognition of Repudiations in Dutch Legal Practice 244

13.7.1 Article 2 or Article 3 WCE? 244

13.7.2 Recognition of Repudiation-Based Divorces in Court 246

13.7.3 Hoge Raad 13 July $2001 \quad 248$

13.7.4 Litigation Division of the Council of State 3 March $2010 \quad 250$

13.7.5 Decisions of Courts after 'Hoge Raad 13 July 2001' 252

13.7.6 The Registrar and Recognition of Repudiation-Based Divorces 254

13.8 Article 10:57 BW and Hoge Raad 13 July 2001 Revisited 256

13.8.1 Article 10:57 BW for Repudiations 256

13.8.2 Hoge Raad 13 July 2001: Strikwerda’s Legal Opinion 258

13.8.3 Hoge Raad 13 July 2001

13.8.4 Council of State 3 March $2010 \quad 261$

13.9 Closing Remarks 264

$\begin{array}{llr}14 & \text { England } & 267\end{array}$

14.1 General Legal Framework 267

14.2 Recognition of Overseas Divorces Obtained by Proceedings 269

$\begin{array}{lll}\text { 14.2.1 Requirements } & 271\end{array}$

14.2.2 Extra-Judicial Divorces Obtained by Proceedings 272

14.3 Recognition of Foreign Divorces Obtained without Proceedings 276

$\begin{array}{lll}\text { 14.3.1 Requirements } & 277\end{array}$

14.4 Recognition of Transnational Divorces 278

14.4.1 Transnational Divorces with Proceedings 278

14.4.2 Transnational Divorces without Proceedings 281

14.5 Refusal of Recognition 281

14.5.1 Mandatory Grounds for Refusal 281

14.5.2 Discretionary Grounds for Refusal 282

14.6 Closing Remarks 288

15 France 291

15.1 General Legal Framework 292

15.2 Recognition of Divorce Judgments and Public Acts 294

15.2.1 Automatic Recognition 294

15.2.2 Requirements of International Regularity 295

15.2.3 Recognition of Egyptian and Moroccan Divorce Judgments 297 
15.3 Recognition of Repudiation-Based Divorces 299

15.3.1 A Variety of Approaches 300

15.3.2 The 2004 Turning Point 304

15.3.3 The 2004 Moroccan Divorce Law in the Cour de Cassation 309

15.4 Closing Remarks 312

16 Evaluation and Conclusion 315

$\begin{array}{lll}16.1 & \text { Introduction } & 315\end{array}$

$\begin{array}{ll}16.2 & \text { Evaluation } \\ 16.2 .15\end{array}$

16.2.1 Frameworks for Assessment Compared 315

16.2.1.1 Comparison at the Macro Level 316

$\begin{array}{ll}\text { 16.2.1.2 Comparison at the Micro Level } & 318\end{array}$

16.2.1.2.1 Criteria in the Netherlands 318

16.2.1.2.2 Criteria in England $\quad 319$

16.2.1.2.3 Criteria in France $\quad 320$

16.2.1.3 Comparison Criteria Repudiation-Based Divorces 321

16.2.1.3.1 Comparison Criteria Repudiation-Based Divorces after Proceedings 322

16.2.1.3.2 Comparison Criteria Repudiation-Based Divorces without Proceedings 324

16.2.1.3.3 Public Order 325

16.2.2 Issues of Understanding and Classification $\quad 325$

16.2.2.1 Different Terminology 328

16.2.2.2 Discretion of Each Authority 329

$\begin{array}{lll}\text { 16.2.3 Approach } & 330\end{array}$

16.3 Conclusion 332

Part III Managing Legal Diversity: Exploring Solutions for Its Shortcomings and Restrictions

$17 \quad$ Introduction

18 The EU Context 341

$\begin{array}{lll}18.1 & \text { Introduction } & 341\end{array}$

18.2 EU Citizen or Third-Country National? 341

18.2.1 EU Citizens 342

18.2.2 Distinctions among Third-Country Nationals (TCNs) 342

18.2.2.1 Family Members of EU Citizens 344

18.2.2.2 Other Categories of TCNs 345 
18.3 EU Legislative Competences in PIL Matters 347

$\begin{array}{lll}\text { 18.3.1 Internal Legislative Competence } & 348\end{array}$

18.3.1.1 Situation prior to the Treaty of Amsterdam 348

18.3.1.2 Situation since the Treaty of Amsterdam 349

18.3.1.3 Special Position Denmark, United Kingdom, and Ireland 353

18.3.1.4 Legislative Procedures $\quad 354$

18.3.2 External Legislative Competence 355

19 Diversity of Recognition Policies within Europe 357

19.1 Why Diversity? 357

19.2 Harmful Consequences of the Diversity Illustrated 357

19.3 Continuity of Personal Status at Stake 359

$20 \quad$ How Can Legal Diversity Be Managed? 363

20.1 Legal Education, Trainings, Guidelines, and Manuals 363

$20.2 \quad$ Principles, Model Rules, or Model Law 364

20.2.1 CEFL Principles of European Family Law 365

20.2.2 Towards Principles on the Recognition of Third-State Divorces 365

20.3 Towards Mutual Recognition of Decisions of EU Member States on the Recognition of Third-State Divorces 371

$\begin{array}{lll}20.3 .1 & \text { Introduction } & 371\end{array}$

20.3.2 The Principle of Mutual Recognition in ECJ Case Law 374

20.3.2.1 Cassis de Dijon: Its Origin 375

20.3.2.2 The Principle of Mutual Recognition and Free Movement of Persons in Matters of Civil Status 379

20.3.2.2.1 Dafeki: Acceptance of Probative Value of Documents of Other Member States $\quad 379$

20.3.2.2.2 Garcia Avello et al:: Mutual Recognition and Limping Names 381

20.3.2.3 Lessons to Be Learned from This Case Law 394

20.3.3 The Principle of Mutual Recognition: A Cornerstone of the Area of

20.3.3.1 The Tampere, the Hague, and the Stockholm Programmes 401

20.3.3.2 The Green Paper $2010 \quad 404$

20.3.3.3 The Proposal for a Regulation $2013 \quad 405$

20.3.4 Brussels I, Brussels I Recast, and Brussels II-bis 408

20.4 Towards Harmonization of Recognition of Non-EU Third-State 
TABLE OF CONTENTS

21 Conclusion

21.1 Shortcomings of the Differing National Recognition Policies 419

21.2 Relevance of the EU Context 420

$\begin{array}{lll}21.3 & \text { Solutions } & 421\end{array}$

21.3.1 Soft Law Solutions 421

21.3.2 Hard Law Solutions 423

21.3.2.1 Mutual Recognition of Decisions of EU Member States on the Recognition of Third-State Divorces 423

21.3.2.2 Harmonization of Recognition of Third-State Divorces in the EU 425

22 Conclusions and Recommendations $\quad \mathbf{4 2 7}$

$22.1 \quad$ Diversity in Islamic Divorce Laws and Practices 427

22.2 Diversity in National Recognition Policies in Europe 428

22.3 Solutions for a Better Management of Legal Diversity in Europe 432

$22.4 \quad$ Research Questions 439

Samenvatting: Islamitische echtscheidingen in Europa 443

$\begin{array}{ll}\text { Bibliography } & 445\end{array}$

Internet sources (if not in footnotes) $\quad 469$

$\begin{array}{ll}\text { Miscellaneous } & 472\end{array}$

$\begin{array}{ll}\text { Acknowledgements } & 475\end{array}$

$\begin{array}{lr}\text { Curriculum Vitae } & 479\end{array}$ 


\section{Note ON Transliteration}

In this book, (Modern Standard) Arabic terms and expressions are presented and transliterated into English. For reasons of readability and pragmatism, I have adopted a simplified version of the transliteration system of the Arabic alphabet.

The transliteration used in this book indicates the Arabic letters 'ayn (') and hamza ('); however, the hamza is used only in the middle or at the end of a word. It omits diacritical marks and does not distinguish between the extended and the short vowels. Moreover, no ط, ض, ظ, and their emphatic variants ت, د, ذ, س distinction is made between the letters $ص$. Finally, no distinction is made between the letters $ح$ and $\circ$. The is written by means of doubling the respective consonant.

I use conventional English spelling for most personal, place, and proper names as well as frequently translated Arabic words such as Koran. Foreign, meaning not English or Arabic, words are italicized.

\begin{tabular}{|c|c|}
\hline Arabic & Transliterated into English \\
\hline$ء$ & ' (only in the middle or at the end of a word) \\
\hline I & a, i, u (as initial character) \\
\hline ب & $\mathrm{b}$ \\
\hline ت & $\mathrm{t}$ \\
\hline$\dot{H}$ & th \\
\hline ج & j \\
\hline 乙 & $\mathrm{h}$ \\
\hline$\dot{c}$ & $\mathrm{kh}$ \\
\hline د & $\mathrm{d}$ \\
\hline j & $\mathrm{dh}$ \\
\hline ر & $\mathrm{r}$ \\
\hline j & $\mathrm{Z}$ \\
\hline 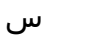 & $\mathrm{s}$ \\
\hline 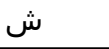 & $\operatorname{sh}$ \\
\hline ص & $\mathrm{s}$ \\
\hline ض & $\mathrm{d}$ \\
\hline b & $\mathrm{t}$ \\
\hline ظ & $\mathrm{dh} / \mathrm{z}$ \\
\hline
\end{tabular}


NOTE ON TRANSLITERATION

\begin{tabular}{|c|c|}
\hline Arabic & Transliterated into English \\
\hline$\overline{\dot{\varepsilon}}$ & gh \\
\hline ف & $\mathrm{f}$ \\
\hline 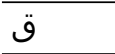 & $\mathrm{q}$ \\
\hline كاك & $\mathrm{k}$ \\
\hline J & 1 \\
\hline م & $\mathrm{m}$ \\
\hline$\dot{ن}$ & $\mathrm{n}$ \\
\hline$\circ$ & $\mathrm{h}$ \\
\hline 9 & $\mathrm{w}$ (as consonant) / u (as vowel) \\
\hline ي & $\mathrm{y}$ (as consonant) / i (as vowel) \\
\hline
\end{tabular}




\section{List of Frequently Used Arabic Terms}

Any attempt to render precise legal terminology into another language and conceptual system is fraught with peril

(Quotation taken from Ali 2008, p. 27, footnote 3).

\begin{tabular}{|c|c|}
\hline 'adl (sing.) / 'udul (pl.) & $\begin{array}{l}\text { official witnesses (notably in personal status and family law, but also for } \\
\text { example at real estate transactions, and who draw up authentic acts of e.g. } \\
\text { marriage and repudiation) }\end{array}$ \\
\hline $\begin{array}{l}\text { ahadith (pl.) / hadith } \\
\text { (sing.) }\end{array}$ & the statements or acts of the Prophet that are passed down in traditions \\
\hline $\begin{array}{l}\text { 'alim (sing.) / 'ulama' } \\
\text { (pl.) }\end{array}$ & religious scholar \\
\hline 'amal & judicial (customary) practice (one of the additional sources of fiqh) \\
\hline asl (sing.) / usul (pl.) & source of Shari'a \\
\hline ba'in & irrevocable (e.g. repudiation) \\
\hline $\operatorname{bid}^{\prime} a$ & disapproved, irregular \\
\hline faskh & the dissolution of marriage through annulment by the judge \\
\hline fiqh & $\begin{array}{l}\text { literally meaning 'understanding' or 'knowledge', corpus of rules with a } \\
\text { legal and a religious dimension }\end{array}$ \\
\hline Fiqh (ilm fiqh) & $\begin{array}{l}\text { the science of Islamic jurisprudence, which is the scholarly discipline in } \\
\text { which Islamic jurists, fuqaha, are engaged in exegesis and the elaboration } \\
\text { of Shari'a law }\end{array}$ \\
\hline $\begin{array}{l}\text { fuqaha (pl.) / faqih } \\
\text { (sing.) }\end{array}$ & jurist, a person who is learned in figh \\
\hline hadana & $\begin{array}{l}\text { duty of care (custody) for the child by both parents during marriage and } \\
\text { preferably by the mother after the dissolution of marriage }\end{array}$ \\
\hline $\begin{array}{l}\text { hadith (sing.) / ahadith } \\
\text { (pl.) }\end{array}$ & the statements or acts of the Prophet that are passed down in traditions \\
\hline Hanafi & $\begin{array}{l}\text { relating to one of the (four) established Sunni schools of jurisprudence } \\
\text { named after the scholar Abu Hanifa an-Nu'man ibn Thabit; legists loyal } \\
\text { to the principles of Hanafism }\end{array}$ \\
\hline Hanbali & $\begin{array}{l}\text { relating to one of the (four) established Sunni schools of jurisprudence } \\
\text { named after the scholar Ahmad Ibn Hanbal; legists loyal to the principles } \\
\text { of Hanbalism }\end{array}$ \\
\hline 'ibadat & $\begin{array}{l}\text { religious and ethical rules that govern the relationship between humans } \\
\text { and Allah; they concern devotional, spiritual, ritual matters, and acts which } \\
\text { include obligations or recommendations concerning the five pillars of } \\
\text { Islam (belief in God, ritual prayers, fasting, the pilgrimage or haj, and the } \\
\text { gifts to the poor), religious purity, circumcision, form of prayer, etcetera }\end{array}$ \\
\hline
\end{tabular}

1 The abbreviations 'sing.' and 'pl.' refer to the use of the singular and plural form respectively of a word. 


\begin{tabular}{|c|c|}
\hline Ibadi & $\begin{array}{l}\text { most significant group of the Kharijite, the smallest denomination within } \\
\text { Islam next to the Sunni and Shi'a denominations }\end{array}$ \\
\hline 'idda & $\begin{array}{l}\text { waiting period of the wife for the dissolution of marriage by divorce, } \\
\text { annulment, or death }\end{array}$ \\
\hline ijma & $\begin{array}{l}\text { general consensus among Islamic scholars, expressed or tacit, on a question } \\
\text { of law }\end{array}$ \\
\hline ijtihad & $\begin{array}{l}\text { legal reasoning or derivation of law through interpreting, clarifying, or } \\
\text { supplementing the implicit rules of the Koran and/or Sunna }\end{array}$ \\
\hline isma & $\begin{array}{l}\text { form of self-repudiation (in Egypt): the repudiation of the wife by herself } \\
\text { after authorization to that end by the husband }\end{array}$ \\
\hline Isma'ili & or Sabiyah (Seveners): a sectarian subdivision of Shi'a Islam \\
\hline istihsan & juristic preference or equity (source that originates in ijthihad) \\
\hline istishab & presumption of continuity (source that originates in ijthihad) \\
\hline istislah & consideration of public interest \\
\hline Ithna 'Ashari & or Twelver Shi ites or Ja'fari: a sectarian subdivision of Shi ${ }^{\prime} a$ Islam \\
\hline Jafari & or Ithna 'Ashari or Twelver Shi ites, a sectarian subdivision of Shi' a Islam \\
\hline Kharijite & $\begin{array}{l}\text { the smallest denomination within Islam next to the Sunni and Shi'a } \\
\text { denominations }\end{array}$ \\
\hline$k_{\text {hhul }}^{\circ}$ & $\begin{array}{l}\text { repudiation of the wife by the husband on her demand in exchange for a } \\
\text { compensation by her }\end{array}$ \\
\hline Koran & $\begin{array}{l}\text { the holy book of Islam that includes the revelations from God to } \\
\text { Muhammad through the archangel Gabriel; literally meaning 'the recita- } \\
\text { tion' }\end{array}$ \\
\hline $\begin{array}{l}\text { madhhab (sing.)/ } \\
\text { madhahib (pl.) }\end{array}$ & school of jurisprudence \\
\hline mahr (or: sadaq) & $\begin{array}{l}\text { dower, marital gift from the groom to the bride at the occasion of the } \\
\text { conclusion of their marriage }\end{array}$ \\
\hline Maliki (adj. Malikite) ${ }^{2}$ & $\begin{array}{l}\text { relating to one of the (four) established Sunni schools of jurisprudence } \\
\text { named after its founder, the scholar Malik bin Anas; legists loyal to the } \\
\text { Maliki principles }\end{array}$ \\
\hline maslaha & consideration of public interest \\
\hline ma’zun & notary (in Egypt e.g. competent to draw up marriage or repudiation acts) \\
\hline mu'amalat & $\begin{array}{l}\text { legal and social rules applying to the relationship between human beings } \\
\text { among themselves; they concern the social or contractual acts and include, } \\
\text { for example, rules of substantive and procedural (family, contract, penal, } \\
\text { administrative) and international law, but they also concern moral } \\
\text { ordinances and medical recommendations }\end{array}$ \\
\hline mubara'a & $\begin{array}{l}\text { repudiation by the husband based on mutual agreement and including a } \\
\text { mutual waiver of financial obligations }\end{array}$ \\
\hline $\mathrm{Mul}$ & $\begin{array}{l}\text { messenger and the (last) Prophet sent by God who received revelations } \\
\text { from God through the archangel Gabriel }\end{array}$ \\
\hline
\end{tabular}

2 'Adj.' is the abbreviation of 'adjective'. 


\begin{tabular}{|c|c|}
\hline $\begin{array}{l}\text { mut'a (sing.) / muta' } \\
\text { (pl.) }\end{array}$ & $\begin{array}{l}\text { consolation gift by the husband for the repudiation due to his fault or as } \\
\text { a substitute for the unfixed or invalid dower }\end{array}$ \\
\hline mut'a & temporary marriage (only acknowledged by the Ithna 'Ashari) \\
\hline nafaqa & $\begin{array}{l}\text { duty of maintenance of husband towards his wife and children, including } \\
\text { lodging, food, clothing, and possibly domestic service }\end{array}$ \\
\hline nikah & marriage \\
\hline qadi & judge \\
\hline qanun & legislation of the secular authorities (one of the additional sources of fiqh) \\
\hline qiyas & $\begin{array}{l}\text { finding new solutions through (judicial) interpretation of existing legal } \\
\text { norms by analogy }\end{array}$ \\
\hline raj'i & revocable (e.g. the revocable repudiation) \\
\hline Sab'iyah & or Isma'ili (Seveners): a sectarian subdivision of Shi'a Islam \\
\hline Shafi $i$ & $\begin{array}{l}\text { relating to one of the (four) established Sunni schools of jurisprudence } \\
\text { named after the scholar Al-Shafi'i; legists loyal to the principles of the } \\
\text { Shafi }{ }^{\prime} i \text { school }\end{array}$ \\
\hline Shari'a & $\begin{array}{l}\text { the general normative system of Islam including social, ethical, religious } \\
\text { and legal rules }\end{array}$ \\
\hline Shari'a law & the legal subject matter that originates in and is part of Shari' $a$ \\
\hline Shi'a (adj.: Shi'ite) & second large denomination within Islam after the Sunni denomination \\
\hline shiqaq & (procedure based on) discord, irretrievable breakdown of the marriage \\
\hline siyasa & $\begin{array}{l}\text { discretionary legal powers of secular authorities to issue laws, in particular } \\
\text { in administrative affairs }\end{array}$ \\
\hline sunna & recommended, approved, regular \\
\hline Sunna & $\begin{array}{l}\text { second source of Shari'a (law), not only including pre-Islamic and local } \\
\text { customs that were followed by the Prophet and his disciples, but also } \\
\text { including statements and acts of the Prophet or his closest disciples as } \\
\text { corroborations, explanations, specifications of, and additions to the rules } \\
\text { of the Koran, whenever the Koran remains silent }\end{array}$ \\
\hline Sunni & relating to the largest denomination within Islam \\
\hline $\begin{array}{l}\text { tafriq (or: talaq al- } \\
\text { tafriq) }\end{array}$ & $\begin{array}{l}\text { modality of judicial repudiation (divorce) based on one of the Maliki } \\
\text { grounds that has been adopted by non-Maliki legal systems }\end{array}$ \\
\hline $\begin{array}{l}\text { tafwid (or: talaq al- } \\
\text { tafwid) }\end{array}$ & $\begin{array}{l}\text { form of self-repudiation (authorization by the husband to his wife to } \\
\text { repudiate herself whether or not in the form of an option) }\end{array}$ \\
\hline takhayyur & $\begin{array}{l}\text { selection and adoption of each other's principles, (a (reforming) method } \\
\text { used and permitted among Sunni schools of jurisprudence) }\end{array}$ \\
\hline $\begin{array}{l}\text { takhyir (or: talaq al- } \\
\text { takhyir) }\end{array}$ & $\begin{array}{l}\text { specific form of self-repudiation (the repudiation of the wife by herself } \\
\text { after authorization to that end by the husband) in which the authorized } \\
\text { wife has the option to choose between the continuation and the definitive } \\
\text { dissolution of the marriage }\end{array}$ \\
\hline talaq & $\begin{array}{l}\text { dissolution of marriage; in particular the repudiation of the wife by the } \\
\text { husband }\end{array}$ \\
\hline talaq al-ibra & $\begin{array}{l}\text { repudiation of the wife by the husband in return for renouncing some or } \\
\text { all of her rights (in Egypt) }\end{array}$ \\
\hline
\end{tabular}




\section{List of FreQUentLy Used ARABIC Terms}

\begin{tabular}{|c|c|}
\hline talfiq & $\begin{array}{l}\text { a method by which the doctrines of more than one school of law are } \\
\text { combined so as to produce a hybrid ruling which does not belong to any } \\
\text { of them }\end{array}$ \\
\hline $\begin{array}{l}\text { tamlik (or talaq al-tam- } \\
\text { lik) }\end{array}$ & $\begin{array}{l}\text { specific form of self-repudiation: the repudiation of the wife by herself } \\
\text { after authorization to that end by the husband }\end{array}$ \\
\hline taqlid & imitation of (one of) the established doctrines \\
\hline $\begin{array}{l}\text { tatliq (or: talaq al-tat- } \\
\text { liq) }\end{array}$ & divorce on a limited number of grounds by judicial process \\
\hline $\begin{array}{l}\text { tawkil (or: talaq al- } \\
\text { tawkil) }\end{array}$ & the husband's mandate to repudiate to another person or to his wife \\
\hline 'udul (pl.) / 'adl (sing.) & $\begin{array}{l}\text { official witnesses, notably in personal status and family law, but also for } \\
\text { example at real estate transactions, and who draw up authentic acts of e.g. } \\
\text { marriage and repudiation }\end{array}$ \\
\hline $\begin{array}{l}\text { 'ulama' (pl.) / 'alim } \\
\text { (sing.) }\end{array}$ & (religious) jurists \\
\hline 'urf & local customary law (one of the additional sources of fiqh) \\
\hline usul (pl.) / asl (sing.) & source of Shari'a \\
\hline wali & legal guardian \\
\hline wilaya & legal guardianship \\
\hline Zaydiyya & sectarian subdivision of Shi'a Islam (named after Zayd ibn Ali') \\
\hline
\end{tabular}




\section{INTRODUCTION}

\subsection{Islamic Divorces in Europe}

A Moroccan-Dutch man marries a Moroccan woman in Casablanca, Morocco, on 8 May 1996. ${ }^{1}$ After their marriage, they reside together in the Netherlands until the wife returns to Morocco. The marriage breaks down and a divorce through $\mathrm{khul}^{\prime}$ (the negotiated repudiation) is settled in Morocco. Two 'udul of the 'Tribunal de Première Instance' in Casablanca draw up an 'acte de repudiation compensatoire' in accordance with the Moroccan Family Code of 1993 on demand of the wife and the man's authorized representative on 28 April 1999. The man submits a request for registration of this Moroccan divorce to the Dutch registrar in Summer 1999. He presents the homologated 'acte de repudiation compensatoire' to that end. ${ }^{2}$ The Dutch registrar refuses to recognize and register the khul'. He puts forward in court, inter alia, the following defence: the khul' has not been established after proper judicial proceedings as neither the authorities nor the wife are able to prevent the divorce. However, relevant characteristics of the Moroccan khul' are the wife's request for divorce through khul'; the mandatory reconciliation session after a summons to appear; and the mandatory judicial authorization that allows the husband to repudiate his wife, after the husband's payment of a mandatory deposit to the court in order to guarantee his compliance with his wife's and children's post-divorce provisions.

The case is illustrative for the object of study of this book, the issue of the recognition of Islamic divorces established abroad, in European states. ${ }^{3}$ Some of these terms need clarification beforehand. 'Islamic divorces' is used for pragmatic reasons as a collective term in this study. The term 'divorces' covers the most common, formal modalities of dissolution of marriage by the act of one or both parties or by judicial process. The term does not include informal arrangements to dissolve the marriage, so it does not include divorces that are not lawfully established. 'Islamic' refers to their establishment in mostly Muslim-majority countries with legislation that incorporates, at least to some extent, laws and customs that originate in the legal subject matter of the Shari' $a$ (see chapter 4). One should realize, however, that the Islamic law or the Islamic divorce does not exist, as this study will also demonstrate. Islamic law is not some single, supranational legal system, but

1 The facts of this case are an extract from the decision of the District Court (Rechtbank) Amsterdam 21 December 1999, petition No. $99.2902 \mathrm{H}$.

2 A 'homologated' act of repudiation refers to an act of repudiation that has been 'judicially approved'.

3 The text of sections 1.1 to 1.3 was, for the greater part taken from and, previously published in Kruiniger 2013, p. 465-470. 
a system of legal norms and standards on which various religious and/or national legal systems have been based. Depending on its context, it denotes for instance classical Islamic - or rather classical Shari' $a$ law - or Moroccan or Pakistani law. One should thus preferably refer to 'Moroccan (divorce) law' or the 'Pakistani repudiation'. Whenever the notion of 'Islamic law' is used in this study, the notion is to be understood in its purely occidental sense and therefore restricted to the legal subject matter of Shari' $a$ law. The words 'Europe' and 'European' have various meanings in this book. 'Europe' and its adjective 'European' may refer to the (territory of the) supranational organization of the European Union (hereinafter EU). 'European country', for example, should then be read as an EU Member State. But 'Europe' may also be read in the context of another supranational organization, the Council of Europe, being home of the European Convention on Human Rights (hereinafter ECHR). ${ }^{4}$ European country or state can then also be read as Contracting State to the ECHR and/or member of the Council of Europe. ${ }^{5}$

\subsubsection{Cultural Diversity in Law}

The issue of the recognition of Islamic divorces in European states is an outstanding illustration of cultural diversity in law. In the first place, diversity is an inherent result of the coming together of Islamic divorce laws and their occidental counterparts as expressed in the recognition policies of European states. Second, various types of divorce exist in Islamic countries and are as diverse as the approaches of European countries towards their recognition. ${ }^{6}$ Cultural diversity refers to the variety of human societies and cultures in a specific state or region or in the world as a whole. ${ }^{7}$ Accordingly, cultural diversity in law, or legal diversity, refers to the variety of legal cultures in a specific area. The intrinsic value of cultural diversity, as recognized in Article 1 of the UNESCO Universal Declaration on Cultural Diversity (hereinafter UNESCO Declaration), is its value for humankind as a source of exchange, innovation, and creativity, and it is, in that sense, the common heritage

4 The 'Convention for the Protection of Human Rights and Fundamental Freedoms' or the 'European Convention on Human Rights' (hereinafter ECHR; Convention of the Council of Europe of 4 November 1950, entry into force on 3 September 1953).

5 All 28 EU Member States are also Contracting States to the ECHR. The Council of Europe include in total 47 states. See for the EU: <www.europa.eu> and for the Council of Europe: <www.hub.coe.int>.

6 Whenever the collective term 'Islamic countries' is used in this contribution, it denotes Muslim-majority states with legislation that incorporates or reflects, at least to some extent, Islamic law and customs.

7 Art. 4 of the UNESCO Convention on the Protection and Promotion of the Diversity of Cultural Expressions (Paris, 20 October 2005) states: 'cultural diversity refers to the manifold ways in which the cultures among groups and societies find expression. The expressions are passed on within and among groups and societies.' Culture is defined in the preamble of the UNESCO Universal Declaration on Cultural Diversity (hereinafter UNESCO Declaration; Paris, 2 November 2001) as follows: 'culture should be regarded as the set of distinctive spiritual, material, intellectual and emotional features of society or a social group, and that it encompasses, [...] lifestyles, ways of living together, value systems, traditions and beliefs [...].' 
of humanity. Article 22 of the Charter of Fundamental Rights of the European Union (ChFREU) also underlines the value of cultural diversity by stating that it shall be respected by the EU. ${ }^{8}$

The confrontation of Islamic divorces with recognition policies of European states often appears to be a clash because of cultural and religious differences in the notions of divorce. Although divorce is a universal phenomenon, its modes of establishment, procedures, and forms are not uniform. Domestic divorce laws have been designed by historically, culturally, and/or religiously influenced views dominant within individual states. ${ }^{9}$ The worldwide diversity in forms, laws, and procedures of divorce implies that in cross-border situations the divorce that has been lawfully established and thus has legal effect in one state may often not be automatically 'accepted', in legal terms 'recognized', in another state. Foreign judgments or acts of divorce need to be recognized in order to have legal effect in that other state. ${ }^{10}$ However, parties involved have reasonable and legitimate expectations that their divorce that has been lawfully established in the one state, will also be accepted in another state. ${ }^{11}$ The recognition of extra-judicial divorces, i.e. divorces being established out of court, and those dependent on the consent of the husband, such as the repudiation or the negotiated repudiation, $k h u l^{\mathrm{d2}}$ (hereinafter repudiation-based divorces), both being of Islamic origin, is particularly problematic. These types of marriage dissolution are considered to infringe upon fundamental rights of women, notably upon the right of

8 The Charter of Fundamental Rights of the European Union (hereinafter ChFREU); 18 December 2000, O.J. (C 364/1), which is effective as from 1 December 2009.

9 See e.g. Art. 1 of the UNESCO Declaration: 'Culture takes diverse forms across time and space. This diversity is embodied in the uniqueness and plurality of the groups and societies making up mankind'. See also Struycken 2009.

10 Other judgments, dependent on their content, may also be required to be enforced. The state that is required to recognize must take additional measures for the judgment to become effective in that state. Foreign judgments awarding damages or maintenance are exemplary in this respect. When the maintenance creditor wants to obtain maintenance in his state of domicile or residence, he or she has to seek recognition and subsequently the enforcement of that foreign judgment by the court of his or her state of domicile or habitual residence.

11 See e.g. Clarkson \& Hill 2011, p. 10-12.

12 See part I in this book. 
equal access to divorce ${ }^{13}$ and upon procedural rights, ${ }^{14}$ and therefore upon the public order of European states. The recognition of judicial divorces, i.e. divorces established in court, on the other hand, is in general not problematic because of the interference of state authority ${ }^{15}$ and the implementation of procedural and substantive guarantees for the litigants. But the issue of recognition of Islamic divorces goes beyond women's rights issue, as this study will demonstrate.

\subsubsection{Bridging Gaps in Legal Diversity: Private International Law}

In situations in which different legal cultures come into contact because of cross-border legal relationships, the formulation of rules of private international law (hereinafter PIL) is 'one of the possible reactions' in order to bridge their gaps. ${ }^{16} \mathrm{PIL}$ aims to offer an efficient and fair solution in any cross-border conflict that arises, inter alia, to meet the legitimate expectations of the parties involved. Not providing for such a solution, for example by disregarding foreign laws or decisions, could result in injustices for parties in concrete cases such as situations of limping legal relationships. A limping legal relationship is created whenever a legal relationship is recognized in one country but not in another country.

Such a solution should ideally be achieved through international, at least bi- or multilateral, treaties in order to guarantee as much as possible a uniform regulation of the conflict; in other words, to further an international harmony of decisions. ${ }^{17}$ But often, as in the case of the recognition of Islamic divorces in Europe, national PIL instruments handle the issue. This study will demonstrate that the various recognition policies of European states show a great disparity in their approaches towards Islamic divorces.

13 See Art. 5 of the 7th Protocol to the European Convention of Human Rights (hereinafter ECHR; Council of Europe protocol of 22 November 1984; entry into force on 1 November 1988) as manifestation of the right to equality based on gender. The Netherlands and the United Kingdom have never signed and/or ratified this protocol to the ECHR. See also Art. 23 ChFREU. See more in general for equal rights of the spouses upon divorce: Art. 16 Section 1 of the Universal Declaration of Human Rights (hereinafter UDHR; adopted by the General Assembly of the United Nations on 10 December 1948, GA res. 217 A (III) in Paris); Art. 23 Section 4 of the International Covenant on Civil and Political Rights (hereinafter ICCPR; adopted by the General Assembly of the United Nations on 16 December 1976, GA res. 21/2200 (XXI), entry into force on 23 March 1976) and Art. 16 Section 1 sub c of the Convention on the Elimination of All Forms of Discrimination against Women (hereinafter the Women's Convention; adopted by the United Nations' General Assembly on 18 December 1979, entry into force on 3 September 1981).

14 As formulated in Art. 6 ECHR and Art. 47 ChFREU.

15 In this contribution it will be demonstrated that divorces which were traditionally established out of court, but which are submitted to judicial interference nowadays, such as the Moroccan repudiation, still appear to be problematic in view of their recognition.

16 Van Hoek 2012, p. 362.

17 This principal goal of classic PIL was introduced by Friedrich Carl Von Savigny in his: A treatise on the Conflict of Laws, translated by William Guthrie, Edinburgh: T \& T. Clark, Law Publishers 1869, p. 69 et seq. 
'Private international law deals with the diversity of systems of private law'. ${ }^{18}$ The reality of cultural diversity demands a 'harmonious interaction among people and groups with plural, varied and dynamic cultural identities as well as their willingness to live together'. ${ }^{19}$ Thus cultural diversity and PIL are closely linked to each other.

The core issue of PIL is the question of how legal diversity can be managed. Its pragmatic, basic principle is respect for foreign law in that the 'otherness' of foreign law, independent of its origin, is accepted on an equal footing with domestic law by the receiving legal order. Hence, PIL is also called the Law of Tolerance (Derecho de Tolerancia) ${ }^{20}$ Here the PIL principle meets one of the tenets of the UNESCO Declaration which affirms 'that respect for the diversity of cultures, tolerance, [...] are among the best guarantees of international peace and security'. ${ }^{21}$ Moreover, this Declaration underlines the defence of cultural diversity as 'an ethical imperative'. ${ }^{22}$

However, the acceptance of foreign law may, although exceptionally, be restricted if it conflicts with the fundamental standards and values of the receiving legal order; in other words, the acceptance of foreign law may be restricted on grounds of public policy. Hence, PIL and cultural diversity may only operate within the framework of fundamental rights. ${ }^{23}$ Consequently, a state often denies the recognition of an Islamic divorce, because it is presumed to be extra-judicial and hence violating fundamental rights and thus the public policy of that state. Accordingly, the major task of PIL in the receiving legal order is to understand the foreign law in a correct manner. Only the correct understanding of the different modalities of Islamic divorces will allow for a correct decision on their recognition in Europe. Thus the 'intercultural dialogue' is the best guarantee 'to reject outright the theory of the inevitable clash of cultures and civilizations. ${ }^{24}$

\subsection{Formulation of Two Problems}

This study will demonstrate at least two major shortcomings in the issue of recognition of Islamic divorces in Europe. First of all, the legal nature of Islamic divorces, in particular of the originally extra-judicial modalities of divorce, is - whether unconsciously or con-

18 Struycken 2009, p. 28. See also Strikwerda 2012, p. 1-2.

19 Art. 2 of the UNESCO Declaration.

20 Expression introduced by Prof. Werner Goldschmidt in Derecho internacional privado; Derecho de la tolerancia. Basado en la teoria trialista del mundo juridico (edition actualized by Alicia M. Perugini Zanetti), Buenos Aires, Argentina: Abeledo Perrot S.A. 2011.

21 See the preamble of the UNESCO Declaration.

22 See Art. 4 UNESCO Declaration.

23 Art. 4 of the UNESCO Declaration underlines that infringement upon or limiting of human rights in the name of cultural diversity may not occur: the defence of cultural diversity as ethical imperative inseparable from respect for dignity involves a commitment to human rights.

24 Ibidem. 
sciously - not always understood in a correct manner resulting in their wrongful recognition, recognition under too strict conditions, or their non-recognition and consequently in limping legal relationships. Limping legal relationships will be created whenever a person is considered to be divorced in one state while that person is considered to be still married in another, non-recognizing state. This causes evident legal, economic, financial, and social problems: for instance that the person is not allowed to remarry or has to go through double divorce proceedings or may not have access to social benefits or a residence permit. A limping legal relationship thus results in violating human rights such as the right to respect for private and family life pursuant to Article 8 ECHR or Article 7 ChFREU or the right to marriage pursuant to Article 12 ECHR or Article 9 ChFREU. This shortcoming partly explains the disparity in approaches towards Islamic divorces among European states.

The second shortcoming directly concerns the disparity in approaches towards Islamic divorces and consequently the variety of national recognition policies in Europe. This variety may result in divergent outcomes, and thus it may influence the continuity of the personal status of an individual; consequently it may result in a limping legal relationship including the consequences addressed above. Moreover, this lack of harmony in decisions may hamper the right to free movement of persons within the EU. ${ }^{25} \mathrm{~A}$ typical situation is the following: ${ }^{26}$

A Dutch-Moroccan woman is repudiated in Morocco. She remarries a Moroccan man in Morocco. Then she moves from the Netherlands to Belgium. Although her repudiation had been recognized in the Netherlands, Belgian authorities refuse to recognize her repudiation. Consequently, she is still seen as being married to her former husband in Belgium and she cannot bring her

25 See Art. 18 of the Treaty establishing the European (Economic) Community (hereinafter EC-Treaty; Rome, 25 March 1957, entry into force on 1 January 1958) or Art. 21 of the Treaty on the Functioning of the European Union (hereinafter TFEU; 9 May 2008, O.J. (C 115/47), effective as from 1 December 2009) on the right to move freely which applies to EU citizens (nationals) and Arts. 39 et seq. EC-Treaty or Arts. 45 et seq. TFEU of the right to free movement of employees and self-employed persons which applies to EU citizens (nationals) and specified family members who do not necessarily have to be nationals of EU member states, to workers from the European Economic Area, and to long-term residents (under restrictions, see EC-directive 2003/109/EC of 25 November 2003). It may also apply to non EU nationals on the basis of Association Agreements (e.g. with Morocco and Turkey) which include special provisions on the right of free movement for workers. See also Art. 45 of the EU Charter of Fundamental Rights on the Freedom of movement of EU citizens and, if granted, of third-country nationals (TCNs). See also EC-Directive 2004/38/EC of 29 April 2004 on the right to free movement and residence within the EU which apply to EU citizens and their family members. It must be kept in mind that today the majority of immigrants have acquired the nationality of an EU Member State during their stay in Europe or is a long-term resident, or may belong otherwise to one of the abovementioned categories and that accordingly they are entitled to the right of free movement within the EU.

26 Case described by Verhellen 2012, p. 455-456. 
latest husband from Morocco to Belgium. There is a discontinuity of her personal status and thus a limping legal relationship.

This situation being a harmful consequence of legal diversity is unsatisfactory as it results in legal inequality, legal uncertainty, and unpredictability with regard to the legal status of Muslim migrants in Europe. Moreover, it affects the legitimate expectations of persons as they rely on the continuity of their identity and personal status, validly arranged in accordance with a specific legal system, whenever they cross borders in a more and more globalized world. By hampering the right to free movement of persons, it also affects the 'official objective' of the EU of increasing the 'internationalization of legal relationships' and thus the legitimate expectations of society at large. ${ }^{27}$

\subsection{Research Questions}

The issues sketched out above have prompted the following main research question:

How should Europe deal with the various modalities of Islamic divorce? In other words: how should Europe manage the legal diversity at issue?

This question has prompted two sub-questions that this research also seeks to answer:

a. Whether and to what extent should Western legal systems through their recognition policy acknowledge and accommodate the legal differences emanating from Islamic legal institutions (such as the repudiation) $?^{28}$

To state it differently: should cultural diversity - in this context - be protected or rejected? Or is there an alternative, a third way?

b. What are adequate legal approaches or instruments to deal with the recognition of Islamic divorces, notably of the repudiation-based modalities, in Europe? What are suitable legal approaches or instruments for an adequate management of this legal diversity?

27 Van Hoek 2012, p. 363.

28 According to R. Ballard et al. accommodation refers to the practices, e.g. recognition policies, 'through which the law, or social actors operating in its shadow, are sensitive to take into account and make room for values and meanings which differ from their own'. They also mention that accommodation 'encompasses, but is not confined to changes in legislation to allow practices or institutions previously prohibited or discouraged [...] or doctrines [...]'. See Ballard et al. 2009, p. 20. 
This research has adopted a threefold approach to enable formulating answers to the research questions: first, the scrutiny of the divorce laws of Egypt, Iran, Morocco, and Pakistan (part I); second, the analysis of the policies of recognition of England, France, and the Netherlands (part II); and third, the exploration of legal approaches and instruments that are suitable for an adequate management of the legal diversity at stake (part III). This approach is further explained in the following sections.

\subsubsection{Identifying the Diversity of Islamic Divorces}

It can first be addressed why the scrutiny of the divorce laws of Egypt, Iran, Morocco, and Pakistan is of value. As mentioned above, the status of women at Islamic divorce and the issue of recognition of Islamic divorces are strongly intertwined because it is presumed that women's substantive and procedural rights are not observed and guaranteed in the context of these divorces. Consequently, this presumption may influence the decision for recognition or non-recognition of an Islamic divorce. From a broader perspective, the status of women as parties to an Islamic divorce includes legal, social, and economic aspects before, during, as well as after the divorce and its (non-) recognition, both in the state of origin as well as in the state of residence. This research focuses on two of the legal aspects: the right of equal access to divorce as a manifestation of the principle of gender equality and the right to equal procedural rights. ${ }^{29}$

Notably the extra-judicial Islamic divorces, such as the repudiation, talaq, and the negotiated repudiation, $k h u l$ ', are notorious. These types of divorce that are based on the repudiation (hereinafter repudiation-based divorces) violate the female spouses' right of equal access to divorce since women have - in principle - no right to repudiate. ${ }^{30}$ They also infringe upon their procedural rights such as the right to be summoned or the right to have both sides heard. The presence of the wife at the pronouncement of the repudiation is not required nor can she defend herself otherwise against dissolution of the marriage.

But the legal reality of divorce and its laws and practices in Islamic states is much more complex and diverse as will be demonstrated in this study. As previously mentioned, the

29 One could also think of the right to self-determination (as a manifestation of the principle of autonomy of the will) as for example reflected in having the possibility to choose for (a specific type of) divorce. Although this legal principle is relevant in the context of Islamic divorces, it is less relevant in relation to their recognition. For this reason this principle is not included in the framework of the assessment of European states.

30 Unless the husband has delegated or assigned this right to his wife, e.g. through a clause inserted in the marriage contract. However, the repudatiation by mandate or authorization to the wife (self-repudiation) rarely occurs. 
Islamic law and therefore the Islamic divorce do not exist. Great differences among the divorce laws in Islamic states can be distinguished. A closer inspection reveals that Islamic divorces, especially the repudiation-based divorces, differ considerably in their legal nature, i.e. regarding their form and procedure, from state to state. The specific form and procedure of a certain type of Islamic divorce depends on its origin in one of the Islamic schools of jurisprudence as well as on legal, social, economic, historical, and political developments in a specific Muslim-majority country that may have resulted in reforms. These reforms were in particular aimed at improving the legal and social status of women within society.

States did not implement similar changes. The Moroccan repudiation, for example, has been submitted to mandatory judicial intervention. It is very different from the Egyptian and Pakistani out-of-court variants that are subject to a registration and notification pro-

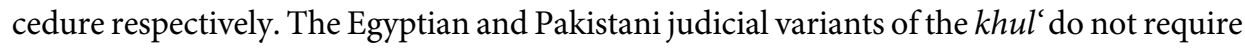
the consent of the husband, whereas the Moroccan variant, despite mandatory judicial intervention, still requires the consent of the husband in order to be established.

The correct understanding of these modalities is of utmost importance as it directly affects the assessment of the recognition of the divorce involved. It requires a comprehensive knowledge of the various modalities of Islamic divorce. This study aims to provide more information on and insights into the specific divorce modalities that occur in the Muslimmajority states under investigation in this research. For this reason, part I examines the specific legal nature of the modalities of divorce in these states. It notably examines the presence or lack of the right of equal access to divorce as well as of procedural rights and their observance both in black letter law and in legal practice of the Muslim-majority states under review as is identifiable from, for instance, case law. Each modality is examined separately and in the context of the entire system of divorce law of a specific Muslimmajority state in which that modality occurs. A comprehensive knowledge of the law and legal practice allows for a correct understanding and subsequent classification of the Islamic divorce modalities and the assessment of their recognition; it also contributes to answering the sub-question whether and to what extent European states, through their recognition policy, should acknowledge and accommodate the legal differences emanating from Islamic divorces. The findings of part I are used to indicate how the various divorce modalities should be correctly characterized.

This study does not discuss the choices and motives of persons for divorce according to the legal system of their country of origin. ${ }^{31}$

\subsubsection{Exploring the Diversity of European Recognition Policies}

The second approach consists of an analysis of the recognition policies of three European countries, all of them being EU Member States: England, France, and the Netherlands.

31 See in this respect for example: Mir-Hosseini 2000; Sonneveld 2012; Sportel 2014. 
Different national judicial and administrative authorities in Europe, such as registrars, consular employees or diplomats, and the judiciary, are regularly confronted with a request for the recognition of an Islamic divorce. They have to assess the Islamic divorce in respect of its significance for and effects on domestic law, inter alia, from the perspective of fundamental rights and, thus, of the public order. Sociopolitical interests of a specific state may also play a role, as is shown by the increase in an instrumental (ab-)use of PIL, for instance, in order to restrict migration to Europe. ${ }^{32}$

This study will demonstrate that European states use different criteria and approaches when assessing the recognition of a specific Islamic divorce modality. A variety of recognition policies exists within Europe, thus leading to diverse outcomes and the harmful consequences thereof. Some states, such as France, have adopted an approach in abstracto, and other states, such as the Netherlands, have adopted an approach in concreto. In the approach in abstracto, the foreign legal institution as such is being evaluated. In the case of the repudiation or repudiation-based divorce modality, the unequal access to divorce and/or the lack of procedural rights for women are often emphasized. As a result, the public policy exception is regularly invoked to reject the recognition of such divorces. Through the approach in concreto, the legal institution is evaluated with reference to the circumstances of the individual case. Hence, the repudiation may, in view of all specific circumstances of the case, be considered compatible with the public order and will be recognized.

The consequence of non-recognition of an Islamic divorce that affects both women and men is discontinuity of the personal status of the person(-s) involved and, thus, the limping legal relationship. Paradoxically, the refusal to recognize an Islamic divorce because of an alleged violation of protective fundamental rights (the right to equal access to divorce and procedural rights) results in the violation of fundamental rights (the right to respect for private and family life and the right to marry) of the person involved; that person - woman or man - is not protected from the previously mentioned harmful effects.

The French systematic refusal to recognize any repudiation as soon as there is some proximity to the French legal order is exemplary in this regard. The argument put forward is that the repudiation violates the right to gender equality because of its inaccessibility to women. This refusal results in a limping legal relationship. In the context of the entire divorce system of Morocco, however, this violation should not be considered as an absolute but as a relative violation of gender equality. This study will demonstrate that Moroccan women have alternative divorce modalities at their disposal such as the divorce grounded in the irretrievable breakdown of the marriage, the shiqaq; the negotiated repudiation, the

32 See Van den Eeckhout 2002, p. 76, p. 82-84, p. 86-88; Van den Eeckhout 2003, p. 181, p. 186-189; Van den Eeckhout 2012; Van den Eeckhout 2013, p. 266-267, p. 275-278, p. 284-289; Verhellen 2010, p. 152-155; Verhellen 2012, p. 461-463; Wautelet 2009. 
khul'; and possibly self-repudiation, tamlik. And although the spouses do not have identical 'arms', at least in theory they have equally effective 'arms' to dissolve the marriage. The application of an approach in concreto may result in a fair outcome for the individual involved, thus avoiding limping legal relationships and their consequences and protecting their positions.

This example demonstrates the danger of a 'superficial' view of Islamic divorces that would give the impression of a total deadlock between Islamic law and International human rights in respect of the issue of gender equality. It underlines once more the interest in and importance of a sound understanding of the foreign legal institution, its procedure, and the entire divorce system. Otherwise the risk of misunderstanding the foreign divorce, consequently leading to its wrong classification and thus to a wrongful (non-) recognition, including all its harmful effects, is great. This example also raises the question for the rationale behind the non-recognition of the repudiation.

For these reasons, the second research part aims to clarify how the three European states under study deal with the 'otherness' of the Islamic divorces at present and why they deal with the 'otherness' in that specific way. The answers to these questions enable answering the main question how European countries or Europe should deal with the various modalities of Islamic divorce, more specifically the question for adequate legal approaches or instruments.

\subsubsection{How to Manage the Legal Diversity Adequately?}

Two major shortcomings in the management of legal diversity in the context of the recognition of Islamic divorces in Europe have been specified in section 1.2: misunderstanding Islamic divorces and a variety of recognition policies within Europe. Both shortcomings may have harmful consequences. For these reasons, the third approach aims to identify adequate legal approaches and instruments for the recognition of the differing Islamic divorce modalities in Europe. To this end, conceivable solutions - varying from soft to hard law - are examined in part III of this study.

\subsubsection{Methodology}

This study is mainly based on text analyses of relevant literature, legislation and other regulations and their preparatory acts, explanatory reports, manuals and court decisions of national courts, the European Court of Justice, and the European Court of Human Rights. This study uses the comparative law method. It is a multilayered comparative law research in which a fundamental/human rights methodology is applied. The main research for this book was closed in March 2014 although sporadic adaptations have been made after that time. 


\subsubsection{Part I: Islamic Divorces in Classical Islamic and Contemporary Law Compared}

The first research part aims at exploring the various divorce laws and practices in the Muslim-majority countries under study to enable answering the main question of how Europe should deal with the various modalities of Islamic divorce and the underlying subquestions. This part starts with a discussion and analysis of the original types of Islamic divorce in classical Islamic law. This analysis helps to explain the legal nature of similar modalities of Islamic divorce that occur in the Muslim-majority states under research at present and that have been grafted on the original types. The original types of Islamic divorce are used as tertium comparationis. However, as previously stated, it should be stressed that a specific legal nature of an Islamic divorce modality not only depends on its origin in one of the Islamic schools of jurisprudence, but in particular on legal, social, economic, historical, and political developments in the specific Muslim-majority country where it occurs. The subsequent chapters address the contemporary modalities of Islamic divorce in the laws and practices of the selected Muslim-majority states of Egypt, Iran, Morocco, and Pakistan, in particular from the perspective of the right of equal access to divorce and equal procedural rights. Whereas judicial Islamic divorces will also be included in the discussion in order to provide the full picture, the focus of this research will be on the extra-judicial and/or the repudiation-based Islamic divorce modalities.

\subsection{Functional Classification of Islamic Divorces}

This study uses a specific, functional classification that includes the following types of dissolution of marriage as a starting point for the discussion:

1. the divorce on the initiative of the husband covering the repudiation (talaq);

2. the divorce on the initiative of the wife covering: ${ }^{33}$

a. the divorce on a limited number of grounds by judicial process or the judicial divorce (talaq al-tatliq/talaq al-tafriq) and

b. the dissolution of marriage through annulment by the judge or the judicial annulment (faskh);

3. the divorce based on an 'agreement' by both spouses about or the involvement of both spouses in the repudiation covering:

a. the handing over of the power to repudiate to the wife by means of a mandate or authorization, or the self-repudiation (talaq al-tawkil and talaq al-tafwid including the talaq al-tamlik and the talaq al-takhyir),

33 Strictly speaking, the husband can also demand a judicial divorce or a judicial annulment. However, in contrast to the wife, the husband always has the possibility to pronounce the repudiation. Specific grounds for a judicial divorce or judicial annulment can only be invoked by women such as the long absence of the husband and the husband's non compliance with his duty to provide for maintenance. 
b. the repudiation by the husband on demand of the wife in exchange for compensation or the negotiated repudiation, $k h u l$ ', and

c. the repudiation by the husband based on mutual agreement and including a mutual waiver of financial obligations or the repudiation by agreement, (mubara'a).

This classification is arbitrary. Other classifications are possible as well. ${ }^{34}$ This classification has in particular been chosen to clarify the involvement of women in and the accessibility or inaccessibility for women to specific types of divorce. The annulment as mode of dissolution of the marriage has been included as 'divorce', since legal systems of some Muslimmajority countries do not acknowledge, or hardly grant possibilities, for a judicial divorce. Instead these legal systems acknowledge the judicial annulment of the marriage or faskh.

\subsection{Focus on the Status of Women}

As stated above, all these types are not only discussed and analysed separately but also in the context of the whole system of Islamic divorce law, in which they occur in a specific Muslim-majority country. The aim is to provide the full picture of all the alternatives available to women. The description of the entire system of Islamic divorce law shows the crucial importance of correctly assessing and characterizing all the different forms of divorce permitted by the legal system involved. Thus one is able to judge and assess, at their true value, all the possible alternatives, both separately and in the context of the whole divorce system, and in particular in view of their actual significance for the formal and substantive position of women. The latter is of the utmost importance with regard to the various European recognition policies towards Islamic divorce.

As has previously been stated, this research focuses in particular on the following aspects of the position of the wife:

- equal access to divorce as a manifestation of the right of equality based on gender; as articulated in Article 5 to the 7th Protocol to the ECHR, Article 16(1) UDHR, Article 23(4) ICCPR, and Article 16(1)(c) Women's Convention;

- procedural rights such as the right to appear, the right to a defence, the right to hear both sides in a fair hearing within a reasonable time by an independent and impartial court established by law, as articulated in Article 6 ECHR, Article 10 UDHR, Article 14 ICCPR, and Article 15(2) Women's Convention.

34 Linant de Bellefonds (1965, vol. II, p. 305-306), for example, departs from the following classification: the unilateral repudiation by the husband (talaq), the negotiated repudiation $\left(\mathrm{khul} \mathrm{l}^{\mathrm{l}}\right.$ ), and the judicial repudiation or dissolution of marriage (tatliq, tafriq or faskh). According to Linant de Bellefonds occidental and modern Shari' $a$ law jurists are familiar with this order, but classical fuqaha were not; they were familiar with the distinction between repudiation and resolution to be discussed in this section. Fyzee (2002, 4th edition, p. 148-149) proposes another, broader classification which is not restricted to divorce only; his classification is as follows: the dissolution of marriage: (1) by death of the parties; (2) by the act of the parties (subdivided into dissolution by the husband, by the wife or by common consent); and (3) by judicial process. 
The standards as incorporated in European or International law, like the Convention on the Elimination of All Forms of Discrimination Against Women (hereinafter the Women's Convention), ${ }^{35}$ the European Convention on Human Rights (hereinafter ECHR), ${ }^{36}$ the Universal Declaration of Human Rights (hereinafter UDHR) ${ }^{37}$ which has been elaborated in the International Covenant on Civil and Political Rights (hereinafter ICCPR) ${ }^{38}$ are relevant in this respect. The standards in the Women's Convention and the ECHR serve as a frame of reference. Egypt, Morocco, and Pakistan are bound by the standards in the Women's Convention. Moreover, the standards in the Women's Convention and the ECHR are used as guiding principles with regard to recognition by legislators and policy makers in Europe. Chapter 2 explains these standards more in detail. Hence, they serve to assess whether and to what extent Western legal systems should, through their recognition policies, acknowledge and accommodate the legal differences emanating from Islamic divorce modalities.

\subsection{Islamic Divorce: Private or Public Act or Judgment?}

The next step is to characterize the various modalities of divorce. It is very important to determine the legal character of the repudiation or divorce in a specific Muslim-majority state in relation to the question for its recognition in another state. The system of characterization as developed by El-Husseini Begdache is used. ${ }^{39}$ This system includes the following concepts: the private act, the public act, and the judgment. The characterization of a specific modality depends on which features of the modality of divorce are seen as predominant; especially the extent of judicial involvement is of importance. The modality is characterized as a private act if the prerogative and exclusive discretionary competence of the husband is stressed and judicial involvement is merely considered instrumental and marginal. If the emphasis is put on judicial involvement ranking this higher than its nature, the characterization 'judgment' would fit the modality. If the modality is seen as a hybrid, it is characterized as a public act.

35 The Convention on the Elimination of All Forms of Discrimination Against Women, adopted by the United Nations General Assembly on 18 December 1979, entry into force on 3 September 1981; ratified by Egypt in 1981, by Morocco in 1993; available at <www.un.org/womenwatch/daw/cedaw/text/econvention.htm\# intro>.

36 Convention for the Protection of Human Rights and Fundamental Freedoms, Rome, 4 November 1950, entry into force on 3 September 1953, available at <http://conventions.coe.int/Treaty/en/Treaties/ $\mathrm{Html} / 005 . h t m>$.

37 Universal Declaration of Human Rights, adopted and proclaimed by the United Nations' General Assembly resolution 217 A (III) of 10 December 1948, available at <www.un.org/Overview/rights.html>.

38 The International Covenant on Civil and Political Rights, adopted by United Nations' General Assembly resolution 2200A (XXI) of 16 December 1966, entry into force on 23 March 1976; ratified by Egypt in 1982, by Morocco in 1979; available at <www.unhchr.ch/html/menu3/b/a_ccpr.htm >.

39 Distinction made by R. El-Husseini Begdache in: Le droit international privé français et la répudiation islamique, Paris: LGDJ, 2002. 
The research in part I is mainly based on text analyses of relevant literature, legislation and other regulations, explanatory reports, manuals, and court decisions of national courts.

\subsubsection{Part II: Fourfold Analysis of National Recognition Policies in Europe in a Comparative Perspective}

In order to answer the question of how Europe should deal with the various modalities of Islamic divorces, the second research part examines how the European states under study deal with the 'otherness' at present and the rationale behind their specific way of dealing with that 'otherness'. For this reason, it consists of a fourfold analysis of their recognition policies. The recognition policies are then compared on the elements of this analysis.

\subsection{Identification of the Framework for Assessment of the Recognition}

In the first place, part II identifies the framework for the assessment of the recognition of Islamic divorces employed in these states. It explores the criteria that constitute the framework for assessment, the rationale of the legislator or policy maker behind these criteria, and the role of the PIL public order in a specific state under study. Are the right to equal access to divorce and equality in procedural rights the only and always decisive aspects that are taken into consideration? Or are, in view of the PIL public order, other interests taken into account as well? And how does this affect the assessment and the decision for recognition?

\subsection{Attention to the Correct Legal Nature of an Islamic Divorce?}

Second, this part examines whether or not these states pay attention to the correct legal nature of a specific divorce modality in the process of its characterization; and how taking into account of an incorrect legal nature affects the process of characterization of the specific divorce modality. Hence, it provides more and better insights into the understanding and subsequently the characterization of the various Islamic divorce modalities in the selected states.

\subsection{Assessment of the Degree of 'Openness' towards Islamic Divorces}

Third, this study evaluates the approaches in a recognition policy that have been adopted by a specific European state from the perspective of the degree of their 'openness' towards Islamic divorce modalities, apart from the usual perspective of the approaches in abstracto and in concreto. More specifically, the degree of openness of a state depends on its willingness to acknowledge the legal differences that emanate from a foreign legal institution such as an Islamic divorce and, hence, to acknowledge it as an integral part of a specific legal culture. The individual recognition policy may then be characterized as 'more open' or 'less open'. This evaluation also provides information about the rationale behind the 
approaches towards Islamic divorce modalities that the selected states have adopted in their recognition policy.

\subsection{Attention to Limping Legal Relationships?}

Fourth, part II addresses whether the consequence of non-recognition, the limping legal relationship, is considered sufficiently in (the adoption of) a specific recognition policy. Hence, it provides more insight into the extent to which the recognition policy is aimed at furthering recognition of the distinct divorce modalities in view of the continuity of the legal status of the persons involved in Europe.

The fourfold analysis is based on text analyses of relevant literature, legislation and other regulations and their preparatory acts, explanatory reports, manuals and court decisions of national courts, the European Court of Justice, and the European Court of Human Rights.

\subsubsection{Part III: How to Identify Adequate Legal Instruments}

The legal comparative analysis of part II thus provides the overture to identifying adequate legal approaches and/or instrument(-s) for the recognition of Islamic divorces within Europe. An adequate legal approach or instrument should be fair and effective, should provide for a consistent application of the legal framework, and do justice to the plurality of the legitimate interests at stake. Examples of these legitimate interests are gender equality in access to divorce and procedural rights; the protection of substantive, for instance, financial rights of in particular women; the prevention of limping legal relationships, in principle respect for the 'otherness' of an Islamic divorce modality and thus for legal diversity; respect for the legitimate expectations of the parties involved vis-à-vis continuity of their personal status; legal certainty and predictability; the prevention of harmful financial/economic, legal, and social consequences for the parties involved; the aim to prevent from fraud by any party involved; and respect for the right of free movement within Europe. These interests are therefore part of the frame of reference for an adequate legal approach or instrument. They serve also to assess how the European supranational and the national legal systems should accommodate the legal differences emanating from Islamic legal divorces, in particular the repudiation-based modalities.

To that end, chapter 20 explores various soft and hard law instruments as solutions for the shortcomings in the management of the legal diversity at present. But previous to this exploration, chapter 19 examines the consequences of the variety of recognition policies on the European level in order to clarify the need for solutions. And before presenting and exploring these solutions, two contextual issues are addressed in chapter 18. Some of these solutions stem from law of the EU (hereinafter EU law). Moreover, individuals of whom their marriage was dissolved by means of an Islamic, in particular repudiation-based divorce and who reside in and move within Europe may fall within the scope of the EU 
and EU law. They may have the status of an EU citizen or of a third-country national (hereinafter TCN) seen from an EU perspective. Depending on their status within the EU, these individuals can or cannot rely on specific provisions in EU law. And depending on that status, they can or cannot rely on specific solutions that will be presented in chapter 20. For these reasons, chapter 18 explores the distinction of the population in the EU into $\mathrm{EU}$ citizens and third-country nationals (TCNs), the relevant rights that can be derived from a specific status within the EU and the competences of the EU in PIL matters. In chapter 20, the core and kernel of part III, various soft and hard law solutions to remedy the found shortcomings are presented and explored. They concern solutions that may be effective on the national or on the supranational, European level or on both levels. The research in this part is mainly based on text analyses of relevant literature, legislation and other regulations and their preparatory acts, explanatory reports, and manuals and court decisions of the European Court of Justice. This study can and does not pursue the examination of an exhaustive number of solutions. It should be kept in mind that other solutions may be conceivable as well.

\subsection{SOURCES}

The research was carried out by analysing textual sources such as relevant legal and nonlegal literature, statutes, treaties, and other regulations, as well as their preparatory acts, explanatory reports, policy documents, reports of the Committee on the Elimination of All Forms of Discrimination Against Women (hereinafter CEDAW) and other reports of governmental or non-governmental organizations, and case law of the various countries under study, of the European Court of Justice, and of the European Court of Human Rights. The sources were either available as hardcopy and/or were accessible via the Internet.

The sources consulted were authentic sources, translations of authentic (e.g. Arabic or Farsi) sources, and sources in Dutch, English, French, and German. The quantity and quality of the materials available was as such that they suffice to obtain the relevant, essential information. Several sources, for example in Morocco, are not only published in Arabic but also in authentic French versions; the same holds true for Pakistan where many authentic English texts are available. To a lesser extent, this is also the case in Egypt. In the case of Iran, translations of authentic sources or sources in English, French, and German were used. An example is the new Iranian Family Protection Law that entered into force in April 2013. ${ }^{40}$

40 Ms. Khalidah Ahmadi, a student at the Law Faculty of Maastricht University, from Iranian descent and native speaker, was of great help as she translated the authentic Farsi text of this Act for me. 
For this study, not only literature concerning 'the law in the books' but also legalanthropological studies were consulted. The legal-anthropological studies enabled to provide a broader picture of the divorce modalities and Islamic laws and practices under study. A selection of these legal-anthropological studies is: Buskens 1999 on Morocco, Mir-Hosseini 2000 on Iran and Morocco, Sonneveld 2012 on Egypt, Kulk 2013 on Egypt and Morocco, and Sportel 2014 on Egypt and Morocco.

Apart from using written sources, a number of congresses, symposia, or workshops on 'Islamic (family) law' and/or private international law were attended to gather information, improve knowledge, and meet colleagues in the field in the Netherlands and abroad. Examples are the 9th Mediterranean Research Meeting at the European University Institute in Florence/Montecatini Terme, Italy, in 2008 and the World Congress on Middle Eastern Studies (WOCMES) in Barcelona, Spain, in 2010.

At the invitation of Professor Flinterman, one of the members of the Committee on the Elimination of Discrimination against Women at the time, I had the occasion to attend the meetings of the CEDAW considering the country reports of Tunisia in 2010. Although Tunisia is not one of the countries under study in this book, this occasion proved to be a fascinating and informative experience. I gained a clear understanding of the functioning of the CEDAW and of the Women's Convention and its persuasive power.

Furthermore, I undertook study trips to key cities (e.g. Hamburg, Leiden, London, Rabat, The Hague) where expert knowledge is available, in order to verify, discuss, and/or evaluate the findings from the textual sources. Another goal was to visit specialized libraries to collect materials and case law such as the library of the Peace Palace in The Hague, the libraries of the School of Oriental and African Studies (SOAS) and the British Institute of International and Comparative Law in London, the library of the University of Cambridge in Cambridge, and the library of the Max Planck Institute for Comparative and International Private Law in Hamburg. Other sources of information were the Workshops on Family Law at the annual Ius Commune Conferences, the various Spring or Autumn Schools of the Netherlands Interuniversity School for Islamic Studies (NISIS), and the annual meetings of the Researchers in Islamic Family Law (RIF) that I attended.

\subsection{Account for Selection}

Islamic divorces and Occidental recognition policies provide the framework in this research. To remind the reader: the wording 'Islamic divorces' is used as collective term in this study for pragmatic reasons. The term 'Islamic' refers to the establishment of the divorces in mostly Muslim-majority countries with legislation that incorporates, at least to some 
extent, laws and customs that originate in the legal subject matter of the Shari' $a$ law. ${ }^{41}$ The term 'divorces' covers the most common, formal types of dissolutions of marriage by the act of the parties or by judicial process, including the annulment of marriages. That term does not include informal or non-state arrangements to dissolve the marriage. Not commonly used types of dissolutions of marriage, including ila' (oath of abstinence from intercourse by the husband), zihar (an injurious imprecation), and li'an (imprecation of adultery of the wife by the husband), will not be discussed in this study since they rarely occur. Although this study discusses all types of divorce as mentioned in the classification above in order to provide the full picture, it focuses on the originally non-judicial types of divorce based on the repudiation (or repudiation-based divorces): the repudiation, the negotiated repudiation, the repudiation by agreement, and the self-repudiation.

In the analysis of Islamic divorces, the repudiation (talaq), the judicial divorce or annulment (talaq al-tatliq/tafriq or faskh), the self-repudiation (talaq al-tawkil/tafwid), the negotiated repudiation ( $(k h u l)$, and the divorce by agreement (mubara'a) are discussed. As mentioned above, they represent the most commonly used types of divorce in Muslimmajority states. The repudiation (talaq) should be discussed because it is traditionally the type of divorce that is at the disposal of the husband. It is also the most commonly used type of Islamic divorce. Furthermore, this type of divorce is considered to be the most problematic in respect of its recognition in European states because of its inaccessibility to and its lack of procedural rights for women. However, the repudiation has been subjected to procedural restraints to improve the status of women in a number of Muslim-majority countries. The judicial repudiation and annulment (tatliq and faskh) are less commonly used apart from the judicial divorce based on shiqaq in Morocco, but they are significant in two respects: their accessibility to women and their less problematic recognition because of judicial involvement. The two forms of self-repudiation (talaq al-tawkil/tafwid) are less known and rarely occur in Muslim-majority countries. However, these forms are rather significant for women as they may offer independent access to divorce to women once the husband has handed over the power to repudiate by mandate - and does not withdraw that mandate - or by authorization.

The negotiated repudiation, $\mathrm{khul}^{\mathrm{l}}$, a hybrid form of divorce, based on the repudiation (talaq) but also on elements of mutual agreement between man and woman, is a most interesting type of Islamic divorce. Because of its basis in the talaq, this type of divorce is often associated with the original talaq and, hence, considered to be problematic in respect of its recognition. Another important aspect of this divorce is its mutual agreement, which is not always sufficiently appreciated. This study will demonstrate that it has led to the rejection of the recognition of this specific type of divorce in France. In fact the khul' is one of the alternative types of Islamic divorce that is accessible to women, although they

41 For more about Shari'a law, see chapter 4. 
are still dependent on the cooperation of the husband to be repudiated and they still have to renounce (some of their) (financial) rights. This type of divorce has been subjected to reforms in order to improve the status of women in several Muslim-majority states. The repudiation by agreement that resembles the negotiated repudiation, as far as it is also based on the repudiation, is also less known and used in Muslim-majority states. However, it may offer women access to divorce, although it still requires the cooperation of the husband to be repudiated.

The Islamic divorce laws and divorce practices in case law of Egypt, Iran, Morocco, and Pakistan are explored in this research. The selection of these Muslim-majority states was based on three criteria: first, these countries represent various Islamic schools of jurisprudence: for Egypt the Hanafi/Maliki school, for Iran the Shi'a school, for Morocco the Maliki school, and for Pakistan the Hanafi or (in minority) the Shi'a school. Second, the selected types of Islamic divorce are found in different modalities in the legal systems of these states. In the third place, because of the number of residents or citizens in the selected European countries that originate from these states: in England in particular a large number of permanently residing Pakistani nationals; in France large representations of Moroccans and Egyptians; in the Netherlands in particular a strong representation of Moroccans, but also of Iranians and to a lesser extent Egyptians.

In respect of the latter criterion the same holds true, mutatis mutandis, for the selection of the European states, England, France, and the Netherlands. For this reason, these states and their authorities are familiar with and have some knowledge of the recognition of Islamic divorces as well as of the Islamic background of the several types of divorce. They have also been selected because of their divergent recognition policies. Moreover, England represents a common law approach whereas France and the Netherlands have a civil law tradition.

\subsection{Societal and Academic Relevance}

The aims of this research and the answers to the leading questions - addressing whether and to what extent European states should acknowledge and accommodate Islamic divorces and the issue for adequate instruments to manage the legal diversity - will first of all contribute to the participation and integration of Muslim citizens or residents, females and males, in society in Europe. It is meant to, and will strengthen their position. This is not only of importance to these citizens or residents themselves, but it also serves the actual multi-religious and multicultural societies in Europe as a whole. After all, it boosts the quality of such a society in general and the permanence of residence of Muslims in particular. 
Furthermore, this research is of the utmost importance for legal practitioners in European states: registrars, notaries, the judiciary, lawyers, legislators and policy makers, and other legal professionals. It provides them with more detailed knowledge of and insights into the various Islamic divorce modalities that are of the utmost importance in order to characterize and subsequently to assess their recognition correctly. In the Netherlands, for example, the research on Islamic (divorce) law has focused on Egyptian, Indonesian, and Moroccan laws and practices. With the study of the Iranian and Pakistani divorce laws and practices, this book fills a gap in Dutch legal practice. Legal practitioners will also gain a clear insight into recognition policies and their consequences. The research will provide European legislators and governments with useful tools regarding their (recognition) policies towards Muslim residents.

This research will also be relevant at EU level. At this level, Brussels II-bis Regulation currently provides for the obligation to mutually recognize divorces that have taken place in another EU Member State without any special procedure being required..$^{42}$ Harmonization of conflict rules on international divorce law within Europe has been partly realized through the entry into force of the Rome III Regulation that was based on the so-called enhanced cooperation procedure. ${ }^{43}$ However, until present, attention for harmonization of recognition policies in respect of non-European divorces is lacking. The question that examines adequate legal instruments that could manage the legal diversity at issue results in a proposal for such a harmonized or uniform recognition policy at the Community level. Thus, it will meet this lack.

Finally, the ongoing discussion regarding the relations between Islam and Europe and, in addition, a discussion regarding the relations between Islamic law and private international law in Europe can be referred to. In this debate, there is still a lack of up-to-date and sufficient knowledge of the many modalities of Islamic divorces and, consequently, also of adequate private international law rules on their recognition. This research fills this gap by the in-depth research into the correct legal nature of a specific divorce modality in view of its significance for a recognition policy. The debate about and study on legal diversity thus also contributes to the development of the discipline of PIL.

42 Regulation (EC) No. 2201/2003 of the Council of 27 November 2003, concerning Jurisdiction and the Recognition and Enforcement of Judgments in Matrimonial Matters and the Matters of Parental Responsibility, O.J. (L 338/1-29); entered into force on 1 August 2004 and is in general applicable since 1 March 2005.

43 Council Regulation (EU) No. 1259/2010 of 20 December 2010 implementing enhanced cooperation in the area of the law applicable to divorce and legal separation (Rome III), 29 December 2010, O.J. (L 343), p. 0010-0016, entry into force on 21 June 2012. See for the enhanced cooperation procedure Arts. 326-334 TFEU. 



\section{ConteXt}

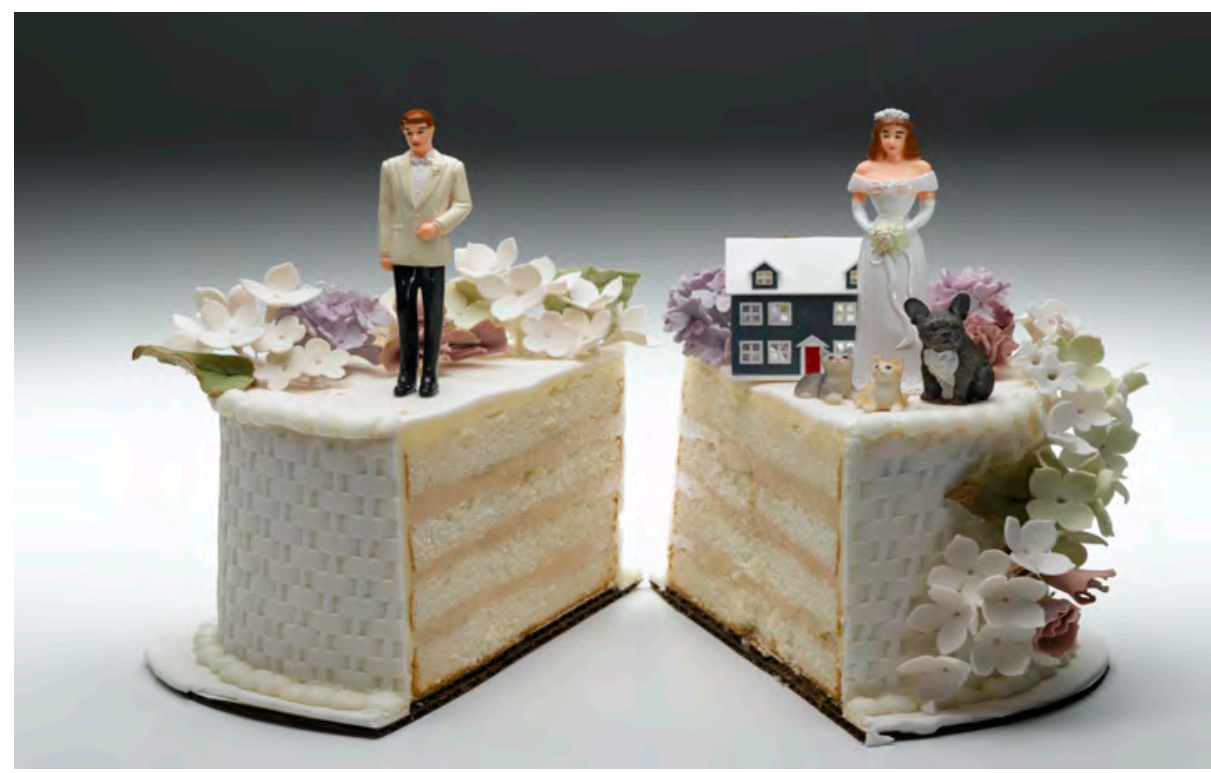

\subsection{Divorce in Europe}

Originally, the notions of marriage and divorce ${ }^{1}$ in Western European legal orders were strongly influenced by (Catholic) Canon Law. ${ }^{2}$ Today, a distinction has to be made between the civil marriage that is a legal covenant and the religious marriage. In all European states, either or both spouses have access to the dissolution of a civil marriage by divorce through judicial or administrative proceedings. ${ }^{3}$ Although a great variety of divorce systems exists among these states, the principle of gender equality at the dissolution of marriage, more specifically the principles of equal access to divorce, and equal procedural rights for the spouses in order to guarantee a fair trial are of paramount importance, especially for women. These principles have implications for the fulfilment of many of their other fundamental and substantive rights. They are guaranteed in nearly all European legal systems

1 For the purpose of this contribution 'divorce' in the context of 'Western European divorce' only comprises divorce and not legal separation or annulment. This chapter was for the greater part previously published in Kruiniger 2013, p. 472-474.

2 See Antokolskaia 2003, p. 52-69.

3 For a legal comparative overview of divorce laws in 22 states in Europe, see Boele Woelki et al. 2003; and: Boele Woelki et al. 2004. 
and reflect the almost generally accepted possibility of divorce, the governance of the divorce by law, the access to divorce usually on one or more grounds, by common consent or on demand by either spouse or both spouses, ${ }^{4}$ and the mandatory interference of a judicial or administrative authority having jurisdiction.

These common fundamental values have found legal expression in Article 5 of the 7 th Protocol to the ECHR and Article 6 ECHR, Articles 23 and 47 ChFREU, and also at the international level, in Article 16 Section 1 sub c of the Women's Convention and its parallels, Article 16 Section 1 UDHR, and Article 23 Section 4 ICCPR. ${ }^{5}$ All these instruments serve as a common frame of reference for European states regarding their domestic divorce laws and practices as well as their recognition policies towards, inter alia, Islamic divorces. The international instruments that are considered to represent universal values, however, also serve as frames of reference for Muslim-majority countries. At least this is true if the states have ratified the instrument(s) and have not entered any declarations and/or reservations in order to avoid their observance.

Of all these instruments, the Women's Convention addresses the broadest notion of equality (of the spouses upon divorce): full gender equality. ${ }^{6}$ This multiform notion not only covers equal treatment of the spouses before the law or formal gender equality and gender equality in practice or substantive/de facto equality, it also covers equality of opportunities reached by the removal of apparently neutral, but unjustifiable, barriers and equality of results or outcome for the spouses. Moreover, in the context of the CEDAW, the notion of 'gender equality' is not neutral but appropriately takes gender into consideration by specifically aiming at non-discrimination against women in the public and private sphere. Since this instrument not only serves as a framework of reference for European states regarding their domestic laws and practices, but also for a number of Islamic states such as Egypt, Morocco, and Pakistan, it will be addressed in greater detail in the next chapter.

In accordance with all the above-mentioned instruments, the notion of 'equal procedural rights' in the context of divorce more specifically includes the following core elements of due process: ${ }^{7}(1)$ equal access to an impartial and independent tribunal established by law; (2) proceedings within a reasonable time; (3) a public hearing with a decision/judgment

4 In Spain the so-called 'divorce on demand' can be obtained on the request of one or both spouses without mentioning any grounds (Art. 86 of Spanish Civil Code as amended by Act 15/2005). The same possibility as 'unilateral divorce' on the request of one of the spouses occurs in Finland and Sweden (paras. 25 et seq. Finnish Marriage Act and Chapter 5, paras. 1 et seq. Swedish Marriage Code). See Boele Woelki et al. 2004, p. 24-25.

5 The UDHR and ICCPR provisions are gender neutral and aimed at formal equality of men and women. The Women's Convention-provision goes further as it is aimed at achieving non-discrimination against women in particular and full gender equality in the public and private sphere; see Schöpp-Schilling 2007, p. 10, 1718.

6 Fredman 2003, p. 111

7 Mole \& Hardy 2006. 
pronounced publicly in order to render the administration of justice visible and enable public scrutiny (however, public and press may be excluded in the interests of the privacy of the parties); (4) the right to defence which includes, inter alia, a summons to appear, the parties' presence at the proceedings, and the right to hear both sides; (5) the principle of 'equality of arms' which entails that 'a party to proceedings must have a reasonable opportunity to present his/her case to the court under conditions which are not substantially disadvantageous vis à vis his/her opponent ${ }^{3}{ }^{8}$ (6) the right to an adversarial procedure which means that parties have the right to knowledge of all evidence and observations; and (7) legal aid when necessary.

These elements are not only the basic requirements of due process in the context of divorce in Europe, they are also the criteria for acceptability of the foreign legal institution, the Islamic divorce, in the process of assessment for recognition in European states. The assumed lack of any of these elements which consequently results in, for example, unequal accessibility to divorce, extra-judicial proceedings, absence in and/or ignorance of the proceedings by the wife appears to be an obstacle to recognition as part II of this study will demonstrate. For this reason, part I of this study will pay attention to the right of equal access to divorce and the procedural rights from the perspective of the status of women in law and in practice of Egypt, Iran, Morocco, and Pakistan.

\subsection{Women's Rights upon Divorce}

\subsubsection{Introduction}

There seems to be a tension between the status of women in Islam and the status of women as defined under international human rights law. ${ }^{9}$ Women's rights appear to be the most controversial and hotly debated issue in the discussion about the compatibility of Islam and human rights. The rights of women under Islam are influenced by religion, whereas human rights, including women's rights, depend on universal values in order to guarantee the full realization of these rights worldwide. ${ }^{10}$ In this respect, one may speak of a situation of legal diversity in women's rights.

As stated in chapter 1, the most comprehensive and 'specialized' of the various human rights instruments that deal with combating the above-mentioned violations by guaranteeing equal rights for men and women, in society and in the family, is the Convention on the Elimination of All Forms of Discrimination Against Women (hereinafter the Women's

8 Mole \& Hardy 2006.

9 Yahyaoui Krivenko 2009, p. 4. This chapter was previously published as part of Kruiniger 2012.

10 Baderin 2005, p. 23-26. 
Convention or the Convention). ${ }^{11}$ Today, at least 36 out of the 187 states that have ratified or acceded to this legally binding, international human rights treaty ${ }^{12}$ are 'Islamic' states. ${ }^{13}$ The ideal of sex equality in the Women's Convention originates in and has to compete with prevailing views on the status of men and women which maintain the discrimination against women in society, despite the existence of instruments addressing discrimination. ${ }^{14}$ These views are based on the idea of the perceived superiority of men and/or inferiority of women that can be found in and are affirmed by social, cultural, and/or traditional patterns, practices, and sometimes even laws and result in stereotyped gender roles. ${ }^{15}$ Such views hamper the development of women and their participation in the political, social, economical, cultural, and other fields of life. ${ }^{16}$ Non- or insufficient participation of women in society results in obstacles to the development of society as a whole. ${ }^{17}$ Hence, the Women's Convention seeks to modify, combat, and abolish such harmful social, cultural, and/or traditional patterns, practices, and laws in order to ensure freedom from discrimination and full equality for women. ${ }^{18}$

Article 16 of the Women's Convention aims at guaranteeing equal rights for men and women in marriage and family relations. Article 16 of the Women's Convention, in relation to the status of women upon divorce in 'Islamic' states, is therefore the focus of this chapter. The following section will first discuss the context and the nature of the contents of Article 16 Women's Convention and pay attention to the issue of declarations and reservations. The third section will address the significance of Article 16 of the Women's Convention on gender equality upon divorce - especially in view of equal access to divorce and procedural rights - for Muslim women.

11 Adopted by the General Assembly of the United Nations on 18 December 1979, G.A. Res. 34/180, U.N. GAOR, 34th Sess., Supp. No. 46, at 193, U.N. doc. A/34/46 (1979); entry into force on 3 September 1981. See for its electronic version: <www.ohchr.org/Documents/ProfessionalInterest/cedaw.pdf $>$.

12 Status as at 26 February 2014, see at $<$ https://treaties.un.org/Pages/ViewDetails.aspx? src=TREATY\&mtdsg_no $=\mathrm{IV}-8$ \&chapter $=4$ \&lang=en $>$.

13 The exact number of 'Islamic' states depends on the criteria used to define a state as 'Islamic'; in this chapter, Islamic states refers to states 'with legislation which incorporates or at least reflects to some extent Islamic laws and customs', see Yahyaoui Krivenko 2009, p. 115.

14 Evenhuis \& Van Eijk 2001, p. 9. Yahyaoui Krivenko 2009, p. 23.

15 See para. 6 of the Preamble to the Women's Convention; see also General Recommendation No. 21, UN doc. A/49/38, 13th Session, 1994, para. 3; and General Recommendation No. 29, UN Doc. CEDAW/C/GC/29, 54th Session, 2013, both available at <www2.ohchr.org/english/bodies/cedaw/comments.htm>; see also Schöpp-Schilling 2007, p. 16 \& 23.

16 See para. 7 of the Preamble to the Women's Convention.

17 Ibidem.

18 Schöpp-Schilling 2007, p. 23. 


\subsubsection{Context}

For a better understanding of the context of Article 16, its relationship with (similar provisions in) other instruments, the meaning of the Women's Convention's core notions, and its relationship with other articles within this Convention will be discussed first.

\subsubsection{1 'Specialized' Sequel to Other Human Rights Instruments}

The Women's Convention, an elaboration of the Declaration on the Elimination of Discrimination against Women, ${ }^{19}$ can be considered as the 'specialized' sequel to other international human rights instruments. ${ }^{20}$ These instruments, the Universal Declaration of Human Rights (hereinafter UDHR), ${ }^{21}$ the International Covenant on Civil and Political Rights (hereinafter ICCPR), ${ }^{22}$ and the International Covenant on Economic, Social and Cultural Rights (hereinafter ICESCR $)^{23}$ and their related general comments, also call for equality of men and women and outlaw sex discrimination. The lookalikes of Article 16 (1)(c) of the Women's Convention which prescribe equal rights and responsibilities for the spouses upon divorce are Articles 16 (1) UDHR and 23 (4) ICCPR.

Article 16 of the Women's Convention clarifies the meaning of the norm of gender equality as reiterated in Articles 16 (1) UDHR and 23 (4) ICCPR. But these other instruments and their provisions are gender neutral and aimed at formal equality of men and women. The Women's Convention goes further. It aims to achieve non-discrimination against women in particular, and full - formal and de facto - gender equality in the public as well as in the private sphere. ${ }^{24}$ For these purposes, it recognizes 'the importance of culture and tradition in shaping the thinking and behaviour of men and women and the significant part they play in restricting the exercise of basic rights by women'. ${ }^{25}$

\subsection{Discrimination and Gender Equality: Its Core Notions}

The core notions of discrimination and gender equality have specific meanings in the context of the Women's Convention. Article 1 of the Women's Convention includes a comprehensive definition of the concept of discrimination specifically as discrimination

19 Proclaimed by United Nations General Assembly Resolution 2263 (XXII) of 7 November 1967.

20 Schöpp-Schilling 2007, p. 10.

21 Adopted by the General Assembly of the United Nations on 10 December 1948, GA res. 217 A (III) at the Palais de Chaillot in Paris.

22 Adopted by the General Assembly of the United Nations on 16 December 1976, GA res. 21/2200 (XXI), entry into force on 23 March 1976.

23 Adopted by the General Assembly of the United Nations on 16 December 1976 by GA res. 21/2200 (XXI), entry into force on 3 January 1976.

24 Schöpp-Schilling 2007, p. 10, 17, 18; Yahyaoui Krivenko 2009, p. 26.

25 CEDAW General Recommendation No. 21, para. 3. 
against women, which goes beyond the common view of discrimination. ${ }^{26}$ Women often encounter combined, and thus multiple, forms of discrimination because they are women and belong to other groups based on ethnicity, status, age, religion, disability, etcetera. Moreover, women are part of a male-dominated world in which the specific needs of women are often disregarded.

The Women's Convention addresses a multiform notion of (gender) equality. This notion not only covers equal treatment before the law or formal equality and equality in practice or substantive or de facto equality, it also covers equality of opportunities reached by the removal of apparently neutral, but unjustifiable, barriers and equality of results or outcome. ${ }^{27}$ All these notions are interdependent and interrelated in order to achieve full (gender) equality. In the context of the Convention, equality is not synonymous with gender neutrality, but it appropriately takes gender into consideration. Fredman identifies this concept of equality as 'equality as transformation' ${ }^{28}$ Thus, the Convention not only prohibits discrimination but also requires positive actions in order to bring about a change in the harmful structures, patterns, and practices underlying discrimination and inequality.

\subsection{Its Relation to Other Articles within the Women's Convention}

Hence, States parties have to take into account and to apply the framework provisions, Articles 2 to 5 , supplementary to any of the substantive provisions, Articles 6 to $16 .^{29}$ Article 2 stipulates that the appropriate measures to eliminate discrimination against women should not only be taken by the state but also by private persons, organizations, or enterprises. Article 3 prescribes that States parties shall take 'all appropriate measures, including legislation' to improve the position of women in all fields of life so that they can fully exercise and enjoy the human rights and fundamental freedoms on the basis of equality with men. Article 4 states that States parties shall be allowed to adopt temporary special measures, so-called affirmative action, as a corrective mechanism to accelerate de facto equality. These measures are then considered not to be discriminatory in view of that purpose as long as they are effective.

Furthermore, Articles 2 and 5 deal in particular with the detrimental effects of culture and tradition on women. Article 2 sub-paragraph (f) requires that 'all appropriate measures' be taken 'to modify or abolish existing laws, regulations, customs and practices which constitute discrimination against women'. Article 5 stipulates that States parties shall take all appropriate measures to combat stereotyped roles and traditional or cultural role patterns that are detrimental to women. Article 23 allows for the application of any other legal

26 Ibidem. For the Articles of the Women's Convention which are mentioned in this contribution see the Women's Convention at <www.ohchr.org/Documents/ProfessionalInterest/cedaw.pdf >.

27 As described by Fredman 2003, p. 111.

28 Fredman 2003, p. 115-118.

29 Schöpp-Schilling 2007, p. 17. 
provision that is more conducive to gender equality than any legal provision in the Women's Convention. Article 24, finally, prescribes that States parties 'undertake to adopt all necessary measures at the national level aimed at achieving the full realization of the rights recognized in the present Convention'. The formulation of these articles indicates that the States parties have the discretion to select the means for their implementation, although the Convention can also impose specific means.

Furthermore, Article 9 on the abolition of discrimination in nationality laws and regulations is of utmost importance for women upon divorce: the status of being a national or citizen of a state guarantees facilities such as access to public benefits and a choice of residence. ${ }^{30}$ Article 15 is of major significance to Article 16 as it stresses in strong terms the importance of equal legal autonomy for women. Article 15 prescribes that 'States parties shall accord to women equality with men before the law' and equal legal capacity and rights in civil matters, among other things, by treating them equally in court proceedings. Recognition of equal legal autonomy and an equal status as a citizen is essential for women to enjoy and exercise all their other human rights. ${ }^{31}$

\subsection{The Women's Convention's Monitoring Mechanisms}

The Women's Convention and the later adopted Optional Protocol (hereinafter OP) provide for various monitoring mechanisms that may be used by the Committee on the Elimination of All Forms of Discrimination Against Women (hereinafter CEDAW). The Reporting procedure of Article 18, in combination with CEDAW's ability to make Suggestions and General Recommendations as contained in Article 21 of the Convention, appear to be significant for the interpretation of the meaning of Article 16 (1)(c). Although Suggestions and General Recommendations are not legally binding, their strength is their power of persuasion. Two other procedures, which are contained in the $\mathrm{OP},{ }^{32}$ are the Communication procedure and the Inquiry procedure. The Communication procedure (Article 2) allows individual women or groups of women to submit a complaint to CEDAW about an alleged violation of any of the rights set forth in the Convention by a State party under whose jurisdiction they are. The Inquiry procedure (Article 8) entails that the Committee may conduct an investigation on 'grave or systematic violations by a State party of rights set forth in the Convention' on the basis of reliable information that has been received. The Communication procedure has been used in relation to Article 16 of the Women's Convention on several occasions, but neither of these cases appeared to be relevant for this study (and some of them were declared inadmissible under Article 4 of

30 CEDAW General Recommendation No. 21 on Art. 9, in para. 6.

31 Schöpp-Schilling 2007, p. 24.

32 Optional Protocol to the Women's Convention, adopted by the General Assembly of the UN on 6 October 1999 (A/RES/54/4) entry into force on 22 December 2000. The full text of the Optional Protocol can be found at <www.ohchr.org/EN/Professionalinterest/Pages/OPCEDAW.aspx $>$. 
the $\mathrm{OP}$ for reasons of failure to exhaust domestic remedies or being insufficiently substantiated) ${ }^{33}$ As yet, the Inquiry procedure has not been used in relation to Article 16 Women's Convention from the perspective of this study. ${ }^{34}$

The Palais des Nations in Geneva where the CEDAW sessions with the States parties are held in order to discuss and consider the States parties' periodic reports concerning their compliance with and implementation of the Women's Convention.

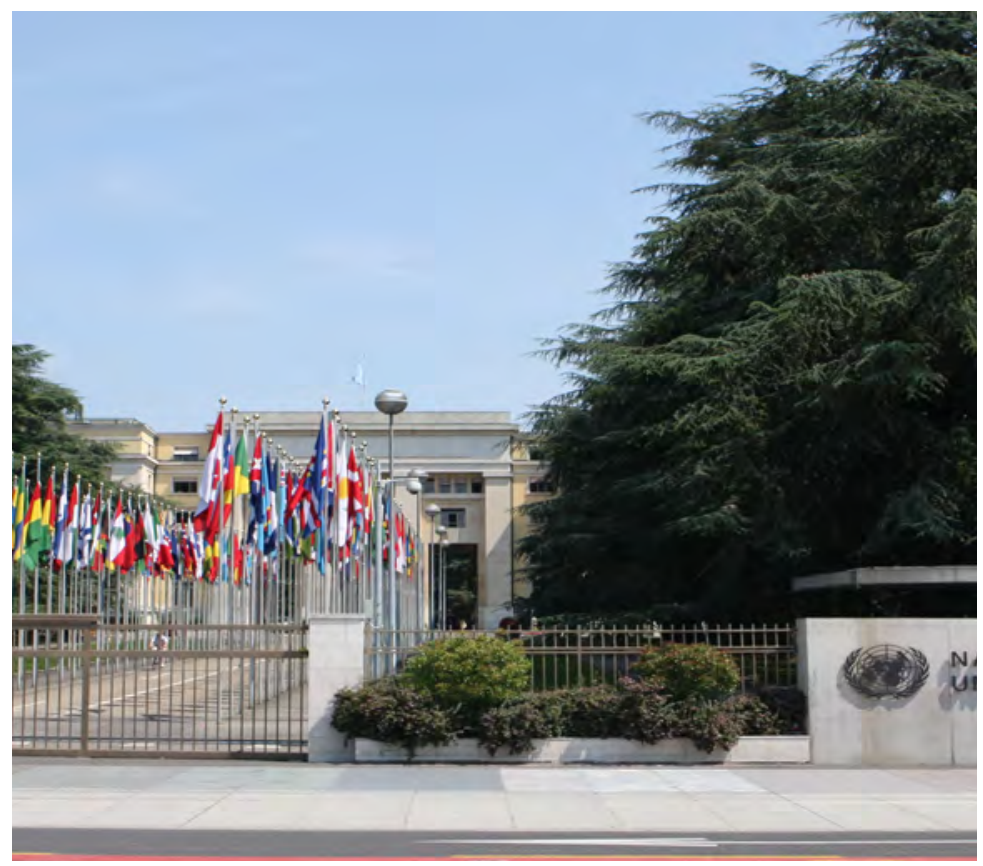

\subsubsection{Nature of Article 16}

Article 16 affirms gender equality in marriage and the family and clarifies the meaning of gender equality during marriage and at its dissolution. This is further elaborated in the

33 See, inter alia, the cases M.S. v. Spain, CEDAW/C/56/D/29/2011, Communication 29/2011 and Jallow v. Bulgaria, CEDAW/C/52/D/32/2011, via <www.ohchr.org/EN/HRBodies/CEDAW/Pages/Jurisprudence.aspx $>$.

34 See $<$ www.ohchr.org/EN/HRBodies/CEDAW/Pages/InquiryProcedure.aspx $>$. As yet, CEDAW has conducted one inquiry, under Art. 8 of the Optional Protocol, into the abduction, rape, and murder of women in and around Ciudad Juarez in Mexico. 
General Recommendations No. 21 and No. 29 by CEDAW, in the latter General Recommendation in particular in relation to the economic consequences of marriage and its dissolution, and family relations. Hence, Article 16 regulates matters belonging to the socalled private sphere.

A public/private sphere divide has characterized society and international and human rights law for a long time. ${ }^{35}$ Because of their biological and social role, women traditionally belong to the domestic or private sphere that originally, contrary to the public sphere of life, was not or at least was less regulated by law. Accordingly, women have fewer rights, powers, and resources. Their activities were treated as inferior, as the private sphere is the domain in which cultural norms, traditions, and practices, especially with regard to the alleged nature of women and their roles in the family and the society, are dominant. That is why several States parties are disinclined to grant women equal rights and they have shown their reluctance by formulating reservations to Article 16. However, on several occasions CEDAW has declared that the exercise and enjoyment of equal rights in the family by women is a prerequisite for their exercise and enjoyment of human rights in other areas of life. Hence, General Recommendation No. 21 stresses that, as the activities of women in the domestic sphere 'are invaluable for the survival of society, there can be no justification for applying different and discriminatory laws or customs to them'. ${ }^{36}$ CEDAW continues by stating the following objective: whatever form the family takes, 'and whatever the legal system, religion, custom or tradition within the country, the treatment of women in the family both at law and in private must accord with the principles of equality and justice for all people, as Article 2 of the Convention requires ${ }^{37}$ This is affirmed by General Recommendation No. 29 by calling '[u]pon States parties to take legal and policy measures as required under article 2 of the Convention and general recommendation No. 28.' ' [i]n order to achieve 'a de jure and de facto egalitarian regime under which the economic benefits and costs of family relations and the economic consequences of their dissolution is borne equally by men and women. ${ }^{38}$

Hence, the full text of Article 16(1)(c) and (h) of the Women's Convention reads as follows:

1. States parties shall take all appropriate measures to eliminate discrimination against women in all matters relating to marriage and family relations and in particular shall ensure, on a basis of equality of men and women:

(c) The same rights and responsibilities during marriage and at its dissolution;

35 CEDAW General Recommendation No. 21, para. 11; Schöpp-Schilling 2007, p. 23-24; Yahyaoui Krivenko 2009, p. 9, 16, 38, 128-129.

36 CEDAW General Recommendation No. 21, para. 12.

37 Ibidem, para. 13.

38 CEDAW General Recommendation No. 29, paras. 6 and 9. 
(d) The same rights for both spouses in respect of the ownership, acquisition, management, administration, enjoyment and disposition of property, whether free of charge or for a valuable consideration.

Nevertheless, CEDAW observes that many countries rely on, among other things, the application of religious or customary law with regard to rights and responsibilities of the spouses 'rather than by complying with the principles contained in the Convention'. 39 CEDAW concludes that 'these variations in law and practice' result in 'invariably restricting' women's 'rights to equal status and responsibility within marriage' that contravene the provisions of the Convention. ${ }^{40}$ An unequal status of women in marriage will consequently affect the status of women upon divorce. Article 16 and General Recommendations No. 21 and No. 29 therefore elaborate on specific issues that have been observed as problematic in view of the status of women in marriage and upon divorce. An example in this respect is that the Committee, while clarifying Article $16(1)(\mathrm{h})$, advocates the necessity of an equal property share at the end of a marriage, or de facto relationship, among other things, 'in view of the woman's practical ability to divorce her husband and to support herself and dependent family members, 'and to live in dignity as an independent person'. ${ }^{41}$ In this respect, financial as well as non-financial contributions to the property such as raising children and taking care of the household, tasks often performed by the wife, should be accorded the same weight. ${ }^{42} \mathrm{CEDAW}$ also stresses the importance of legal capacity for the status of women in the family as included in Article 15 Women's Convention, inter alia, to provide women with a full right to litigate before the courts. ${ }^{43}$

General Recommendation No. 29 addresses economic issues and consequences observed as problematic in view of the status of women that can be related to Islamic marriages and their dissolution. Examples are, for instance, the lack of (implementation of) marriage registration that affects the protection of the rights of spouses with regard to property issues upon death or divorce; the economic and financial risks of polygamous marriages and de facto unions, such as informal (religious) marriages, for women and their children; the dower, the payment given to the bride by the groom that is considered as a violation of women's right to freely choose her spouse; discriminatory systems of marital and nonmarital property management by giving, for example, the man the role of sole economic agent as head of the household; legal systems that link grounds for divorce to financial consequences of divorce and that have different standards of fault for wives and husbands; the (financial) compensation paid by the wife in exchange for her repudiation by the hus-

39 CEDAW General Recommendation No. 21, para. 17; CEDAW General Recommendation No. 29, para. 2.

40 Ibidem.

41 Ibidem.

42 Ibidem, para. 32; affirmed by CEDAW General Recommendation No. 29, para. 47.

43 CEDAW General Recommendation No. 21, para. 8. 


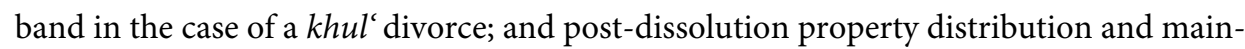
tenance regimes that are favourable to husbands. ${ }^{44}$

For these reasons, CEDAW urges States parties to take the necessary measures to ensure the protection of the economic rights of women. More specifically States parties should, inter alia, establish a legal requirement of marriage registration and provide for its implementation through education and effective awareness-raising activities; take all measures to abolish polygamous marriages or to ensure the protection of economic rights of women and children in existing polygamous unions and de facto unions; not require payments such as the dower, as condition for the validity of a marriage; provide equal rights to (and access to and legal capacity to manage and own) marital and non-marital property to both spouses; revise legal provisions that create opportunities for the husband to abuse them by linking grounds for divorce and financial consequences; revise legal provisions to ensure that they contain equal standards of fault for wives and husbands; provide or revise legal provisions to guarantee that women are compensated for their contributions to family economic well-being and marital property during the marriage including the valuation of their non-financial contribution to marital property; etcetera. ${ }^{45}$

\subsubsection{Declarations and Reservations}

Article 16, however, appears to be the most problematic provision of the Women's Convention for 'Islamic' states. In its General Recommendation No. 21 of 1994, CEDAW 'notes with alarm' the number of States parties which have, if not entered general reservations or declarations to the Convention, massively entered reservations on the whole or part of this provision, inter alia, based on Shari' $a{ }^{46}$ The significance of the mechanism of the reservation is that it allows a state to ratify or accede to a treaty while not committing itself to observe the reserved provision(s). And although the Convention only allows states to enter reservations that are compatible with its object and purpose, ${ }^{47}$ it appears that incompatible or impermissible reservations cannot effectively be precluded, but they can only be affected by the constant pressure of the Committee to withdraw them.

44 CEDAW General Recommendation No. 29, paras. 25-28, 30-31, 33, 36-48.

45 Ibidem.

46 Also endorsed by the Committee in its 1998 Statement on Reservations to the Convention, Report of the Committee on the Elimination of Discrimination against Women, A/53/38/Rev. I (part two), para. 6, 19th Session, 1998 and in CEDAW General Recommendation No. 29. See for an overview of the status of ratifications of and declarations or reservations made to the Women's Convention the website of the United Nations Treaty Collection: $<$ https://treaties.un.org/Pages/ViewDetails.aspx?src=TREATY\&mtdsg_no=IV$8 \&$ chapter $=4 \&$ lang=en $>$. See also General Recommendation No. 21, paras. 41-44. Although it appears that in particular Islamic States have made reservations and declarations, it goes beyond the scope of this contribution to discuss the topic more extensively. See for more general information on reservations: Yahyaoui Krivenko 2009, p. 75-113.

47 Pursuant to Art. 28 Women's Convention which is in line with Art. 19 (c) of the Vienna Convention on the Law of Treaties. 
Parts of the Women's Convention, and especially Article 16, are the most sensitive for 'Islamic' states, and this is expressed in numerous reservations and declarations in order to avoid the observance of that provision. It is often contended that the reservations and declarations made by 'Islamic' states are expressions of the clash between Islam and the universal, secular Women's Convention. The reservations and declarations are religious of character and are aimed at preserving Islamic laws and practices. ${ }^{48}$ Moreover, 'Islamic' states have the right to make such reservations and declarations in the exercise of religious freedom. An analysis of these reservations and declarations made by two of the four Islamic states under study, Morocco and Pakistan, offers not only insights into the diversity of views on rights of women, but also into the real motives of the states that make them. ${ }^{49}$

In Morocco's initial reservation to Article 16, the full equality of men and women upon divorce was considered to be incompatible with Shari ${ }^{4} .^{50}$ This was, according to the Moroccan government, based on the view that Shari'a guarantees 'to each of the spouses rights and responsibilities within a framework of equilibrium and complementary in order to preserve the sacred bond of matrimony'. ${ }^{51}$ The background of this view is that Shari' $a$ confers the right of divorce on women only by decision of the judge because it is the husband who bears all the financial responsibilities for his spouse and family at, during and after the marriage, while the wife does not have any financial obligations and has control of her own property. ${ }^{52}$ This reservation to Article 16 should be read with the Moroccan declaration on Article 2 of the Women's Convention in which the Moroccan government states that it 'express[es] its readiness to apply the provisions of this Article provided that: [...] they do not conflict with the provisions of Islamic Shariah'. ${ }^{53}$ Moreover, the Moroccan Government declared that: 'certain of the provisions contained in the Moroccan Code of Personal Status according women rights that differ from the rights conferred on men may not be infringed upon or abrogated because they derive primarily from the Islamic Shariah, which strives, among its other objectives, to strike a balance between the spouses in order to preserve the coherence of family life..$^{54}$

According to Morocco's representative in 1997, the reservations were 'the result of national consensus and were not simply a decision of the Government'. 'Pressure on the

48 Hamid 2006, p. 121; Yahyaoui Krivenko 2009, p. 130.

49 Yahyaoui Krivenko 2009, p. 75-76.

50 Morocco withdrew its reservation to the Arts. 9(2) and 16 in 2011. See the document with reference C.N.176.2011.TREATIES-2 (Depositary Notification) at $<$ https://treaties.un.org/doc/Publication/CN/2011/ CN.176.2011-Eng.pdf>.

51 See the full text of this reservation: $<$ http://treaties.un.org/Pages/ViewDetails.aspx?src=TREATY\&mtdsg_no= IV -8 \& chapter $=4 \&$ lang $=$ en $\# 57>$.

52 Ibidem

53 Ibidem.

54 Ibidem. 
Government, therefore, would not change that situation. ${ }^{55}$ Morocco's representative defended the reservations mainly 'as being an anti-fundamentalist prophylactic ${ }^{36}{ }^{56} \mathrm{He}$ stated that Islam was 'a lifestyle and an integral part of Morocco's culture and traditions' and 'a rampart against fundamentalism and terrorism' and that 'a basic concern of his country was religious fundamentalism which would seek to impose intolerance. ${ }^{57}$ The representative also made it appear as if the Moroccan Government was constrained in its attempts to repeal discriminatory laws not only by the threat of fundamentalism, but also by Morocco's limited sources and popular resistance to change the law. ${ }^{58}$

Pakistan's general declaration makes the compliance with the provisions of the Women's Convention subject to the Articles of the Pakistani Constitution. The Pakistani Constitution requires that all Pakistani laws shall be in accordance with Shari' $a$. The Pakistani Government has explained the declaration as facilitating Pakistan's accession to the Convention by 'assuaging the concerns' of its opponents and that '[s]ubjecting the implementation of the Convention to the Constitution of Pakistan was a sensible course of action' ${ }^{59}$ The fact that no direct reference to Islamic law was made in the Women's Declaration can be explained as the eagerness of Pakistan to improve its image in the International Community. ${ }^{60}$

Nevertheless, CEDAW has urged the two governments to withdraw the declaration and the reservations without delay as the reservations go against the object and purpose of the Women's Convention and they prohibit the full implementation of the Convention in Morocco and Pakistan. ${ }^{61}$ As stated, Morocco has withdrawn its reservation to the Article 9 (2) and 16 in the meantime. Whereas Yahyaoui Krivenko interprets these reservations as to be 'no more than indicators of areas of concern', Mayer dismisses the explanations of both governments. ${ }^{62}$ She considers the declaration and the reservations invoking Islam 'as the products of skewed political processes'. According to Mayer, the reservations simply express the refusal of the states to comply with the Women's Convention while pleading the apparent religious grounds as excuses. ${ }^{63}$ This implies the need for a political will to reform the Family Codes in order to comply with the Convention. Furthermore, Mayer contends that the reservations and declaration in Islamic law terms cannot be considered

55 Women's Anti-Discrimination Committee - Press Releases WOM/937 320th Meeting (AM) 20 January 1997, at <www.un.org/News/Press/docs/1997/19970120.wom937.html>.

56 Mayer 2001, p. 107.

57 Women's Anti-Discrimination Committee - Press Releases WOM/937 320th Meeting (AM) 20 January 1997, at <www.un.org/News/Press/docs/1997/19970120.wom937.html>.

58 Mayer 2004, p. 147-149, 155.

59 Combined initial, second, and third periodic reports of Pakistan, 2005, paras. 2 \& 3.

60 Mayer 2001, p. 109; Yahyaoui Krivenko 2009, p. 166.

61 Concluding Comments of CEDAW (Morocco), 2008, para. 15 and Concluding comments of CEDAW (Pakistan) 2007, para. 13.

62 Yahyaoui Krivenko 2009, p. 163 \& 167; Mayer 2001, and Mayer 2004.

63 Mayer 2001, p. 106 \& 114. 
to be exercises of the right to religious freedom, inter alia, as this right can only be invoked to protect the religious beliefs and practices of minorities and not of the majority, as is the case with Islam being the (state) religion in 'Islamic' states. Furthermore, the version of 'Islamic' law that is officially applied within a specific state does not necessarily represent the individual religious beliefs of the inhabitants in that state. ${ }^{64}$ In reality, 'Islamic' states do not even invoke the right to religious freedom in order to justify their deviations from the Women's Convention. If they would do so, this right would not be a license to overrule the equality rights of women. Mayer finally stresses that in reality - instead of a clash between 'Islamic beliefs' and the secular Women's Convention - there is 'a clash of views within Muslim societies over whether there is any Islamic authority for discriminatory laws and policies affecting women and over whether Islamic law should in any case be the governing standard'. ${ }^{65}$

Remarkably, both the Moroccan and the Pakistani Governments portray their states as being supportive of equal rights for women and as being, or at least as trying to be, compliant with the Women's Convention. The Pakistani report, for example, reads that the Pakistani divorce laws ensure the same rights and responsibilities for the spouses during marriage and at its dissolution, and hence that the Pakistani divorce laws are in compliance with Article 16 of the Convention. ${ }^{66}$ It declares the different types of divorce for men and women as 'a difference of terminology in the case of Muslims ${ }^{37}{ }^{67}$ Morocco's representative explained that the unequal treatment of women and men is actually equitable because of the difference in nature of men and women. ${ }^{68}$ Although, they thus try to rationalize their departures from the Convention, they are also aware of their shortcomings as they refer to some of these shortcomings in their reports. ${ }^{69}$

\subsubsection{Closing Remarks}

What is the significance of Article 16 of the Women's Convention on gender equality upon divorce - especially in view of equal access to divorce and procedural rights - for Muslim women?

In order to further the road to equality for women upon divorce in Islamic states such as those under study, the Women's Convention has proven to be of the utmost importance.

64 Mayer 2001, p. 110.

65 Mayer 2001, p. 110. See for an elaboration on this view Mayer 2008, p. 12-32.

66 Combined initial, second, and third periodic reports of Pakistan, 2005, para. 494.

67 Ibidem.

68 Women's Anti-Discrimination Committee - Press Releases WOM/937 320th Meeting (AM) 20 January 1997, at <www.un.org/News/Press/docs/1997/19970120.wom937.html>.

69 See e.g. Concluding Comments of CEDAW (Morocco), 2008, paras. 388-391; and Combined initial, second, and third periodic reports (Pakistan), 2005, paras. 31, 47-51, 86, 495. 
Although these states have not always (yet) constitutionalized the primacy of international law, the power of the Women's Convention to apply pressure as well as its reporting procedure to CEDAW, being a type of soft law, should not be underestimated. They have both resulted in the fact that both states, Morocco and Pakistan, are eager to create the image of being supportive of equal rights for women in the international community (and that Morocco has withdrawn some of its reservations). This is significant in two, interrelating respects: it corrodes the legitimacy of the discriminating domestic divorce laws, as it becomes more and more difficult for these states to justify their application; and it indicates that their legal systems and practices are already in a transitional stage towards reform and actual compliance with the Convention. ${ }^{70}$ Moreover, these 'external' pressures are indispensable for and complementary to the domestic pressures for reforms towards equality of women by NGOs.

The reservations and declarations made by, inter alia, Morocco and Pakistan, perceived as expressions of the contended clash between Islam and the universal and secular Women's Convention, appear especially to be of a political character. The clash is first and foremost a clash of views within Muslim societies concerning the extent of the supremacy of religious values in the law. The Women's Convention, as such, does not oppose religious influences other than those that are harmful to gender equality and the rights of women and that result in inferior stereotyped roles for women.

70 Mayer 2004, p. 133-134, 156. 



\section{PART I \\ IsLAMIC Divorce LAWS AND Practices}





\section{INTRODUCTION}

\subsection{Islamic versus Occidental Notion of Divorce}

Although marriage is considered to be of the utmost importance, divorce or the dissolution of marriage by a human act is permitted in Islamic school of thought. Divorce may even be mandatory in the case of a disharmonious or harmful relationship, in particular to avoid extra-marital relationships and harm to children. ${ }^{1}$ This is in contrast with the Christian tradition in which spouses can only be separated by death and the dissolution of marriage by a human act is in principle not allowed. ${ }^{2}$ According to the Prophet, however, divorce is of all permitted things the most reprehensible to God. ${ }^{3}$ Reconciliation as recommended in the Koran should therefore be tried first. ${ }^{4}$

The Islamic notion of divorce differs from the Occidental notion (meaning the dissolution of marriage by judicial decision, at least in most Occidental countries). The Islamic divorce denotes the dissolution of marriage by a human act, primarily by the husband, or his agent, or by the judge. Dependent on the school of jurisprudence, the judge is considered to be acting on behalf of the husband or on his own authority.

\subsection{Divorce in Islam: The Prerogative of the Husband}

Divorce originally is the prerogative of the husband in Islamic (Shari $\left.{ }^{\prime} a\right)$ law and in Islam. ${ }^{5}$ The talaq or divorce is mentioned in the Koran and referred to in several ahadith. ${ }^{6}$ No explanation about or justification of this exclusive right of the husband, which entails

1 See for several classifications of the (non-)permissibility of divorce, varying from obligatory to prohibited: Doi 2008, p. 268-269; Linant de Bellefonds 1965, vol. II, p. 317-320.

2 Matthew 19: 1-3: 'Some Pharisees came to put him to the test. "Is it lawful for a man to divorce his wife for any reason?" they asked. Jesus replied, "Haven't you read that the one who created people in the beginning made them male and female? He said, 'This is the reason why a man will leave his father and mother and unites with his wife, and the two become one. So they're no longer two, but one. What God's joined together nobody should separate"'.

3 Doi 2008, p. 266; Esposito 2001, p. 27; Fyzee 2002, p. 146-147; Linant de Bellefonds 1965, vol. II, p. 317-320.

4 Koran 4:35: 'If you fear a breach between a couple, send an arbiter from his people and an arbiter from her people. If the couple desires to put things right, Allah will bring about a reconciliation between them. Allah is All-Knowing, All-Aware'; see also Koran 4:128: 'If a wife fears cruelty or desertion on her husband's part, there is no blame on them if they arrange an amicable settlement between themselves; and such settlement is best'; Doi 2008, p. 267.

5 Linant de Bellefonds 1965, vol. II, p. 315-316.

6 See especially Sura 65 'at-Talaaq' entirely dedicated to divorce and, for example, Koran 2:229: 'Divorce may be (pronounced) twice, then keep (them) in good fellowship or let (them) go with kindness'; see furthermore Koran 2:226-228; 2:230-232; 2:236-237; 4:128; and 33:49. 
inequality between men and women, can be found in Islamic (Shari' $a$ ) law. Its characteristic gender inequality is considered to be an 'a priori principle' and taken for granted as 'the natural order of things. ${ }^{8}$ A traditional, patriarchal image in society stemming from preIslamic Arabia and of the division of roles between men and women prevailed in the beginning of Islam despite the principles of justice and equity that are inherent in Shari' $a$ ideals. ${ }^{9}$ This image has influenced Islamic family law, the foundations of which were laid in that era.

Contemporary authors defend divorce as being the exclusive right of the husband by contending that men are considered to be more capable of taking and emotionally more stable to take that important decision than women are. ${ }^{10}$ Furthermore, men are entitled to make this decision because of their dominant position in the family and society. Moreover, men have made financial sacrifices for and during the marriage; have financial obligations towards the wife, children, and family; and are confronted with the financial consequences of divorce, such as payment of the (deferred) dower and maintenance during the waiting period of the wife. ${ }^{11}$ Finally, a divorce (talaq) represents the husband's renouncement of his rights on his wife. ${ }^{12}$ The renouncement is unilateral, as it does not require the converging wills of two persons. Marriage, on the other hand, is a contract and, inherently, requires two converging wills.

Women cannot divorce without the consent of her husband (or the judge) ${ }^{13} \mathrm{~A}$ woman can try to induce her husband to divorce her by offering (financial) compensation (divorce via $k h u l$ ). Furthermore, women are entitled to request judicial divorce on a limited number of specific grounds. If the request is granted, the judge will compel the husband to pronounce the divorce or pronounce it himself on behalf of the husband in the case of the refusal of the husband or on his own authority. Hence, either spouse has his or her own, whether or not restricted, modalities of divorce. These principles, based on Islamic divorce law, can still be found in the modern divorce laws of most Muslim-majority countries today.

\section{3 'Islamic Divorce' Further Explained}

The Islamic law, the Islamic family law, and therefore the Islamic divorce do not exist as was explained above. First, the terms 'Islamic divorce' and 'divorce' in the context of Islam

7 See about gender inequality in the Koran: sura al-baqara 2:223, 2:228, and sura al-nisa 4:34.

8 Mir-Hosseini 2009, p. 77.

9 Mir-Hosseini 2009, p. 86; Van der Velden 2004b, p. 61; Wadud 2004, p. 166-167.

10 Linant de Bellefonds 1965, vol. II, p. 316.; Nayyeri 2013, p. 61.

11 Esposito 2001, p. 29; Linant de Bellefonds 1965, vol. II, p. 316-317; Maudoodi 2000, p. 26.

12 Linant de Bellefonds 1965, vol. II, p. 316.

13 Mir-Hosseini 2009, p. 82-83. 
and/or Islamic law are used as a collective term in this research for pragmatic reasons. The term 'Islamic' refers to the establishment of the divorces in mostly Muslim-majority countries with legislation that incorporates, at least to some extent, laws and customs that originate in the legal subject matter of the Shari'a law. ${ }^{14}$ The term 'divorces' covers the most common, formal types of dissolutions of marriage by the act of the parties or by judicial process, including the annulment of marriages. Not common types of dissolutions of marriage, including ila' (oath of abstinence from intercourse by the husband), zihar (an injurious imprecation), and li'an (imprecation of adultery of the wife by the husband), will not be discussed in this study as they rarely occur.

To remind the reader, this study uses the following functional classification scheme as a starting point for the discussion:

1. divorce on the initiative of the husband covering the repudiation (talaq);

2. divorce on the initiative of the wife covering: ${ }^{15}$

a. the divorce on a limited number of grounds by judicial process, the judicial divorce (talaq al-tatlliq/talaq al-tafriq); and

b. the dissolution of marriage through annulment by the judge, the judicial annulment (faskh);

3. divorce based on an 'agreement' about or the involvement in the repudiation of both spouses covering:

a. the handing over the power to repudiate to the wife by means of a mandate or authorization, the self-repudiation (talaq al-tawkil and talaq al-tafwid including the talaq al-tamlik and the talaq al-takhyir);

b. the repudiation by the husband on demand of the wife in exchange for a compensation, the negotiated repudiation $(\mathrm{khul})$; and

c. the repudiation by the husband based on mutual agreement and including a mutual waiver of financial obligations, the repudiation by agreement (mubara'a).

This classification is arbitrary. Other classifications are possible. ${ }^{16}$ This classification has been chosen to clarify the involvement of women in and the accessibility or inaccessibility

14 For more about Shari'a law, see chapter 4.

15 Strictly speaking, the husband can also demand judicial divorce or judicial annulment; however, in contrast to the wife, the husband always has the possibility to pronounce a repudiation. Specific grounds for a judicial divorce or judicial annulment can only be invoked by women such as the long absence of the husband and the husband's noncompliance with his duty to provide for maintenance.

16 Linant de Bellefonds (1965, vol. II, p. 305-306), for example, departs from the following classification: the unilateral repudiation by the husband (talaq), the negotiated repudiation $(k h u l c)$, and the judicial repudiation or dissolution of marriage (tatliq, tafriq, or faskh). According to Linant de Bellefonds, Occidental and modern Shari' $a$ law jurists are familiar with this order, but classical fuqaha were not; they were familiar with the distinction between repudiation and resolution to be discussed in this section. Fyzee (2002, 4th edition, p. 148-149) proposes another broader classification which is not restricted to divorce only; he departs from 
for women to specific types of divorce. The annulment as mode of dissolution of the marriage has been included as 'divorce', since legal systems of some Muslim-majority countries do not acknowledge, or hardly grant possibilities for, a judicial divorce. Instead, these legal systems acknowledge the judicial annulment of the marriage or faskh. Although this study discusses all types of divorce as mentioned in the classification above, it focuses on the originally non-judicial, repudiation-based types: the repudiation, the negotiated repudiation, the repudiation by agreement, and the self-repudiation.

Furthermore, these modalities may differ considerably in form and procedure from state to state. Their form and procedure depend on their origin in one of the schools of jurisprudence as well as on legislative, judicial, political, economical, social, and historical developments in contemporary Muslim-majority countries.

\subsection{Structure of Part I}

A concise introduction to Islamic law is given in the fourth chapter for the reader who is not or hardly familiar with its subject matter. In the previous sentence, 'Islamic law' refers to the term as a collective and more general notion in this study for pragmatic reasons. It is actually incorrect to use the notion 'Islamic law' as Islamic law does not exist as one single legal system, but as a system of rules and standards on which various - religious and/or national - legal systems have been based. Depending on its context, it denotes, for example, classical Islamic or, even better, Shari' $a$ law or Moroccan or Pakistani law.

The fourth chapter intends to provide a better understanding and appreciation of Shari' $a$ law before introducing Islamic divorce laws and contemporary divorce laws and practices of states with an Islamic tradition. Although the latter are mostly governed by secular legislation, the exception usually concerns family and inheritance laws that are still based on Islamic law, as illustrated by the examples of Egypt, Iran, Morocco, and Pakistan (to be discussed in chapters 6 to 9). In the fifth chapter, relevant issues of and developments in Shari' $a$ family law and the Shari ${ }^{\prime}$ rules on divorce are discussed ${ }^{17}$ in order to contextualize the current divorce laws and practices in Egypt, Iran, Morocco, and Pakistan. The main types of divorce and their distinctive features, legal effects, and provisions after divorce are set out from the perspective of the various schools of jurisprudence as presented in their legal treatises. These serve as tertium comparationis for the divorce types

the following classification: the dissolution of marriage: (1) by death of the parties, (2) by the act of the parties (subdivided into dissolution by the husband, by the wife, or by common consent), and (3) by judicial process.

17 The following literature was consulted for information in this paragraph: Esposito 2001; Fyzee 2002, 4th edition, Glassé 2001, Linant de Bellefonds 1965, vols. I and II; Nasir 2002; Pearl 1987; Schacht 1982; Welchman 2007. 
and provisions in contemporary Muslim societies. This chapter does not deal with the application of divorce law by the judiciary in the past.

Although Muslims are seen as a distinct community within multicultural Europe, they do not form a uniform distinct community because of the divergences in religious affiliations and nationalities. These divergences also affect the modalities of and laws on divorce. It is thus necessary to portray the divorce laws of Egypt, Iran, Morocco, and Pakistan as examples of Islamic divorces in the law and in practice in chapters 6 to 9. The basic procedural requirements of due process will be highlighted, as the absence of due process is the first reason for the non-recognition of Islamic divorces in European countries. Finally, the question shall be addressed whether there is an insurmountable incompatibility between Islamic and Western values regarding divorce in the conclusion in chapter 10. 



\section{ConteXt: Islamic LAW in a Nutshell}

\subsection{ISLAMIC OR SHARI'A LAW?}

The term 'Islamic law' is often - confusingly and misleadingly - used as a translation of the notion Shari' $a .{ }^{1}$ Shari' $a$ literally means 'way to the watering-place' or, in a metaphorical sense, 'path to seek felicity and salvation' and it is also translated as 'right way of religion'. Shari' $a$ is often denoted as a religious law, and Islam is considered to be a law-based religion. ${ }^{3}$ Shari' $a$ is the general normative system of Islam, originating in Allah's divine authority. It regulates the life of Muslims in all its dimensions. The ultimate goal in the life of Muslims is to gain access to Paradise through observance of its rules of conduct in life. Shari' $a$ therefore comprises rules of a religious, social, ethical, and legal nature.

Religious and ethical rules govern the relationship between man and Allah. They concern the so-called 'ibadat or devotional, spiritual, ritual matters and acts which include obligations or recommendations concerning the five pillars of Islam (belief in God, ritual prayers, fasting, the pilgrimage or haj, and the gifts to the poor), religious purity, circumcision, form of prayer, etcetera. Allah judges compliance with these rules in the hereafter. Acts can be evaluated in accordance with the following scale of moral qualifications: obligatory (wajib), recommended (sunna $a^{4}$ or mandub), permissible or neutral (mubah), reprehensible (makruh), or forbidden (haram). The performance of an obligatory act such as the daily prayers is rewarded in the hereafter; their non-performance is punished there. The nonperformance of the repudiation that is exemplary for the reprehensible act is rewarded, whereas its performance is not punished in the hereafter.

The legal and social rules apply to the relationship between human beings among themselves. They concern the so-called mu'amalat or social or contractual acts and include, for example, rules of substantive and procedural (family, contract, penal, administrative) and international law, but they also concern moral ordinances and medical recommendations. Compliance is enforced by the qadi, the judge, or by any other secular authority.

1 The following literature, except where otherwise specified, was consulted for information in this paragraph: Berger 2006; Coulson 1964; Esposito 2009; Fyzee 2002, 4th edition; Glassé 2001; Hallaq 2009; Kamali 2008; Schacht 1982 . Yet occasionally one of these authors is referred to explicitly.

2 Kamali 2008, p. 2.

3 Schacht 1982, p. 1; Peters 2002, p. 82-83. Shari'a can be defined as religious, as the basis of its validity is Allah's will, and it contains rules of a purely religious character. However, Kamali questions 'whether Islam was meant to be as much of a law-based religion as it has often been made out to be' and points out 'the tendency to overlegalize Islam' of both Muslims and Orientalists (Kamali 2008, p. 1).

4 This notion of sunna must be distinguished from the notion of Sunna in the meaning of the example of the Prophet through his statements and acts. 
Acts or transactions can also be qualified in accordance with their legal validity: acts may be valid (sahih), defective (fasid), reprehensible (makruh), or void or invalid (batil).

Some acts or matters may belong to both the categories of 'ibadat and mu'amalat such as prayer in public, funeral, and war.

The sets of moral and legal qualifications may apply to the same act(s): an act may be permissible from a religious point of view and valid from a legal point of view. Repudiation, for example, may be legally valid, but in general it is considered to be reprehensible at the same time. These qualifications are, however, not absolute: the consumption of wine or pork is in principle forbidden unless one risks death.

Hence 'Islamic law', being used as translation of Shari' $a$, not only denotes the legal, but it also refers to the other aforementioned norms. The legal subject matter, however, is one part of Shari'a. The term 'Shari'a law' should thus be used when referring to this strictly legal subject matter that originates in Shari' $a$. Whenever the notion of 'Islamic law' is used in this study, the notion should be understood in its purely Occidental sense, and therefore restricted to the legal subject matter, Shari'a law.

\subsection{SOURCES}

Shari' $a$ law is primarily based on the Koran and the Sunna. The holy Koran, literally meaning 'the recitation' and being the principal source, comprises Allah's commands and injunctions that were revealed to humanity through his Prophet Muhammad. The Koran consists of 114 chapters (surat) and 6,235 verses (ayat). As its rules are the expression of Allah's will imposed on humans, they are eternally valid, immutable, and unchangeable by humans. The Koran does not include many legal rules. Legal rules have been restricted to a few legal areas, such as family and inheritance law, some crimes, and their penalties. ${ }^{5}$ Approximately 350 of the 6,235 verses in the Koran appear to be legal (ayat al-ahkam), of which 70 verses, especially in chapters 2,4 and 33, are devoted to issues such as marriage, divorce, custody of children, maintenance, etcetera. Some rules are explicit, but not all rules are manifestly clear.

$5 \quad$ Kamali 2008, p. 19. 
Koranic school in The Rif, Morocco, 2009 (photograph by Prof. dr. F. van der Velden)

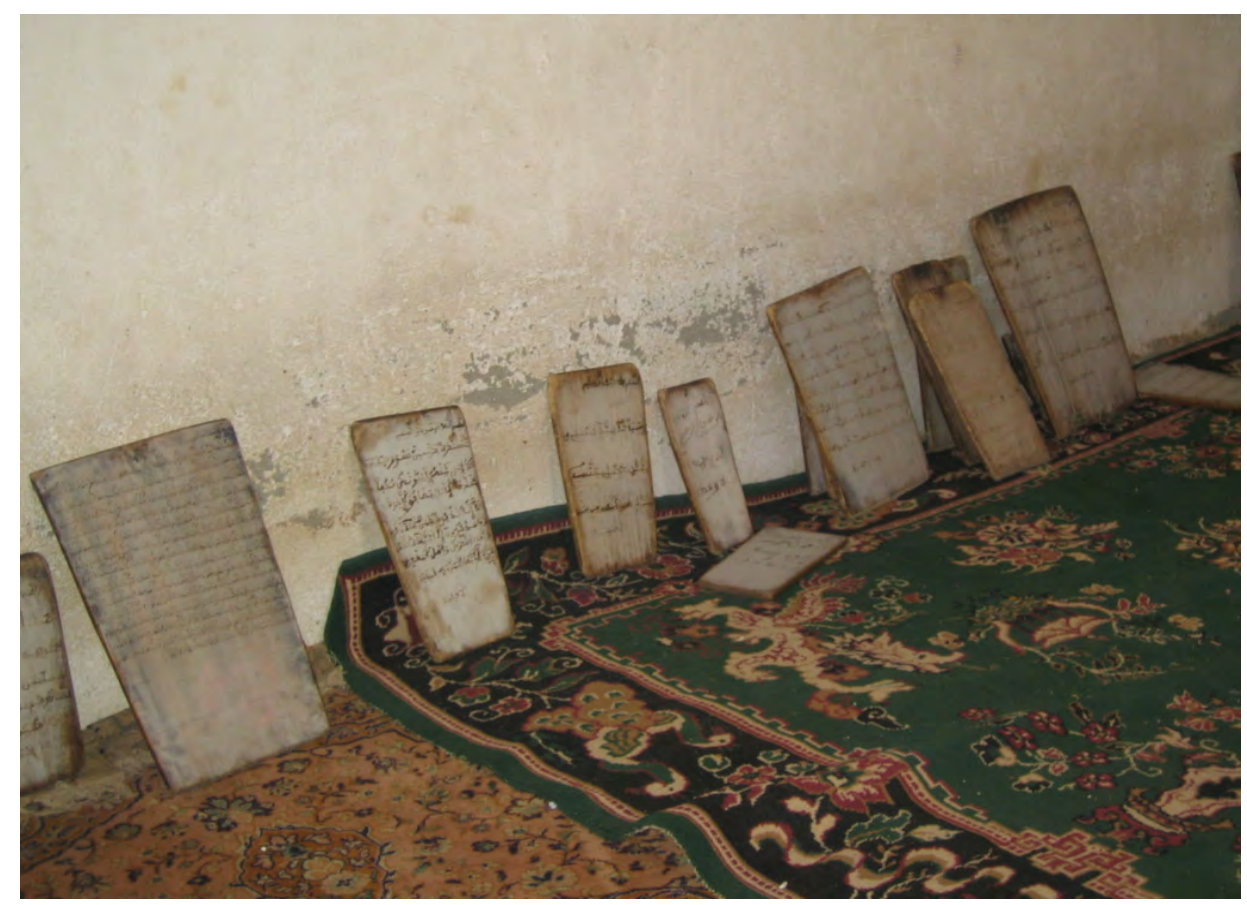

Sunna or custom is complementary to the Koran. It not only includes pre-Islamic and local customs that were followed by the Prophet and his disciples, but it also includes statements and acts of the Prophet or his closest disciples as corroborations, explanations, specifications of, and additions to the rules of the Koran whenever the Koran remains silent. These statements or acts of the Prophet were passed down in traditions or ahadith, at first orally and later in writing. ${ }^{6}$ Its rules are considered to be the product of their time and mutable. However, the Koran and Sunna, being the revealed sources (usul) of Shari' ${ }^{\prime}$, do not provide for answers to all variable situations in human life.

Muslim scholars have therefore elaborated both sources of legal rules through ijtihad (literally: 'endeavour'): legal reasoning or derivation of law through interpreting, clarifying, or supplementing the implicit rules of the Koran and/or Sunna. The general view is that only texts of the Koran and Sunna on civil and secular transactions, that are not specified,

6 Hadith (sing.), ahadith (pl.) literally means: speech, report, account. These traditions deal with the contents of the Koran, social and religious life and everyday conduct (Glassé 2001, p. 159). 
are open to ijtihad. Already in the early days of Islam, ijtihad was the monopoly of private, Muslim scholars, the 'ulama', who derived their authority from their religious knowledge.

Two other, additional sources of Shari'a originate in ijtihad and are thus based on human reason: ijma', which is a general consensus among Islamic scholars, expressed or tacit, on a question of law, and qiyas, finding new solutions through (judicial) interpretation of existing legal norms by analogy. These sources can be used whenever the Koran and Sunna do not provide answers.

The use of ijtihad has resulted in a corpus of rules with a legal and a religious dimension, the Islamic jurisprudence or figh. The same term Fiqh, literally meaning 'understanding' or 'knowledge', also denotes the science of Islamic jurisprudence, 'ilm Fiqh, which is the scholarly discipline in which Islamic jurists, fuqaha, are engaged in exegesis and the elaboration of Shari' $a$ law. For this reason, Shari' $a$ is also denoted as being the jurists' law, as the jurists, and not the state, originally had the exclusive authority to formulate rules of Shari'a. ${ }^{8}$

For the sake of clarity: Shari 'a cannot be equated with Fiqh. ${ }^{9}$ Fiqh is the human process of interpreting and deriving rules from Shari' $a$, the Revealed Law. It is therefore mundane, temporal, and local while Shari' $a$ is sacred, eternal, and universal. Shari' $a$ law or Islamic law, in its narrow, Occidental meaning, is derived from and part of Shari ${ }^{\prime} a .^{10}$

Other sources that originate in ijthihad are, inter alia, juristic preference or equity (istihsan), presumption of continuity (istishab), or consideration for the public interest (maslaha) (istislah). ${ }^{11}$

Additional sources of fiqh, which are subsidiary to the four sources mentioned above, are local customary law ('urf), the judicial (customary) practice ('amal), and the legislation of the secular authorities (qanun). Secular authorities have discretionary legal powers to issue laws, particularly in administrative affairs, siyasa. Although these authorities have a wide margin of appreciation, the legal rules issued under siyasa should not conflict with Shari' $a$. The primary responsibility of the state is to protect and to enforce Shari' $a$ law correctly. A conflict will be highly unlikely, however, as the rules issued under siyasa are mostly concerned with issues that are not governed by Shari' $a$ law. Hence, these rules supplement Shari'a whenever Shari'a remained silent or did not provide for clear rules. Furthermore, there is the legal stratagem, hiyal, which is a legal technique developed by Islamic jurists in order to circumvent the rules of Shari'a law through grammatical or

7 The other part of Shari' $a$, the theological-dogmatic part, concerns the science of the Islamic religious doctrine, 'ilm kalam.

8 Peters 2002, p. 84. Apart from the fact that Allah is the ultimate legislator in Islam.

9 Mir-Hosseini 2009, p. 79.

10 Kamali 2008, p. 16, 41.

11 Schacht 1982, p. 60-61; Kamali 2008, p. 19. 
systematic interpretation. Hence, aims can be achieved which cannot directly be pursued in a legal manner.

Whenever all these sources do not provide for a (clear-cut) solution, the judge, legislator, or believer can ask the mufti to issue a responsum or legal opinion, fatwa, ${ }^{12}$ based on ijtihad. The fatwa has a non-binding character in Sunni Islam, whereas it may even have the force

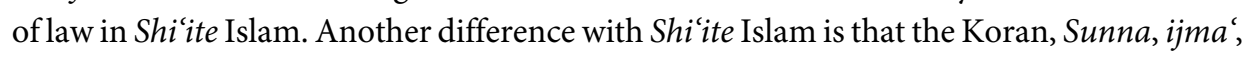
and qiyas are in general accepted sources within Sunni Islam. But notably the Shi ites and some more recent, conservative movements such as Wahhabism and Salafism restrict the legitimate sources of Shari' $a$ and fiqh to the Koran and Sunna.

At the beginning of the tenth century A.D., the consensus among most Sunni Muslims prevailed that the interpretation of Shari' $a$ by ijtihad had to end as the law had reached its perfection: the so-called 'gate' of ijthihad was closed. A period of strict imitation of the established doctrines, taqlid, followed. The Shi' $a$ and, at least in theory, the Hanbali preserved the rule of ijthihad. This development is often presented as the explanation for the immutable and static nature of Shari' $a$ law. However, recent research reveals that the law nevertheless changed because of social and political developments. ${ }^{13}$ The 'closure of the gate of ijthihad' also had a political and legal functionality. Taqlid could be used to prevent state intervention within Shari $a$. When the jurists were not allowed to use ijtihad, then certainly the state authorities were not. Taqlid also provided for more legal certainty and predictability as the jurists, judges, and other legal practitioners were no longer allowed to use their own interpretations of the revealed texts. This lasted until the reforms of Shari'a law in the Ottoman Empire in the mid-nineteenth century A.D. in order to bring the law into more conformity with modern needs and circumstances. Since then, reforms and modifications of the law regularly take place for this reason in all Muslim states.

\subsection{SCHOOLS OF JURISPRUDENCE}

After the death of the Prophet (632 A.D.), the divergence of opinions about the succession of the caliph, the substitute for the Prophet as leader of the Muslim community, led to a schism in Islam. Consequently, various denominations in Islam can still be distinguished nowadays: the Sunni, the most significant denomination in view of its scope; the Shi ${ }^{i}$; and the Kharijite ${ }^{14}$ denomination, the smallest. Shi'a Muslims believe that the source of religious guidance after the Prophet passes to his descendants, the Imams, which began with Ali, the Prophet's cousin and son-in-law. Sunni Muslims deny that the Prophet des-

12 Fatwa (sing.), fatawa (pl.).

13 Peters 2002, p. 86.

14 The most significant group within this denomination is the Ibadi, present in Oman, Algeria (Kabylia), and Djerba. 
ignated Ali as his successor and adhere to the belief that the leadership after the Prophet passes to an elected Caliph.

Within these denominations, various schools of legal thought emerged at different places and times. Today four Sunni schools of jurisprudence or madhahib - the Hanafi, Maliki, Shafi $i$, and Hanbali - exist. These four Sunni schools confine their differences to matters of interpretation of the revealed texts and the use of the hermeneutical tools. ${ }^{15}$ There are also several sectarian subdivisions of Shi' $a$ Islam - the Ithna 'Ashari, Ja'fari, or Twelver Shi' ites, ${ }^{16}$ the Zaydiyya, ${ }^{17}$ the Isma 'ili or Sab'iyah (Seveners), ${ }^{18}$ the Alawites, ${ }^{19}$ and the Alevites ${ }^{20}$ - still in existence. The Hanafi madhhab, offering the largest scope for ijtihad, is in general considered to be the most liberal Sunni school in that respect, while the Hanbali is considered to be the most conservative one, because of its literal interpretation of the Koran and Sunna. It is permitted to select and adopt certain principles of each other within the Sunni schools of law, for example the adoption of specific Maliki grounds for divorce by the Hanafi. The possibility of selecting and adopting each other's principles, takhayyur, can be considered to be an instrument to prevent schisms in society. And legal scholars used this possibility to adapt mostly rigid law to new developments in society. The exchange of principles between Sunnis and Shi'ites is absolutely forbidden and considered to be heresy.

\subsection{Some Characteristic Features}

The first characteristic feature is that one can distinguish between two different aspects within Shari' $a$ law: the sacred and divine aspect and the secular aspect. ${ }^{21}$ Shari' $a$ law is in the first place sacred and thus indefeasible, because it is the divine revelation that is considered to be the source of law in Islam. It is indefeasible, because the law is part of the path that leads to salvation, the law's main purpose. After all, Shari' $a$ means 'the right way'. The indefeasibility and hence the immutability of Shari' $a$ law is thus restricted to the rules and institutions that are mentioned in the two primary, revealed sources of Shari' $a$ law:

15 Nowadays the Hanafi school of law can be found in Turkey, Syria, Lebanon, Jordan, Egypt, Iraq, the Balkans, the Caucasus, Central Asia, Afghanistan, Pakistan, and India; the Maliki school of law in Morocco, Algeria, Tunisia, the South of Egypt, Bahrain, Kuwait, West Africa, Sudan, and North Nigeria; the Shafi $i$ madhhab in Middle and South-East Asia, especially in Indonesia, East Africa, partly in the North of Egypt and Jordan, and in the South of the Arab peninsula; and the Hanbali school of law primarily in Saudi Arabia (see also Berger 2006, p. 25; Schacht 1982, p. 63-67).

16 Are found in Iran, Iraq, Lebanon, and Azerbaijan.

17 Are found in Northern Yemen.

18 Are found in the Middle East.

19 Are found in Syria.

20 Are found in Turkey.

21 See also Mir-Hosseini 2000, p. 1. 
the Koran and Sunna. This does not imply that current leaders or legislators of Muslim states actually enforce all explicit rules of the Koran and Sunna. Slavery for example, although approved of in the Koran, is not applied by any contemporary Muslim state with laws based upon Shari'a law. The so-called $h u d u d$, the penalties for specific crimes as mentioned in the Koran, such as stoning to death or flogging, only occur in some Muslim states such as Saudi Arabia, Yemen, Iran, and Pakistan. The secular aspect can be found in the law as a product of legal interpretation. Especially in contemporary Islamic family law, both aspects can be found: it is dominated by many, originally religious rules that have been cast in the mould of (modern) legal systems.

The second characteristic feature follows from the first in that Shari $a$ law represents both law in theory and/or law as an ideal system as law in practice or law in reality. On the one hand, Shari' $a$ law is immutable; on the other hand, it accommodated pre-Islamic customs and developed legal devices in order to adapt itself to changing needs and circumstances. Mir-Hosseini points out a distance, a gap, or an intrinsic tension between Shari ${ }^{\prime} a$ law as law in theory and Shari ${ }^{a}$ law as law in practice. ${ }^{22}$

The third characteristic is that Shari' $a$ law is a legal doctrine. It requires transformation to 'law of the land' in order to function as positive law. ${ }^{23}$ In this transformation, the head of the state and the judiciary have played and still play a variable role from place to place and from time to time.

The fourth characteristic is that Shari' $a$ law is an all-embracing legal doctrine. Shari' $a$ provides norms for 24 hours a day, seven days a week, and does not only regulate the society but also the life of an individual. Shari' $a$ law provides for extensive regulations of specific areas of law such as family and inheritance law. Other areas of law such as administrative, social, or procedural law, for which the primary sources only provide rudimentary rules, are further specified by means of ijtihad. Anyone including the secular legislator may deviate from a specific Shari' $a$ rule that is neutral (mubah).

In the fifth place, Shari'a law is neither a uniform nor a homogeneous legal doctrine. It is primarily not because of the emergence of different schools of jurisprudence with their differences in interpretations of the revealed texts and in the use of hermeneutical tools, even within one school. The legitimacy of difference of opinion, disagreement, or diversity of views, ikhtilaf, is even characteristic for Shari' $a$ law as laid down by jurists.

The sixth characteristic is that Shari 'a law originally is, as mentioned, jurists' law as the jurists and not the state had the exclusive authority to formulate Shari' $a$ legal rules. Consequently figh texts are, in contrast to law codes, open-ended in the sense of not offering final solutions. They are discursive and often include contradictory or conflicting opinions because of the differences in interpretations and in the use of hermeneutical tools.

22 Mir-Hosseini 2000, p. 8, 10.

23 Peters 2002, p. 86-87. 
At last but not least, Shari' $a$ law is not an unambiguous notion but can be understood differently: ${ }^{24}$ originally as the divine plan for a fair and just society. The legal rules that have been developed in the first centuries of Islam, as result of the science of law, are generally denoted as the classical Shari $a$ law. And the current variants of the classical legal system that occur - in different interpretations - within contemporary national legal systems are also denoted as Shari' $a$ law. But it is an error to equate such variants with classical Shari' $a$ law as will be demonstrated in the next section.

\subsection{Shari'a Law Today}

Shari' a law today should not be perceived as a supranational, world-embracing legal system in the contemporary Muslim world. It only exists within the context of a state, mostly in one or some areas of its legal system and especially in the area of family and inheritance law. Furthermore, it is only enforceable by decree of that state. From jurists' law it has become codified law enacted by the legislator in most of the states with a Muslim-majority population. It is thus a hybrid law that consists of reformed Shari ${ }^{a}$ law grafted on to a modern Western codified legal system. Exceptions to its codification can be found in, inter alia, Saudi Arabia and Egypt. In Egypt, non-codified Shari'a law is applicable to all personal status issues for which no law has been enacted.

This process of codification through the introduction of Western law codes and Western concepts of law, thus originating in the continental civil code tradition, started in the Ottoman Empire in the second half of the nineteenth century A.D. ${ }^{25}$ Reasons for codification were reform and modernization, centralization, legal unification and state control over the law, and facilitation sourcing the law for judges. Codification implies that the state determines the (contents of) law as it presupposes that the state enacts legislation that governs a specific area of law, in principle, to the exclusion of other types of law. Not only were new laws enacted, but also existing laws have been reformed and/or modernized through the introduction of changes. The socially undesirable interpretations of Shari' $a$ were thus eliminated. At the same time, states made great efforts to show and stress the compatibility of these changes with Shari'a in order to further their acceptance and implementation.

Consequently, the authority to define Shari' $a$ law shifted to a large extent from the 'ulama' to the state, although the 'ulama' may still play a role in the preparation and legitimization of legislation; ${ }^{26}$ its application shifted from using fiqh texts to using legislation; its character moved from being typified by a scholarly discussion and therefore being dis-

24 As pointed out by Berger 2006, p. 16-18.

25 Peters 2002, p. 87-91.

26 Peters 2002, p. 89-95. 
cursive and often contradictory in opinions without offering a final solution as inherent in fiqh texts to being authoritative, clear, and unequivocal, without contradictory opinions, offering a definitive solution and without religious norms as intrinsic to provisions of a Western law code. The discourse on codified and non-codified Shari' $a$ also shifted from belonging to the exclusive domain of the intellectual class of the 'ulama' to becoming subject to often politicized, public debates in which also non-religiously trained intellectual Muslims participate.

According to the role of Shari' $a$ in its legal system, four types of states with a Muslimmajority population can be distinguished today. ${ }^{27}$ The first type is represented by most of the contemporary states in which Shari' $a$ still plays a restricted role. Shari' $a$ may even be an official source of law as reflected in some of the constitutions. In particular, family and inheritance law continue to be based upon Shari' $a$ law, although nearly everywhere it has been reformed and codified and is applied by a modernized legal apparatus. ${ }^{28}$ Some states, such as Iran, Pakistan, and Sudan, have re-Islamized their legal systems: Islamic law codes have been introduced in many areas of law, noticeably in criminal law. These states represent the second type. In the third type of state, the state has substituted its entire Islamic legal system by Western oriented, secular law, as is the case in Turkey and Albania. However, at the unofficial level, especially in rural areas, Shari' $a$ is still important. The opposite is found in states such as Saudi Arabia and Yemen that represent the fourth type of state. In these states Shari' $a$ law remains dominant in the entire legal system of the state. However, the laws of the states with a Muslim-majority population where Shari'a plays a role differ depending on their origin in one of the schools of law and on judicial, historical, legislative, economical, and societal developments of the state involved.

27 See also Mir-Hosseini 2000 for a distinction of three types of Muslim state.

28 See Mir-Hosseini 2000, p. 10-11, 12 for several reasons explaining why Shari' $a$ law has been retained in especially family, inheritance, and endowment law. 



\section{Divorce in SHARI'A LaW}

\subsection{INTRODUCTION}

Nowadays, the legal systems of most Muslim-majority nation states are governed by secular legislation based on European legal systems and codes. However, this is not quite the case for, inter alia, the area of family law and, thus, divorce law that still remains the domain of law originally based on Shari'a law. Contemporary Egyptian divorce laws for Muslims are an area in which the rules of the Hanafi school of jurisprudence originally were predominant. These rules are still considered to be default rules if Egyptian legislation does not provide for a solution in a given matter. ${ }^{1}$ Contemporary Iranian divorce laws are still based on the Ithna 'Ashari (Twelver) school of jurisprudence, a denomination within Shi' $a$ law. Contemporary Moroccan family law not only has its roots in the Maliki school of jurisprudence, but rules of the latter may be used as default rules in the event that the Moroccan Family Code of 2004 does not provide for a solution. ${ }^{2}$ The divorce laws for Muslims in Pakistan are rooted in Shari' $a$ divorce laws of various schools of jurisprudence, predominantly of the Hanafi but also of the Shi'a schools.

For this reason, this section sets out the various modalities of dissolution of marriage and its legal effects or post-divorce provisions in accordance with the views of the four Sunni schools of jurisprudence and of the Twelver' Shi'ites or Ithna 'Ashari. This section does not deal with the application of divorce law by the judiciary in the past. Knowledge of the various concepts in Shari'a law is indispensable for a better understanding and appreciation of the contemporary variants of modalities of divorce and their legal effects in the Muslim-majority countries under review.

Moreover, the notions in Shari' a law may serve as tertium comparationis for the notions used in contemporary Islamic states. However, the classical and contemporary notions used in Islamic states may differ from each other considerably due to, inter alia, historical and social, legal, judicial, and legislative developments in the Islamic states being researched. The classical and contemporary notions stem from different contexts.

In order to provide for a better understanding and appreciation of divorce in Shari'a law, this chapter subsequently discusses the institution of marriage, its lawful existence being a conditio sine qua non for divorce in Shari' $a$ law, in section 5.2. The main distinction in divorce modalities in Shari' $a$ law, the repudiation and the annulment, their distinctive criteria, and legal effects are addressed in section 5.3; all further modalities of divorce can

Art. 3 of Law No. 1 of 2000 .

Art. 400 of the Moroccan Family Code of 2004. 
be traced to these two main modalities. This chapter then continues by providing the features and requirements for the validity of the derivatives of these main modalities of divorce: first of the modality of divorce by the husband, the unilateral repudiation, is presented in section 5.4; then of the modalities of the dissolution of marriage on the initiative of the wife, the judicial divorce and judicial annulment, are addressed in section 5.5; and the various modalities of divorce that require the involvement of both spouses, the divorce by mandate or authorization, the negotiated repudiation, and the divorce by agreement, are discussed in section 5.6; finally, the legal effects and post divorce provisions of these modalities of divorce are set out in section 5.7.

\subsection{Marriage in Islam and Shari'a LaW}

\subsubsection{Definition, Characteristics, Purposes, and Types of Marriage}

The dissolution of marriage, in general, presupposes the existence of a marriage. Divorce presupposes the existence of a legally valid marriage. Marriage in Islam and in Shari' $a$ law and its various categories of (in-)validity are therefore the focus of this subsection. One should distinguish between the (in principle) permanent marriage and its temporary variant. The permanent marriage is concluded for an indefinite period of time; the temporary variant is concluded for a definite period of time. This section discusses the permanent marriage unless the temporary marriage is explicitly referred to.

The institution of marriage in Islam, aqd al-nikah, literally 'contract of coitus', is a solemn covenant between man and woman. ${ }^{3}$ It has social, moral, religious, and legal characteristics. ${ }^{4}$ Marriage, as an act, thus belongs to both 'ibadat, the devotional acts, and mu'amalat, the social/contractual acts. ${ }^{5}$ Compared with the pre-Islamic period, Islamic marriage has improved the subordinated status of women, inter alia, through the restriction of unlimited polygamy. Marriage realizes the essence of Islam, as it is considered to be the foundation of the family that is the keystone of Islamic society, the Umma. ${ }^{6}$

First, it aims at safeguarding chastity in society by legalizing sexual intercourse. ${ }^{7}$ Sexual intercourse outside the marriage is prohibited in Islam. It is considered to be fornication or adultery (zina) to be punished by the fixed penalty of flogging as provided in the Koran or the penalty of stoning as provided in the Sunna. Second, its purpose is to further the creation of a family through procreation in order to enlarge the Umma. It is therefore in

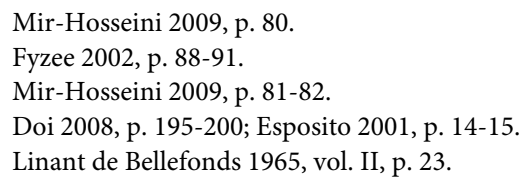


general recommended or even obligatory that anyone who is physically and/or financially able to do so should marry. ${ }^{8}$ But marriage is prohibited to those men who will render their wives deeply unhappy. A man is allowed to marry up to four wives simultaneously provided that he is able to treat them fairly and equally.

Marriage in Shari' $a$ law is the civil contract based on a bilateral agreement with reciprocal obligations and rights between man and woman. ${ }^{9}$ The husband undertakes to provide the dower ( $m a h r$ ) and maintenance ( nafaqa; including lodging, food, clothing, and possibly domestic service) to his wife in exchange for her obedience towards him including the right to sexual intercourse. To the latter end, the man may exercise control over his wife's mobility, for example, by forbidding her from leaving the house, having an employment, and visiting relatives, as these activities may hamper his right to sexual intercourse. No matrimonial regime of community of goods exists in Shari ${ }^{a}$ law: the husband is the owner of the matrimonial assets, whereas the wife owns her dower and her own earnings. Because of the fact that marriage is classified as an act having obligatory effects (a contract), it cannot be annulled by the sole intention of one of the parties involved, but only by their mutual agreement. ${ }^{10}$ However, the fuqaha do not equate the repudiation with an annulment. The marriage can thus be dissolved through repudiation, although it is based on the sole intention of one of the spouses in principle being the husband.

The consummation of the marriage, although not being constitutive for the (conclusion of the) marriage, plays a significant role in view of its legal effects. It results in the marriage becoming fully operative and, thus, in the enforceability of the husband's obligations towards his wife and vice versa. It may also result in the legitimate parentage of the children born from a marriage that appears to be null and void. And it also creates mutual inheritance rights.

It is contended that classical legal scholars sometimes equated the Islamic marriage contract in its form to the contract of sales. ${ }^{11}$ Mir-Hosseini refers to the legal logic of "ownership" (tamlik) and sale' which underlies these jurists' 'conception of marriage and defines the parameters of law and practices, where a woman's sexuality', even her person, becomes 'an object of exchange'. She points out that this logic 'defines the rights and duties in marriage of each spouse'. ${ }^{12}$ Esposito, on the other hand, stresses the requirement of consent of the adult woman to the marriage and hence the contractual nature of the Islamic marriage that 'makes the woman a party to the marriage agreement, rather than an object

Doi 2008, p. 200-204; Linant de Bellefonds 1965, vol. II, p. 26-28.

9 Ali 2008, p. 11-13; Esposito 2001, p. 21-27; Linant de Bellefonds 1965, vol. II, p. 23-26; Mir-Hosseini 2009, p. 80-83; Schacht 1982, p. 161-163.

10 Linant de Bellefonds 1965, vol. I, p. 89-90; vol. II, p. 167-168.

11 Schacht 1982, p. 161; Mir-Hosseini 2009, p. 80-81; Fournier 2010, p. 13-20. This interpretation of the marriage contract as a contract of sales is a much cited theory but concerns just one of the theories about the marriage contract.

12 Mir-Hosseini 2009, p. 81. 
of sale'.$^{13}$ Linant de Bellefonds demonstrates that the marriage contract and the sales contract, both belonging to the category of the contract with reciprocal obligations, may differ in result after application of their rules. ${ }^{14}$ The sale is, for example, null and void if no price has been fixed, whereas the marriage is valid even without the stipulation of the dower.

In Shi' $a$ law, the temporary marriage or 'the marriage of pleasure', $m u t^{\prime} a$, is acknowledged as lawful by the Twelver' Shi'ites. ${ }^{15}$ It is concluded for a definite period of time varying from mere minutes up to 99 years, for which the husband pays a reward to the wife. The Sunni schools of law do not acknowledge the mut' $a$ marriage. The Twelver' Shi $i$ ites refer to the Koran and some ahadith to account for its acknowledgement. ${ }^{16}$ The Koran (4:24) mentions that spouses are allowed to contract anything else apart from the dower. ${ }^{17}$ Some ahadith narrate that the Prophet allowed the temporary marriage during the war against Mecca. Its aim is to legitimate sexual relationships and the children born in such a marriage, although procreation is strongly discouraged. The objective of the $m u t^{\prime} a$ is sexual enjoyment, whereas the objective of the permanent marriage is procreation. The temporary marriage further differs from the permanent variant in the requisites of validity and the rights and duties of the spouses during and after the marriage.

\subsubsection{Categories of (In-)Validity of Marriage}

A rather complex issue within Islamic law concerns the various categories of (in-)validity of the marriage. These categories range from, as translated and placed into the Occidental legal terminology and conceptual system, legally valid to irregular (being voidable) to invalid (being non-existent or absolutely null and void). Sunni schools distinguish these three categories, whereas Shi' $a$ schools only acknowledge the two concepts of legally valid and void marriages. ${ }^{18}$ Discussion of these categories of (in-)validity of the marriage is necessary in order to clarify the distinction into two modes of the dissolution of marriage, notably the annulment, faskh, and the (various types of) divorce, talaq, and consequently their differing legal effects.

13 Esposito 2001, p. 15.

14 Linant de Bellefonds 1965, vol. II, p. 25.

15 The Arabic notion mut'a literally means enjoyment, pleasure, and use. Fyzee 2002, p. 117-121; Haeri 1989, p. 50; Mir-Hosseini 2000, p. 164-165; Damad 2004, p. 62-63; Schacht 1982, p. 163; this type of marriage still occurs in Iran, where it is known as sigha.

16 Van der Velden 2013-2014, p. 62.

17 Koran 4:24 reads: '[...] so with those of whom you have enjoyed sexual relations, give them their Mahr as prescribed; but if after a Mahr is prescribed, you agree mutually (to give more), there is no sin on you [...]'.

18 Fyzee 2002, 4th edition, p. 113. 


\subsubsection{The Valid Marriage}

If the substantive and formal requisites of the marriage and its conclusion have been observed, the Islamic marriage is legally valid (sahih). ${ }^{19}$ The offer (ijab) of marriage and its acceptance ( $q a b u l$ ), as well as the absence of absolute and relative impediments to the marriage, are absolutely required according to all schools. The offer and its acceptance must be stated in unambiguous wordings in one sitting by legally capable spouses and/or their legal representatives. Impediments to the marriage can be the illicit relationships of the spouses based on consanguinity or unrestricted polygamy. The presence of one of these impediments precludes the legally valid marriage and may result, depending on the impediment, in an irregular or invalid marriage. These impediments and their consequences will be further discussed below.

Other essential requisites for validity may be the presence of witnesses at the conclusion of the marriage, ${ }^{20}$ the payment of the dower (mahr) by the groom to the bride, ${ }^{21}$ and the representation of the major or minor bride by the marriage guardian (wali nikah) at the conclusion of the marriage. The minor or otherwise incapable bride also needs the consent of her legal guardian, wali (or wasi, the guardian appointed by testament, or muqaddam, the dative guardian), when that guardian does not already act as her marriage guardian. The minor or otherwise incapable groom is represented by his wali (or testamentary guardian or dative guardian). The contents of these requisites differ among the different schools of jurisprudence.

The legally valid marriage being an act having obligatory effects is also classified as an irrevocable act - meaning that the act cannot be annulled by the sole intention of the parties, but only after mutual agreement - if additional requisites next to those mentioned above have been fulfilled. ${ }^{22}$ They include the absences of mésalliance and of rescinding vices, which will be discussed further in the next section that will address the irregular marriage.

Essential requisites for the legal validity of the temporary marriage as allowed in Shi' $a$ law are, in addition to those mentioned above, notably the specifications for the duration of the marriage and stipulations on the amount of dower in the marriage contract. ${ }^{23}$ The

19 Ali 2008, p. 13-21; Doi 2008, p. 208-212, p. 222-265; Esposito 2001, p. 15-17, p. 18-21; Fyzee 2002, 4th edition, p. 91-112; Linant de Bellefonds 1965, vol. II, p. 39-151; Schacht 1982, p. 161-163; Van der Velden (20132014), p. 63-84.

20 See also Koran 2:282: ' ... And get two witnesses out of your own men. And if there are not two men (available), then a man and two women, such as you agree for witnesses, so that if one of them (two women) errs, the other can remind her. And the witnesses should not refuse when they are called on (for evidence) ...'.

21 See Koran 4:4: 'And give the woman (on marriage) their dower as free gift; but if they, of their own accord, remit any part of it to you, take it and enjoy it'.

22 Linant de Bellefonds 1965, vol. I, p. 89-90; vol. II, p. 167-191. A repudiation, for example, which is based on the sole intention of the husband, can dissolve the marriage. However, a repudiation cannot be equated with an annulment.

23 Haeri 1989, p. 52-54; Mir-Hosseini 2000, p. 165; Shid 2005, p. 147; Van der Velden 2013-2014, p. 62. 
absence or ambiguous specification of one or both of these requirements may render the temporary marriage null and void. The spouses can conclude a temporary marriage, as previously stated, for the duration of mere minutes up to 99 years. The payment of the dower and the observance of the marital duty by the wife, i.e. her sexual submission, are interrelated. The wife may subordinate her sexual submission to (full) payment of the mahr. The husband may make his claim for reimbursement of the dower contingent upon the wife's observance of her marital duty. The man can conclude as many temporary marriages as he can afford, whereas the woman is restricted to contract one temporary or permanent marriage at a time. ${ }^{24}$ The man can temporarily marry a Muslim, Jewish, Christian, or a so-called fire-worshipping woman, whereas the Shi' $a$ woman may only contract such a temporary marriage with a Muslim man. The divorced wife or widow does not need a wali nikah.

Today, the requisites for a legally valid marriage may be determined by statutory laws, case law, local custom, and/or by reference to Shari' $a$ law. ${ }^{25}$ And although national laws seem to share similar requisites, their interpretation or application across Muslim countries may differ considerably as they depend largely upon the source of the law. Moreover, laws and practices even within one country may show an immense gap.

Legally valid permanent marriages can be dissolved either through the operation of the law, a legal act such as the repudiation or khul', or judicial process. ${ }^{26}$ Examples of the dissolution of marriage by the operation of law are dissolution through death, apostasy, or a difference in religion. The legally valid temporary marriage can be dissolved by the operation of law through death or the termination of the period of time agreed upon or by waiver or 'gift' of the remaining term by the husband whether or not induced by the wife through offering him compensation. ${ }^{27}$ The temporary marriage cannot be dissolved through divorce.

If the above-mentioned requisites have not been observed, the Islamic marriage is either irregular or legally invalid. Some Shi' $a$ schools of jurisprudence, such as the Ithna 'Ashari, do not distinguish between irregular or legally invalid marriages: marriages are either legally valid or invalid. ${ }^{28}$ The irregularity or the invalidity of the marriage does have legal consequences as well as undesirable social effects. ${ }^{29}$ Women's and their children's rights in marriage may not be recognized. Women may be prosecuted for zina, having sex

24 Mir-Hosseini 2000, p. 165.

25 WLUML 2006, p. 60.

26 The dissolution of marriage by legal act and by judicial process in accordance with the classical Islamic doctrines will be the subjects of sections 5.4,5.5, and 5.6; their manifestations and procedures in contemporary Egyptian, Iranian, Moroccan, and Pakistani law will be discussed in detail in chapters 6 to 9 .

27 Fyzee 2002, p. 120; Haeri 1989, p. 56; Mir-Hosseini 2000, p. 165; Van der Velden 2013-2014, p. 62-63.

28 Fyzee 2002, 4th edition, p. 113.

29 WLUML 2006, p. 59. 
outside a valid marriage. Or they may become social outcasts and/or be left destitute after their husband's departure or desertion.

\subsubsection{The Irregular Marriage}

It follows from the previous subsection that the marriage is deemed to be legally valid after the fulfilment of its substantive and formal requisites. However, it is still susceptible to dissolution until the fulfilment of two additional requisites, those of the absence of mésalliance and the absence of rescinding vices. ${ }^{30}$ Consequently, irregular marriages are characterized by the non-fulfilment of one or more of its repairable requisites at the conclusion of the marriage or thereafter.

This implies first that the marriage may be irregular because of a lack of a rectifiable requisite or the existence of a removable, relative impediment. Situations such as when rules concerning the dower, mahr, have not correctly been taken into consideration or when the marriage has been concluded without enough or qualified witnesses are examples of marriages failing to fulfil the requirements. ${ }^{31}$ Relative impediments are, for example, unrestricted polygamy; the religion impediment, such as the (sexual) relationship between Muslim woman and non-Muslim man; the unconsummated marriage during the waiting period of the wife after the dissolution of another marriage; ${ }^{32}$ and the engagement of the wife to another man and the triple repudiation. ${ }^{33}$

Second, the marriage may be irregular because of mésalliance or rescinding vices. The absence of mésalliance entails that the husband is at least the equal of the wife from a social and/or religious perspective at the moment of the conclusion of the marriage. ${ }^{34}$ These perspectives, depending on the doctrine of the school involved, are concerned more specifically with aspects such as the equality in birth or seniority in Islamism of each of the spouses; equal honourableness of the professions of the husband and his father in law; equality in virtue; equality in property, means, and wealth; and the not-too-great disparity in age between the spouses. The theory of mésalliance plays an important role in the Hanafi doctrine since this doctrine allows the wife to conclude her marriage without a marriage guardian. Hence, the risks of mésalliance regarding the honourableness of the wife's family and of herself may be more considerable here than in the other schools of jurisprudence. These other schools, notably the Maliki, attach less importance to the theory of mésalliance because of the mandatory intervention of the wife's guardian at the conclusion of the marriage. The Hanafi doctrine exceptionally acknowledges that the husband may also claim the existence of mésalliance if he discovers the inferior status of his wife either after

30 Linant de Bellefonds 1965, vol. II, p. 167-191.

31 Fyzee 2002, 4th edition, p. 113.

32 See Koran 2:235.

33 Linant de Bellefonds 1965, vol. II, p. 105-106, 121-146.

34 Esposito 2001, p. 21; Linant de Bellefonds 1965, vol. II, p. 171-181. 
he has been married to her under the authority of his guardian while he was minor or incapable ${ }^{35}$ or after his marriage to his wife through a representative.

The schools of jurisprudence that attach great significance to the theory of mésalliance attach less importance to the theory of rescinding vices and vice versa. The latter theory varies within the different schools of jurisprudence. The theory refers to the defects or diseases, of either the husband or wife at the moment of the conclusion of the marriage, that directly or indirectly affect the marital relationship. They thus result in the marriage being voidable. All schools agree that sexual deformities and leprosy, vitiligo, and insanity of the husband or wife are rescinding vices. The neo-Hanbali and Zaydiyya even acknowledge every physical defect of either spouse as such.

All these causes for irregularity of the marriage are repairable, whether they exist at the moment of the conclusion of the marriage or they manifest or arise thereafter. The recovery of the defect or the removal of the impediment that manifests after the conclusion of the marriage results in the legal validity of the marriage. Relative or temporary impediments can, in contrast to absolute impediments, be removed so that the spouses can still marry. Some defects may be repaired through the consummation of the irregular marriage. The marriage that has been concluded during the 'major' pilgrimage $\left(\right.$ hadj) ${ }^{36}$ or the 'minor' pilgrimage ('umrah) ${ }^{37}$, for example, is repaired through its consummation. ${ }^{38}$

If the cause of irregularity is not or cannot be repaired, the marriage is voidable (nikah faskh). The marriage may be dissolved by either spouse, by the guardian of the wife, or by the judge, depending on the cause and the doctrine of the school of jurisprudence on that subject. Esposito and Fyzee mention that such marriages may be dissolved by one of the spouses by saying 'I have relinquished you' at any time. ${ }^{39}$ The examples of irregular marriages cited by these authors appear to be caused by a lack of a rectifiable requisite or of a relative impediment. Fyzee also refers to 'the duty of the kazi to separate the spouses'. ${ }^{40}$ Linant de Bellefonds contends that all schools are unanimous about the mandatory intervention of the judge to dissolve the irregular marriage due to rescinding vices. ${ }^{41} \mathrm{He}$ argues

35 The claim of the husband concerning the mésalliance for such a cause is sanctioned by the absolute nullity of the marriage; see Linant de Bellefonds 1965, vol. II, p. 178.

36 The 'major' pilgrimage or hadj is one of the religious duties of a Muslim, one of the five pillars of Islam. Every able-bodied Muslim who can afford it must carry out this pilgrimage to Mecca in Saudi Arabia during the twelfth month of the Islamic calendar, at least once in his or her lifetime.

37 The 'minor' pilgrimage or 'umrah is the pilgrimage to Mecca in Saudi Arabia that is recommended and that can be undertaken by Muslims at any time of the year.

38 Van der Velden 2013-2014, p. 72-73. According to the Ja fari school of jurisprudence, the marriage that has been concluded when either spouse is in a special spiritual state, the Ihram, during the Hadj is null and void. Moreover, this results in an absolute impediment to marry the other person involved if either spouse knew that it was forbidden (haram) to marry in that state; see Ja'far al-Sadiq 2012, p. 66.

39 Esposito 2001, p. 18; Fyzee 2002, 4th edition, p. 113.

40 Fyzee 2002, 4th edition, p. 113.

41 Linant de Bellefonds 1965, vol. II, p. 189-190. 
that such dissolution requires an assessment of the facts that have been invoked by the requiring party and that the judge may decide to postpone the dissolution if recovery of the defect is feasible.

In Hanafi law, only the wife may invoke the theory of rescinding vices in order to claim the dissolution of a marriage and only for reasons of impotence, castration, leprosy, vitiligo, or insanity of her husband. The husband cannot invoke this theory of rescinding vices as he has the power to repudiate. The other Sunni doctrines also allow the husband to invoke this theory. They also take into consideration the rescinding vices of the husband or, dependent on the school involved, those of the wife that have occurred after the conclusion of the marriage. All schools, except for the Shafi $i$, acknowledge that either spouse or only the wife according to the Hanafi does not lose the option to claim dissolution, if it is not immediately claimed at the moment of discovery of the vice. The Shafi $i$ argue that the spouse has accepted the existence of the vice in the latter case and therefore loses this option.

The schools differ in opinion whether the dissolution of an irregular marriage equals the (judicial) repudiation or divorce, talaq, talaq al-tatliq/talaq al-tafriq, or the dissolution through annulment, $f a s k h .{ }^{42}$ This distinction in talaq or faskh (judicial), divorce/repudiation or annulment, is significant for the differing legal effects of either type of dissolution.

\subsubsection{The Invalid Marriage}

The invalid marriage is characterized by the presence of an irreparable impediment or defect or a total lack of one or more of its essential requirements. The presence of an absolute impediment, for example, results in making it impossible to marry or the invalidity of the marriage in the case of its discovery thereafter. ${ }^{43}$ Such irreparable impediments are, inter alia, the relationship between the spouses based on an illicit degree of consanguinity (close blood relationship), affinity (relationships acquired through marriage), or fosterage (relationship based on nursing); the consummated marriage during the waiting period of the wife ('idda) after the dissolution of another marriage; or the imprecation (li'an), ${ }^{44}$ the husband's accusation of his wife's fornication under oath. The free consent of either spouse is an essential requirement.

The invalid marriage is theoretically considered to have never existed. ${ }^{45}$ Its consummation is problematic, as it equals fornication in Shari' $a$ law with the penalty from the Koran of stoning as the ultimate consequence. Islamic legal scholars have developed the theory of shubha that may exonerate the 'spouses' involved from this severe penalty. The shubha theory gives the illicit sexual relationship an appearance of legitimacy if under circumstances

42 Doi 2008, p. 269-271; Linant de Bellefonds 1965, vol. II, p. 189-191, 307-311.

43 Linant de Bellefonds 1965, vol. II, p. 105-120; see for absolute impediments Koran 4: 22-24.

44 The imprecation (li'an) creates a relative impediment according to the Hanafi school of jurisprudence.

45 Linant de Bellefonds 1965, vol. II, p. 153-155. 
(the cause of) the invalidity was controversial, the 'spouses' were ignorant of (the cause of) the invalidity, or the invalid marriage simply resembled a legitimate union. The marriage that appears to be invalid before its consummation is less problematic. ${ }^{46}$ The 'spouses' cannot be accused of fornication since the marriage has not been consummated. The marriage cannot be repaired, is automatically annulled by operation of law, does not have any legal effect and does not require the interference of the judge unless the 'spouses' refuse to separate. In that case, the judge acts as protector of the mores, the essential characteristics of a community.

In principle, all Sunni schools, including some Hanafi except for Abu Hanifa, agree upon the radicalness of the invalidity of the marriage irrespective of its cause, if the cause is discovered after consummation. ${ }^{47}$ The nullity cannot be undone or repaired. The marriage is automatically annulled by the operation of law, and the parties have to separate. However, despite the invalidity of the marriage, these schools and Abu Hanifa diverge in their views on possible legal effects of the 'marriage' because of its consummation.

The Maliki, Shafi $i$, and Hanbali and two disciples of the Hanafi school, Abu Yusufand Šaybani, invoke the shubha theory in two different situations in order to preserve as many legal effects as possible from the invalid, albeit consummated marriage. ${ }^{48}$ These are, first, the situation in which there is no unanimity among the scholars of the various schools of jurisprudence about the cause of the invalidity and, second, when there is unanimity among the scholars about the cause of invalidity but where both parties were ignorant about the law or made a mistake. The invocation of the shubha theory in the first situation results in the production of reduced legal effects whether the parties were in good faith or not. In the second situation, the nullity is restricted in its consequences after invoking the shubha theory if both 'spouses' acted in good faith.

Apart from exoneration from the penalty for fornication as a result of invoking the shubha theory, the following legal effects of a valid marriage also remain: the mandatory observance of the waiting period by the wife, entitlement of the wife to the fair or the stipulated dower, legitimacy of the children born from such an invalid marriage, and the impediment for either spouse to marry the ascendants or descendants of the other spouse. The 'spouses' do not retain mutual inheritance rights. When the parties cannot appeal to either of the two above-mentioned situations, the marriage is completely annulled. ${ }^{49}$ None of the reduced legal effects survive this nullity, and the sexual relationship between the parties, because of the consummation, is considered to be fornication.

The founder of the Hanafi school, Abu Hanifa, distinguishes between two degrees of invalidity of the marriage, consummated or not: non-existent (batil) or absolutely void

46 Linant de Bellefonds 1965, vol. I, p. 110-112, 114; Linant de Bellefonds 1965, vol. II, p. 153, 155-156.

47 Linant de Bellefonds 1965, vol. II, p. 156.

48 Linant de Bellefonds 1965, vol. II, p. 156-159.

49 Linant de Bellefonds 1965, vol. II, p. 159. 
(fasid).$^{50}$ These degrees are also used to indicate the invalidity of any act in general. If the marriage lacks one or more of its constitutive elements, it is considered to be non-existent (nikah batil) as the act cannot have been constituted. The conclusion of the marriage in violation of one of the absolute and thus irreparable impediments results in the absolute nullity of the marriage (nikah fasid).

The not yet consummated invalid marriage, whether non-existent or absolutely void, does not produce any legal effect. ${ }^{51}$ The consummated non-existent marriage (nikah batil) in principle does not produce any legal effect, despite its consummation, as the act cannot have been constituted. ${ }^{52}$ However, if the marriage contract has the appearance of validity, the shubha theory provides for exoneration from the penalty of stoning and the entitlement to the dower by the wife. As the marriage (act) can have been constituted in the case of the consummated, absolutely void marriage (nikah fasid), it may produce certain legal effects. ${ }^{53}$ These effects are the exoneration from the penalty of stoning for fornication, the wife's entitlement to a specific type of dower, the wife's duty to observe the waiting period ('idda) after the separation, and the legitimacy of the children born from such a marriage. Moreover, both degrees of invalidity entail the impediment to marry the ascendants or descendents of the other spouse.

The validity of the marriage concluded by the incapable should be discussed separately. The marriage concluded by totally incapable persons among whom the insane man/woman or the minor without discernment is considered to be invalid in the sense of non-existent (nikah batil). ${ }^{54}$ It produces no legal effects. The insane person, however, is exonerated from the penalty for fornication because he or she cannot be held responsible for his or her deeds. In Hanafi law, the marriage concluded by partial incapable persons, such as the minor beyond the age of reason, the prodigal, and the slave, is held to be valid in theory but inefficacious. ${ }^{55}$ The marriage's final validity depends on the decision for approval or not by the guardian. If the guardian approves of the marriage, it produces all the effects of the legally valid marriage; if not approved of, the marriage is considered to be nonexistent. Accordingly, it produces restricted legal effects: the exoneration from the punishment for fornication, the wife's entitlement to the due dower, and the impediment to marry the ascending or descending relatives of the other 'spouse'. The Maliki share these views

50 Linant de Bellefonds 1965, vol. I, p. 111-112; vol. II, p. 160-161; Linant de Bellefonds (1965, vol. I, p. 114115; vol. II, p. 152 footnote 1) warns that the characterization in Shari $a$ law of (marriage) acts as batil and fasid does not correspond with the characterization of acts as absolutely and relatively null in French law (or in other Occidental legal systems). The scholars Esposito and Fyzee, for example, deviate from the classification as mentioned by Linant de Bellefonds and use the notion nikah batil to denote the void marriage and the notion nikah fasid to denote the irregular marriage, Esposito 2001, p. 17-18; Fyzee 2002, p. 112-115.

51 Linant de Bellefonds 1965, vol. II, p. 160.

52 Linant de Bellefonds 1965, vol. II, p. 160-161.

53 Linant de Bellefonds 1965, vol. II, p. 160.

54 Linant de Bellefonds 1965, vol. II, p. 161.

55 Linant de Bellefonds 1965, vol. II, p. 161-162. 
on the marriage by the semi-incapable, although in their opinion the wife is not entitled to any dower. The Shafi $i$ and Hanbali invoke the shubha theory as they consider such a marriage to be null and void. Consequently, such a marriage produces the restricted legal effects of exoneration from the penalty for fornication, legitimacy of the children, and the wife's entitlement to the due dower.

As invalid marriages cannot be made undone or repaired and are automatically annulled by operation of the law, they do consequently not need to be dissolved. The spouses have just to separate or are separated by the judge.

\section{$5 \cdot 3$}

Dissolution of Marriage: TalaQ versus Faskh

The legal scholars in classical Shari $a$ law distinguished between the following two modes of dissolution of marriage: talaq, the repudiation, and fask $h$, the annulment. ${ }^{56}$ This distinction was the common one at the time. Talaq, the repudiation, represents the mode of dissolution that is proper to the marriage (contract), whereas faskh, the annulment, is the mode of dissolving contracts in general, including the marriage contract. ${ }^{57}$ Talaq in this context has to be broadly understood and is used as a generic notion. It does not only stand for the unilateral repudiation by the husband, denoted as talaq as well, but also other modalities of divorce based on the repudiation are identified with talaq, such as the repudiation by mandate or authorization, talaq al-tamlik or talaq al-tafwid, the negotiated repudiation, $\mathrm{khul}^{\text {' }}$, and the judicial divorce or repudiation, talaq al-tatliq or talaq al-tafriq. ${ }^{58}$

Linant de Bellefonds considers the fact that contemporary legal scholars, legal practitioners, and others still use the term talaq for indicating talaq in its broad meaning at present as an unfortunate usage..$^{59}$ The term talaq should nowadays be used in its restricted meaning: the unilateral repudiation by the husband.

Talaq, repudiation, originally is the prerogative of the husband. Women were and still are depending on the consent of their husband or the judge in their request for judicial divorce on a limited number of grounds.

Talaq should be distinguished from fask $h$ because of its distinctive criterion and legal consequences or effects. ${ }^{60}$

56 Linant de Bellefonds 1965, vol. II, p. 167; p. 306.

57 The noun 'talaq' has been derived from its verbal root 'tallaqa' which literally means to release, to untie. Talaq thus signifies the release of the wife from the marital ties. Faskh literally means 'to annul a deed' or 'to rescind a sale'. See also Doi 2008, p. 266, 269; Fyzee 2002, p. 168; Linant de Bellefonds 1965, vol. II, p. 307; Van der Velden 2003, p. 2-3.

58 Doi 2008, p. 269-271; Linant de Bellefonds 1965, vol. II, p. 309-311. See paragraph 3.5.1 for the explanation about the distinction between the notions of talaq al-tatliq and talaq al-tafriq.

59 Linant de Bellefonds 1965, vol. II, p. 315.

60 Doi 2008, p. 269-271; Linant de Bellefonds 1965, vol. II, p. 307-308. 
It is often assumed that talaq in its broad meaning is an extra-judicial modality of the dissolution of marriage, whereas faskh is necessarily judicial. ${ }^{61}$ Nothing is further from the truth: both repudiation and annulment occur with and without judicial intervention.

The distinctive criterion to determine whether the dissolution equals repudiation or annulment differs between the various schools of law. ${ }^{62}$ According to the Hanafi, for example, this criterion is the person who is entitled to dissolve the marriage. ${ }^{63}$ If this right is attached to the husband, even when the wife initiates the dissolution, the dissolution equals repudiation. If the right exclusively belongs to the wife, it concerns an annulment since the wife is never entitled to repudiate. The wording used by the parties is the decisive criterion for the Shafi $i$ and Hanbali: the dissolution equals the repudiation if the husband or his agent uses words that are characteristic for the repudiation, and otherwise it is an annulment. ${ }^{64}$ Contemporary legislations have been influenced by the Maliki criterion, and therefore the cause of the dissolution is the essential element. If the cause is independent of the intention of both spouses, even when they, for example, want to remain married, but the law prohibits the marriage, then it is an annulment and otherwise the dissolution is a repudiation. ${ }^{65}$

According to the Shafi $i$ and Hanbali schools of law, any dissolution of a marriage that requires judicial intervention is an annulment, fask $h .{ }^{66}$ According to these schools, the wife may have her marriage dissolved through annulment by the judge, for example, in the case of a (hidden) defect of the husband such as impotence or insanity. ${ }^{67}$ It is on the same grounds that the wife has the right to demand a judicial repudiation according to the Hanafi and Maliki. ${ }^{68}$ But one should bear in mind that not every annulment, faskh, is necessarily judicial. ${ }^{69}$ The marriage is dissolved through $f a s k h$ without judicial interference if it concerns a cause for nullity of the marriage contract, such as a forbidden relationship between the spouses because of fosterage.

\subsection{2}

\section{Distinctive Legal Effects}

Talaq should also be distinguished from faskh because of three distinctive legal effects.

61 Linant de Bellefonds 1965, vol. II, p. 308.

62 Linant de Bellefonds 1965, vol. II, p. 308-311.

63 Linant de Bellefonds 1965, vol. II, p. 309.

64 Linant de Bellefonds 1965, vol. II, p. 309.

65 Linant de Bellefonds 1965, vol. II, p. 309.

66 Linant de Bellefonds 1965, vol. II, p. 451, p, 465.

67 Linant de Bellefonds 1965, vol. II, p. 451 and p. 469.

68 Linant de Bellefonds 1965, vol. II, p. 454-457.

69 Linant de Bellefonds 1965, vol. II, p. 465 footnote 1. 
First, the various modalities of divorce based on repudiation, talaq, in its broad meaning, can be either revocable ( $\left.r a j^{\prime} i\right)$ or irrevocable ( $\left.b a^{\prime} i n\right)$, depending on the way it has been pronounced and the number of pronouncements. ${ }^{70}$ The annulment, faskh, immediately and definitively ends the marriage and the duties and rights emanating from that marriage.

In the case of the revocable repudiation, the husband is allowed to revoke his pronouncement of divorce by words or deeds during the waiting period, 'idda, of the wife in order to exercise his right of taking her back and to reconcile and resume the marriage. The spouses will then continue the marriage. ${ }^{71}$ The revocation is subject to specific substantive and formal requirements. The irrevocable repudiation excludes the revocation of the repudiation by the husband. It results in the immediate and definitive end of the marriage as soon as the repudiation has been pronounced.

Second, after a total of three dissolutions of a marriage, another remarriage between the same spouses is prohibited. ${ }^{72}$ Remarriage becomes possible again after the dissolution of the consummated marriage of the wife with another man, the so-called tahlil procedure. ${ }^{73}$ According to the Shi' $a$ doctrine, three times three repudiations (and the wife intermediately being married to two other men) will result in an absolute impediment to remarriage between the same spouses. ${ }^{74}$ This is in contrast with the situation after the annulment: the same spouses are allowed to remarry indefinitely irrespective of the number of annulments but, of course, except for the occurrence of other impediments.

The third and last distinctive legal effect concerns the right of the wife to the dower, mahr, in the case of the dissolution of the marriage before the consummation of the marriage. ${ }^{75}$ In that case, the wife is entitled to half her dower after the repudiation for which she cannot be blamed. In this case, after an annulment, the wife cannot claim any (part of the) dower.

The different modalities of the talaq and the faskh in Shari' $a$ law will be set out below in accordance with the classification that was chosen as a starting point for the discussion of the specific modalities of divorce in this study.

70 Doi 2008, p. 277; Linant de Bellefonds 1965, vol. II, p. 307, p. 393-418. Although most consulted authors refer to the talaq $b a^{\prime}$ in as being irrevocable, Doi refers to the talaq $b a^{\prime} i n$ as being final but not irrevocable.

71 Talaq raj' $i$ is based upon Koran 2:228 and 2:229.

72 Doi 2008, p. 277; Linant de Bellefonds 1965, vol. II, p. 307.

73 Koran 2:232.

74 Baillie 1887, p. 28.

75 Linant de Bellefonds 1965, vol. II, p. 308. 
The repudiation or talaq in its restricted meaning is the extra-judicial dissolution of marriage at the exclusive discretion of the husband. ${ }^{76}$ At all times, the repudiation has been seen as the most commonly used modality for the dissolution of marriage in Islam. Nowadays, it is also considered to be one of the most problematic modalities in relation to its recognition by other, especially non-Muslim, countries. Before discussing its contemporary manifestations in four Muslim countries, it is therefore essential to take a closer look at the legal and, because of possible reciprocal influences, moral and religious character, validity requirements, and forms and regulations relating to repudiation in Shari ${ }^{\prime} a$ law first.

\subsubsection{Nature and Legal, Moral, and Religious Characteristics}

Talaq is the husband's exclusive, discretionary, and absolute right to terminate the marriage. He may transfer this power to an agent or to his wife. ${ }^{77} \mathrm{He}$ or his agent does not need the consent of the wife to motivate the decision to repudiate. Furthermore, the presence of witnesses, except in the Shi ${ }^{i} a$ doctrine, or judicial intervention is also not required.

In accordance with the moral classification system of Shari ${ }^{\prime}$, repudiation is considered to be reprehensible (makruh), at least when a valid motive is lacking. ${ }^{78}$ It is the belief that the judgment of the motive takes place in the afterlife and is the concern of Allah and the husband. A motive is therefore still not required in contemporary, national codifications of divorce law. The repudiation can still be established in a legally valid way and produce legal effects if its conditions for legal validity have been fulfilled. Nevertheless, the repudiation is still considered to be detestable, as an ultimum remedium or the last resort to which the husband should have recourse. ${ }^{79}$ Therefore, an attempt of reconciliation, as recommended in the Koran, was and still is obligatory, as demonstrated in current national codifications. ${ }^{80}$ In specific circumstances, it may even be forbidden (haram) to repudiate, such as during the menstrual period of the wife. ${ }^{81}$ Yet, the repudiation may be recommended (mandub) or even obliged (wajib), for example, when (one of) the spouses (is) are prejudiced by the marriage. ${ }^{82}$

76 Linant de Bellefonds 1965, vol. II, p. 315.

77 Linant de Bellefonds 1965, vol. II, p. 315.

78 Linant de Bellefonds 1965, vol. II, p. 317-320; in the latter case (lack of valid motive), the repudiation is even considered to be forbidden, haram, by Ibn Hanbal, founder of the Hanbali school of law.

79 See e.g. in Art. 70 of the Moroccan Mudawwana.

80 See e.g. in the Koran: surat al-nisa 4:35; Arts. 81, 89, and 94 of the Moroccan Mudawwana; Art. 1 of the Iranian Law of the amendments to the rules on divorce.

81 Linant de Bellefonds 1965, vol. II, p. 318.

82 Linant de Bellefonds 1965, vol. II, p. 317-318. 


\section{ISLAMIC DIVORCES IN EUROPE}

The repudiation can be either revocable or irrevocable. As a consequence of his decision to terminate the marriage, the husband has to pay the (deferred) dower, (possibly) financial compensation, and, at least during the waiting period of the revocable repudiation, maintenance to the wife.

\subsubsection{Requirements of Validity}

The legal validity of the repudiation requires the fulfilment of various substantive and formal conditions. The substantive requirements to legal validity of the repudiation have to be discerned in the requirements related to the (person of the) divorcer or husband, requirements related to the (person of the) divorcee or wife, and another substantive requirement related to the moment of repudiation.

\subsubsection{Substantive Requirements of Validity Related to the Divorcer}

\subsection{Legal Capacity}

First, the divorcer (al-mutalliq) should have legal capacity to repudiate. Hence, he should be mature and sane, and, according to some non-Hanafi, it should be an act of free volition. $^{83}$

These requirements imply that the minor boy before becoming mature, the insane or demented, the sleeping or unconscious man, and the man in delirium because of high fever or who is beside himself with anger cannot validly repudiate as their ability and/or intention to repudiate is absent or insufficient. The minor before becoming of age or the otherwise incapable person cannot be replaced by his legal guardian except according to the Maliki ${ }^{84}$ They authorize the legal guardian of the minor, the demented, and the insane to replace the incapable husband in order to repudiate the wife.

Exceptions to the requirement of full capacity exist. ${ }^{85}$ The prodigal and the weak-minded (and the slave) are considered to be capable to validly repudiate, even without a guardian. The Hanbali recognize that the repudiation by a discerning minor is legally valid.

\subsection{Intention to Repudiate}

The second and the first requirements are more or less interrelated. The Shafi $i$, Maliki, Hanbali, and Ithna 'Ashari require the divorcer's serious, unambiguous, and full intention

83 Baillie 1887, p. 107-108; Doi 2008, p. 273-274; Fyzee 2002, p. 150; Ja'far al-Sadiq 2012, p. 80; Linant de Bellefonds 1965, vol. II, p. 327-330; Maghniyyah 1997, vol. VI, p. 1-2.

84 Linant de Bellefonds 1965, vol. II, p. 327-328, 330; Maghniyyah 1997, vol. VI, p. 3-4.

85 Linant de Bellefonds 1965, vol. II, p. 328; Maghniyyah 1997, vol. VI, p. 1. 
to repudiate ${ }^{86}$ Circumstances of a lacking or deficient intention, under which the husband has repudiated his wife, such as duress or error in language, result in an invalid repudiation according to these schools. The Hanafi, however, consider the repudiation under these circumstances to be effective. ${ }^{87}$ And all Sunni schools of jurisprudence in principle agree that the divorcer does not necessarily need to have had the serious intention to repudiate, meaning that he can validly repudiate in jest, as long as he has used an explicit formula of repudiation. These schools also share the opinion that the repudiation pronounced in deliberate drunkenness or under deliberate intoxication is legally valid, whereas the nonculpable drunkenness or intoxication results in an ineffective repudiation. The Ithna 'Ashari hold the repudiation that has been pronounced under duress, by mistake, without serious intention, thus in jest, in drunkenness, or under intoxication, to be invalid; the husband should have had the serious intention to repudiate. ${ }^{88}$

The pronouncement of the repudiation under circumstances such as fatal illness or disease, combat of war, death penalty, or similar, in articulo mortis, does not invalidate the repudiation itself (insofar as the mental capacity of the husband has not been affected by any of these circumstances). ${ }^{89}$ Two stands related to the legal effects of such a repudiation as result of ijtihad occur. On the one hand, all Sunni schools of jurisprudence are unanimous in their opinion that such repudiation, being legally valid, although morally reprehensible, produces all its legal effects.

On the other hand, all these schools, including the Ithnä 'Ashari, but except for the Shaf $i$ i, do share the view that such an act of the husband should in principle not deprive the wife of her right to inherit. ${ }^{90}$ The theory underlying this view is that if the fiqh condemns a specific act, for example, the deprivation or limitation of the right to inherit of an individual, every other act, although being licit itself but facilitating the accomplishment of the condemned act, will be annulled itself or at least be limited in its effects. ${ }^{91}$ The conditions of 'survival' of the right of the wife to inherit differ per school. ${ }^{92}$

According to the Ithna 'Ashari, the wife's right to inherit from her husband will 'survive' after a revocable or irrevocable repudiation under the above-mentioned circumstances if he dies within a year after the repudiation, provided that the repudiation was not on her demand, that she has not been remarried, and that he has not recovered meanwhile. ${ }^{93}$

86 Baillie 1887, p. 108-109; Doi 2008, p. 274; Fyzee 2002, p. 150-151; Ja far al-Sadiq 2012, p. 80; Linant de Bellefonds 1965, vol. II, p. 340-345; Magniyyah 1997, vol. VI, p. 1-3.

87 But see Doi (2008, p. 274) who claims that the divorce pronounced by mistake is not binding according to all jurists so including the Hanafi.

88 Maghniyyah 1997, vol. VI, p. 3.

89 Baillie 1887, p. 122; Linant de Bellefonds 1965, vol. II, p. 334-339.

90 Baillie 1887, p. 122-124; Doi 2008, p. 286.

91 Linant de Bellefonds 1965, vol. II, p. 339.

92 Linant de Bellefonds 1965, vol. II, p. 335-339; Magniyyah, vol. VI, p. 50-51.

93 Baillie 1887, p. 122. 
The Hanafi take the stance that the wife will remain being entitled to inherit after an irrevocable repudiation, without her consent and in articulo mortis of the husband, if he dies before the expiration of the waiting period of the wife. But if the presumption that he intends to deprive her of her inheritance can be refuted, the wife's right to inherit will not 'survive'. An example of this is the situation that the husband has been constrained to repudiate. According to the Hanbali, the wife nevertheless will inherit after an irrevocable repudiation, insofar as she has not been remarried at the moment of death of her former husband.

The Maliki doctrine is the most favourable for the wife as she retains her right to inherit after an irrevocable repudiation under the above-mentioned circumstances whether or not her former husband has been deceased before the lapse of the waiting period and whether or not she has been remarried to other men before his death.

The Shafi $i$ deny the wife the right to inherit from her former husband after an irrevocable repudiation. Such a repudiation has definitively dissolved the marriage which is the underlying ground of existence of that right. They are of the opinion that the wife can still inherit until the expiration of the waiting period of the revocable repudiation as the marriage has not yet been definitively dissolved.

\subsection{Being a Muslim}

The last requirement is rather obvious: the divorcer should be a Muslim as Shari ${ }^{\prime}$ law applies to Islamic marriages, being the marriage in which at least the husband is a Muslim. ${ }^{94}$

\subsubsection{Substantive Requirements of Validity Related to the Divorcee}

\subsection{Specific Status of the Divorcee}

First, the divorcer can only repudiate the wife to whom he is actually, permanently (validly) married; the wife who has been repudiated in a revocable manner, during her waiting period; or, according to the Hanafi, the wife who has been repudiated in a minor, irrevocable way, during her waiting period. ${ }^{95}$ The Ithna 'Ashari allow the repudiation of five categories of wives regardless of their state of menses or purity: (1) the minor wife under the age of nine, (2) the wife with whom the marriage has not been consummated, (3) the menopausal wife, (4) the pregnant wife, and (5) the wife whose husband was absent for at least a month in which period he has repudiated her; for this reason, he could not determine her state. ${ }^{96}$

94 Fyzee 2002, p. 150.

95 Baillie 1887, p. 109-110; Linant de Bellefonds 1965, vol. II, p. 347-351.

96 Maghniyyah 1997, vol. VI, p. 7. 


\subsection{During Her Period of Purity?}

The second requirement concerns the moment of repudiation in relation to the divorcee. ${ }^{97}$ That moment should be in a period of purity, the period between two menses, tuhr, of the wife. The repudiation should not be pronounced during the menses or puerperal bleeding after childbirth of the wife whose marriage has been consummated. The repudiation should also not be pronounced in a period of purity in which sexual intercourse between the spouses has taken place. The latter does not apply in the case of a post-menopausal wife, a pregnant wife, or a wife who has not attained to puberty. The Sunni schools of law agree that the pronouncement of the repudiation in one of the above-mentioned prohibited

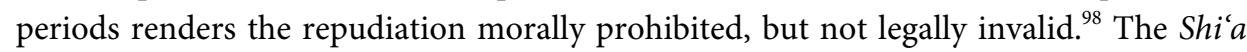
take the opposite stance that the pronouncement during one of these moments (legally) invalidates the repudiation, but does not render it morally prohibited.

\subsection{Indication of the Divorcee}

The third requirement, at least with the Ithna 'Ashari, is that the husband should unambiguously indicate the wife whom he repudiates, especially in the case of a polygamous marriage. ${ }^{99}$

\subsubsection{Substantive Requirement of Validity Related to the Moment of Repudiation}

The Sunni schools of jurisprudence acknowledge the legal validity of the suspended or deferred repudiation or the repudiation in the future and of the conditional repudiation, whereas the Ithna 'Ashari do not. ${ }^{100}$ In the case of the - rarely occurring because heavily disputed - repudiation in the future, the repudiation is pronounced at a specific moment, while its effects are suspended until the occurrence of a specified event in the future. ${ }^{101}$ Formulations such as 'you are repudiated when the next month of Ramadan starts' or 'you are repudiated tomorrow' provide examples of this. The Maliki, however, consider the repudiation as being valid but its suspended term ineffective. The repudiation will immediately be effective in order to avoid a situation resembling a temporary marriage that is prohibited according to the Sunni schools.

The more common conditional repudiation is the variant, the accomplishment of which is subjected to a future and uncertain event. ${ }^{102}$ For this reason, it is most harmful for women. But the formulation by the husband such as 'you will be repudiated if I want to' is prohibited. As long as the condition has not been accomplished, the repudiation is

97 Baillie 1887, p. 110-111; Doi 2008, p. 274-275, 279-280; Fyzee 2002, p. 152-155; Ja far al-Sadiq 2012, p. 8082; Linant de Bellefonds 1965, vol. II, p. 347-351; Maghniyyah 1997, vol. VI, p. 4-7.

98 Maghniyyah 1997, vol. VI, p. 6.

99 Baillie 1887, p. 111-112, 117; Ja'far al-Sadiq 2012, p. 82.

100 Baillie 1887, p. 115-117; Linant de Bellefonds 1965, vol. II, p. 384-392; Maghniyyah 1997, vol. VI, p. 10.

101 Linant de Bellefonds 1965, vol. II, p. 385-386.

102 Linant de Bellefonds 1965, vol. II, p. 386-388. 
deferred, and the marriage, including its duties and obligations, subsists. ${ }^{103}$ If the condition is never accomplished, the repudiation will be considered as never having been pronounced. And if the condition has been accomplished, the wife is repudiated as from that moment and, hence, without retroactive effect until the day of its pronouncement. If the condition has been accomplished without the knowledge of the spouses, the repudiation is immediately effective as from its pronouncement. The impracticable condition - the event cannot be produced or the condition is subjected to the intention of Allah - renders the repudiation invalid according to all Sunni schools of jurisprudence with the exception of half of the Hanbali school. That other half defends the opposite solution of the immediately effective repudiation. The Maliki consider the pronouncement of the repudiation with the impracticable condition because of its being subjected to the intention of Allah, as well as with the useless condition of being immediately effective.

\subsubsection{Formal Requirements of Validity}

\subsection{Expression of the Repudiation}

The repudiation should be expressed verbally, in written, or by signs or gestures in order to exteriorize the intention to repudiate of the husband. ${ }^{104}$ The verbal pronouncement of the repudiation must consist of the use of either an explicit or figurative formula according to most schools of jurisprudence. ${ }^{105}$ The use of the explicit formula automatically brings about the repudiation and dispenses the need for proof of the intention of the husband.

According to the Hanafi, the formula does not have to consist of specific terms such as talaq, its equivalent, or its derivatives, as long as their constant usage signifies their explicit character. It explains why the pronouncement of such a formula in error, culpable drunkenness or under duress by the husband, does not automatically affect the legal validity of the repudiation. ${ }^{106}$ The Shafi $i$ and the majority of the Hanbali consider only three terms and their derivatives as being an explicit formula: talaq, furaq (separation), and sarah (return). The Maliki only consider the term talaq and its direct derivatives to be explicit; other terms could express, for example, a temporary separation instead of a real intended dissolution. Most authors claim that the Ithna 'Ashari require a strict formula that indicates a clear and unambiguous intention to repudiate; that formula should be properly and unconditionally pronounced, preferably in Arabic when possible, such as 'you are repudiated' or "'name" is repudiated'. ${ }^{107}$ Fyzee, however, suggests that although the Ithna 'Ashari require the explicit formula, they also allow the figurative or allusive

103 Linant de Bellefonds 1965, vol. II, p. 388-390.

104 Linant de Bellefonds 1965, vol. II, p. 352; Maghniyyah 1997, p. 7-11.

105 Doi 2008, p. 273; Fyzee 2002, p. 150-151; Linant de Bellefonds 1965, vol. II, p. 353-355.

106 See also Doi 2008, p. 273.

107 Baillie 1887, p. 113-117; Fyzee 2002, p. 151; Ja'far al-Sadiq 2012, p. 82; Maghniyyah 1997, vol. VI, p. 7-8. 
formula in which case the intention needs to be proven if the words are ambiguous. ${ }^{108}$ The use of the figurative or allusive formula only then results in the repudiation if the husband's intention to repudiate is beyond question. ${ }^{109}$ Although this type of formula may consist of a variety of other terms than talaq or its equivalents or derivatives, the figurative or allusive formula should be somehow related to the dissolution of marriage.

The Sunni schools of jurisprudence distinguish among three categories of figurative or allusive formulas, ranging from formulas manifestly conveying the intention to repudiate to formulas with a latent allusive character. This distinction is highly relevant in view of the different legal consequences regarding the nature of the repudiation that each of these categories produces: the revocability or - minor or major - irrevocability. Only according to the Shafi $i$ does a figurative or allusive formula bring about a revocable repudiation.

The intention of the husband is thus the essential element of the repudiation through a figurative or allusive formula. Yet it appears in practice that it has only to be proven through its affirmation under oath by the husband when he wants to deny the claim of the wife that he has repudiated her. The intention to repudiate cannot be deduced from any circumstances but from the husband's oath according to the Shafi i and Maliki. But the Hanafi and the Hanbali agree that under specific circumstances strong presumptions in favour of the repudiation should be taken into account. The husband is then not allowed to deny under oath his intention to repudiate through the use of a figurative or allusive formula.

The majority of the Sunni schools allow the repudiation to be expressed in writing whether or not the husband is mute or the wife and the husband are present in the same place. ${ }^{110}$ The Maliki, Shafi $i$, and Hanbali require the intention of the husband in order to bring about the repudiation in this way. The Hanafi require an expression in writing that is explicitly addressed to the wife in order to be as effective as the verbal pronouncement of the repudiation and to dissolve the marriage, whether or not the husband had the intention to repudiate. The Ithna 'Ashari in principle do not allow the repudiation expressed in writing, except in the case of a mute husband or a husband who is distant from his wife. $^{111}$

The mute is allowed to express the repudiation through signs or gestures under the condition that significance can be read into the signs or gestures. ${ }^{112}$ All Sunni schools except for the Maliki refuse the possibility of repudiation through only signs or gestures to non-mute persons. The latter are allowed to pronounce the repudiation orally accom-

108 Fyzee 2002, p. 150-151.

109 Linant de Bellefonds 1965,vol. II, p. 353, 355-358.

110 Doi 2008, p. 273; Linant de Bellefonds 1965, vol. II, p. 360-362; Maghniyyah 1997, vol. VI, p. 10-11.

111 Baillie 1887, p. 113-114; Linant de Bellefonds 1965, vol. II, p. 361; Maghniyyah 1997, vol. VI, p. 8. But see Baillie (1887, p. 114) who claims that it cannot be relied on the opinion of some that the repudiation written by the husband who is absent from his wife is lawful.

112 Baillie 1887, p. 113-114; Linant de Bellefonds 1965, vol. II, p. 362-364; Maghniyyah 1997, vol. VI, p. 8. 
panied by signs. For example, the triple repudiation could be expressed through the formula 'I repudiate you in this way' and showing three of his fingers. The non-Maliki Sunnis and the Ithna 'Ashari allow the mute, who is able to write, the choice between expressing the repudiation using signs or gestures and expressing it in writing.

\subsection{Witnesses}

The Sunni schools do not require the presence of witnesses as a constitutive element of the repudiation at its expression. ${ }^{113}$ The presence of witnesses serves evidential purposes. However, the Maliki require and the Hanafi consider it to be recommendable that the husband revokes the repudiation in the presence of witnesses. ${ }^{114}$ The Shi' $a$, especially the Ithna 'Ashari, hold the repudiation expressed without the presence of two male and just Muslim witnesses to be null and void. ${ }^{115}$ Their mere presence is not sufficient. The witnesses should have heard the pronouncement or have seen the writing of the repudiation or have understood the signs or gestures of the repudiating husband at the moment of the repudiation. Women are not allowed to be witnesses. The presence of the witnesses serves to diminish the number of repudiations since they could advice and discourage the couple from divorcing.

\subsection{Mandate, Authorization, or Agreement}

As the talaq is the husband's exclusive and discretionary right to dissolve the marriage, he can give a mandate to repudiate to another person, including his wife (tawkil), or he can authorize his wife to repudiate herself or give her an option (tafwid). ${ }^{116}$ The husband can also agree with his wife upon the dissolution of marriage through repudiation either in the form of a khul' or mubara'at. All these modalities of dissolution of marriage will be discussed more in detail in section 5.6.

\subsubsection{Forms of Talaq}

\subsubsection{The Single Repudiation}

The single repudiation is the repudiation that is pronounced only once by making use of wording that reflects a single repudiation. The single repudiation is considered to be the regular or sunna type of regulation of the repudiation. It may result in a revocable repudiation unless, for example, the husband repudiates the same wife through a single repudiation

113 Doi 2008, p. 273; Linant de Bellefonds 1965, vol. II, p. 381-382.

114 Koran 65:2; Doi 2008, p. 273.

115 Baillie 1887, p. 117-118; Fyzee 2002, p. 151; Linant de Bellefonds 1965, vol. II, p. 383; Maghniyyah 1997, vol. VI, p. 11-13.

116 Linant de Bellefonds 1965, vol. II, p. 315. 
for the third time or it concerns the self-repudiation by authorization, tamlik, or the negotiated repudiation, $k h u l$. The latter are all irrevocable, as will be discussed in subsection 5.7.

\subsubsection{The Triple Repudiation}

The triple repudiation is the pronouncement of three repudiations in one act or the (pronouncement of the) repudiation through the use of figurative wording while having the intention to repudiate ${ }^{117}$ or gestures or signs that reflect a triple repudiation. ${ }^{118}$ It represents a form of the irregular or regulation of repudiation. The triple repudiation can be assimilated with the third, single repudiation, also in view of its legal effects according to most doctrines. It is irrevocable and entails the relative marriage impediment that an immediate remarriage between the spouses is impossible. The triple repudiation is therefore probably the most criticized institution in the Fiqh, but at the same time it is also the most successful form of repudiation for men. And although the Hanafi and Maliki hold it to be legally valid, they consider it to be morally reprehensible or even prohibited. The Hanbali and Shafi $i$ expressly declare the triple repudiation to be not prohibited. But the majority of the Ithna 'Ashari holds the triple pronouncement to be null and void. They assimilate the triple repudiation with a single, revocable repudiation.

\subsubsection{Regulations of Talaq}

As already mentioned above, two types of regulation of repudiation occur in Shari ${ }^{\prime}$ law: the regular or approved, sunna, regulation of repudiation and the irregular or disapproved or innovated, bid'a, regulation of repudiation. ${ }^{119}$ Regardless of which type of regulation underlies it, the repudiation is legally valid if the substantive and formal conditions to validity have been fulfilled.

\subsubsection{Talaq Al-Sunna}

The talaq al-sunna, being inspired by strictly interpreted precepts in the Koran and being in conformity with the dictates of the Prophet, is considered to be the ideal regulation of the repudiation. For this reason, the repudiation that is pronounced in accordance with

117 The Shäfi' do not acknowledge the triple repudiation through the use of figurative wordings, while the Maliki do not necessarily require the intention of the husband while repudiating through the use of figurative wordings (Linant de Bellefonds 1965, vol. II, p. 370).

118 Linant de Bellefonds 1965, vol. II, p. 365-373. The following formulations are examples: 'I repudiate you, I repudiate you, I repudiate you' or 'I repudiate you three times'; or making signs by raising three fingers followed by pronouncing a formula of repudiation by the non-mute husband.

119 See, for example, Baillie 1887, p. 118; Esposito 2001, p. 30-31; Fyzee 2002, p. 151-155; Linant de Bellefonds 1965, vol. II, p. 321-325; Pearl 1987 p. 100-102. 
this regulation is called 'regular' and 'approved'. The sunna repudiation has to satisfy the following requirements: (1) the single pronouncement of the repudiation (according to the Maliki and Hanbali) or three pronouncements in one setting, the so-called triple repudiation (according to the Shafi $i$ ); (2) in the period in which the wife does not have her menstruation, the tuhr period, and before the husband and wife resume their sexual relationship which has been interrupted by her last menstruation; (3) and not during the waiting period of the wife. ${ }^{120}$

In Hanafi law, the talaq al-sunna is subdivided into the ahsan, the best or most approved, and the hasan, the good or approved subtype of regulation. The hasan is less approved and thus less acceptable than the ahsan subtype. ${ }^{121}$ The ahsan subtype responds to the requirements of the sunna repudiation according to the Maliki and Hanbali as described above. As it concerns only one pronouncement of repudiation, this subtype is also referred to as the minor, sughra, method: the husband can remarry his wife after the expiration of the waiting period. ${ }^{122}$ In accordance with the hasan subtype, the husband repudiates his wife through three successive single pronouncements during three subsequent tuhr periods of his wife. ${ }^{123}$ The first two repudiations are revocable, but the third repudiation is final, $b a^{\prime}$ in, and it immediately ends the marriage, although the woman must still observe her waiting period. ${ }^{124}$ It also implies that the husband cannot remarry the former wife after she has a bona fide consummated marriage with another man and the valid dissolution of that marriage, the tahlil procedure. ${ }^{125}$ Since immediate remarriage is impossible, the hasan subtype is considered as a major, kubra, talaq. ${ }^{126}$

The most important characteristic of the Sunna regulation is the revocability of the repudiation implying that the husband can take back his wife during the waiting period. Its requirements and characteristics are all aimed at a well-considered decision of the husband in order to prevent a permanent breach and thus to protect the wife. ${ }^{127}$ If he does regret his decision, he can reconsider it during her waiting period. ${ }^{128}$ However, the prescriptions of the sunna repudiation have remained 'a dead letter' in judicial practice, and their non-observance is not legally sanctioned. ${ }^{129}$

120 See in the Koran with regard to (the requirements of) the repudiation: 2:226-232, 2:236-237, 4:128, 33:49, and 65:1-7. Fyzee 2002, p. 152; Linant de Bellefonds 1965, vol. II, p. 322-323; Pearl 1987, p. 100.

121 Fyzee 2002, p. 151, 152-154; Linant de Bellefonds 1965, vol. II, p. 323; Pearl 1987, p. 100-101.

122 Pearl 1987, p. 101.

123 Fyzee 2002, p. 153; Pearl 1987, p. 101.

124 Fyzee 2002, p. 153.

125 Fyzee 2002, p. 153; Linant de Bellefonds 1965, vol. II, p. 324 footnote 6; Pearl 1987, p. 101.

126 Pearl 1987, p. 101.

127 Doi 2008, p. 275; Linant de Bellefonds 1965, vol. II, p. 321-322.

128 Fyzee 2002, p. 151.

129 Linant de Bellefonds 1965, vol. II, p. 321-322. 


\subsubsection{Talaq Al-Bid'a}

The talaq al-bid'a represents a resurrection of pre-Islamic customs. It is morally considered to be reprehensible (makruh) or even forbidden (haram) and therefore named irregular or disapproved. ${ }^{130}$ The name 'innovated' is not justified according to Linant de Bellefonds. ${ }^{131}$ It suggests that the talaq al-bid'a came into existence after the talaq al-sunna. Both types of regulation already coexisted during the lifetime of the Prophet, and the talaq al-bid' $a$ appeared to even precede the ideal regulation. It should be repeated that the bid' $a$ repudiation is nevertheless legally valid if the conditions for legal validity of the repudiation have been fulfilled. It is the regulation of the repudiation without requirements or the repudiation that has been pronounced in conflict with the above-mentioned requirements of the talaq al-sunna. Examples are the triple pronouncement of the hasan form in one single sitting, ${ }^{132}$ or the pronouncement of the repudiation during the menstruation period, or the postnatal period after childbirth of the wife, ${ }^{133}$ or the pronouncement of the (single) repudiation before consummation of the marriage. ${ }^{134}$ And although the Maliki consider the talaq albid' $a$ during the menstruation period of the wife to be morally reprehensible, but legally effective, the husband will be obliged to retract it, or the judge will order its retraction ex officio. ${ }^{135}$ The triple repudiation, although being considered morally reprehensible as well, produces all its legal effects according to the Hanafi, Maliki, and Hanbali.

The bid'a repudiation is irrevocable, $b a^{\prime}$ 'in, as soon as it is pronounced, ${ }^{136}$ and the marriage ends immediately. ${ }^{137}$ In the case of the triple pronouncement of the repudiation in one sitting, the husband can only remarry his wife after the tahlil procedure. ${ }^{138}$ The sunna and bid'a regulations can still be recognized in contemporary regulations of repudiation.

130 Linant de Bellefonds 1965, vol. II, p. 321-322, 323.

131 Linant de Bellefonds 1965, vol. II, p. 321.

132 Except in shafi' $\mathrm{i}$ law where the triple repudiation is nevertheless considered to be a regular or approved form or a talaq al-sunna, if the other requirements of the talaq al-sunna have been taken into account; see Linant de Bellefonds 1965, vol. II, p. 322-323 (also footnote 5). In Shi'a law (in the Ithna 'Ashari and the Fatimid laws), the triple form of talaq is not permissible (see Fyzee 2002, p. 154).

133 This form of talaq is not recognized by the Ithna 'Ashari and the Fatimid school of law (Fyzee 2002, p. 155).

134 Fyzee 2002, p. 154-155; Linant de Bellefonds 1965, vol. II, p. 323; Pearl 1987, p. 100, 101, 102. The single talaq pronounced in definite wording is not recognized by the Ithna 'Ashari and the Fatimid school of law either (Fyzee 2002, p. 155).

135 Linant de Bellefonds 1965, vol. II, p. 325.

136 Pearl 1987, p. 100, 101.

137 Except in Shafi $i$ law (see footnote 132) where the triple repudiation in one sitting is seen as a form of a talaq al-sunna and thus is consequently considered as a revocable talaq that will end the marriage after the 'idda without a revocation. See also Linant de Bellefonds 1965, vol. II, p. 325.

138 Except in Shafi $i$ law where the husband can remarry his wife after a triple repudiation in one sitting. See also Linant de Bellefonds 1965, vol. II, p. 325; Pearl 1987, p. 101. 

or Judicial Annulment (Talaq Al-Qadi or Faskh)

In Islamic law, notably the wife can petition for the dissolution of her marriage by judicial process. ${ }^{139}$ Hence, it is one of her possibilities to have the marriage dissolved. She must base her claim on specific recognized grounds. If she succeeds in establishing (one of) these grounds, the dissolution of marriage will be understood as repudiation, talaq al-tatliq, ${ }^{140}$ according to the Maliki and Hanafi schools of jurisprudence (the Maliki system). ${ }^{141}$

The Maliki school of jurisprudence recognizes more grounds for the dissolution of marriage than other schools. The Hanafi school of jurisprudence recognizes the least number of grounds: sexual defects of the husband and non-conversion of the non-Muslim husband married to a converted wife. ${ }^{142}$ The Hanafi school of jurisprudence only allows the wife to demand judicial divorce in exceptional cases because divorce is the husband's prerogative. ${ }^{143}$ The next chapter will reveal that legislators of modern Islamic nation states of a Hanafi background, such as Egypt and Pakistan, have sought to improve the position of women, inter alia, by enlarging the grounds for judicial divorce through takhayyur. This is the method of borrowing grounds from other schools of jurisprudence, such as from the Maliki school. The modality of judicial repudiation based on one of the Maliki grounds that has been adopted by non-Maliki legal systems is called talaq al-tafriq (instead of talaq al-tatliq). Tafriq is then used to distinguish the dissolution of marriage by judicial authority that is not an annulment from repudiation in its strictest meaning.

The Hanbali and Shafi $i$ schools in general ignore the judicial repudiation, but they acknowledge instead the judicial annulment of the marriage or faskh (the Shafi $i$-Hanbali system). ${ }^{144}$ The Ithna 'Ashari do not allow the judicial repudiation either except on the ground of a missing husband and possibly - here the opinions diverge - on the ground of non-provision of maintenance. ${ }^{145}$

For pragmatic purposes, both modalities of dissolution of marriage by judicial process, the judicial repudiation and the judicial annulment, may be addressed as 'judicial divorce' in this study.

139 Linant de Bellefonds 1965, vol. II, p. 449-470. See especially his distinction between repudiation and annulment on p. 310; See also the distinction by Doi, p. 269-271.

140 The notion tatliq has been derived from talaqa that, inter alia, means 'to repudiate'. 'Tatliq' thus means 'to make repudiate'.

141 Doi 2008, p. 269-270; Linant de Bellefonds 1965, vol. II, p. 330, 451, 453.

142 Apart from the husband's oath to abstinence from intercourse, ila' and the husband's imprecation of adultery by the wife, li'an Doi 2008, p. 269-270; Linant de Bellefonds 1965, vol. II, p. 451.

143 Linant de Bellefonds 1965, vol. II, p. 452; Maghniyyah 1997, vol. VI, p. 65.

144 Linant de Bellefonds 1965, vol. II, p. 451, 465-470.

145 Maghniyyah 1997, vol. VI, p. 68-69. 


\subsubsection{The Maliki System: Judicial Repudiation}

The Maliki consider the judicial divorce to be a repudiation by the judge who acts on behalf of the husband. ${ }^{146}$ The judge may replace the husband if the husband does not act or refrains from acting in accordance with his marital obligations or in the case of a defect contrary to the nature, features, purposes, rights, and obligations of the Islamic marriage. If the husband himself does not repudiate in such cases, the judge is allowed to replace him in order to grant the wife her right to the dissolution of the marriage.

Such acting, refraining from acting or defects can be found in the wording of the exhaustive account of grounds for divorce. Two types of grounds should be distinguished: the special or peremptory grounds being physical or mental diseases or defects, ${ }^{147}$ nonpayment of the dower, long and unjustified absence of the husband, non-payment of maintenance, and the general grounds being harm ${ }^{148}$ and discord. ${ }^{149}$ The special or peremptory grounds concern specified causes for divorce. ${ }^{150}$ The judge (on behalf of the husband) proceeds to dissolve the marriage once he has established the existence of the ground. Hence, the term 'peremptory' is used, as these grounds do not leave any margin of appreciation to the judge once their existence has been established. In the case of the general grounds, the judge has a wide margin of appreciation concerning their interpretation on the one hand. On the other hand, these grounds require a more cautious procedure. The judge (on behalf of the husband) cannot dissolve the marriage but after an unsuccessful attempt of reconciliation between the spouses.

According to the Maliki, the judge is only allowed to dissolve the marriage on his own authority in the case of the irregularity or nullity of the marriage, the husband's imprecation of adultery by the wife, $l i$ ' $a$, and the non-conversion of the non-Muslim spouse married to a converted spouse. ${ }^{151}$

146 Linant de Bellefonds 1965, vol. II, p. 330, 451.

147 On the ground of specific diseases or defects, the husband may also petition for judicial divorce; hence, this ground is to be considered as a common divorce ground and not as a ground exclusively for the wife; see Linant de Bellefonds 1965, vol. II, p. 454.

148 This ground is not found in other doctrines. The Maliki account for this ground through a combination of the opinion in a hadith that harm should not occur in Islam and the wording of Koran 4:35 'And if you fear dissension between the two, send an arbitrator from his people and an arbitrator from her people. If they both desire reconciliation, Allah will cause it between them. Indeed, Allah is ever Knowing and Acquainted [with all things]'.

149 Doi 2008, p. 271; Linant de Bellefonds 1965, vol. II, p. 453-464.

150 Linant de Bellefonds 1965, vol. II, p. 453-454.

151 Linant de Bellefonds 1965, vol. II, p. 189-190, 453. Imprecation in this context means that the husband affirms under oath that his wife has committed adultery. 


\subsubsection{The Shafi'i-Hanbali System: Judicial Annulment}

Contrary to the Maliki are the Shafi $i$ and Hanbali scholars who are of the opinion that the judge himself dissolves the marriage. ${ }^{152}$ The dissolution of marriage should therefore not be characterized as repudiation but as an annulment, faskh. The Shafi $i$ and Hanbali consider any judicial dissolution of a marriage to be a fask $h$, although not every fask $h$ is necessarily judicial. In this context, the faskh has to be understood as the dissolution of a marriage through the authority of the judge, because of specific diseases or defects in either spouse or non-payment of maintenance by the husband. ${ }^{153}$ The Hanbali also acknowledge the long absence of the husband and the situation that the husband does not act in accordance with (one of) the conditions of the marriage contract to be grounds for annulment.

In advance of their discussion in paragraph 3.7, the following addressing the legal effects of the judicial divorce can be mentioned briefly. The legal effects of the judicial repudiation, tatliq, largely correspond to those of the unilateral repudiation, talaq, and thus they reveal their relationship. The judicial repudiation is in principle irrevocable, but it is revocable if the divorce is based on grounds that are retrievable, such as non-payment of maintenance or refusal to sexual intercourse. If the husband actually pays the maintenance, no longer refuses sexual intercourse, etcetera, the ground for dissolution lapses, and the possibility to continue the marriage should exist. The judicial dissolution of the marriage by annulment definitively ends the marriage. After the judicial repudiation, the wife may be entitled to maintenance, the unpaid dower, and compensation; after the judicial dissolution by annulment, she is entitled to the unpaid dower.

Divorce Based on Agreement between the Spouses

In Islamic law, two modalities of divorce by agreement are traditionally distinguished: khul' and mubara'a. Khul' in its most common form is the repudiation by the husband on the demand of the wife, in exchange for compensation by her. ${ }^{154}$ The wife either renounces some or all of her financial post-divorce rights or loses her claim to them depending on the school of jurisprudence involved. She may also pay financial compensation or renounce her right to custody. Mubara'a is the repudiation by mutual consent of the spouses because

152 Linant de Bellefonds 1965, vol. II, p. 451, 465-470.

153 Linant de Bellefonds 1965, vol. II, p. 467-470.

154 Doi 2008, p. 297-299; Fyzee 2002, p. 163; Ja ‘far al-Sadiq, 2012, p. 86; Linant de Bellefonds 1965, vol. II, p. 421, 423; Maghniyyay 1997, vol. VI, p. 22; Mernissi 2004, p. 50; Schacht 1982, p. 164; Baillie (2010, p. 129, footnote 1) does not give any definition, but describes its form, ransom, conditions, and laws (p. 129-136). 
of mutual aversion and with the mutual waiving of their financial obligations. ${ }^{155}$ The Hanafi modality of the talaq 'ala mal resembles the $\mathrm{khul}^{\prime}$ 'but differs from it in respect of a specific legal effect. ${ }^{156}$ The husband receives compensation in exchange for the repudiation, but the mutual claims that have arisen from the marriage do not perish unless otherwise agreed upon. All these modalities give clearly evidence of their consensual element: either spouse demands divorce and the other spouse consents by his or her cooperation.

The repudiations by mandate and by authorization, talaq al-tawkil and talaq al-tafwid, are other modalities of divorce 'by mutual consent'. Depending on the specific modality, the husband hands over the right to repudiate to his wife or another person at the time of marriage or later. ${ }^{157}$ By exercising this right, if a particular event occurs in the case of a conditionally handed-over repudiation or otherwise, the wife 'consents' to the repudiation. For this reason, these modalities of repudiation have been classified in the category of divorce based on an agreement between the spouses.

\subsubsection{The Negotiated Repudiation, Khul}

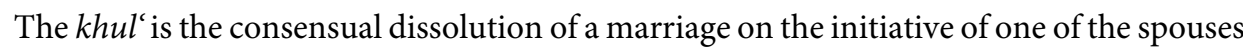
or a third person. ${ }^{158}$ As mentioned above, $k h u l$ ' has, in particular, to be understood as the wife's offer for compensation to the husband in exchange for the husband's renouncement of his marital rights to her through repudiating her.

The Arabic word $k h u l$ ' has been derived from the verb 'khala' $a$ ' that literally means 'to take off. ${ }^{159}$ In the context of the dissolution of marriage, it has to be interpreted as 'to lay down one's authority over the wife'. The word alludes to a metaphor from the Koran (2:187) that refers to the wife being the clothing for the husband and the husband being the clothing for the wife. When a wife feels aversion to her husband, ${ }^{160}$ she may take off

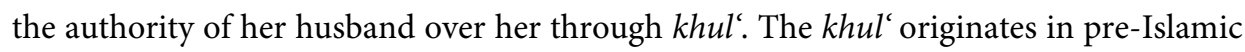
times. ${ }^{161}$ It was the right of the wife to dissolution of the marriage at that time. ${ }^{162}$ This

155 Baillie 1887, p. 137; Esposito 2001, p. 32; Fyzee 2002, p. 163; Ja'far al-Sadiq, 2012, p. 87; Mir-Hosseini 2000, p. 39; Schacht 1982, p. 164. Doi deviates from this definition by pointing out that it is mentioned in the fiqh that the wife drops a right or pays a consideration (2008, p. 298-299, 302). Linant de Bellefonds also deviates by stating that in the case of the mubara'a either the compensation lacks or is not of a pecuniary nature (1965, vol. II, p. 421 footnote 1).

156 Linant de Bellefonds 1965, vol. II, p. 446.

157 Linant de Bellefonds 1965, vol. II, p. 330-333.

158 Linant de Bellefonds 1965, vol. II, p. 423; Maghniyyah 1997, vol. VI, p. 24.

159 Fyzee 2002, p. 163; Mir-Hosseini 2000, p. 38-39.

160 Baillie 1887, p. 135; Ja'far al-Sadiq 2012, p. 86.

161 See for a legal-historical discussion of the khul': Kruiniger 2008, p. 92-95.

162 Naamane 1994, p. 157-158. 
modality of the dissolution of marriage is later found in the Koran and several ahadith. ${ }^{163}$ Its foundation is mentioned in Koran 2:229:

[...] It is not lawful for you, (Men), to take back any of your gifts (from your wives), except when both parties fear that they would be unable to keep the limits ordained by Allah. If ye (judges) do indeed fear that they would be unable to keep the limits ordained by Allah, there is no blame on either of them if she give something for her freedom. These are the limits ordained by Allah; so do not transgress them if any do transgress the limits ordained by Allah, such persons wrong (Themselves as well as others). ${ }^{164}$

The following can be derived from this text:

1. If it is feared that the spouses are unable to live in harmony and thus that 'they would be unable to keep the limits ordained by Allah', it is allowed that the wife ransoms herself by returning a gift from her husband; in such a situation, the $k h u l$ ' is permitted.

2. The gift of the husband refers to the dower; in the above-mentioned situation, the wife can demand that her husband repudiate her in exchange for the return or giving up of the dower.

3. The Koran text demonstrates that the $k h u l$ ', in order to be effective, demands not only the return of the dower to the husband by the wife but also his acceptance of the dower and, subsequently, the repudiation of the wife by him.

4. The use of 'both parties' in the first sentence refers to the requirement of the agreement on or consent to the khul' of both husband and wife.

5. If the husband refuses the offer of the wife to ransom herself, she has the right to demand the intervention of the judge for the settlement of the compensation and the repudiation; the judge has to supervise on earth that the limits ordained by Allah should not be transgressed.

Legal scholars, including the contemporary Moroccan scholar Khamlichi, have later used this text to defend the view that the khul' is the right to dissolution of the marriage of the wife. ${ }^{165}$ It should be considered as the mirror image of the right of the husband to repudiation. For this reason, the enforcement of this right by the wife should not be made dependent upon the consent of the husband. This view is in sharp contrast to the prevailing opinion among the classical schools of jurisprudence that the repudiation is the prerogative

163 Linant de Bellefonds 1965, vol. II, p. 422; Maudoodi 2000, p. 35-38.

164 See <http://quran.al-islam.org $>$.

165 Jordens-Cotran 2000, p. 160-161. 
of the husband and that, for this reason, the wife needs his consent to the repudiation and the compensation.

If, according to Shari' $a$ law, the wife wants to divorce, she has two options: either she seeks to convince her husband to agree upon the $k h u l$ ' in exchange for a compensation or she seeks to obtain a judicial divorce on certain grounds that allows her to keep her postdivorce rights and provisions. Because women have the choice between these two options,

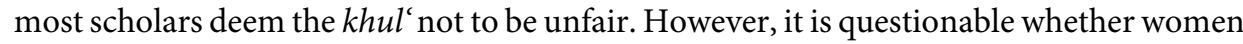
really have a choice. After all, their 'choice' for, more specifically, their access to a judicial divorce is restricted by the limited number of grounds for a judicial divorce. Moreover, women only obtain a judicial divorce if they are able to prove the ground invoked for the divorce.

The negotiated repudiation appeared to be rather successful, notably in those areas where the Hanafi and the Shafi $i$ doctrines prevailed. These two schools only occasionally grant the wife the possibility of the judicial divorce. The wife is left no other option than to buy off the repudiation from her husband. This was considered to be acceptable since it is the husband who has to provide for the dower and who has expenses in relation to the marriage. Hence, it is justified that the wife returns or gives up the dower if she would

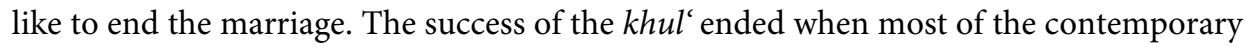
legislators, such as the Egyptian and Pakistani legislators, enlarged the grounds for judicial divorce with several grounds of Maliki origin through the method of takhayyur. ${ }^{166}$ This enlargement of the grounds facilitates the wife's access to divorce and, hence, to all its possible (financial) advantages. If, after a nevertheless long trial, the judge grants the divorce to the wife, she will retain most of her (financial) rights: her right to the (deferred) dower, possibly to the consolation gift (mut'a), the (outstanding) maintenance (nafaqa), the remuneration for the care for the children (ajr), and her right to custody (hadana). She should either have given up or forfeited by right these rights in the event of the khul'. Furthermore, the khul ' may induce blackmail practices. ${ }^{167}$ The husband can oppress his wife or make her life such a misery that she is forced to buy herself out of the marriage. The husband may ask any compensation of any proportions.

\subsubsection{Nature and Characteristics}

The khul' is, as the repudiation, morally considered either to be permissible, sometimes as recommendable, or even as obligatory depending on the circumstances of the spouses and their marriage. If a valid motive lacks, the khul' is reprehensible, which is judged by Allah in the hereafter in view of the Sunni schools of jurisprudence. ${ }^{168}$ Aversion to the

166 Linant de Bellefonds 1965, vol. II, p. 447.

167 Mernissi 2004, p. 51

168 Maghniyyah 1997, vol. VI, p. 22-23. 
husband is seen as a morally valid motive. The Ithna 'Ashari hold that a khul' that is not based on aversion is legally invalid. ${ }^{169}$ Consequently, the husband is not entitled to the compensation, although the repudiation, if it has been pronounced, will be valid and revocable!

A valid motive is not legally required, which explains the original absence of judicial

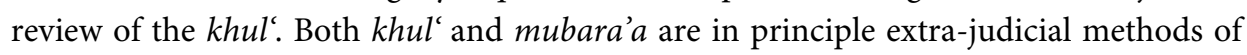
dissolving the marriage based on the mutual agreement of the parties, although the $\mathrm{khul}^{\mathrm{c}}$ can also be achieved through the order of the qadi. ${ }^{170}$ The opinion prevails within Islam that particular issues, including conflicts between the spouses, should preferably be solved 'at home', within the family, and certainly not in public court. ${ }^{171}$ Today, several contemporary legal systems, such as those of the four Muslim states being researched, require to various extents - the intervention of the judge, as will be discussed later.

The four Sunni schools of jurisprudence differ in opinion about the legal nature of the khul ${ }^{172}$ The Hanafi take the stance that the khul ${ }^{\prime}$ is a complex transaction that differs in character depending on the perspective of the wife or of the husband. The offer to repudiate by the husband is compared with an oath to repudiate. This view has a number of consequences including, inter alia, the prohibition for the husband to withdraw his offer to repudiate during the period of negotiations and his right to make the (pronouncement of the) repudiation subject to the factual payment of the compensation by the wife. From the perspective of the wife, the negotiated repudiation is a patrimonial act that is closely related to the gift. One of the consequences of this view is that the wife may reconsider her request.

The other three Sunni schools hold the khul' to be a bilateral contract, a reciprocal agreement (mu'awada). This implies that both spouses reciprocally perform according to the principle do ut des (I give so that you give). ${ }^{173}$ The husband renounces his marital rights to his wife through the repudiation, while in exchange the wife renounces specific (future) claims or compensates him. These three schools discern between the regular or 'pure' khul'

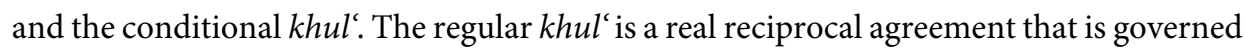
by the same rules as, for example, the contract of sales. The conditional $\mathrm{khul}^{\prime}$ deviates from the regular modality in that the effect of the khul' is made dependent on the accomplishment of a condition such as the actual payment of the compensation instead of just the obligation of the wife to pay the compensation. Hence, the modality of the conditional $k h u l$ ' approaches the view of the legal character of the khul' of the Hanafi.

All Sunni schools are concordant in their opinion that the khul' is an agreement or contract by nature. For this reason, the negotiation of the $k_{h u l}{ }^{c}$ is subject to the rules of

169 Baillie 1887, p. 133.

170 Doi 2008, p. 297; Linant de Bellefonds 1965, vol. II, p. 421; Pearl \& Menski 1998, p. 283.

171 Maudoodi 2000, p. 36.

172 Linant de Bellefonds 1965, vol. II, p. 423-429.

173 Buskens 1999, p. 146. 
the law of obligations. Consequently, it is required that both the husband and the wife (or the third person) are present when they enter into the agreement and that witnesses are present at the offer and acceptance; the absence of real and voluntary consensus between

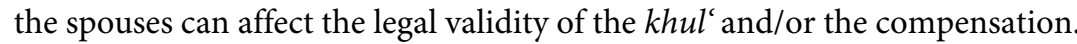

The Sunni schools also differ in opinion concerning two characteristics of the khul: the modality of the dissolution of the marriage that results from the khul' and the condition of the compensation. ${ }^{174}$ All schools except for the Hanbali and the Ithna 'Ashari consider the dissolution of marriage through the khul' to be a repudiation, talaq. The Hanbali and the Ithna 'Ashari have two views: either the dissolution of marriage through the khul' is a repudiation, talaq, or an annulment, faskh. ${ }^{175}$ All Sunni schools, except for the Shafi $i$, do not consider the (payment of the) compensation as an essential condition for the conclusion of the contract, although a lack of compensation is uncommon in practice. The Shafi ${ }^{i} i$

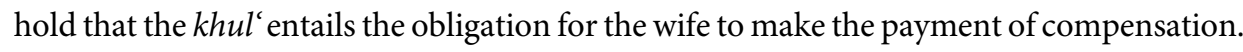
If the compensation is not mentioned in the contract or gets lost before payment to the husband, the wife should pay the (equivalent of the) proper dower.

The question arises why a husband should opt for the dissolution through $\mathrm{khul}^{\text {' } \text { instead }}$ of a unilateral repudiation if the compensation is not an essential condition for the khul and the husband does not insist on a compensation. The answer is that the khul' immediately results in an irrevocable and thus a definite dissolution of a marriage that in principle allows the spouses to remarry each other unless it was the third dissolution through a repudiation. The husband can achieve this result but through the khul' and the judicial divorce (on certain grounds). The unilateral repudiation is in principle revocable and, thus, does not immediately result in a final dissolution of marriage. And if it results in a final dissolution, because it is the third repudiation, it also has the effect of blocking the possibility of remarrying the same wife. Moreover, according to Hanafi law, the khulc without compensation entails the lapse of all the (financial) claims arising out of the marriage of both spouses. The husband may thus benefit from the $k h u l '$ if only because of this Hanafi rule, since it is the wife who is mostly the creditor because of her claims for the (deferred) dower and the overdue maintenance.

In practice, the contract is usually concluded between the husband and his wife or her legal guardian or representative. ${ }^{176}$ The contract can theoretically also be concluded between the husband and another third person, not being the legal guardian or representative of the wife. The husband, wife, and a third person are all allowed to initiate the negotiation of the khul', although it appears to be the wife who initiates it in practice. ${ }^{177}$ Whether or not she herself or a third person concludes the contract, the consent of the wife is required

174 Linant de Bellefonds 1965, vol. II, p. 423-425.

175 Baillie 1887, p. 129.

176 Linant de Bellefonds 1965, vol. II, p. 428-429.

177 Linant de Bellefonds 1965, vol. II, p. 436. 
if she bears the burden of the compensation and/or her property is being affected. If a third person bears this burden, her consent to the contract will not be required. In that situation, a khul' will nevertheless be established, if the husband accepts the proposal of the third person to pay for compensation in exchange for the repudiation and the husband repudiates his (own) wife.

To conclude this section about the nature and characteristics of $\mathrm{khul}^{\prime}$, it can be stated that the khul' is in fact a hybrid construction of a contract on the one hand and a dissolution of marriage by repudiation according to most schools of jurisprudence, on the other hand. An important feature of this type of divorce is its basis on the repudiation. Hence, the above-mentioned remarks on the type and characterization of the talaq also apply to the khul'.

\subsubsection{Requirements of Validity}

\subsection{Substantive Requirements of Validity}

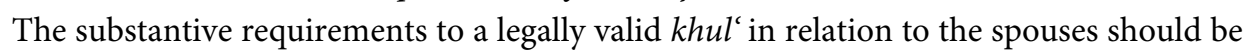
divided into the requirements of the husband and requirements of the wife. The husband should satisfy the same requirements as those for the repudiation concerning his legal capacity (being mature or, according to the Hanbali, at least a discerning minor and sane), his intention, and his being Muslim. ${ }^{178}$ This holds true at least for the all schools except the Hanbali and Ithna 'Ashari that see the khul' as a repudiation from the perspective of the husband. However, those Hanbali and Ithna 'Ashari that consider the khul' as an annulment require the same conditions: maturity, sanity, freedom of choice, and intention. ${ }^{179}$ As the $\mathrm{khul}^{\text {c }}$ is considered to be a patrimonial act closely related to the gift from the perspective of the wife, she should meet the following requirements of legal capacity (being mature and sane or represented by her legal guardian) and the absence of coercion in respect of her consent to the khul'. ${ }^{180}$ The Ithna 'Ashari are of the opinion that the wife should meet all the requirements that she has to fulfil in respect of a repudiation such as that she is in her period of purity. ${ }^{181}$

The Ithna 'Ashari and Hanbali require the khul' to be unconditional and the payment of the compensation at the moment of the pronouncement of the khul. ${ }^{182}$ The other Sunni schools are divided in opinion in these respects. The Hanafi, for example, allow the condi-

178 Linant de Bellefonds 1965, vol. II, p. 326-346, 430; Maghniyyah 1997, vol. VI, p. 30-31.

179 Baillie 1887, p. 133.

180 Baillie 1887, p. 134; Linant de Bellefonds 1965, vol. II, p. 430-435; Maghniyyah 1997, vol. VI, p. 28-30. See for a more elaborate discussion: Kruiniger 2008, p. 100-101.

181 Baillie 1887, p. 133.

182 Baillie 1887, p. 133; Magniyyah 1997, vol. VI, p. 31-32. 


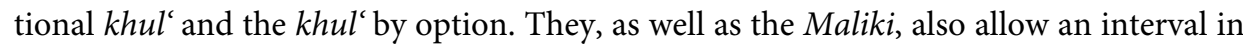
time between the pronouncement of the $\mathrm{khul}^{\mathrm{c}}$ and the payment of the compensation.

\subsection{Formal Requirements of Validity}

As far as the formal requirements are concerned, the four Sunni schools are unanimous

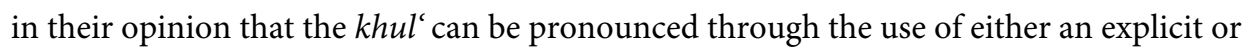
an implicit formula. ${ }^{183}$ The Hanbali even allow the pronouncement through the use of explicit wordings although the intention is lacking. The Ithna 'Ashari only allow the use of the wordings 'al-khul' and 'al-talaq' although they may be used in combination with other explicit or even implicit wordings. ${ }^{184}$ Moreover, the Ithna 'Ashari require the presence of two just witnesses as well. ${ }^{185}$

\subsubsection{Nature and Proportions of the Compensation}

All schools of jurisprudence agree that the compensation, 'iwad or badal, by the wife may include anything that can be offered as dower by the husband. ${ }^{186}$ According to the Shafi $i$,

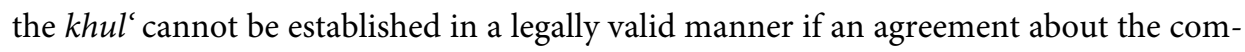
pensation is lacking. If the compensation includes indefinite elements, the husband will be entitled to a compensation that equals the value of the proper dower. The other three

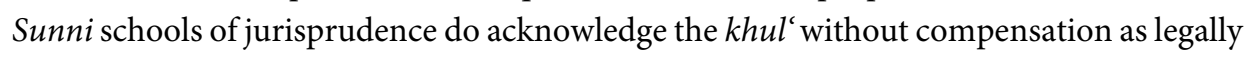
valid and allow a compensation that includes indefinite elements. The effects that the schools attach to the khul' with such a compensation depend on the nature of the indefiniteness. First, the indefiniteness that concerns the nature or proportions of the compensation is at the husband's risk if he has accepted the offer for compensation from the wife and has repudiated her. The husband is entitled to an amount equal to the value of the contracted or proper dower as has been received by the wife, if the offer for compensation appears to be void according to the Hanbali and Hanafi. In the opinion of the Maliki, the husband does not receive anything, but the wife has been repudiated. Second, if the indefiniteness does not concern the nature or proportions but the quality of the object of compensation, the husband will be entitled to an object of a standard quality. If, according to the Hanbali and Hanafi, that quality determines the value of the object, the husband will be entitled to the dower that has been received by the wife. Third, if the compensation consists of an object that does not exist yet, for example, a harvest in the future, the husband will also be entitled to the dower as has been received by the wife.

In the Hanbali, Shafi $i$, and Maliki doctrine, the compensation usually consists of the renouncement of (future) claims on the husband by the wife, such as the claim for the

183 Maghniyyah 1997, vol. VI, p. 31-32.

184 Baillie 1887, p. 129.

185 Baillie 1887, p. 134; Maghniyyah 1997, vol. VI, p. 30.

186 Linant de Bellefond 1965, vol. II, p. 436-441; Maghniyyah 1997, vol. VI, p. 23-24. 
deferred dower or for overdue maintenance. The claims arising out of the marriage cannot be stipulated as compensation since they expire by right through the $\mathrm{khul}^{\text {' according to }}$ the Hanafi doctrine, unless the husband has explicitly excluded a compensation. ${ }^{187}$ In their opinion, the purpose of the khul' is not only to end the marriage but also the financial problems between the spouses. This is a cause of the bad relationship between them. Therefore, the mutual claims that arise from the marriage should perish together with the marriage itself. If not, the main purpose of the khul', its calming effect as expressed in the Koran, cannot be realized. ${ }^{188}$ However, one should realize in this respect that it is the wife who usually is the creditor of the husband and, what is more, that she also has to pay compensation.

The compensation by the wife according to the Hanafi usually consists of an amount of money, for example, for the value of the dower, or the taking over of (one or more of the) post-divorce obligations of the husband such as the maintenance obligation of the children. The latter is rejected from an ethical-religious perspective, but it is acceptable from a legal perspective. The compensation may also be related to (the modification of) the custody, hadana ${ }^{189}$ However, custody, especially its order of custodians, is a subject of imperative law in the fiqh. The spouses are thus not allowed to deviate from these rules by agreement. If the agreement contains such a deviating clause, the $\mathrm{khul}^{\text {' }}$ will be legally valid and the repudiation will be established, but the clause is considered as not to be agreed upon and thus as null and void. An exception occurs in the Hanafi doctrine: if the clause concerns a stipulation about the custody of a daughter and this stipulation is not disadvantageous, the clause will be legally valid.

Furthermore, the compensation should not consist of unlawful, illegal, or improper objects, issues, or goods, such as pork meat, alcohol, etcetera. If the husband nevertheless wittingly accepts such a compensation, the $\mathrm{khul}^{\text {' }}$ is partially null and void. The repudiation will be established and even possibly revocable in the opinion of the Ithna 'Ashari, but the husband will not be entitled to anything or, according to the Shafi $i$, to an amount that equals the value of the proper dower. ${ }^{190}$ If the husband has been misled about the unlawful, illegal, or improper content of the compensation by the wife, the khul' is null and void. The compensation is neither bound to a minimum nor to a maximum. The latter though may lead to abuse.

187 Linant de Bellefonds 1965, vol. II, p. 443-444.

188 See Koran 2:229.

189 Maghniyyah 1997, vol. VI, p. 26-28.

190 Maghniyyah 1997, vol. VI, p. 25. 
The mubara'a resembles the khul' insofar as the marriage is also dissolved through the repudiation of the wife by the husband. However, the Hanafi consider these terms as synonyms. ${ }^{191}$ The $k$ hul $^{\prime}$ originates in the aversion of her husband by the wife, whereas in the case of the mubara' $a$ the aversion is mutual. ${ }^{192}$ The word mubara' $a$ refers to the 'act of "freeing one another mutually"' ${ }^{193}$ The mubara'a requires the pronouncement of the word talaq in order to bring about the dissolution according to all schools, whereas these schools are divided in opinion regarding the necessity of the wordings of talaq and khul in the case of the khul'.

The compensation by the wife may not exceed the value of the gifts by her husband in the case of the mubara'a. ${ }^{194}$ In the case of the khul', the compensation, as mentioned in section 5.6.1.3, is not limited to a minimum or maximum. The mubara' $a$ in principle results in a single, irrevocable divorce because of the mutual exchange of compensation. But if the wife reclaims the compensation during her waiting period, the husband will be entitled to revoke the repudiation as well. ${ }^{195}$

\subsubsection{The Repudiation by Mandate or Authorization, Talaq Al-Tawkil or Talaq Al-Tafwid}

\subsubsection{Tawkil: The Mandate to Repudiate}

Two main forms of handing over the power to repudiate should be distinguished. ${ }^{196}$ First, all schools of jurisprudence acknowledge the tawkil: the mandate to repudiate on his behalf that the husband can give to any other competent person, including to his wife. ${ }^{197}$ The mandate may be subject to conditions. The husband can in principle withdraw the mandate until the moment of its execution by the other person unless the mandate has been made dependent on a right of the wife. ${ }^{198}$ An example is the mandate to the wife to repudiate herself, if her husband marries a second wife. The husband himself retains the power to repudiate. The repudiation as a result of the mandate is in principle revocable unless it concerns repudiation before the consummation of the marriage or a third repudiation. ${ }^{199}$

191 Linant de Bellefonds 1965, vol. II, p. 421 footnote 1.

192 Baillie 1887, p. 136-137; Fyzee 2002, p. 163; Ja'far al-Sadiq 2012, p. 87.

193 Fyzee 2002, p. 163.

194 Ja'far al-Sadiq 2012, p. 87.

195 Baillie 1887, p. 137; Ja'far al-Sadiq 2012, p. 87.

196 See Koran 33:28-29.

197 Boumans 1990, p. 104-105; Linant de Bellefonds 1965, vol. II, p. 330-331; Baillie 1887, p. 109.

198 Linant de Bellefonds 1965, vol. II, p. 331; Boumans 1990, p. 105.

199 Boumans 1990, p. 105. 
According to the Hanafi, the wife is not allowed to use the mandate to repudiate herself but only to repudiate other wives of her husband. ${ }^{200}$

\subsubsection{Tafwid: The Authorization to Repudiate}

The mandate can explicitly not be equalled to the second form, the authorization to repudiate or tafwid. The tafwid is the assignment of the authority to repudiate to the wife by the husband. From relevant literature, it is unclear as to whether or not her consent is required. ${ }^{201}$ The tafwid does not require a specific formula as long as it expresses the intention of the husband to authorize his wife to repudiate herself..$^{202}$ The Hanafi and the Maliki may attach different legal effects to the formula depending on the one that the husband has used. The Hanafi consider, for example, the formula 'you are the captain of your soul' only to be effective if it is expressed accompanied by the intention of the husband to terminate the marriage. The Maliki consider this formula to express the right of option, takhyir, one of the two sub-forms of tafwid to be discussed below. By assigning the authorization to repudiate to his wife, the husband does not renounce the right to repudiate his wife. ${ }^{203} \mathrm{He}$ retains this right although it is unclear whether he is allowed to exercise the right himself while the wife has not yet done it herself. Once he has authorized his wife, he cannot revoke the authorization except in the case of authorization before the consummation of the marriage. ${ }^{204}$ The Shafi $i$ and Hanbali hold that the tafwid given to a person other than the wife is nothing more than a mandate, tawkil. The majority of the Ithna 'Ashari withholds legal validity from the tafwid. ${ }^{205}$ In their opinion, the right to repudiate is attached to the person of the husband who is not allowed to renounce this right.

The Maliki distinguish two sub-forms of tafwid. ${ }^{206}$ The first sub-form, takhyir, gives the authorized wife the option to choose between the continuation and the definitive dissolution of the marriage. Through the second form, tamlik, the authorized wife can repudiate herself in a revocable or irrevocable manner.

\subsubsection{The Self-Repudiation Further Explained}

When the husband hands over the power to repudiate to his wife through one of these three forms, she obtains in principle the right to repudiate herself (self-repudiation) without

200 Linant de Bellefonds 1965, vol. II, p. 331.

201 According to Linant de Bellefonds 1965 (vol. II, p. 332-333), her consent is not required. However, Boumans (1990, p. 104) states that the wife's right to self-repudiation is invalid if she does not accept or refuses the offer to authorization to repudiate from her husband.

202 Linant de Bellefonds 1965, vol. II, p. 359.

203 Boumans 1990, p. 104, notably endnote 5.

204 Boumans 1990, p. 104.

205 Baillie 1887, p. 114; Linant de Bellefonds 1965, vol. II, p. 359; Maghniyyah 1997, vol. VI, p. 8.

206 Boumans (1990, p. 103) does not mention this subdivision; he just distinguishes among the tamlik, takhyir, and tafwid. 
interference by the judge. ${ }^{207}$ The husband can hand over this power at any moment or during the marriage, inter alia, as stipulation in the marriage contract, through an oral statement, or preferably in a separate contract. ${ }^{208}$ Marriage settlements in a marriage contract are considered to be condemned.

The wife may lose the right to self-repudiation through authorization, inter alia, through lapse of the period within which she had to use this right or if she allows her husband to have sexual intercourse. ${ }^{209}$ The latter stands for the return of conjugal power. After all, the right to self-repudiation through authorization is not intended to last without restriction. ${ }^{210}$ As soon as the wife has been authorized to repudiate, she must decide as to whether or not to make use of this right, unless the authorization has been made dependent on a specific condition, whether or not in the future. Then that condition activates the wife's right as soon as it has been fulfilled. The tafwid should in any case not be stipulated unconditionally in the marriage contract. An unconditional authorization to repudiate would lapse as soon as the marriage has been consummated.

The conditions should be reasonable and not violating public policy. ${ }^{211}$ Some conditions may offer the wife broad prospects for divorce. ${ }^{212}$ An example in this respect is the wife's right to self-repudiation for harm done by her husband without having the obligation to produce evidence of this harm. A stipulation for the authorization to self-repudiation by the wife may also reinforce marriage settlements, for example, in relation to a possible polygamous marriage of the husband, since these marriage settlements are merely morally binding. The sanction on noncompliance with these settlements is then the self-repudiation by the wife.

The right to self-repudiation can thus be distinguished as either the 'absolute' or 'dependent' right. ${ }^{213}$ The absolute right is immediately effective. The husband gives the wife the choice between the continuation and the termination of the marriage. It thus requires the cooperation of the husband for the dissolution. The dependent right to selfrepudiation is the wife's right to dissolution that depends upon the fulfilment of a condition, whether or not in the future. Hence, the cooperation of the husband for the dissolution is not required if, of course, that condition has been fulfilled. At that moment, the wife becomes entitled to dissolve the marriage through self-repudiation.

The wife is entitled to the same post-divorce provisions as in the case of the repudiation by the husband himself. ${ }^{214}$ For this reason, the wife is not entitled to a consolation gift in

207 Boumans 1990, p. 104.

208 Boumans 1990, p. 103-104, 105.

209 Boumans 1990, p. 104.

210 Boumans 1990, p. 104.

211 Fyzee 2002, p. 158-159.

212 Boumans 1990, p. 104.

213 Boumans 1990, 105.

214 Boumans 1990, p. 106. 
relation to tafwid. One should not perceive the tafwid as the repudiation by the husband himself.

Repudiation is, as has already been mentioned above, in principle, the absolute right of the husband. He is considered to be more rational and to bear the heaviest financial burdens in relation to marriage and divorce. Islam has therefore assigned those rights (or duties) to the husband or wife, to whoever is suitable. Handing over the power to repudiate modifies the existing division of marital rights and duties. For these reasons, handing over the power to repudiate has encountered and still encounters opposition in Islamic society and from men in particular.

\subsection{After Divorce}

The divorce in principle ends the legal relationship between the spouses for the future. The dissolution through the annulment or faskh ends the marriage definitively and at once, whereas the various modalities of divorce based on the repudiation can be either revocable or irrevocable. The significance and consequences of this distinction are set out in the next subsection.

Depending on the modality of the dissolution of the marriage, its revocability or irrevocability, and the individual circumstances of the spouses involved, the (ex-)wife is confronted with specific personal and legal effects of the divorce. ${ }^{215}$ The focus of the other subsections in this section is on the most significant consequences for her: the waiting period or 'idda; the husband's duty to maintenance or nafaqa; her right to the deferred dower or mahr; the financial consolation or $m u t^{\prime} a$; the right to take care of the child, the right to custody or hadana; and inheritance rights.

Divorce and its personal and legal effects and/or post-divorce provisions are intertwined in Shari' a law: the wife's entitlement, or not, to those legal effects may influence her possible choice for divorce and for a specific type of divorce (if she has any choice at all). Consequently, this intertwining influences the wife's accessibility to divorce. However, recognition of the divorce by another state does not automatically involve the recognition of the legal effects or post-divorce provisions. Recognition of these issues is usually assessed individually and separately from the issue of the recognition of the divorce itself in private international law. As this study focuses on the recognition of the various modalities of 'Islamic' divorce in Europe and not on their legal effects or provisions, the discussion of the latter is therefore restricted to their most significant features.

215 Most of these legal consequences of divorce have been mentioned in the Koran, such as the waiting period, the (im-)possibility to remarry, the (ir-)revocability of the divorce, the duty of maintenance of the husband, the dower, etcetera; see Koran 2:226-232; 2:234-237; 2:49; 65:1-7. 


\subsubsection{Revocability or Irrevocability of the Divorce}

The faskh, as it has already been mentioned, immediately and definitively dissolves the marriage. The various modalities of divorce based on the repudiation, talaq, in its broad meaning, can be either revocable $\left(r a j^{i} i\right)$ or irrevocable $\left(b a^{\prime} i n\right) .{ }^{216}$ In the case of the revocable repudiation, the husband has the right to revoke the pronouncement of the repudiation during the waiting period of his wife in order to take her back and to resume the marriage, whereas in the case of the irrevocable repudiation, he does not have this right. The revocable repudiation does not immediately dissolve the marriage and its ensuing rights and duties, whereas the irrevocable repudiation does upon its pronouncement (or execution in another form). The legal effects of the repudiation-based divorce may differ depending on, inter alia, this distinction. Whether the repudiation-based divorce is revocable or irrevocable is dependent on its form (single or triple) and the number of its pronouncements, on the issue of whether or not the underlying marriage has been consummated, and on the issue of whether or not a consideration has been paid for the divorce and thus on the modality of repudiation-based divorce. ${ }^{217}$ The repudiation in the case of a marriage that has not been consummated is always irrevocable, as the repudiated wife does not have to observe a waiting period during which the repudiation could be revoked. ${ }^{218}$

A more detailed discussion of this distinction between revocable and irrevocable divorces is the focus of the next two subsections.

\subsubsection{The Revocable Repudiation-Based Divorce}

After the first and second single repudiation of the same wife after the consummation of the marriage, the husband can revoke the repudiation during the waiting period of his wife in order to reconcile and resume the subsisting marriage. ${ }^{219}$ The revocation results in the continuation of the marriage.

The revocable repudiation does not immediately and completely end the marital bond. ${ }^{220}$ The marriage subsists during the waiting period of the wife. The obligation of the husband to provide maintenance to his wife, the obedience duty of the wife except for her sexual submission, and the mutual inheritance rights of the spouses continue to exist during this period. The husband cannot require his wife's sexual submission, as resuming their sexual

216 Doi 2008, p. 277; Linant de Bellefonds 1965, vol. II, p. 307, p. 393-418; Maghniyyah 1997, vol. VI, p. 15. Although most consulted authors refer to the talaq ba'in as being irrevocable, Doi refers to the talaq ba'in as being final, but not irrevocable.

217 Maghniyyah 1997, vol. VI, p. 16.

218 Based on Koran 33:49.

219 Talaq raj' $i$ is based upon Koran 2:228, 2:229, and 2:231. Linant de Bellefonds 1965, vol. II, p. 395-403. Maghniyyah 1997, vol. VI, p. 15-16.

220 Linant de Bellefonds 1965, vol. II, p. 395-396. 
relationship implies an explicit or tacit revocation. ${ }^{221}$ The husband may repudiate again, if the maximum number of three repudiations that equals a marriage impediment has not yet been reached, or the spouses may agree upon a khul' during the waiting period. All the marriage impediments that result from the marital bond of the spouses continue to exist for the husband, while the wife cannot remarry, until after the expiration of her waiting period. The wife cannot claim her (deferred) dower but upon the expiration of that period.

\subsection{The Revocation}

The revocation has to be understood as the unilateral right of the husband to retract his pronouncement of the repudiation that is revocable in order to resume the marriage before the expiration of the waiting period of the wife. ${ }^{222}$ The husband exercises his right to take back his wife through the revocation. The revocation should not be considered as equal as remarriage including its requirement of a new dower. The husband cannot renounce his right to revocation since it is a right of public order. ${ }^{223}$

\subsection{Requirements to the Revocation}

The modalities of and the substantive and formal requirements of revocation may vary depending on the view of the various schools of jurisprudence. The following is relevant in relation to the capacity of the husband who revokes. ${ }^{224}$ The insane husband, nor his wali as his substitute except according to the Shafi $i$ i and Hanbali, is allowed to revoke. As it is the unilateral right of the husband, he can in principle not be forced to revoke, for example, by the judge or his wife. ${ }^{225}$ Revocation under duress annuls the revocation except according to the Hanafi. The Maliki hold that the husband should revoke the repudiation that he has pronounced during the menstruation of his wife. The revocation pronounced in drunkenness is legally valid if the husband has become drunk voluntarily and on purpose; it is invalid if the husband is not to blame for his drunkenness. The revocation pronounced by the person who is insolvent, by the prodigal and the revocation pronounced in jest is legally valid. However, the Hanafi hold that all the above-mentioned rules concerning the revocation by the insane, the insolvent person, and the prodigal or pronounced under duress, in drunkenness, or in jest apply in the case of an explicit revocation. The implicit

221 The Hanafi and the Hanbali authorize the husband to resume the sexual relationship with his wife without a formal revocation; resuming the sexual relationship is seen as a tacit revocation. The Maliki and Shafi $i$ require a formal revocation before the spouses are allowed to resume their sexual relationship; resuming their sexual relationship without formal revocation is considered to be fornication, zina. Fornication between persons who have already had legitimate sex in their life is punishable by lapidation if it has been proven or confessed (Linant de Bellefonds 1965, vol. II, p. 396).

222 Linant de Bellefonds 1965 vol. II, p. 397.

223 Linant de Bellefonds 1965, vol. II, p. 397.

224 Linant de Bellefonds 1965, vol. II, p. 397-398.

225 See Koran 2:228. 
or tacit revocation, for example, by restoring the sexual relationship, does not impose requirements of capacity on the husband in order to result in a valid revocation.

The husband can orally revoke, or revoke in writing, through acts or deeds such as sexual intercourse or through gestures in the case that he is mute according to most schools of jurisprudence. ${ }^{226}$ The oral revocation can be done in explicit or in figurative terms. However, the latter form either requires the confirmation under oath of the intention to revoke from the husband or is considered to be invalid according to the Shi ${ }^{\prime} a$ and to some Hanbali. All Sunni and Shi'a schools, except for the Shafi $i$, acknowledge that specific acts or deeds can equal an explicit revocation. According to the Shafi $i$, the husband can only explicitly revoke the repudiation through its oral expression. Resuming the sexual relationship without formal oral revocation equals fornication. The latter can be exonerated through an appeal to the theory of shubha in order to circumvent the severe punishment of stoning provided for by the Koran. The Maliki hold that only the intimate acts and gestures including resuming the sexual relationship, which were initiated by the husband while having the intention to revoke, equal a revocation; without this intention, these intimate acts equal fornication. In the Hanafi doctrine, every intimate act, including resuming the sexual relationship, or gesture by the husband and/or the wife equals a (tacit) revocation. The Ithna 'Ashari in principle consider every act that would convey the husband's intention to take back his wife to be a revocation. But sexual intercourse, even without the intention of the husband to take his wife back, results in a revocation.

The conditional formula of revocation is null and void, although the Maliki consider this issue to be controversial. The husband can authorize another person, including his wife, to revoke on his behalf. The wife's consent to the revocation is not required due to the unilateral character of the revocation and for the reason that she still is his wife. ${ }^{227}$ However, all Sunni and Shi ${ }^{i}$ a schools agree that it is recommended that the husband should inform his wife about the revocation at the earliest occasion possible. She should not remain under the illusion that she will be divorced and be able to marry someone else upon the termination of her waiting period. The presence of witnesses at the revocation is also not required, but it is recommended to provide proof of the revocation. ${ }^{228}$

If the husband does not revoke the first or second single repudiation during the waiting period of the wife, he loses this right upon the expiration of that period. ${ }^{229}$ The repudiation becomes final, and the marriage, including its rights and duties, immediately and definitively ends. The spouses need to remarry in order to re-unite. ${ }^{230}$ The revocable repudiation, whether or not it has been revoked, counts in the total sum of three repudiations after

226 Baillie 1887, p. 127; Ja'far al-Sadiq 2012, p. 85; Linant de Bellefonds 1965, vol. II, p. 396, 398-399, 401-403.

227 Baillie 1887, p. 127. Linant de Bellefonds 1965, vol. II, p. 399-400.

228 Based on Koran 65:2.

229 Linant de Bellefonds 1965, vol. II, p. 393, 396.

230 Koran 2:232. 
which the repudiation becomes irrevocable and the spouses are no longer allowed to remarry each other directly but only after an intermediate marriage of the wife with another $\operatorname{man}^{231}$

\subsubsection{The Irrevocable Repudiation-Based Divorce}

The irrevocable repudiation excludes the possibility of revocation of the repudiation, and the marriage immediately and definitively ends as soon as the repudiation has been pronounced. ${ }^{232}$ Consequently, all duties and rights, including the mutual inheritance rights, ${ }^{233}$ ensuing from the marriage except for the former wife's right to maintenance, end. ${ }^{234}$ The Hanafi entitle her to the entire right of maintenance during her waiting period, whereas the other schools restrict her entitlement to maintenance to the right of accommodation. ${ }^{235}$ The irrevocably repudiated pregnant woman is entitled to the entire maintenance until childbirth. The (deferred) dower is immediately due on the demand of the former wife.

\subsection{Minor versus Major Variant}

The irrevocable repudiation can be subdivided into the minor, sugra, and the major, kubra, variant. ${ }^{236}$ The irrevocable repudiation is considered to be minor if the spouses are allowed to remarry each other after the repudiation. ${ }^{237}$ Minor variants of the irrevocable repudiation are, respectively, the repudiation before the consummation of the marriage; the negotiated repudiation $(\mathrm{khul}) ;{ }^{238}$ the divorce by agreement, mubara' $a$; and, in most cases according to the Maliki, the judicial divorce (repudiation) for rescinding vices of either spouse, because of imprisonment of the husband, because of the long absence of the husband resulting in damage for the wife, because of discord between the spouses or insupportable harm by the husband, because of non-payment of the contracted dower, and because of the inferior religious status of the husband compared with the religious status of the wife. ${ }^{239}$ The Ithnā 'Ashari hold that also the repudiation of the wife in her menopause is irrevocable. ${ }^{240}$ The Hanafi, as opposed to the other schools, acknowledge the use of specific for-

231 Linant de Bellefonds 1965, vol. II, p. 396-397.

232 Linant de Bellefonds 1965, vol. II, p. 393; Maghniyyah 1997, vol. VI, p. 16-18.

233 The mutual inheritance rights cease to exist upon the pronouncement of the irrevocable repudiation, if the repudiation has not been pronounced in articulo mortis of the husband, thus in circumstances of terminal illness or of war. In the latter case, various schools of jurisprudence entitle the wife to inherit from her former husband nevertheless.

234 Based upon Koran 2:241 and 65:6.

235 Linant de Bellefonds 1965, vol. II, p. 404, 410.

236 Linant de Bellefonds 1965, vol. II, p. 393-394.

237 Linant de Bellefonds 1965, vol. II, p. 404-409.

238 Based upon Koran 2:229.

239 Linant de Bellefonds (1965, vol. II, p. 407) mentions that the repudiation because of discord is unknown in all schools in classical Shari'a law except in the Maliki school.

240 Ja'far al-Sadiq 2012, p. 85; Maghniyyah 1997, vol. VI, p. 17. 
mulas to repudiate that result in an irrevocable repudiation of the minor variant, for example, the repudiation that is pronounced in figurative terms or the repudiation that is compared to something voluminous. These formulas should not be assimilated with a triple repudiation and, for this reason, cannot result in the following variant of the irrevocable divorce.

That variant of the irrevocable divorce is the major, irrevocable repudiation in which the husband is not allowed to remarry his former wife but after the so-called intermediate or legitimizing marriage of his former wife with another man (the tahlil procedure). ${ }^{241} \mathrm{An}$ example of this variant is the third repudiation after two previous, revocable or irrevocable, repudiations or the triple repudiation. The major irrevocable repudiation results in a relative marriage impediment for the former spouses. Its implications, apart from the fact that it is impossible to revoke the repudiation, it is impossible to directly remarry his former wife and the tahlil procedure, should be considered as a deterrent from capricious repudiations as well as a sanction for the husband who has abused the repudiation. According to the $S h i^{\prime} a$, three times three repudiations result in an absolute impediment to marriage between the same spouses. ${ }^{242}$

\subsection{Tahlil Procedure}

The tahlil procedure consists of several steps: (1) the repudiated wife has to contract a legally valid and genuine permanent marriage with another man,(2) that marriage should be consummated, (3) that marriage should be dissolved through death of or repudiation/divorce by that other husband, and (4) the wife should observe the prescribed waiting period after that specific dissolution; upon termination of that waiting period, she may remarry her previous husband. ${ }^{243}$ The crux of this procedure is the consummation of the intermediate marriage. The thought alone that his wife would sleep with another man should deter the husband from repudiating his wife for a third time or thrice. Yet, the wife is not held to confirm, even not under oath, that her intermediate marriage has been consummated; the consummation will be presumed. Fraud is not feared, as fraud is considered to be a sin.

The tahlil marriage should have been contracted for genuine reasons such as starting a family. ${ }^{244}$ It should not have been contracted with the sole intention to legitimize the remarriage of the wife with her previous husband. It will not remove the impediment except in the view of the Hanafi. They hold that whether or not an explicit agreement in view of such a legitimizing purpose between the previous and second husband exists, the

241 Based on Koran 2:230. Linant de Bellefonds 1965, vol. II, p. 410-418.

242 Baillie 1887, p. 119; Maghniyyah 1997, vol. VI, p. 21.

243 Baillie 1887, p. 124-126; Ja'far al-Sadiq 2012, p. 86; Linant de Bellefonds 1965, vol. II, p. 413-418; Magniyyah 1997, vol. VI, p. 19-20.

244 Linant de Bellefonds 1965, vol. II, p. 416-417. 
intermediate marriage is legally valid but morally reprehensible. Moreover, the marriage results in the possibility of remarriage between the previous husband and the wife after her repudiation by the second husband.

The Hanafi are also of the opinion that the consummated marriage of the former wife with another man should not be understood as an intermediate marriage, so not as part of the tahlil procedure, and nevertheless purges the previous repudiations of the first husband. When the latter remarries his former wife after such a marriage, he will be entitled to a new right to repudiate her three consecutive times.

\subsubsection{Waiting Period}

After almost every revocable and irrevocable modality of dissolution of the - permanent or temporary - marriage, the wife should observe a period of continence or waiting period, 'idda, during a prescribed number of menstrual cycles or months before being capable of re-marriage. ${ }^{245}$ Only in the case that the marriage has not been consummated and that marriage has been dissolved otherwise than by the death of the husband, the waiting period is not mandatory for the wife. The meaning of the notion refers to the counting of the periods of chastity that have to be observed by the wife after the dissolution of marriage or for another reason. ${ }^{246}$ Various types of waiting periods should be distinguished dependent on the school of jurisprudence, apart from the waiting period after the divorce or annulment: the waiting period of the widow after the death of her husband, the waiting period of the wife who had sexual intercourse by mistake, the waiting period of an adulteress, and the waiting period of the wife whose husband has disappeared. ${ }^{247}$

\subsubsection{Purposes}

The purposes of this period in relation to divorce or annulment are twofold. ${ }^{248}$ The first one is to ascertain a possible pregnancy, and, thus, it serves the interest of certainty of the paternity of unborn children. ${ }^{249}$ The pregnant wife has to observe a waiting period until the delivery of the child. The waiting period after both the revocable and the irrevocable divorce serves this goal. Second, the waiting period offers the spouses the opportunity to reconcile. ${ }^{250}$ The husband can revoke his pronouncement of the repudiation in the case of

245 Baillie 1887, p. 160-173; Doi 2008, p. 307-313; Fyzee 2002, p. 107-109; Ja far al-Sadiq 2012, p. 82-84; Linant de Bellefonds 1965, vol. II, p. 393-417 (relevant passages); Maghniyyah 1997, vol. VI, p. 32-53; Schacht 1982, p. 166.

246 Doi 2008, p. 307

247 Maghniyyah 1997, vol. VI, p. 33.

248 Doi 2008, p. 307-308.

249 Fyzee 2002, p. 108.

250 Linant de Bellefonds 1965, vol. II, p. 393, 395. 
a revocable repudiation and the judicial divorce on specific grounds before the lapse of the waiting period. Hence, the marriage can be resumed. In the case of an irrevocable repudiation, the spouses can also reconcile during the waiting period, but in that case they have to remarry.

The expiration of the waiting period of the revocable divorce without revocation results in the effectiveness of the divorce and thus in the definitive end of the marriage and its inherent marital rights and duties. ${ }^{251}$ The wife regains the capability to marry.

\subsubsection{Duration}

The waiting period of the wife starts on the day of the (pronouncement of the) divorce. ${ }^{252}$ Its length depends on the condition of the wife at the moment it begins and, if relevant, on the type of marriage, temporary or permanent. The condition of the wife refers to her having her menses or not (for example because of being before puberty or after the menopause) or being pregnant or not. The waiting period after a temporary marriage, for example, lasts two months; the waiting period of a pregnant woman lasts, as mentioned, until the delivery of the child; the waiting period of an adult woman who has regular menses is three periods of purity from her menses or three periods of menses dependent on the school of law involved. ${ }^{253}$

\subsubsection{Rights and Duties of the Wife}

The wife has several rights and duties during her waiting period. ${ }^{254}$ She is not allowed to have any sexual intercourse nor to get engaged or marry during this period. Sexual intercourse between the spouses during the waiting period of a revocable divorce amounts to revocation of the divorce by the husband. During the waiting period of the revocable divorce, the marriage and, thus, most marital rights and obligations subsist. One could think of the right to maintenance of the wife including her right to stay in the marital house and the mutual inheritance rights. ${ }^{255}$ The irrevocably repudiated wife is in principle not entitled to maintenance and to stay in the marital house during her waiting period unless she is pregnant. The wife's right to maintenance is further discussed in the next subsection.

251 Linant de Bellefonds 1965, vol. II, p. 396.

252 Baillie 1887, p. 172; Ja'far al-Sadiq 2012, p. 83; Linant de Bellefonds 1965, vol. II, p. 396.

253 Baillie 1887, p. 160-164; Doi 2008, p. 308-310; Fyzee 2002, p. 108; Ja far al-Sadiq 2012, p. 82-83; Maghniyyah 1997, vol. VI, p. 34-39; Mir-Hosseini 2000, p. 165; Schacht 1982, p. 166.

254 Baillie 1887, p. 169-172; Doi 2008, p. 310-313; Linant de Bellefonds 1965, vol. II, p. 396, 404, 410; Maghniyyah 1997, vol. VI, p. 50-54.

255 See e.g. Koran 65:2 or 65:6. 


\subsubsection{Maintenance}

\subsubsection{Nafaqa versus Alimony}

The concept of maintenance in Shari'a law, nafaqa, has to be distinguished from the Occidental concept of alimony, as maintenance in Shari' $a$ law is one of the financial obligations of the husband that he undertakes to fulfil towards his wife and that indirectly stems from the marriage, irrespective of her own wealth and property and, thus, of her need. ${ }^{256}$ The European concept of alimony is a genuine post-divorce provision. Furthermore, the notion nafaqa has a wider purport than its English translation 'maintenance' or the Occidental concept of alimony. It not only includes food and clothing but also accommodation, (remuneration for) medical care, and, for wealthy wives, domestic service. The husband is obliged to maintain his wife in fairness and accordance with her requirements based on custom or usage.

\subsubsection{The Wife's Entitlements to Maintenance}

Not only during the marriage but also in the waiting period of the revocable divorce and in some cases such as pregnancy of the definitive dissolution of marriage the wife is entitled to maintenance, nafaqa, unless she is disobedient or the dissolution was her fault. During the waiting period after the termination of the temporary marriage, the wife is not entitled to maintenance unless otherwise stipulated in the marriage contract. ${ }^{257}$ After the lapse of the waiting period or in most cases after the definitive dissolution of the marriage, the husband is no longer obliged to maintain his wife as this obligation ensues from the marriage and ends at its definitive dissolution. The wife falls back on the duty of her father or other (male) relatives to maintain her that is based on kinship.

\subsubsection{Child(-ren)'s Entitlements to Maintenance}

Although the father's duty to maintain his children is not a direct consequence of divorce, but is based on parentage, this subsection will nevertheless pay attention to this subject matter. Legitimate children are in principle entitled to maintenance from their father dependent on their need for maintenance, not only during the permanent or temporary marriage but also after its termination. ${ }^{258}$ If the children are well- to- do and the father is needy, the children have to provide for maintenance themselves. If both the father and the children are needy, the mother should provide for maintenance of her children; however, the Maliki school of jurisprudence does not acknowledge this duty of the mother, irrespective of her fortune. The mother may also take over the obligation to maintain the children

256 Baillie 1887, p. 97-102; Doi 2008, p. 315-320; Fyzee 2002, p. 211-214; Linant de Bellefonds 1965, vol. II, p. 256-286.

257 Bailie 1887, p. 98; Mir-Hosseini 2000, p. 165.

258 Fyzee 2002, p. 214-215; Linant de Bellefonds 1973, vol. III, p. 81-138 (relevant passages). 
from the father as compensation in the case of the dissolution of marriage through khul . The paternal obligation to maintain his children in principle lasts until a specific age or until the consummation of their marriage in the case of daughters.

\subsubsection{Maintenance versus Remunerations for Nursing or Custody}

The wife's right to remuneration for nursing or for custody of the children after the definitive divorce has to be discerned from her right to maintenance. ${ }^{259}$ The right to nurse the child is part of the paternal duty to maintain his child(-ren), notably after divorce. As during marriage and the waiting period of the revocable divorce, nursing and care for the children is seen as a religious and respectively legal duty of the mother that stems from the marriage, and she is not entitled to any remuneration then according to the Hanafi and the Maliki. ${ }^{260}$ The other schools allow the mother to claim both remuneration for nursing the child and remuneration for custody in these periods. During the waiting period of the irrevocable divorce and after its final dissolution, she may claim remuneration for nursing the child according to all schools of jurisprudence and remuneration for custody according to all schools except for the Maliki school that under no circumstances allow the latter remuneration. ${ }^{261}$

\subsubsection{Dower}

\subsubsection{Definition and Characteristics}

Another right of the wife that ensues from the legally valid marriage and that played and still plays a significant role at the dissolution of marriage is the dower or nuptial gift, mahr or sadaq. It is the obligatory gift from the bridegroom to the bride upon contracting the marriage. ${ }^{262}$ Koran 4:4 reads: 'Give women their dowry as an outright gift'; Koran 4:24 inter alia states: '[...] When you consummate your marriage with them give them their prescribed dowry $[\ldots] .{ }^{263}$ Dower is seen as a legal effect of the marriage according to all schools of jurisprudence except for the Maliki. ${ }^{264}$ They consider the dower in principle to be a condition for a legally valid conclusion of the marriage. This implies that the spouses are not allowed to include in their marriage contract a clause that the dower shall not be paid. It does not imply that the spouses have to stipulate (the amount or value of) a dower in the marriage contract. A clause in the marriage contract that excludes the dower results

259 Linant de Bellefonds 1973, vol. III, p. 145, p. 154-156. See also Koran 65:6.

260 Linant de Bellefonds 1973, vol. III, p. 146-147, 154.

261 Linant de Bellefonds 1973, vol. III, p. 145, 154.

262 Baillie 1887, p. 67-82; Doi 2008, p. 253-264; Fyzee 2002, p. 132-145; Linant de Bellefonds 1965, vol. II, p. 199-255.

263 Doi 2008, p. 253-254

264 Linant de Bellefonds 1965, vol. II, p. 195, 200-203. 
in the nullity of the marriage contract according to the Maliki. However, they are also of the opinion that consummation of the marriage repairs the nullity of the marriage contract that includes such a clause and that the wife will be entitled to the so-called proper dower to be discussed below.

The dower in consideration of the marriage should not be interpreted as meaning that the marriage constitutes the purchase of the wife with the dower as a kind of purchase price. ${ }^{265}$ The wife does not become the property of the husband. But some classical scholars nevertheless interpreted the dower as analogous to the purchase price: part of the wife herself, her vagina, as an expression of sexual submission, was sold in exchange for the dower. ${ }^{266}$ Marriage was also seen as a contract 'whose object is that of dominion over the vagina, without the right of its possession'. 267

The dower represents financial value and can be monetary or non-monetary in nature as long as its subject matter is not contrary to Islam. Anything that can be legally acquired is a valid subject of dower. A dower that consists of pork or wine or the exchange of women, for example, is not allowed. Examples of the dower of a non-monetary nature are goods, services such as Koran lessons, or rights such as the right of the wife that the husband shall not marry another woman. The agreement about the amount or value of the dower is left to the will of the husband and wife. Although there is no maximum to the amount or value of the dower, it is recommended that the dower should not be too large or disproportional. The amount or value of the dower should be quantifiable or capable of appreciation in order to avoid uncertainty. It becomes available for the disposal and use of the wife and only she has the control over it and it becomes her personal property by the mere contract. ${ }^{268}$ In Shari $a$ law, the separate matrimonial regime of property prevails. Hence, the dower provides the wife with (some) financial independence.

\subsubsection{Types of Dower}

Various types of dower should be distinguished. The dower is usually agreed upon, which is called the mahr al-musamma, by the spouses or their representatives at the conclusion of the marriage or later. The amount of this type of dower is at least the minimum amount as laid down by the law according to the Hanafi and Maliki; the Hanbali, Shafi $i$, and Ithna 'Ashari do not require a minimum value for the dower. It may occur that the dower has not been fixed, which is called the proper dower or mahr al-mitl. The social standing of the family of the wife's father and her personal qualities such as age, beauty, and virtue determine the amount of the unfixed dower. The dowers the wife's other female family members received are used as a standard for the unspecified dower. In Ithna 'Ashari law,

265 Fyzee 2002, p. 133; Linant de Bellefonds 1965, vol. II, p. 201.

266 Fournier 2010, p. 13.

267 Fournier 2010, p. 13.

268 Koran 4:4. 
a third type of dower, the mahr-e sunnat, exists. This is a dower that does not exceed 500 dirhams, which was the amount of the dower of Fatima, the Prophet's daughter. ${ }^{269}$

\subsubsection{The Wife's Entitlement to the Dower}

Although the dower becomes the property of the wife from the day of the conclusion of the legally valid marriage, the spouses may arrange the moment(-s) that the dower is due. For example, the payment of the whole or partial dower may be due at the conclusion of the marriage or later. A part of the fixed dower is usually paid at the marriage before its consummation, which is called the prompt dower, while payment in instalments or postponing the payment of the rest of the dower is agreed upon, the so-called deferred dower. According to Ithna 'Ashari law, the entire dower is presumed to be a prompt dower. ${ }^{270}$

The requirements of the postponement of the payment of the dower are twofold. First, the moment that the dower is due should be determined at the time of the conclusion of the marriage. The lack of mentioning such a moment in the case of the postponement of the entire dower results in the legal invalidity of the marriage. Second, the postponement should be reasonable in respect of time and is dependent on the circumstances of the concrete case. If no postponement has been agreed upon, the dower is due in its entirety at the consummation of the marriage. If the husband refuses to pay the prompt dower as from that moment, the wife may refuse to perform her marital duties. ${ }^{271}$ Yet, the husband should pay within a certain period. His persistent failure to pay provides a ground for dissolution of marriage after which he should still pay half of the dower to his wife. The deferred dower is an unsecured debt from the husband, or his estate, to his wife. The deferred dower immediately falls due upon the dissolution of marriage, either by death or divorce. In the latter case, the wife can claim the deferred dower when the repudiation or divorce has become irrevocable. The husband can only be freed from his debts either by their payment to the wife or their discharge by the wife.

The wife is entitled to the entire fixed dower in the following three cases: first, after the factual consummation of the marriage; second, after the presumptive consummation of the marriage; and, third, as mentioned above, upon the death of either spouse, irrespective of whether the marriage has been consummated or not. In the case of the death of the wife, her right to the dower passes on to her heirs. The wife is entitled to half of the fixed dower if the marriage is dissolved through or because of the husband before the consummation of the marriage but after fixation of the dower. ${ }^{272}$ However, if in that case no dower had been fixed, the wife is entitled to the so-called consolation gift that is discussed in the next subsection, according to the Hanafi, Hanbali, Shafi $i$, and Ithna 'Ashari. If an unlawful

269 Baillie 1887, p. 70; Fyzee 2002, p. 138.

270 Fyzee 2002, p. 139.

271 Fyzee 2002, p. 141

272 Koran 2:237. 
dower has been fixed or the dower is fixed after the conclusion of the marriage, the wife is entitled to either a consolation gift according to the Hanafi of either half of the proper dower according to the Hanbali, Shafi $i$, and Ithna 'Ashari before the consummation of the marriage. In such a case, if the marriage has been consummated, the wife is entitled to the entire proper dower. According to the Maliki, an unlawful dower causes the nullity of the marriage if that marriage has not (yet) been consummated; the wife is entitled to half of the proper dower. In the same case, the consummation of the marriage validates the marriage and entitles the wife to the entire proper dower. If the marriage is dissolved because of the wife before the consummation of the marriage, the wife is in principle not entitled to the dower. If in such a case the marriage is dissolved because of suicide of the wife, her heirs will be entitled to the entire dower.

\subsubsection{Dower as Tool of Bargaining Power}

The lawful marriage confers a set of contractual rights on each spouse that is mirrored in a duty for the other spouse: the husband's right to the wife's obedience and sexual availability versus the wife's rights to maintenance, as discussed above, and her right to the dower. ${ }^{273}$ Notably the dower not only plays a significant part before and during the marriage but also thereafter. Its potential use as a tool of bargaining power for the spouses illustrates its significance then and still today. Until the payment of the (prompt) dower, the wife may suspend or refuse her marital duties while she remains entitled to maintenance. However, once the husband has paid the (prompt) dower, she has to fulfil her marital duties in order to remain entitled to maintenance.

Under Shari'a family law, each spouse has his or her own modalities of divorce, as has been discussed in the previous subsections, with corresponding benefits and/or costs. Talaq or the repudiation involves the full payment of the dower to the wife as soon as the dissolution of the marriage is final (and maintenance during her waiting period). Thus, talaq mahr may represent a 'deterrent mahr'. The higher the mahr is, the less likely it is that the husband will repudiate his wife and, vice versa, the more difficult it will be for the wife to obtain her preferred dissolution of the marriage through talaq because of the financial disadvantages for the husband. Khul' may entail that the wife waives her right to the deferred dower and may even require that the wife returns the prompt dower. Khul mahr may thus serve as 'compensation mahr' for the wife in her recourse for divorce. Unfortunately, khul' mahr sometimes serves as an incentive for husbands to force their wives into $\mathrm{khul}^{\prime}$ 'divorces. Hence, they obtain a divorce without the corresponding financial obligations. They will even be rewarded for such a divorce. Faskh or tatliq is the modality that is the most difficult for the wife to obtain due to the burden of proof of the ground

273 This subsection has been derived from and based on Kruiniger 2011, p. 565. 
for divorce, but it is also the most favourable modality of divorce for her from a financial perspective: she is entitled to the dower and maintenance during her waiting period.

\subsubsection{Consolation Gift}

In some cases, the husband has to provide a kind of compensation called mut' $a$ at-talaq as consolation for the repudiation due to his fault or as a substitute for the unfixed or invalid dower as has been mentioned in the previous subsection. ${ }^{274}$

The Hanafi, Hanbali, Shafi $i$, and Ithna 'Ashari consider the consolation gift to be obligatory if no dower has been fixed and the wife is repudiated before the consummation of the marriage. ${ }^{275}$ Conversely, it can also be said that the presence of the dower automatically excludes the obligation to provide a consolation gift. In all other cases, the provision of this consolation gift by the husband is considered to be a commendable act. ${ }^{276}$ The Maliki also see the consolation gift as a commendable act. In their doctrine, it is impossible to conclude a marriage without a dower. Because of the fact that the wife is entitled to the dower and the dower can in principle not lack, there is no obligation to provide a substitute for the dower, such as the consolation gift.

The amount of the compensation is determined by, inter alia, the financial position of the husband, the financial and social position of the wife, the duration of the marriage, and the reason(s) for or any capriciousness of the repudiation. The wife is not entitled to compensation in the case of the repudiation due to her fault or demand, for example, in the case of the dissolution of marriage through khul.

\subsubsection{Parental Authority: Custody and Legal Guardianship}

\subsubsection{Distinction}

In Shari'a law, a distinction should be made between the right to custody (daily care) of the child, Hadana, and the guardianship of the child, wilaya. ${ }^{277}$ A single concept of parental authority does not exist.

The hadana is the prerogative of the mother as she, or another female relative in the case of her absence or being unfit, is considered to be more capable and fit to provide for the primary necessities of life such as nurture, affection, security, and protection in order to guarantee the child's physical and mental well-being. ${ }^{278}$ The father, as a man (the wali)

274 Baillie 1887, p. 71; Linant de Bellefonds 1965, vol. II, p. 215-217. See also Koran 2:236 en 33:49.

275 See Koran 2:236.

276 See Koran 2:241.

277 Doi 2008, p. 321, 326, 331.

278 Linant de Bellefonds 1973, p. 150-176. 
or, in his absence or being unfit, the grandfather or another male relative or the judge is considered to be more rational than females and therefore more capable and fit to take care of the moral, intellectual, and religious education of the child. He also has the authority over and is the legal representative of the child. ${ }^{279}$ One could therefore use the term 'paternal authority' to denote the guardianship by the father. The Hanafi school distinguishes between the authority over the person of the child that lasts until the puberty of the child and the authority over the property of the child that lasts until the age of majority of the child. ${ }^{280}$

\subsubsection{Custody as a Prerogative of the Mother}

All schools agree that, in an undivided family, both the mother and father have the duty and right to take care of the young child. According to the Maliki, the custody is even shared by both parents, whereas the other schools consider the custody to be the prerogative of the mother. ${ }^{281}$ After divorce, it is the mother who has priority over the father for custody. All schools recognize a mandatory hierarchy of female or male relatives who may substitute the mother or father in respect of the custody (respectively the guardianship) whenever they are not able or do not want to fulfil their duties.

The fact that custody is seen as a right of the mother may have several consequences. ${ }^{282}$ The mother may renounce the custody, for example, as compensation in an agreement about the dissolution of marriage through khul'. Yet, she is not allowed to designate her successor. Furthermore, the custody may be subject of any agreement including its further arrangements with the husband. Finally, the mother cannot be forced to exercise her right to custody unless no other person is suitable or available.

The female custodian who is not the mother of the child is entitled to remuneration for custody at any time. ${ }^{283}$ According to the Hanbali and Shafi $i$, the mother is also entitled to remuneration at any time, be it during the marriage or after its dissolution. But the Hanafi only allow the mother to claim such remuneration after the lapse of the waiting period of the dissolution of marriage. The Maliki deny the mother any entitlement to remuneration for custody.

\subsubsection{Requirements to the Custodian}

The requirements of the custodian are, inter alia, being of age, sane, having a good character, having blameless behaviour, and being in good (physical) health. ${ }^{284}$ The female custodian

279 Linant de Bellefonds 1973, p. 177-247.

280 Linant de Bellefonds 1973, p. 178-179, 188, 207.

281 Linant de Bellefonds 1973, p. 157-158.

282 Linant de Bellefonds 1973, p. 152.

283 Linant de Bellefonds 1973, p. 154. See also the discussion about the remuneration for custody in section 5.7.3.

284 Linant de Bellefonds 1973, p. 162-164, 168-169. 
may lose the custody for two reasons. ${ }^{285}$ First, if the non-Muslim female custodian does not bring up the child in accordance with Islam and Islamic values and norms according to the Hanafi or Maliki or is not a Muslim herself according to the Hanbali and Shafi $i$, she may lose custody. Second, she may also lose custody over the child if she remarries (according to the Ithna 'Ashari) ${ }^{286}$ or marries a man who is neither the father nor related to the child within the prohibited degrees (i.e. who is prohibited to marry the child); in a case of remarriage, she will not lose custody, if she is also the guardian as appointed by testament, wasi, of the child or marries the wasi of the child. ${ }^{287}$ The male custodian should profess the same religion as the child according to the Hanbali, Hanafi, and Shafi $i{ }^{288}$ According to the Maliki, the male custodian should be assisted by a female, for example, his wife, another female relative, or a female servant.

\subsubsection{Terms of Custody}

The mother is entitled to custody until the children reach a certain age. The length of the period of custody differs depending on the school of law and on the sex of the child. In general, it lasts from birth until the moment the child no longer depends on its mother for her care. According to the Ithna 'Ashari, it lasts until the child has been weaned from nursing (the first two years of the child's life). ${ }^{289}$ Then the mother remains the custodian of her daughter until the age of seven, whereas the father takes over the custody of a son until the child attains the age of seven years, or ten years, or, in the case of a girl, until she marries. ${ }^{290}$ The prevailing opinion of the Hanafi school is that the mother (or another custodian) has the right to custody until the age of seven or nine for boys and the age of nine for girls or until the girl becomes of age. ${ }^{291}$ In Maliki law, the mother loses custody at the puberty of the boy and at the moment of consummation of the marriage for the girl. Whereas, according to the Shafi $i$ school, both the male and female child have the right to choose the place of residence, either with the mother or with the father, according to the Hanbali, only the boy has this right. ${ }^{292}$ If the child prefers to reside with the mother, her period of custody will be extended.

When the period of custody over the child(-ren) ends for the mother, the father takes over the custody according to the Hanbali and Shafi $i$, or the child falls under the guardianship related to the person of the child according to the Hanafi ${ }^{293}$ The father already was

\footnotetext{
285 Linant de Bellefonds 1973, p. 164-169.

286 Baillie 1887, p. 95, 96.

287 Schacht 1982, p. 167.

288 Linant de Bellefonds 1973, p. 168-169.

289 Baillie 1887, p. 95.

290 Fyzee 2002, p. 198.

291 Schacht 1982, p. 167.

292 Linant de Bellefonds 1973, p. 173-174.

293 Linant de Bellefonds 1973, p. 180-182.
} 
and remains the guardian of the child. The child(-ren) stay(-s) with the parent who is entitled to the custody. The other parent has the right to visit the children and to information about their development and well-being. ${ }^{294}$

\subsubsection{Inheritance Rights}

Mutual inheritance rights of the spouses in principle expire at the moment of the irrevocable or definitive divorce or at the expiration of the waiting period after the revocable divorce of the wife. ${ }^{295}$ An exception exists, for example, according to the Maliki doctrine: in the event that the terminally ill husband repudiates his wife in the knowledge of his approaching death, also in the case of a khul', the wife will still inherit from her husband after his death while the repudiation is legally valid. ${ }^{296}$

294 Fyzee 2002, p. 199.

295 Linant de Bellefonds 1965, vol. II, p. 396, 404, 410.

296 Linant de Bellefonds 1965, vol. II, p. 334-339. 


\section{Divorce IN EgYPT}

\subsection{INTRODUCTION}

Although most of Egyptian law was secularized and based on European and, in particular, Anglo-Saxon legal systems during the twentieth century, family law remained a domain governed by Shari ${ }^{\prime} a .{ }^{1}$ To be more precise, it remained an area in which the rules of the Hanafi school of jurisprudence originally were predominant and are still considered to be default rules if the Egyptian legislature does not rule otherwise in a given matter. ${ }^{2}$ Islamic family law thus governs all Egyptians although each religious community in Egypt is in principle governed by its own marriage and divorce laws. Other areas of personal status or family law are governed by the common law, Islamic law, such as inheritance, capacity, the age of majority, guardianship, etcetera.

The religious communities may apply and use their own marriage and divorce laws if both spouses adhere to the same religion (Islam, Judaism, or Christianity) and belong to the same denomination (for example for the Christians: Orthodox, Catholic, or Protestant; for the Jews: Karaite or Rabbinic) and the same sect (for example for the Orthodox: Coptic, Greek, Syrian, or Armenian; for the Catholics: Coptic, Greek, Syrian, Armenian, Maronite, Chaldean, or Latin) and if the provisions are not violating the Egyptian public order. However, if one of the spouses is Muslim or if the spouses belong to different religions, denominations, or sects or to a denomination that is not recognized in Egypt (such as the $\left.B a h a^{\prime} i\right)$, the spouses are governed by the common law being the Islamic marriage and divorce laws.

Although other domains of law have been codified in comprehensive and exhaustive codes, family law has not. This may complicate the knowledge of and understanding of family law at times. The most important laws dealing with issues of divorce are Decree

1 Berger \& Sonneveld 2010, p. 53, 74. See about the character of Egyptian family law, e.g. Berger \& Sonneveld 2010, p. 74; Bernard-Maugiron \& Dupret 2002, p. 1; El-Ehwany 2012, p. 29; Jansen 2007, p. 198; Qassem 2002, p. 19. The overriding majority of the approximately 86 million Egyptian inhabitants (as of March 2014 via <www.capmas.gov.eg/?lang $=2>$ ) are Sunni Muslim (estimated $90 \%$ ); $9 \%$ are Coptic Christians and $1 \%$ belong to other Christian denominations (Berger \& Sonneveld 2010, p. 53).

2 Art. 3 of Law No. 1 of 2000; Law No. 1 of 2000 or The Law on Reorganization of Certain Terms and Procedures of Litigation in Personal Status Matters of 29 January 2000, al-jarida al-rasmiyya No. 4 of 29 January 2000; this law aims at facilitating and speeding up litigation in matters of personal status, such as divorce, for Muslims and non-Muslims. 
Law No. 25 of $1920^{3}$ and Decree Law No. 25 of $1929^{4}$ which have been amended by Law No. 100 of $1985^{5}$ and, most recently, by Law No. 1 of 2000 .

\subsubsection{Islamic Family Law before the Arab Spring}

Since the late nineteenth century, Islamic family law in Egypt was a target for calls for reform, in particular calls for equality between men and women and gender liberation. ${ }^{6}$ Attempts to reform this area of law by efforts to reconcile the Shari' $a$ with the needs of time proved to be very difficult mainly because of great religious and political resistance. ${ }^{7}$

Welchman describes that one of the main obstacles for reform can be 'found in a general concept of male superiority over females, frequently traced by defenders of this principle to the concept of qiwama in the Koran (Surat al-Nisa, 34) ${ }^{\prime}$. Although this term can be understood as guardianship, protection, control, etcetera, in the context of the verse, some Egyptian scholars like Shaltut and Abu Zeid argued that qiwama meant that men have a responsibility towards women rather than that they have leadership over them. ${ }^{9}$ Welchman further states that Egyptian divorce law is 'a striking example of the principle of qiwama [...]; talaq occurs at the wish of men, while women have to go to court to establish cause [...] Furthermore, in practice, women going to court to seek a judicial divorce faced enormous difficulties. ${ }^{10}$

In general, it can be stated that the difficulties to reform family law originate from the unwillingness of, or even the 'impossibility' for, the legislator to abolish certain institutions like repudiation or polygamy. ${ }^{11}$ In this respect, the legislator refers to the immutability of the rules that govern these institutions because they have been expressly stated in the Koran or Sunna. In order to implement changes in family law nonetheless, the Egyptian legislator

3 Law concerning the provisions on and certain matters of personal status, No. 25 of 12 July 1920, al-waqa' $i^{c}$ al-misriyya No. 61 of 15 July 1920, amended by Law No. 100 of 1985.

4 Law concerning certain provisions on personal status, No. 25 of 10 March 1929, al-waqa' i' al-misriyya No. 27 of 25 March 1929, amended by Law No. 100 of 1985.

5 Personal status (Amendment), Law No. 100 of 1985, al-jarida al-rasmiyya no. 27 (Supplement) of 4 July 1985.

6 See e.g.: Welchman 2004, p. 30; An- Na'im 2002, p. 169. See for a more detailed discussion of the legal-historical and sociolegal developments in Egypt: Berger \& Sonneveld 2010, p. 53-73.

7 See description by Welchman 2004, p. 30-44.

8 Translation of Surat al-Nisa, 34: 'Men are in charge of [are guardians of/are superior to/have authority over] women because God has endowed one with more [because God has preferred some of them over others] and because they spend of their means'. See Welchman 2004, p. 30.

9 Welchman 2004, p. 30-31.

10 Welchman 2004, p. 39.

11 Berger 2006, p. 72. 
made use of siyasa and of several methods like initially talfiq, ${ }^{12}$ takhayyur, ${ }^{13}$ and later ijthihad. ${ }^{14}$ In case of siyasa, the Egyptian legislator promulgated procedural rules of litigation in order to constrain the husband's facility of the repudiation, e.g. by providing that no talaq has effect if a man pronounces the talaq when he is drunk, incoherent with rage, or under duress; ${ }^{15}$ another example is 'balancing' the husband's power of talaq with the introduction of the 'judicial $k h u l$ ' at the unilateral demand of the wife'. ${ }^{16}$ Law No. 1 of 2000

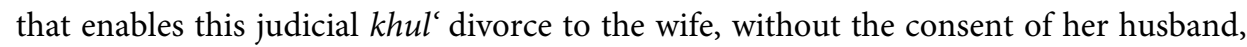
also represents an example of ijthihad as this divorce is based on an interpretation of the so-called Habiba separation case hadith. ${ }^{17}$ Decree Law No. 25 of 1920 and Decree Law No. 25 of 1929 are examples of the use of takhayyur by the legislator as he enlarged the grounds on which a woman could petition for a judicial divorce by introducing the divorce for injury due to causes like systematic maltreatment, non-provision of maintenance, longterm absence, or imprisonment or an incurable or contagious disease, based on Maliki and Hanbali principles. ${ }^{18}$

In order to change the position of women, the Egyptian legislator not only undertook efforts to change family law but also enacted legislation dealing with women's political, social, and economic rights and responsibilities, like the right to vote, and the recognition of equal rights for women in the Constitution of $1956 .{ }^{19}$ 'However', as Welchman states, 'these rights remained restricted and incomplete so long as the law governing family relations remained as it was'. According to her it was 'not surprising that women could not benefit fully from the laws affirming their equality with men while they remained oppressed inside the family. ${ }^{20}$

Improvement in litigation for Muslims and non-Muslims was expected from the establishment of Family Courts dealing with all the different aspects of the dispute concerning a personal status issue in a more speedy and equitable manner, in October $2004 ;^{21}$ until then, families had to move between a number of national courts and judges, courts were overloaded, and judgments delayed. However, new procedures were also introduced

12 A method by which the doctrines of more than one school of law are combined so as to produce a hybrid ruling which does not belong to any of them; see Schacht 1982, p. 303.

13 A method that allows the rules to be chosen and adopted from among the different solutions provided by the various schools of law; see Bernard-Maugiron \& Dupret 2002, p. 16.

14 A method of legal reasoning by interpretation to construe rules of law; see Schacht 1982, p. 299.

15 Art. 1 of Decree Law No. 25 of 1929.

16 Welchman 2007, p. 107-109; Art. 20 Law No. 1 of 2000.

17 Arabi 2001, p. 2-21; Sonneveld 2012, p. 92.

18 See for a more detailed explanation: Bernard-Maugiron \& Dupret 2008, p. 54-56.

19 Welchman 2004, p. 35.

20 Ibidem.

21 Law No. 10 of 2004 establishing Family Courts of 17 March 2004, al-jarida al-rasmiyya No. 12 (Supplement A) of 18 March 2004; Human Rights Watch 2004, p. 52; Berger \& Sonneveld 2006, p. 34; El-Ehwany 2012, p. 30 . 
that could delay a process; e.g. within each Family Court, Family Dispute Settlement Offices were established in order to counsel and mediate each couple in divorce before the judge would hear the case. ${ }^{22}$

In the period 2005-2010, different governmental and non-governmental organizations, inter alia, the now dissolved National Democratic Party (NDP), the legislative committee at the National Council for Women (NCW), and the Network for Women's Rights Organizations (NWRO), took initiatives to reform the substantive personal status laws, Decree Law No. 25 of 1920 and Decree Law No. 25 of 1929 as amended by Law No. 100 of 1985. Apart from contributing to comprehensive legal reforms, the NWRO also aimed 'to help create an enabling societal environment, which would facilitate the effective implementation of proposed changes to the personal status laws. ${ }^{23}$ Some of the key proposals by the NDP, NCW, and NWRO that are relevant for this study concern, first, the restriction of the husband's right to unilateral repudiation to be achieved, inter alia, by making the husband's right dependent on court approval; second, the construction of 'a new legal definition of marital roles which stresses equal partnership between spouses', inter alia, by abolishing existing laws that makes a wife's right to spousal maintenance dependent on her (sexual) availability to her husband; third, the extension of full parental guardianship of children to the mother; fourth, the father's visiting rights that should be made dependent on his payment of maintenance for the children; fifth, the extension of the father's visiting rights from three hours per week to weekends and Summer holidays; and, sixth, the restriction of the judges' discretionary power to allocate maintenance for the wife and children by setting a minimum amount. ${ }^{24}$ The organizations submitted their proposals to the Department of Legislation at the Ministry of Justice that reviewed them and used them for drafting a comprehensive family code. It was expected that that code would be presented in 2009 or 2010, but the Ministry stated that it was not ready yet. Then the Egyptian Revolution broke out and the regime was overthrown, and the draft was never presented.

\subsubsection{Islamic Family Law since the Arab Spring}

On 18 December 2010, a revolutionary wave of demonstrations and protests instigated by dissatisfaction with the rule of local governments began in Tunisia following the selfimmolation of a man in protest of police corruption and ill treatment. ${ }^{25}$ This series of

22 Human Rights Watch 2004, p. 53-54.

23 Al-Sharmani 2013, p. 73.

24 See for these and other key proposals: Al-Sharmani 2013, p. 76-78.

25 Information about the Arab Spring was retrieved from the Internet, inter alia, from the BBC website about the Arab uprisings in the Middle East and its country profiles via <www.bbc.com/news/world-middle-east12813859> or via $<$ http://en.wikipedia.org/wiki/Arab_Spring $>$. 
protests and demonstrations that spread to other countries in the Middle East and North Africa became known as the 'Arab Spring'. Numerous causes such as dictatorship, human rights violations, political corruption, economic decline, unemployment, extreme poverty, increasing food prices, etcetera, led to overall felt dissatisfaction. The Arab Spring also struck Egypt on 25 January 2011. 18 days of massive protests, having its centre on Tahrir Square (Liberation Square, but also known as Martyr Square), resulted in the overthrow and resignation of the Egyptian President Hosni Mubarak and the government on 11 February 2011 and the assumption of power by the Armed Forces. Democratic presidential elections, held in two rounds in May and June 2012, led to the election of a candidate of the Islamist Muslim Brotherhood, Mohammed Morsi, as president. However, he was ousted in a military coup led by General Abdel Fattah el-Sisi following a second revolution in July 2013. The Muslim Brotherhood was designated as a terrorist organization on 25 December 2013.

One of the focuses of the protests in 2012 was the Constitution of the Arab Republic of Egypt (2012 Constitution) that was signed into law as a replacement of the Constitution of 1971 by President Morsi on 26 December 2012. The 2012 Constitution included some controversial articles. ${ }^{26}$ Article 2 that was essentially unchanged from the old Constitution of 1971 made the principles of Islamic law the main source of legislation. However, Article 219 of the 2012 Constitution defined the principles of Islamic law in terms of Muslim Sunni jurisprudence, more specifically the evidence, rules, jurisprudence, and sources as accepted by Sunni Islam. Moreover, Article 4 of the 2012 Constitution declares that 'the Azhar's Body of Senior Scholars is to be consulted in matters pertaining to Islamic law', thus giving unprecedented powers in the legislative process to al-Azhar. In a presentation at a conference on Islamic family law in June 2013, Sonneveld pointed out a fear among Egyptians that in particular Article 219 would lead to a conservative reading of the sources of Islamic law. ${ }^{27}$ According to her, this applies in particular to the area of family law in which the principles of Shari $a$ law are still predominant. The risk of abolishing the legal provision concerning the judicial $k h u l$ ', for example, was not inconceivable when its legitimacy would be challenged in the High Constitutional Court that would have to consult the al-Azhar. However, the 2012 Constitution was suspended by order of the Egyptian army on 3 July 2013 and superseded by the Egyptian Constitution of 2014 (2014 Constitution) that was passed in a referendum and took effect on 18 January 2014. This Constitution, also based on the Egyptian Constitution of 1971, maintains the provision that the principles of Islamic law are the principal source of legislation in Article 2 but left out the controversial Articles 4 and 219 of the 2012 Constitution. ${ }^{28}$ Article 11 of the draft 2014 Constitution

26 Sonneveld 2013, p. 13; translation of the 2012 Constitution via <http://niviensaleh.info/constitution-egypt2012-translation/\#ch-one-1>.

27 Sonneveld 2013 (lecture).

28 See 'What's new in Egypt's proposed new constitution' via <www.aljazeera.com/news/middleeast/2014/ 
states that 'The state shall ensure the achievement of equality between women and men in all civil, political, economic, social and cultural rights in accordance with the provisions of the constitution'. ${ }^{29}$ This article furthermore states that it shall ' $[t]$ ake measures ensuring the adequate representation of women in parliament, as prescribed by law, and to ensure women's right to hold public office and senior management positions in the state and to be recruited by judicial institutions without discrimination'.

Egypt claims to adhere to human rights and has ratified numerous treaties and conventions, inter alia, the International Convention on Economic, Social and Cultural Rights (hereinafter ICESCR), the International Convention on Civil and Political Rights (hereinafter ICCPR), the Convention on the Rights of the Child (hereinafter CRC), and the Convention against Elimination of All Forms of Discrimination against Women (hereinafter the Women's Convention). ${ }^{30}$ Egypt has not yet acceded to the 'Optional Protocol to the Women's Convention' despite repeated calls upon the state party from the CEDAW Committee. ${ }^{31}$ Apart from a general reservation on Article 2, Egypt also entered reservations in respect of Articles 9 (2), 16, and 29 of the Women's Convention upon the ratification of the Women's Convention. In its reservations to Article 2 and Article 16, Egypt invoked the Islamic Shari'a principle stating in general terms that the Convention should not run counter to principles or provisions of Islamic Shari $a{ }^{32}$ Although these reservations resulted in a few objections by other states parties, it also resulted in a large amount of criticism and frequent calls to withdraw them from the CEDAW (-committee). ${ }^{33}$ They are incompatible with the object and purpose of the Women's Convention and therefore impermiss-

01/what-egypt-proposed-new-constitution-201411312385987166.html>.

29 Retrieved via <http://english.ahram.org.eg/NewsContent/1/0/88644/Egypt/0/Egypts-constitution-vs-Acomparison.aspx $>$.

30 Date of ratification ICESCR and ICCPR: 14 January 1982 (both conventions include a declaration that the text annexed to the convention should not conflict with the provisions of Islamic Shari'a); date of ratification CRC: 6 July 1990; date of ratification Women's Convention: 18 September 1981; see for an overview of the status of these treaties and possible declarations and/or reservations: <http://treaties.un.org/Pages/Treaties.aspx?id=4\&subid=A\&lang=en $>$.

31 As at 10 March 2014, see <https://treaties.un.org/Pages/ViewDetails.aspx?src=TREATY\&mtdsg_no=IV-8b\&chapter=4\&lang=en $>$. The CEDAW Committee made the last call to accede to the Optional Protocol to the Women's Convention in its concluding observations (CEDAW/C/EGY/CO/7 of 5 February 2010) on the occasion of its considerations of the combined sixth and seventh report of Egypt (CEDAW/C/EGY/7 at its 918th and 919th meetings on 28 January 2010 (CEDAW/C/SR.918 and 919), para. 53.

32 The general reservation on Art. 2 Women's Convention e.g. states that 'The Arab Republic of Egypt is willing to comply with the content of this article, provided that such compliance does not run counter to the Islamic Shari' $a$ '.

Egypt did not invoke the Shari'a in its reservation on Art. 9(2) Women's Convention that deals with equal rights with respect to the nationality of children. In its reservation, Egypt used a general argument that seemed to be based on the 'best interests of the child' principle and the mother's consent in order to defend that a child should acquire the nationality of his father. Egypt withdrew this reservation by notification to the Secretary-General on 4 January 2008 after a ten-year campaign led by women's groups in Egypt that resulted in an amended nationality law under Law No. 154; see also Moussa 2011, p. 104.

33 See concluding observations (CEDAW/C/EGY/CO/7) of 5 February 2010, at paras. 5, 13, and 14. 
ible. ${ }^{34}$ The most important reason is that a reservation on the core and kernel and thus on the object and purpose of the Women's Convention implies a general reluctance to implementing the substantive provisions into domestic policy. Egypt's reservation in respect of Article 16 of the Women's Convention that specifically refers to the issue of divorce also demonstrates this reluctance. At the time that Egypt articulated this reservation, the Egyptian legislator had not yet introduced the judicial khul'. Notwithstanding the implementation of the judicial $\mathrm{khul}^{\prime}$ and assertions concerning actively working on the withdrawal of the reservations by Egypt's representatives, it appears that Egypt still persists in maintaining the reservation in respect of Articles 2 and 16 at the time of finalizing this study. ${ }^{35}$

34 Moussa 2011, p. 104-113. See also concluding observations (CEDAW/C/EGY/CO/7) of 5 February 2010, at para. 14.

35 As at 10 March 2014, see <https://treaties.un.org/Pages/ViewDetails.aspx?src=TREATY\&mtdsg_no=IV-8b\&chapter=4\&lang=en $>$. See also Moussa 2011, p. 110-112. 
First page of the Egyptian Law No. 1 of 2000 (in Arabic) that introduced the judicial $k h u l$, a modality of non-fault judicial divorce for women without the need for the consent of the husband or the need for the establishment of a specific ground for divorce, but in exchange for renouncing her financial rights.

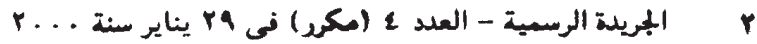

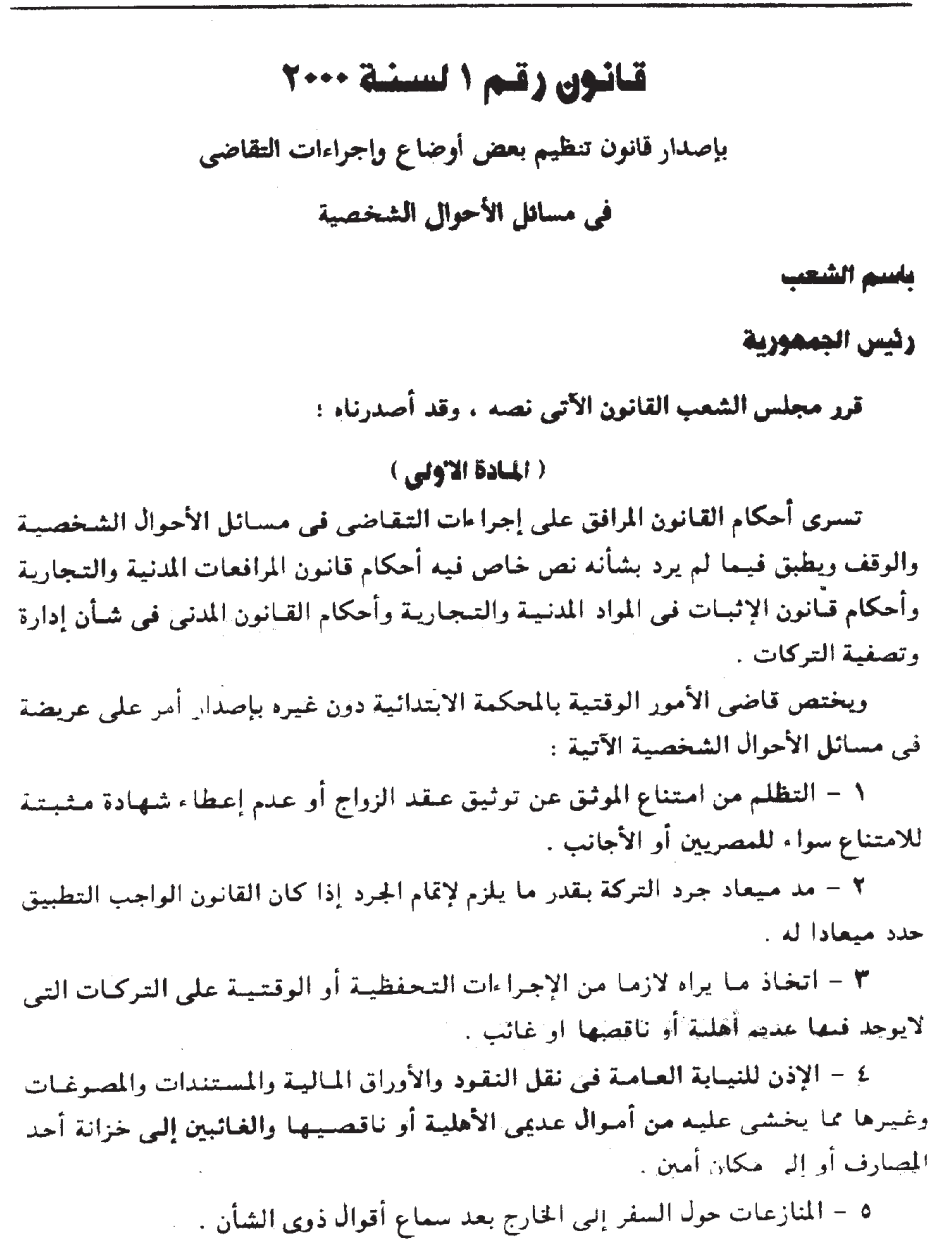




\subsection{DivorCE}

Egyptian Islamic divorce laws and practices encompass the following modalities of dissolution of marriage (apart from its dissolution due to the death of either spouse or because of the nullity of the marriage based on the apostasy or conversion of one of the spouses):

- divorce on the initiative of the husband, the repudiation (talaq);

- divorce on the initiative of the wife, the judicial repudiation (talaq al-tatliq/al-tafriq) and the judicial khul'; and

- various modalities of divorce based on agreement between or that require the involvement of both spouses being:

- the authorization of the right to repudiate by the husband to the wife, the selfrepudiation (isma), and

- the negotiated repudiation ( $k$ hul' or talaq al-ibra).

\subsubsection{Divorce on the Initiative of the Husband}

The repudiation or talaq is still an out-of-court, unilateral facility of the husband to dissolve the marriage. He does neither need to justify his decision nor to produce a valid reason for the dissolution of marriage. This facility has been constrained by several statutory interventions in order to mitigate the unilateral and prerogative character of the repudiation and to offer some protection to women over the course of time. Hence, the repudiation is null and void if it is expressed under intoxication or coercion, conditionally, or in an ambiguous way that does not express the clear intention of the husband to repudiate. ${ }^{36}$ Moreover, the repudiation that has been expressed more than once in one sitting is only effective as a single and revocable repudiation. ${ }^{37}$

Another statutory restriction imposed on the man from the year 1985 on is the obligation to register the written certification of the repudiation within 30 days after its occurrence at the ma'zun (a state notary), which, from the year 2000 on, involves the witnessing and documenting of the repudiation, to make the divorce official. ${ }^{38}$ Only the act of repudiation can demonstrate the existence of the repudiation in the case of its negation or denial. The procedure to be followed at the ma'zun is specified in Article 40 bis of the Decree of the Minister of Justice No. $1727 .^{39}$ The ma'zun must draw up the act of repudiation in the following situations: when both spouses are present, if they insist on an immediate repudiation or affirm that the repudiation has already been pronounced; when only the husband

36 Arts. 1, 2, and 4 of Decree Law No. 25 of 1929.

37 Art. 3 of Decree Law No. 25 of 1929.

38 Art. 5 bis of Decree Law No. 25 of 1929 as amended by Law No. 100 of 1985 and Art. 21 of Law No. 1 of 2000 .

39 El-Ehwany 2012, p. 60-61. 
is present, if he states that he already pronounced the repudiation; and when only the wife is present, if she states that she repudiated herself in accordance with a clause in the (marriage) contract. The ma'zun should inform the spouses about the risks and consequences of the repudiation. He should also undertake an attempt to reconcile them within a fixed period of time while using mediators that are designated by the spouses when both spouses are present and state that the repudiation has not yet been pronounced while the husband expresses his intention to repudiate whereas the wife expresses her wish not to be repudiated; or when the wife expresses her intention to use her right to selfrepudiation whereas her husband expresses his wish to reconciliation. When merely the husband or merely the wife (in the case of a self-repudiation) is present and demands the repudiation and its registration, the ma'zun should inform that spouse about the risks and consequences of the repudiation and ask him or her to designate a mediator in order to undertake an attempt at reconciliation. The ma'zun must also notify the other spouse in person through a bailiff and invite that person to designate a mediator for the attempt at reconciliation.

The repudiation takes legal effect from the moment that both spouses were present (from the year 1985 on) or were represented by a third person at the ma'zun (from the year 2000 on) or from the moment that the other spouse has knowledge of the repudiation through its notification by a bailiff or through another official document (from the year 1985 on). However, an unregistered repudiation will have religious effect, and the husband risks imprisonment and/or a fine and the ma'zun risks imprisonment and a fine or dismissal or suspension of his duties. ${ }^{40}$ Law No. 100 of 1985 did not challenge the validity of the repudiation without notification. ${ }^{41}$ This may result in the wife being in a legal limbo as she is legally still married, with all of its consequences, such as obedience to the husband, no right to remarry, etcetera, but having been religiously repudiated. ${ }^{42}$ Although the ma'zun must call on both spouses to appear and try reconciliation through arbitrators, ${ }^{43}$ this is not absolutely obligatory since he must document the repudiation immediately after witnessing it, if the spouses or husband insists on its occurrence. ${ }^{44}$

It is important to point out that a couple can agree upon including a right to repudiate for the wife as a condition in the marriage contract (repudiation by authorization, isma, thus without resort to the court).$^{45}$ This modality of divorce will be discussed below.

40 Arts. 23 and 23 bis Law No. 100 of 1985.

41 Bernard-Maugiron \& Dupret 2008, p. 61.

42 Welchman 2004, p. 68, Berger and Sonneveld 2006, p. 33.

43 Arts. 18 and 21 of Law No. 1 of 2000.

44 Art. 21 of Law No. 1 of 2000.

45 Bernard-Maugiron \& Dupret 2002, p. 15. 
Egyptian women have three options to ask for judicial divorce: a fault-based or no-fault divorce, or a judicial divorce based on non-compliance by the husband with a contractually stipulated ground for divorce. ${ }^{46}$ However, before they can institute divorce proceedings, they have to petition for pre-litigation mediation as an alternative opportunity for resolving the dispute. ${ }^{47}$

A fault-based judicial divorce may be obtained if the wife suffers severe harm by the husband on the following, limited, number of grounds: a serious, contagious, or incurable disease including a mental disease, unless she had knowledge of the disease before the marriage or she accepted it during the marriage $;^{48}$ the non-provision of maintenance $;^{49}$ an unjustified absence for more than one year without a legitimate motive or imprisonment for at least three years of which at least one year has passed; ${ }^{50}$ injury $(\text { dharar })^{51}$ including physical and/or mental maltreatment; and material and/or moral harm caused by polygamy within one year of its knowledge. ${ }^{52}$ The court is only allowed to grant a divorce after at least one mandatory attempt at reconciliation has failed; in the case that the spouses have children, two attempts have to be undertaken within a period of not less than 30 days and not exceeding 60 days. ${ }^{53}$ If the wife obtains a judicial divorce on the ground of harm caused by polygamy, the judge may order 'a financial settlement proportionate to the allocation of blame' to the spouses, or the wife may even forfeit some or all of her financial rights. ${ }^{54}$ In addition to these grounds, spouses can agree to include a right to judicial divorce in their marriage contract, for example, if the husband is to prevent the wife from finishing her education or from working. ${ }^{55}$ However, including such a right to judicial divorce is rarely done in practice for reasons such as lack of knowledge of this possibility and its unacceptability in Egyptian society. The latter is also the case in respect of the inclusion of the equal right to repudiation that is discussed below.

The restricted access to judicial divorce because of the limited number of grounds is not the only difficulty for women. ${ }^{56}$ During these divorce proceedings, women need to

46 Human Rights Watch 2004, p. 21-22.

47 See for a more detailed discussion of the mechanism of pre-litigation mediation: Al-Sharmani 2009, p. 9394. She also describes the drawbacks of the mediation: a mediation period that often takes longer than the already extended period of one month and the fact that husbands often do not show up (2012, p. 94).

48 Arts. 9-11 of Decree Law No. 25 of 1920 as amended by Law No. 100 of 1985.

49 Ibidem, Arts. 4-6.

50 Art. 5 of Decree Law No. 25 of 1920 as amended by Law No. 100 of 1985 and Arts. 12-14 of Decree Law No. 25 of 1929 as amended by Law No. 100 of 1985.

51 Arts. 6-11 (bis 2) of Decree Law No. 25 of 1929 as amended by Law No. 100 of 1985.

52 Art. 11 (bis) of Decree Law No. 25 of 1929 as amended by Law No. 100 of 1985.

53 Art. 18 (2) and Art. 19 (1) Law No. 1 of 2000.

54 Ibidem, Art. 11.

55 Human Rights Watch 2004, p. 18.

56 Al-Sharmani 2012, p. 86. 
have legal counsel, to have proof of the harm, and to have proof of the husband's income and assets; they are submitted to (a) compulsory reconciliation attempt(s) and have to deal with a mandatory advisory opinion on the divorce by the public prosecutor; and they are dependent on the judge's discretionary power of assessment before a divorce can be pronounced. ${ }^{57}$ Providing evidence of the harm, for example, in the case of physical maltreatment, may be a huge barrier to obtaining a divorce for several reasons. Such reasons include the approaches towards abuse by the judiciary, a lack of official records, or the need for witnesses, since in Egypt a woman's testimony is worth half that of a man, resulting in a required number of witnesses being one man and two women or alternatively four women. ${ }^{58}$ Moreover, the woman has to prove that the harm is intolerable for 'women like her' meaning for women from a similar social and cultural background. ${ }^{59}$ In order to avoid lengthy, costly, burdensome, and uncertain court proceedings, women are willing to 'choose' for or, rather, to bargain a so-called out-of-court, negotiated divorce, khul' or talaq al-ibra, which is a repudiation by their husbands that is agreed upon in return for renouncing some or all of their (financial) rights and/or even paying compensation and/or the ma'zun's divorce costs. ${ }^{60}$

Article 20 of Law No. 1 of 2000 introduced the no-fault judicial divorce by $k h u l^{r^{61}}{ }^{\text {Th }}$ This type of khul' has to be distinguished from the abovementioned 'traditional' khul' or talaq al-ibra, the out-of-court, negotiated repudiation. The traditional $\mathrm{khul}^{\prime}$ already existed in Egyptian law and takes place before the $m a^{\prime} z u n .^{62}$ It requires the involvement of both spouses and thus also the consent and cooperation of the husband.

The no-fault judicial divorce by $\mathrm{khul}^{\text {' }}$ provides wives the possibility to obtain a judicial, unilateral divorce without the consent of their husband (or of the judge) and without having to establish a ground for divorce; they merely have to submit a claim seeking khul, if the spouses themselves do not agree on it. The court shall rule for an irrevocable divorce on four conditions. ${ }^{63}$ First, the woman has to state explicitly the 'incompatibility' between her and her husband and that, as a result, she is afraid that she may transgress the limits set by God. ${ }^{64}$ She does not need to justify her request or to prove the incompatibility or

57 Human Rights Watch 2004, p. 20, 21; see e.g. Arts. 6-11 of Law No. 25 of 1929; Arts. 18, 19 Law No. 1 of 2000; and Arts. 5, 6, and 8 Law No. 10 of 2004.

58 Human Rights Watch 2004, p. 22.

59 Welchman 2004, p. 39; Bernard-Maugiron \& Dupret 2008, p. 56.

60 Human Rights Watch 2004, p. 20.

61 See for an ethnographic study on the $\mathrm{khul}^{\text {' }}$ and $k h u l^{\prime}$ law that examines the realities of daily life for women in khul' procedures in relation to the public debates on khul': Sonneveld 2009.

62 Bernard-Maugiron \& Dupret 2008, p. 58; Human Rights Watch, p. 20. Al-Sharmani mentions that this tra-

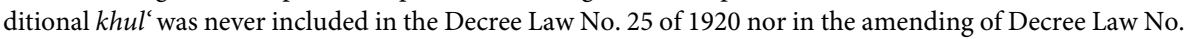
25 of 1929 or in the Decree Law No. 100 of 1985 (2012, p. 87); in the same sense Sonneveld 2012, p. 32.

63 Art. 20 para. 4 of Law No. 1 of 2000. See for a more detailed discussion of the steps to be taken in a judicial khul' procedure: Al-Sharmani 2012, p. 94; Sonneveld 2012, p. 33.

64 The legislator has quoted from Koran 2:229 (Surat al-Baqara). 
harm nor to produce two witnesses. Second, there must be a failed attempt at reconciliation by two arbiters. ${ }^{65}$ Third, the wife must agree to forfeit all her financial rights in return, such as her right to maintenance, the financial consolation, and her deferred dower. Fourth, she must repay her prompt dower. The ruling is not open to appeal. ${ }^{66} \mathrm{Al}$-Sharmani refers to statistics of the Ministry of Justice and a study conducted by Soliman and Salah that demonstrate an increase in the number of $\mathrm{hull}^{\circ}$ cases filed in family courts since the law was passed in $2000 .{ }^{67}$ She also refers to a study by Halim who found that the legal process in $\mathrm{khul}^{\text {' }}$ cases was shorter and the costs of litigation lesser than in fault-based divorce cases. The findings of her own study also suggest that the judicial khul' is beneficial to women and in particular to women who have limited financial means, because it offers 'a relatively fast and a guaranteed way out of marriage' and the costs for litigation are considerably lesser than those for fault-based divorces. ${ }^{68}$ Consequently, it appears that many women who had valid reasons to file for a judicial divorce opted instead for the judicial hhul $^{6}{ }^{69}$

One specific, important, and recurring motive for women to seek a judicial divorce by khul $^{\mathrm{c}}$ is significant. ${ }^{70}$ That motive is to be able to file for a social security pension that is offered by the Ministry of Social Solidarity to poor divorced or widowed women or to be able to rely on other financial and non-financial services offered to those categories of women by non-state NGOs and charity groups run by mosques. Al-Sharmani points out that there is a huge discrepancy between the legal model of marital roles and realities of these roles in Egyptian society. ${ }^{71}$ Family laws and state and non-state policies expect that men financially provide for their wives (and children) and household, while women take care of their household and children. It is daily reality, however, that many women in fact fulfil both the role of provider and caretaker and contribute to a large extent to financially support their family, while many men do not financially provide. This 'change of roles' results in ambivalence felt by both spouses, for women, in particular, in respect of the combination of household and work in often low-paid jobs and for men resulting in resentment and related problems such as drug abuse, spousal abuse, or even them abandoning their families. Consequently, in particular poor women sought ways to secure their financial position for themselves and their children in the future and to exit the

65 Arts. 18 (2) and 19 (1 and 2) Law No. 1 of 2000. If the couple has children, two attempts have to be carried out. This court-ordered reconciliation process should in theory not exceed three months, but Al-Sharmani claims that it often does and thus unduly prolongs the procedure (2012, p. 86, 95).

66 Art. 20 para. 5. Law No. 1 of 2000.

67 Al-Sharmani 2012, p. 88-89.

68 Al-Sharmani 2012, p. 96-97, 99. Al-Sharmani found that the involvement of many of the fault-based divorce litigants in other proceedings such as for child maintenance, etcetera, explained the higher costs for litigation in fault-based divorce cases as compared to the costs for litigation in $\mathrm{khul}^{\prime}$ cases.

69 Al-Sharmani 2009, p. 103.

70 Al-Sharmani 2012, p. 93, 103.

71 Al-Sharmani 2012, p. 92, 102-103. 
hopeless and burdensome situation of their, often abusive, marriage. They could do so 'by playing the role of dependent, man-less woman'. ${ }^{72}$

However, several drawbacks in the judicial $\mathrm{khul}^{\text {' }}$ procedure may disadvantage women. ${ }^{73}$ First, the reconciliation process may unduly prolong the procedure, as it is often unwanted by women. Second, the wife as plaintiff often has to pay for the court-appointed arbiter since both husband and wife do not trust the other spouse's relative as arbiter; these costs may be burdensome for the wife. Third, men often use strategies to frustrate their wife's effort to seek a $\mathrm{khul}^{\prime}$ such as disputing and claiming a higher prompt dower. Fourth, apart from the fact that the wife has to renounce or return all her financial rights, there are also indications of a judiciary practice that the wife is ordered to return or compensate her engagements gifts, qayma, as well as the deferred dower, that she normally has to renounce instead of having to compensate as well. ${ }^{74}$ This will make her position economically vulnerable.

Law No. 1 of 2000 also provides relief for women who want to end their urfi marriage, a 'customary' marriage which is not legally acknowledged, although it is valid according to Shari'a law. The problem was that, according to Shari' a law, a (marriage) contract does not require an official document to be valid. Such a document, however, was required by Decree Law No. 78 of 1931 that provided that in the event of denial, claims of marriage [...] shall not be heard unless established by an official marriage document' ${ }^{75}$ Article 17 of Law No. 1 of 2000 solves this problem by adding that 'nevertheless, claims for judicial divorce $[\ldots]$ shall be heard [...] if the marriage is established by any written document'. The woman will thus be able to obtain a divorce although she is not entitled to a (deferred) dower, maintenance, or any financial compensation.

\subsubsection{Divorce through the Involvement of Both Spouses}

A couple can agree upon including a right to the self-repudiation for the wife, isma, as a condition in the marriage contract or in a separate contract drawn up during the marriage. ${ }^{76}$ It is a modality of repudiation by means of an authorization by the husband to repudiate in his place. This means that the wife can repudiate herself before the ma'zun without having to resort to the court. Including this right to the self-repudiation in the (marriage) contract will save the wife a lengthy, costly, burdensome procedure for judicial divorce

72 Al-Sharmani 2012, p. 103.

73 Al-Sharmani 2012, p. 95-96; concluding observations CEDAW of 5 February 2010, CEDAW/C/EGY/CO/7, p. 12.

74 Sonneveld 2012, p. 93-94, but Al-Sharmani states that she did not come across this judiciary practice in her observations of court session in a specific study conducted by her (2012, p. 96).

75 Welchman 2004, p. 42.

76 Bernard-Maugiron \& Dupret 2002, p. 15; El-Ehwany 2012, p. 63; Zulficar 2009, p. 252. 
that is, moreover, often uncertain in outcome. Alternatively, she will not lose all her financial rights as in the case of a khul'. In practice, this modality of self-repudiation rarely occurs simply because women are not informed about this possibility, and, if they have been informed, it is rejected for being considered unacceptable in Egyptian society. ${ }^{77}$

Furthermore, it was already mentioned above, the 'traditional' khul', which has to be distinguished from the judicial $\mathrm{khul}^{\text {' }}$ and which already existed in Egyptian law, still occurs. The 'traditional' khul' also known as talaq al-ibra or mukhala' a divorce, is the out-of-court repudiation by the husband on demand of the wife in exchange for renouncing some or all of her (financial) rights and/or even paying compensation and/or the divorce costs by the her. Many Egyptian women bargain such a divorce to avoid lengthy, costly, burdensome and uncertain court proceedings, but it is also the most costly means to divorce for women. ${ }^{78}$

\subsection{After Divorce}

The legally valid repudiation has specific legal effects that are dependent on whether the repudiation is revocable or irrevocable. ${ }^{79}$ The first and second repudiations are revocable during the waiting period of the wife. The marriage is suspended during that period. The husband can revoke the repudiation by words or acts within the waiting period of the wife. Consent by the wife is not required although she must be informed about the revocation in order to protect her since $2000 .{ }^{80} \mathrm{He}$ can only prove the revocation by an authentic act of the revocation that notifies the wife of his intention to resume the marriage; the wife must be notified within a period of 60 or 90 days from the day that she was notified of the repudiation..$^{81}$ If that period of 60 or 90 days lapses without resumption of the marital life, the repudiation becomes irrevocable. The wife may prove by any means that the marital life was resumed.

The self-repudiation in principle results in a revocable repudiation; if the husband revokes the repudiation, the wife may repudiate herself again if allowed by the contract. ${ }^{82}$ If the husband does not revoke the repudiation, the repudiation becomes irrevocable upon the lapse of the waiting period of the wife. Any repudiation is irrevocable and ends the marriage forthwith if it concerns the third separately expressed repudiation, any repudiation

77 Human Rights Watch 2004, p. 16-18.

78 Human Rights Watch 2004, p. 20, 35.

79 Bernard-Maugiron \& Dupret 2008, p. 61.

80 Art. 22 of Law No. 1 of 2000.

8160 days in the case of women who menstruate; 90 days for women who do not menstruate (anymore); ElEhwany 2012, p. 61.

82 El-Ehwany 2012, p. 63. 
before consummation, and any repudiation in consideration for compensation or in the cases provided for by law. ${ }^{83}$

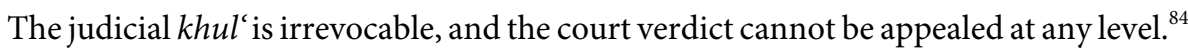

The judicial divorce on specific grounds may be revocable or irrevocable dependent on the ground for divorce. The husband can, for example, revoke the divorce on the ground of not providing maintenance by resuming support of the wife. Furthermore, the ruling is open to appeal and to request for re-examination. ${ }^{85}$ Article 14 of Law No. 10 of 2004 abolished the possibility of appealing a case at the level of the Court of Cassation to protect women against lengthy appeal processes by legal manoeuvres of their husbands. Since the year 2000, the time frames within which divorce cases must be settled are reduced. ${ }^{86}$

Upon notification of the repudiation or the judicial divorce, the wife has to file a lawsuit to claim her rights to the deferred dower, her spousal maintenance during the waiting period, and her compensation or mut' $a$ and to a remuneration for custody if the wife takes care of their children under the age of 15 . She is not automatically entitled to these rights. Moreover, it appears in practice that many men do not comply with their financial duties to their former wives (and also to their children), resulting in litigations against non-paying husbands that linger on for years. ${ }^{87}$ It appears that the enforcement of court judgments is so problematic and inadequate that most women are deprived of and will never enjoy their financial rights in the end. For this reason, CEDAW expressed its concerns about this problem of non-implementation of family court judgments due to a lack of adequate enforcement mechanisms on the occasion of the combined sixth and seventh report of Egypt; CEDAW thus recommended establishing 'effective mechanisms for the timely enforcement of family court judgments' ${ }^{88}$ Furthermore, the wife will lose all her (financial)

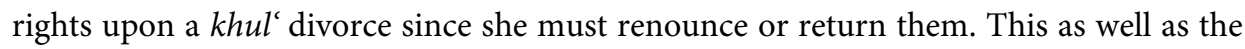
lack of equal distribution of marital property upon divorce is another concern of CEDAW, because it may result in economic vulnerability of the wife. ${ }^{89}$ For these reasons, CEDAW calls on the Egyptian government: first, 'to consider a revision of Law No. 1 of 2000 in order to eliminate the abovementioned financial discrimination against women' and second 'to provide for the equal distribution of property accumulated during the marriage upon divorce, taking into consideration non-financial contributions to the accumulation of marital property'. ${ }^{90}$

83 Art. 5 of Law No. 1 of 2000; El-Ehwany 2012, p. 59.

84 Art. 20 para. 4 and para. 5. Law No. 1 of 2000.

85 Art. 56 of Law No. 1 of 2000; Bernard-Maugiron 2004, p. 366-367; Al-Sharmani 2009, p. 94.

86 Arts. 61-63 Law No. 1 of 2000.

87 Bernard-Maugiron and Dupret 2008, p. 72-73.

88 Concluding observations CEDAW of 5 February 2010, CEDAW/C/EGY/CO/7, p. 11-12.

89 Concluding observations CEDAW of 5 February 2010, CEDAW/C/EGY/CO/7, p. 12.

90 Concluding observations CEDAW of 5 February 2010, CEDAW/C/EGY/CO/7, p. 12. 


\subsubsection{Waiting Period}

The waiting period ('idda) starts on the day of the repudiation regardless of whether the wife has been informed about the repudiation. ${ }^{91}$ It lasts 60 days for women who menstruate and 90 days for those women who count the waiting period by month, and it lasts until the birth of the child in the case of a pregnant woman.

\subsubsection{Maintenance}

The former wife is entitled to maintenance (nafaqa) from her husband during her waiting period for a maximum of one year after the repudiation or judicial divorce. ${ }^{92}$ She has to petition for maintenance within a period of one year from the date of divorce; in case of urgency, the court can issue a temporary ruling. ${ }^{93}$ The maintenance includes food expenses, clothing, housing, and medical expenses and must cover her essential needs. She will lose this right upon remarriage (with another man). Former husbands who do not comply with their maintenance duty are punishable and can be sentenced to prison for a maximum of 30 days. ${ }^{94}$ Ahmed Chowdhury refers to the establishment of a family insurance system in order to guarantee the enforcement of issued rulings upon maintenance for the wife, children, or relative. ${ }^{95}$ Family Courts will include an alimony fund 'to quickly provide women and children' with maintenance until the amount is collected from the husband.

\subsubsection{Dower}

A legally valid Islamic marriage in Egypt requires that a dower or mahr, either a specified or a proper dower, is mentioned in the marriage contract. The payment of the dower by the bridegroom is divided into two parts, the prompt dower, to be paid upon marriage, and the deferred dower that becomes due upon divorce, except in the case of a divorce by $k h u l$ ', or upon death of the husband. It is common practice in Egypt that husbands register a symbolic amount as prompt dower in order to avoid the payment of high taxes, charges between one and five percent of the registered dower, to the ma'zun, the notary who registers marriages and divorces. ${ }^{96}$ Furthermore, it appears that nowadays the wife-to-be

91 Art. 18 of Decree Law No. 25/1929; El-Ehwany 2012, p. 65.

92 Arts. 17 and 18 of Decree Law No. 25 of 1929; El-Ehwany 2012, p. 65; Bernard-Maugiron 2008, p. 58 (footnote 19).

93 Arts. 16 and 17 of Decree Law No. 25 of 1929 as amended by Law No. 100 of 1985; Ahmed Chowdhury 2006, p. 14.

94 Art. 76 bis of Law No. 1 of 2000; Berger \& Sonneveld 2010, p. 77.

95 Ahmed Chowdhury 2006, p. 14.

96 Sonneveld 2012, p. 88. 


\section{ISLAMIC DivorCES IN EUROPE}

and her family prefer engagement presents in the form of gold, so-called shabka, and a well-furnished apartment instead of a high prompt dower. Sonneveld reports that a number of women told her that they not only had to pay compensation for or give back the engagement presents, shabka, but that they also had to hand over their personal property including the furniture that was recorded in the so-called qayma or furniture list. ${ }^{97}$

\subsubsection{Remuneration}

The wife who was repudiated against her will and for a cause that cannot be attributed to her can claim a remuneration or $m u t^{\prime} a .^{98}$ The amount of the remuneration should at least equal the value of two years of maintenance. The judge will settle the amount while taking into consideration the financial means of the husband, the length of the marriage, and the circumstances under which the repudiation or divorce took place.

\subsubsection{Provisions for Children}

The distinction into custody (hadana) and guardianship (wilaya) as in Shari' a law can also be found in Egyptian family law. ${ }^{99}$

\subsubsection{Legal Guardianship}

The father is the legal guardian (wali) of the children, also after divorce, until the children reach the age of 21 years, the age of majority. ${ }^{100}$ In his absence, unfitness, or for another reason, another male (relative) in a specific order can be eligible to become the guardian of the children. The legal guardian can take decisions regarding the person and the property of the child.

\subsubsection{Custody}

After divorce, the mother has the first right and duty of custody (hadana); in the case of her remarriage, absence, unfitness, etcetera, another female relative in a specific order and, by lack of a female relative, the father and other male relatives in a specific order are eligible for custody of the children. ${ }^{101}$ Since 2008 , the custodian also has in principle the educational

97 Sonneveld 2012, p. 93-94; see also Al-Sharmani 2012, p. 92.

98 Art. 18 bis of Law No. 25 of 1929 as amended by Law No. 100 of 1985. Bernard-Maugiron 2008, p. 58 (footnote 20); Al-Sharmani 2012, p. 85; El-Ehwany 2012, p. 63.

99 Ahmed Chowdhury 2006, p. 15; Berger \& Sonneveld 2010, p. 77; Bernard-Maugiron \& Dupret 2002, p. 9 11.

100 Kulk 2013, p. 53-54.

101 Kulk 2013, p. 53. 
guardianship of the children. ${ }^{102}$ In 2005, the age for custody of the children was raised from the age of 10 for sons and the age of 12 for daughters to the age of 15 for both sons and daughters. ${ }^{103}$ From the age of 15 years, the father may become the custodian of the children, unless the child chooses to stay with his mother and the court determines that it is in the best interest of the child to remain with his mother. In that case, the extended custody of the mother lasts for sons until the age of 21 and for daughters until her marriage. The mother is not entitled to remuneration or custody fees for the children during the extended period of custody. The parent who is not the custodian is entitled to visit the children once a week; in the case of disagreement about the visiting arrangements, the judge will make these arrangements. ${ }^{104}$

From the start of the Arab Spring in Egypt in 2011, calls were also voiced for a revolution in family law. ${ }^{105}$ Small, vocal men's groups such as 'The Movement for Saving the Egyptian Family', 'Revolution of Men', or 'The Network of Men Harmed by the Personal Status Laws' sought to amend a number of - in their eyes - controversial family laws such as Law No. 1 of 2000, the khul' law, and Law No. 4 of 2005 that raised the ages for custody of children. They supported their claims by arguments such as that the laws were contradicting the Shari' $a$ and had been passed in an undemocratic way or were a Western invention or part of a Zionist conspiracy and were to destruct the family and Egyptian society. These men's and father's rights activists demand the extension of visiting rights, the right to take their children with them at home, and measures against mothers who prevent fathers from visiting their children, such as transfer of the right to custody or imprisonment and even joint care by parents after divorce but also the removal of the judicial khul.

\subsubsection{Maintenance}

The father has the duty to provide maintenance for his children if they have no resources of their own: for a daughter until her marriage or until she is able to earn a sufficient income and for a son until the age of 15 years or until he is able to earn a sufficient income. ${ }^{106}$ The father shall continue to provide maintenance for a son who has reached the age of 15 years but who is not able to earn a sufficient income due to continuation of his education or mental or physical illness. ${ }^{107}$ The maintenance should cover the needs of the child and be provided according to the means of the father.

102 Art. 54 of Law No. 126 of 2008.

103 Art. 1 of Law No. 4 of 2005 amending Art. 18 (bis-2) of Decree Law No. 25 of 1929 as amended by Law No. 100 of 1985. Law No. 4 of 2005, Al-Jarida Al-Rasmiyya No. 9 (bis) of 8 March 2005.

104 Art. 20 of Law No. 100 of 1985; see also Sportel 2014, p. 129.

105 Lindbekk \& Sonneveld, forthcoming.

106 Art. 18 (bis-2) of Decree Law No. 25 of 1929 as amended by Law No. 100 of 1985; Ahmed Chowdhury 2006, p. 14; Bernard-Maugiron 2002, p. 10.

107 Art. 18 (bis-2) of Decree Law No. 25 of 1929 as amended by Law No. 100 of 1985. 


\subsection{Assessment}

Egyptian women have access to divorce in four ways: first, to a divorce by isma (selfrepudiation) if this possibility has been included in the (marriage) contract; second, to a divorce by a negotiated repudiation (talaq al-ibra or $k h u l '$ ), although she will be dependent on her husband's consent and she will have to renounce some or all of her (financial) rights and may even have to pay a compensation and/or the costs of the divorce; third, since 2000 , to a divorce by the so-called judicial $\mathrm{khul}^{\text {' }}$ which she can obtain without the consent of her husband but by forfeiting all of her financial rights; or, fourth, to a judicial divorce on a limited number of grounds (including a specific ground if that ground has been mentioned in the marriage contract in order to give right to a judicial divorce). Egyptian men can exercise their unilateral right to repudiate (out-of-court talaq) in order to divorce although their right is in principle constrained by the obligation to register the repudiation at the ma'zun. The conclusion is that men and women do not formally have equal access to divorce despite reforms in Egyptian family law.

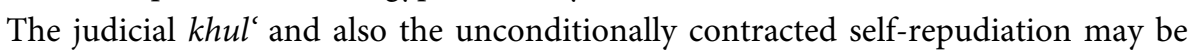
considered to offer women an independent access to divorce. Dissolving the marriage through judicial $k h u l$ ' is quicker than through a normal judicial divorce, its litigation costs are lower, and the judicial $\mathrm{khul}^{\prime}$ provides more certainty in respect of its outcome than a normal judicial divorce. The wife does not depend upon the consent from her husband or the discretion of the judge nor has to provide proof of the existence of harm, but its drawbacks are the heavy financial consequences for women. As stated above, it appears that many women with valid reasons to file for a judicial divorce opted instead for the $k h u l$ '. Remarkably, there is one other specific and recurring motive for notably poor women to seek a divorce by khul': the possibility to apply for a social security pension from the state in order to secure their uncertain financial position for themselves and their children. They are only entitled to such a pension if they are widow or divorced.

As also stated above, the self-repudiation would save the wife a lengthy, costly, burdensome procedure for judicial divorce that is, as stated, often uncertain in outcome. Alternatively, she would not lose all her financial rights as in the case of a (judicial) khul'. However, in practice this modality of delegated repudiation rarely occurs because women are not informed about this possibility and, if informed, it appears to be socially unacceptable.

The wife's procedural rights with regard to the out-of-court repudiation-based divorces can be specified to be poor or even non-existent since even the prescribed reconciliation attempt is not absolutely obligatory and the husband can shirk his obligation to register the repudiation at the ma'zun. The exercise of the procedural rights by the wife in case of tatliq is complicated by, for example, evidence problems, long-lasting procedures, and difficulties of a financial nature. The exercise of the procedural rights by the wife in a 


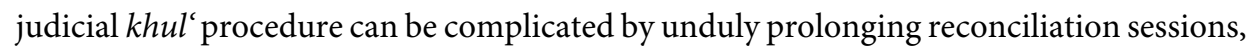
extra costs because of the mandatory arbitrator, the use of strategies by the husband to frustrate the procedure, and the judiciary practice of ordering the wife to compensate more than usual.

Finally, the out-of-court repudiation-based divorces can be qualified as public acts; they may, however, be qualified as semi-public acts in which features of a private act dominate, if the repudiation-based divorce was not pronounced in the presence of, but only registered at the ma'zun. The judicial $\mathrm{khul}^{\text {' }}$ may be equalled to a judgment as the wife is no longer dependent on the consent of her husband and the divorce is ruled upon by a judge. This also holds true for the judicial divorce (tatliq) which may also be qualified as judgment. 



\section{DivorCe IN IRAN}

\subsection{INTRODUCTION}

The revolution in Iran of 1978/1979 brought about the shift from an autocratic monarchy under the Pahlavi dynasty (1925-1979) to the Islamic republic under Ayatollah Khomeini. For the legal system in Iran, this landmark meant a shift from modernization and secularization to Islamization. Legal and political developments in both the pre- and postrevolutionary period have moulded contemporary Iranian divorce laws and practices. This introduction provides the indispensable background information to understanding these laws and practices. The procedural and substantive laws dealing with the various modalities of divorce and annulment are the subject of the following sections that set out the personal consequences and the substantive effects of the divorce in particular from the perspective of women.

\subsubsection{Family Law in Pre-Revolutionary Iran}

Until 1928, family law was the monopoly of the clerics and based on Shari $a$ law, more specifically on the Ithnă 'Ashari (Twelver) school of Shi' a law. ${ }^{1}$ Reza Shah Pahlavi initiated radical legal reforms and codification of the law inspired by modern European Codes in order to establish a secular legal system. Shari'a law was set aside in most areas of law except for civil and in particular family law. ${ }^{2}$ Volume two of the new Civil Code of 1935 (hereinafter Iranian Civil Code or ICC), concerning personal status and family law, was the codification of the majority opinion within Shi' $a$ jurisprudence; however, the codification followed the Belgian, French, and Swiss Codes as models. Being based upon patriarchal notions, the personal status and family law of Iran underwent reforms, for example, through the use of takhayyur in order to enlarge the grounds for judicial divorce for women. ${ }^{3}$

Another instrument of reform was the use of procedural devices. An example of this is the mandatory procedure for the registration of marriages and divorces in civil bureaus. ${ }^{4}$ The legislation is not explicit, and scholars are not univocal about the civil effects of the

1 Mir-Hosseini 2000, p. 23; Mir-Hosseini 2010, p. 350; see for a more detailed account of the period until 1925: Mir-Hosseini 2010, p. 322-327.

2 Mir-Hosseini 2000, p. 23-24; Mir-Hosseini 2010, p. 327-328, 351-352; Yassari 2002, p. 1088.

3 Takhayyur is a method that allows to choose and adopt rules and principles among the different solutions provided by the other schools of law.

4 At first based on Arts. 1 and 2 of the Marriage Act 1931. Later also based on Arts. 14 and 16 Family Protection Law of 1967 (FPL 1967) and Art. 10 Family Protection Law of 1975 (FPL 1975). Since 2013 based on Art. 20 Family Protection Law of 2013 (FPL 2013). Yassari 2002, p. 1089. 
registration of the divorce. Mir-Hosseini states that compliance with the registration requirement confers legal validity upon the marriage or divorce. ${ }^{5}$ But Bergmann et al. do not deem the registration to be required for their effectiveness by stating:

Diese gerichtliche Beteiligung im Scheidungsverfahren ist jedoch für eine wirksame Scheidung nicht nötig, da die Erklärung des Scheidung durch den Mann ohne Beteiligung des Gerichts zivilrechtlich wirksam ist, strafrechtlich jedoch nach $\$ 10$ Abs 4 FamSchG geahndet wird. [...] Die Eintragung der Scheidung ist, ebenso wie die Beteiligung des Gerichts, keine Wirksamkeitsvoraussetzung. Sobald der Mann die nötige Scheidungsformel unter Anwesenheit zweier gerechter, also gesetzestreuer Männer nach $\$ 1134$ ZGB ausspricht, sind die Parteien geschieden. ${ }^{6}$

Furthermore, Bergmann et al. state:

Der Widerruf bzw die Rückkehr benötigt zur zivilrechtlichen Wirksamkeit zwar keine Eintragung, eine fehlende Eintragung kann aber Geld- oder Freiheitsstrafe bis zu einem Jahr Haft mit sich bringen, $\$ 654$ IslamStrafG. ${ }^{7}$

However, the requirement of Article 1 of the Marriage Act 1931 that imposes on the husband the obligation to have his informal marriage or divorce registered within twenty days after the date of marriage or divorce (under penalty of 6 months of imprisonment) might be in support of the view of Mir-Hosseini being the right opinion, at least until the abrogation of this article in 2013. The Iranian legislator obviously wanted to prevent the existence of informal marriages, although they are religiously valid anyhow. Mir-Hosseini also mentions that the Family Protection Law of 1967 (hereinafter FPL 1967) made the registration of the temporary marriage impossible. ${ }^{8}$ According to her, the fact that the mandatory registration procedure thus only concerned the permanent marriage aimed at the discouragement, and even the ban, of contracting a temporary marriage. At least this development curtailed the validity of the temporary marriage as it lacks legal validity without registration. Mir-Hosseini points out that precisely the 'dual notion of validity', legal versus religious, as a result of the registration procedure may imply a drawback for permanent marriages at the same time: non-observance of the procedure of registration results in the legal invalidity of the marriage and a penalty, but it does not result in its

\footnotetext{
Mir-Hosseini 2010, p. 351.

Bergmann et al. 2002, p. 63.

Bergmann et al. 2002, p. 66.

Mir-Hosseini 2000, p. 166.
} 
invalidity from a religious perspective. ${ }^{9}$ Another example of a procedural device concerns the requirement that the court must give permission for a polygamous marriage by the husband and imposes conditions such as the consent of the first wife. ${ }^{10}$ The last example refers to the requirement of the 'Certificate of Impossibility of Reconciliation' (hereinafter the Certificate), evidence of the irretrievable breakdown of the marriage, issued by the court. This Certificate was initially required as authorization to register a divorce and later as authorization for the divorce and its registration. ${ }^{11}$ Until 1967, the repudiation was still the husband's exclusive, out-of-court facility to divorce his wife, although he was required to register the repudiation. ${ }^{12}$ The Certificate was introduced in the FPL 1967 to curtail the arbitrary, extrajudicial repudiation by the husband and thus to prevent legal uncertainty and abuse of justice and to give equal rights at divorce to men and women. ${ }^{13}$ The husband thus had to submit an application for divorce in court. The Certificate was issued by the court when the mutual consent to divorce of the spouses lacked, after an unsuccessful attempt at reconciliation by arbitration and upon the fulfilment of one of the grounds for divorce that are included as a condition in the marriage contract.

Grounds for divorce included as a condition in the marriage contract in combination with the provision of the power of attorney for the wife to execute a divorce was a legal stratagem. ${ }^{14}$ Its purpose was to avoid a clash with Shari' $a$ and, hence, also with the Iranian Constitution, according to which all Iranian laws had to be in accordance with Shari' $a$ law. ${ }^{15}$ Divorce is considered to be the exclusive right of the man in Shari' $a$ law as also reflected in Article 1133 ICC. $^{16}$ Article 17 FPL 1967 suggests that men still have this exclusive right and that the wife has a comparable right but only when the husband has delegated this right to her. ${ }^{17}$ Pursuant to Article 17 FPL 1967, he is obliged to do so. According to Shari'a law, stipulations that are not contrary to the essence of marriage can be made in the marriage contract. Hence, the procedural devices had been given an 'Islamic

9 Mir-Hosseini 2010, p. 351.

10 Art. 16 FPL 1975; Mir-Hosseini 2000, p. 24; Mir-Hosseini 2010, p. 352.

11 Arts. 8, 11, 16, 17, 19 FPL 1967; Arts. 8-12 FPL 1975; Art. 24 FPL 2013; Mir-Hosseini 2000, p. 24, 54-55; Mir-Hosseini 2010, p. 352; Yassari 2002, p. 1089.

12 Art. 1 Marriage Act 1931; Yassari 2002, p. 1089.

13 Art. 8 and Art. 19 FPL 1967.

14 Hinchcliffe 1968, p. 518-519.

15 Art. 2 of the Supplementary Constitutional Law of 1907 forbids the enactment of any law which is contrary to 'the sacred precepts of Islam and the laws laid down by' the Prophet. See also Article 4 of the Iranian Constitution of 1979.

16 Art. 1133 ICC states that a man can divorce his wife whenever he wishes. See also concerning conditions as stipulations in marriage contracts Art. 4 Marriage Act 1931 and Art. 1119 ICC. Under the FPL 1967, the conditions as stipulations were included in a standard way, whereas under the other laws the stipulations had to be negotiated in order to be included.

17 Art. 17 FPL 1967 reads: 'the provisions of Art. 11 shall be inserted in the marriage document in the form of a condition of the contract of marriage and an irrevocable power of attorney for the wife to execute a divorce will be explicitly provided. In accordance with the provisions of the Civil Code such a divorce will be irrevocable'. 
look'. Yassari points out that the controversial issue was whether Article 11 FPL 1967, enlarging the grounds for divorce, also applied to men and thus restricted his unilateral right to divorce. ${ }^{18}$ The relationship between Article 11 FPL 1967 and Article 1133 ICC seemed unclear. According to her, the coming into force of the FPL 1975 (hereinafter FPL 1975) $)^{19}$ clarified the issue. Its Article 8 further enlarged the grounds on which women and men could request divorce without reference to Article 1133 ICC. Hence, Article 8 FPL 1975 implicitly abrogated Article 1133 ICC according to Yassari.

To recapitulate, the FPL 1967 and 1975 introduced major legal reforms aimed at combating abuse of justice and legal uncertainty due to polygamy and extrajudicial and unilateral divorces. Notably these devices curtailed men's rights to polygamy and repudiation and deprived the latter of its extrajudicial nature. The FPL 1975 formally repealed all prior laws that were conflicting with the content of the FPL 1975. The Law of 1936 prohibiting women from wearing a chador or headscarf in public already represented a strong signal of the 'emasculation of religious-based law and practice'. ${ }^{20}$

Under the Pahlavi rule, marriage validity and divorce issues were initially dealt with in 'special courts'. These courts were the redefinition of the former Shari' $a$ courts presided over by clerics until 1936; since then they have been under the authority of state courts. ${ }^{21}$ They were later replaced by 'Family Protection Courts', which were based upon the 1967, respectively 1975, FPL, presided over by civil judges trained in modern jurisprudence and having their own procedural rules. ${ }^{22}$ These courts also had the discretionary power to decide on child custody issues - even contrary to classical Shi' a custody rules, thus putting women on a more equal footing with men in these matters - as from $1975 .^{23}$

The opposition to the autocratic Pahlavi reign, because of the fast secularization, the legal reforms in the absence of democracy, the bad governance, the undermining of the judiciary, the corruption, the extravagancies, the wide gap in wealth and income within the population, the numerous violations of civil and political human rights, and the increasing influence of the United States of America (USA), led to the 1978/1979 Revolution and the subsequent establishment of the Islamic Republic of Iran. ${ }^{24}$

In the following section, a concise overview of the various state actors and their most important features will be presented in order to provide essential insight into the relationship between the secular and religious spheres and especially the extent of influence of Islam on the functioning of the contemporary, post-revolutionary Iranian state, society, and its legal system.

18 Yassari 2002, p. 1090.

19 Published in Ruzname-e rasmi, No. 8785 of 03-03-1975.

20 Mir-Hosseini 2010, p. 328.

21 Mir-Hosseini 2010, p. 327.

22 Art. 1 FPL 1975; Execution Order of the Family Protection Law.

23 Arts. 1, 2, 12-15 FPL 1975; Mir-Hosseini 2000, p. 24, p. 154; Mir-Hosseini 2010, p. 329, 352-353.

24 Mir-Hosseini 2010, p. 328-331. 
On the one hand, the 1979 Constitution of the Islamic Republic of Iran ${ }^{25}$ (hereinafter the Iranian Constitution) refers to democratic principles and establishes democratic institutions. Examples of these democratic principles and institutions are the election by direct popular vote of the President, the highest authority after the Supreme Leader; ${ }^{26}$ the separation of the legislative, judicial, and executive powers; ${ }^{27}$ and the establishment of the unicameral parliament, the Islamic Consultative Assembly (majles-e shora-ye eslami) which has the legislative power. ${ }^{28}$

On the other hand, the Iranian Constitution also establishes theocratic and semi- or undemocratic institutions. The Constitution thus subordinates the people to the clergy, the Supreme Leader (velayat faqih), ${ }^{29}$ who is the highest authority in Iran and appears to have the control over the legislative, executive, and judiciary state powers ultimately because of his influence on the following two institutions: the Assembly of Experts ${ }^{30}$ and the Guardian Council (shoray-e negahban).$^{31}$ The Assembly of Experts consists of 86 clerics elected by popular vote who elect the Supreme Leader and supervise his activities. The Guardian Council (shoray-e negahban) is a complementary institution to the parliament that consists of six clerical jurists appointed by the Supreme Leader and six non-clerical jurists elected by parliament. The primary functions of these institutions are to check the compliance of laws with Shari' $a$ and the Iranian Constitution and to confirm the legislative status of decisions of the parliament. This council is also allowed to supervise all elections by popular vote. Finally, the Expediency Council (mahm 'a-e tashkhis-e maslehat-e nezam), ${ }^{32}$ which consists of two groups of permanent and non-permanent members which are appointed by the Supreme Leader, is also complementary to the parliament, as one of its functions is arbitration between the Guardian Council and parliament in the case of a dispute between these institutions about the parliament's legislation. The Expediency Council may give effect to legislation that has been found by the Guardian Council to contradict the Shari ${ }^{4} .^{33}$ Another function of the Expediency Council is that of adviser to the Supreme Leader.

25 The 1979 Iranian Constitution was amended in 1989. See for detailed information about the 1979 Iranian Constitution: Mir-Hosseini 2010, p. 347-350; see for the text of the amended Iranian Constitution: $<$ www.servat.unibe.ch/icl/ir00000_html > and Abghari 2008, appendix 4, p. 163-246.

26 Arts. 113-142 Iranian Constitution; see also Abghari 2008, p. 17-20, Mir-Hosseini 2010, p. 333.

27 Art. 57 Iranian Constitution.

28 Arts. 62-90 Iranian Constitution; see also Abghari 2008, p. 9-11; Mir-Hosseini 2010, p. 349.

29 Arts. 107-112 Iranian Constitution; see also Abghari 2008, p. 25-27; Mir-Hosseini 2010, p. 333, 349.

30 Arts. 107, 108, 111 Iranian Constitution; see also Abghari 2008, p. 25; Mir-Hosseini 2010, p. 333, 349.

31 Arts. 91-99 Iranian Constitution; see also Abghari 2008, p. 11-13; Mir-Hosseini 2010, p. 333, 349.

32 Or the Assembly to Discern the Best Interest of the System, Art. 112 Iranian Constitution; see also Abghari 2008, p. 13-17; Mir-Hosseini 2010, p. 338-339, 349.

33 Ansari-Pour 2005-2006, p. 421. 


\section{ISLAMIC DIVORCES IN EUROPE}

The judiciary exercises the judicial power, but it is also indirectly involved with the other powers. It, inter alia, nominates the six jurist members of the Guardian Council to the parliament and must guarantee the consistency of case law, which is one of the sources of the codified Iranian law. ${ }^{34}$ The head of the judiciary, the highest authority, is appointed by the Supreme Leader.

This overview shows an imbalance between the democratic, secular sphere on the one hand, and the theocratic, religious sphere in the state and its apparatus on the other hand in favour of the latter.

\subsubsection{Family Law in Post-Revolutionary Iran}

The 'reigns of terror' of the first years of the Islamic Republic of Iran are characterized by the implementation of the 'hard line interpretations' of Shari' a law, especially in the areas of family and criminal law, and the strengthening of the Islamic state and the clerical government. ${ }^{35}$ Article 4 of the Iranian Constitution of 1979 prescribes that all laws and regulations must be based upon Islamic criteria. Article 167 of the Iranian Constitution declares Shari' $a$ law to be a complementary source of law for the judiciary whenever the codified law is silent, deficient, or ambiguous. But if the codified law contradicts Shari'a law, the judge is not allowed to disregard the codified law and to adjudicate the case on the basis of Shari' $a$ law. ${ }^{36}$ Instead the judge must refer the case to another chamber or branch of the same court. European-inspired codes were either replaced by new codes based on Shi'a fiqh or accordingly amended. Nevertheless, the legislator did not formally repeal many laws, and the judiciary retained many laws and legal concepts of the Pahlavi era.

The courts were restructured on several occasions, and civil judges were gradually replaced by clerics trained in the High Judicial School of Qom. ${ }^{37}$ Although the FPL 1975 has never formally been repealed, the 'Family Protection Courts' were subsequently replaced by new 'Special Civil Courts' in 1979, ${ }^{38}$ the General Courts in $1994,{ }^{39}$ and the Family Courts in 1998/1999, which were structured as special branches within the General and Revolutionary Courts. ${ }^{40}$

34 Arts. 156-174 Iranian Constitution; see also Abghari 2008, p. 21-25; Mir-Hosseini 2010, p. 349-350.

35 Mir-Hosseini 2010, p. 331-332, 334.

36 Ansari-Pour 2005-2006, p. 421.

37 Mir-Hosseini 2010, p. 333.

38 Art. 3 of the Special Civil Courts Legislation of 1979 (hereinafter SCCL); Abghari 2008, p. 73.

39 Pursuant to the Law of Formation of General Courts; Mir-Hosseini 2000, p. ix; 2010, p. 355.

40 Established by 'the Act on the Allocation of some of the Courts as Courts Subject to Art. 21 of the Constitution (Family Court)' in conjunction with The Establishment of General and Revolutionary Courts Act and, later, Art. 4 of the Reform for the Establishment of General and Revolutionary Courts Act of 2002. Abghari 2008, p. 69, 73; Mir-Hosseini 2000, p. ix; 2010, p. 355; Shid 2005, p. 141-142. 
Despite the fact that the FPL 1975 has never formally nor totally been repealed, women's rights deteriorated under the post-revolutionary regime. Men's rights to unilateral repudiation and polygamy were restored, and women's own rights to divorce and child custody were restricted. ${ }^{41}$ In its note 2 to Article 3, the Special Civil Courts Legislation of 1979 (hereinafter SCCL) ${ }^{42}$ replaces the repealing effect of the FPL 1975, notably its Article 8, through restoring the Civil Code articles and the Shari' $a$ injunctions concerning divorcerelated issues. ${ }^{43}$ But the same note also retains an element of the FPL 1975: the requirement to the husband of the court's permission for divorce and its registration after an unsuccessful arbitration for reconciliation, unless the spouses agree upon divorce. ${ }^{44}$ This element, the judicial intervention, is contradictory to the Shari' $a$ view concerning the extrajudicial nature of the unilateral divorce by the husband. It was defended by making reference to the Koran 4:35, which refers to the duty to appoint arbiters in the case of marital discord. The SCCL - in contrast to Article 15 of the FPL 1975 - also severely restricted the discretionary power of the judge to deviate from the Shi' $a$ views and the civil code's articles about custody in favour of the mother after remarriage. The same law enabled the registration of temporary marriages through a court order and herewith their acquisition of a legal status. $^{45}$

The regime change resulted in many changes. Wearing the hijab became compulsory for women. There was segregation of the sexes in the educational system. Women were prohibited to study specific subjects or to enter specific professions such as becoming a judge. Alcohol, music, recreation in public, prostitution, and homosexuality were prohibited. The adherence to another religion, other than Islam, was not tolerated. The state censorship of the media intensified, and human rights violations including, inter alia, violations of the right to a fair trial by means of closed hearings, secret verdicts, and mass executions continued despite the regime change. All of these changes became signals of the Islamization of the Iranian state and society.

But the tide was turning in the 1980s and 1990s. ${ }^{46}$ The 'New Religious Thinkers' criticized the Islamic state from an Islamic perspective. A new school of 'Dynamic Jurisprudence', which pursued a new interpretation of Islamic law by taking into account factors such as place and time, emerged. Reformists argued for a demarcation between state and religion, and they also argued for a distinction between the sacred, universal, eternal Shari' $a$ and the local science of fiqh being subjected to change in its doctrines and premises. An increasingly critical generation of women, who had played a pivotal role in the revolution

41 Mir-Hosseini 2010, p. 334-335, 340, 353-354.

42 Published in Ruzname-e rasmi, No. 10088 of 11-10-1979.

43 Yassari 2002, p. 1090.

44 Mir-Hosseini 2000, p. 55.

45 Mir-Hosseini 2000, p. 166.

46 Mir-Hosseini 2010, p. 340-341, 354-356. 
and had taken over many tasks and responsibilities of their deceased husbands and sons in the war with Iraq, stood up. ${ }^{47}$ They claimed their position as equal and valuable members of the Iranian society. An 'Islamic feminism' emerged. Gender debates regenerated. Progressive fatwas about social issues including women's rights were issued. Women could become advisory judges and make use of freely available family planning, etcetera.

Consequently, divorce laws were amended or enacted. In 1982, Article 1130 ICC was amended in that the court had more power to grant a judicial divorce on the ground of extreme hardship and harm (osr wa haraj). ${ }^{48}$ These grounds were further expanded in 2002. New marriage contracts were introduced aimed at curtailing the men's privilege to (arbitrarily) repudiate through (financially) compensating women for the divorce. ${ }^{49}$ The new marriage contracts include two stipulations that have to be signed by each spouse individually: one stipulation entitles women, under certain conditions, to half of the property that was built up during the marriage, upon divorce; the other stipulation entitles women to the delegated divorce on grounds almost similar to those in the FPL 1975. The Amendment to Divorce Regulations of 1991/1992 (hereinafter ADR) ${ }^{50}$ upheld the mandatory judicial intervention at divorce and the necessity of the Certificate. Furthermore, the ADR mandatorily prescribes arbitration for all divorcing couples including those that agreed upon the divorce and irrespective of the person who initiated the divorce, whether it was the husband or wife; payment of the wife's dues, the deferred dower and her maintenance during the waiting period, by the husband before the court will deliver its Certificate about the irretrievable breakdown of the marriage; and, under certain conditions, payment of any 'exemplary wages' or ojrat al-methl by the husband, the indemnity for the services and labour of the wife voluntarily rendered during the marriage. ${ }^{51}$

Despite the focus of the parliamentary election in 2000 on the reform of family law and women's rights, only 21 out of the 41 bills presented after the election were passed into law. Furthermore, those that were passed came into force in watered-down form regarding the 'gender-egalitarian tone' or intent or were even passed having nullified the 'gender-egalitarian tone' or intent of the original bill. ${ }^{52}$ An exception is the amendment of Article 1133 ICC in 2002. Whereas the old article stipulated that the husband could divorce his wife whenever he wishes, the amended article stipulates:

47 Yassari 2002, p. 1093.

48 Nayyeri 2013, p. 40.

49 Nayyeri 2013, p. 41-42; Yassari 2002, p. 1092-1093, 1094.

50 One article law published in Ruzname-e Rasmi, No. 13914 of 10-12-1992.

51 Art. 1 and sub-arts. 1, 2, 3, and 6 ADR and its adjacent legislation: Decree on the Execution of sub-art. 1 of Art. 1 ADR; Act on the Explanation of the sub-arts 3 and 6 ADR, Act on the Determination of the Duration Concerning the Delivery of the Certificate of the Irretrievable Breakdown of the Marriage. Bariklou 2011, p. 2; Mir-Hosseini 2012, p. 73; Nayyeri 2013, p. 41.

52 Mir-Hosseini 2012, p. 76-77. 
A man can divorce his wife under the conditions of the current law and by applying to the court.

Note- A woman, too, and according to articles 1119, 1129 and 1130 of the current law can request a divorce from the court. ${ }^{53}$

Conservative governments as of 2005 succeeded the reformist governments of the late 1990s. The most recent development in family law concerns the presentation of the Family Protection Bill in August 2007 by the hardliner government of Ahmadinejad. ${ }^{54}$ The Bill aimed to fill a legal vacuum that had been created in 1979 when the post-revolutionary government suspended the FPL 1975. As this Bill aims at reversing important, retained pre-revolutionary reforms and protective measures of the 1980s and 1990s, it is also called the Destruction of the Family Bill. ${ }^{55}$ The Bill was heavily disputed domestically and internationally. Both women's rights activists and members of the Iranian Shi'a 'ulama' heavily criticized key articles for being against the family, women's rights, and Islamic principles. The Bill facilitated polygamy for men through abolishing the requirement of the consent of the first wife upon the court's decision that the husband can afford a second wife. ${ }^{56}$ However, this article was withdrawn by an amendment in 2011 and finally not adopted in the FPL 2013. ${ }^{57}$ The Bill as amended in 2011 also proposed to register temporary marriages only in three specific situations such as pregnancy or if it is stipulated in the agreement or as condition of the marriage, thus ending the requirement of registration for all temporary marriages to the detriment of the legal and financial protection of women as mentioned in a prior amendment. ${ }^{58}$ It also made women pay taxes at marriage if they stipulate an excessive and uncommonly high dower. ${ }^{59}$ The latter measure thus frustrates that men deter from divorce.

The Bill entered into force as the Family Protection Law on 27 April 2013 (FPL 2013).$^{60}$ The entry into force of the FPL 2013, inter alia, abrogated the Marriage Act 1931 and the

53 Nayyeri 2013, p. 41.

54 Mir-Hosseini 2012, p. 77-79; Nayerri 2013, p. 46-48; Osanloo 2013, p. 125. See Osanloo 2013 for a more detailed discussion of the Bill in relation to the sociolegal developments and reforms in Iranian family law and the debates it evoked.

55 See for the last amended version of the Family Protection Bill of 21 August 2011: <www.iranhrdc.org/english/human-rights-documents/iranian-codes/3199-family-protection-act.html\#.UBeY61Gd7Jw >.

56 Before the amendment of the Bill in August 2011, its Art. 23 stated: 'Taking a second temporary wife is subject to permission from court after approval of the man's financial ability and his guarantee for executing justice between his wives'.

57 Yassari 2014, p. 125.

58 Art. 22 Family Protection Bill as amended on 21 August 2011 or Art. 21 FPL 2013. For an exhaustive study of the temporary marriage: S. Haeri, Law of desire: Temporary marriages in Iran, London: I.B. Tauris 1989.

59 Concerning the dower, see Art. 25 Family Protection Bill as amended on 21 August 2011.

60 Family Protection Law of 19 February 2013, ruzname-e-rasmi Nr. 19835 of 11-04-2013. To my knowledge, the official text of the Family Protection Law 2013 is only available in the Farsi language as yet (1 March 2014). I obtained an informal translation from Ms. Khalidah Ahmadi, a law student at Maastricht University 
ADR, however with the exception of B under sub-article 6 ADR; it did not explicitly abrogate its predecessor the FPL $1975 .{ }^{61}$ The FPL 2013 contains a number of procedural provisions in particular concerning the establishment of family courts and Family Counselling Centres and the registration of the marriage, divorce, and annulment in sections 1 to 4. According to Yassari, these provisions reflect or concretise the already existing legal situation until the entry into force of the FPL $2013 .{ }^{62}$ Furthermore, it contains provisions regarding care and custody and maintenance in its section 5. Sections 6 and 7 deal with pensions and widow pensions and penal provisions, respectively. The stipulation regarding the tax on the dower was not maintained in the FPL 2013. However, the stipulation regarding the requirement of the mandatory registration of the temporary marriage that is restricted to three situations is maintained in Article 21 FPL 2013. This article stresses the importance of the permanent marriage. Further consequences of the entry into force of the FPL 2013 in as far as relevant for divorce and post-divorce provisions will be discussed below. It should be realized that information that is provided on the abrogated laws nevertheless continues to be relevant in relation to those divorces that have been established in accordance with these laws before the entry into force of the FPL 2013.

\subsubsection{Features of Contemporary Iranian (Family) Law}

The current Iranian legal system is based on Romano-Germanic and Shari' $a$ law. ${ }^{63}$ Its sources are, on the one hand, sources of Iran's codified legislation including the law (the Iranian Constitution, legislation, treaties, official regulations, directives), case law, custom, and doctrine (opinions of legal scholars) and, on the other hand, Shari' $a$ law sources including the Koran, Sunna, consensus, and reason. ${ }^{64}$

Notably the personal status in Iranian law and Iranian family law originates, as said, in Shari' $a$ law. It is religiously split pursuant to Articles 12 and 13 of the Iranian Constitution: the family and personal status affairs of adherents to a specific, recognized denomin-

who is of Iranian descent and native speaker. Furthermore, Yassari published an introduction to and short overview of the articles in the FPL 2013 in Das Standesamt 2014, No. 4 after the closure of this research. I made use of her publication while I prepared the manuscript for publication.

61 See Article 48 FPL 2013.

62 Yassari 2014, p. 125.

63 Abghari 2008, p. 63-69.

64 The Shi'a meaning of Sunna deviates from the Sunni meaning of Sunna as the spoken and acted example of the Prophet and his companions; the Shi' a use Sunna in the meaning of words, behaviour, or silence endorsing behaviour of the Fourteen Impeccant Leaders (Abghari 2008, p. 67). The meaning of consensus in Shi'a law is restricted to unanimity about a legal issue among impeccants instead of unanimity among legal scholars as in Sunni law (Abghari 2008, p. 69). The fourth source of law in Shi' a law is reason, whereas it is analogy in Sunni law (Abghari 2008, p. 69). 
ation should be dealt with in accordance with the laws of that denomination. ${ }^{65}$ Article 12 of the Iranian Constitution declares Islam as based on the Ithnă 'Ashari (Twelver) school to be the official religion while explicitly stating respect for the other Islamic schools including the Hanafi, Maliki, Shafi i, Hanbali, and Zaydiyya. Article 13 of the Iranian Constitution officially recognizes the Zoroastrians, the Jews, and the Christians as religious minorities. $^{66}$

The previous sub-section demonstrates that a mixture of pre- and post-revolutionary laws based on the Ithnă 'Ashari (Twelver) school of Shi'a law recently was and/or (still) is normative for Iranian divorce laws and practices in relation to Muslims. Since April 2013, the Family Protection Law 2013 (which, inter alia, abrogates the Marriage Act 1931 and the Amendment to Divorce Regulations (ADR), but with the exception of B under subarticle 6 ADR) and the Iranian Civil Code are relevant; the relevant laws until 2013 were the Marriage Act 1931, the Iranian Civil Code, the Special Civil Courts Legislation of 1979, and the Amendment to Divorce Regulations of 1992.

As far as human rights obligations are concerned, Iran has ratified, inter alia, the International Convention on Economic, Social, and Cultural Rights (hereinafter ICESCR), ${ }^{67}$ the International Convention on Civil and Political Rights (hereinafter ICCPR), and the Convention on the Rights of the Child (hereinafter CRC). But Iran still did not ratify the Convention against Elimination of All Forms of Discrimination against Women (hereinafter CEDAW) due to its frustration by the Guardian Council in spite of the approval by the Iranian parliament in August 2003. ${ }^{68}$ Let alone that Iran has acceded to its Optional Protocol. Yet, Shari'a law prevails over international law, including human rights law, pursuant to Article 4 of the Iranian Constitution. Other articles of the Iranian Constitution emphasize the significance of:

65 Yassari 2002, p. 1088. See also 'Law on the permission for application of civil rights on the own customs and traditions of non- Shi' $a$ Iranians' of 1933 and 'Law on the handling of legal proceedings concerning civil rights and the religious doctrine of Iranian Zoroastrians, Jews and Christians' of 1993.

66 Mir-Hosseini (2010, p. 322) states that of a population of over 70 million, $89 \%$ is Shiite, $9 \%$ is Sunni, and the remaining 1-2\% of the population is Christian, Jew, Zoroastrian, or Baha' $i$. The Baha'i is a religious minority group that is not recognized as such, but rather as a political movement by the Iranian government. The Baha'is are also seen as apostates from Islam as their teachings are not in conformity with traditional Islam and they are thus classified as 'unprotected infidels'. Persecutions of Baha'is in the form of inter alia unwarranted arrests, false imprisonments, torture, unjustified executions, destruction and confiscation of their properties, and denial of civil rights, employment, and access to higher education in Iran are reported. See e.g. the Fédération Internationale des Ligues des Droits de l'Homme (FIDH) report about 'Discrimination against religious minorities in Iran' of 2003 and the Iran Human Rights Documentation Center (IHRDC) report 'A faith denied: The Persecution of the Baha'is in Iran' of December 2006.

67 Date of ratification ICESCR: 24 June 1975; date of ratification ICCPR: 24 June 1975; date of ratification CRC: 13 July 1994 including a reservation upon ratification that 'The Government of the Islamic Republic of Iran reserves the right not to apply any provisions or articles of the Convention that are incompatible with Islamic Laws and the international legislation in effect'; see for an overview of the status of these treaties: $<$ http://treaties.un.org/Pages/Treaties.aspx?id=4\&subid=A\&lang=en $>$.

68 Mir-Hosseini 2010, p. 362; Nayyeri 2013, p. 59-60. 
the law and the ethics of Islam' and 'Islamic criteria' for national notably civil and family law as well. Article 10 Iranian Constitution says that 'Since the family is the fundamental unit of Islamic society, all laws, regulations, and pertinent programs must tend to facilitate the formation of a family, $[\ldots]$ and the stability of family relations on the basis of the law and the ethics of Islam.

Article 20 of the Iranian Constitution reads that 'all citizens of the country, both men and women, equally enjoy the protection of the law and enjoy all human, political, economic, social, and cultural rights, in conformity with Islamic criteria'. Article 21 of the Iranian Constitution states that 'The government must ensure the rights of women in all respects, in conformity with Islamic criteria and accomplish', inter alia, 'the following goals: [...]'.

This introduction already shows that several issues and provisions of Iranian family law, such as those concerning divorce, are not (yet) in conformity with human rights law. This is stressed by the recommendation made by the Human Rights Committee in 2011 that entails that Iran should 'amend its Civil Code and Family Protection Act to grant women equal access before the law, including in matters of marriage, divorce, custody, inheritance, transmission of citizenship and freedom of movement'. ${ }^{69}$ The next section will illustrate this as well.

\subsection{Divorce}

Iranian divorce laws and practices encompass the following modalities for the dissolution of marriage apart from dissolution due to the death of either spouse: ${ }^{70}$

- Divorce on the initiative of the husband, the repudiation (talaq)

- Divorce on the initiative of the wife:

- The judicial divorce on a limited number of grounds (talaq al-tatliq)

- Various modalities of divorce based on agreement between or that require the involvement of both spouses being:

- The assignment of the power to repudiate to the wife, the self-repudiation (talaq al-tafwid)

- The negotiated repudiation (khul' or chol-i (Farsi)

- The repudiation by agreement (mubara'a or mo-barat (Farsi))

- Judicial annulment on the initiative of either spouse (faskh)

69 Report of the Special Rapporteur on the situation of human rights in the Islamic Republic of Iran of 4 October 2013 to the General Assembly of the United Nations, A/68/503, p. 10, retrieved via <http://shaheedoniran.org/wp-content/uploads/2013/10/N1350031.pdf>.

70 Although Art. 1120 ICC does not state death as one of the causes of a dissolution of marriage. 
Permanent marriages can be dissolved through, among others, divorce proper, whereas temporary marriages cannot. ${ }^{71}$ Temporary marriages can only end by operation of the law through lapse of its duration or death of either spouse or can be dissolved through annulment or waiver of the remaining period by the husband.

The divorce in general is, irrespective of the person who initiated it, the dissolution of marriage through the unilateral declaration of the husband or his representative, whereas in the case of annulment, either or both spouses can dissolve the marriage. ${ }^{72}$ The modalities of divorce proper should especially be distinguished from the annulment regarding the nature of the judicial intervention. ${ }^{73}$ All modalities of divorce proper, irrespective of the person(-s) who initiated the divorce, are subjected to mandatory intervention of the court and registration and thus to procedural restraints. The judicial intervention is aimed at the authorization of the divorce and its registration through issuance of the Certificate after a mandatory attempt to reconciliation. Either or both spouses did not need to observe any of the aforementioned formal procedures in the case of an annulment until 2013. ${ }^{74}$ The judicial intervention in the case of annulment was declaratory of character as it confirms that the claimant has the right to annul the marriage. Since April 2013, Article 20 FPL 2013 also stipulates a mandatory registration in the case of an annulment.

The judicial intervention and the registration procedure are discussed first before discussing the various modalities of divorce under Iranian family law.

\subsubsection{Judicial Intervention and Registration of the Divorce}

\subsubsection{Procedure until 2013}

The judicial intervention consisted of the following procedure: either or both spouses who wished to divorce, also in the case of mutual agreement to divorce, had to file a request for divorce at the Family Court in order to obtain authorization to divorce and to register the divorce. ${ }^{75}$ The court or, when it was not successful, two arbiters (dawar) outside the court then tried to reconcile the spouses. ${ }^{76}$ The arbiters were often chosen from among family members, one by each spouse. A successful reconciliation rendered the case closed. Upon failure of the attempt at reconciliation, the court would in principle issue the 'Certificate of Impossibility of Reconciliation' (hereinafter the Certificate) and sent it to the

71 Arts. 1120 and 1139 ICC.

72 Bergmann et al. 2002, p. 58, 61; Hamidian 2004, p. 94-95.

73 Bergmann et al. 2002, p. 58, Hamidian 2004, p. 95.

74 Art. 1132 ICC; Bergmann et al., 2002, p. 58; Shid 2005, p. 148.

75 Art. 1 ADR and Art. 3 SCCL; Mir-Hosseini 2010, p. 355; Safa'i 2004, p. 76-77; Shid 2005, p. 149; Yassari 2002, p. 1089-1090. See for a detailed report of court divorce procedures in the post-revolutionary Special Civil Courts in Tehran in 1985: Mir-Hosseini 2000, p. 58-83.

76 Art. 1 ADR, Notes 1, 2 to Art. 1 ADR, Arts. 1-8 decree for the execution of Note 1 to Art. 1 ADR and Note 2 to Art. 3 SCCL; Mir-Hosseini 2000, p. 61. 
Bureau for Registration of Divorces (daftar-e rasmi-e talaq; hereinafter Divorce Bureau). ${ }^{77}$ The Certificate provided the authorization to divorce and was required for the mandatory registration of the divorce at this Bureau. ${ }^{78}$ The court could delay its authorization or even refuse it to the wife or, for example, order the husband to pay compensation when it established that the husband abused his right to divorce. ${ }^{79}$ The court could not deny the (authorization for) divorce to the husband in the end, according to Hamidian. ${ }^{80} \mathrm{He}$ argues that this is obvious in view of Article 1133 ICC according to which the husband can divorce his wife whenever he wishes. On the basis of this article, the court only had 'the role of an executor' and could not prevent the husband from divorcing his wife despite advice to the contrary by the arbiters or invalid reasons for the divorce. ${ }^{81}$ But Safa'i claims that the judge could refuse the authorization for the divorce to the husband for reasons of abuse of his right for divorce. ${ }^{82}$ Moreover, the formulation of Article 1133 ICC to which Hamidian refers was modified in 2002. The modified formulation 'a man can divorce his wife under the conditions of the current law' seems to restrict the husband's freedom 'to divorce his wife whenever he wishes' as stated under the old formula of Article 1133 ICC. This conclusion may invalidate the argument of Hamidian and thus his claim that the judge cannot deny the authorization for divorce to the husband.

The Certificate had to be presented at the Bureau for Registration of Divorces within its validity date being three months upon its date of issue. ${ }^{83}$ The holder of the Bureau summoned both spouses in order to execute and register the divorce. In Iranian law, as in Shari' $a$ law, divorce is not a judicial act. ${ }^{84}$ The decision of the court to authorize the divorce does not result in the divorce by operation of law. The divorce remains the unilateral act of the husband pronounced by him or by his agent such as the judge.

The execution of the divorce and its registration depended upon the compliance of the husband with the (financial) rights of the wife, such as payment of the deferred dower, maintenance, etcetera, unless the wife was at fault, did not perform her marital duties, had

77 Art. 1 ADR and Note 2 to Art. 3 SCCL.

78 Art. 1 ADR in conjunction with the Act of Explanation of the sub-arts. 3 and 6 to the ADR, Arts. 1 and 2 Marriage Act 1931.

79 Abuse of law is prohibited in Iranian law as in Shari'a law. Art. 40 of the Iranian Constitution reads 'No person may exercise his own rights as a means of constraining others or violating the public interest'; Safa' $i$ 2004, p. 77.

80 Hamidian 2004, p. 85.

81 Hamidian 2004, p. 85.

82 Safa'i 2004 , p. 77

83 (One article) Act on the Validity Period of the Certificate of Incompatibility (Act of 02-11-1997 published in Ruzname-e Rasmi, No. 15384 of 17-12-1997). More statutory provisions about the registration procedure and the bureaus for registration: the amended 'Decree concerning the first article of the Marriage Act 1931' of 1933; 'Decree of the registration bureau for marriage and for divorce' of 1931; 'Decree concerning the second article of the bureau for registration of marriage and divorce' of 1931; 'Decree concerning the equalization of the registration of marriage and divorce' of 1932.

84 Bergmann et al. 2002, p. 61; Safa'i 2004, p. 76. 
relinquished any of these rights, or upon a court order establishing the husband's inability to pay. ${ }^{85}$ Moreover, the wife could also be entitled, under certain conditions, to remuneration for her work and services on his demand that were not part of her marital duties according to the religious order, ojrat-ol-mesl. ${ }^{86}$

In the case that the court had authorized the wife to divorce, the authorization obliged the husband to pronounce the divorce.$^{87}$ If the husband did not comply with this obligation, the judge would pronounce the divorce instead, as his representative, and have the divorce registered at the Bureau. ${ }^{88}$ If the wife did not appear, the husband would pronounce the divorce and have it registered at the Bureau, and the Bureau would subsequently inform the wife. ${ }^{89}$ The execution and registration of a divorce without a Certificate was not allowed and was punishable for, inter alia, the holder of the Bureau through suspending its license. ${ }^{90}$

If, in the case of a revocable divorce, the husband had decided to resume the marital life during the waiting period of the wife, the revocation also needed to be registered, and failure to do so could result in a penalty of imprisonment. ${ }^{91}$ Non-registration of the divorce by the husband was also punishable by imprisonment. ${ }^{92}$ The civil effect of the non-registration of the divorce or of the revocation of the divorce, however, is unclear, and it might be that the non-registration will withhold the legal validity (legality) to the divorce and to the revocation of the divorce, respectively. ${ }^{93}$ The divorce or the resumed marriage is nevertheless valid according to Shari'a law.

\subsubsection{Procedure since 2013}

Section 4 (Articles 24-39) of the FPL 2013 regulates the divorce and the annulment. Since 2013, Article 20 FPL 2013 stipulates the mandatory registration of the permanent marriage, the divorce, the revocation of the divorce, and, moreover, the annulment of the marriage. The registration of the divorce or annulment in the Divorce Bureau is only permitted after

85 Note 3 to Art. 1 ADR; Shid 2005, p. 149-150.

86 Note 6 to Art. 1 ADR, Safa'i 2004, p. 77; Shid 2005, p. 150; Yassari 2002, p. 1094.

87 Safa'i 2004, p. 76.

88 (One article) Act on the Validity Period of the Certificate of Incompatibility.

89 (One article) Act on the Validity Period of the Certificate of Incompatibility.

90 Art. 1 ADR.

91 Sub-art. 4 to Art. 1 ADR; Hamidian 2004, p. 87.

92 Art. 1 Marriage Act 1931.

93 See the discussion under 7.1.1 in relation to the views of Mir-Hosseini (2010, p. 351) and, otherwise, Bergmann et al. (2002, p. 63): 'Diese gerichtliche Beteiligung im Scheidungsverfahren ist jedoch für eine wirksame Scheidung nicht nötig, da die Erklärung des Scheidung durch den Mann ohne Beteiligung des Gerichts zivilrechtlich wirksam ist, strafrechtlich jedoch nach $\$ 10 \mathrm{Abs} 4$ FamSchG geahndet wird. [...] Die Eintragung der Scheidung ist, ebenso wie die Beteiligung des Gerichts, keine Wirksamkeitsvoraussetzung. Sobald der Mann die nötige Scheidungsformel unter Anwesenheit zweier gerechter, also gesetzestreuer Männer nach $\$ 1134$ ZGB ausspricht, sind die Parteien geschieden’. And Bergmann et al. 2002, p. 66: 'Der Widerruf bzw die Rückkehr benötigt zur zivilrechtlichen Wirksamkeit zwar keine Eintragung, eine fehlende Eintragung kann aber Geld- oder Freiheitsstrafe bis zu einem Jahr Haft mit sich bringen, § 654 IslamStrafG’. 
the court or the Family Counselling Centre (in the case of agreement of the spouses on divorce) issued the 'Certificate of Impossibility of Reconciliation' or a court order or divorce decree. $^{94}$

Section 2 (Arts. 16-19) FPL 2013 deals with these Family Counselling Centres that aim to strengthen family values and prevent family disputes, in particular divorce, by, inter alia, offering mediation. They also aim 'to ensure that the best interests of women and their families are represented', by providing for the presence of legal advisers during all family court matters. ${ }^{95}$ The Family Counselling Centre shall strive to reconcile the spouses; if the reconciliation fails, they will offer their expert opinion to the court that has to be taken into account by the court.

Since 2013, the court shall issue the Certificate stating the irreconcilable differences that is mandatory for the registration of the divorce, only upon the demand for divorce from the husband or from both spouses. ${ }^{96}$ When it is the wife who petitions for the divorce, the court shall issue either a court order to compel the husband to pronounce the divorce or a divorce decree in the case of a power of attorney of the wife to divorce. ${ }^{97}$ According to Yassari, it only concerns a change in terminology: the court order or divorce decree is, as well as the Certificate, mandatory for the registration of the divorce. ${ }^{98}$ If the spouses disagree on a divorce, the court shall first refer the case for arbitration before issuing the Certificate, court order, or divorce decree. ${ }^{99}$

Upon issuance of the Certificate, court order, or the divorce decree, the court shall settle matters such as the payment of the dower, the maintenance for the wife and for the children, the recovery of the dowry, the custody of the (unborn) children, and the visiting rights for the noncustodial parent and other relatives. To this end, the court shall take into account the clauses and other provisions of the marriage contract and the emotional dependency and the best interests of the child. ${ }^{100}$ Remarkably, Article 29 FPL 2013 also refers to settling a claim for reward pursuant to Article 336 ICC. The registration of the divorce or annulment presupposes the settlement of the aforementioned rights. ${ }^{101}$ Moreover, the divorce or annulment can also be registered when the wife agrees to its registration or when a definite order of insolvency of the husband or a payment arrangement has been issued. If the wife should agree on the divorce without ensuring the aforementioned rights,

94 Art. 24 in connection with Art. 26 FPL 2013. Yassari 2014, p. 125.

95 Report of the Special Rapporteur on the situation of human rights in the Islamic Republic of Iran of 4 October 2013 to the General Assembly of the United Nations, A/68/503, p. 10, retrieved via $<$ http://shaheedoniran.org/wp-content/uploads/2013/10/N1350031.pdf $>$.

96 Art. 26 FPL 2013.

97 Art. 26 FPL 2013.

98 Yassari 2014, p. 125.

99 Art. 27 FPL 2013.

100 Art. 29 FPL 2013.

101 Art. 29 FPL 2013. 
she can claim these rights in court after the registration of the divorce. New is Article 30 FPL 2013 that stipulates the post-divorce obligation of the husband to reimburse the costs of their common household to his wife - the costs that belong to the responsibility of the husband - when she can prove in court that she has taken care of these costs on his instruction or with his permission. ${ }^{102}$

The spouse(-s) has/have to appear in and to submit the Certificate within three months to the Divorce Bureau since the Certificate is only valid for three months from the date of its issuance. ${ }^{103}$ The divorce will be pronounced and executed in the Divorce Bureau or any other official place in the presence of the notary public or his representative. ${ }^{104}$ Article 38 FPL 2013 stipulates that in the case of a revocable divorce, the pronouncement and execution of the divorce depends on the testimony in writing of at least two witnesses that the divorced wife resided in the marital home until the end of her waiting period, unless the wife agrees to the registration of the divorce. If the divorce is revoked, the registration will be annulled; if there is no revocation, the registration is finalized. Upon request of the wife, she will receive a statement concerning the final divorce and its non-revocation. Nonregistration of the divorce, annulment, or revocation of the divorce by the husband is punishable by a fine or imprisonment pursuant to Article 49 FLA 2013.

\subsubsection{Divorce by the Husband}

Talaq, originally the man's exclusive and extrajudicial right to repudiation, has thus been deprived of these characteristics because of the mandatory judicial intervention. It is remarkable that the various translations of the relevant articles concerning the repudiation in the ICC and in the literature used do not mention the term 'repudiation', but they use the term 'divorce' instead. ${ }^{105}$ This usage in relation to Iranian repudiation has been adopted in this study as well. That is, the term divorce is used to refer to repudiation hereinafter.

The husband's right to divorce is also restricted by the post-divorce financial obligations of the husband towards his wife such as the dower, maintenance, and the remuneration gift for services rendered and labour. During her research in Tehran family courts in the mid-end 1980s, Mir-Hosseini came across a practice of men who resorted to deploying strategies such as demanding for restitution of marital rights instead of (directly) a

102 Yassari 2014, p. 125.

103 Article 34 FPL 2013. Article 33 FPL 2013 deals with the period of validity of the divorce decree. This article also stipulates that the head of the Divorce Bureau is authorized to pronounce the divorce when the husband refuses to do so.

104 Article 37 FPL 2013.

105 See e.g. Bergmann et al. 2002, p. 61; Hamidian 2004, p. 84-85; Safa'i 2004, p. 77; Soleimani 2004, p. 63-64; and the Iranian Civil Code available at the Internet: for example, <www.alaviandassociates.com/documents/civilcode.pdf $>$; (Arts. 1133-1142). 
divorce. ${ }^{106}$ These men mainly had two motives: first, to avoid to have to produce grounds for the divorce in order to satisfy that their action was not based on a caprice and, second, to avoid the financial consequences which are different if the man can prove that the divorce was at fault of the wife.

The execution of the divorce is subject to specific requirements. The husband or his representative has to pronounce the divorce in the presence of two just, male witnesses. ${ }^{107}$ The pronouncement requires a specific formula in Arabic or Persian. ${ }^{108}$ The husband must be competent in order to pronounce an effective divorce, i.e. he must be of age, sane, act of his own free will and without coercion, and show determination. ${ }^{109}$ The divorce must be unconditional; a divorce upon (a) noncommittal condition(-s) is invalid. ${ }^{110}$ The divorce is also invalid if it is executed during specific conditions of the wife. ${ }^{111}$ First, the divorce will be invalid if it is executed during the wife's menses or postpartum bleeding, unless it is executed before the consummation of the marriage or unless the absent husband was not aware of the impure status of his wife. Second, if the spouses had intercourse just after the wife's menses during her pure status, unless the wife is pregnant or postmenopausal, the divorce will also be invalid. This implies that the husband has to await the end of the next menses of his non-pregnant wife in order to pronounce a valid divorce. The so-called triple talaq, the pronouncement of three divorces in one sentence or the pronouncement of the divorce in three subsequent sentences in one sitting, in order to seek to establish an irrevocable divorce, is not recognized in Iranian divorce laws. ${ }^{112}$ The divorce by the husband is in principle revocable.

\subsubsection{Divorce by the Wife}

In current times, the wife has the right to request a judicial divorce (talaq al-tatliq) on three grounds: the husband's inability or persistent refusal to pay maintenance, extreme hardship and harm caused by continuation of the conjugal life, and absence of the husband for more than four years. ${ }^{113}$ Originally, the Shi' $a$ Ithna 'Ashari only recognized the husband's impotence as ground for talaq al-tatliq. ${ }^{114}$ Through the use of takhayyur (meaning the

106 Mir-Hosseini 2000, p. 59.

107 Art. 1134 ICC.

108 Bergmann et al. 2002, p. 63-64.

109 Art. 1136 ICC. Pursuant to sub-art. 1 to Art. 1210 ICC, the man is considered to be of age from the age of 15 years according to the lunar calendar.

110 Art. 1135 ICC; Bergmann et al. 2002. p. 62.

111 Arts. 1140 and 1141 ICC.

112 Bergmann et al. 2002, p. 64.

113 Articles 1129, 1130, and 1029, ICC; Bergmann et al. 2002, p. 64; Yassari 2002, p. 1090-1092.

114 Mir-Hosseini 2000, p. 39; Mir-Hosseini 2010, p. 351. 
adoption of principles from other schools of jurisprudence), the grounds of divorce for women were extended.

Before discussing these grounds more in detail, it should be mentioned that, according to Mir-Hosseini, courts appeared to be reluctant to grant a divorce (or to annul a marriage) irrespective of the ground for divorce and the parties who initiate the divorce. ${ }^{115}$ The courts employ every means possible to achieve reconciliation between the spouses such as appointing other arbiters or securing the wife's position by making promises from the husband legally binding. One strategy of the court to oblige the husband to comply with his promises is to make him sign a contract in which he assigns an unconditional right to divorce to his wife in the case that he resumes his former behaviour.

The first ground for divorce concerns maintenance: one of the rights of the wife in a permanent marriage, to be paid by her husband in exchange for her compliance with her marital duties towards him. ${ }^{116}$ The temporary wife is not entitled to maintenance unless it was agreed upon at the time of the marriage. ${ }^{117}$ Whenever the husband fails to provide for maintenance without her fault, ${ }^{118}$ the wife can recover the maintenance in two ways. Either she can file a complaint in order to have her husband punished with imprisonment before the public prosecutor's office or she can bring an action for compensation against him in court. ${ }^{119}$ When, in the latter case, the husband establishes that he is unable to pay maintenance, for example, due to lack of financial means, illness and hence inability to work, or imprisonment, the wife has the right to request divorce directly. ${ }^{120}$ But in the event that the husband, although being able to pay maintenance, does not comply with his duty, the court will first compel him to provide maintenance. Upon court order, he can be sentenced to a penalty of lashes. ${ }^{121}$ If he nevertheless persists in his refusal, despite the execution of the court's decision that maintenance must be provided, the wife also obtains the right to file for divorce. ${ }^{122}$ The court will issue the court order (and would issue the Certificate before 2013) upon the wife's request for divorce in both cases.

The second ground, that of extreme hardship and harm caused by the continuation of the marriage, osr wa haraj, ${ }^{123}$ is based upon the Shari ${ }^{\prime}$ principle that (the result of) a rule

115 Mir-Hosseini 2000, p. 71-72.

116 Arts. 1106, 1107, and 1108 ICC.

117 Art. 1113 ICC.

118 Arts. 1108 and 1127 ICC.

119 Art. 642 Iranian Penal Code; Art. 1111 ICC.

120 Arts. 1112 and 1129 ICC.

121 Art. 105 'Offences Related to Public and Moral Chastity and Familial Obligations'.

122 Arts. 1112 and 1129 ICC.

123 Based on Koran 22:78: '[...]He has chosen you (to convey His Message of Islamic Monotheism to mankind by inviting them to His religion, Islam), and has not laid upon you in religion any hardship, [...]' and Koran 65:7: 'Let the rich man spend according to his means, and the man whose resources are restricted, let him spend according to what Allah has given him. Allah puts no burden on any person beyond what He has given him. Allah will grant after hardship, ease'. 
may be adapted or lifted when adherence to the rule entails hardship or harm in general (for all) or for an individual. ${ }^{124}$ The primary rule in Shari' $a$ law is that divorce is the prerogative of the husband. If continuation of the marriage causes hardship or harm to the wife and the husband does not use his privilege to divorce her, she is entitled to request a divorce on the ground of osr wa haraj in court. The ground covers diverse circumstances which can render the marital life intolerable for the wife, such as unjustified long-term abandonment by the husband, ${ }^{125}$ his incurable drug addiction, his persistent refusal to support her, ${ }^{126}$ an infectious and badly curable disease, illness or ailment of the husband that endangers the wife's health and aggravates the marital life, his impotency or sterility unknown to the wife before the marriage, and maltreatment or unfair treatment among other things because of the polygamous marriage of the husband, misconduct, and his imprisonment for at least five years. ${ }^{127}$ In short, it includes all those circumstances that result in financial and/or material negligence of the wife or that result in a lack of mental and physical harmony and security or other elements being characteristic and indispensable for a standard conjugal life. The wife needs to provide conclusive evidence of any of these grounds and the underlying circumstances, which may be extremely difficult in particular in the case of physical or mental harm. Mir-Hosseini found in her research in Iran in the 1980s, for example, that a doctor's Certificate stating physical harm is not sufficient but that tangible evidence such as a broken arm or a police report is required. ${ }^{128}$ She also mentions that the court disregards mental harm. The court assesses whether or not continuation of the marriage is more harmful to her than its dissolution on the ground of osr wa haraj. Upon a positive answer and after failure of reconciliation, the court will issue the court order (and would issue the Certificate before 2013).

In the case of divorce on either of the two above-mentioned grounds, the court will oblige the husband to divorce his wife. ${ }^{129}$ If the husband refuses, the court will pronounce the divorce as the legal representative of the husband. The divorce on either of these grounds is irrevocable.

The last ground for divorce, the absence of the husband for more than four years, will result in granting the divorce to the wife upon the establishment of the presumptive death of the missing husband by the court. ${ }^{130} \mathrm{~A}$ legal representative will pronounce the divorce on behalf of the missing husband. ${ }^{131}$ The divorce is revocable. If the husband returns during

\footnotetext{
124 Mir-Hosseini 2000, p. 65; Mir-Hosseini 2012, p. 65-66; Safa'i 2004, p. 77; Yassari 2002, p. 1091-1092.

125 If the wife is not entitled to a request for divorce pursuant to Art. 1029 ICC, as the husband has not yet been missing for four years, she can invoke the ground of Art. 1130.

126 Which is also a ground for divorce for the wife pursuant to Art. 1129 ICC.

127 Art. 1130 as amended on 24 June 2002; Bergmann et al. 2002, p. 65-66.

128 Mir-Hosseini 2000, p. 71.

129 Arts. 1129 and 1130 ICC.

130 Arts. 1029, 1023, 1020, 1021, and 1022 ICC.

131 Bergmann et al. 2002, footnote 196, p. 64.
} 
the mandatory waiting period of four months and ten days that the wife has to observe because of his presumptive death, he can revoke the divorce. ${ }^{132}$ After the lapse of the waiting period, the returned husband cannot claim any rights from his wife anymore.

Apart from the judicial divorce, Iranian family law also acknowledges the dissolution of marriage through annulment, faskh. ${ }^{133}$ This is in contrast with the legal systems of some countries such as that of Pakistan. Pakistani family law only acknowledges the dissolution of marriage through annulment on specific grounds, instead of the judicial divorce on specific grounds as a possibility for the wife to end her marriage.

However, not only the wife but either spouse can be entitled to annul the marriage in Iranian family law because of an irregularity in the substance or form of the marriage contract, a specific, listed physical or mental defect or illness or the absence of a promised specific quality in one of the spouses. ${ }^{134}$ Articles 1121 and 1122 ICC mention the mental illness and the defects of the husband upon which the wife has a right to annulment even if the mental illness or defect has arisen after the marriage. ${ }^{135}$ All the listed defects, castration, lack of masculinity, and a too short or cutoff penis, hinder a satisfying sexual relationship and procreation. The illness or defect has to exist at the moment of dissolution. ${ }^{136}$ Apart from 'reparation' of the defect or illness, the marriage cannot be annulled when the requesting spouse was familiar with the existence of the defect before contracting the marriage. ${ }^{137}$ If the husband lacks a specific quality such as honesty or loyalty that was claimed to be present before the conclusion of the marriage, the wife is also entitled to its annulment pursuant to Article 1128 ICC.

The right to dissolution through annulment is personal and time limited. ${ }^{138}$ Only the person who is entitled to it can execute the annulment. The annulment has to be realized preferably as soon as he or she was acquainted with the facts of the case. ${ }^{139}$ The right to annul the marriage is not a duty to annul. One can renounce this right, or the spouses can agree upon the renouncement of their rights in their marriage or another contract.

The annulment of the marriage terminates the marriage forthwith and definitively. Apart from its legal structure, the annulment should also be distinguished from the divorce proper because of its differing personal and substantive effects to be discussed in more detail below.

132 Arts. 1030, 1156, and 1154 ICC.

133 Mir-Hosseini 2000, p. 39-40.

134 Arts. 1121-1128 ICC concern the exhaustive list of the various defects and the lack of a claimed, specific quality and the requirements to dissolution of marriage.

135 Art. 1125 ICC.

136 Bergmann et al. 2002, p. 59.

137 Art. 1126 ICC.

138 Bergmann et al. 2002, p. 60-61.

139 Art. 1131 ICC. 
The spouses can agree upon the delegation of the husband's right to divorce to the wife. ${ }^{140}$ She can exercise this right to divorce on specific grounds that are stipulated in the marriage contract or in any other contract by the spouses. Article 1119 ICC, and before 2013 also Article 4 of the Marriage Act 1931, lists grounds such as the polygamous marriage of the husband or his absence or his unacceptable behaviour, but the lists are not exhaustive. ${ }^{141}$ Any other ground that is stipulated in the contract should not be contrary to the essence of marriage, unlawful, immoral, or offensive against public decency. The model marriage contract, as used by notaries (at least until 2013), appears to partly cover the grounds for divorce as were mentioned in Article 8 FPL 1975 in separate clauses. ${ }^{142}$ Each spouse has to sign the relevant clause individually in order for it to have been contracted and to become applicable. ${ }^{143}$ The prevailing view is furthermore that the wife should be able to use her delegated power at her own discretion and not only on specific grounds as stipulated in the marriage contract. ${ }^{144}$ The delegated divorce is an irrevocable divorce. ${ }^{145}$ The delegated right would be illusory if the husband is entitled to revocation.

Two other modalities of an irrevocable divorce by agreement in Iranian family law concern the negotiated divorce, chol-i (cf. khul), and, simply, the divorce by agreement, mo-barat (cf. mubara'a). The chol-i is the divorce whereby the wife seeks to convince the husband to divorce her and renounce his right of revocation because of her dislike of him in exchange for compensation. ${ }^{146}$ The compensation may be equal to the value of her dower or less or more. The mo-barat is the divorce whereby the spouses reimburse or waive their mutual financial obligations because of a mutual aversion. ${ }^{147}$ The value of the reimbursement or waiver may not exceed the value of the dower of the wife. In the case of both modalities of divorce, the husband cannot return the ransom in exchange for the revocation of the divorce. ${ }^{148}$ The agreement between the spouses is a legal act independent of the divorce. ${ }^{149}$ If the agreement is, for example, null and void, the divorce can still be legally valid, while the husband is entitled to revocation of the divorce. In the case of chol-i, the wife is entitled to revoke the agreement during her waiting period. ${ }^{150}$ Her revocation results in the return

140 Art. 1119 ICC.

141 Yassari 2002, p. 1092-1093.

142 Yassari 2002, p. 1093; Annex B: Stipulations included in the marriage contract or in another contract, in Basedow \& Yassari 2004, p. 173-175.

143 Safa'i 2004, p. 78-79.

144 Bergmann et al. 2002, p. 66.

145 Bergmann et al. 2002, p. 66.

146 Art. 1146 ICC.

147 Art. 1147 ICC.

148 Bergmann et al. 2002, p. 68.

149 Bergmann et al. 2002, p. 68.

150 Bergmann et al. 2002, p. 68. 
of the compensation by the husband and the divorce becoming revocable instead of irrevocable.

\subsection{After Divorce}

Both the divorce and the annulment end the marriage ex nunc. ${ }^{151}$ However, the annulment ends the marriage definitively at once, whereas the divorce can be irrevocable (ba-en) and thus definitive, or the divorce can be revocable (rozj-i). ${ }^{152}$ The revocable divorce may result in the recovery of the marriage if the husband or his representative revokes the divorce by demonstrating through any word or deed his resolute intention hereto in the waiting period of the wife..$^{153}$ The consent, cooperation, or even the knowledge of the revocation by the wife is not required, although her marital duties only revive after she has been informed about the revocation. ${ }^{154}$ The revocation is often considered to be a 'remarriage' that has to be registered by the husband in order to avoid penalties. ${ }^{155}$ Non-revocation of the divorce during this period terminates the marriage forthwith. The revocable divorce can be revoked two times; the third divorce is irrevocable. ${ }^{156}$ The irrevocable divorce cannot be revoked by the husband and definitively terminates the marriage. ${ }^{157}$

The divorce is irrevocable in the following situations: if the marriage has not been consummated; if the wife is postmenopausal; in the case of a negotiated divorce (chol-i or $k h u l$ ) or a divorce by agreement (mo-barat or mubära'a); in most cases that the wife has requested and obtained the divorce; and if the revocable divorce is pronounced for the third time. ${ }^{158}$ The husband is allowed to divorce and remarry his wife up to three subsequent times. ${ }^{159}$ The third divorce results in a ban for the same spouses to remarry. ${ }^{160}$ However, if the wife marries another man after the third divorce of her former husband and this marriage is dissolved through death or divorce after its consummation, the wife is allowed to remarry her former husband. The ban on remarriage becomes permanent and 'irreparable' if the same spouses divorce nine times of which six are successive. ${ }^{161}$ Irrespective of the number of annulments of marriage between the same spouses, the annulment can

151 Bergmann et al. 2002, p. 58.

152 Arts. 1143-1149 ICC.

153 Arts. 1148 and 1149 ICC; Bergmann et al. 2002, p. 67.

154 Bergmann et al. 2002, p. 67.

155 Bergmann et al. 2002, p. 66.

156 Sub-art. 4 to Art. 1145 ICC.

157 Arts. 1144-1145 ICC.

158 Art. 1145 ICC does not exhaustively enumerate the cases in which the divorce is irrevocable.

159 Art. 1057 ICC.

160 Art. 1057 ICC and sub-art. 4 to Art. 1145 ICC.

161 Art. 1058 ICC. 
never result in such a ban on remarrying. Another difference between divorce and annulment becomes manifest in the right of the wife to the dower.

The court settles the financial consequences of the divorce and the custody and maintenance of the children when dealing with the request for divorce itself. ${ }^{162}$ The financial consequences may in particular concern the maintenance for the wife and children, the dower, and the reclamation of the dowry and the gift (before 2013: remuneration) for services rendered and labour. The settlement of these consequences may differ depending on the revocable or irrevocable character of the divorce, the person who initiates the divorce, and possible, legally valid clauses in the marriage or another irrevocable contract. Through legally valid clauses in the marriage or another irrevocable contract, the spouses can in principle adapt or change the legal effects of their divorce (and marriage), if it is within the boundaries of the law and the requirement of non-infringement upon the essence of marriage of the clause pursuant to Article 1119 ICC. ${ }^{163}$ The execution of the divorce and its registration depend upon the fulfilment of these duties by the husband towards his wife. ${ }^{164}$ Since 2013, Article 8 FPL 2013 stipulates that the family court can issue a temporary order for up to six months in matters that have urgency such as custody, visiting rights of the child, and maintenance, before deciding about the main subject of the dispute.

\subsubsection{Waiting Period}

The wife has to observe a waiting period, $e d d a$ (cf. 'idda), immediately after the dissolution of marriage through death, (the revocable or irrevocable) divorce, annulment, or the lapse or waiver of the (remaining) period of a temporary marriage. ${ }^{165}$ Its duration may vary depending upon the physical condition of the wife, the modality of dissolution, and the type of marriage. If the marriage has not been consummated or the wife is in her menopause, she does not have to observe a waiting period after the divorce or the annulment of the marriage. ${ }^{166}$ The waiting period after the divorce or annulment of any permanent marriage lasts three menstrual cycles plus the period of purification for the wife who regularly has her menses or three menstrual cycles for the wife who does not have her menses anymore because of her age. ${ }^{167}$ The waiting period after a temporary marriage takes two menstrual cycles plus the period of purification afterwards for the wife who still

162 Art. 29 FPL 2013; sub-arts. 2, 3, and 6 to Art. 1 ADR before 2013; Hamidian 2004, p. 88; Yassari 2002, p. 1093.

163 Bergmann et al. 2002, p. 70-71; see, for example, Arts. 232 and 1069 ICC.

164 Art. 29 FPL 2013; sub-art. 3 to Art. 1 ADR before 2013.

165 Arts. 1150-1157 ICC.

166 Art. 1155 ICC.

167 Art. 1151 ICC. 
has her menses or 45 days for the wife without menses due to her age. ${ }^{168}$ The waiting period for a pregnant wife lasts until the delivery of the child. ${ }^{169}$ And the waiting period because of a deceased or missing husband lasts at least four months and ten days. ${ }^{170}$

The husband can return to his wife during the waiting period of a revocable divorce but not during the waiting period of the irrevocable divorce. ${ }^{171}$ The wife is entitled to housing and maintenance during the waiting period of the revocable divorce and in the case of pregnancy during the waiting period of the irrevocable divorce or annulment. ${ }^{172}$ During the waiting period of the revocable divorce, she has to fulfil all her marital duties towards her husband except for those that are irreconcilable with divorce, such as sexual intercourse. ${ }^{173}$ The obligation to fulfil these marital duties ends with the expiration of the waiting period of the revocable divorce as well as immediately after the irrevocable divorce.

\subsubsection{Maintenance}

Upon divorce, the wife is entitled to maintenance from her husband during the waiting period of the revocable divorce, also in the case of pregnancy, and during the waiting period of the irrevocable divorce or annulment in the case of pregnancy. ${ }^{174}$ The maintenance has to be in accordance with her physical and emotional needs and in proportion to her living conditions and status. ${ }^{175}$ It includes the costs of - if necessary separate - housing accommodation, clothing, food, and furniture and possibly the costs of servants. She has this right independent of her own ability to provide for herself. ${ }^{176}$ But she forfeits these rights it if she does not comply with her marital duties without valid reason during the marriage. ${ }^{177}$ She has priority over other relatives who are entitled to maintenance to be provided by her husband. ${ }^{178}$ The legal rules related to the wife's maintenance are part of the public order and cannot be derogated from by the spouses. ${ }^{179}$

Apart from the above-mentioned modality of maintenance during the waiting period, Bergmann et al. refer to the possibility of a claim to post-marital maintenance. ${ }^{180}$ This

168 Art. 1152 ICC.

169 Arts. 1153 and 1154 ICC.

170 Arts. 1154, 1155, and 1156 ICC.

171 Arts. 1148 and 1144 ICC.

172 Art. 1109 ICC.

173 Bergmann et al. 2002, p. 69.

174 Arts.1109 and 1110 ICC.

175 Art. 1107 ICC; Hamidian 2004, p. 91

176 Hamidian 2004, p. 91.

177 Arts. 1108-1109 ICC; see Arts.1115 and 1127 ICC for the wife's right of maintenance in the case of noncompliance with her marital duties for valid reasons; Shid 2005, p. 145.

178 Art. 1203 ICC.

179 Safa'i 2004, p. 75.

180 Bergmann et al. 2002, p. 70. 
modality of maintenance could be claimed in court by one spouse, upon the issuance of the Certificate pursuant to Article 11 FPL 1975, in the case of divorce due to the misconduct or failure of the other spouse. But the legal status of FPL 1975 is unclear in view of Article 4 of the Iranian Constitution and the Shari' $a$-oriented regulation of maintenance under the ICC. The other authors referred to in this study do not mention this modality of postmarital maintenance. According to Yassari, the prevailing Islamic-Iranian law does not acknowledge such a possibility. ${ }^{181}$ She refers to the possibility for spouses to stipulate postmarital maintenance in their marriage contract with reference to Article 11 FPL $1975 .{ }^{182}$

Shid et Safa'i refer to the possibility of the spouses to contract at the time of marriage that the husband shall hand over up to the maximum of half of his assets earned during the marriage to his wife upon his demand for divorce. ${ }^{183}$ This lump sum might be considered to be post-marital maintenance.

\subsubsection{Dower}

Before focussing on the rights of the wife to the dower upon the dissolution of the marriage, some general aspects of the dower, also called mahr or mehriye in Farsi, need to be discussed first. The specified dower, the proper dower, and the divorce dower that are discussed more in detail below all these types of dower occur in Iranian law. ${ }^{184}$ The dower is an asset in Iranian law; it can be anything that represents financial value and is subject to being property whether it is an amount of money or a tangible object. ${ }^{185}$ It is common practice to agree upon the proportions and content of the dower, to determine the specified dower, upon the conclusion of the marriage. ${ }^{186}$ It is even mandatory to determine the dower at the conclusion of a temporary marriage, as not specifying the dower would invalidate the temporary marriage. ${ }^{187}$ The spouses or, if needed, the court may later determine the dower in the case of a permanent marriage. ${ }^{188}$ When the spouses have not specified any dower at the time of the marriage or thereafter and the marriage is consummated, the proper dower, to be determined by experts of the court, is due. ${ }^{189}$ These experts must take into account circumstances such as the social and family position of the wife, her family honour, the position of similar women and female relatives, and the customs and practices of her place

181 Yassari 2002, p. 1093.

182 Yassari 2002, p. 1093 footnote 69.

183 Shid 2004, p. 150-151; Safa'i 2005, p. 74; also Annex B: Stipulations included in the marriage contract or in another contract, under A, in Basedow \& Yassari 2004, p. 173.

184 Arts. 1078/1101 ICC.

185 Art. 1078 ICC.

186 Art. 1080 ICC.

187 Arts. 1077 and 1095 ICC.

188 Art. 1087 ICC.

189 Shid 2005, p. 143. 
of residence when determining the proper dower. ${ }^{190}$ If the spouses have not specified any dower upon or after the marriage and the husband divorces his wife before the marriage has been consummated, the divorce dower is due. ${ }^{191}$ This type of dower is determined in consideration of the financial position of the husband. ${ }^{192}$ Either or both spouses or a third person can be assigned to determine the dower, but the wife cannot specify a dower that exceeds the proper dower. ${ }^{193}$

If the dower is an amount of money, its daily value will be calculated, adapted, and determined according to the inflation rate as announced annually by the Central Bank of the Islamic Republic of Iran at the moment of demand, unless spouses have agreed otherwise in their marriage contract pursuant to a note to Article 1082 ICC. ${ }^{194}$ The adaptation of the daily value of the dower according to the inflation rate appears to be of the utmost importance for the post-divorce financial situation of those women who married before the 1979 Revolution. Before that time, spouses used to agree upon a symbolic dower, a dower small in amount or proportion. Article 11 FPL 1975, however, provided for the possibility of post-divorce maintenance for either spouse. Hence, this provision guaranteed the ex-wife certain financial independence that would have been guaranteed otherwise by a regular dower. But after the 1979 Revolution, the ex-wife was just entitled to her symbolic dower and probably not to post-divorce maintenance. As already stated, the legal status of FPL 1975 was and still is unclear in view of Article 4 of the Iranian Constitution and the Shari ${ }^{a}$-oriented regulation of maintenance under the ICC. The increasing inflation aggravated this situation. For this reason, the note to Article 1082 ICC remedies these harmful effects in order to accommodate social demands and economic changes to the legal possibilities as from $1998 .{ }^{195}$ The note applies to all dowers regardless whether they were stipulated before or after the ratification of the note.

190 Art. 1091 ICC.

191 Art. 1093 ICC; differently: Shid 2005, p. 143, who claims that 'the wife will be entitled to the value of a dower due in a temporary marriage', if the husband divorces his wife before the consummation of the marriage and having determined a dower.

192 Art. 1094 ICC.

193 Arts. 1080, 1089, and 1090 ICC.

194 Note to Art. 1082 ICC and Executive Regulation of the Addition of one Note to Art. 1082 ICC; Ansari-Pour 2005-2006, p. 417; Hamidian 2004, p. 89-90; Mir-Hosseini 2000, p. X; Safa'i 2004, p. 75; Shid 2005, p. 144; Yassari 2002, p. 1094; see Annex A: Calculation of the dower adapted to the inflation rate of the Iranian Currency Rial in Basedow \& Yassari 2004, p. 171-172. The daily value of the dower will be determined according to the following formula: 'inflation-coefficient of the year previous to the year where payment of the dower is requested divided by the inflation-coefficient of the year of marriage times the sum of the dower in Rial equals the actual value of the dower' (Art. 2 of Executive Regulation of the Addition of one Note to Art. 1082 ICC; Shid 2005, p. 144).

195 Note to Art. 1082 ICC and Executive Regulation of the Addition of one Note to Art. 1082 ICC; published in Ruzname-e rasmi, No. 15497 of 14-05-1998; Ansari-Pour 2005-2006, p. 417; Hamidian 2004, p. 89-90; Mir-Hosseini 2000, p. X; Shid 2005, p. 144; Yassari 2002, p. 1094. 
The spouses can agree upon a term of delivery or payment in instalments for a dower. ${ }^{196}$ But the agreement in the marriage contract that non-payment or non-delivery of the dower within a specific term entails the dissolution of the marriage does not dissolve the marriage nor negate the dower, but is invalid itself. ${ }^{197}$ The husband is responsible for any defect in the dower, when the dower includes object until the dower has been delivered to the wife. ${ }^{198}$

Although the dower becomes the property of the wife and is immediately due as from the moment that the marriage has been concluded, she often does not immediately or entirely claim it at that time. ${ }^{199}$ She may refuse to fulfil her marital duties towards her husband, without any consequences for her right to maintenance, until his payment or the delivery of the dower. ${ }^{200}$ But if the wife has voluntarily fulfilled her marital duties, albeit she has not yet received the dower, she losses her right to refrain from her marital duties without consequences for her right to maintenance. ${ }^{201}$

If the husband did not deliver or pay the dower upon the demand of his wife, she could recover it in the following two ways, at least until the entry into force of the FPL $2013 .{ }^{202}$ The first way was that the dower was paid from the proceeds of an auction after the confiscation of the property of the husband by the Execution Department of the Deeds and Properties Registration Organisation. The second way was that the wife claimed her dower in the Family Court. If the husband could not afford to pay the dower, he could claim his insolvency in court and be exempted from payment or be allowed to pay in instalments if he so requested..$^{203}$ If he was solvent, however, the court could order his imprisonment or bar him from leaving the country until he paid the dower. ${ }^{204}$

The entry into force of the FPL 2013 brought about a change in the procedure for recovery of the dower as described above. Article 22 FPL 2013, under reference to Article 2 of the 'Act on the enforcement of monetary claims', stipulates that the claim of the wife to a dower at the maximum value of 110 gold coins at the date of the marriage is immediately enforceable. ${ }^{205}$ The wife can apply for the enforcement of such a claim without the need for evidentiary proceedings or a review of the solvability of the husband. When the husband does not pay, either the court compels him to pay and can confiscate his property to that end, if he has any, or the wife can apply for a warrant for his arrest. ${ }^{206}$ Furthermore,

\footnotetext{
196 Art. 1083 ICC.

197 Art. 1081 ICC.

198 Art. 1084 ICC.

199 Arts. 1082 and 1118 ICC. Yassari 2002, p. 1093.

200 Arts. 1085-1086 ICC.

201 Art. 1086 ICC.

202 Shid 2005, p. 144.

203 Art. 3 'Act concerning the Procedure for the Execution of Financial Convictions' of 28-11-1988.

204 Art. 2 'Act concerning the Procedure for the Execution of Financial Convictions'.

205 'Act on the enforcement of monetary claims' of 01-11-1998 published in Ruzname-e rasmi, No. 15666 of 07-12-1998.

206 Art. 2 'Act on the enforcement of monetary claims'.
} 
Article 22 FPL 2013 stipulates that the solvability of the husband is taken into account in respect to the amount that exceeds the value of 110 gold coins when the dower exceeds the value of 110 gold coins. If the husband appears to be solvent, he has to pay that amount on demand of the wife. If the husband appears to be not solvent, the court will arrange the payment in instalments of the residual debt according to the husband's ability. The wife cannot apply for his arrest in respect of the residual debt. The observance of the abovementioned note to Article 1082 ICC and the Executive Regulation of the Addition of one Note to Article 1082 ICC is still mandatory.

When the husband has not yet delivered or paid the entire dower during the marriage, he has to do so upon the dissolution of the consummated marriage at the latest, irrespective of which spouse requested the divorce or dissolution. ${ }^{207}$

Closer consideration of the right of the wife to the dower upon the dissolution of marriage reveals the following distinct situations. The wife is not entitled to any dower whenever:

- the spouses did not specify the dower nor consummate the permanent marriage, and either wife or husband dies;

- the not consummated, permanent, or temporary marriage appears to be invalid; and,

- the marriage has not been concluded owing to unforeseen circumstances, but not due to the lack of masculinity of the intended husband. ${ }^{208}$

The wife is entitled to half the dower when:

- the husband divorces his wife before the consummation of their marriage;

- the husband waives the remaining period of the temporary marriage before its consummation; or

- the marriage has not been concluded because of lack of masculinity of the intended husband. ${ }^{209}$

The wife is entitled to the proper dower if:

- the spouses did not specify a dower, and their marriage has been consummated;

- the wife specified the dower;

- she was ignorant about the invalidity of the marriage, and this marriage has been consummated; or

- the dower is unknown or not subject to being property (for example including things such as alcohol or pigs) at the conclusion of the marriage. ${ }^{210}$

207 Yassari 2002, p. 1093.

208 Arts. 1088, 1098, and 1101 ICC.

209 Arts. 1092, 1097, and 1101 ICC.

210 Arts. 1087, 1090, 1093, 1099, and 1100 ICC. 
The wife is entitled to the divorce dower in the case of divorce by the husband before the consummation of the marriage. ${ }^{211}$ Therefore, the wife is entitled to the entire, specified dower upon its dissolution if the valid, temporary, or permanent marriage has been consummated and the spouses are not ignorant about the content or proportions of the dower. If the object of the dower belongs to a third person, the wife is entitled to its value unless this person renounces his right to this object in favour of the wife. ${ }^{212}$

Mir-Hosseini describes how the different actors involved in a divorce procedure use the dower as main bargaining strategy. ${ }^{213}$ Women belonging to lower strata in society and lacking the means to remain economically independent after divorce appear to use the dower either to prevent or delay an unwanted divorce by using the dower as deterrent. The husband often is not able to pay the dower immediately as its value usually goes beyond his financial means at that moment. Women belonging to the middle or upper strata and who are economically independent or supported by their families may use the dower to bring about a divorce by using the dower as incentive. The court sometimes uses the dower to convince the spouses of the advantages of reaching a compromise. But already before the stage of a procedure, the mere threat by a wife who wants to divorce to claim her dower appears to be sufficient to obtain the cooperation with and consent to a divorce. MirHosseini's study showed that more than $50 \%$ of all divorces that were registered in Tehran in the 1980s appeared to be divorces by khul' in which the wife waived her claim to the dower in exchange for her husband's consent for divorce. ${ }^{214}$ She also found in her research that women rarely obtain any portion of their dower unless, for example, it is the husband who insists on a divorce.

\subsubsection{Remuneration}

The ADR introduced a favourable innovation for women in its sub-article 6 to Article 1 in 1992: the remuneration or exemplary wages or ojrat al-methl. Women could claim this type of remuneration until the entry into force of the FPL 2013 that abrogated the ADR, however except for B under sub-article 6 to Article 1 ADR that deals with the monetary gift from the former husband to his former wife. The remuneration or exemplary wages or ojrat al-methl concerns the indemnity paid by the former husband for the services and labour that the wife involuntarily and on the demand of the husband rendered during the

211 Art. 1093 ICC.

212 Art. 1100 ICC.

213 Mir-Hosseini 2000, p. 75-83; in the same sense Nayyeri 2013, p. 42.

214 Mir-Hosseini 2000, p. 82. 
marriage and that were not part of her marital duties on religious grounds. This can include breastfeeding a child or doing the housekeeping. ${ }^{215}$

The background of this innovative post-divorce provision was twofold: the former husband has to remunerate the former wife for her services in the case of divorce initiated by him, and the husband should not exclude the wife from his professional and financial gains that he also owes to his wife, by an arbitrary divorce. ${ }^{216}$ The former wife could claim this remuneration if the divorce was, first, not requested by her and, second, not requested because of her negligence of marital duties or misbehaviour. Yassari also mentions the insistence on the continuation of the marriage by the wife as a third requirement. ${ }^{217}$ The wife could submit her claim upon receipt of the Certificate of Impossibility of Reconciliation. ${ }^{218}$

If the wife established that she rendered the services and labour that were not part of her marital duties, involuntarily and on demand of the husband, the court calculated the rendered labour in accordance with similar hired labour. ${ }^{219}$ Thereupon, the court obliged the husband to pay these exemplary wages.

If the wife could and still cannot establish any of these conditions, the court will determine an adequate amount of money to be paid by the husband to the wife as a gift (nehleh) in accordance with B under sub-article 6 to Article 1 ADR. ${ }^{220}$ This provision was not abrogated in 2013. That sum should be commensurate to the duration of the marriage, the type of services and labour rendered by the wife in her former marital home, and the financial status of the husband. The court will first try to reach a compromise about the amount between the spouses. ${ }^{221}$ If such a compromise cannot be reached, the court will take into consideration possible agreements about financial issues as stipulated in the marriage contract. If such conditions lack in the marriage contract, a judicial expert will assess the sum of remuneration in accordance with the above-mentioned criteria and present it to the spouses and the court. ${ }^{222}$ The spouses can contest both the assessment and the expert, who can be replaced.

\footnotetext{
215 Arts. 1176 and 1107 ICC. The fact that the maintenance duty of the husband includes the costs of servants may be considered as an indication for the wife's non-obligation of housekeeping. See regarding the wife's non-obligation of housekeeping also Hamidian 2004, p. 90; Shid 2005, p. 149; Yassari 2002, p. 1094.

216 Yassari 2002, p. 1094.

217 Yassari 2002, p. 1094.

218 Act on the Explanation of the sub-arts. 3 and 6 ADR.

219 Sub-art. 6 under A to Art. 1 ADR.

220 Sub-art. 6 under B to Art. 1 ADR; Shid 2005, p. 148.

221 Shid 2005, p. 150.

222 Shid 2005, p. 150; Yassari 2002, p. 1094.
} 


\subsubsection{Provisions for Children}

The provisions regarding the minor children to be settled by the court in the case of divorce concern the custody of and the maintenance for them. ${ }^{223}$ These provisions are mainly regulated in the ICC and also in section 5 (Articles 40-47) FPL 2013 since 2013. Article 45 FPL 2013 puts the principle of the best interest of the child first by stipulating that the court should urgently take into consideration the best interest of the child in all its decisions and in their implementation. Article 41 FPL stipulates that the court can take all the necessary measures while taking into account the best interest of the child when the arrangements or agreements concerning visiting rights, custody, and other matters that affect the child are not in accordance with the welfare and the best interest of the child.

The clear distinction between custody and guardianship as set in Shari'a law can also be found in Iranian family law. It should be noted that he rules related to custody and guardianship of minor children after the dissolution of either the permanent or the temporary marriage are identical.

\subsubsection{Custody}

Where both spouses have the right and duty to custody (hezānat), including the care and education of their minor children during the marriage, the mother is granted custody of the children until the age of seven years with priority over the father upon divorce. ${ }^{224}$ If she appears to be insane or remarries within this period or otherwise when the children become seven years old, the custody automatically devolves to the father. ${ }^{225}$ In the case of a dispute concerning the custody of a child of seven years or older, the family court will decide upon the custody while taking into consideration the best interest of the child. ${ }^{226}$ The minor children after puberty - nine years for girls and fifteen years for boys - have the right to choose with which of the parents they wish to reside. ${ }^{227}$

The parent who exercises the custody of the minor child cannot cede his or her duty and is forced by law to continue to take care of the child. ${ }^{228}$ The court can replace the parent who has custody of the child if he or she endangers the health or proper education of the child because of negligence or the moral disqualification or unworthiness of the parent, in the interest of the child, upon the demand of, inter alia, relatives or the legal guardian. ${ }^{229}$ Hamidian states that the requirements to be a fit custodian are 'rationality, practical ability,

223 Sub-art. 2 to Art. 1 ADR.

224 Arts. 1168 and 1169 ICC; Ansari-Pour 2005-2006, p. 427; Hamidian 2004, p. 92-94; Shid 2005, p. 146.

225 Arts. 1169 and 1170 ICC.

226 Art. 1169 ICC.

227 Hamidian 2004, p. 94.

228 Hamidian 2004, p. 93; see also Art. 41 FPL 2013.

229 Art. 1173 ICC; see also Art. 41 FPL 2013. 
meritorious character, freedom from contagious diseases and Muslim faith in the case of a Muslim child ${ }^{230}$ Since 2013, the family court can also appoint a supervisor. ${ }^{231}$

The parent who has no custody over and does not cohabit with the minor children has visiting rights regarding his or her children in a fixed place and time. ${ }^{232}$ The court will specify these visiting rights in the case of a dispute between the parents. If the custodian denies the other parent or other persons with visiting rights access to the children twice, it will result in a monetary fine, and if for the third time, it results in a transfer of the custody. ${ }^{233}$ If the parent without custody does not return the child to the custodian, he or she can be imprisoned until the child has returned to the custodian. ${ }^{234}$ If a third person prevents the return of the child to the custodian, this person will be imprisoned from three to six months and has to pay a monetary fine. ${ }^{235}$ The parent with whom the children live is not allowed to move with the child to another town or country without the consent of the other parent or, if needed, the consent of the court in order to guarantee the rights of the other parent. ${ }^{236}$ So, both parents determine in principle the residence of the child.

The duty of custody of the mother (or her marital duties) does not entail an obligation to breastfeed the child, unless breastfeeding is indispensable for the child. ${ }^{237}$ When a mother breastfeeds her child, she is entitled to remuneration from her husband.

\subsubsection{Guardianship}

Divorce does not have consequences for the guardianship of minor children. The minor child or the immature or mentally ill child of age remains under the natural guardianship of his father and paternal male ancestors after the divorce of his parents. ${ }^{238}$ The guardian legally represents the child in all issues concerning his property or other financial matters. ${ }^{239}$ On the request of a relative of the child, including the child's mother, or the public prosecutor, the court can replace the guardian if he does not act in, or prejudices, the interests of the child or does not administer the child's affairs well. ${ }^{240}$ Upon the death of the father, the mother becomes the legal guardian of the child, unless the court establishes that it is not in the best interest of the child. ${ }^{241}$

230 Hamidian 2004, p. 93.

231 Art. 41 FPL 2013.

232 Art. 1174 ICC.

233 Cf. Art. 14 FPL 1975; Art. 41 FPL 2013; Hamidian 2004, p. 94.

234 Art. 40 FPL 2013; Hamidian 2004, p. 94.

235 Art. 632 Islamic Penal Code (of 22 May 1996, published in Ruzname-e rasmi, No. 14943 of 24 June 1996).

236 Cf. sub-art. 1 to Art. 14 FPL 1975; see also Art. 42 FPL 2013; Hamidian 2004, p. 93.

237 Art. 1176 ICC.

238 Arts. 1180 and 1181 ICC; Shid 2005, p. 146-147.

239 Art. 1183 ICC.

240 Art. 1184 ICC.

241 Art. 45 FPL 2013. 


\subsubsection{Maintenance}

The father or, in the absence of the father or because of his inability, his paternal ancestors or, in their absence or because of their inability, the mother is/are responsible for the maintenance of the children. ${ }^{242}$ Hamidian states that if a parent neglects his or her maintenance duty towards the child, the court will order that the other parent maintains the child. ${ }^{243}$ If that parent does not comply with this duty, the court will assign a third person as custodian. The family court will settle the amount and manner of payment. ${ }^{244}$ The payment of the maintenance for the wife and children will take precedence over all other payments. $^{245}$

\subsection{Assessment}

While the Iranian Constitution claims to guarantee gender equality, women do not have equal access to divorce. Iranian women who are in a permanent marriage have access to the conditional or unconditional self-repudiation (talaq al-tafwid), the repudiation by agreement (mo-barat or mubara'a), the negotiated repudiation (chol-i or khul), the judicial repudiation (talaq al-tatliq), and the judicial annulment (faskh). However, in the case of the former three forms, the wife needs at least the cooperation and consent of her husband in order to have access to divorce; in the case of all forms, she is also dependent on the authorization to the divorce and/or the registration by means of the Certificate or the court/divorce order by the court. Moreover, the fact that the wife has to renounce one or more of her (financial) rights such as her dower in the case of a negotiated repudiation or a repudiation by agreement may influence her access to divorce as well. Evidential problems may restrict her access to a judicial divorce based on the ground of harm. Iranian women in a temporary marriage are in a worse position because they do not have access to any of these forms at all. Their temporary marriage can only end by operation of the law through lapse of its duration or death of either spouse or can be dissolved through annulment or waiver of the remaining period by the husband. However, the wife in a temporary marriage could negotiate its dissolution by using her dower as bargaining strategy to induce her husband to waive the remaining period of the marriage. Women in a permanent marriage can only realize partially equal access to divorce by an unconditional self-repudiation.

242 Art. 1199 ICC, but cf. Art. 1172 ICC that states that the father is responsible for the costs of maintenance of the child(-ren) in the first place and that, if he is deceased, the mother becomes responsible for the costs of maintenance, and Art. 12 FPL 1975 states that the father or the mother or both pay the costs of the maintenance for the child(-ren).

243 Hamidian 2004, p. 94; see also Art. 41 FPL 2013.

244 Art. 47 FPL 2013.

245 Arts. 1202 and 1203 ICC. 
A number of procedural devices aim to guarantee substantive and procedural rights of women: first, the mandatory intervention by the court for all modalities of divorce proper including the repudiation by the man, and also for annulments since 2013, irrespective of the person(-s) who initiated the dissolution of marriage, and, second, the mandatory registration at the Divorce Bureau. The divorce cannot be registered without the authorization to the divorce through issuance of the Certificate or a court or divorce order after a mandatory attempt to reconciliation by the court (since 2013, through a Certificate from the Family Counselling Centre in the case of spouses who agree on the divorce). The authorization can be refused to the wife, but it is not clear whether the authorization can be refused to the husband. Either or both spouses did not need to observe any of the aforementioned formal procedures in the case of an annulment. ${ }^{246}$ Third, the authorization to and execution and registration of the divorce depend on the compliance of the husband with the (financial) rights of the wife such as payment of the deferred dower, maintenance, etcetera, unless the wife was at fault, did not perform her marital duties, has relinquished any of these rights, or upon a court order that has established the husband's inability to pay.

All these measures aim to protect women from an instantaneous divorce and/or a divorce for caprice, a divorce without their knowledge, and from being deprived of their financial rights and the rights in relation to the children. However, the registration requirement may also be considered as a drawback. As stated above, the legislation is not explicit, and scholars are not univocal about the civil effects of the registration of the divorce, whether the registration is a requirement for the legitimacy of the divorce. If it is, then non-observance of the registration requirement results in the legal invalidity of the divorce, however, not in its religious invalidity. That situation brings women in a legal limbo: religiously being divorced, but legally not with all consequences such as not being able to remarry. Another problem that undermines their rights is the abolishment of the remuneration due to the abrogation of the ADR since the entry into force of the FPL 2013.

The procedure with regard to the repudiation should be distinguished from the procedure with regard to the judicial divorce. The procedure regarding the repudiation is similar in the case of the self-repudiation, negotiated repudiation, or repudiation by agreement although in the latter forms there is involvement of the wife. It may be concluded that the first type of procedure does not represent a truly adversarial procedure (a defended action). It can be defined as a procedure monitored by a judge in which women have certain procedural rights (like the right to be called on to appear and be heard) in order to establish a divorce by repudiation under certain guarantees for women and children and settling provisions like the maintenance, dower, etcetera. Although the position of women has improved because of the requirement of judicial intervention, fundamentally it remains

246 Art. 1132 ICC; Shid 2005, p. 148. 
a type of divorce that is unilaterally at the disposition of men and that has to be pronounced by the man. However, his prerogative and exclusive discretion has been constrained by the mandatory judicial authorization and the registration procedure.

The second procedure, the judicial divorce (talaq al-tatliq), technically speaking implies an adversarial procedure under supervision of a judge in which women have certain procedural rights (like the right to be summoned and to be heard) in order to establish a divorce under certain guarantees. However, one has to take into account that the drawback of the divorce procedure based on extreme hardship and harm is the difficult position of women in respect of providing proof or evidence of that ground.

Finally, the repudiation-based divorce based on the first type of procedure should be characterized as a hybrid, public act at the prerogative discretion of the husband but restricted by administrative and judicial requirements. Notwithstanding the mandatory intervention of the judge, the husband still needs to pronounce the repudiation in order to dissolve the marriage in the end. The judicial divorce should be characterized as a judgment if the judge issues the divorce as the decision of the judge is constitutive for the divorce. If it is the husband who pronounces the repudiation, it should be characterized as a public act. Since the character of the judicial intervention in the case of an annulment is merely declaratory as the judge confirms the right of the claimant to annul, the annulment should also be characterized as a public act. 


\section{Divorce in Morocco}

\section{$8.1 \quad$ INTRODUCTION}

Family law is one of the few domains of law in Morocco that is still based on Shari' a law, more specifically on the Maliki school of jurisprudence. ${ }^{1}$ Moreover, the rules of the Maliki school of jurisprudence are still considered to be default rules in the event that the Moroccan Family Code of 2004 (hereinafter MFC 2004) does not provide for a solution. ${ }^{2}$

Moroccan family law was codified in the Code of Personal Status, the Mudawwana (hereinafter Mud.), in 1958 just after Morocco gained its independence in 1956. Since then it has been amended and reformed several times, in particular in 1993 and - rather radically - in 2004. ${ }^{3}$ The aim of the reforms was, inter alia, to impede the exercise and use of talaq and polygamy by men through introducing procedural and financial obstacles. Their purpose was also to reinforce the position of women and children in law and society, inter alia, through enlarging and liberalizing the wife's possibilities to divorce. The preamble of the MFC 2004 explicitly refers to equality between men and women in respect of marriage and the family on several occasions. ${ }^{4}$ Articles 4 and 51 paragraph 3 MFC 2004, for example, state that the spouses share the same rights and duties in respect of and have joint responsibility for the family and the household. Significantly, the wife's legal requirement of obedience to her husband was abolished. As far as equality between men and women upon divorce is concerned, the Moroccan King Mohammed VI stated it as follows in his speech to parliament on 10 October 2003 on the occasion of the presentation of the Bill of the new Moroccan Family Code:

1 The Preamble of the latest 2011 Constitution describes the kingdom of Morocco as a sovereign Muslim state (al-dawla al-islammiyya); Art. 3 of the 2011 Constitution states that Islam is the religion of the state, which guarantees all the free exercise of beliefs. See the 2011 Constitution via <www.maroc.ma/en/content/constitution $>$.

2 Art. 400 Moroccan Family Code 2004 (MFC 2004); see, e.g., An-Na'im 2002, p. 179; information in this section has been based on Buskens 2003, p. 70-131; Buskens 2006, p. 43-66; Buskens 2008, p. 31-41; Buskens 2010, p. 100-111; Jansen 2007, p. 202-205; Jordens-Cotran 2007, p. 17-28, 34-63; Kruiniger 2008, p. 27-33; Sarehane 2004, p. 2-17; Van der Velden 2005, p. 4-10.

3 Since 2004, the Mudawwana is called the Mudawwana al-Usra. In this research, it is referred to as the Moroccan Family Code of 2004 (MFC 2004) in order to discern this Code from the codification of family law before 2004 but after 1993, the Code of Personal Status and Succession, the Mudawwana of 1993 (Mud. 1993).

4 See preamble of the MFC 2004, in 'Guide pratique du Code de la Famille', available via $<$ http://ejustice.gov.ma/justice/fr/documentation>. 
[F]aire du divorce, en tant que dissolution des liens de marriage, un droit exercé et par l'époux et par l'épouse, selon les conditions légales propres à chacune des parties et sous contrôle judiciaire....

This statement has subsequently been enshrined in Article 78 MFC 2004. The fact that each spouse has his or her own right or possibilities to divorce, to be exercised in accordance with conditions that are characteristic for each spouse, cannot be interpreted as providing full equality between the spouses upon divorce. However, this chapter will demonstrate that the reform of the Mudawwana indeed resulted in one possibility for divorce, the shiqaq or divorce on the ground of irretrievable breakdown, which may offer such equality at least in theory.

The reforms turned out to be rather tricky and risky projects again and again. The subsequent kings, Hassan II and Mohammed VI, were not only confronted with opposition from the 'uluma, the scholars of Shari' $a$, who felt deprived of their primacy to lawmaking and their function as 'legislator', despite being involved in the reforms on the sidelines. The kings were also faced with divergent opinions of diverse population groups in society, like Berbers and Arabs, as well as with political opponents such as fundamentalists, orthodox groups, and progressives and also with women's organizations, human rights organizations, etcetera. In order to carry out these reforms, to 'satisfy' religiously opposed groups and to prevent escalations, the Moroccan kings presented the reforms as being based on and being compatible with the Islamic tradition and Shari ${ }^{\prime} a$ and appealed to the public interest, maslaha. ${ }^{6}$

The kings made use of siyasa and methods like takhayyur and ijthihad. In order to justify the use of the takhayyur and ijthihad, Hassan II and Mohammed VI referred to their capacity as leaders of all believers, Amir al Muminin. By introducing procedural rules of litigation in the substantive Mudawwana, they influenced and adapted the character of the substantive rules, and they strengthened the observance of the procedural rules of litigation. The procedural rules were not observed when they were still part of the Moroccan Code of Civil Procedure as they often deviated from the Maliki doctrine and were strongly influenced by French law.

Despite the aims of the reforms, the two most controversial issues, polygamy and repudiation, were not abolished by the reforms in 2004, although their use was discouraged and restricted by procedural and financial obstacles. The most important element of these restrictions concerns the fact that the procedure regarding the repudiation has become a procedure under judicial supervision before the family court and requires judicial permis-

5 Mohammed VI, Réforme du Code de la famille: le discours du Roi au parlement, 10 October 2003, via $<$ http://mincom.gov.ma $>$.

6 See, e.g., the speech of Mohammed VI to the parliament in October 2003 (via <http://mincom.gov.ma>) and the preamble of the Moroccan Family Code of 2004, ibidem. 
sion. King Mohammed VI justified the non-abolition of polygamy and repudiation by invoking religiously determined limits: 'as leader of the faithful, I cannot allow what God has forbidden, nor forbid what God has permitted'. ${ }^{7}$ Furthermore, the possibilities of the wife to obtain a judicial divorce have been broadened and liberalized, as this chapter will demonstrate. In this respect, the introduction of the divorce on the ground of an irretrievable breakdown and making it available to either spouse and the introduction of the divorce based on mutual agreement are examples of this. This chapter will also show that the status of women and children at and after divorce has been improved.

The MFC 2004 contains seven books including the following subjects: marriage and engagement (book one), the dissolution of marriage and its legal effects (book two), birth and its legal effects (book three), legal capacity and legal representation (book four), the testament (book five), inheritance (book six), and transitional and final provisions (book seven). The first article in book two concerning the dissolution of marriage, Article 70 MFC 2004, refers to and expresses the views about marriage and dissolution of marriage in Shari'a:

Le recours à la dissolution du marriage par le divorce ou le divorce judiciaire ne doit avoir lieu qu'exceptionnellement et en observant la règle du moindre mal et ce du fait que cette dissolution entraîne la dislocation de la famille et porte préjudice aux enfants. ${ }^{8}$

It is noteworthy that the Moroccan legislator employs the term talaq in the Arabic MFC 2004, whereas he uses the term 'divorce' instead of the term ré pudiation in its French translation and in the (French) Guide Pratique. ${ }^{9}$ The legislator may have intended to avoid the negative connotation of the term 'repudiation', in particular abroad, while intentionally maintaining the original notion for 'internal' purposes, for example, in order not to upset the fundamentalists and orthodox groups in society. ${ }^{10}$

With the exception of Moroccan Jews, the MFC 2004 applies to all Moroccan nationals except Moroccan Jews, to refugees without nationality, and to relationships in which at least one Moroccan national is involved or a relationship between two Moroccans of which

7 Translation of the French text in Réforme du Code de la famille: le discours du Roi au parlement, 10 octobre 2003, par S.M. le Roi Mohammed VI, p. 5 via <www.legislation-psy.com/spip.php?article811>; see also the preamble of the MFC 2004 in Guide Pratique 2005, p. 13.

8 Art. 70 in Guide Pratique 2005, p. 57.

9 See, for example, Arts. 79, 80, 89, 114, and 115 MFC 2004.

10 Nevertheless, I prefer to maintain the use of the term 'repudiation or talaq' in order to demonstrate clearly its authentic character (despite the mandatory imposed judicial intervention since 2004): the dissolution of marriage on the initiative of and/or (partly) established by the man. 
at least one is Muslim pursuant to Article 2 MFC $2004 .{ }^{11}$ This article thus contains a unilateral conflict rule that determines the international scope of the MFC. Before 2004, the provisions about typical Islamic institutions such as polygamy, repudiation, etcetera, in the Mudawwana did not explicitly apply to Christian Moroccans and Jews. ${ }^{12}$ The commentary to Article 2 MFC 2004 states that the legislator has repealed the second paragraph of Article 3 of the Moroccan Nationality Code regarding the exceptions provided for the Moroccans that are neither Muslims nor Jews. ${ }^{13}$

As the MFC 2004 does not contain any transitional provisions, the MFC may apply to or govern already existing legal relationships. It enables, for example, spouses who have already been married for years to conclude an agreement about the management and distribution of the assets that were acquired during the marriage. ${ }^{14}$

In addition to the coming into force of the new family law in 2004, separate family chambers were added to the courts of first instance. ${ }^{15}$ All procedures concerning the dissolution of marriage have become judicial procedures. These chambers have absolute competence in other matters of personal status, inheritance, civil status, kafala, homologation (judicial approval), and all procedures in relation to the care and protection of the family. A family chamber may consist of a panel of three judges: a family judge, a judge for marital affairs, and a judge for affairs concerning minors. Any family matters, except for procedures for maintenance, are dealt with in full courts. The role of the homologation judge and ' $u d u l$ has been reduced in favour of the specially trained family judge who is considered to be more expert and to be better equipped to execute the law in a meticulous manner. ${ }^{16}$

Morocco acceded to the Women's Convention on 21 June 1993 and entered declarations and reservations concerning Articles 2, 9, 15, 16, and 29. ${ }^{17}$ It took until 26 December 2000 before the Convention was proclaimed by royal decree by the king; the text of the Convention was never published in the Bulletin Officiel. ${ }^{18}$ The status of the Convention, as well as

11 Art. 2 MFC 2004 in connection with Art. 3 Moroccan Law on Nationality. The personal status of Moroccan Jews is governed by the Hebrew-Moroccan Personal Statute as stated in Art. 2 MFC 2004.

12 Art. 3 of the Moroccan Nationality Code.

13 Commentary to Art. 2 MFC 2004, Guide Pratique 2005, p. 17. Van der Velden (2005, p. 5, note 5) notes that it was no longer necessary to include the restriction on the application of specific legal institutions to nonMuslims in the MFC 2004, since the application of these legal institutions has become dependent on the permission of the court that, as may be expected, will not give this permission in the case of non-Muslims.

14 See for more examples Van der Velden 2005, p. 10.

15 Art. 18 Moroccan Code of Civil Procedure (hereinafter MCCP) as amended by Law nr. 72-03, published in Bulletin Officiel No. 5184 on 5 February 2004; the family chamber, although part of the Court of First Instance, has a separate entrance and its own support services to facilitate its accessibility (Sarehane 2004, p. 3).

16 The judges must have knowledge of human rights, in particular of the rights of the family and the child and the principle of equality, and family law.

17 See the status of the Women's Convention at $<$ http://treaties.un.org/Pages/ViewDetails.aspx? src= TREATY\&mtdsg_no=IV-8\&chapter $=4 \&$ lang $=$ en $\# 57>$.

18 Buskens 2003, p. 110. 
of other ratified international instruments vis-à-vis national law, however, is not clear. ${ }^{19}$ And although the government has expressed the intention to reconsider its reservations and to accede to the Optional Protocol on several occasions, these intentions have partly been realized so far. ${ }^{20}$ On 8 April 2011, the Depositary Notifications, the Secretary-General of the United Nations, received notification from the government of Morocco that it decided to withdraw the reservations made upon accession in relation to Articles 9(2) and 16 of the Convention in accordance with Article 28(3) of the Convention. ${ }^{21}$

One of the shadow reports presented to the CEDAW in 2008 mentioned that the principle of equality between women and men as defined in the Women's Convention has neither been incorporated in the Constitution nor in the domestic laws. ${ }^{22}$ As already said, inter alia, the preamble of the MFC 2004 and its Articles 4 and 51 explicitly refer to equality between men and women in marriage and in the family as well as to the spouses' joint responsibility for the family and the rights and duties that are relevant in this respect. ${ }^{23}$

The Arab Spring hit Morocco on 20 February 2011. Protests in Rabat and other cities demanded greater social justice and democratic reforms. As a result, the Constitution was amended in the sense that, inter alia, several powers of the king were limited in favour of the prime minister, and parliamentary elections, less heavily controlled by the royal court than previously, were held on 7 October $2011 .{ }^{24}$ The new Constitution was enacted on 29 July $2011 .{ }^{25}$ Article 19 establishes equality between men and women as stipulated, inter alia, in international conventions and pacts duly ratified by Morocco. However, this article adds that it must be in accordance with the provisions of the Constitution and the permanent characteristics of the Kingdom and of its laws. For this reason, a critical report on the 2011 Constitution concludes, inter alia, that 'the role of international treaties remains ambiguous in the constitution' and that 'the new constitution does not clearly establish the supremacy of international treaties over domestic law. ${ }^{26}$ It explicitly refers to the

19 Concluding Comments of CEDAW, 2008, UN doc. CEDAW/C/MAR/CO/4, paras. 12 and 13, available via $<$ www2.ohchr.org/english/bodies/cedaw/docs/CEDAW.C.MAR.CO.4_en.pdf $>$.

20 Combined third and fourth periodic report of Morocco 2006, para. 29. See also the NGOs' shadow report to the third and fourth periodic report coordinated by ADFM, 2007, paras. 21-36. See for the status of the reservations and declarations made by Morocco: $<$ http://treaties.un.org/Pages/ViewDetails.aspx?src=TREATY \&mtdsg_no=IV-8\&chapter=4\&lang=en\#EndDec $>$.

21 See the document with reference C.N.176.2011.TREATIES-2 (Depositary Notification) available via $<$ https://treaties.un.org/doc/Publication/CN/2011/CN.176.2011-Eng.pdf >.

22 NGOs' shadow report to the third and fourth periodic report coordinated by ADFM, 2007, paras. 52 and 59.

23 The preamble of the MFC 2004, and Arts. 4 and 51 para. 3 of the MFC 2004. Also in combined third and fourth periodic report of Morocco 2006, paras. 18, 95, 365.

24 See e.g. <www.bbc.co.uk/news/world-africa-13976480>.

25 La Constitution, Dahir no. 1-11-91 du 27 Chaabane 1432 (29 juillet 2011), Bulletin Officiel no. 5964 bis - 28 chaabane 1432 (30-7-2011) via <www.maroc.ma/en/content/constitution>.

26 International IDEA, 'the 2011 Moroccan Constitution: A Critical Analysis', p. 6, 23 via <www.idea.int/ publications/the_2011_moroccan_constitution/>. 
resulting confusion that 'does not facilitate the work of the judiciary, as there is no clear obligation for judges to uphold international law, including the promotion of human rights'. The report therefore recommends that 'Gender equality should be recognized without restrictions' and that the 'Moroccan state should recognize the supremacy of international treaties ratified by Morocco over domestic law'. ${ }^{27}$

\subsection{Divorce}

Since 2004, Moroccan divorce laws and practices encompass the following modalities for the dissolution of marriage apart from its dissolution due to the death of either spouse: ${ }^{28}$

- divorce on the initiative of the husband, the repudiation (talaq);

- divorce on the initiative of the wife (in most cases) including the shiqaq (on the initiative of either the wife or the husband or both spouses), the judicial repudiation (talaq altatliq);

- various modalities of divorce based on agreement between or that require the involvement of both spouses being:

- the assignment of the power to repudiate to the wife, the self-repudiation (tamlik),

- the negotiated repudiation ( $k h u l$ ),

- the repudiation by agreement (mubara'a), and

- the judicial annulment of the deficit marriage (judicial annulment or faskh).

All of these modalities require judicial intervention, whether or not the word 'judicial' has been added to the various terms of these modalities. ${ }^{29}$

Ibidem, p. 7.

28 Art. 71 MFC 2004

29 Arts. 74, 77, 78, 89, 94, 98, and 114 MFC 2004. 
Moroccan $\boldsymbol{k h u l}$ ' act dated 2010.

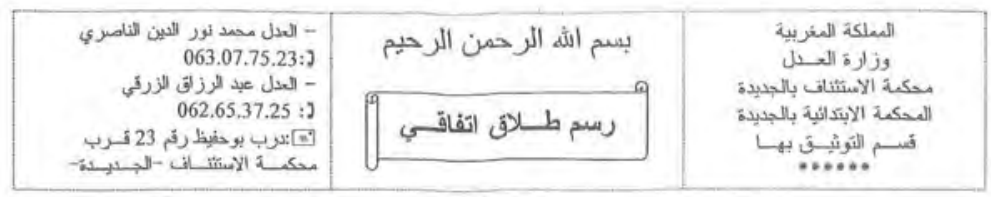

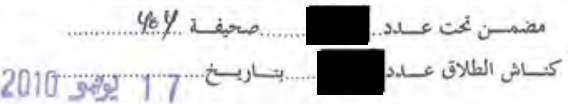

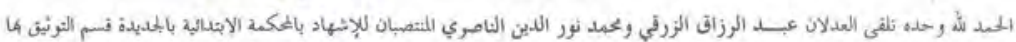

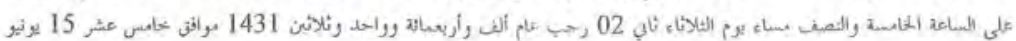

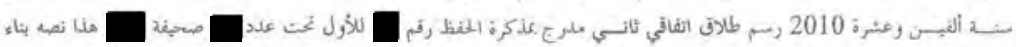

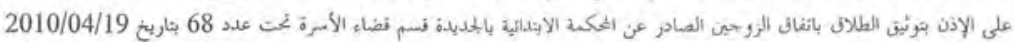

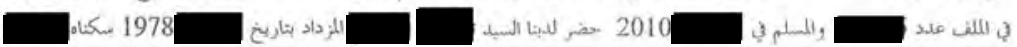

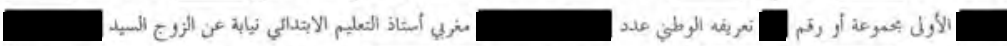

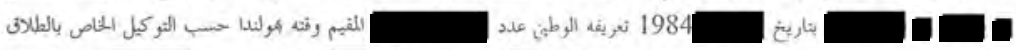

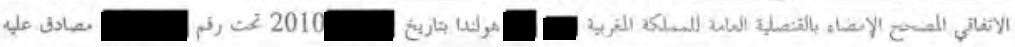

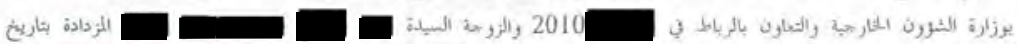
1983

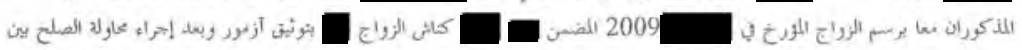

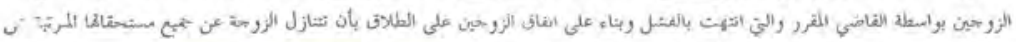

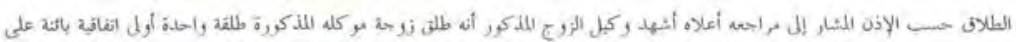
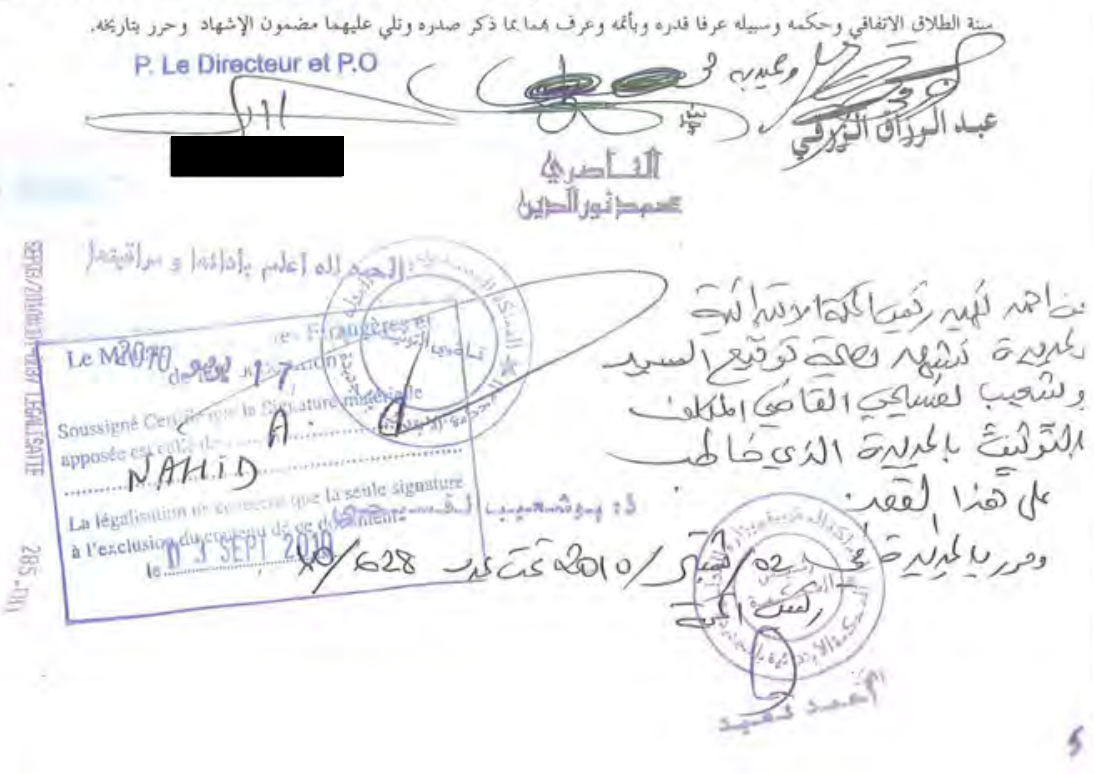
French text of the Dahir (No. 1-04-22) on the promulgation of Law No. 70-03 concerning the Moroccan 'Code de la Famille’ of 2004.

\title{
DAHIR N 1-04-22 DU 12 HIJA 1424 (3 FEVRIER 2004) PORTANT PROMULGATION DE LA LOI N $\mathrm{N}^{\circ}$ 70-03 PORTANT CODE DE LA FAMILLE
}

\author{
( Bulletin Officiel n 5358 du 2 ramadan 1426 ( 6 octobre 2005 ), p. 667 )*
}

\section{LOUANGE A DIEU SEUL !}

(Grand Sceau de Sa Majesté Mohammed VI)

Que l'on sache par les présentes - puisse Dieu en élever et en fortifier la teneur!

Que Notre Majesté Chérifienne,

$\mathrm{Vu}$ la Constitution, notamment ses articles 26 et 58 ,

\section{A DÉCIDÉ CE QUISUIT :}

Est promulguée et sera publiée au Bulletin officiel, à la suite du présent dahir, la loi $n^{\circ} 70-03$ portant Code de la Famille, telle qu'adoptée par la Chambre des représentants et la Chambre des conseillers.

Fait à Rabat, le 12 hija 1424 (3 février 2004).

Pour contreseing :

Le Premier ministre, DRISS JETTOU.

${ }^{*}$ ) Le texte en langue arabe a été publié au Bulletin Officiel ( édition générale ) n 5184 du 14 hija 1424 (5 février 2004) page 418. 
The talaq has been deprived of its exclusively discretionary and extra-judicial character in Morocco. ${ }^{30}$ The intended legal effect, the dissolution of marriage, is no longer at the sole and absolute discretion of the husband. Already since its reform in 1993, the Mudawwana required the husband to complete a specific procedure that included the following: his request to the homologation judge for permission to repudiate ${ }^{31}$ a summons for both spouses to appear; (a) compulsory reconciliation attempt(-s) at the occasion of which the wife may provide information concerning and to defend the post-divorce provisions; the permission of the homologation judge for the husband to repudiate and to have the act of repudiation drawn up, upon the fulfilment of the condition of the husband's payment of a mandatory deposit at the court in order to guarantee the wife's and children's financial post-divorce provisions; ${ }^{32}$ the decision about the post-divorce provisions for the wife and children from the homologation judge; ${ }^{33}$ the mandatory witnessing, recording, and registration of the pronouncement of the repudiation in an act by two ' $u d u l$, ${ }^{34}$ in principle in the presence of the wife; the approval of that act by the homologation judge; and the registration of the repudiation in the registry of marriage and divorce at the court. ${ }^{35}$ The wife is entitled to the original act of repudiation, while the husband will receive a copy of that act.

The 2004 talaq procedure entails an even more extensive, judicial procedure before the Family Court that takes a motivated decision, the qarar moeallal, after the witnessing,

30 The regulation of the repudiation or talaq encompasses Art. 78-93 MFC 2004; Art. 121-141 MFC 2004 may be relevant as well in the context of the repudiation.

31 The homologation judge should be distinguished from the 'regular' judge who belongs to the judiciary in Morocco. The homologation judge supervises the (duties) of the 'udul. When he homologates, for example, the act of repudiation, the homologation judge certifies through his signature that he has seen and approved the act. He checks whether the ' $u d u l$ have been appointed for this task in his district and whether they have recorded and registered the act of repudiation in the manner prescribed. He does not verify the correctness of the content of the act.

32 Post-divorce provisions such as maintenance for the wife and child(-ren) and indemnification ( mut $\left.^{\prime} a\right)$.

33 Post-divorce provisions such as maintenance and residence of the wife during the waiting period of the wife, possibly the payment of the remainder of the dower, the possible indemnification, the maintenance for and residence of the children, and the visiting rights for the father. The decision concerning these provisions was directly enforceable and cannot be appealed pursuant to Art. 179 MCCP. The parties may file proceedings with the 'regular' judge (at the Court of First Instance (Tribunal de première instance)).

34 The ' $a d l$ (single; pluriel: ' $u d u l$ ) is an official who functions as witness, notably in personal status and family law, but also, for example, at real estate transactions, and draws up authentic acts of events such as marriage and repudiation. The act of repudiation as drawn up by the ' $u d u l$ reproduces the procedure that has been followed. Hence, it can be established whether the legal requirements, notably the reconciliation attempt and the presence of the wife, have been observed.

35 Arts. 48, 80, 81 Mud. 1993, Arts. 179-180 MCCP and Art. 22 Law on Civil Status in connection with Art. 26 of the Order Implementing (the Law on) Civil Status. Before the entry into force of the Law on Civil Status and the Order Implementing (the Law on) Civil Status on 3 respectively 9 October 2002, the act of repudiation had to be registered in the register of divorce at the Registry Office (see Jordens-Cotran 2005, p. 183). 
recording, and registering the pronouncement of the repudiation by the ' $u d u l$. This decision shows all the information regarding the talaq, the procedure followed, and the provisions that have been settled. ${ }^{36}$ The husband has to pay the mandatory deposit at the court within 30 days; non-payment is considered as a renunciation of his attention to repudiate. ${ }^{37}$ As said, the Moroccan legislator raised these procedural and substantive obstacles in order to discourage the husband from making use of the repudiation and to enhance the status of women and children. But the intended full equality between men and women has not been achieved. The talaq is still a unilateral act; the husband does not need the consent or cooperation of his wife.

The husband's motives or reasons for the repudiation play a part in the determination of the (financial) rights of the wife by the court, in particular in relation to the consolation gift $\left(m u t^{\prime} a\right) \cdot{ }^{38}$ The repudiation expressed while intoxicated, under coercion, in anger, as an oath, or upon conditions is ineffective; a talaq to which a number is attached is effective as a single repudiation only. ${ }^{39}$ Since 2004 , a revocation has to be witnessed and recorded by two ' $u d u l$ and ratified by the homologation judge who has to inform the wife in advance. If the wife disagrees, she may appeal to the procedure of Article 94 MFC 2004 on the ground of an irretrievable breakdown of the marriage. ${ }^{40}$ The husband can also assign the right to repudiate to his wife pursuant to Article 89 MFC 2004. This modality of divorce, the tamlik, will be discussed in more detail later.

\subsubsection{Divorce on the Initiative of the Wife}

Before 2004, the wife could only petition for a judicial divorce, tatliq, on a limited number of grounds: non-payment of maintenance by the husband; physical or mental harm (also in the case of polygamy $)^{41}$ by the husband, a ground that was difficult to establish in court; an unjustified, long absence of the husband; the oath not to have intercourse (ila') by the husband; oath of abstinence (hajr) by the husband; and severe physical or mental illness of the husband; the latter, severe physical and mental illness, but of the wife, also provides a ground to petition for judicial divorce to the husband. ${ }^{42}$

On the occasion of the reform of the Mudawwana in 2004, the legislator added two new grounds in order to liberalize the possibilities to divorce for the wife: harm caused by non-compliance with one or more of the conditions in the marriage contract by the hus-

36 Arts. 78-93 MFC 2004.

37 Art. 86 MFC 2004.

38 Art. 84 MFC 2004.

39 Arts. 49-52 Mud. 1993 and Arts. 90-93 MFC 2004.

40 Art. 124 MFC 2004.

41 Art. 30 par. 2 Mud. 1993.

42 Arts. 53-60 Mud. 1993. 
band, which is a ground that the wife may invoke; ${ }^{43}$ and the revolutionary ground of irretrievable breakdown of the marriage (hereinafter: shiqaq). ${ }^{44}$ Either or both spouses may invoke the ground of shiqaq without having to establish, but only having to state, the irretrievable breakdown of the marriage, which is defined as 'a situation of profound and persistent disagreement between the spouses of a gradation that makes continuation of the marital relationship impossible'. ${ }^{45}$ This ground first provides for a procedure of mediation for those spouses who want to solve their marital problems without directly having to resort to divorce and second for a judicial and egalitarian mode of dissolution of marriage. ${ }^{46}$ Moreover, the wife can also resort to divorce on the ground of the irretrievable breakdown of the marriage if she fails to establish the harm caused by the non-compliance with one or more conditions in the marriage contract by the husband. ${ }^{47}$ And the wife may invoke this ground in case of (a) her refusal to consent to a polygamous marriage by her husband (Art. 45 MCF 2004), (b) her refusal to consent to revocation of the talaq (Art. 124 MFC 2004), (c) the husband's refusal to consent to $\mathrm{khul}^{\prime}$ (Art.120 MFC 2004), and (d) her inability to prove harm as ground for divorce (Art. 100 MFC 2004). For all these reasons, the introduction of this ground is considered to be the most innovative of the reforms in the MFC 2004. ${ }^{48}$

Before 2004, the procedure in general involved a call for reconciliation by the civil judge. The reconciliation could result in either success and the end of the proceedings or in failure and the continuation by settlement of temporary provisions for the wife and children, investigation of the dispute on the basis of the principle of hearing both sides, and the hearing of witnesses in chambers; then the judge would either order the husband to divorce his wife or he himself would immediately pronounce the divorce or he would set a term in which the husband was offered the opportunity to 'repair' the cause. If the husband did not comply with his duties within the term set, the judge granted a divorce. ${ }^{49}$

Since 2004, the family chamber added to the courts of first instance, consisting of three specialized judges, has absolute competence in dealing with a request for judicial divorce. ${ }^{50}$ Subsequently, the places of marital residence, of the domicile or residence of the wife, or of the conclusion of the marriage determine the relative competence of the court. ${ }^{51}$ Although the procedure of the judicial divorce on the ground of irretrievable breakdown, shiqaq,

43 Arts. 98-101 MFC 2004.

44 Arts. 94-97 MFC 2004.

45 Arts. 94-95 MFC 2004 and Guide Pratique 2005, Art. 95.

46 Jordens-Cotran 2007, p. 354; Sarehane 2004, p. 15.

47 Art. 100 MCF 2004.

48 Sarehane 2004, p. 15

49 The procedure could differ depending on the ground on which divorce was sought; see in particular Arts. 53-59 Mud. 1993; see also Arts. 180, 212-216 Moroccan Code of Civil Procedure.

50 Art. 94 respectively Art. 98 MFC 2004.

51 Art. 79 MFC 2004. 
should be discerned from the procedure of the judicial divorce on one of the other grounds, for which the procedure may vary according to the ground upon which the request for divorce is based, they have some similarities. ${ }^{52}$

In general, the procedure for judicial divorce includes a personal summons in order to guarantee the appearance in court of both spouses; ${ }^{53}$ the hearing of both spouses and possible witnesses $;{ }^{54}$ if relevant, an assessment of the evidence regarding the ground for divorce $;^{55}$ and, indispensable in any procedure but of paramount importance in the case of shiqaq, reconciliation attempt(s) in principle in the presence of the spouses possibly with the assistance of arbitrators (mandatory in the case of shiqaq), a Family Council, or other suitable persons except in the event of a request for divorce based on absence of the husband. ${ }^{56}$ The arbitrators in the procedure of shiqaq investigate the cause of discord between the spouses and have to undertake everything possible to end the dispute. ${ }^{57}$ If the arbitrators or any other mediators in the divorce procedure succeed in reconciling the spouses, they record the reconciliation in an official report, signed by the arbitrators and the spouses, and they send the report to the court. ${ }^{58}$ Reconciliation ends the procedure. If the reconciliation fails and the discord in the case of shiqaq continues, the court will settle post-divorce provisions for the wife and children in accordance with Articles 83, 84, and 85 MFC $2004 .{ }^{59}$ In the case of the procedure for shiqaq, the court takes into account 'the extent of responsibility for the divorce of either spouse', in other words, the question of guilt, when settling the post-divorce provisions. ${ }^{60}$ The court may also settle temporary provisions concerning the lodging of the wife and children if cohabitation between the spouses has become impossible. The court will then grant the divorce, if necessary after other attempts to 'solve the problem', like setting a term within which the husband can

52 Arts. 94-97 MFC 2004 concerning the judicial divorce based on shiqaq and Arts. 98-113 MFC 2004 concerning the judicial divorce based on other grounds as stated in Art. 98 MFC 2004.

53 Art. 81 MFC 2004.

54 Arts. 82, 111 MFC 2004.

55 Arts. 100, 102, 104, 108, and 111 MFC 2004; this assessment is not necessary in order to establish the ground of irretrievable breakdown of the marriage, as the requesting spouse(-s) only has to state and not to establish that the marriage has irretrievably broken down. However, this assessment will play a part in the determination of the post-divorce provisions pursuant to Art. 97 MFC 2004.

56 Art. 94 in connection with Arts. 82 and 95-96 and Art. 113 in connection with Art. 82 MFC 2004. Henricot (2011, p. 5) mentions, with reference to case law of the court of Khenifra of 2007, that the court has the possibility to send a rogatory commission to the consulate of the country in which Moroccan spouses reside in order to undertake reconciliation between the spouses.

57 Arts. 95-96 MFC 2004.

58 Arts. 82 and 95 MFC 2004.

59 Arts. 97 and 113 MFC 2004. It is assumed that the husband does not have to deposit an amount of money in order to guarantee his compliance with the post-divorce provisions for wife and child(-ren) in the case of judicial divorce, notably the shiqaq procedure (see Jordens-Cotran 2007, p. 355, footnote 199). The financial security by the husband is a requirement to the authorization to pronounce the repudiation to the husband, by the court.

60 Art. 97 MFC 2004 
comply with his duties or imposing an injunction on him. After all, divorce is an ultimum remedium. The legislator has stipulated that the judge has to take the decision about divorce within six months after having received the request for divorce in order to avoid an endlessly protracted procedure. ${ }^{61}$

The wife, but also the husband, can request the annulment of a deficit marriage upon one of the grounds as stipulated in Articles 60-63 MFC 2004, for example, if the dower does not meet the legal conditions; if the marriage was concluded when either spouse had a serious contagious disease, unless the sick person was cured after the marriage; if the marriage took place without the presence of the marital guardian when his presence is required; or if the marriage was concluded under duress, error, or fraud. The defective marriage because of a dower that did not meet the legal conditions can be validated after consummation of the marriage by the establishment of a proper dower by the court. Article 77 MFC 2004 stipulates that the annulment of the defective marriage is decreed by the court in the cases and under the conditions set out in the Mudawwana. Deficit marriages that have been consummated may result in legal effects, for example, in relation to the dower, the waiting period, and the parentage of the children. ${ }^{62}$

Courts are often used as a last resort due to the stigma surrounding airing private affairs such as marital disputes in public. ${ }^{63}$ Mir-Hosseini found in her research, conducted in the mid- and end 1980s, that the majority of litigants in Morocco (and Iran) were from the popular classes, where material needs are more important than honour. More women than men would initiate court proceedings, and courts appeared to be 'arenas for negotiations' and strategies. ${ }^{64}$ Men and women use the law and court systems in different ways and for different purposes. Women often want to improve their bargaining position. For example, a woman may start a procedure for maintenance in order to obtain a divorce, while a man often wants to pre-empt or offset the actions of the wife. Thus, the husband claims the return to the marital home (and before 2004 also the submission) by his wife in order to avoid paying maintenance. But the court system is most often used to induce reluctant husbands to consent to a divorce.

\subsubsection{Divorce through the Involvement of Both Spouses}

Moroccan law covers all three types of divorce in the category 'divorce by agreement or through the involvement of both spouses' since 2004: the self-repudiation, the negotiated repudiation, and the repudiation by agreement of both spouses. Article 78 in connection

61 Arts. 97 and Art. 113 MFC 2004.

62 Art. 64 MFC 2004.

63 Mir-Hosseini 2000, p. 29.

64 Mir-Hosseini 2000, p. 41-53. 
with Article 89 MFC 2004 deals with the self-repudiation, tamlik, the right of the wife to repudiate herself, if her husband has assigned this right to her, and that results in an irrevocable divorce. ${ }^{65}$ Article 114 MFC 2004 refers to a type of consensual divorce that was newly introduced in the MFC 2004: the repudiation through mutual consent, whether or not upon conditions and provided that they do not infringe upon the provisions of the MFC 2004 and the interest of the child(-ren) (mubara'a or attalaq al-ittifaki). Article 115 MFC 2004 concerns the repudiation by the husband on the demand of the wife in exchange for compensation by her, the negotiated repudiation or talaq bi l-khul or khul ${ }^{66}{ }^{66}$ As mentioned in the introduction to this chapter, it is noteworthy that the French Guide Pratique 2005 does use the term 'repudiation' but refers to 'divorce' instead, in the relevant articles.

Apart from the mandatory compensation in the case of the negotiated repudiation, the difference between the latter two types of 'consensual' divorce is not quite clear. It appears that the first type rather indicates an end of the marriage by friendly agreement, whereas the second points at the initiative of the wife, either when the husband refuses to repudiate her or when she seeks to divorce, but she cannot rely on any ground for divorce nor provide evidence of the ground at issue. ${ }^{67} \mathrm{It}$ is argued that repudiation based on mutual agreement, which is intended to represent a respectful, civilized, and egalitarian type of divorce, sometimes appears to be equalized to the negotiated repudiation, $\mathrm{khul}^{\mathrm{c}}{ }^{68}$

Both types of consensual divorce are subject to a largely similar procedure as the repudiation that is solely initiated by the husband, talaq. In contrast to the talaq, both types of consensual divorce result in an irrevocable divorce. ${ }^{69}$ The procedure includes the submission of the request for divorce, including the act of agreement to the divorce by either or both spouses and (the) mandatory reconciliation attempt(s); obligatory judicial authorization; the homologation (approval) of the act of repudiation drawn up by the homologation judge; and the decision (qarar) by the court, including the report of the procedure, if relevant the compensation agreed upon by the spouses, and the post-divorce provisions, not being part of the compensation. ${ }^{70}$ The judicial decision, in relation to the divorce, cannot be appealed in a higher court. ${ }^{71}$ According to Sarehane, the judge would play an active part in respect of a demand for divorce through $k h u l$ ' by checking whether

65 Since 1993 but prior to 2004, Art. 44 Mud. 1993.

66 Art. 114-120 MFC 2004; see before 2004: Arts. 61-65 Mud. 1993.

67 Guide Pratique 2005 at Art. 114 MFC 2004; See also, e.g., Jordens-Cotran 2007, p. 334-339.

68 Henricot 2011, p. 645 who illustrates the equalization of the repudiation based on mutual consent to the negotiated repudiation by means of a case dealt with by the Court of First Instance of Marrakech in 2007; see for a more neutral formulation: Jordens-Cotran 2007, p. 336; Rhissassi and Berjaoui 2010, p. 79.

69 Art. 123 MFC 2004.

70 Art. 114 MFC 2004, Guide Pratique 2005 at Art. 114 MFC 2004 and circular no. 47 S2 by the Moroccan Ministry of Justice of 5 December 2006; Kruiniger 2008, p. 120-121; see also Jordens-Cotran 2007, p. 337.

71 Art. 128 MFC 2004. 
the consent of the wife to the $\mathrm{khul}^{\text {' }}$ and the compensation were voluntary. He would also check whether the rights of the children have sufficiently been guaranteed. ${ }^{72}$ It often appears in practice that the wife has not at all agreed to the khul' and compensation, but she has been coerced or she thought she agreed to something else.

The compensation in the case of the khul' may consist of anything that can legally be the object of an obligation. ${ }^{73}$ Examples are the renunciation of property rights, assets, goods, or rights or services, such as the renunciation of the right to maintenance, the deferred dower, the consolation gift, the right to custody of the children, etcetera. But wives may also agree upon taking on the maintenance for the children as compensation, unless the wives themselves are needy. ${ }^{74}$ The use of unlawful objects, such as alcohol, pork, the promise to never marry again, etcetera, as compensation is forbidden.

Article 117 MFC 2004, and already before 2004 Article 63 Mud. 1993, stipulates that the wife can recover the compensation upon proof that the divorce through $\mathrm{khul}^{\text {' }}$ is the result of coercion or harm by the husband. If the latter is the case, the dissolution of marriage by khul' is legally valid, but the husband is not entitled to any compensation. The

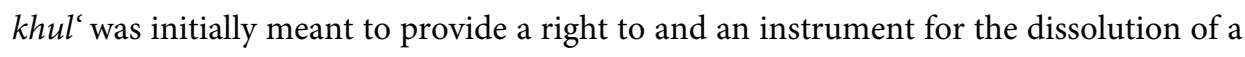
marriage to a woman who could no longer live with her husband but could not realize a divorce. ${ }^{75}$ But it appears to have become a means of blackmail and/or a financially attractive alternative to repudiation for men instead. ${ }^{76}$ Men can render the lives of their wives so miserable that it may force women 'to ransom' themselves from the marriage.

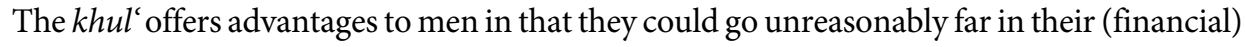
demands in respect of the compensation due by their wives and that, in addition, men are 'relieved of two financial obligations due after a regular repudiation: the consolation gift and the maintenance during the waiting period for the wife. For these reasons, women's organizations and various Moroccan political parties have advocated the abolition of the

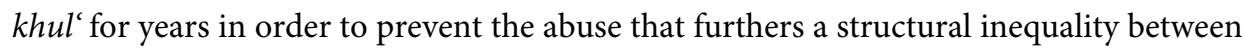
men and women. ${ }^{77}$

The Moroccan legislator maintained the $\mathrm{khul}^{\mathrm{l}}$ and sought to further strengthen the position of women in two ways in order to protect women from those situations. ${ }^{78}$ First, the Moroccan legislator stresses in Article 118 MFC 2004 that the (amount of) compensation may not be the result of abuse and may not be excessive. Second, the legislator provides

72 Sarehane (2005) in her presentation on the occasion of the workshop 'Le nouveau Code Marocain de la famille...' in Brussels on 2 December 2005.

73 Art. 64 Mud. 1993 and Art. 118 MFC 2004

74 Art. 65 Mud. 1993 and Art. 119 MFC 2004.

75 Kruiniger 2008, p. 95, 107, 116, 119-120.

76 Jordens-Cotran 2007, p. 310-311; Mernissi 2004, p. 51.

77 Jordens-Cotran 2002, p. 128.

78 Kruiniger 2008, p. 119-120. 
for additional judicial intervention in the following two situations. ${ }^{79}$ First, when spouses disagree about the compensation, the court may intervene to attempt reconciliation and eventually set a fair compensation upon failure of the reconciliation. When determining the amount of compensation, the court takes into account the amount of the (deferred) dower, the duration of the marriage, the motive for the negotiated repudiation, and the financial situation of the wife. Second, when the wife persists in her request for divorce

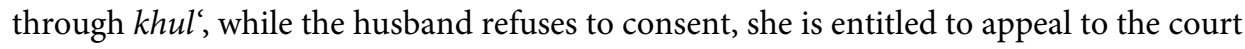
in order to obtain a divorce on the ground of an irretrievable breakdown or shiqaq. ${ }^{80}$

It still appears to frequently occur in practice that women not only agree to renounce all their rights, but they also renounce their rights to custody of the children. ${ }^{81}$ In certain cases, women, while maintaining the latter right to custody, renounce all of their own financial rights and those of the children (maintenance, costs for housing of the children, her 'salary' for the custody). Ex-wives who have renounced the right to custody of the children frequently have recourse to Article 117 MFC 2004 in order to recover that right. Moroccan case law demonstrates a restrictive interpretation of this legal provision and use of rigid conditions to its operation by the judiciary. It appears that the Moroccan Supreme Court repeatedly dismissed the appeal of the ex-wife under consideration that the blackmail could not be proven as the wife had agreed to the compensation. ${ }^{82}$ Furthermore, the Moroccan Supreme Court dismissed an appeal for the annulment of a transaction for compensation of which the wife claimed to have consented to under coercion. ${ }^{83}$ The Court held that the ex-wife had not observed the prescribed conditions: the period of a year within which she had to bring this action for annulment and the production of the required document establishing her consent to the renouncement of her rights under coercion. However, in another case in which the wife claimed recovery of her right to custody that she had renounced while her child was still unborn in order to obtain a divorce through $\mathrm{khul}^{\text {', }}$, the Court of Appeal of Nador annulled the transaction under consideration of the best interest of the child. ${ }^{84}$

79 Art. 120 MFC 2004. The Moroccan legislator was inspired to Art. 120 by the introduction of the judicial khul' in Egypt in Law No. 1 of 2000 that provides the wife the right to unilateral divorce through $\mathrm{khul}^{\text {' }}$ without the consent of the husband, if, inter alia, the wife is prepared to return her dower and/or to renounce other financial rights (confirmed by Buskens at the occasion of the RIMO symposium in Leiden on 3 June 2005; Sonneveld 2012, p. 1).

80 Art. 120 in connection with Art. 97 MFC 2004.

81 Henricot 2011, p. 645.

82 See, for example, C.S., 4 janvier 2006, dossier 2004/2/1/2/343 and C.S., 4 octobre 2006, dossier 2006/2/1/2/143, ministère de la Justice, Choix de jurisprudence relative à l'application du Code de la famille (publié en Arabe), p. 175-178 as referred to by Henricot 2011, p. 645 and footnote 37.

83 C.S., 22 Novembre 2006, dossier 2006/1/2/230, ministère de la Justice, Choix de la jurisprudence relative à l'application du Code de la famille (publié en Arabe), p. 177-178 as referred to by Henricot 2011, p. 645-646 and footnote 38 .

84 Cour d'Appel Nador, 14 Mars 2007, dossier 06/9/3/301, ministère de la Justice, Choix de jurisprudence relative à l'application du Code de la famille (publié en Arabe), p. 181-182. 


\subsection{After Divorce}

A repudiation-based divorce is revocable except for the third consecutive repudiation, the repudiation that takes place before the consummation of the marriage, the repudiation by agreement, the negotiated repudiation, and the self-repudiation. ${ }^{85}$ If the husband does not revoke his decision during the waiting period of the wife, the dissolution of the marriage becomes final. ${ }^{86}$ It has already been mentioned above that the Moroccan legislator introduced in 2004 an important requirement in order to prevent a tacit revocation: the revocation must be pronounced in the presence of and drawn up in an act by the ' $u d u l .^{87}$ Prior to the homologation of that act, the homologation judge summons the wife to appear in order to inform and hear her. If she persists in refusing to resume the marriage, after a reconciliation attempt by the homologation judge, she can start a procedure for divorce based on shiqaq pursuant to Article 94 MFC $2004 .^{88}$

A judicial divorce, except for the divorce on the grounds of non-payment of maintenance and the oath of abstinence, results in an irrevocable divorce and ends the marriage forthwith. ${ }^{89}$ Another important requirement introduced by the Moroccan legislator in 2004, in order to prevent fraud, concerns the registration of any judicial divorce, repudiation(-based divorce), revocation, or annulment of marriage, in the birth certificates of both spouses by the registrar or by the public prosecutor of the Court of First Instance in Rabat in the case that the divorcé(es) was/were not born in Morocco. ${ }^{90}$

Judicial decisions with regard to the post-divorce provisions taken in respect of a repudiation-based divorce are open to appeal. ${ }^{91}$ Judicial decisions concerning the judicial divorce were open to appeal before $2003^{92}$; however, since 2004, judicial decisions in respect of a judicial divorce or divorce by $\mathrm{khul}^{\text {' }}$ or an annulment of the marriage are no longer open to appeal with regard to the decision that concerns the dissolution of marriage. ${ }^{93}$ Since 2004, foreign divorce judgments may be more easily recognized in Morocco if the judgment is ruled upon by a competent court upon a ground for divorce that is not incompatible with the provisions of the MCF 2004. ${ }^{94}$ Since the MCF 2004 has no transitional provision, this Article 128 may be applied to divorce judgments obtained before 2004.

85 Art. 67 Mud. 1993; Guide Pratique 2005 at Art. 123 MFC 2004; see Arts. 67-71 Mud. 1993 and Arts. 122-127 MFC 2004 with regard to revocable and irrevocable divorces.

86 Art. 68 Mud. 1993; Art. 124-125 MFC 2004.

87 Art. 124 MFC 2004.

88 According to Sarehare (2004, p. 13), the wife must start such a procedure if she rejects a revocation.

89 Art. 66 Mud. 1993; Art. 122 MFC 2004.

90 Art. 141 MFC 2004.

91 Art. 179 Moroccan Code of Civil Procedure, Art. 88 MFC 2004.

92 Ibidem Art. 147, 213, 216, 353 MFC 2004.

93 Art. 128 MFC 2004.

94 Ibidem. 
The judge will settle post-divorce provisions irrespective of the mode of dissolution in accordance with Articles 83, 84, and 85 MFC 2004. Article 84 MFC 2004 stipulates the provisions after divorce to which the wife is entitled the (remainder of) the dower; maintenance during the waiting period of a revocable divorce or pregnancy; the consolation gift; and, if relevant, an indemnification and the right to stay in the marital home or to another appropriate lodging during her waiting period. Article 85 MFC 2004 concerns the maintenance for the child(-ren) after divorce of their parents. These post-divorce provisions are discussed separately in greater detail below.

However, Articles 83, 84, and 85 MFC 2004 do not refer to the division of assets that were acquired during the marriage, upon the dissolution of marriage. The Moroccan legislator introduced in Article 49 MFC 2004 the possibility for the spouses to agree on a specific marriage settlement in relation to the investment and distribution of those assets that are or have been acquired during the marriage. This possibility deviates from the regime of total separation of property that is common in Shari ${ }^{\prime} a$ law and that still is the starting point in Article 49 MFC 2004 and Article 34 MFC 2004 (concerning the trousseau of the wife). However, the Moroccan legislator based the possibility on Shari'a law: it concerns an optional agreement that is derived from the qualified acts in accordance with the figh on the one hand and on contract law in which the principle of party autonomy enjoys a prominent position, on the other hand. ${ }^{95}$ The Moroccan legislator aimed at preventing the injustice that the wife could not claim any of these assets although she had contributed to their development and increase by means of her work in the household or outside the home. ${ }^{96}$ At the time of marriage, the ' $u d u l$ should inform the spouses of this possibility. The agreement on the investment and distribution of the assets is indicated in a written document that is separate from the marriage contract. In the absence of such an agreement and in the case of a dispute, the judge can nevertheless divide the family assets. In that case, he has recourse to general standards of evidence, while he takes into consideration the work of each spouse, the efforts and costs made, as well as the responsibilities assumed in relation to the development and increase of these assets. ${ }^{97}$

\subsubsection{Waiting Period}

After any form of dissolution of marriage, the wife has to observe a waiting period or 'idda except when the marriage has not been consummated. ${ }^{98}$ The waiting period starts on the day of the (revocable or irrevocable) repudiation-based divorce, divorce, or annulment.

95 Guide Pratique 2005 at Art. 49 MFC 2004.

96 Kruiniger 2008, p. 64.

97 Guide Pratique 2005 at Art. 49 MFC 2004.

98 Arts. 72-79 Mud. 1993 and Arts. 129-137 MFC 2004. 
Its duration varies dependent on the physical condition (having menses or not, being pregnant, etcetera) of the wife and the mode of dissolution of marriage (by divorce or by death). The waiting period of a pregnant woman lasts until the birth or abortion of the child. The waiting period of the woman who is not pregnant lasts three menstrual cycles for the wife who menstruates and three months for the wife who does not yet menstruate or is in menopause. In accordance with Shari' $a$ (law), Article 131 MFC 2004 stipulates that the wife shall observe the waiting period in the marital home or, in the case of a problematic situation, in another home such as a so-called dar ath-thiqa. ${ }^{99}$ This is a special home under supervision of a woman who guards the chastity of the women staying in that home.

\subsubsection{Maintenance}

The husband is in principle no longer obliged to maintain his former wife upon dissolution of marriage except in two situations: first, during the waiting period after a revocable repudiation or divorce and, second, during the waiting period after a revocable or irrevocable divorce if the wife is pregnant. ${ }^{100}$ If the wife who has been revocably repudiated leaves the marital home or another home where she should observe her waiting period, she does not lose her right to maintenance, but she shall lose her right to accommodation. The wife's right to maintenance by the husband expires at the end of the waiting period.

\subsubsection{Dower}

One of the financial rights of the wife upon divorce is the payment of the dower or mahr by her husband. The dower is one of the substantive requirements to a legally valid marriage in Morocco. ${ }^{101}$ The spouses themselves can specify the amount of the dower upon the conclusion of the marriage contract, the specified dower. By lack of their agreement, the court shall determine its amount by taking into consideration the social position of both spouses, the proper dower. The spouses may agree on the immediate or deferred payment of the specified dower, for the entire amount or for part of it. The wife has the right to the totality of the dower from the moment of consummation of the marriage or the death of either spouse. She has the right to half of the dower, if divorce occurs before the marriage is consummated. The wife is not entitled to the dower before the marriage is consummated when the marriage contract is nullified, when the marriage contract is dissolved by faskh because of a defect in the wife or a defect in the husband, or when divorce occurs in a

99 In contrast with Mud. 1993 that remained silent about the housing of the wife during the waiting period. 100 Art. 119 Mud. 1993 in connection with Arts. 179 and 494 MCCP (and Art. 1248 of the Moroccan Code of Contract Law); Art. 84 in connection with Art. 196 MFC 2004.

101 Arts. 16-24 Mud. 1993; Arts. 13, 26-34 MFC 2004. 
marriage in which the determination of the dower has been delegated. When the husband has not yet delivered or paid the entire dower during the marriage, he has to do so upon the dissolution of the consummated marriage at the latest, irrespective of which spouse requested the divorce or dissolution. ${ }^{102}$

\subsubsection{Consolation Gift (Mut'a)}

One of the other financial duties of the husband to the wife after repudiation or divorce, pursuant to Articles 84 and 97 MFC 2004, concerns the consolation gift (mut'a) in order to compensate the wife for the damage caused by the dissolution of the marriage. ${ }^{103}$ When determining its amount, the court should take into consideration the duration of the marriage, the financial situation of the husband, and the motives for the repudiation, in other words the degree of arbitrariness or abuse by the husband or the responsibility for the divorce. ${ }^{104}$

Although the Moroccan legislator neutrally stipulates that account must be taken of the (extent of) responsibility of either spouse for the divorce in Article 97 MCF 2004, the Moroccan Supreme Court seemed to interpret these wordings in relation to the consolation gift in the context of Article 84 MFC 2004, to which Article 97 MFC 2004 refers. The Moroccan Supreme Court stated that the 'don de consolation' (the consolation gift) can only be granted to women who have been repudiated or to women who are the defendants in a procedure for divorce instituted by the husband. ${ }^{105}$ The fact that the wife in the case at issue had instituted the procedure based on shiqaq and could not sufficiently prove the responsibility of her husband for the divorce deprived her de facto of the right to claim the consolation gift.

\subsubsection{Indemnification}

When determining the duties of the husband towards his wife and child(-ren) after divorce in the procedure based on shiqaq, the court may also decide to grant an indemnification to the injured spouse, be it the husband or the wife, pursuant to Article 97 in connection with Article 84 MFC 2004. When determining its amount, the court should take into account the (extent of) responsibility of either spouse for the divorce. Henricot illustrates through examples in Moroccan case law of the Supreme Court and lower courts that this

102 Art. 84 in connection with Art. 32 MFC 2004.

103 See prior to 2004: Arts. 22 and 52 bis Mud. 1993.

104 Art. 84 MFC 2004 and Guide Pratique 2005, at Art. 84 MFC 2004.

105 C.S., chambre de statut personnel et succession, arrêt no. 433 de 21 September 2010, Revue de la jurisprudence et des lois (published in Arabic), no. 158/2010 as referred to by Henricot 2011, p. 643. 
case law could indicate that judges seem to hold the wife, whether being the applicant or the defendant in the procedure for divorce, systematically responsible for the divorce and that judges subsequently order her to pay an indemnification for the prejudice as suffered by her husband thus being the injured spouse. ${ }^{106}$

In one case, the court of appeal of El-Jadida determined the legal basis of the request of the wife for indemnification by the husband in a tort that consists of the breach of obligations of the spouses and not in contractual responsibility. ${ }^{107}$ In another case, the court of appeal of Oujda held that the indemnification of 7,000 Moroccan dirhams (MAD), which the wife had been ordered to pay by the Court of First Instance, was not high enough. Instead, the court ordered the wife to pay 10,000 MAD for moral and material prejudice since the court held the wife to be responsible for the breakdown of the marriage. The wife had persisted in her request for divorce despite a judicial order that she must return to the marital home. The request for the order to return reflected the willingness of the husband to maintain the marriage. Apparently, the dossier also stated that the husband had mistreated the wife. Furthermore, it appeared that the amount of indemnification to which the wife had initially been ordered to pay (7,000 MAD) was equal to the value in money of the rights to which she was entitled: 5,000 MAD as a consolation gift, 1,500 MAD for her lodging, $350 \mathrm{MAD}$ for maintenance of the child, and $200 \mathrm{MAD}$ as her remuneration for the custody of the child. For this reason, Henricot rightly notes first of all that the 'search for equivalence between the spouses' by the judiciary by ordering the wife to pay an indemnification that is equal to her rights due by her husband comes down to depriving her of her financial rights in practice. Furthermore, Henricot states that the implementation of the divorce based on shiqaq in this way comes dangerously close to the negotiated repudiation $(\mathrm{khul})$ ). Lastly, Henricot notes that the indemnities that were granted to the wife would be unfair and even humiliating since they did not reflect the wives' participation, efforts, and share in the building up of the matrimonial property. ${ }^{108}$ Such practices may be aimed at discouraging, and may indeed discourage, women from having recourse (too easily) to judicial divorce by shiqaq.

\subsubsection{Provisions for Children}

Provisions regarding the minor child(-ren) in the case of divorce concern its/their custody and maintenance and are settled by the court. A divorce in principle does not influence

106 Henricot 2011, p. 643.

107 El-Jadida, 12 Decembre 2006, dossier 2006/101/34, ministère de la Justice, Choix de jurisprudence relative à l'application du Code de la famille, p. 118-119 (published in Arabic) as referred to by Henricot 2011, p. 643.

108 Henricot 2011, p. 643-644. 
the guardianship of these child(-ren) by the father who was already its/their legal guardian during marriage.

The distinction between custody and guardianship as in Shari' $a$ law can still be found in Moroccan family law. The reformed 2004 MFC did not introduce the concept of (undivided) parental authority despite the fact that the new code replaced the formula of the husband being the head of the family by the formula that the family is under supervision of both spouses and stresses the equal position of men and women before the law. ${ }^{109}$

\subsubsection{Custody}

During marriage, in principle, both parents have custody of their minor child(-ren). ${ }^{110}$ The custody of both girls and boys lasts until they reach the legal age of majority, which is 18 years according to Moroccan law. ${ }^{111}$ Article 171 MFC 2004 stipulates the order of custodians after the dissolution of marriage, starting with the mother, who is then followed by the father, who is followed by the maternal grandmother. ${ }^{112}$ The introduction of the father as the custodian second in line is the result of the reform of the Mud. 1993. When the aforementioned persons do not want to be or do not fit the requirements for being a custodian, the court will determine which other family member is most capable to be custodian of the child(-ren), or, such a family member being unavailable, the court will appoint an institution as such. ${ }^{113}$

The reforms of 2004 introduced that the child who has reached the age of 15 years has the right to choose whether his or her father or mother will be his or her custodian. ${ }^{114}$ If either parent lacks, the child may choose for one of the relatives in accordance with Article 171 MFC 2004 to be his or her custodian, provided that the choice is in his or her best interest and the guardian consents. The parent who is not the custodian has the right to visit the child(-ren) and the right to receive the child(-ren) for visits. ${ }^{115}$ The court will include the visiting arrangements as agreed upon by the parents in its decision concerning the divorce. If the parents cannot agree upon these arrangements, the court will determine the visiting arrangements while taking into account the best interest of the child and will include these arrangements in the divorce decision. The custodian, unless it concerns the

109 Preamble MFC 2004, Art. 4 MFC 2004. See also Jordens-Cotran 2007, p. 581-582 and 628-629; and Kulk 2013, p. 154.

110 Art. 164 MFC 2004; see Art. 163 MFC 2004 for the definition of custody (hadana).

111 Art. 166 MFC 2004 in accordance with Art. 209 MFC 2004. According to Art. 102 Mud. 1993, the custody of a girl lasted until the age of 15 years, while custody of a boy lasted until the age of 12 years. Art. 102 Mud. 1958 stipulated that the custody of boys lasted until they became sexually mature and that custody of girls ended at the consummation of their marriage.

112 See for requirements to the person that exercises the custody of a child, Art. 173 MFC 2004.

113 Art. 165 MFC 2004.

114 Art. 166 MFC 2004 in connection with Art. 171 MFC 2004.

115 Arts. 180-186 MFC 2004. 
mother who has been remarried, is entitled to remuneration by the father or another person who is responsible for maintaining the child. ${ }^{116}$

\subsubsection{Guardianship}

The (major) father is the guardian (wali) of his minor child(-ren) during marriage and after divorce. ${ }^{117}$ Failing the father or when he lacks capacity, it is the (major) mother who is second in line to be guardian of the child(-ren) since the reform of the Mud. $1993 .{ }^{118}$ If the mother also lacks capacity, the next in line are the testamentary guardian as appointed by the father, the testamentary guardian as appointed by the mother, the judge, etcetera. ${ }^{119}$ The mother may also replace the father as guardian when he is temporarily unable to exercise his guardianship because of illness or absence. ${ }^{120}$

\subsubsection{Maintenance}

The principle in Shari' $a$ law that every Muslim is responsible for his or her own maintenance entitles only (legitimate) children in need to the right to maintenance by their parents, if the parents are able to provide for their own maintenance according to Moroccan law. ${ }^{121}$ Maintenance consists of food, clothing, medical treatment, education, and anything else that is indispensable and necessary. ${ }^{122}$ The father, who is the first parent responsible for maintaining his legitimate child(-ren), has this duty at least until the child's legal majority or until the child reaches the age of 25 years if the child studies. ${ }^{123}$ His maintenance obligations towards his daughter lapse if her husband takes over that duty or if she can provide her income herself. ${ }^{124}$ The father remains obliged to provide for maintenance towards his disabled child or the child that is not able to earn any income.

Apart from maintenance, the father of a child also has to provide for lodging of the child(-ren), whether or not they are in the marital home. ${ }^{125}$ Whenever the father is unable to (partially) provide for maintenance of his child(-ren) and the mother is well-to-do, the mother has to take over that part of the obligation which the father is unable to fulfil. ${ }^{126}$ The mother who is well-to-do can also agree to undertake the duty of maintenance towards the child(-ren) as compensation in respect of a divorce through $\mathrm{khul}^{\mathrm{c}}{ }^{127}$ But the father has

116 Art. 167 MFC 2004.

117 Arts. 230, 231, and 236 MFC 2004.

118 Arts. 230, 231, 236, and 238 MFC 2004.

119 Art. 231 MFC 2004.

120 Art. 236 and its commentary in the Guide Pratique 2005.

121 Arts. 187, 188, 197 MFC 2004.

122 Art. 189 MFC 2004.

123 Art. 198 in connection with Arts. 144 and 152 MFC 2004.

124 Art. 198 in connection with Art. 194 MFC 2004.

125 Art. 168 in connection with Art. 189 MFC 2004.

126 Art. 199 MFC 2004.

127 Arts. 118 and 119 MFC 2004. 
to take on this duty if she becomes insolvent; in that case, the father has a claim on the mother as soon as she is able to pay off her debt.

The court will hear both parents and take into account the living conditions and costs for the education of the child(-ren) before divorce in order to settle the extent of maintenance for the child(-ren) after divorce. ${ }^{128}$ The court should issue its decision with regard to maintenance within one month and should provide for measures concerning the enforcement of that decision. ${ }^{129}$ Whenever the father does not comply with his duty, the court can order him to provide maintenance from the date that he was required to do so. ${ }^{130}$ The father can also be prosecuted on the ground of neglect of the family if he has not complied with his duty to provide maintenance without good reason for at least one month. $^{131}$

\subsection{Assessment}

Moroccan women may have access to the self-repudiation if she was authorized to that end by the husband, to the negotiated repudiation although she will be dependent on her husband's consent, and to the judicial repudiation or divorce on a limited number of grounds of which the most significant ground for her is that of shiqaq to be discussed in more detail below. Men have access to the repudiation and the judicial divorce on the ground of severe illness. Since 2004, both spouses have the possibility of the repudiation by mutual consent and have, individually or together, access to the judicial divorce on the ground of irretrievable breakdown (shiqaq procedure). Thus, the shiqaq procedure appears to offer an 'independent' possibility to divorce for women. ${ }^{132}$

Surveys of the Moroccan Ministry of Justice and NGOs overall demonstrate a shift from the modes of dissolution of marriage that are based on the repudiation, such as the

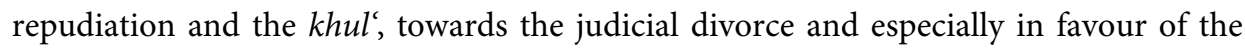
shiqaq in the period 2004-2008. ${ }^{133}$ The relative proportions between repudiation-based divorces (divorce sous contrôle judiciaire) and judicial divorces (divorce judiciaire) shifted

128 Art. 190 in connection with Arts. 85 and 189 MFC 2004.

129 Arts. 190 and 191 MFC 2004.

130 Art. 200 MFC 2004.

131 Art. 202 MFC 2004.

132 'Independent' in the meaning of independent access, because in order to obtain a divorce, it has to be certain that the dispute is unsolvable and that reconciliation is impossible.

133 See the 2008 overview of the Moroccan Ministry of Justice at <http://adala.justice.gov.ma/FR/Statistiques/Statistiques.aspx >. But see also Association Marocaine de lutte contre la violence à l'égard des femmes, l'application du Code de la Famille: acquis \& défis, 2005; La ligue démocratique pour les droits des femmes, rapport annuel sur l'application du code de la famille, March 2005; La ligue démocratique pour les droits des femmes (LDDF), rapport annuel sur l'application du code de la famille 2006; Benradi et al. 2007; Association Marocaine de lutte contre la violence à l'égard des femmes, La perception $d u$ Code de la Famille et de son environnement social et professionnel, 2007 (all available at the Internet); Henricot 2011, p. 642, footnote 6. 
from approximately 4:1 in 2004 to $1: 1$ in 2008 according to the Moroccan Ministry of Justice. ${ }^{134}$ Henricot demonstrates the growing number of judicial divorce based on shiqaq in relation to the total number of all modes of dissolution of marriage according to the statistics of the Moroccan Ministry of Justice. In 2006, 10,313 divorces were based on shiqaq (out of a total of 43,030 of all modes of divorce); in 2007, 18,562 divorces were based on shiqaq (out of a total of 49,232 of all modes of divorce); and in 2008, 24,854 divorces were based on shiqaq (out of a total of 55,376 of all modes of divorce). ${ }^{135}$

A recent survey of the Moroccan Ministry of Justice concerning the period 2009-2011 demonstrates a continuation of this trend of a decrease in repudiation-based divorces versus an increase in judicial divorces. In 2009, there were 24,170 repudiation-based divorces (divorces sous controle judiciaire) versus 31,085 judicial divorces (divorces judiciaires) (approximately 4:5); in 2010, there were 22,452 divorces sous controle judiciaire versus 33,564 divorces judiciaires (approximately 2:3); and in 2011, there were 22.937 divorces sous controle judiciaire versus 33,261 divorces judiciaires (approximately 2:3). ${ }^{136}$ Regarding the category of repudiation-based divorces, the decrease in revocable repudiations and negotiated repudiations and the increase in repudiations based on mutual agreement in the period 2010-2011 are striking. ${ }^{137}$ The category of judicial divorces shows an increase of the judicial divorce based on shiqaq and a decrease in judicial divorces based on other grounds in the period 2010-2011. ${ }^{138}$ The Moroccan Ministry of Justice also reports 91,478 cases of judicial divorce based on shiqaq (pending and new requests) in 2011 of which 32,365 cases ended in the pronouncement of the divorce by the court; 9,679 cases ended in the reconciliation of the spouses; in 17,383 cases, the divorce was refused by the court; and 32,051 cases are still pending in court. ${ }^{139}$ This implies that approximately one-third of these cases ended in divorce, one-third was still pending, and that in nearly one-fifth of the cases the divorce based on shiqaq was refused by the court.

Of the 64,729 registered requests for divorce based on shiqaq in $2011,38,435$ or $59.38 \%$ concerned requests by the wife, and 26,294 or $40.62 \%$ concerned requests by the husband. ${ }^{140}$ A number of constraints regarding judicial procedures have also been observed: difficulties to obtain hearings and lengthy procedures because of congestion and an inadequate

1342008 overview of the Moroccan Ministry of Justice at <http://adala.justice.gov.ma/FR/Statistiques/Statistiques.aspx $>$.

135 Henricot 2011, p. 642, footnote 6.

136 Statistiques des sections de la justice de la famille Annee 2011, Tableau 1; see also Table 6 for an overview of the decrease of the repudiation-based divorces (divorce sous contrôle judiciaire) during the period 20002011, at <http://adala.justice.gov.ma/production/statistiques/SJF/FR/30-10-12\%20VR\%20Finale\%20Statistique\%20Francais.pdf $>$.

137 Statistiques des sections de la justice de la famille Annee 2011, Tableau 4.

138 Statistiques des sections de la justice de la famille Annee 2011, Tableau 12.

139 Statistiques des sections de la justice de la famille Annee 2011, Tableau 11.

140 Statistiques des sections de la justice de la famille Annee 2011, Tableau 14. 
number of courts, ${ }^{141}$ the corruption of the judiciary, reluctance by some judges to implement the new provisions such as the shiqaq procedure, ${ }^{142}$ partiality of the judges, ${ }^{143}$ ' an inadequate sensitization and training of persons responsible for enforcing' the MFC, a persisting culture of discrimination against women, 'as well as the illiteracy and poverty of litigants, especially women', and poor knowledge of their rights among women. ${ }^{144}$

Although men and women have equal access to the shiqaq procedure, at least theoretically speaking, women in Morocco still do not have fully equal access to divorce. Despite its 'growing diversity' under Moroccan law since 2004, men and women do not equally share the same possibilities to dissolve their marriage apart from the shiqaq. The man still has the option of repudiation, and although it is restricted by the court's authorization to its pronouncement, women do not have an independent access to the repudiation, nor can they influence their husband's exercise of this option. The latter also means that women cannot object to the repudiation (only to its revocation). To state it briefly, women have 'no say' in it. And although women have access to various possibilities whether or not dependent on the cooperation of their husband (the self-repudiation, repudiation by mutual agreement, the negotiated repudiation, and the judicial divorce including the shiqaq), these options do not completely counterbalance the strong effect of the talaq (procedure).

As to the procedural position of women, the procedure with regard to repudiation-based divorces should be distinguished from the procedure with regard to the judicial divorce. It may be concluded that the first type of procedure, based on the talaq, does not represent a truly adversarial procedure (a defended action). It can be defined as a procedure monitored by a judge in which women have certain procedural rights (like the right to be summoned and to be heard) in order to establish a divorce by repudiation under certain guarantees for women and children and settling provisions like the maintenance, consolation gift, etcetera. Although the position of women has improved due to the requirement of judicial intervention, fundamentally, it remains a type of divorce that is unilaterally at the disposition of men, although his prerogative and exclusive discretion has been constrained by the mandatory judicial approval.

The second procedure, the judicial divorce (tatliq), generally speaking implies an adversarial procedure under supervision of a judge in which women have certain procedural rights (like the right to be summoned and to be heard) in order to establish a divorce under

141 See the combined third and fourth periodic report of Morocco 2006, UN Doc. CEDAW/C/MAR/4 paras. 389-390. See also Statistiques des sections de la justice de la famille Annee 2011, Tableau 11.

142 Henricot 2011, p. 642.

143 According to Sarehane at the workshop 'Le nouveau Code Marocain de la famille, son application en Belgique' on 2 December 2005 in Brussels, Belgium, see Kruiniger 2008, p. 85-86.

144 See the NGOs' shadow report to the third and fourth periodic report coordinated by the Association Démocratique des Femmes du Maroc, 2007, paras. 200-201 (at <www2.ohchr.org/english/bodies/cedaw/ cedaws40.htm >; and Skalli, N. (2008), Implementing CEDAW: Third and Fourth Periodic Reports, Geneva, 24 January 2008, presentation at the fortieth session of the CEDAW, Geneva, 24 January 2008. 
certain guarantees. In the context of the shiqaq procedure, the procedural position of men and women is, technically speaking, equal. However, as to the divorce procedure, one has to take into account that the drawback of this procedure is the difficult position of women in respect of providing proof or evidence of the grounds, the costs, the long-standing proceedings, the inadequate number of courts, the corruption and discrimination, the illiteracy, poverty and poor knowledge of women themselves, etcetera, as demonstrated in the various reports for CEDAW.

With regard to its characterization, the Moroccan repudiation-based divorce can be defined as a hybrid, public act at the discretion of the husband but restricted by administrative and judicial requirements. Notwithstanding the mandatory intervention of the judge, the husband still needs to pronounce the repudiation in order to dissolve the marriage in the end. The Moroccan judicial divorce can beyond doubt be characterized as a judgment as the decision of the judge is constitutive for the divorce.

The overall conclusion is that the position of women in Morocco has improved, although full equality in access to divorce or of procedural rights has not yet been achieved. Adding a procedure in which both spouses have an equal position as to access and procedure, the shiqaq, at least theoretically speaking, is, however, not enough because the mere existence of the repudiation implies inequality. The existence of a procedure under judicial supervision in order to guarantee certain rights or provisions to women (and children) and an independent possibility for divorce can only mitigate this inequality. Moreover, the protection of women (and children) depends to a great extent on the implementation of the law by the judiciary. However, to end with a hopeful quotation from Mounira M. Charrad:

Although the Moroccan reforms of 2004 do not go quite as far as those in Tunisia, they are nevertheless important in that they place Morocco in second place in the Arab world in regard to gender equality in family law. ${ }^{145}$

145 Charrad 2012, p. 2. 



\section{Divorce in Pakistan}

\subsection{INTRODUCTION}

Contrary to the legal state of the art in Egypt and Morocco, the entire contemporary Pakistani legal system is infused with appeals to Islam and thus with Shari' $a$ law. The basic principle in the area of family law is that each religious community is governed by its own personal law. The 1962 Shari' ${ }^{\prime}$ at Application Act ${ }^{1}$ directs the application of Muslim personal law in all matters of family law whenever the parties are Muslims. Pakistani Muslims are far from being a homogeneous group: the predominant school of law is the Hanafi, but the Shi' $a$ school is also represented. ${ }^{2}$ Muslims are therefore considered to be Hanafi unless they prove the contrary. ${ }^{3}$

The diversity in schools of law is not the only factor that contributes to the composite character of contemporary Pakistani Muslim personal law. At its Partition from India in 1947, Pakistan inherited a legal system which was partly based on English common law and partly based on Anglo-Mohammedan law, a hybrid of Shari' $a$ law which was 'heavily influenced by English principles of law, with rules borrowed from a number of foreign legal systems' and local customs. ${ }^{4}$ The Anglo-Mohammedan law could most notably be found in the area of family and inheritance law. However, the aim to strengthen the identity of Pakistan as a homeland for South-Asian Muslims urged a desire to Islamize the entire legal system by 'attempts to cleanse' the Anglo-Mohammedan legal system of unacceptable colonial, customary, and Hindu elements. ${ }^{5}$ Such attempts of Islamization can already be discovered in the area of family law under the former colonial regime in India: the Dissol-

1 The West Pakistan Muslim Personal Law (Shari'at) Application Act 1962; this act has repealed its predecessor the Muslim Personal Law (Shari'at) Application Act of 1937 and provincial legislation on the application of Muslim personal law to Muslims (An-Na'im 2002, p. 232). The Muslim Personal Law (Shari'at) Application Act of 1937 had already been enacted by the British government in order 'to do away with customary laws which regulated the 'private' lives of Muslims' and which were found to be conflicting with Islamic law (see Jahangir 1998, p. 93).

2 Within the Sunni majority in Pakistan, two sects are mainly represented: the Barelwis and the Deobandis; within the Shia minority sizeable Ja'fari and Isma'ili groups can be found in Pakistan, see An-Na'im 2002, p. 230.

3 The Islamic religious movement of Ahmadiyya and its adherents, the Ahmadis, are left out of discussion in this chapter. Although the largest group of Ahmadis in the world lives in Pakistan (estimated 2-5 million), Pakistan has officially declared them to be non-Muslims, because they do not believe in the finality of the Prophet Muhammad. (The exercise of) their freedom of religion and their civil rights in Pakistan have been severely curtailed by ordinances, acts, and constitutional amendments, and they are persecuted and the target of frequent attacks by other religious groups. Lau 2010, p. 396-397, 420, 422.

4 Menski 2006, p. 369.

5 Menski 2006, p. 365. 
ution of Muslim Marriages Act of 1939 (hereinafter called DMMA), ${ }^{6}$ which expanded the classical Hanafi grounds for divorce by women to nine, was meant to prevent Hanafi Muslim wives from converting to another religion in order to get a divorce. The Act, which is still in force in Pakistan, thus also represents a reform of divorce law through the use of takhayyur by adopting divorce grounds from Maliki origin. The first Pakistani reformist legal developments, which were at the same time rather moderate attempts of Islamization, also focused on family law: the Muslim Family Laws Ordinance of 1961 (hereinafter called MFLO) ${ }^{8}$ was aimed at social reform and the amelioration of the position of women, among other things through restricting the unilateral power of the husband regarding repudiation, protecting the wife against instantaneous, oral divorce by making all forms of divorce revocable and enlarging the limited rights of women to divorce. ${ }^{9}$ But the law also has lacunas as it does not grant women substantive rights such as the right to maintenance. ${ }^{10}$ Judicial activism also plays a major role in reforming family law. Through the method of ijthihad, a new form of dissolution at the demand of the wife, the judicial $k h u l '$, has been created. ${ }^{11}$ The acceleration of the Islamization of the law in the 1970s was especially detrimental for the rights of women. One of its results, the Offence of Zina (Enforcement of Hudood) Ordinance of 1979 (Ordinance no. VII of 9 February 1979) which introduced severe penalties for committing adultery or fornication had a rather

6 Act VIII of 1939, in force on 17 March 1939. Nowadays, the DMMA still applies to Muslim women in Pakistan, Bangladesh, and India, whether they are Sunni or Shia. The promulgation of the DMMA has been of utmost importance for Muslim women's right to divorce since they had no legal right to divorce as customary practice blocked the access to the khul' (Sardar Ali \& Naz 1998, p. 108). In 1961 section 13 MFLO amended the DMMA by adding the ground of the husband's failure to follow the legal procedure for a polygamous marriage as stated in section 6 MFLO; this ground was abolished in 1981 under the Federal Laws (Revision and Declaration) Ordinance (XXVII of 1981).

7 See for an interesting, detailed report on the immediate cause for the promulgation of the DMMA: Carroll 2008, p. 194-195.

8 Act VIII of 1961, in force on 15 July 1961. The Act addresses all Pakistani Muslim citizens and thus has intra- and extraterritorial jurisdiction (section 1 (2) MFLO). The MFLO does not follow any school of law in particular. Although the Ordinance extends to the whole of Pakistan it is not enforced in the Tribal Areas (Sardar Ali \& Arif 1998, p. 51). Ever since its promulgation (parts of) the Act has survived several attacks for being repugnant to Islam and thus being invalid. See e.g. Aziz Khan v. Muhammad Zarif PLD 1982 FSC 156 in which case the Federal Sharia Court held that 'it was barred from examining the Muslim Family Laws Ordinance 1961 on the basis of Islam' as Art. 203-B of the Constitution contains a jurisdictional bar on matters relating to Muslim personal law; see also Allah Rakha v. Federation of Pakistan (PLD 2000 FSC 1) in which case the Federal Sharia Court held that the notice requirement in section 7 MFLO is not un-Islamic; see for more details: Pearl 1987 p. 113-114; Lau 2006, p. 155-160; Menski 2006, p. 374-379.

9 See sections 7 and 8 MFLO.

10 In the CEDAW Shadow report on Pakistan, submitted on 15 February 2007, it is observed that 'family laws are silent on the rights of divorced women' (available at <www.iwraw-ap.org/resources/pdf/Pakistan\%20SR\% 20(NCJP).pdf $>$. Although the sections 9 and 10 MFLO and section 5 DMMA (and section 5 FCA, but is a procedural law) indeed are dedicated to maintenance and/or dower and the jurisdictions of the Family Court regarding these matters, these matters have not been clearly formulated as rights of women.

11 See Mst. Balqis Fatima v. Najm-ul-Ikram Qureshi, PLD 1959 Lahore 566; Khursid Bib v. Muhammad Amin, PLD 1967 Supreme Court 97. For more details see Carroll 1996, p. 91-126. 
nasty side effect. Remarried women were charged of zina by the Public Prosecutor after a claim of their ex-husband that there had never been a divorce, since there had been no notification of the repudiation as prescribed in section 7(1) MFLO. The judiciary reacted to this abuse by recognizing repudiations as valid even without compliance with the mandatory notification procedure. ${ }^{12}$ However, this reaction of weakening the obligatory character of the mandatory notification procedure can be seen as undermining the MFLO. The Protection of Women (Criminal Laws Amendment) Act of 2006 (Act VI of 1 December 2006) was the legislative reaction as it amended the Zina Ordinance of 1979 among others by redefining zina by omitting the word 'validly' into 'A man and a woman are said to commit "Zina" if they wilfully have sexual intercourse without being married to each other' (section 5); thus the redefinition prevented a possible accusation of zina of the remarried women in the above mentioned situation if the wife could convince the court that she had good reasons to believe that her previous divorce and her subsequent marriage were valid. Lau refers to an analysis of recent case law that demonstrated that section 7 MFLO is upheld in purely family, not criminal law cases. ${ }^{13}$

The process of Islamization was decelerated because of the emergence and increase of Islamic extremism particularly in the larger cities in the 1990s.

In accordance with the West Pakistan Family Courts Act 1964 (hereinafter called FCA), ${ }^{14}$ the Family Courts have 'exclusive' jurisdiction over matters related to, for example, the dissolution of marriage, dower, maintenance, custody of children and visitation rights of parents to meet them, guardianship, and personal property and belongings of a wife. This Act has been amended by the Family Courts (Amendment) Ordinance 2002 in order to expedite divorce proceedings by combining multiple claims in one suit and setting a time limit of 6 months for all types of family suits. ${ }^{15}$ Appellate jurisdiction lies with the superior courts, the High Courts, and next the Supreme Court. ${ }^{16}$ However, the parallel Shari'at judicial system, i.e. the Federal Shariat Court and the Supreme Court Shariat Appellate Bench, also strongly affects matters related to divorce by its rulings.

Contemporary Pakistani Islamic divorce law is thus the composite of classical Shari' $a$ divorce laws of different origins, amended by reformist statutes and case law and moulded in a Common Law framework. A substantial portion remained un-codified and is thus subject to interpretation by the courts.

12 Examples are the case of Noor Khan v. Haq Nawaz 1982 FSC 265 (Pearl 1987, p. 112-113); and the case of Bashiran v. Mohammad Hussain PLD 1988 SC 186 (SardarAli and Naz 1998, p. 126-127).

13 See for more details Lau 2005-2006, p. 452-456 and p. 471-472; Lau 2010, p. 416.

14 See section 5 West Pakistan Family Courts Act 1964, Act XXXV of 18 July 1964.

15 For example to complete a case concerning a claim for divorce and a claim for maintenance within six months; Family Court amendment Ordinance, LV of 2002; implementation of the Family Court Act is facilitated through the West Pakistan Family Court Rules of 1965; Lau 2005-2006, 12, p. 463.

16 See Art. 185 resp. 199 Constitution. 


\section{ISLAMIC DIVORCES IN EUROPE}

Pakistan has been rather slow in undertaking international human rights obligations in comparison to other Islamic states. In the meanwhile, Pakistan has ratified treaties and conventions such as the International Covenant on Economic, Social and Cultural Rights (hereinafter ICESCR) in 2008, the International Convention on Civil and Political Rights (hereinafter ICCPR) in 2010, the Convention on the Rights of the Child (hereinafter CRC) in 1990, and the Convention against Elimination of All Forms of Discrimination against Women (hereinafter the Women's Convention) in 1996. ${ }^{17}$ Pakistan has not yet acceded to the Optional Protocol to the Women's Convention despite repeated calls upon the State party from the CEDAW Committee and NGO's. ${ }^{18}$ Apart from a general declaration that subjects the accession of Pakistan to the provisions of the Constitution of the Islamic republic of Pakistan, Pakistan also entered a reservation in respect of Article 29 (1) of the Women's Convention upon its accession.

\subsection{Divorce}

Pakistani divorce laws and practices encompass the following modalities for the dissolution of marriage apart from dissolution due to the death of either spouse:

- divorce on the initiative of the husband, the repudiation (talaq),

- divorce on the initiative of the wife:

- the judicial annulment (faskh)

- the judicial khul

- various modalities of divorce based on agreement between or that require the involvement of both spouses being:

- the assignment of the power to repudiate to the wife, the self-repudiation (talaq altafwid),

- the negotiated repudiation $(\mathrm{khul})$, and

- the repudiation by agreement (mubara'a).

17 Date of ratification ICESCR and ICCPR respectively: 17 April 2008 and 23 June 2010; date of ratification CRC: 12 November 1990; date of accession to Women's Convention: 12 March 1996; see for an overview of the status of these treaties and possible declarations and/or reservations: $<\mathrm{http} / /$ treaties.un.org/Pages/Treaties.aspx?id=4\&subid=A\&lang=en $>$.

18 As at 10 March 2014, see <https://treaties.un.org/Pages/ViewDetails.aspx?src=TREATY\&mtdsg_no=IV-8$\mathrm{b} \&$ chapter $=4 \&$ lang $=\mathrm{en}>$. The CEDAW Committee made the last call to accede to the Optional Protocol to the Women's Convention in its Concluding observations (CEDAW/C/PAK/CO/4) on the occasion of its considerations of the fourth report of Pakistan (CEDAW/C/PAK/4 at its 1101th and 1102nd meetings on 12 February 2013 (CEDAW/C/SR.1101 and 1102), paras. 9,10 and 39. Another call has been formulated by, for example, the NGO Shirkat Gah in its shadow report of 25 January 2013. 
In order 'to prevent the hasty dissolutions of marriage by repudiation (talaq) pronounced by the husband unilaterally, ${ }^{19}$ section 7 MFLO subjects the repudiation by the husband to procedural restraints such as a mandatory, immediate notice in writing which must be submitted to the Chairman of the Union Council. ${ }^{20} \mathrm{~A}$ copy thereof must be submitted to the wife and there must be an attempt at reconciliation. ${ }^{21}$ If the reconciliation fails and/or the husband does not revoke the repudiation, it takes effect after 90 days from the day of notification. But the Pakistani courts have had to consider the operation and implications of Section 7 MFLO - especially regarding the mandatory nature of its requirements and its Islamic nature - on many occasions. ${ }^{22}$ Assessment of Pakistan's case law reveals that the notice requirements and the arbitration requirement eventually appear not to be mandatory but optional and desirable. ${ }^{23}$ The non-compliance with the notice requirement results in principle in the legal invalidity of the repudiation..$^{24}$ But the non-compliance with the notice requirement does not entail the total non-validity of the repudiation as the repudiation will be valid in any case and effective under Shari' $a$ law 'either at once or after the 90 days stipulated by the MFLO'. ${ }^{25}$ Non-compliance with the notice requirement is punishable by a prison sentence of up to one year or a fine at worst. ${ }^{26}$ One of the objectives of the MFLO, to protect women against instantaneous, oral divorce by making all forms

19 According to Judge S.A. Rahman in a leading case on the implications of the MFLO: Syed Ali Nawaz Gardezi v. Lt.Col. Muhammad Yusuf 1963 PLD SC 51, p. 75.

20 Warraich \& Balchin (1998, p. 185) mention that since the Chairmen are often locals, not well educated and/or legally trained, they may be guided by customary practice rather than by statutory law.

21 Non-compliance with this provision will be punishable with imprisonment or a fine (section 7(2) MFLO); section 7(4) MFLO.

22 See Pearl \& Menski 1998, p. 338-373. Regarding the issue of the notice requirement, two cases before the Pakistani Supreme Court are significant: in Syed Ali Nawaz Gardezi v. Lt. Col. Muhammad Yusuf(1963 PLD SC 51) the Supreme Court held that the notice to the Chairman is mandatory and that a failure of notice has to be understood as a revocation of the talaq by the husband. However, in Mst. Kaneez Fatima v. Wali Muhammad (PLD 1993 SC 901. p. 915-916) the Supreme Court held that 'failure to send notice of talaq to the Chairman of the Union Council does not by itself lead to the conclusion that talaq has been revoked. It may only be ineffective but not revoked'.

Case law also deals with other uncertainties regarding section 7 MFLO, e.g. the questions for the mode of pronouncement of the repudiation (which influences the nature of the repudiation), for the form of notification, for which a notification has to be sent to the Union Council, for the exact time period within which the notification has to be sent, and, in the case the wife has initiated the divorce, who has to send the notification to the Union Council, the wife or the court.

23 Pearl and Menski 1998, p. 372-373.

24 Lau 2010, p. 416.

25 Pearl and Menski (1998, p. 372) refer to the landmark case of Kaneez Fatima v. Wali Muhammad, PLD 1993 SC 901.

26 But reality proves that punishments are rarely imposed. Lau 2010, p. 416. 
of divorce revocable pursuant to section 7(3) MFLO was undermined when, in 1996, the court held that a verbal, triple repudiation was irrevocable and thus immediately effective. ${ }^{27}$

\subsubsection{Divorce on the Initiative of the Wife}

The judicial annulment or faskh is the least accessed form of marriage dissolution by women, notwithstanding the advantage of retaining her financial rights, because of an inordinate delay in litigation, stringent evidence requirements, and the lesser social acceptance of invoking judicial interference. ${ }^{28}$ In general, women prefer the judicial $\mathrm{khul}^{\mathrm{c}}$ as an alternative remedy as it may be rather difficult to obtain a judicial annulment under the DMMA. Article 2 of the DMMA stipulates the following grounds for the dissolution of marriage: ${ }^{29}$ absence of the husband for at least four years, his negligence or failure to maintain the wife for at least two years, ${ }^{30}$ his imprisonment for at least seven years, his failure to perform marital duties without reasonable cause for at least three years, his continuing impotence, his insanity for at least two years or leprosy or venereal disease, his bad treatment of the wife, ${ }^{31}$ the option of puberty, ${ }^{32}$ and any other ground which is recognized as valid for the dissolution of marriage under Muslim law. Pursuant to section 8 MFLO and section 21 FCA, section 7 MFLO also applies to the fask $h$, except for the option of puberty, referred to above. ${ }^{33}$ The Pakistani judicial divorce is thus revocable as it is effective 90 days after receipt of the Court's decree of dissolution by the Union's Council. The wife may revoke the judicial divorce within this 90 -day period. ${ }^{34}$

As it was stated above, women in general prefer the judicial $\mathrm{khul}^{\mathrm{c}}$ as an alternative remedy instead of a judicial annulment. In Pakistan two varieties of $k h u l^{\prime}$ occur: the tradi-

27 Zubeida Khatoon 1996 MLD 1689.

28 Therefore lawyers even discourage women from filing a petition for divorce purely under the DMMA; see Warraich \& Balchin 1998, p. 199-200.

29 Another ground for divorce which was an amendment of the DMMA by section 13 MFLO, i.e. taking an additional wife in contravention of the provisions of the MFLO has been omitted under the Federal Laws (Revision and Declaration) Ordinance (XXVII of 1981) in 1981.

30 The ground of failure to provide for maintenance is the most commonly used ground of the DMMA.

31 Art. 2 subsection viii specifies cruelty as: habitually assaulting the wife or making her life miserable amounting to mental or physical ill-treatment; association with women of ill repute; attempting to force the wife to lead an immoral life; disposal of the wife's property; obstructing her in the observance of her religious profession or practice; if having more than one wife, not treating her equitably in accordance with the injunctions of the Koran.

32 The option of puberty offers the wife who was married by her father or guardian before the age of 16 (and her husband) the opportunity to repudiate her marriage before the age of 18 as long as the marriage has not been consummated.

33 It is unclear whether the remarks on the optional notice requirements and arbitration in the text on repudiation above, which apply to (extrajudicial) repudiation-based divorces according to case-law, also apply to the judicial annulment and the judicial khul'. In the latter cases, not only section 8, but also section 21 FCA expressly state the notification and arbitration requirements.

34 Women Living Under Muslim Laws 2006, p. 284. 
tional, extra-judicial form by agreement of the spouses and initiated by the wife, which is discussed below, and the judicial form as a result of judicial activism. In two reformist judgments the High and the Supreme Court respectively held that the wife may be entitled to the khul' decreed by the court without the consent of her husband under three conditions: ${ }^{35}$ the refusal of consent to an extra-judicial khul' of the husband; the determination of the wife to have her marriage dissolved by renouncing and returning to the husband the dower, mahr, and/or other (financial) benefits received from him during the marriage; the conviction of the judge 'that the limits of God will not be observed', in other words that the couple cannot live a harmonious marital life as envisaged by Islam, if the marriage is not dissolved. ${ }^{36}$

It is not obvious that the judicial $\mathrm{khul}^{\text {' }}$ must be considered as a 'charter granted to the wife ${ }^{37}$ Munir contends that 'the majority of women avoid going to court for $k h u l^{\prime}{ }^{\prime}{ }^{3}{ }^{38}$ But Lau reports that the high number of reported $k h u l l^{\prime}$ cases in case law is noticeable. ${ }^{39}$ This 'charter' has its drawbacks. It appears that judicial $k h u l$ ' is usually pleaded as an alternative remedy should the wife not be able to prove one or more of the grounds for divorce (annulment) under the DMMA. ${ }^{40}$ Two harmful types of decisions, particularly by the lower courts, can be consequently distinguished in case law. Either the judicial khul' (and the divorce) was not granted since the woman was not entitled to it because of her failure to establish one or more grounds for the divorce; ${ }^{41}$ either the judicial $\mathrm{khul}^{\text {' }}$ was granted and the wife had to renounce her financial rights, although she should have been entitled to divorce under one or more of the grounds of the DMMA. ${ }^{42}$ High(-er) Courts have not always been able to correct these decisions which are detrimental to women. ${ }^{43}$ The liability

35 Mst. Balqis Fatima v. Najm-ul-Ikram Qureshi, PLD 1959 Lahore 566; Khursid Bibv. Muhammad Amin, PLD 1967 Supreme Court 97. In these cases the courts have relied upon the Quranic verses Q. 2:228, Q. 2:229, and Q. 4:35, and upon the Jamila hadith and have thus made use of ijtihad. See Carroll 1996, especially p. 102-110.

36 PLD 1959 Lahore 566, p. 593; PLD 1967 Supreme Court 97, p. 121.

37 Characterization of the Quranic verse regarding khul ' Q.2:229 in: Mst. Kurshid Bibi v. Muhammad Amin, PLD 1967 Supreme Court 97, 117-118.

38 Women would have been influenced by views of $m u f t i s$ (experts in Islamic law that are qualified to give legal

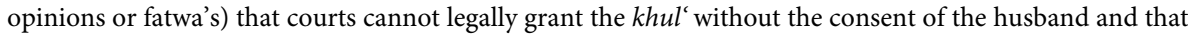
the judicial $\mathrm{khul}^{\prime}$ therefore result in an invalid dissolution, see Munir 2005-2006, note 70 on p. 246-247.

39 Lau 2005-2006, p. 464.

40 Carroll 1996, p. 113-119; Sardar Ali \& Naz 1998, p. 130.

41 See e.g., Bashiran Bibi v. Bashir Ahmad, PLD 1987 Lahore 375. But in Shahid Javed v. Sabba Jabeen (1991 CLC 805) the court stresses the right of $\mathrm{khul}^{\prime}$ as an independent right to the wife. The mere fact that she is not able to establish any ground for divorce, does not prejudice the right of the wife to khul'.

42 See e.g. Abdul Majid v. Rizia Bibi, PLD 1975 Lahore 766; Bibi Anwar Khatoon v. Gulab Shah, PLD 1988 Karachi 602. Sardar Ali \& Naz (1998, p. 130) confirm this trend of the courts of using invoked and proved grounds for divorce as material elements for granting the khul:

43 On the contrary, see e.g. Mst Hakimzadi v. Nawaz Ali, PLD 1972 Karachi 540 in which case the Karachi

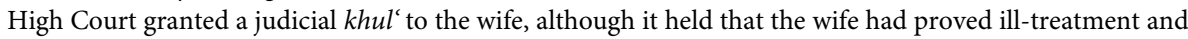
false accusation of adultery, both of which are grounds for divorce. See also the Lahore High Court in Abdul Majid and the Karachi High Court in Bibi Anwar Khatoon. But see the opposite in Farida Khanum v. Maqbul 
of the wife for compensation to the husband can be seen as a drawback as it deteriorates the generally weak financial position of divorced women. ${ }^{44}$ Compensation has been the issue in many lawsuits and the Karachi High Court has clarified the significance of its requirement for the judicial $\mathrm{khul}^{\text {' }}$ as follows: in the case of a dispute over the return of the dower, the court has to dissolve the marriage once it comes to the conclusion 'that the parties could not remain within the limits of God'; the settlement of the dispute over the dower 'would only create civil liabilities upon the wife and would not have any effect upon the dissolution itself. ${ }^{45}$ In another case the Court confirms that other benefits than the dower do not have to be returned to the husband as compensation. ${ }^{46}$

\subsubsection{Divorce through Involvement of Both Spouses}

The first type of divorce in Pakistani law that requires the involvement or agreement of both spouses is the talaq al-tafwid, the authorization of the right to the repudiation to the wife by the husband (the self-repudiation). The spouses can agree on the right of selfrepudiation by ticking the box of clause 18 in the standard form of the marriage contract or they can later agree on it in a contract drawn up at any time during the marriage. Although section 8 MFLO refers to the self-repudiation, its application appears to be extremely rare. ${ }^{47}$ In addition to the fact that couples in rural areas often do not formally register their marriages, most Pakistani's are ignorant about the existence of the selfrepudiation. Some Nikah registrars ${ }^{48}$ appear to favour this procedure, while many of them do not encourage it and even impede incorporating the stipulation of talaq al-tafwid by specifying this in Clause 18 in the marriage contract, the nikahnama, because they are against this concept or deem it 'haram', prohibited, or un-Islamic, or against social order. Sometimes even the wording of Clause 18 is 'faulty largely due to misperceptions' as it is stated 'in the form of $\mathrm{khul}^{\mathrm{c}} .^{9} \mathrm{The}$ misperception is that the wife can only initiate a divorce

Ilahi 1991 MLD 1531 in which the High Court held that the wife did not have to renounce her financial rights since several grounds for divorce had been proved and accepted.

44 Shari'a law does not provide for alimony, at least not after the waiting period, the 'idda, nor is familiar with the concept of matrimonial property.

45 Aurangzeb v. Gulnaz PLD 2006 Karachi 563, p. 567. See for an earlier, similar decision: Caroline Rehman v. Chairman Union Council 1985 MLD 2486.

46 Abdul Sattar v. Kalsoom PLD 2006 Karachi 272. The court thus mitigates the second requirement to the judicial khul: Although in the Balqis Fatima case the Lahore High Court held that benefits received by the husband may be taken into account when determining the compensation to be paid by the wife, the courts have in general ignored this statement which favours the wife's financial position.

47 Based on a random sample survey carried out by M. Munir who concluded that 'overall the percentage of delegation in Pakistan is less than one'; see for further details: Munir 2005-2006, p. 248-254.

48 The Nikah registrar, who is licensed by the Union Council pursuant to section 5 subsection 2 MFLO, has been authorized to solemnize and register marriages.

49 Warraich \& Balchin 1998, p. 197. 
in the form of a negotiated repudiation $(k h u l)$. Finally, the few couples that have included this stipulation often belong to the highly educated (often abroad) elite, living in the wealthy urban areas. Remarkably, most of these stipulations were unconditional, 'whereas Islam recommends conditional stipulations'. ${ }^{50}$ The unconditional self-repudiation stipulation, however, equalizes the access to divorce by the spouses. But these stipulations, either conditional or unconditional, are in any case of the utmost importance as they may prevent a husband from abusing his authority or shirking his responsibilities towards his wife and/or family.

Section 8 MFLO declares the provisions of section 7 MFLO to apply mutatis mutandis to the self-repudiation talaq al-tafwid, and to modalities of divorce such as the negotiated repudiation, $k h u l$; t the repudiation by agreement, mubara'a; and also the judicial annulment, faskh. Consequently, the abovementioned remarks on the optional notice requirements and arbitration may also apply to these forms of dissolution.

The two other types of extrajudicial dissolution of marriage by mutual agreement in Pakistan are the negotiated repudiation, $k h u l$ ' and the repudiation by agreement, mubara'a. In Ghulam Sakina v. Umar Baksh the court has clarified the distinction between the negotiated repudiation, $\mathrm{khul}^{\prime}$ and the repudiation by agreement, mubara'a. It is a khul when the wife has an aversion towards her husband and initiates the dissolution, but when the aversion is mutual and the initiative has been taken by both the husband and wife, it is a mubara' $a^{51}$ The $k h u l^{\prime}$ form also requires a payment of compensation, the $z a r-i-k h u l$ ', by the wife for her release. It appears in practice that the mubara' $a$ is rarely accessed. ${ }^{52}$

\subsection{After Divorce}

It was already mentioned above that one of the important objectives of the MFLO was to protect women against instantaneous, oral divorce by making all forms of divorce revocable during the 90 -days waiting period of the wife.$^{53}$ However, there are exceptions to this rule. The (judicial or non-judicial) khul' cannot be revoked by the husband; it can only be revoked by the wife. ${ }^{54}$ The mubara'a is also irrevocable for the husband. ${ }^{55}$ Furthermore, the judicial annulment on the ground of option of puberty is not revocable; the wife can

50 Especially the Shi' $a$ school, but the survey by Munir revealed 'that in more than $1 \%$ of marriage contracts husbands have delegated the right of divorce to their wives unconditionally', see Munir 2005-2006, p. 244, 251 and 252.

51 Ghulam Sakina v. Umar Baksh PLD 1964 SC 456.

52 WLUML 2006, p. 252.

53 Arts. 7 and 8 MFLO.

54 WLUML 2006, p. 276.

55 Fyzee 2002, p. 166; Princess Aiysha Yasmin Abbasi v. Maqbool Hussain Qureshi, PLD 1979 Lahore 241; Ghulam Fatima v. Abdul Qayyum, PLD 1981 SC 460.; but see WLUML 2006, p. 253 where it is stated that 'S. 8 does not clearly spell out who has the authority to revoke a mubarat [...]', the husband or both spouses? 
revoke the judicial annulment on one of the other grounds within the 90 -days period. The wife can also revoke the self-repudiation within 90 days after she has notified the Union Council. However, practice shows that local authorities may differ in their treatment of such revocations, either because of their ignorance of this type of divorce, or because of their disapproval of the possibility of delegated repudiation by women. ${ }^{56}$ The wife is entitled to the same post-divorce provisions after a self-repudiation as in the case of a unilateral repudiation by the husband.

\subsubsection{Waiting Period}

The repudiated or divorced wife is required to observe a waiting period of 90 days from the date of notification of the repudiation to the Union Council or the Union Council's receipt of the court decree of the dissolution of marriage pursuant to section 7(3) MFLO. ${ }^{57}$ Her waiting period in the case of a pregnancy lasts until the delivery of the child (the foetus in the case of abortion of the pregnancy, but at least always 90 days) pursuant to section 7(5) MFLO. However, the contradictions and drawbacks arising out of the existence of parallel legal systems were well illustrated in the cases Allahdad v. Mukhtar and Allah Rakha v. Federation of Pakistan. ${ }^{58}$ In this case the Appellate Bench held that the period of the waiting period could be much shorter than the prescribed 90 days in order to protect a woman who faced the charge of zina. The judgment was strongly criticized by, inter alia, women's rights organizations because it set a precedent for shortening the waiting period that is meant to protect a wife from an instantaneous and arbitrary divorce. ${ }^{59}$ The shortening of the waiting period could also have negative results for (suits for) maintenance because it would shorten the period of payment of maintenance. In order to avoid such contradictions and negative results the CEDAW called upon Pakistan 'to take measures to establish a unified judicial system, to eliminate all parallel legal systems [...]' in its Concluding observations on the fourth periodic report of Pakistan in March $2013 .^{60}$

\subsubsection{Maintenance}

The divorced wife can claim her maintenance, or nafaqa, for the waiting period in two ways. First, she can apply to the Union Council for a grant of a maintenance certificate

56 WLUML 2006, p. 268.

57 Mohammad Hussain Patel 2003, p. 106.

58 Allahdad v. Mukhtar 1992 SCMR 1273; Allah Rakha v. Federation of Pakistan, PLD, 2000, FSCI.

59 Balchin 1994, p. 86-87; Naz and Zia 2012, p. 3.

60 Concluding observations (CEDAW/C/PAK/CO/4) on the occasion of its considerations of the fourth report of Pakistan (CEDAW/C/PAK/4 at its 1101th and 1102nd meetings on 12 February 2013 (CEDAW/C/SR.1101 and 1102), paras. 15 and 16. 
that specifies the amount that is due pursuant to section 9 MFLO. Second, she can file a suit to claim maintenance at the Family Court from the date of pronouncement of the repudiation or her knowledge thereof, or the date of divorce. ${ }^{61}$ The Family Court has exclusive jurisdiction in matters of maintenance pursuant to section 5 in connection with the attached schedule to the FCA. Pursuant to section 17 A FCA the court may pass an interim order. Pearl and Menski refer to fieldwork that shows practices of abuse of entitlement to maintenance during the waiting period. ${ }^{62}$ Men would send their (former) wives to their parental home in order to be maintained by their parents while not informing the wife of the divorce. Or men would send their (former) wives to their parental home and resort to strategies in order to delay or even to prevent law suites for maintenance. Maintenance orders by the Union Council can be revised within 30 days of the order. ${ }^{63}$ Maintenance decrees by the Family Court cannot be appealed if the amount is below a specific amount per month.

Spouses can agree on including a stipulation concerning post-divorce maintenance, maintenance that is paid by the husband to the wife after her waiting period, in their marriage contract. ${ }^{64}$ The Family Court will recognize such a stipulated right upon the dissolution of marriage.

\subsubsection{Dower}

The specified dower and the terms of payment must in principle be stipulated in the marriage contract. ${ }^{65}$ Where a specified dower is not stipulated, section 10 MFLO presumes that the proper dower is due. Furthermore, section 10 MFLO presumes the dower to be prompt where it is not determined whether the dower is prompt or deferred. The husband must pay the prompt dower in full on demand of the wife. In box 20 in the standard marriage contract spouses may include stipulations relating to, inter alia, the dower. The wife may claim the (deferred) dower upon the repudiation, self-repudiation, or judicial annulment either as a separate suit or as part of the dissolution suit at the Family Court. The wife is entitled to the whole (deferred) dower if the marriage was consummated; if the marriage was not consummated, she is entitled to half the dower. ${ }^{66}$ The recovery of the dower by women also appears to be a problematic issue. First, the dower may only be claimed within a time limit of three years; second, Family Court cases are lengthy and expensive and discourage women from claiming the unpaid dower; and third, women

61 Mahmood 2010, p. 179; Pearl \& Menski 1998, p. 203

62 Pearl \& Menski 1998, p. 205.

63 WLUML 2006, p. 223.

64 WLUML 2006, p. 327

65 WLUML 2006, p. 183.

66 Fyzee 2002, p. 186. 


\section{ISLAMIC DivorCES IN EUROPE}

often use the dower as a bargaining tool to get the custody of their children. ${ }^{67}$ Although Pakistani women may file a separate suit for division of the marital property with the Civil Court, they are often discouraged because of the costs and lengthy proceedings, and the fact that such a division is not socially accepted. ${ }^{68}$

\subsubsection{Remuneration}

The remuneration or $m^{\prime} t^{\prime} a$ is not recognized under Pakistani law. ${ }^{69}$

\subsubsection{Provisions for Children}

The Guardians and Wards Act 1890 that governs the issues of guardianship and custody of children stipulates that the personal law of the child involved must guide the courts. ${ }^{70}$ The personal law of the child is supposed to be the personal law of the father. For Muslims, the mother has custody until the age of seven years for boys and until puberty for girls in accordance with the Hanafi school of jurisprudence. ${ }^{71}$ If the mother (or other custodian) remarries, she will lose the custody to the father. The father is in principle guardian of the children; in his absence the mother becomes their guardian. The Family Court is competent in matters of custody and guardianship, maintenance for children, and visitation rights of the non-custodial parent. If the Family Court has to decide upon custody or guardian matters, it will act in consideration of the best interests of the child and may therefore deviate from the Hanafi (or other Islamic) law rules. ${ }^{72} \mathrm{~A}$ female child is entitled to maintenance by her father until her marriage; a male child until the age of puberty. ${ }^{73}$

\subsection{Assessment}

Pakistan stresses the importance of gender equality in its legislations, but the husband's option of repudiation is not equally accessible to women. ${ }^{74}$ Pakistani women have, theor-

67 WLUML 2006, p. 314-315, p. 327-328.

68 WLUML 2006, p. 317 and 327.

69 WLUML 2006, p. 321.

70 An-Na'im 2002, p. 235.

71 Pearl \& Menski 1998, p. 411, 413.

72 Pearl \& Menski 1998, p. 418; WLUML 2006, p. 345.

73 Pearl \& Menski 1998, p. 430.

74 The Pakistani Constitution dedicates various articles to the principle of equality and non-discrimination, such as Art. 25 that establishes equality of all citizens before the law, and non- discrimination on the basis of sex. The Constitution of the Islamic Republic of Pakistan was approved by the legislative assembly on 10 April 1973 and ratified on 14 August 1973. The Constitution cannot be changed; for this reason 20 amendments have been added over time. It declares Islam to be the state religion of Pakistan (Art. 2 Consti- 
etically speaking, access to: the self-repudiation, talaq-al-tafwid; the repudiation by agreement, mubara'a; the traditional khul'; the judicial khul'; and the judicial annulment (faskh). The former three procedures are only options insofar as the husband cooperates and if the wife renounces her financial rights in the case of the traditional and judicial $k_{h u l}$. The latter is practically less feasible because of financial, evidential, and social obstacles. The wife's main tool for divorce seems to be the judicial khul', but she has no absolute or 'independent' right to it because of (1) the control on the irretrievableness of the marriage by the court ('conviction of the judge') and (2) the financial penalty of the compensation, although it will be fixed by the court, which may constrain her access. The conclusion is that this restricted 'charter' does not equal the repudiation, and that the spouses under Pakistani law, in principle, have no equal right in respect of access to divorce. Equal access can only be realized partially by an unconditional talaq al-tawfid. Practice has shown that its access is strongly restricted by ignorance, social unacceptability, and opposition by authorities.

A distinction has to be made between the extrajudicial and the judicial divorce modalities in respect of the procedural rights of women. In respect of the divorces (and their procedures) that are based on the repudiation (repudiation-based divorces) the wife has poor to no procedural rights. The notification requirement of Section 7 MFLO, if it is applied at all, provides women no other protection than knowledge of the repudiation and the avoidance of an instant and definite divorce. In this respect their position has slightly improved, but the repudiation still remains a type of divorce at the discretion of men, although the latter has been restricted by the administrative requirement of notification.

The judicial $\mathrm{khul}^{\text {' }}$ represents a procedure under supervision of a judge, in which the wife has the right to be heard in order to enable the judge to decide upon the granting or not of the khul ${ }^{\text {l }}$ and upon the compensation. Moreover, there are lesser evidential requirements than in case of a judicial annulment based on one of the narrow-defined grounds. Faskh implies an adversarial procedure under the supervision of the judge, but the enforcement of the wife's procedural and substantive rights is complicated by longlasting and thus expensive procedures, stringent evidence requirements, and the lesser social acceptance of invoking judicial interference, notwithstanding the advantage of retaining financial post-divorce rights. ${ }^{75}$

tution). It also established the Council of Islamic Ideology that shall make recommendations about laws conforming to the Koran and Sunna to the parliament and the Provincial Assemblies; advise the parliament, government, president, or governor about any question as to whether a proposed law is not repugnant to the injunctions of Islam; and that shall make recommendations to bring current laws in conformity with the injunctions of Islam (Arts. 227-231 Constitution). The Constitution is available via $<$ www.pakistani.org/pakistan/constitution/>

75 See Warraich \& Balchin 1998, p. 199-200, p. 220; and Sardar Ali \& Naz 1998, p. 130. But see also WLUML 2006, p. 290. 
The most serious problems that obstruct women's access to divorce and undermine her rights are the following: first, the non-uniform application of the law because of lacunas in it due to non-codification of specific substantive rights that 'leaves room for interpretations' based on the various sects of Shari ${ }^{\prime} a$ law and custom. ${ }^{76}$ Second, the existence of parallel judicial systems, the Family Courts on the one hand and the Shari' $a$ court system on the other hand, also has serious impacts on the rights of women as the example of the ruling on the waiting period of the wife above demonstrated. Moreover, as a consequence, frequently conflicting interpretations result in unstable case law. Thus women often are in a legal limbo between statutory and Shari' $a$ law, and it is often unclear which set of rules prevails. An example in this respect is the notification requirement for the repudiation under Section 7 MFLO. Its mandatory nature has been affected in case law, paradoxically in order to protect women. The third problem is that the objective of the MFLO to protect women against instantaneous, oral divorce by making all forms of divorce revocable was undermined when the Pakistani courts held that a verbal, triple repudiation was irrevocable and thus immediately effective. Fourth, the judicial practice of granting women a divorce by $k_{h u l}$ ' entailing the wife's liability for compensation instead of annulling the marriage on the ground to which the women were entitled. Fifth, the liability of the wife for financial compensation in the case of $\mathrm{khul}^{\text {, }}$, and the lack of a legal provision that provides women equal rights to property acquired during the marriage, that make them economically vulnerable. Hence, it can be stated that the legislation and judicial system has serious shortcomings and that the judiciary has an ambiguous attitude towards divorce and women's rights. Courts have (played), as demonstrated, a pivotal role in supporting women's rights while they also show a tendency to gender discrimination and a hostile attitude to women.

It can be stated that the status of Pakistani women has evolved to a much lesser extent on the road to equality compared to, for example, the status of Moroccan women. 'Much more needs to be done in achieving gender equality according to CEDAW. ${ }^{, 77}$ The recommendations made in relation to Morocco, such as constitutionalizing the primacy of international law, withdrawing the declaration and reservation, acceding to the Optional Protocol, combating the harmful stereotypes, illiteracy, poverty, facilitating the approach to courts etcetera, are even more relevant for Pakistan. CEDAW's latest recommendations, inter alia, urge Pakistan to revise and repeal discriminatory provisions against women in the DMMA of 1939; to take appropriate measures to ensure that family cases are efficiently handled and heard by all civil courts; to provide systematic trainings to judges, prosecutors, and lawyers on women's rights; and to enact legal rules to ensure that women have equal legal rights to property acquired during the marriage. ${ }^{78}$

76 Warraich \& Balchin 1998, p. 181.

77 M.S. Mahmood, Presentation of Pakistan's combined Periodic Report 2007, p. 16. Concluding observations (CEDAW/C/PAK/CO/4) of 27 March 2013, paras.16, 37-39.

78 Concluding observations (CEDAW/C/PAK/CO/4) of 27 March 2013, paras.16, 37-39. 
Finally, the Pakistani extra-judicial types of divorce can, if section 7 MFLO is observed, be characterized as public acts in which, however, features of the private act dominate. The unilateral and discretionary power of the husband has not further been restricted than by the notification requirement. Without observance of section 7 MFLO, the Pakistani extra-judicial types of divorce are only a private act. The Pakistani judicial divorces

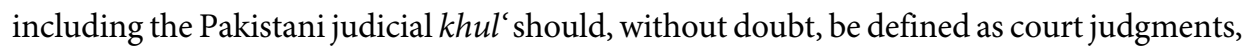
as the judicial decision for the dissolution of the marriage is constitutive for these types of divorce. 



\section{Conclusion: An Unbridgeable INCOMPATIBILITY?}

This overview of the Islamic divorce modalities, illustrated by contemporary Egyptian, Iranian, Moroccan, and Pakistani examples, demonstrates the legal diversity within the divorce laws and practices of Muslim-majority countries. A correct understanding of the specifics of each of these divorce modalities is therefore of great importance as it affects their assessment for recognition within the European legal orders.

Under all the legal systems under review, women do not enjoy (full) equal access to divorce; however, they may partially enjoy equal access where it concerns the common modality of the unconditional delegated repudiation and, only in Morocco, the judicial divorce on the ground of irretrievable breakdown (shiqaq). The inequality in access to divorce can be explained by the fact that it is based on the principle of Islamic divorce laws that provides for individual gender-based divorce grounds for the spouses. Full equality would require the elimination of this Islamic principle.

It is to be considered whether full or a formalistic type of equality should be pursued. It may be a better option to strive for enhancing the position of women by reconciling the respect for the 'otherness' of the foreign law and the respect for fundamental values. This implies a more nuanced and step-by-step approach towards equality. Substantive equality in respect of divorce can be reached if either spouse can effectively obtain a divorce with procedural guarantees and without financial obstacles. The fact that each spouse has his or her own divorce modalities is not per se discriminatory under these circumstances and, therefore, not incompatible with Western standards. Moreover, a step-by-step approach may pave the road to full equality.

In order to achieve such a balanced system of divorce modalities, Muslim-majority countries have to further reform their domestic divorce laws and practices. Morocco is a shining example in this context as the Moroccan legislator has introduced an independent accessible judicial divorce for both spouses next to the other types of divorces: the judicial divorce on the ground of irretrievable breakdown (shiqaq).

Equally, the judicially monitored repudiation-based divorces in Iran and Morocco, the Egyptian judicial $\mathrm{khul}^{\prime}$, and the possibility of an unconditional self-repudiation must be highlighted. As regards unilateral forms of divorce, a distinction should be made between the different modes of repudiation: from the 'bare' repudiation without any procedural guarantees to the repudiation subjected to a notification and registration procedure, as in Pakistan and Egypt respectively, to the repudiation with judicial interference from the outset, as in Iran and Morocco. As far as the repudiation-based divorce encompasses a 
procedure under supervision of a competent authority that guarantees the rights of the wife both in the law and in practice, it should not be considered to be incompatible with European standards. The same holds true for the divorce by agreement of both spouses.

Finally, two issues should be kept in mind. First of all, the repudiation is often the only accessible type of divorce for men in many Muslim-majority countries. Second, it is also possible to obtain a divorce against the will of the other spouse in European legal systems. As long as the law and legal practice provides either spouse with the opportunity to obtain a divorce while guaranteeing the procedural position of the other spouse, there is no unbridgeable incompatibility between Islamic and Western principles regarding divorce. 


\section{PART II \\ Recognition of Islamic Divorces \\ IN EUROPE}



How do European states deal with the 'otherness' of a repudiation-based divorce at present? And why does a European state deal with that 'otherness' in a (that) specific way? The answers to these questions enable answering the main research question: how Europe could deal with the various modalities of Islamic divorce. To that end, one must first understand how Europe - and more specifically European states, since a policy on the supranational level is still lacking - deals with these modalities at present. In order to explore this, this part sets out the recognition policies of three European states, also being EU Member States, i.e. the Netherlands, England, and France, and provides a comparative analysis of their policies. Attention will be paid in particular to the recognition of repudiation-based divorces, because of the alleged violation of the right of equality between the spouses upon divorce, and therefore the violation of the public order of European states.

It should be realized that the question relating to the acceptability of the Islamic divorce modality asks from the various national authorities involved to make a judgment about the status of a person that has already been decided on and arranged abroad. The national authority involved does not need to establish a new status. As stated in the Introduction to this study, the authority involved has to assess the significance for and the effects on domestic law of the status of a person that has already been established abroad. Previous research results have demonstrated that other interests such as social-political interests may influence this assessment and overshadow the role of PIL today, as is shown by the increase in (ab-)use of PIL in migration policies in order to restrict migration to Europe. ${ }^{1}$

What is the framework for the assessment of Islamic divorces that the various authorities of the three European states being researched employ? More specifically: what are the criteria within the assessment frameworks; what is the role of the PIL-public order; and does, and if so to what extent, the recognition policy of a specific EU Member State take into account limping legal relationships as consequence of non-recognition? What is the rationale behind the various recognition policies? Which approach is employed by a specific state?

EU Member States use different approaches towards the recognition of Islamic divorces. Some have adopted an approach in abstracto, others an in concreto approach. In the approach in abstracto, the foreign legal institution is being evaluated as such. In the case of the repudiation or repudiation-based divorce, the unequal access to divorce is often emphasized. As a result, the public policy exception is regularly invoked to reject its

1 See Van den Eeckhout 2002, p. 76, p. 82-84, p. 86-88; Van den Eeckhout 2003, p. 181, p. 186-189; Van den Eeckhout 2012; Van den Eeckhout 2013, p. 266-267, p. 275-278, p. 284-289; Verhellen 2010, p. 152-155; Verhellen 2012, p. 461-463; Wautelet 2009. 
recognition. With the approach in concreto, the legal institution is considered under the circumstances of the individual case. Hence, the repudiation may, in view of all the specific circumstances of the case, be considered to be compatible with the public order and thus will be recognized. These approaches require a solid knowledge of the foreign legal institution at issue, as otherwise the risk of a one-dimensional view is great, leading to misunderstanding and wrongful appreciation of the foreign divorce.

The distinction between an approach in abstracto and an approach in concreto, as well as the distinction court involvement versus non-court involvement, is considered relevant in relation to a recognition policy. However, no explicit attention is paid to the diversity of Islamic divorces in this respect. This leads to the question whether the various recognition policies provide for a fair result considering the characteristics of a specific form of Islamic divorce as well as the perspectives and interests involved, especially those of women.

One could also evaluate the approaches on the basis of the 'openness' of a particular state towards the foreign legal institution. More specifically, the degree of 'openness' would depend on the willingness of a state to acknowledge this legal institution as an integral part of a specific legal culture. The individual recognition policy may then be characterized as 'more open' or 'less open'. The more open the position of the state is, the more the state lives up to the basic principle of PIL of respect for the 'otherness' of the foreign legal institution. ${ }^{2}$ This approach also responds to the demands of the reality of cultural (legal) diversity, the harmonious interaction among groups with plural identity, and the willingness to live together. ${ }^{3}$ As this approach would do more justice to the intrinsic values of PIL and legal diversity, it has been chosen here as the point of departure for the discussion on the recognition policies of England, France, and the Netherlands.

The selected states have in common that their PIL rules distinguish between the recognition of foreign divorces without interference of a competent authority, considered as private acts, on the one hand, and foreign divorces resulting from proceedings with state or judicial interference, considered as public acts and judgments, on the other hand. Judicial divorces in Muslim-majority countries established by a court decision and accessible to women with a guarantee of a fair trial are less problematic and will be recognized more easily. Hence, in the following, attention will especially be paid to recognition policies towards extra-judicial divorces, repudiation-based divorces, and divorces by agreement that are based on repudiation. These types of divorces are considered to violate fundamental rights and public policy.

See Introduction, chapter 1.

See Introduction, chapter 1. 


\section{Context: Migration}

Because of the massive migration of Muslims, national judicial and administrative authorities, as well as other legal professionals such as lawyers within European countries, have been and still are confronted with specific, quite unfamiliar, legal institutions such as the Islamic repudiation. In 2010, between 15 and 20 million Muslims, a number that is expected to double by 2025, were already residing in Europe as residents or citizens, temporarily or permanently. ${ }^{1}$

In general, two waves of migration can be discerned in the period after World War II. The first wave had its peak in the 1960s-1970s. It took place for economic reasons and was often initiated and mediated by the receiving states. ${ }^{2}$ This labour migration wave resulted in secondary migration by means of family reunification. It then became clear that the anticipated temporary stay was evolving into a (more) permanent settlement. ${ }^{3}$ The second wave from the 1960s until the present concerns the (involuntary) migration of refugees or asylum seekers. ${ }^{4}$ Today, Muslims do not only immigrate into Europe, they also migrate

1 Muslims in Europe - A report on 11 EU cities, Open Society Institute, 2010, p. 22, 36-37 available at $<$ www.soros.org/initiatives/home/articles_publications/publications/muslims-europe-20091215/a-muslimseurope-20110214.pdf> and Muslims in the EU - Cities Background Research Reports: France, the Netherlands, United Kingdom, Open Society Institute, EU monitoring and advocacy program 2007, available at $<$ www.soros.org/initiatives/home/articles_publications/publications/muslims-europe-20091215/a-muslimseurope-20110214.pdf> (hereinafter report and countryname). In France: an estimation of 3.5-5 million Muslims representing 6.0-8.5\% of its total population (58.5 million) in 1999, of which 2 million Muslims are French citizens (report France: p. 11-18). In the Netherlands: approximately 1 million Muslims representing $5.8 \%$ of its total population, of which $75 \%$ is of Moroccan or Turkish origin, of which $50 \%$ are Dutch citizen (report the Netherlands: p. 9-13). In Great Britain: approximately 1.6 million Muslims representing $3 \%$ of its total population (57.1 million) in 2001 (based on 2001 Census), of which $50 \%$ were born in the United Kingdom (report United Kingdom, p. 10-15). The text of this chapter was for the greater part taken from and previously published in Kruiniger 2013, p. 470-472.

2 Muslim migrants in France originate from the Maghreb, sub-Saharan Africa, Turkey, and the Middle East (report France, ibidem, p. 6). In the Netherlands, they originate from Morocco and Turkey (report the Netherlands, ibidem, p. 6). Muslim migrants in the United Kingdom originate from South Asia, especially Pakistan (report United Kingdom, ibidem, p. 5).

3 Family reunification refers to the situation in which mostly the wives and children join the male migrants in the country of residence, whereas family formation sees to the situation that migrants marry persons from their country of origin who then move to the country of residence of the migrant.

4 In the Netherlands, there was migration from Suriname around 1975 and there were migrations for political reasons from Bosnia, Somalia, Iran, Iraq, Afghanistan, and Pakistan from the 1990s until the present (report the Netherlands, ibidem, p. 11 ). In France, there was migration by Turks and Turkish Kurds for political reasons from the 1980s (report France, ibidem, p. 17-18). In the United Kingdom, there was migration by East-African Asians because of 'Africanization policies' in Kenya and Tanzania during the late 1960s-early 1970s and because of a forced expulsion from Uganda during the 1960s; but also the 1990 migration for political reasons by Turkish Cypriots, Turks, and Kurds and from 1990 migration for political reasons from Somalia, East Africa, the Middle East, Bosnia, and Iraq (report United Kingdom, ibidem, p. 11-12). Due to the civil war in Libya in 2011, especially the United Kingdom was confronted with an increase of Libyan 


\section{ISLAMIC DivorCES IN EUROPE}

between EU states, whether as citizens or (long-term) residents. ${ }^{5}$ In general, mobility within Europe is a practical reality that is encouraged and facilitated by the EU by the rights attached to EU citizenship, in particular the right of free movement. ${ }^{6}$

Muslim migrants, refugees, and asylum seekers 'import' their personal status, regulated by Islamic law, into Europe. The majority of the labour migrants and their descendants nowadays voluntarily reside in, or even have the nationality of, a European state and live in a 'transnational way'. Many feel more familiar with the legal system of their country of origin and have strong ties with that country. They prefer to settle family affairs in their countries of origin, as they attach great importance to the fact that these affairs be settled according to Islamic law and traditions. Sometimes other motives prevail: whereas some fear to lose parts of their identity, others may have the desire to avoid financial obligations. However, this research does not deal with the motives and the choices of people to settle their divorce in accordance with the legal system of their country of origin. ${ }^{8}$

asylum seekers in the first four months of 2011 (CBS Webmagazine of 29 August 2011 via < www.cbs.nl/nl$\mathrm{NL} / \mathrm{menu} /$ themas/dossiers/allochtonen/publicaties/artikelen/archief/2011/2011-3460-wm.htm>.

5 In 2008, 3,800,000 persons, however not only Muslims, immigrated into the EU of which 1,400,000 persons were citizens of the EU migrating in the EU; $1,800,000$ persons were not citizens of EU states, and 600,000 nationals of an EU member state, see Oblak Flander 2011.

6 Green paper 'Less Bureaucracy for citizens: promoting free movement of public documents and recognition of the effects of civil status records', $\operatorname{COM}(2010) 747$ final, p. 1; Proposal for a Regulation of the European Parliament and of the Council on promoting the free movement of citizens and business by simplifying the acceptance of certain public documents in the European Union and amending Regulation (EU) No. 1024/2012, $\operatorname{COM}(2013) 228$ final, p. 4.

7 This situation refers to transnational migration which is mainly characterized by repeated border crossings during the migrant's lifetime and the entertainment of multiple social, economic, and cultural ties to more than one country at the same time by the migrant because of pluri-directional or circular migration movements; see Farahat 2009, p. 254.

8 See in this respect, for example, the dissertation of Iris Sportel, 'Maybe I'm still his wife; Transnational divorce in Dutch-Moroccan and Dutch-Egyptian families', Wolf Legal Publishers 2014. 


\section{The NetherLands}

The Dutch Supreme Court, Hoge Raad, in the Hague, the Netherlands. Its landmark case of 13 July 2001 has shaped Dutch recognition policy towards repudiation-based divorces.

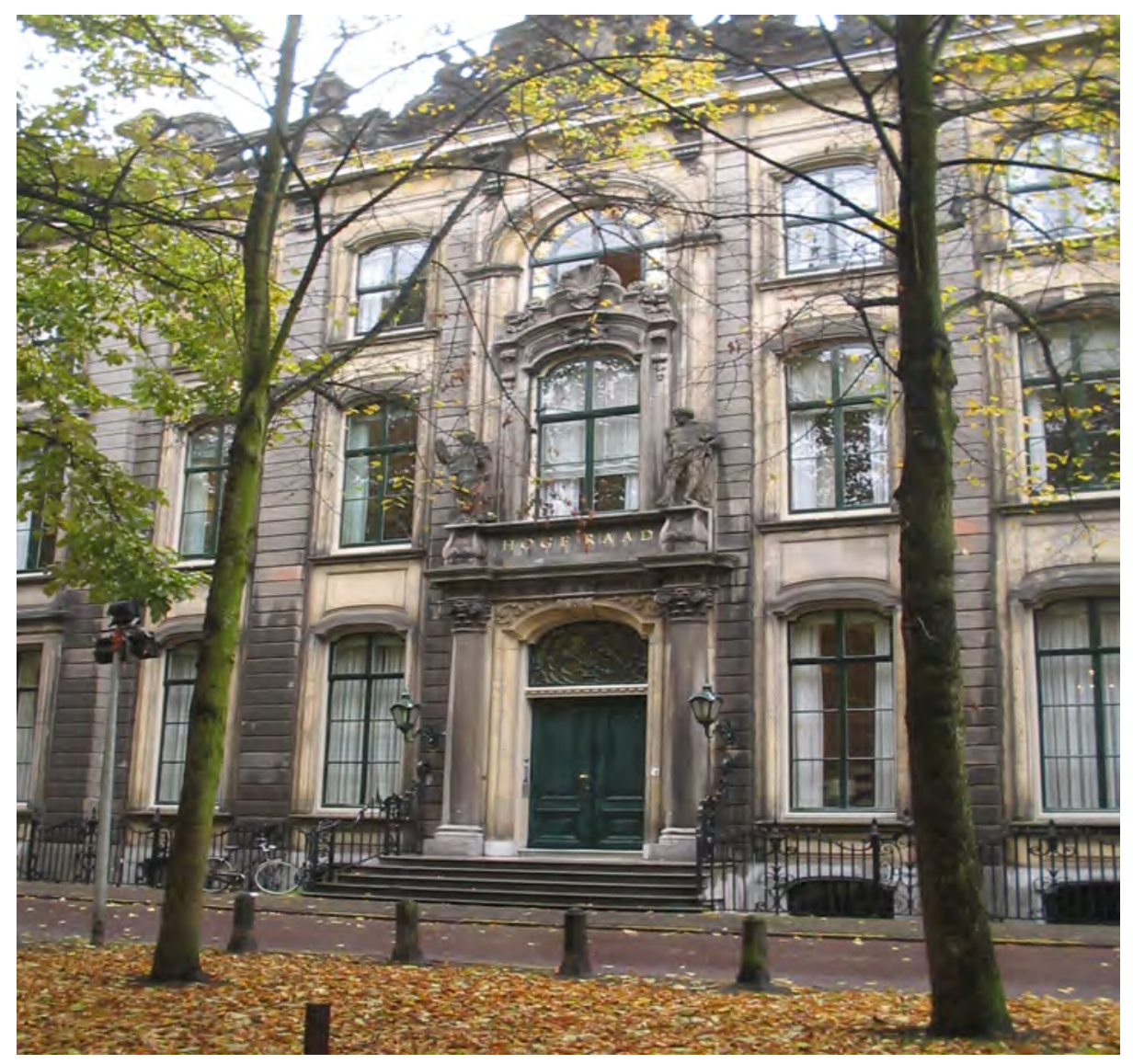

\subsection{General Legal Framework}

Today, mainly two legal instruments govern the recognition of foreign dissolutions of marriage (divorces) in the Netherlands. The recognition of foreign divorces (including legal separations but excluding annulments) that have not been established within the EU 
(hereinafter non-EU divorces) is de facto governed by domestic law, Articles 10:54, 10:57, 10:58, and 10:59 of the Dutch Civil Code (Burgerlijk Wetboek, hereinafter BW) since its date of coming into force on 1 January 2012. ${ }^{1}$ Before this date, Articles 2 and 3 of the National Conflict Rules Governing Divorce Act (Wet Conflictenrecht Echtscheiding, hereinafter WCE) governed the recognition of foreign, non-EU divorces in the Netherlands since $1981 .^{2}$

Articles 21-22, 24-27, and 46 of the supranational legal instrument Brussels II-bis Regulation $^{3}$ govern the recognition of foreign judgments on the dissolution of marriage,

1 Vaststellings-en Invoeringswet Boek 10 Burgerlijk Wetboek, Act of 19 May 2011, Stb. 2011, 272. Arts. 10:54 and 10:57/10:59 BW are part of Title 3, Chapter 4 of Book 10 in the Dutch Civil Code (Burgerlijk Wetboek). The general provisions of Title 1 of Book $10 \mathrm{BW}$ are also relevant for these articles. This regime also governs the recognition of dissolutions of marriages that have been established in Denmark, since Denmark did not participate in the adoption of the Brussels II-bis Regulation and is therefore not bound by its application (see Principle 31 of the preamble to Brussels II-bis Regulation). Book 10 BW codifies and consolidates a number of general principles of private international law, supplemented with concrete regulations of a number of specific subjects of private international law in a systematic and coherent manner. The regulation of specific subjects of private international law, such as name, parentage, marriage, corporations, property law/goods, and contractual/noncontractual obligations, was previously spread over various separate acts. Book 10 has not fundamentally reformed these subjects, but it provides for some substantive modifications because of the developments in legal practice and new views in literature and case law. It primarily contains conflict rules and to some extent rules concerning recognition. Procedural legal rules that refer to the international jurisdiction of the Dutch judge and to the recognition and enforcement of judgments are primarily to be found in the Dutch Code of Civil Procedure. Book 10 aims to provide for practical applicability, understanding, and accessibility of private international law by legal practitioners. Book $10 \mathrm{BW}$ has the same layered structure as that which characterizes the entire Civil Code: the general principles affect the regulations of the specific subjects. Except for Art. 10:56 BW, Book 10 BW does not include any transitional provisions since there are no relevant differences with the acts that were previously in force. (Explanatory Memorandum to Book 10 BW, Kamerstukken II 2009/10, 32 137, No. 3, p. 1-6 (Memorie van Toelichting, hereinafter $\mathrm{MvT}$ ) ).

2 The National Conflict Rules Governing Divorce Act (Wet Conflictenrecht Echtscheiding hereinafter WCE), Act of 25 March 1981, Stb. 1981,166; entry into force on 10 April 1981. The WCE regulates the recognition of foreign dissolutions of marriage that have been established after 10 April 1981, its date of entry into force. The WCE does not include transitional provisions. However, in accordance with the doctrine, Arts. 2 and 3 WCE do apply retroactively since neither the principle of legal certainty nor the legitimate expectations of parties were to give precedence to the more generous regime and effects of these two articles (Vonken, Titel 1.9.ipr, Art. 4-2).

3 Council Regulation (EC) No. 2201/2003 of 27 November 2003 Concerning Jurisdiction and the Recognition and Enforcement of Judgments in Matrimonial Matters and the Matters of Parental Responsibility, O.J. (L 338/1), 29; entry into force on 1 March 2005 (except for Denmark). See for background information Practice Guide for the application of the new Brussels II Regulation, drawn up by the Commission services in consultation with the European Judicial Network in civil and commercial matters (updated version of 1 June 2005) available at $<\mathrm{http} / / /$ ec.europa.eu/civiljustice/divorce/parental_resp_ec_vdm_en.pdf $>$. The Brussels II-bis Regulation replaced its predecessor the Brussels II Regulation, Council Regulation (EG) No. 1347/2000 of 29 May 2000 Concerning Jurisdiction and the Recognition and Enforcement of Judgments in Matrimonial Matters and Matters of Parental Responsibility for mutual children, PbEG $2000 \mathrm{~L}$ 160/19, entry into force on 1 March 2001 (except for Denmark). See also for background information the 'Explanatory Report on the Convention on Jurisdiction and the Recognition and Enforcement of Judgments in Matrimonial Matters' by Dr. A. Borrás, Doc. 98/C 221/04, published in: O.J. (C 221/27) via <http://eurlex.europa.eu/LexUriServ/LexUriServ.do?uri=OJ:C:1998:221:0027:0064:EN:PDF>. 
including legal separations and annulments, that have been established by a court or another competent authority in another EU Member State, except for Denmark (hereinafter EU divorces), and of which its legal proceedings were instituted after 1 March 2005, and the recognition of authentic documents concerning the same subjects that have been drawn up after the aforementioned date. ${ }^{4}$ As it is based on the principle of reciprocity or the principle of mutual trust, it provides for the recognition of these judgments without any special procedure being required. Therefore, it provides for automatic recognition (Art. 21), in principle without a review of the jurisdiction of the court of origin (Art. 24), without the possibility of a refusal of recognition as based on differences in applicable law (Art. 25), and without a review as to its substance (révision au fond; Art. 26). The latter two articles limit the scope of the public policy provision in Article 22 sub a of the Brussels II-bis Regulation that provides for non-recognition of a judgment if its recognition is manifestly contrary to the public policy of the receiving state. Article 22 Brussels II-bis Regulation also specifies other grounds for the refusal of recognition of matrimonial decrees under specific conditions, where the judgment was given in default of appearance, and where the judgment is irreconcilable with another judgment given in proceedings between the same parties. Article 60 of the Brussels II-bis Regulation stipulates that the Regulation has precedence over the two conventions that are discussed below.

Articles 10:57 and 10:58 BW implement 'the Luxembourg ICCS Convention on the recognition of decisions relating to the matrimonial bond' of 1967 (hereinafter the 1967 Luxembourg ICCS Convention) $)^{5}$ and 'the Hague Convention on the recognition of divorces and legal separations' of 1970 (hereinafter the 1970 Hague Convention) ${ }^{6}$ pursuant to Article 10:1 BW in connection with Article 10:54 BW. ${ }^{7}$ These two Conventions aim at the mutual

4 Pursuant to the substantive, formal, and temporal scopes in, successively, Arts. 1-2, 21, 46, and 64 in connection with Art. 72 Brussels II-bis Regulation. With regard to decisions that have been established after 1 March 2005, but of which its legal proceedings have been instituted before 1 March 2005, as well as with regard to decisions that have been established before 1 March 2005, see the transitional arrangement in Art. 64 paras. 2,3, and 4 of the Brussels II-bis Regulation. Brussels II-bis Regulation may apply to these decisions if the requirements that are mentioned in Art. 64 have been met. See also Art. 10:1 BW concerning the prevalence of international and supra-national instruments over Book $10 \mathrm{BW}$.

5 'The Luxembourg ICCS Convention on the recognition of decisions relating to the matrimonial bond' of 8 September 1967, Trb. $1979 \mathrm{nr}$. 130; entry into force in the Netherlands on 30 July 1981. This Convention refers to the recognition of any decision relating to release from or the dissolution, existence or non-existence, validity, or nullity of the matrimonial bond given in one of the Contracting States, in the other Contracting States pursuant to its Art. 1; in short, it regulates divorces, legal separations, and annulments.

6 'The Hague Convention on the recognition of divorces and legal separations' of 1 June 1970, Trb. 1979 No. 131; entry into force in the Netherlands on 22 August 1981. This Convention applies to the recognition in one Contracting State of divorces and legal separations (excluding annulments) obtained in another Contracting State pursuant to its Art. 1.

7 Explanatory Memorandum to Book 10 BW, Kamerstukken II 2009/10, 32 137, No. 3, p. 7, 41-42 (MvT); Asser 10-II 2012, p. 104; Ibili 2010, p. 4. 
recognition of marriage dissolutions on a large scale and are based on the principle of reciprocity. ${ }^{8}$

Article 13 of the 1967 Luxembourg ICCS Convention and Article 17 of the 1970 Hague Convention allow their member states to apply a more generous regime of recognition. ${ }^{9}$ Articles 10:57-10:59 BW include such a regime and may thus have precedence over these two Conventions. ${ }^{10}$ In January 2010, the Hague Court of Appeal nevertheless applied the stricter regime of the Luxembourg ICCS Convention. It recognized a Turkish divorce pursuant to Article 10 of this Convention. ${ }^{11}$ More specifically, Articles 10:57-10:59 BW apply to 'import situations', whereas the Conventions are applicable to 'export' situations, the recognition of Dutch divorce judgments in other member states being not EU Member States. ${ }^{12}$ Hence, the recognition regimes in these Conventions serve as basic provisions.

\subsection{Articles 10:57, 10:58, And 10:59 BW: A General Overview}

Articles 10:57 BW and 10:58 BW have adopted - with some technical modifications - the contents of their predecessors, Articles 2 and 3 WCE. ${ }^{13}$ For this reason, parliamentary documents about the WCE, notably its Explanatory Memorandum, and its case law are also relevant for the understanding of these articles. ${ }^{14}$ Yet Article 10:59 BW does not have an equivalent in the WCE. Articles 10:57 and 10:58 BW only deal with the recognition of divorces and legal separations. They do not address the recognition of annulments of marriage. ${ }^{15}$ Article 10:57 BW is distinguished from Article 10:58 BW by, at least, the intervention of a competent civil or religious authority that provides for the dissolution of marriage with a procedure through which the dissolution of marriage is established under certain guarantees. ${ }^{16}$ Article 10:58 BW lacks these characteristics of intervention of a competent authority and any procedure and thus these guarantees: the divorce has been brought about by the decision of either spouse and lacks any procedure. As the notion 'marriage' in these articles means 'marriage' in the sense of a marriage in Book 1 of the

8 Asser 10-II 2012, p. 122; Tekst \& Commentaar Burgerlijk Wetboek, Boek 10, Artikel 57, No. 3a, 2012.

9 See also Explanatory Memorandum to Book 10 BW, Kamerstukken II 2009/10, 32 137, No. 3, p. 41 (MvT).

10 Despite the fact that provisions of treaties normally take precedence over national legal provisions such as Arts. 10:57 and 10:58 BW by virtue of Art. 94 of the Dutch Constitution (Grondwet).

11 Gerechtshof 's-Gravenhage 11 January 2010, LJN BV3130; JPF 2012/133, m.nt. ICS; REP 2013/1, p. 36.

12 Explanatory Memorandum to Book 10 BW, Kamerstukken II 2009/10, 32 137, No. 3, p. 41 (MvT); Oderkerk 2012, p. 145; Strikwerda 2012, p. 276.

13 Explanatory Memorandum to Book 10 BW, Kamerstukken II 2009/10, 32 137, No. 3, p. 41, 44 (MvT); Oderkerk 2012, p. 150; Tekst \& Commentaar Burgerlijk Wetboek, Boek 10, Artikel 57, No. 1, 2012; Tekst \& Commentaar Burgerlijk Wetboek, Boek 10, Artikel 58, No. 1, 2012.

14 Explanatory Memorandum to Book 10 BW, Kamerstukken II 2009/10, 32 137, No. 3, p. 5 (MvT).

15 Annulments of marriage are governed by the Hague Convention on Celebration and Recognition of the Validity of Marriages, the Hague, 14 March 1978, Trb. 1987, p. 137; see Ibili 2010, p. 1 (Internet version).

16 Explanatory Memorandum to the WCE, Kamerstukken II 1979/80, 16 004, No. 3, p. 17 (MvT). 
Dutch Civil code, these articles also include the recognition of the dissolution of same-sex marriages. ${ }^{17}$

The articles deal with the dissolutions of marriage and legal separations that have been established 'abroad', thus replacing the formulation 'outside the Kingdom' as was used in the WCE. ${ }^{18}$ The fact that the dissolution should have been established abroad implies that the dissolutions of marriage that have been established in, for example, Aruba or Curaçao and that are thus established within the Kingdom of the Netherlands, are not governed by these articles in Book 10 BW but by Article 40 of the Charter for the Kingdom of the Netherlands (Statuut voor het Koninkrijk der Nederlanden). ${ }^{19}$

The requirement of establishment abroad of the divorce should be read in connection with Article 10:55 BW. This article states that dissolutions of marriage and judicial separations in the Netherlands are exclusively to be pronounced by the Dutch judge. ${ }^{20}$ This legal rule is the codification of a 1986 decision of the Dutch Supreme Court, the Hoge Raad (hereinafter Hoge Raad), as a result of an appeal in cassation in the interest of a uniform application of the law (in Dutch cassatie in het belang der wet). The decision confers the exclusive right to grant a divorce on the Dutch judge. A central issue in this case was whether a dissolution of a marriage by means of repudiation that was established in the Moroccan consulate in the Netherlands may be recognized, possibly by virtue of analogous application of Article 3 WCE. The Hoge Raad ruled that marriages are exclusively to be dissolved through the decision of the Dutch judge followed by its registration in the Register of Birth, Marriages and Death pursuant to Article 1:163 BW. ${ }^{21}$ The repudiation at the Moroccan consulate in the Netherlands has to be considered as established on Dutch territory. ${ }^{22}$ The Hoge Raad rejected the possibility of an analogous application of Article 3 WCE. A repudiation that lacks any form of procedure violates Dutch public order to such an extent that it can in principle not be recognized in the Netherlands. ${ }^{23}$ The Hoge Raad based its ruling on the principle of legal certainty that has great significance in this respect. After all, a dissolution of marriage has far-reaching legal consequences not only for the spouses themselves but also for third parties, and therefore, their interests are best served by judicial intervention.

17 Since the entry into force of the Wet Openstelling Huwelijk on 1 April 2001 (Stb. 2001, 9), Asser 10-II 2012, p. 123; Ibili 2010, p. 1 (Internet version).

18 Ibili 2010, p. 3 (Internet version).

19 Ibili 2010, p. 3 (Internet version); Ibidem under the WCE, see Kruiniger 2008, p. 134 footnote 32.

20 Explanatory Memorandum to Book 10 BW, Kamerstukken II 2009/10, 32 137, No. 3, p. 42 (MvT); Asser 10 II 2012, p. 105-106, 132-133; Strikwerda 2012, p. 277; Tekst \& Commentaar Burgerlijk Wetboek, Boek 10, Artikel 55, 2012; Tekst \& Commentaar Burgerlijk Wetboek, Boek 10, Artikel 58, No. 2, 2012.

21 HR 31 October 1986, NJ 1987, 924 under 3.

22 Such a repudiation established in a Consulate results in the dissolution of the marriage of the spouses involved and is legally valid in the country of origin (if all requirements have been satisfied).

23 See also Explanatory Memorandum to the WCE, Kamerstukken II 1979/80, 16 004, No. 3, p. 19 (MvT). 
This exclusive right of the Dutch judge to grant the divorce aims to guarantee that post-divorce arrangements are also made. It is in the interest of the public order, and the decision should be understood as a special mandatory rule. ${ }^{24}$ Consequently, divorces established in an embassy or consulate in the Netherlands have to be considered as not being established abroad and, hence, cannot be recognized in the Netherlands. Such divorces are no longer recognized since the 1986 decision of the Hoge Raad. ${ }^{25}$ JordensCotran refers to the Moroccan consulates in the Netherlands that in principle obey the ban on consular divorces. ${ }^{26}$ All envoys of states that have ratified the 1963 Vienna Convention on Consular Relations being established in the Netherlands are bound to the 1986 Hoge Raad decision pursuant to its Article $5 .{ }^{27}$ Preparations that have already been made in the consulate of the country of origin in the Netherlands, in order to further complete the divorce in that country, do not violate the exclusive right of the Dutch judge to grant the divorce. An example of such preparations could include collecting all of the required information and making reconciliation attempt(-s). Acts such as the permission to draw up the act of repudiation and the final judicial decision, the qarar, in respect of Moroccan law have to originate in Morocco.

It is exclusively the Dutch judge who can dissolve marriages in the Netherlands. In international cases, he may have to apply foreign law. The Hoge Raad ruled in 2001 that the Dutch court is not allowed to pronounce the divorce in accordance with Moroccan law by using the institute of the repudiation. ${ }^{28}$ The latter is considered to infringe the public order because of the inequality based on gender at divorce as only the husband has the right to repudiate.

Furthermore, marriages dissolved through a unilateral declaration of either spouse or through a religious or administrative authority in the Netherlands cannot, in principle, be recognized in the Netherlands either. The Dutch legislator, however, created exceptions to the, in principle, non-recognition of the extra-judicial repudiations or divorces through the intervention of a civil (administrative) or religious authority that were established abroad under severe conditions, in Articles 2 and 3 WCE, at present Articles 10:57 BW and 10:58 BW.

These articles do not deal with the recognition of so-called negative decisions refusing to grant a divorce, legal separation, or annulment. ${ }^{29}$ All articles have been based on the principle of favor divortii and the interests of the wife in the recognition of the repudiation,

24 Asser 10-II 2012, p. 106.

25 See also Jordens-Cotran 2007, p. 463 footnote 181.

26 Jordens-Cotran 2007, p. 461-462.

27 Vienna Convention on Consular Relations of 24 April 1963, entered into force on 19 March 1967; see <http://untreaty.un.org/ilc/texts/instruments/english/conventions/9_2_1963.pdf>.

28 HR 9 November 2001, NJ 2002, 279 at 3.3.4.

29 Asser 10-II 2012, p. 130-131; Tekst \& Commentaar Burgerlijk Wetboek, Boek 10, Artikel 57, No. 4 h, 2012. 
in order to prevent limping legal relationships. ${ }^{30}$ Pursuant to Article 10:2 BW, the Dutch judge has to examine ex officio the nature of the dissolution of marriage in order to assess whether that dissolution should be tested against Article 10:57 BW or Article 10:58 BW and, thus, whether it can be recognized. ${ }^{31}$ The interested party must provide convincing evidence for the (legally valid establishment of the) dissolution of marriage. ${ }^{32}$

The following subsections discuss these articles more in detail.

\subsection{Recognition of Divorce Decisions: Article 10:57 BW}

Article 10:57 reads as follows:

(1) A dissolution of marriage or legal separation, acquired abroad after a sound legal procedure, is recognized in the Netherlands, if it has been brought about by the decision of a judge or another authority and if that judge or other authority had competence in the matter.

(2) A dissolution of marriage or legal separation acquired abroad, which does not meet one or more of the requirements laid down in the previous paragraph, is nevertheless recognized in the Netherlands, if it is apparent that the other party either during the foreign procedure has explicitly or implicitly agreed with, or after that procedure acquiesced in the dissolution of the marriage or the judicial separation. [translation by the author]

Article 10:57 paragraph $1 \mathrm{BW}$ deals de facto with the recognition of the foreign non-EU (and Danish) dissolution of marriage (divorce) or legal separation that has been established abroad on three procedural requirements: the dissolution should have been acquired after a sound legal procedure; the decision should have been taken by a judge or another authority; and the judge or that other authority should have been competent to take the decision..$^{33}$ Article 10:57 paragraph 2 BW encompasses the remedying facility in which the consent of the other spouse is pivotal.

Before discussing the requirements of paragraph 1 of Article 10:57 BW, a general remark is called for. It follows from the procedural character of the requirements in this

30 Explanatory Memorandum to the WCE, Kamerstukken II 1979/80, 16 004, Nos. 3 \& 4; Explanatory Memorandum to Book 10 BW, Kamerstukken II 2009/10, 32 137, No. 3, p. 41; Asser 10-II 2012, p. 125; JordensCotran 2007, p. 443; Kruiniger 2008, p. 130, 154-155.

31 See also HR 19 April 1996, NJ 1997, 467 annotated by ThMdB; after all, it concerns an issue of state.

32 Afd. Bestuursrechtspraak Raad van State 11 November 1999, AB 2000, 3 at 2.4 (caseno. H01.98.2024); see also Afd. Bestuursrechtspraak Raad van State 18 November 1999, NIPR 187 at 2.4 (case no. H01.98.2025).

33 Explanatory Memorandum to Book 10 BW, Kamerstukken II 2009/10, 32 137, No. 3, p. 44-45 (MvT); Asser 10-II 2012, p. 123; Tekst \& Commentaar Burgerlijk Wetboek, Boek 10, Artikel 57, Nos. 1 \& 4, 2012. 
paragraph that the review on whether the applicable law related to the decision was in accordance with the Dutch conflict rules should not be applied in the assessment for recognition. $^{34}$

The requirement of a sound legal procedure aims at protecting the interests and rights of the other spouse, the spouse that has not initiated or cooperated in the divorce. ${ }^{35}$ The standard applied refers to the internationally accepted principles of a sound legal procedure. ${ }^{36}$ Examples of important elements in the sound legal procedure are the timely and proper serving of a writ of summons to the respondent, thus enabling him or her to defend his or her case, respect for the principle of hearing both sides of the argument, and the proper examination of the views of both parties. ${ }^{37}$ It follows, inter alia, from ECHR case Pellegrini v. Italy that the Dutch judge should examine ex officio whether or not the internationally accepted standards of a sound legal procedure including human rights have been observed in the foreign procedure. ${ }^{38}$ This is also the case for a foreign procedure in a non-member state to the ECHR.

As regards the requirement of a decision that is taken by another authority, that authority can be an administrative authority, such as the registrar or notary, or a religious authority. ${ }^{39}$ The competence of that authority has to be assessed in accordance with a private international law standard. It should be assessed whether the competence of that authority has been based on an internationally acceptable regulation of competence such as Articles 2-5 of the 1970 Hague Convention or Article 3 of the Brussels II-bis Regulation. ${ }^{40}$ The competence solely based on the nationality or Muslim faith of one spouse, as may

34 Tekst \& Commentaar Burgerlijk Wetboek, Boek 10, Artikel 57, No. 4e, 2012. It follows from the Explanatory Memorandum to the WCE, Kamerstukken II 1979/80, 16 004, No. 3, p. 18 (MvT) that the conflicts of law review was no longer required nor advisable for two reasons: first, a regime that specifically applies to Dutch litigants and thus is restrictive for them in respect of recognition of foreign dissolutions of marriage is not in accordance with the changed, liberalized views about divorce; second, the restriction on testing the two procedural requirements is more in accordance with the international development that manifests itself in the law of treaties.

35 Asser 10-II 2012, p. 124-125; Tekst \& Commentaar Burgerlijk Wetboek, Boek 10, Artikel 57, No. 4b, 2012.

36 It follows from the ECJ case Krombach v. Bamberski that the procedural public order in EU Member States not only includes their internal legal principles but also the rights as guaranteed by the ECHR (ECJ 28 March 2000, Case C-7/98; NJ 2003, 626).

37 Explanatory Memorandum to Book 10 BW, Kamerstukken II 2009/10, 32 137, No. 3, p. 44 (MvT).

38 It follows from the ECHR case Pellegrini v. Italy that any judge of an ECHR member state should examine whether the requirements of Art. 6 ECHR have been observed in the foreign procedure in the case of recognition of a foreign decision concerning matrimonial matters (ECHR 20 July 2001, case 30882/96, RJ\&D ECHR 2001-VIII). See also Vonken 2004, Titel 1.9 ipr, Arts. 2-28-38.

39 Tekst \& Commentaar Burgerlijk Wetboek, Boek 10, Artikel 57, No. 4c, 2012.

40 Explanatory Memorandum to the WCE, Kamerstukken II 1979/80, 16 004, No. 3, p. 17-18 (MvT); Explanatory Memorandum to Book 10 BW, Kamerstukken II 2009/10, 32 137, No. 3, p. 44 (MvT); Asser 10-II 2012, p. 125; Tekst \& Commentaar Burgerlijk Wetboek, Boek 10, Artikel 57, No. 4d, 2012; see also Mostermans 2003, No. 280; see also HR 27 May 1988 (NJ 1988, 832) in which the Dutch Hoge Raad confirmed that the Dutch Court of Appeal (het Hof) has used Art. 2 of the 1970 Hague Convention correctly as a guideline in order to accept the international jurisdiction of the Colorado district court in the case at issue. 
occur in Islamic states, especially when both spouses reside in the Netherlands, is questionable. ${ }^{41}$ Apart from the fact that the 1970 Hague Convention and the Brussels II-bis Regulation do not provide for these criteria as ground for competence, the criterion of nationality is seen as too weak and for this reason as unacceptable according to the Explanatory Memorandum to the WCE. ${ }^{42}$

These procedural requirements do not have an absolute character. ${ }^{43}$ It is not in the interest of the parties to refuse recognition when the other spouse has consented to the divorce. For this reason, Dutch law offers a remedying facility in the second paragraph of Article 10:57 BW. When the requirements of the first paragraph of Article 10:57 BW have not been met, the foreign dissolution of marriage is nevertheless recognized, if it is apparent that the other spouse has explicitly or implicitly agreed to the divorce during, or acquiesced in the divorce afterwards, pursuant to the second paragraph of Article 10:57 BW. ${ }^{44}$ This paragraph thus reflects the consensus between the parties, either because they both wanted the divorce or because the other party has accepted the divorce through his or her unequivocal consent (agreement or acquiescence). Hence, this provision aims to achieve an efficient and fair regulation of international judicial matters and to prevent, as much as possible, limping legal relationships. In this way, this provision reflects the principle of favor divortii.

The terms 'apparent' and 'implicitly' grant the recognizing authority some discretion in assessing the facts of the case. ${ }^{45}$ The consent may become apparent from the facts or circumstances, such as that both spouses have demanded the divorce; that the divorce has been pronounced by reference or by default while service has been properly effected on the respondent; from not putting forward a defence at appearance; from remarriage of the other party; from the fact that the respondent requires for alimony, guardianship, or custody after divorce; and from a new marriage by the other spouse or his or her request for registration of the divorce. ${ }^{46}$ However, the fact that the other spouse did not have recourse to a legal remedy against the foreign dissolution of marriage does not imply that that spouse has acquiesced in the foreign decision for the dissolution of the marriage. ${ }^{47}$

Apart from not having fulfilled the requirements of the first and/or second paragraph of Article 10:57 BW, a foreign dissolution of a marriage cannot be recognized if the

41 Jordens-Cotran 2007, p. 444-447. Rutten 2003, p. 229.

42 Explanatory Memorandum to the WCE, Kamerstukken II 1979/80, 16 004, No. 3, p. 17 (MvT).

43 Asser 10-II 2012, p. 123, 125-126; Tekst \& Commentaar Burgerlijk Wetboek, Boek 10, Artikel 57, No. 4f, 2012.

44 Explanatory Memorandum to Book 10 BW, Kamerstukken II 2009/10, 32 137, No. 3, p. 44-45 (MvT).

45 Explanatory Memorandum of Reply (MvA), Kamerstukken II 1980/81, 16 004, No. 8, p. 2.

46 Explanatory Memorandum to the WCE, Kamerstukken II 1979/80, 16 004, No. 3-4, p. 19 (MvT) and Explanatory Memorandum of Reply (MvA), Kamerstukken II 1980/81, 16 004, No. 7, p. 5 (MvA); Plasschaert 2002, p. 881.

47 Hof Amsterdam 29 July 1991, NIPR 1991, No. 315; Asser 10-II 2012, p. 126; Vonken, Titel 1.9. ipr, Art. 2 39. 
recognition is obviously irreconcilable with the Dutch PIL public policy by virtue of Article 10:59 BW. This article will be discussed below. Although it has not been stipulated explicitly in Article 10:57 BW, nor in its predecessor Article 2 WCE, a foreign dissolution of a marriage can also not be recognized if it is irreconcilable with an already existing Dutch divorce decision, whether or not the latter has been established later than the foreign decision. ${ }^{48}$ The priority of the Dutch decision can be inferred from the principle of the closed system of legal remedies in Dutch procedural law. The legal effect of a Dutch judgment can only be affected by having recourse to one of the legal remedies that has been provided for by law. ${ }^{49}$ Furthermore, recognition is only possible if the foreign decision has the authority of res judicata, i.e. that one of the parties can no longer have recourse to one of the legal remedies as provided for by the law in the country of origin. ${ }^{50}$

\subsection{Article 10:57 BW: Broadening the Scope}

Article 10:57 BW not only regulates the recognition of foreign dissolutions of marriage established abroad through the decision of a competent authority and after a sound legal procedure or, by lack of the fulfilment of one of these requirements, through the consensus of the spouses. A legal-historical interpretation of this article extends its scope..$^{51}$ Article 10:57 BW also regulates, next to the regime in Article 10:58 BW and under certain conditions, the recognition of the dissolution of marriage that has been established by means of the declaration of either spouse, notably the husband, thus the repudiation or repudi-

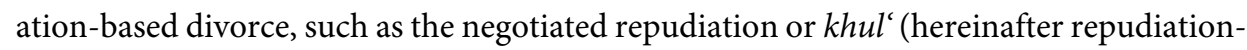
based divorce(-s)). It follows from the Explanatory Memorandum to the WCE that the repudiation-based divorce that has been established with the cooperation or under the supervision of a civil or religious authority may be recognized pursuant to Article 2 WCE (at present Art. 10:57 BW), if the intervention of that authority provided the repudiation with a procedural character so as to establish the dissolution under certain guarantees. ${ }^{52}$

Examples of such interventions, and thus of a form of procedure, are (1) that the authority involved tests whether or not the statutory regulations have been met; (2) that the authority involved tries to reconcile the spouses; (3) that that authority tests whether certain financial conditions have been met; or (4) that the dissolution of marriage took

48 Cf. Art. 2 sub c Brussels II-bis Regulation; Art. 91970 Hague Convention; Art. 11967 Luxembourg ICCS Convention; Mostermans 2003, Nos. 289-293.

49 Tjittes \& Asser 2007, p. 3.

50 Mostermans 2003, Nos. 294-296.

51 Asser 10-II 2012, p. 126.

52 Explanatory Memorandum to the WCE, Kamerstukken II 1979/80, 16 004, Nos. 3 \& 4, p. 17 (MvT); Asser 10-II 2012, p. 124. 
place under supervision of the Court (for example the Family Law Court). ${ }^{53}$ The automatic registration or homologation (approval) of the repudiation does not suffice. ${ }^{54}$ In the case of the repudiation-based divorce, not only the contents of the act of repudiation but also the foreign (procedural) law involved and the current foreign legal practice regarding divorce should demonstrate the cooperation or supervision of the judge or other authority, and the procedural character of the repudiation that arises as a consequence. ${ }^{55}$ The act of repudiation can only be used as supporting evidence of that law and/or practice and not as separate evidence.

A teleological interpretation endorses the abovementioned legal-historical interpretation. ${ }^{56}$ After all, the regulation of the recognition of foreign divorces has been based on the principle of favor divortii in order to prevent limping legal relationships. This matches with a moderation of the role of the judge.

Although the legislator in the Explanatory Memorandum does not explicitly pay attention to paragraph 2 of Article 2 WCE with regard to repudiations, it is logical to maintain this paragraph as remedying facility for repudiation-based divorces in respect of the requirement of the competence of the judge or another authority. ${ }^{57}$ The requirement of some form of procedure cannot be 'repaired' since it is the essential requirement in the assessment of the repudiation pursuant to Article $2 \mathrm{WCE}$, at present Article 10:57 BW.

Based on a teleological interpretation, Article 10:57 paragraph 2 BW can also be applied to administrative divorces that are based on mutual consent and that have been lawfully established out of court. ${ }^{58}$ As mentioned above, favor divortii is the basis of the regulation of recognition in Article 10:57 BW (and Art. 10:58 BW) in order to prevent limping legal relationships. Article 10:57 BW may thus be relevant in the context of extra-judicial repudiation-based divorces if they are based on the mutual consent of the spouses, established through the intervention of administrative authorities, and lawfully established, meaning that they are established in accordance with the formal and substantive requirements of the law of the place of establishment. Examples are the current Egyptian modalities of the out-of-court $\mathrm{khul}^{\text {' }}$ or the talaq al-ibra. The administrative authority, such as the registrar or notary, has the duty to check the fulfilment of the formal requirements in

53 Asser 10-II 2012, p. 132; Tekst \& Commentaar Burgerlijk Wetboek, Boek 10, Artikel 57, No. 2, 2012; Feteris 1984, p. 9.

54 Mostermans 1999, No. 197.

55 Kruiniger 2008, p. 137 and footnote 46.

56 Asser 10-II 2012, p. 126.

57 Kruiniger 2008, p. 139.

58 Asser 10-II 2012, p. 129-130; Tekst \& Commentaar Burgerlijk Wetboek, Boek 10, Artikel 57, No. 4 et seq., 2012. See for administrative divorces Jordens-Cotran 2002, p. 123-124; Mostermans 2003, p. 95-96. Exemplary is Rechtbank Amsterdam 6 June 1984 (NIPR 1985, 11) in which the court has recognized the divorce by mutual consent in the presence of a Thai registrar under Art. 2 WCE. 
relation to the establishment of the divorce and to draw up the act of divorce that has the same legal effect as the judicial dissolution of marriage.

Reference to Article 10:88 BW that applies to the recognition of registered partnerships is also relevant in this context. This article draws a distinction between the recognition of the termination of a registered partnership by mutual consent (para. 1) and its recognition by the decision of a competent judge or other authority (para. 2).

Accordingly, the text of Article 10:57 section 2 BW in relation to these administrative divorces should be understood or read as follows:

A dissolution of marriage acquired abroad, that has been established out of court, but through intervention of an administrative authority and that has been based on the mutual consent of both spouses, is nevertheless recognized in the Netherlands, if it has legal effect in the country of establishment.

Since Article 10:57 section 2 BW enables the recognition of this type of divorce and may thus prevent limping legal relationships, it also endorses the principle of favor divortii. ${ }^{59}$

Repudiation-based divorces that have been established through the cooperation or under the supervision of any competent authority, and after some form of judicial procedure, may be recognized under Article 10:57 BW. For those repudiation(-based divorces) that do not fulfil these requirements, the specific provision of Article 10:58 BW offers a facility for its recognition on certain conditions. ${ }^{60}$

\subsection{Recognition of Divorce Exclusively by Unilateral Declaration of Either Spouse: Article 10:58 BW}

Article 10:58 BW regulates the recognition of the foreign dissolution of the marriage that has exclusively been established by means of the unilateral declaration of either spouse on four conditions. The article in particular refers to the unilateral out-of-court repudiation.

Article 10:58 BW reads as follows:

A dissolution of marriage abroad that has exclusively been brought about by a unilateral declaration of either spouse, is recognized if:

a. the dissolution in this form is in accordance with any national law of the spouse who has unilaterally dissolved the marriage;

59 In the same vein, annotation De Boer under HR 13 July 2001, NJ 2002/223; Jordens-Cotran 2002, p. 139140; Mostermans 2003, p. 95-96. See also Joustra 2001, p. 408.

60 Asser 10-II 2012, p. 123-124; Tekst \& Commentaar Burgerlijk Wetboek, Boek 10, Artikel 57, No. 2, 2012. Tekst \& Commentaar Burgerlijk Wetboek, Boek 10, Artikel 58, No. 1, 2012. 
b. the dissolution has legal effect in the state where it occurred; and

c. it is apparent that the other spouse explicitly or implicitly has agreed with the dissolution of the marriage or has acquiesced therein. [translation by the author]

It differs from its predecessor Article 3 WCE in three respects. ${ }^{61}$ First, Article 3 WCE dealt with the recognition of the foreign dissolution of marriage that had exclusively been established through the unilateral statement of the husband instead of either spouse, as in Article 10:58 BW. In contrast to Article $3 \mathrm{WCE}$, Article 10:58 BW has been formulated in a sex-neutral manner. The sex-neutral formulation implies that this article may also include the self-repudiation by the wife. ${ }^{62}$

Second, Article 3 WCE had been formulated in a negative manner. Such a foreign dissolution of marriage is not recognized unless four cumulative requirements have been met. The background to this attitude of non-recognition is the fact that repudiations without any form of procedure are considered to infringe upon the PIL public order, the fundamental norms and values of the Dutch legal order. ${ }^{63}$ An example of such an infringement is the unequal position of women in comparison to men. ${ }^{64}$ The fact that women do not have an identical or effectively identical power to dissolve the marriage is also seen as a violation of these norms and values. It is explicitly not the issue of the unilateral power to the dissolution of the husband, characteristic for the repudiation, that is seen as such violation. ${ }^{65}$

The Dutch legislator nevertheless had the intention to make an exception to the, in principle, non-recognition in order to avoid harm to the wife's interests when she had acquiesced in the repudiation. ${ }^{66}$ An example in this respect is the Dutch wife who has been repudiated by her Muslim husband and who may have an interest in being considered as divorced. By clearly describing the requirements for the recognition of such repudiation, the Dutch legislator had the intention to provide for more legal certainty with regard to its legal validity in the Netherlands.

In contrast to Article $3 \mathrm{WCE}$ has Article 10:58 BW been formulated in a positive manner. Such a foreign dissolution is recognized if four cumulative requirements have been met: 1) the dissolution has been established abroad;2) the dissolution of the marriage has been rendered in accordance with any national law of the spouse who has unilaterally

61 Explanatory Memorandum to Book 10 BW, Kamerstukken II 2009/10, 32 137, No. 3, p. 45 (MvT).

62 Asser 10-II 2012, p. 132; Oderkerk 2012, p. 151.

63 HR 13 July 2001, NJ 2002, 223 under No. 20 of the opinion of Advocate General Strikwerda.

64 See, for example, also Hof Amsterdam 14 December 2000, case No. 144/00 (in: Van der Velden 2003, p. 1).

65 See also Van der Velden 2003, p. 12-13.

66 Explanatory Memorandum to the WCE, Kamerstukken II 1979/80, 16 004, Nos. 3 \& 4, p. 19 (MvT). 
dissolved the marriage; 3 ) it has legal effect in the state of its establishment; and 4) the other spouse unequivocally consented to the divorce during or after the proceedings. ${ }^{67}$

Oderkerk presumes that through the positive formulation of Article 10:58 BW and through formulating a public policy exception in the separate provision of Article 10:59 BW at the same time, the Dutch legislator intended to make more evident the possibility of invoking the public policy exception. ${ }^{68}$ The negatively formulated Article 3 WCE was based entirely on the public policy exception. In my opinion, the legislator intends to highlight even more the principle of favor divortii that underlies this article by changing the formulation into a positive formulation.

As regards the first requirement of the establishment of the dissolution abroad, it has already been mentioned that the dissolution of a marriage in the Netherlands can only be established by means of its pronouncement by the Dutch judge, followed by its registration in the Register of Births, Marriages and Deaths in the Netherlands. This exclusive right of the Dutch judge to grant a divorce in the Netherlands, laid down in Article 10:55 BW at present, stands in the way of the recognition of the divorce through the declaration of the husband (the repudiation) made in the Netherlands, whether or not it is a case of a transnational divorce of which possible other formalities take place in the country of origin. ${ }^{69}$ This is also the case if the divorce has been pronounced in a consulate or embassy of a foreign state in the Netherlands. ${ }^{70}$ The Hoge Raad also rejected an analogous application of Article $3 \mathrm{WCE}$, at present Article 10:58 BW. The judicial intervention serves the interests of all parties involved including third parties, best and thus also serves the principle of legal certainty.

The second requirement of Article 10:58 BW contains the third difference in relation to Article 3 WCE. It refers to 'any national law', whereas Article 3 WCE contains the wording 'the personal law'. The latter was used since some states have separate family laws for each religious section of the population within their state instead of one uniform national family law for all its citizens. ${ }^{71}$ Article 10:58 BW should now be read in connection with Article 10:15 BW that provides for a regulation in the case of a plurality of legal systems within one state. Hence, one can determine the relevant legal system in accordance with the interpersonal law of the lex causae, the person's national law.

Article 10:58 BW requires the dissolution to be in accordance with any national law of the divorcing spouse. Assessment of fulfilment of this requirement should concern his or her situation at the time of divorce. In the first place, the requirement implies that that

67 Asser 10-II 2012, p. 132; Oderkerk 2012, p. 151; Tekst \& Commentaar Burgerlijk Wetboek, Boek 10, Artikel 58, No. 1, 2012.

68 Oderkerk 2012, p. 151.

69 Asser 10-II 2012, p. 132-133. See also Mostermans 2003, p. 117-118.

70 HR 31 October 1986, NJ 1987, 924 under 3.

71 Explanatory Memorandum to Book 10 BW, Kamerstukken II 2009/10, 32 137, No. 3, p. 45 (MvT); Asser 10 II 2012, p. 133. 
national law not only acknowledges but also allows the unilateral dissolution of the marriage, notably the repudiation. ${ }^{72}$ A Dutch Muslim husband cannot repudiate his wife since Dutch law does not allow or acknowledge the repudiation as a way to dissolve the marriage. It also implies that this type of dissolution must actually result in having dissolved the marriage according to that national law. For this reason, the recognizing authority in the Netherlands has to check whether or not the husband has revoked the repudiation. ${ }^{73}$

Furthermore, this requirement may refer to any national law of the divorcing spouse having more than one nationality, implying that the so-called effectiveness test does not have to be applied. ${ }^{74}$ This test is to determine the nationality with which a person who has two or more nationalities has the closest tie in view of all circumstances involved. This matter was unclear under the WCE. ${ }^{75}$ The Hoge Raad ruled in 2001 that the judge did not have to apply this test in the assessment for the recognition of a divorce by virtue of Article $3 \mathrm{WCE}^{76}$ Although the case involved the recognition of a Moroccan $\mathrm{khul}$ ' or negotiated repudiation, it may be assumed that the Hoge Raad's opinion on the effectiveness test also related to the recognition of the talaq or 'ordinary' repudiation. In support of this opinion, the Hoge Raad referred to the principle of favor divortii in order to avoid limping legal relationships and to the interest of the wife in recognition of the repudiation in the Netherlands. If the wife has unequivocally consented to the repudiation, it is also in her interest to be able to refer to the repudiation. The fact that the foreign nationality of the husband is not his effective nationality should not impede this. Hence, it is plausible that the effectiveness test related to a person having two or more nationalities, as regards recognition of a divorce based on Article 3 WCE, should be omitted under all circumstances.

On the basis of the same ruling of the Hoge Raad, it should a fortiori be assumed that the judge is also not allowed to test the extent to which the husband is (still) tied to his country of nationality. ${ }^{77}$ In other words, he is not allowed to apply the so-called reality test in determining the personal law of the husband who has one nationality.

The third requirement for the dissolution to have legal effect is that the state of its establishment voices the locus regit actum principle. This requirement can be met in two

72 Asser 10-II 2012, p. 133; Tekst \& Commentaar Burgerlijk Wetboek, Boek 10, Artikel 58, No. 3, 2012.

73 Kruiniger 2008, p. 143.

74 Explanatory Memorandum to Book 10 BW, Kamerstukken II 2009/10, 32 137, No. 3, p. 45 (MvT); Asser 10II 2012, p. 134. See also Opinion Strikwerda (No. 17) in HR 31 July 2001, NJ 2002, 223; Annotation De Boer under HR 31 juli 2001, NJ 2002, 223; Joustra 2001, p. 408-410.

75 See also the discussion by Plasschaert (2002, p. 883) regarding the issue whether a Dutch person having two or more nationalities is allowed to repudiate. According to him, some were of the opinion that such a person is not allowed to repudiate, whether or not he is allowed to repudiate according to the law of his other nationality; however, others were of the opinion that that person is allowed to repudiate since the requirements of Art. 3 sub a and b have been met, if at least the wife had consented to the repudiation as well. Plasschaert has the impression that the repudiation of such a person should be accepted.

76 HR 31 July 2001, NJ 2002, 223 under 3.4.3-3.4.4.

77 Asser 10-II 2012, p. 134. 
ways. ${ }^{78}$ Either the dissolution of marriage is in accordance with the law of the state of its establishment or that state recognizes the dissolution of marriage, despite the fact that it is unknown in or even infringes upon its own law. A marriage dissolved at a consulate or embassy in the Netherlands (also) does not meet this third requirement. After all, such a divorce cannot have legal effect in the Netherlands because of the exclusive right of the Dutch judge to grant a divorce and the requirement of the registration of the divorce in the Register of Birth, Marriages and Death, as was previously mentioned under the first requirement.

The most significant requirement is the fourth and last one, the explicit or implicit agreement with or acquiescence in (also hereinafter unequivocal consent) the dissolution of marriage of the other spouse. ${ }^{79}$ In order to meet this requirement, the Dutch Hoge Raad highlighted in a 2007 decision that that consent (agreement or acquiescence) - back then under Article 3 WCE 'of the wife', at present under Article 10:58 BW 'of the other spouse' has to be unequivocal. ${ }^{80}$ One should not assume too quickly the agreement with or acquiescence in the repudiation by the wife or the other spouse. The Hoge Raad confirms the judgment of the Amsterdam Court of Appeal that a 'declaration about divorce' should not be deemed to be 'an act of acquaintance and acquiescent'. The Litigation Division of the Council of State also appears to stick to this requirement. ${ }^{81}$ In its decision of 21 May 2008, it expressed that an implicit consent of the wife cannot be inferred from an act of repudiation that does not mention anything about the consent of the wife. ${ }^{82}$ The Division also rejected the argument of the appellant that a declaration of consent would not be a requirement since in that case it was no longer a matter of implicit consent.

In the abovementioned proceedings that led to the decision of the Hoge Raad in 2007, the following was remarkable: the Amsterdam Court of Appeal required a declaration about the unequivocal consent to the repudiation by the Egyptian wife that had to be legalized by the Dutch Consulate in Cairo, Egypt. ${ }^{83}$ According to a fax by this Consulate, it followed that the Consulate only legalizes signatures of persons of Dutch nationality. This implied that the signature of the Egyptian wife, who did not have Dutch nationality, could not be legalized, and thus, the fulfilment of the requirement of Article $3 \mathrm{sub} c$ WCE could not be proven, the repudiation could not be recognized, and, consequently, the Court

78 Asser 10-II 2012, p. 134-135; Tekst \& Commentaar Burgerlijk Wetboek, Boek 10, Artikel 58, No. 4, 2012. See also Explanatory Memorandum to the WCE, Kamerstukken II 1979/80, 16 004, Nos. 3 \& 4, p. 19 (MvT); Annotation De Boer under HR 13 July 2001, NJ 2002, 223.

79 Asser 10-II 2012, p. 135-136.

80 HR 21 December 2007, NJ 2009, 268 under 3.3; case No. R06/146 HR; LJN: BB8076; JOL 2007, 882; RvdW 2008, 50; JPF 2008, 50; NIPR 2008, 4.

81 See also Tomson (2009, p. 25) who refers to the Afdeling Bestuursrechtspraak Raad van State 21 May 2008, $A B$ 2008, 299; No. 200708901/1; LJN BD2127.

82 Afdeling bestuursrechtspraak 21 May 2008, AB 2008, 299; No. 200708901/1; LJN BD2127 under 2.3-2.5.

83 HR 21 December 2007, NJ 2009, 268 under 2-3. 
rejected the appeal and upheld the Alkmaar District Court's judgment. However, the statement of the Consulate about not legalizing documents from non-Dutch persons seems to be at odds with the practice of legalization. Legalization actually often concerns the determination of authenticity of the signature of non-Dutch persons such as foreign judges or ministers. ${ }^{84}$ Moreover, it follows from information from the Dutch Ministry of Foreign Affairs that the statement of the Consulate is incorrect. ${ }^{85}$ Upon further inquiry, it appeared that the Dutch Embassy in Rabat, Morocco, is willing to legalize a declaration by a repudiated non-Dutch woman about her consent to the repudiation under certain conditions. ${ }^{86}$ The Hoge Raad quashed the decision of the Court of Appeal on the ground that the Court required proof, although it was obvious that the appellant could not meet this requirement.

The Explanatory Memorandum to the WCE initially connects the requirement of unequivocal consent to the Dutch repudiated wife. ${ }^{87}$ The requirement offers the wife the opportunity to 'use' the repudiation, through its recognition, in order to be considered to be divorced when the wife so wishes. Vonken states that this ratio (behind the consent) of the Dutch legislator does not imply that the requirement only applies to Dutch women and not to foreign women. ${ }^{88}$ Foreign women may have the same interest in being considered to be divorced, in particular when they reside in the Netherlands. For this reason, the requirement of consent pursuant to Article 10:58 BW applies to all repudiated or divorced persons irrespective of their origin or nationality. Furthermore, this requirement applies irrespective of the residence, in or outside the Netherlands, of the repudiated or divorced person at the time of the repudiation or divorce.

It is often difficult to determine whether or not the other spouse has agreed to or acquiesced in the divorce. ${ }^{89}$ The presence of the unequivocal consent should be assessed on a case-by-case basis. It should not be assumed too quickly, ${ }^{90}$ since this requirement concerns an exception to the rule that unilateral repudiations violate Dutch PIL public order and can thus not be recognized.

Factual circumstances from which the unequivocal agreement or acquiescence can be inferred are a written statement of consent by the other spouse; the request to register the repudiation act in the General Register Office (GBA or Gemeentelijke basis administratie or, since 6 January 2014, BRP or Basisregistratie Personen) by that other spouse; the sub-

84 See also the description of the procedure of legalization of Moroccan divorce documents in: Kruiniger 2008, p. 193-194 and footnote 9 on p. 193.

85 Struycken in his annotation to HR 21 December 2007, NJ 2009, 268, under 3.

86 Tomson 2009, p. 25.

87 Explanatory Memorandum to the WCE, Kamerstukken II 1979/80, 16 004, No. 3-4, p. 19 (MvT), but also: HR 13 July 2001, NJ 2002, 223, under: HR 3.4.4. Tekst \& Commentaar Burgerlijk Wetboek, Boek 10, Artikel 58, No. 5, 2012.

88 Asser 10-II 2012, p. 135.

89 Asser 10-II 2012. p. 136; Tekst \& Commentaar Burgerlijk Wetboek, Boek 10, Artikel 58, No. 5, 2012; De Groot 2003, p. 278-279.

90 See also HR 21 December 2007, NJ 2009, 268, under 3.3. 
mission of an act of marriage that shows that the other spouse has been remarried after the dissolution of marriage; the submission of a birth certificate that shows that the female other spouse has given birth to natural children after the dissolution of marriage; the submission of an authentic act in which the other spouse declares to agree with the dissolution of marriage; the remarriage of the other spouse in the presence of the Dutch registrar; the intention of the female spouse to remarry; the act of repudiation that shows that the wife has asked for the repudiation in exchange for compensation ( $k h u l$ ); and the act of repudiation that demonstrates that the wife has repudiated herself after having been handed over the power to repudiate by her husband (talaq al-tawkil or talaq al-tafwid). ${ }^{91}$ The court transcripts of the Moroccan session may also provide evidence of the consent of the wife. ${ }^{92}$

It may be inferred from the act of repudiation that the wife was present at the repudiation, but her presence does not imply that she agreed to the repudiation. Neither does her cooperation with provisions after divorce prove that she agreed to the repudiation. ${ }^{93}$ The fact that the wife petitioned for divorce also does not imply that she agreed to the repudiation. ${ }^{94}$ She may petition for divorce because she disagrees with the legal effects or consequences of the repudiation. The unequivocal consent can also not be inferred from the fact that the wife has received some movables and has let the husband off with the rest that could have been claimed after the repudiation. ${ }^{95}$ Once the other spouse has consented to the dissolution of marriage, he or she cannot reconsider that decision anymore.

Hence, the requirement of the consent of the wife aims to 'repair' the unequal position of that spouse, often the wife, due to the unilateral character of the dissolution and the lack of sound proceedings. The requirement is rather peculiar though, since the consent of the wife to the repudiation is not required in Shari a law nor in the divorce laws of Muslim-majority countries today.

In 1995 it was proposed by amendment to abolish the requirement of unequivocal consent from the repudiated wife who was residing in her country of origin at the time of the repudiation. The amendment aimed at avoiding evidential problems for the husband in respect of the wife's consent. ${ }^{96}$ The minister withdrew this amendment due to a lack of support as it could severely hurt the interests of the wife (and children) in the country of origin. $^{97}$

It follows from the Bill of Amendment to the WCE of 1995 that the requirement of unequivocal consent has to be met irrespective of the time period that has elapsed since

91 See, e.g. $\$ 3.2$ at Art. 8.1 introduction and sub d of the Handleiding voor de toepassing van de Rijkswet op het Nederlanderschap; Hof's-Gravenhage 3 May 2000, NIPR 2000, No. 175.

92 Jordens-Cotran 2007, p. 467.

93 Rechtbank Alkmaar, 14 January 1988, NIPR 1988, 313.

94 See, e.g. Rechtbank Alkmaar, 14 January 1988, NIPR 1988, 313.

95 Rechtbank Alkmaar, 14 January 1988, NIPR 1988, 313.

96 Bill of amendment to the WCE, Kamerstukken II 1995/96, 24 709, No. 2, p. 2.

97 Bill of amendment to the WCE, Kamerstukken II 1995/96, 24 709, No. 6, p. 1-2. 
the establishment of the dissolution of marriage. ${ }^{98}$ The requirement does even not lapse in the case that the place of residence of the other spouse is unknown. In his annotation to HR 21 December 2007, Struycken questions the severity of the requirement of unequivocal consent in relation to the repudiation at issue. ${ }^{99}$ That repudiation took place in Egypt in 1988 and had no connections to the Netherlands or any other Occidental country whatsoever. In support, Struycken refers to the less distant attitude of the United Kingdom in section 46, paragraph sub c of the UK Family Law Act 1986:

The validity of an overseas divorce ..., obtained otherwise than by means of proceedings shall be recognized if - ...(c) neither party to the marriage was habitually resident in the United Kingdom throughout the period of one year immediately preceding that date.

\subsection{Public Policy Exception}

Apart from not meeting the requirements of Article 10:57 or 10:58 BW, a divorce should also not be recognized if its recognition violates Dutch PIL public order pursuant to Article 10:59 BW. ${ }^{100}$ This article reads as follows:

Notwithstanding the Articles 57 and 58 of this Book a dissolution of marriage is withheld recognition if the recognition is apparently incompatible with the public policy. [translation by the author]

This provision refers to the public policy concerning private international law relationships (PIL public policy hereinafter, in short public policy) that encompasses the fundamental values and norms of the Dutch legal order. The WCE did not contain an explicit public policy exception, although it could be invoked. ${ }^{101}$ Book $10 \mathrm{BW}$ also contains a general PIL public policy clause in Article 10:6 BW but this clause regards the issue of the applicable law and not that of recognition. Article 10:59 BW regulates the PIL public policy in respect of the issue of recognition of foreign dissolutions of marriage (and not yet of legal separa-

98 Explanatory Memorandum to the Bill of amendment to the WCE, Kamerstukken II 1995/96, 24 709, No. 3, p. $1(\mathrm{MvT})$.

99 Annotation Struycken under HR 21 December 2007, NJ 2009, 268.

100 Explanatory Memorandum to Book 10 BW, Kamerstukken II 2009/10, 32 137, No. 3, p. 45 (MvT). Apart from Art. 10:59 BW, Art. 37 para. 2 Wet GBA (Wet Gemeentelijke Basisadministratie persoonsgegevens) and Article 2.10 para. 2 Wet BRP (Wet Basisregistratie Personen) read that no information can be extracted from a foreign act, judgment or document, or a statement under oath or affirmation in as far as the Dutch public policy opposes the recognition of the legal validity of the facts mentioned in these documents.

101 Explanatory Memorandum to the WCE, Kamerstukken II 1979/80, 16 004, Nos. 3-4, p. 19; see also p. 31 (MvT). 
tions). ${ }^{102}$ If such foreign divorce, including the repudiation, infringes upon human rights and thus upon public policy, Dutch public policy cannot allow its recognition. ${ }^{103}$

This correction mechanism addresses the effects after the recognition of the foreign divorce as well as the mode of establishment of the foreign divorce. ${ }^{104}$ In the latter case, the public policy exception has an absolute character: the divorce cannot be recognized if its mode of establishment violates Dutch public policy (in Dutch buitengrenscriterium); it concerns an assessment in abstracto: the concrete circumstances of the case and the involvement or not of the Dutch legal order do not play a part.

In the former case, the foreign divorce is withheld recognition if it would result in an effect that cannot be tolerated; according to Dutch views (in Dutch binnengrenscriterium), it concerns an assessment in concreto in which the involvement of the Dutch legal order plays a part with regard to the effects of the recognition. The more involvement of the Dutch legal order, the more of a connection to the forum (Inlandsbeziehung), the more chance of a violation of public policy, and the more likely it is that recognition should be withheld from the divorce. The less the Dutch legal order is involved, the fewer reasons there are for withholding recognition from the divorce. ${ }^{105}$ In other words, the repulsive strength of public policy is relative and depends on the extent of involvement of the Dutch legal order.

The wording 'apparently incompatible with the public policy' indicates that there should be a manifest violation of fundamental norms in Dutch legal order. ${ }^{106}$ One can only resort to the PIL public policy provision in exceptional cases. In order not to frustrate the PIL goal of a smooth regulation of private international law matters, recognition of foreign decisions, including repudiation-based divorces, should not be hampered, but they should be granted as much as possible in accordance with the principle of favor divortii. ${ }^{107}$ For this reason, not every violation of fundamental norms or human rights results in an infringement of Dutch PIL public policy. Recognition should not be withheld from the foreign divorce when the foreign authority or judge has taken another decision than the Dutch judge would have done. Vonken urges for invoking the public policy exception sparingly if it concerns a request for recognition of a foreign decision of which its underlying law stems from a totally different cultural sphere than the sphere to which Dutch

102 Explanatory Memorandum to Book 10 BW, Kamerstukken II 2009/10, 32 137, No. 3, p. 5 (MvT); see Ibili 2010, p. 7 footnote 26.

103 Apart from the violation of human rights and thus of public policy, a foreign divorce or repudiation can also not be recognized if the recognition infringes upon human rights that are incorporated directly into operating provisions of treaties.

104 Kruiniger 2008, p. 147-148.

105 Kruiniger 2008, p. 148.

106 Kruiniger 2008, p. 148.

107 Kruiniger 2008, p. 150-151. 
and the cognate Occidental laws belong. ${ }^{108}$ A pedantic use of public policy would be somewhat arrogant. ${ }^{109}$

However, one may question the 'added value' of the lex specialis regarding public policy in relation to the recognition of foreign divorces and - in the context of this study - in particular of repudiation-based divorces. ${ }^{110}$ It follows from the previous subsections that recognition of repudiation-based divorces is in principle allowed if the repudiation in the concrete case can stand the test of the requirements of Article 10:57 or 10:58 BW, depending on whether it concerns a repudiation-based divorce established after or without any form of procedure. Whenever one or more of the procedural requirements of Article 10:57 paragraph $1 \mathrm{BW}$ have not been met, paragraph 2 of Article 10:57 provides for a remedying facility of this lack or these lacks in the form of the unequivocal agreement of the other spouse to, or by the acquiescence of the other spouse in, the divorce. In other words, if the requirements of Article 10:57 paragraph $2 \mathrm{BW}$ have been met, there is no violation of the principle of a fair trial or due process. For this reason, the recognition of the repudiation-based divorce, after any form of procedure, cannot infringe upon public policy (or human rights). In such a case, the right to a fair trial or due process cannot be put on trial yet with a plea to the public policy exception.

The unequivocal agreement with or acquiescence in the divorce initiated by the other spouse also represents the consensus between the spouses. ${ }^{111}$ The Dutch legislator deemed the requirement of unequivocal consent to be an 'effective counterbalance' for an infringement upon the principle of equality by the repudiation-based divorce. ${ }^{112}$ As the unequivocal consent of the other spouse can compensate for the infringement on the principle of equality, no violation of public policy (and/or of human rights) in this respect occurs. Because of this consensus between the spouses, the principle of equality between men and women cannot be tested in this case by appealing to the public policy exception.

The requirement of the unequivocal consent of the other spouse can also be found in Article 10:58 BW. ${ }^{113}$ This article expresses the intention of the Dutch legislator to enable the recognition of the foreign divorce brought about by one spouse and lacking any form of legal procedure. An example of this is the unilateral repudiation, despite the fact that such divorce infringes upon the principles of equality between men and women and the principle of a fair trial. If the requirements of Article 10:58 BW - notably the unequivocal agreement with or having acquiesced in the divorce initiated by the other spouse that represents the consensus on the repudiation between the spouses - have been met, this is

108 Vonken 1998, p. 135.

109 Citation by Vonken (1998, p. 135) from Jessurun d'Oliveira 1975, p. 256.

110 Asser 10-II 2012, p. 137-138. Kruiniger 2008, p. 153-154.

111 Explanatory Memorandum to the WCE, Kamerstukken II 1979/80, 16 004, Nos. 3-4, p. 18-19 (MvT). Kruiniger 2008, p. 153.

112 Vonken, Titel 1.9.ipr, Art. 3-27.

113 Kruiniger 2008, p. 155. 
also considered to remedy the violation of these principles. Also in this case, it holds true that an appeal to public policy (and/or human rights) can only be made to address the lack of equality between the spouses when there has been no unequivocal consent to the divorce. $^{114}$

It should also be realized that the Dutch legislator has put the favor divortii principle first in the regulation for recognition of foreign divorces in Book $10 \mathrm{BW}$, in order to further an efficient and fair regulation of private international law matters concerning divorce. ${ }^{115}$ For this reason, the legislator deemed the recognition of unilateral repudiations advisable upon fulfilment of specific requirements, of which the most important one is the unequivocal consent of the other spouse. The fact that the Netherlands did not ratify Article 5 of the 7th Protocol to the ECHR may also support the view that the favor divortii, and thus the recognition of foreign repudiation-based divorces, should be given a clear field in the Netherlands. This article guarantees the equal legal rights and duties of spouses in respect of marriage and the dissolution of marriage. The possibility of invoking the public policy exception is not compatible with these views.

\subsection{Recognition of Repudiations in Dutch Legal Practice}

\subsubsection{Article 2 or Article 3 WCE?}

Although the Dutch legislator had specified the requirements to the recognition of foreign divorces in the WCE, differing opinions about the recognition of the negotiated repudiation, $k h u l$ ', have arisen in legal practice and legal doctrine since the mid-1990s due to political and societal developments. The question was raised whether the recognition of the Moroccan negotiated repudiation, $\mathrm{khul}^{\prime}$, should be assessed pursuant to Article 2 or Article $3 \mathrm{WCE} .{ }^{116}$ An immediate cause for concern was the recognition of the repudiation or the negotiated repudiation, notably by the husband with dual nationality. These new Dutch

114 De Boer (1988, p. 187) has doubts about the solidity of a public policy criterion that can be put aside merely by the consent of the wife (at present the other spouse).

115 Kruiniger 2008, p. 154-155.

116 Burgerzaken en recht 1997, p. 50-51, 104, 226-227; 2001, p. 112 en 236; Jordens-Cotran 2000, p. 215; JordensCotran 2001, p. 290-291; Jordens-Cotran 2002, p. 137-138; Jordens-Cotran 2007, p. 454. Jordens-Cotran (2001, p. 290; 2002, p. 123, 137-38) contends that the recognition of the Moroccan khul' was unproblematic until the mid-1990s. It was recognized pursuant to Art. 2 WCE because of the essential element of mutual consent of the spouses and thus seen as a form of administrative dissolution of the marriage. Research for evidence of this statement in NIPR and Burgerzaken en Recht was unsuccessful, apart from finding a dissenting opinion by Attorney-General Berger in HR 31 October 1986, NJ 1987, 924, p. 3121. In his Opinion, Berger pleaded for recognition of the $\mathrm{khul}^{\prime}$ under Art. 3 WCE since he was of the opinion that the repudiation was underlying the khul'. See for evidence of the recognition of a Thai administrative divorce pursuant to Art. 2 WCE: Rechtbank Amsterdam 6 June 1984, NIPR 1985, 111. 
husbands were expected to have settled down in the Netherlands after their naturalization to such an extent that they would not employ a mode of dissolution of marriage that is considered to be condemnable in Dutch society. The bill about the relaxation of the recognition of repudiations from Minister of Justice Sorgdrager and its withdrawal probably resulted in the hardening of the views about recognition of Islamic divorces. ${ }^{117}$ The (assessment for) recognition of judicial divorces was unproblematic and took place under Article 2 paragraph 1 WCE (at present under Art. 10:57, para. 1 BW).

The Minister of Justice at that time pleaded for the recognition of the Moroccan $\mathrm{khul}^{\mathrm{c}}$ pursuant to Article 3 WCE, since Article 2 WCE dealt with dissolutions of marriage that have been brought about by the decision of a competent judge or other authority. ${ }^{118}$ The NVVB Commission, de Vaste Commissie van advies voor IPR van de NVVB, defended the

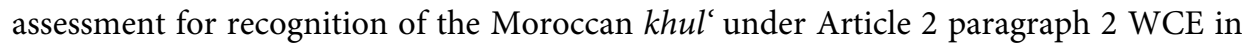
those days. ${ }^{119}$ Its view was that the dissolution of marriage in the case of the khul' was not established by the unilateral declaration of the husband as required by Article $3 \mathrm{WCE}$, but through the mutual consent of the spouses. That Commission also considered the fact that the dissolution of marriage had not been brought about by the decision of the judge or another authority, was remedied by meeting the requirement of consent of the other spouse pursuant to Article 2 paragraph 2 WCE.

Furthermore, recognition of the 'ordinary' Moroccan repudiation was also pleaded pursuant to Article 2 WCE at the time. ${ }^{120}$ The Moroccan Mudawwana of 1993 guaranteed some form of procedure in which the rights of the wife were taken into account to a great extent and the role of the judge had been expanded substantially. Article 3 WCE was not applicable because of its requirement of the dissolution of marriage that lacks any form of procedure. Until the beginning of the 1990s, the Moroccan khul' had been recognized pursuant to Article 2 WCE because of the mutual consent of the spouses. ${ }^{121}$ According to Jordens-Cotran, the recognition was apparent from the fact that legal actions about their recognition were not instituted. ${ }^{122}$

Legal scholars also held different views. Boele-Woelki argued that neither Article 2 paragraph 2 WCE nor Article 3 WCE was fit for the assessment for recognition of the Moroccan $\mathrm{khul}^{\mathrm{c}}{ }^{123}$ She suggested that the assessment for the recognition of the Moroccan

117 Kamerstukken II 1996/97, 24 709. See also Jordens-Cotran 1995 and 1996 and Rutten 1996 about this bill.

118 Van der Velden in: Burgerzaken en Recht 1997, p. 104.

119 Vaste Commissie van Advies voor IPR van de NVVB in: Burgerzaken en Recht 1997, p. 50-51, p. 226-227; 2001, p. 236. The NVVB, Nederlandse Vereniging voor Burgerzaken or the Dutch Association for Civil Status Issues, has a special bureau that advises its municipal members throughout the country about issues that relate to the entire domain of civil status issues, such as issues related to repudiation-based divorces.

120 Plasschaert 2002, p. 883.

121 Jordens-Cotran 2001, p. 290.

122 Jordens-Cotran 2007, p. 456.

123 Boele-Woelki 2000, p. 3971-3972. 
khul' should be submitted if the $k h u l$ ' could not be equalled to the 'ordinary' repudiation, to a similar regulation as for the termination of foreign registered partnerships by mutual consent as proposed by the State Committee for Private International Law, the Staatscommissie voor IPR.

Jordens-Cotran strongly argued in favour of the recognition of the Moroccan $\mathrm{khul}^{\mathrm{c}}$ and repudiation pursuant to Article 2 WCE in those years. She held that the initiative to the $\mathrm{khul}^{\prime}$ by the wife, and her agreement with the repudiation underlying the khul', stood in the way of its assessment for recognition pursuant to Article 3 WCE. ${ }^{124}$ According to her, the recognition of the Moroccan khul ' should be assessed under Article 2 WCE, since the lack of sound procedure and the judicial decision were remedied by the consent of the other spouse. The Moroccan repudiation should be assessed for its recognition under Article 2 WCE because of the increasingly more active role of the Moroccan homologation judge that provides the repudiation with the character of a procedure. ${ }^{125}$ Jordens-Cotran added that it cannot be justified anymore to consider the repudiation as a mode of dissolution that is completely unfamiliar to our Dutch legal order. The Dutch judge cannot block a divorce and his role as 'administrative' inspector differs little from that of the Moroccan judge. In 1987 Bolten already pleaded for the recognition of the Moroccan khul' under Article 2 WCE for similar reasons as Jordens-Cotran. ${ }^{126}$

But Kokkini-Iatridou argued that the khul' should be recognized pursuant to Article 3 WCE since its dissolution is established through the unilateral decision by the man (the repudiation). Article 2 WCE was not applicable since it only dealt with dissolutions of marriage established through the decision of the judge or another authority. ${ }^{127}$ De Boer held the same view that recognition should be permitted under Article 3 WCE because of the dissolution through the repudiation. ${ }^{128}$

\subsubsection{Recognition of Repudiation-Based Divorces in Court}

Case law from that period also demonstrates inconsistency in respect of the recognition of the Moroccan khul'. Sometimes recognition was permitted pursuant to Article 2 WCE and sometimes pursuant to Article 3 WCE. ${ }^{129}$

124 Jordens-Cotran 1991, p. 92.

125 Jordens-Cotran 1995, p. 151.

126 Bolten 1987, p. 60-61.

127 Kokkini-Iatridou 1983, p. 335-338.

128 De Boer 1988, p. 184 in footnote 6; another proponent of recognition pursuant to Art. 3 WCE is ProcuratorGeneral Berger in his legal opinion, in HR 31 October 1986, NJ 1987/924, p. 3121-3122.

129 Also Boele-Woelki 2000, p. 3971-3972; Pellis 2001, p. 1058-1059. 
In 1999 the Amsterdam District Court held that the recognition of the khul' should be assessed pursuant to Article 2 paragraph 2 WCE. ${ }^{130}$ The facts in this case were as follows: ${ }^{131}$ on 17 September 1999, the Dutch-Moroccan K. (hereinafter the man) presents a petition at the Dutch District Court. This petition sets out the relief that the Court will order the registrar to complete the municipal personal records database, the basisadministratie persoonsgegevens (hereinafter GBA), with the registration of his divorce through the Moroccan khul', pursuant to Article 86 GBA Act (Wet gemeentelijke basisadministratie persoonsgegevens). The Advisory committee for objection proceedings GBA had previously rejected the notice of objection on the refusal of the registrar to register this Moroccan $k h u l$ ' in the GBA that the man had lodged in time. For this purpose, the man had submitted an 'acte de repudiation compensatoire' on 28 April 1999 that had been homologated (approved) by the Cadi Notaire, the homologation judge. Two 'udul of the Tribunal de Premiere Instance in Ben Smik - Sidi Othman in Casablanca, Morocco, had drawn up this act in the presence of the authorized representative of the husband on the request of the wife. Hence, the dissolution of marriage concerns a khul' that falls within the ambit of the Moroccan Mudawwana 1993 (Code du Statut Personnel et des Successions).

The Court argues that despite the lack of competence of the Moroccan authorities ${ }^{132}$

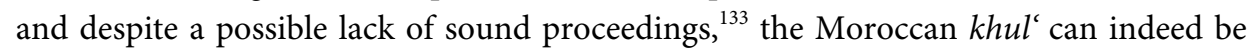
recognized under Article 2 paragraph 2 of the WCE if it is apparent that the other spouse has explicitly or implicitly agreed with or acquiesced in the dissolution after the proceedings. ${ }^{134}$ The Court considers the man to be the other spouse in this case, since it is the wife who requested the acte de répudiation to be drawn up. The Court derived the consent of the husband from his request for recognition of the Moroccan $k h u l{ }^{\text {1.135 }}$

130 Rechtbank Amsterdam 21 December 1999, rekestno. 99.2902 H, No. 4.3-5.

131 Rechtbank Amsterdam 21 December 1999, rekestno. 99.2902 H, No. 1.1-1.6.

132 The Court considers the Moroccan authorities not to be competent since the man has stronger ties with the Netherlands pursuant to Art. 2 of the 1970 Hague Divorce Convention; see Rechtbank Amsterdam 21 December 1999, rekestno. 99.2902 H, at Nos. $3.2 \& 4.2$.

133 With regard to the argument of the registrar that the khul' had not been brought about after sound proceedings, inter alia, since the wife could not prevent the divorce, the Court held that it did not understand this reasoning of the registrar. After all, it was the wife who requested the divorce. In the end the Court presumed that there had been sound proceedings because of the fact that both spouses have been heard. The Court also rejected the argument of the registrar that the $k h u l$ ' had not been validly established in accordance with Moroccan law because of the lack of an attempt for reconciliation. It held that this lack is not of overriding importance because of the mutual consent to the divorce of the spouses. See Rechtbank Amsterdam 21 December 1999, rekestno. 99.2902 H, at Nos. 3.3, 3.4, 4.5, and 4.6.

134 Rechtbank Amsterdam 21 December 1999, rekestno. 99.2902 H, at Nos. 4.3 and 4.4.

135 This is a strange argument. The husband's consent to the khul' can be derived from the khul' act and from his pronouncement of the repudiation as recorded in the repudiation act. 
One year later the The Hague Court of Appeal decides for recognition pursuant to Article 3 WCE in another case. ${ }^{136}$ The Court considers the repudiation to be the essential element of the dissolution of marriage through $k h u l$.

\subsubsection{Hoge Raad 13 July 2001}

The discussion came to an end by the judgment of the Dutch Supreme Court, the Hoge Raad, of 13 July $2001 .{ }^{137}$ It concerned an appeal in the interest of the uniform application of the law lodged by Attorney-General Strikwerda as a result of the aforementioned decision of the Amsterdam District Court in 1999. According to Strikwerda, societal interest in clarity and uncertainty in legal practice about the issue whether such dissolution of marriage should be recognized pursuant to Article 2 or Article 3 WCE demands a decision by the Hoge Raad. ${ }^{138}$

Strikwerda argues that two arguments are decisive for application of either Article 2 or Article 3 WCE: ${ }^{139}$ first, whether some form of procedure has taken place prior to the divorce in which the wife has had the opportunity to be heard, and second, whether a decision from judicial or religious authorities is required in order to be allowed to repudiate or in order to grant legal effect to the repudiation. He concludes that the Moroccan khul does not meet these requirements. ${ }^{140}$ The first requirement of some form of proceedings prior to the divorce is not met since: a) the divorce was directly and irrevocably established through the repudiation; b) the ' $u d u l$ and homologation judge do not have the competence to dissolve marriages; and c) there was no procedure before these authorities. The second requirement that there must be a decision of an authority in order to be allowed to repudiate or to grant legal effect to the divorce is not met since the ' $u d u l$ and homologation judge do not have the competence for such decisions. Strikwerda defends the assessment for recognition of the Moroccan khul' under Article 3 WCE. ${ }^{141}$

As Dutch law should be considered to be the personal law of the man in question, since the Amsterdam District Court concluded that the man has the strongest ties with the Netherlands, Strikwerda furthermore concludes that the requirement of Article 3 sub a WCE has not been met in this case. For this reason, the District Court wrongly judged that there are no objections to recognition. Strikwerda calls for an appeal of the judgment

136 Hof 's-Gravenhage 3 May, NIPR 2000, 175.

137 HR 13 July 2001, NJ 2002, 223.

138 HR 13 July 2001, NJ 2002, 223, at 8.

139 Legal Opinion Strikwerda in: HR 13 July 2001, NJ 2002, 223, at 21. See for a summary of and discussion of his legal opinion Kruiniger 2008, p. 168-175.

140 Legal Opinion Strikwerda in HR 13 July 2001, NJ 2002, 223, at No. 22.

141 Legal Opinion Strikwerda in HR 13 July 2001, NJ 2002, 223, at Nos. 22 \& 24. 
by the Amsterdam District Court, however without prejudice to the vested rights of the person concerned.

The Hoge Raad held that the assessment for recognition of the Moroccan khul' in this case established under the predecessor of the MFC of 2004, the Moroccan Family Code of 1993, must be governed by Article 3 WCE. ${ }^{142}$ The Hoge Raad argued that Moroccan

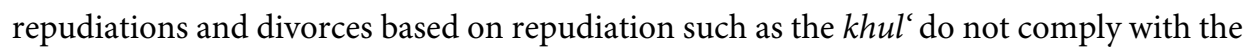
requirements of Article $2 \mathrm{WCE} .{ }^{143}$ First, they are considered to lack a procedure in which the wife has had the opportunity to be heard. The repudiation takes place before two ' $u d u l$ who merely register the repudiation. A procedure before the homologation judge does not exist. Second, it was not a judge or state authority that granted the decision for the dissolution of marriage. The ' $u d u l$ and homologation judge do not have such competence.

The Dutch Supreme Court also decided the issue of the effectiveness test in the case of dual or multi-nationality of the husband. ${ }^{144}$ The Court reminded in this context of the intention of the legislator, as apparent from the Explanatory Memorandum, to pursue to a large extent the recognition of foreign divorce decisions in order to keep limping legal relationships to a minimum. ${ }^{145}$ According to the Hoge Raad, the legislator has therefore enabled the recognition of the repudiation, even the recognition of repudiations under Article 2 as well as under Article 3 upon fulfilment of strict requirements, of which the most important is the consent of the wife. However, the basic principle of the latter is nonrecognition of the repudiation. The requirement of the consent of the wife more or less remedies her unequal position due to the repudiation. It also offers her the opportunity 'to use' the repudiation in order to have the dissolution of marriage recognized as such in the Netherlands.

The Hoge Raad held that in the case of dual nationality or multiple nationalities, the requirement of Article 3 WCE, i.e. that the dissolution is in line with the personal law of the husband, can be satisfied by the law of the nationality even when it is not the effective nationality. The effective nationality usually determines the personal law, but on the requirement of sufficient ties with the other nationality, that nationality may also be considered to be the effective nationality and thus it will determine the personal law. The proximity with the Dutch legal order by the Dutch nationality of the husband should not obstruct recognition. This may not be in the interest of the wife, especially not in the case that she has consented to the repudiation. In a case such as one in which the common nationality of the spouses is the Moroccan nationality, the marriage has been dissolved in accordance with Moroccan law and the consent of the wife is apparent, the Moroccan law, being applicable to the husband, should be considered to be his personal law in the sense

142 HR 13 July 2001, NJ 2002, 223, at HR 3.4.1-5.

143 HR 13 July 2001, NJ 2002, 223, at HR 3.4.2.

144 HR 13 July 2001, NJ 2002, 223, at HR 3.4.3 and 3.4.4; and in legal opinion Strikwerda at 17.

145 HR 13 July 2001, NJ 2002, 223, at No. 3.4.4. 
of Article 3 WCE. From the fact that the spouses met the abovementioned requirements, the Hoge Raad drew the conclusion that the dissolution of their marriage through the $k h u l^{\circ}$ has to be recognized under Article 3 WCE and that the appeal fails. ${ }^{146}$ Consequently, it denied the appeal.

The Hoge Raad decision became a landmark decision for the recognition of the Moroccan $k h u l$ ': the assessment for the recognition of the $\mathrm{khul}^{\text {' }}$ pursuant to Article $3 \mathrm{WCE}$, because of the lack of a decision granting the divorce by the judge or another authority and the lack of a procedure in which the wife has had the opportunity to be heard.

\subsubsection{Litigation Division of the Council of State 3 March 2010}

In 2010 the Litigation Division of the Council of State (Raad van State; in Dutch Afdeling Bestuursrechtspraak van de Raad van State) continued this line of jurisprudence of the Dutch Supreme Court. On 3 March 2010, it confirmed the Rotterdam District Court's rejection of a request for registration in the GBA and thus the recognition of a Moroccan repudiation. ${ }^{147}$ Both courts had assessed the request for recognition by virtue of both the Articles 2 and 3 WCE. These proceedings concerned a Moroccan 'ordinary' repudiation that dated from after the reform of the Moroccan Family Code in 2004.

The facts of this case were as follows: ${ }^{148}$ a Moroccan husband requested for permission to have drawn up the act of repudiation by two ' $u d u l$ at the Moroccan Family Court on 22 June 2006. After failed attempts for reconciliation, the Family Court gave this permission on 15 January 2007 and two ' $u d u l$ drew up the act of (the revocable) repudiation in the presence of the husband on 19 January 2007. The homologation judge approved the act, and subsequently, the Family Court of Taza settled financial provisions and provisions concerning parental authority on 26 February 2007. The Acte de divorce definitive was dated 25 July 2008. Then the Moroccan man requested that the repudiation be registered in the GBA of the municipality of Rotterdam, which was refused by the decision of the bench of Mayor and Aldermen of Rotterdam on 19 May 2008. The Moroccan man lodged an objection on time that was disallowed by the bench of Mayor and Aldermen of Rotterdam on 1 December 2008. The Moroccan man lodged an appeal with the Administrative division of the District Court of Rotterdam that was dealt with in the session of 15 May 2009. He requested the registration of the repudiation in the GBA by the defendant (the bench of Mayor and Aldermen of Rotterdam). ${ }^{149} \mathrm{He}$ argued that the repudiation should be recognized

146 HR 13 July 2001, NJ 2002, 223, at Art. 3.4.5.

147 Afdeling Bestuursrechtspraak Raad van State 3 March 2010, No. 200905642/1/H3, LJN: BL6235, at $<$ www.rechtspraak.nl>.

148 Rechtbank Rotterdam 6 July 2009, AWB 09/70 BESLU-T1, at 1, 2.1; Afdeling bestuursrechtspraak Raad van State 3 March 2010, case No. 200905642/1/H3, LJN: BL6235, at 1, 2.4, 2.4.1; Tomson 2010, p. 120-121.

149 Rechtbank Rotterdam 6 July 2009, AWB 09/70 BESLU-T1, at 2.2. 
pursuant to Article 2 WCE since it concerned a divorce established abroad after a sound procedure or since at least, as far as there is no sound procedure, the requirements of the second paragraph of Article 2 WCE had been met. Furthermore, he argued that the defendant should register the repudiation since the Moroccan divorce had become final by means of a judicial order.

The District Court referred to the decision of the Hoge Raad of 13 July 2001 in its assessment. ${ }^{150}$ It assessed whether the repudiation at issue, ${ }^{151}$ established after the reform of Moroccan family law in 2004, fulfils the criteria of 'a procedure in which the wife has had the opportunity to be heard' and 'a decision for divorce by the judge or another authority'. The court argued that these specific requirements to the assessment for recognition of repudiations pursuant to Article 2 paragraph 1 WCE had not been met. First of all, the dossier would have shown that the wife had not been present at the repudiation nor at the drawing up of the act, had not had the opportunity to be present, nor did she have another opportunity to be heard. Second, the repudiation, and not the decision by the judge or another authority, has brought about the divorce since the judge only checks the correctness of the procedure and not its contents. Subsequently, the Court argued that the requirement of the wife's unequivocal agreement with or having acquiesced in the repudiation pursuant to Article 2 paragraph 2 or Article 3 sub c WCE had also not been met. Her presence at the sessions that were purely aimed at reconciliation should not be seen as (implicit) consent to the repudiation according to the court. The court also referred to the statement by the husband (the plaintiff) that the wife refused to consent due to a quarrel, to support its conclusion. The Court concluded that the defendant, the bench of Mayor and Aldermen, had rightfully refused to register the repudiation in the GBA and that the decision should be upheld. The court disallowed the appeal by the plaintiff. ${ }^{152}$

The husband lodged a higher appeal with the Litigation Division of the Council of State (in Dutch Afdeling Bestuursrechtspraak van de Raad van State) on 30 July $2009 .{ }^{153}$ Under reference to the requirements for the recognition of repudiations pursuant to Article 2

150 Rechtbank Rotterdam 6 July 2009, AWB 09/70 BESLU-T1, at 2.4.

151 The Rotterdam court order mentions once that the dissolution of the marriage at issue concerns a negotiated repudiation or khul' (see Rechtbank Rotterdam 6 July 2009, AWB 09/70 BESLU-T1, at 2.4). It is rather unlikely that it indeed concerns a negotiated repudiation since the text of the court order also refers to a revocable repudiation. If the latter information is correct, the dissolution of the marriage concerns a 'regular' repudiation. The negotiated repudiation is irrevocable. Moreover, the refusal of the wife to consent to the repudiation also refers to a 'regular' repudiation; the negotiated repudiation is initiated by the wife. This initiative should be seen as the consent to the repudiation by the wife. The distinction between repudiation and negotiated repudiation is of vital importance in this case. If the dissolution of marriage was indeed a negotiated repudiation, then at least recognition pursuant to Art. 3 WCE would have been feasible, although I advocate recognition pursuant to Art. 2 WCE. The request of the wife for the repudiation should be seen as the consent of the wife to the divorce, being the most essential requirement of Art. 3 WCE.

152 Rechtbank Rotterdam 6 July 2009, AWB 09/70 BESLU-T1, at 2.4 and 3.

153 Afdeling Bestuursrechtspraak Raad van State 3 March 2010, No. 200905642/1/H3, LJN: BL6235, at $<$ www.rechtspraak.nl>. 
WCE, as formulated by the Hoge Raad on 13 July 2001, the Litigation Division expressed that there is no reason to decide differently about these requirements. ${ }^{154}$ The Litigation Division motivated why it is not apparent that the marriage at issue was dissolved by a decision of a judge or other authority or that the wife had the opportunity to be heard. ${ }^{155}$ The judicial permission does not dissolve the marriage, but allows the husband to continue the repudiation. Furthermore, this permission is a formal requirement that guarantees the undertaking of an attempt for reconciliation and that the husband fulfils his financial obligations resulting from the repudiation. The homologation judge merely checks the correctness of the procedure to draw up the act; the ' $u d u l$ includes the statement of the appellant in the act of repudiation; and the court decision of 26 February 2007 merely includes the financial obligations and provisions about parental authority.

The fact that the wife has been heard during the reconciliation session should not be understood as being heard as another party according to the Litigation Division, since the repudiation itself had not been under discussion during that session. The Litigation Division added that the plaintiff had the duty to show that his or her marriage has been validly dissolved in accordance with its previous decision of 11 November $1999 .{ }^{156}$ According to the Litigation Division, the District Court was correct in considering that the plaintiff had not shown the explicit or implicit consent to the repudiation by the wife. The Acte de divorce définitif of 25 July 2008 does not show this either, since it only includes the statement of the repudiator that the repudiation has become final. The plaintiff had also not shown the consent in another way.

Finally, the Litigation Division concluded that the District Court was correct in deciding that Articles 2 and 3 WCE have not been met, that the argument was unsuccessful, that the higher appeal was without foundation, and that the contested judgment of the District Court should be confirmed. ${ }^{157}$

\subsubsection{Decisions of Courts after 'Hoge Raad 13 July 2001'}

Exploration of case law of other courts after 'Hoge Raad 13 July 2001' showed that these courts assessed the Moroccan repudiation-based divorce at issue under Article 3 WCE and Article 10:58 BW, respectively, in nearly all cases. A selection of that case law that also discusses the grounds for (non-)recognition follows.

154 Afdeling Bestuursrechtspraak Raad van State 3 March 2010, No. 200905642/1/H3, LJN: BL6235, at 2.4.2. 155 Afdeling Bestuursrechtspraak Raad van State 3 March 2010, No. 200905642/1/H3, LJN: BL6235, at 2.4.3.

156 Afdeling Bestuursrechtspraak Raad van State 3 March 2010, No. 200905642/1/H3, LJN: BL6235, at 2.4.4; Afdeling Bestuursrechtspraak Raad van State 11 November 1999, No. H01.98.2024, AB 2000, 3.

157 Afdeling Bestuursrechtspraak Raad van State 3 March 2010, No. 200905642/1/H3, LJN: BL6235, at 2.4.3, $2.4 .4,2.5,3$. 
In 2003 the District Court of Utrecht had to decide about an appeal against a decision upholding the refusal of the registrar to accept the repudiation at stake and thus the refusal to register the latest marriage of the applicant. ${ }^{158}$ The court dismissed the appeal after its conclusion that the Moroccan repudiation that had been established under the Mudawwana of 1993 cannot be recognized due to the lack of consent from the wife pursuant to Article 3 WCE. The consent was not apparent from the act of repudiation or otherwise.

In 2007 the Maastricht District Court, when deciding upon the petition for divorce from a Dutch-Moroccan husband, was confronted with documents concerning the existence of a Moroccan repudiation established in 2005. ${ }^{159}$ According to the husband, the Dutch registrar had refused to register the repudiation. The Court, referring to 'Hoge Raad 13 July 2001', concluded that the documents should have been accepted and recognized and that his civil status should have been modified. For this reason, the Court dismissed the petition for divorce. Instead, the husband should have petitioned the Court to order the registrar to accept and register the repudiation.

In 2008, the Litigation Division of the Council of State upheld the conclusion of the District Court that the Moroccan repudiation could not be recognized because of the lack of (tacit) consent from the wife. Again, her consent was not apparent from the act of repudiation or otherwise. ${ }^{160}$

In 2012, the District Court of The Hague had to decide about a petition for the rectification of the Register of Marriages by cancelling the registration of the Dutch divorce act pursuant to Article 1:24 BW. ${ }^{161}$ The husband claimed that the marriage had already been dissolved by mutual consent in Morocco before the Dutch divorce was established. The Court concluded that the Moroccan repudiation by agreement without conditions could not be recognized pursuant to Article 10:57 BW nor to Article 10:58 BW. The decision from the judge or another authority that dissolves the marriage (first paragraph of Art. 10:57 BW) as well as the consent of the wife (second paragraph of Art. 10:57 BW and Art. 10:58 introduction and sub c, BW) was lacking.

However, in 2003 the District Court of Den Bosch disallowed the petition for divorce by the wife since the marriage had already been dissolved by a Moroccan divorce that had been established under the Mudawwana of 1993 in $2001 .^{162}$ The divorce most likely concerned a repudiation since the husband had submitted, inter alia, a revocable act of divorce. ${ }^{163}$ It is rather unlikely that it concerned a revocable judicial divorce since the only grounds for such a divorce are not providing for maintenance and the oath of abstinence

158 Rechtbank Utrecht 1 May 2003, NIPR 2003, 182 (Reg. No. SBR 02/1001).

159 Rechtbank Maastricht 14 November 2007, NIPR 2008, 31 (LJN: BB7855).

160 Afdeling bestuursrechtspraak Raad van State 21 May 2008, AB 2008, 299, annotated by L.J.A. Damen (LJN: BD2127).

161 Rechtbank 's-Gravenhage 20 February 2012, LJN: BV6671.

162 Rechtbank's-Hertogenbosch 13 May 2003, NIPR 2003, 178 (LJN: AF8914).

163 See also Jordens-Cotran 2007, p. 463 footnote 180. 
or not having intercourse. Referring to all documents that had been submitted by the husband, the court stated that the decision on the divorce had met the requirements of sound proceedings and establishment through the decision of the judge or other authority. It recognized the divorce pursuant to Article 2 WCE.

\subsubsection{The Registrar and Recognition of Repudiation-Based Divorces}

Registrars generally still pursue the line as has been adopted by the Hoge Raad in 2001 by assessing the recognition of Moroccan repudiations or the khul', irrespective of their establishment before or after the Moroccan family law reform in 2004, in accordance with Article 3 WCE before 1 January 2012 and Article 10:58 BW since 1 January 2012.

However, since 2007/2008, the issue of the recognition of Moroccan repudiations, notably established under the MFC of 2004, resurfaced. ${ }^{164}$ Each registrar has his or her own discretion regarding the assessment for recognition of foreign divorces. Some registrars, such as those in Utrecht, started to assess the recognition of Moroccan repudiation or khul pursuant to Article 2 WCE. Furthermore, the objection by the Director Legal Affairs of the Municipality of Amsterdam, following the advice from the Advisory Committee for Objection proceedings in 2007, upheld the recognition of a Moroccan repudiation of 24 August 2004 pursuant to Article 2 WCE. ${ }^{165}$ It was decisive that this Moroccan dissolution of marriage, initiated by the husband, the so-called talaq, can be seen as a judicial decision for the dissolution of the marriage after a sound administration of justice within the meaning of Article 2 section 1 WCE. According to the Advisory Committee for Objection, (1) is it the court that takes the decision to dissolve the marriage, (2) is there a sound administration of justice as (a) the procedure includes so much legal safeguarding that it cannot be seen as a unilateral declaration by the husband within the meaning of Article 3 WCE (meaning that there is a judicial procedure that results in a dissolution of marriage) and (b) there is equality in access to divorce for men and women in Morocco, as the husband has access to the repudiation, whereas the wife has access to the shiqaq. ${ }^{166}$ The qarar or motivated judicial decision and the copie intégrale of the birth certificate of the party involved that proved that the talaq-divorce had become final demonstrated that the talaq-divorce (talaq-scheiding) was a dissolution of the marriage within the meaning of Article 2 WCE.

164 As has been demonstrated by decisions for recognition of repudiations by registrars in Amsterdam and Utrecht in the Netherlands (information obtained by e-mails and fax, in the archives of the author); Gubbels 2008, p. 201.

165 Decision to objection by the Director Legal Affairs of the Municipality of Amsterdam of 10 July 2007.

166 Advice from the Advisory Committee for Objection proceedings in annex to the decision to objection by the Director Legal Affairs of the Municipality of Amsterdam of 10 July 2007, in the archives of the author. 
However, most registrars still argued for recognition under Article 3 WCE, thus pursuing the landmark decision of the Hoge Raad and the 2010 decision of the Litigation Division of the Council of State.

On inquiry in June 2013, Jordens-Cotran mentioned that the registrar in Amsterdam still pursues the same line of assessing repudiation-based divorces for recognition pursuant to Article 10:58 BW. ${ }^{167}$ After lectures by Jordens-Cotran, registrars of some municipalities seemed inclined to adapt their policy to assess for recognition pursuant to Article 10:57 BW. Whether they have actually done this is unknown to Jordens-Cotran. Registrars of other municipalities have stated that they follow the advice from the NVVB Commission, de Vaste Commissie van advies voor IPR van de NVVB. They assess for recognition pursuant to Article 3 WCE or, at present, Article 10:58 BW following the decisions of the Hoge Raad in 2001 and the Litigation Division of the Council of State in 2010. ${ }^{168}$

On inquiry in September 2013, Gubbels mentioned that registrars are rarely confronted with the Pakistani judicial $k h u l$ ' and Iranian repudiation-based divorces. ${ }^{169} \mathrm{He}$ assumed that the Egyptian judicial $\mathrm{khul}^{\text {' }}$ would be assessed for its recognition pursuant to Article 10:57 BW because of the judicial intervention, the request of the wife for divorce, and the lack of need for consent to the dissolution of marriage from the husband.

Gubbels also mentioned that the fact that each registrar, representing the municipality, has his or her own discretion entails that the assessment for recognition of a repudiationbased divorce might vary by municipality. He illustrated this by the example of the registrar of Amsterdam who registered a mubara'a act in the GBA and then the person involved moved to The Hague. The registrar in The Hague has its own discretion to assess for recognition and the source documents underlying the act. If that registrar deems the registration wrongful, he has to demonstrate the wrongfulness of the registration in order to undo its registration and thus its recognition.

Furthermore, Gubbels mentioned that he had not yet faced the situation of being offered an act of a repudiation-based divorce for registration that had already been assessed for its recognition in another EU Member State resulting in its (non-)recognition. He cited a case concerning the adoption of a child from Guatemala by a Turkish-Dutch man in Bahrain. Although a municipality in the Netherlands was not inclined to recognize it at first, it did recognize the adoption because of its prior recognition in Belgium pursuant to Article 23 para. 1 of the Hague Convention on the protection of children and co-operation in respect of intercountry adoption. This article stipulates that 'The measures taken by the

167 E-mail of 3 June 2013 (in the archives of the author) and discussion on 12 June 2013 during the RIMO symposium in Leiden. Dr. L. Jordens-Cotran used to work as a staff lawyer at the Centre for Information and Research of the Register in Amsterdam and was thus well informed about the Amsterdam policy towards recognition of repudiation-based divorces.

168 Tomson 2010, notably p. 121.

169 Conversation by telephone with Eric Gubbels on 20 September 2013. Mr. Gubbels works as advisor of the Adviesbureau Burgerzaken of the municipality in Amsterdam. 
authorities of a Contracting State shall be recognised by operation of law in all other Contracting States' and thus mutual recognition of the Contracting States' measures.

\subsection{Article 10:57 BW and Hoge RaAd 13 July 2001 Revisited}

The Dutch legislator has enabled the recognition of repudiation-based divorces in order to further the favor divortii principle and to prevent limping legal relationships. One should realize that the repudiation is often the one and only modality to dissolve the marriage for men in most Muslim-majority states. The Dutch legislator indicated the requirements for recognition of repudiation-based divorces in two distinct sections in the law. He has created a specific article for those divorces lacking any procedure (previously Article 3 WCE; at present Article 10:58 BW) and enabled recognition for them pursuant to the regular article for divorces, if they are established under supervision or with the cooperation of the judge or another authority and after a procedure under specific conditions (previously Article 2 WCE; at present Article 10:57 BW). The Dutch judiciary has further interpreted these requirements. Are they really clear-cut and do they offer sufficient guidance? Are they applied in a correct manner? Both the legislation and the landmark case law give cause for reflection.

\subsubsection{Article 10:57 BW for Repudiations}

How should Article 10:57 BW be understood in view of the intention of the legislator that can be found in the Explanatory Memorandum to the WCE? ${ }^{170}$ The wording 'dissolution of marriage' should be read as 'dissolution of marriage by means of repudiation'. The requirements of the repudiation-based divorce, as indicated in the Explanatory Memorandum, partly replace the requirements of the dissolution of marriage that are mentioned in the text of Article 10:57 BW. The requirement of the dissolution of 'being acquired abroad' should be retained. The repudiation-based divorce that has been pronounced in the Netherlands will not have any legal effect because of the exclusive right of the Dutch judge to grant a divorce in the Netherlands. The requirement 'after a sound judicial procedure' should be read as 'after some form of judicial procedure' or 'after some form of legal procedure' in the context of the repudiation-based divorce. The Explanatory Memorandum to the WCE requires 'a procedure through which the divorce is established under certain procedural guarantees'. The use of the term 'certain' by the Dutch legislator implies a weakening of the term 'sound'.

170 Kruiniger 2008, p. 137-139. 
The requirement of the establishment of the dissolution of marriage through the decision of a judge or another authority having jurisdiction is more problematic. The establishment of the repudiation is by definition characterized by the (unilateral) declaration by the husband, not or at least not only by the decision of a judge or another authority. Even the judicial repudiation (tatliq) is established through the declaration of the husband or of the judge in his role as substitute for the husband. Yet the Dutch legislator has enabled the recognition of a repudiation-based divorce based on Article 2 WCE, currently Article 10:57 BW, inter alia, if the repudiation has been established with the cooperation or under the supervision of a judge or another authority having jurisdiction. The requirement of a decision (of the judge or another authority) should be broadly understood in the sense of also covering 'cooperation' or 'supervision'. ${ }^{\text {' }}$ These terms should be considered as species of the specific requirement to repudiations 'after some form of procedure'. The terms 'cooperation' or 'supervision' replace the notion of decision. Or it should be understood as meaning that the Dutch legislator, while upholding the term 'decision' as synonymous with 'judgment', has had the intention to cover the repudiation with a procedural character under Article 10:57 BW and thus to create an exception by means of the Explanatory Memorandum. In the case of this interpretation, a 'decision' from the judge or another authority is no longer required. The first interpretation seems most plausible, especially in respect of the legal nature of the (judicial) repudiation-based divorce. Nevertheless, the repudiation should also meet the requirement relating to the competence of the civil or religious authority in order to be recognized.

Accordingly, the text of Article 10:57 section 1 BW in respect of repudiation-based divorces should be understood or read as follows:

A dissolution of marriage by means of the repudiation, acquired abroad after some form of judicial procedure, is recognized in the Netherlands, if it has been brought about with the cooperation or under the supervision of any civil or religious authority that has jurisdiction in the matter.

Although the Dutch legislator kept silent about Article 2 section 2 WCE (at present Art. 10:57 section $2 \mathrm{BW}$ ) in the context of repudiation-based divorces, it seems obvious that this provision remains a remedying facility in relation to the requirement of competence of the judge or of another authority. The requirements of supervision or cooperation of the judge or of another authority and of (some form of) procedure cannot be 'remedied' as these are the essential requirements for the repudiation to fall within the scope of Article

171 See also Mostermans (2003, p. 95) who also upholds a broad interpretation of the term 'decision' in the sense of 'cooperation' or 'supervision'. 
10:57 BW (previously Article 2 WCE). The wording 'dissolution of marriage' should be understood or read as 'dissolution of marriage by means of repudiation'.

\subsubsection{Hoge Raad 13 July 2001: Strikwerda's Legal Opinion}

Two comments on Strikwerda's Legal Opinion demonstrate once more the significance of correct and sufficient information for the correct understanding and assessment of foreign laws and concepts. ${ }^{172}$ First, when discussing the Moroccan $k h u l$ ', Strikwerda refers to the requirement of judicial permission to the husband in order to be allowed to repudiate, but it is misunderstood in its claims with reference to an opinion of Jordens-Cotran. ${ }^{173}$ According to her, this requirement of judicial permission, being the result of the 1993 reform of Moroccan family law, does not influence the fact that the pronouncement of the repudiation by the husband is the constitutive element of the divorce. ${ }^{174}$ However, it was found in chapter 8 that the husband is allowed to have the act of repudiation drawn up and, thus, to repudiate but not until the homologation judge has given his permission. The requirement of judicial permission is thus one of the constitutive elements of the dissolution of marriage and deprives the repudiation of its unilateral character. If Strikwerda would have understood this requirement in a correct manner, it could have led to the conclusion that there is some form of procedure and thus to the conclusion that the recognition of

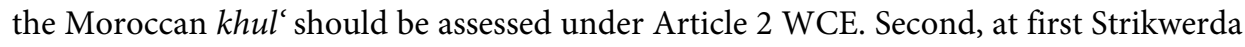
correctly defines the distinctive requirements for recognition under Article 2 or Article 3 WCE. ${ }^{175} \mathrm{He}$ then concludes that the Moroccan $k h u l$ ' does not meet the requirement of 'supervision or cooperation of an authority' in Article 2 WCE that was defined by him as 'the decision of an authority to give permission to repudiate'. If he had had correct and/or sufficient information about this Moroccan legal concept, as well as a sufficient account of the facts of the case by the District Court, then he could have concluded that the khul at issue had met the abovementioned requirement and that its recognition should be assessed under Article 2 WCE instead of Article 3 WCE.

\subsubsection{Hoge Raad 13 July 2001}

Three issues in the decision of the Hoge Raad should be discussed: first, its understanding of Article 2 WCE in the context of repudiation(-based) divorces; second, its view that the basis of the dissolution of marriage through $\mathrm{khul}^{\text {' }}$ is the repudiation; and third, its conclusion

172 See for the full elaboration of my comments Kruiniger 2008, p. 172-175.

173 Legal Opinion Strikwerda in HR 13 July 2001, NJ 2002, 223, at 13.

174 Jordens-Cotran 1995, p. 213.

175 Legal Opinion Strikwerda in HR 13 July 2001, NJ 2002, 223, at 18-22. 
that recognition of the $\mathrm{khul}^{\text {' }}$ should be assessed pursuant to Article 3 WCE instead of

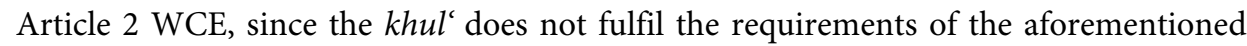
interpretation of Article 2 WCE. ${ }^{176}$

As regards the first concern, the Hoge Raad reads Article 2 WCE for repudiations as follows: ${ }^{177}$

A dissolution of marriage by means of repudiation, acquired abroad after a judicial procedure in some form in which the wife as other party has had the opportunity to be heard, is recognized in the Netherlands, if it has been brought about by the decision from a judge or another authority and if that judge or other authority had jurisdiction in the matter. (emphasis added)

This understanding infringes upon the view and intention of the legislator as expressed in the Explanatory Memorandum to the WCE. The legislator employs the terms 'cooperation' or 'supervision' (that 'provides the repudiation with the character of a procedure through which the divorce is established under certain guarantees') instead of 'decision' ${ }^{178}$ He does not further define or expand on these terms. The legislator has left open the interpretation of these terms in order to enable them to be used in any way as long as it results in some form of procedure that provides the divorce with certain guarantees.

The second concern is the view of the Hoge Raad that the repudiation is the only constitutive element of the dissolution of marriage through $k h u l .{ }^{179}$ The analysis in part I of this study demonstrates that the Moroccan $k h u l$ ' has three constitutive elements: the mutual consent of the parties that is, inter alia, shown by the request for the khul' by the wife; the pronouncement of the repudiation by the husband witnessed by the ' $u d u l$ and its registration in an act; and the permission to this end of the homologation judge (since 2004: the family judge) and, thus, the supervision of the judge. Without judicial consent and supervision, and without the pronouncement of the repudiation in the presence of and its registration by two ' $u d u l$, there is no repudiation. Without repudiation, there is no dissolution of the marriage. And in addition, without the request of the wife, there is no khul'.

The view of the Hoge Raad that is used as base for its assessment for recognition of the

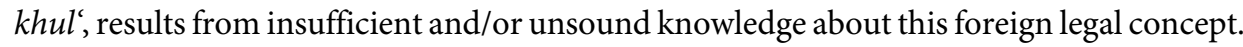
The abovementioned argument already shows that the recognition of the khul'should not be assessed under Article 3 WCE. That article only regards dissolutions of marriage that have exclusively been established by the unilateral statement of the husband, without the

176 See also Kruiniger 2008, p. 178.

177 See also Kruiniger 2008, p. 178-180.

178 Explanatory Memorandum to the WCE, Kamerstukken II 1979/80, 16 004, Nos. 3-4, p. 17 (MvT).

179 See also Kruiniger 2008, p. 180-181; Jordens-Cotran 2007, p. 458. 
cooperation or supervision of any civil or religious authority and without any form of procedure.

The third and last concern relates to the conclusion of the Hoge Raad that the khul does not fulfil the requirements of his understanding of Article 2 WCE. ${ }^{180}$ For this reason, its recognition should be assessed pursuant to Article 3 WCE instead of Article 2 WCE. However, one should realize that the Hoge Raad departs from a requirement that it has newly formulated by filling in the wording of the legislator ('after a procedure in which the wife as other party has had the opportunity to be heard'); from an incorrectly stated requirement (through a decision from the judge or another authority that dissolves the marriage); and that it uses an incomplete description of the function of the ' $u d u l$ and the homologation judge. The occurrence of a procedure in which the wife has had the opportunity to be heard cannot be inferred from that description.

It is useful to address again the relevant elements of the khul' under the Mudawwana of 1993 (hereinafter Mudawwana 1993) that were already discussed in section 8.2.1 in this book. They consist, inter alia, of the following: the request for repudiation to the homologation judge by the wife or by both spouses (including submitting the khul' agreement about the dissolution of marriage and the compensation drawn up by the ' $u d u l$ ); the summons to appear of both spouses; the reconciliation session(-s) during which the homologation judge is able to hear both spouses and the wife can defend her case; the recording of the sessions and the statements of the spouses in the court transcripts; the determination of the mandatory deposit by the homologation judge after (a) failed reconciliation attempt(-s); and, after its payment, the permission for the repudiation and the decision concerning the provisions after divorce by the homologation judge; the pronouncement of the repudiation by the husband before two ' $u d u l$ who will draw up the act of repudiation (that also includes information about, inter alia, the reconciliation session(s), the ground(-s) for the permission for the repudiation and the call to appear, and the presence or not of the wife); the approval of the act of repudiation by the homologation judge; registration of the repudiation (act) at the Registers of Marriage and Divorce at the courts; entitlement of the wife to the original act of repudiation, the husband receives a copy. ${ }^{181}$

This procedure aims to guarantee the rights of the wife and of possible children. In short, the Hoge Raad departs from incomplete and incorrect information and makes use of an incorrect understanding of Article 2 WCE for repudiations while assessing the recognition of the khul'. For this reason, the Hoge Raad wrongly concludes that the assessment for repudiations be according Article 3 WCE instead of Article 2 WCE (for

180 See also Kruiniger 2008, p. 181-183. Also critical about the assessment pursuant to Art. 3 WCE instead of Art. 2 WCE: Jordens-Cotran 2001 and 2002, p. 138-141; Rutten 2003, p. 231-232; Van der Velden 2004a.

181 Notably Arts. 48, 80, and 19 of the Mudawwana 1993 (hereinafter Mud 1993) and Arts. 179 and 180 of the Moroccan Code of Civil Procedure (hereinafter MCCP). 


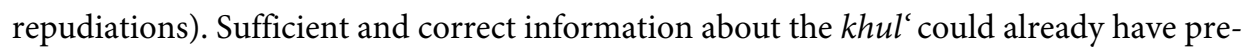
vented this conclusion. Article 3 WCE only addresses divorces exclusively established through the unilateral statement by the husband and without any form of proceedings.

The abolition of the effectiveness test by the Hoge Raad represented a break with some prevailing views in the $1990 \mathrm{~s} .{ }^{182}$ At that time, there was a tendency to equate the $k \mathrm{hul}$ ' to the unilateral repudiation, talaq, in order to render their recognition more difficult in the case of a husband with dual nationality. In this way, their recognition would be assessed under Article $3 \mathrm{WCE}$. When testing against the requirements of Article $3 \mathrm{WCE}$, the $k h u l^{c}$ would fail to meet the requirements for recognition because of Article 3 sub a WCE. The Dutch nationality of the husband would not fulfil the requirement that the dissolution of marriage must be in accordance with the personal law of the husband, since Dutch law

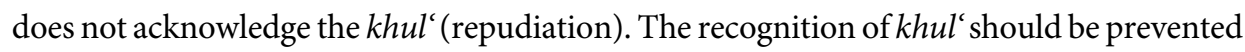
in the case of involvement of a Dutch husband since the repudiation(-based divorce) infringes upon Dutch public policy due to the inequality between men and women. This tendency resulted in limping legal relationships in the cases involved. However, the tendency to prevent the recognition of the $\mathrm{khul}^{\prime}$ in the case of a husband with dual nationality by means of applying the effectiveness test in the 1990s made a 180-degree turn. Instead, the view has become dominant that its recognition should be furthered in the interest of the wife and to prevent limping legal relationships through the abolition of the effectiveness test by the Hoge Raad from that moment on. ${ }^{183}$

\subsubsection{Council of State 3 March 2010}

It is rather unfortunate that subsequently both the Rotterdam District Court and the Litigation Division of the Council of State indiscriminately adopted the two criteria for recognition of repudiations as set by the Hoge Raad in 2001: (1) the decision to grant a divorce by the judge or another authority and (2) the procedure in which the wife as the other party has had the opportunity to be heard. Both courts - and the Hoge Raad at the time - 'misunderstand' (a) the purport of Article 2 WCE for repudiations in respect of the first criterion and (b) the contents of the Moroccan procedure for repudiations since 2004 (already since 1993 in relation to the Hoge Raad) in respect of the second criterion. For these reasons, it is also rather unfortunate that, apparently, the courts did not directly consult and involve in their assessment the Explanatory Memorandum to the WCE.

Sub a: it was already previously discussed why the requirement of a 'decision for divorce by the judge or another authority' is wrongly retained in the context of repudiation-based divorces by the Hoge Raad. First of all, this requirement infringes upon the essence of the

182 See also Kruiniger 2008, p. 158, 183-184. 183 See also Van den Eeckhout 2002, p. 7-8. 
repudiation. It is in principle the husband, by means of his declaration to start with and not the judge or another authority alone, who brings about this type of dissolution of marriage. Second, the Dutch legislator has enabled the recognition of a repudiation-based divorce based on Article 2 WCE, at present Article 10:57 BW, inter alia, if the repudiation has been established with the cooperation of or under the supervision of a judge or another authority. As argued in the subsection about Article 10:57 BW for repudiation-based divorces above, it is most plausible, especially in respect of the legal nature of the repudiation-based divorce, that the requirement of 'decision of the judge or another authority' should be broadly understood as covering 'cooperation' or 'supervision'. The term 'cooperation' or 'supervision' then replaces the notion of decision. ${ }^{184}$

The Moroccan procedure for judicial permission pursuant to the Articles 79-88 MFC 2004 (as well as previously Arts. 48, 80, and 81 Mudawwana 1993 and 179 and 180 MCCP) just fills in this requirement of 'cooperation or supervision of a civil or religious authority' that the Explanatory Memorandum stipulates in the case of recognition of repudiations. The procedure under the supervision of the judge more specifically includes a reconciliation session that offers the wife the occasion to be heard and to defend her case and the settlement of the husband's financial and other obligations towards the wife and children. Nota bene, the authority that tests whether or not the statutory regulations have been met, that attempts reconciliation between the spouses, or that checks whether or not certain financial conditions have been met, has previously been discussed in section 3.4 in this chapter as an example of a civil or religious authority that supervises the dissolution of marriage in the context of Article 2 WCE or Article 10:57 BW for repudiations. ${ }^{185}$

Sub b: the Hoge Raad already departed from a requirement that it has newly formulated through filling in the wordings of the legislator ('after a procedure in which the wife as the other party has had the opportunity to be heard') as has been demonstrated above. Apart from the fact that the Council of State indiscriminately adopts this requirement, it follows from the procedure under the supervision of the Moroccan judge, be it the homologation judge before 2004 or the specialized family judge since 2004 , that the wife is actually heard as the other party and has the opportunity to defend her case. To remind once more, this procedure consists, inter alia, of the following relevant elements: ${ }^{186}$ a summons to appear for the reconciliation attempt(-s) that encompasses guarantees to ensure that both spouses

184 Accordingly, the text of Art. 2 para. 1 WCE, at present Art. 10:57 section 1 BW, in relation to repudiation(s)(based divorces) should be understood or read as follows:

'A dissolution of marriage by means of repudiation, acquired outside the Kingdom of the Netherlands (Art. $3 \mathrm{WCE}$ )/abroad (Art. 10:57 BW) after some form of legal procedure, is recognized in the Netherlands, if it has been brought about with the cooperation or under the supervision of any civil or religious authority that had competence in the matter'.

185 Asser 10-II 2012, p. 132; Tekst \& Commentaar Burgerlijk Wetboek, Boek 10, Artikel 57, No. 2, 2012; Feteris 1984, p. 9.

186 Notably the Arts. 48, 80, \& 81 Mud 1993 and 179, 180 MCCP, respectively, 79-85 MFC 2004. 
including the wife will participate in the reconciliation session(-s) and that she will be informed about the intended repudiation; the reconciliation session(-s) during which the judge is able to hear the spouses and to allow the wife to defend her case; the recording of the sessions and the statements of the spouses in the court transcripts; the determination by the judge of the mandatory deposit to be paid by the husband to guarantee his financial obligations towards wife and children after the failed reconciliation attempt(-s); and, after its payment, the permission for the repudiation; the pronouncement of the repudiation by the husband before two ' $u d u l$ who will draw up the act of repudiation (that also includes information about, inter alia, the reconciliation session(-s), the ground(-s) for the permission to the repudiation and the summons to appear and presence or not of the wife); the homologation (approval) of the act of repudiation by the homologation judge; since 2004: the motivated decision, qarar moeallal, by the family court that includes, inter alia, information about the summons to appear to the spouses, the presence notably of the wife at the procedure, the developments in the procedure including claims and defences of the parties and the provisions after divorce); registration of the repudiation (act) in the birth certificates of the former spouses by the registrar (before 2004 registration in the Register for Marriages and Divorces at the courts); entitlement of the wife to the original act of repudiation, the husband receives a copy.

In regard to the khul', it can be added that, since 2004, the wife is entitled to address the court in the case of disagreement with the husband about the compensation. ${ }^{187}$ If the husband persists in his disagreement and refusal to cooperate with the repudiation, the wife is entitled to petition for judicial divorce on the ground of an irretrievable breakdown. ${ }^{188}$ Moreover, the court has an active role: it checks whether the wife has acted voluntarily in respect of the $\mathrm{khul}^{\text {' }}$ and the content of the compensation. The court may withhold its permission for the divorce in the case of any doubts in this respect, thus preventing the divorce. ${ }^{189}$ The active role contributes to preventing a situation in which the wife is forced

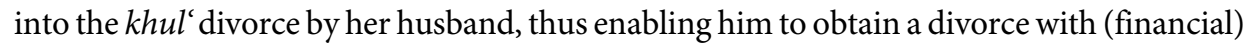
advantages instead of specific financial obligations. Dutch legal practice has previously used such a situation to plea for recognition of the khul' pursuant to Article 3 WCE. This argument should no longer impede the assessment for recognition of the khul' pursuant to Article 10:57 BW in view of the guarantee of the active role of the judge since 2004 .

This procedure aims to guarantee the rights of the wife and of possible children. The Hoge Raad may have had the intention to provide for guarantees concerning these rights by formulating the requirement of hearing the wife as the other party. The husband cannot

187 Art. 120 MFC 2004.

188 Art. 120 in connection with Arts. 94-97 MFC 2004.

189 According to Sarehane in her lecture at the symposium 'Le nouveau Code Marocain de la famille ...' in Brussels on 2 December 2005. 
repudiate until he has received permission from the judge..$^{190}$ The judge will in principle give permission, as the procedure is not intended to set aside the intention of the husband. But the reconciliation attempt has to have failed and the husband has to pay an amount of money at the court's office in advance that the judge has fixed in order to guarantee the husband's compliance with his financial obligations towards his wife and possible children after the divorce. ${ }^{191}$ The wife cannot prevent the repudiation, but it should be realized and this is crucial - that Dutch law also allows any spouse to petition for and to obtain a divorce while the other spouse disagrees with the dissolution of marriage. Both the Moroccan and the Dutch judge supervise that the rights concerning finances, children, housing, etcetera, of the other spouse are guaranteed. And although the Moroccan legislator has maintained the possibility to repudiate in the MFC 2004, the judicial procedure based on the ground of irretrievable breakdown, the shiqaq procedure that either spouse can initiate was also introduced in that Code. ${ }^{192}$ The introduction of this ground for divorce and procedure has counterbalanced the unequal position of men and women due to the repudiation in Moroccan divorce law. And apart from this procedure, the wife also has other possibilities to obtain a divorce. ${ }^{193}$

\subsection{Closing Remarks}

The Dutch legislator has enabled the recognition of repudiation-based divorces established abroad upon fulfilment of specific requirements. This is motivated by the principle of favor divortii and the interests of the wife in recognition of the repudiation, in order to avoid limping legal relationships. Repudiation-based divorces that have been established on Dutch territory as well as transnational divorces of which the pronouncement of the repudiation took place in the Netherlands and other formalities in the country of origin cannot be recognized in the Netherlands because of the exclusive right of the Dutch judge to grant a divorce in the Netherlands as (also) laid down in Article 10:55 BW.

Dutch legislation discerns repudiations established under supervision or with cooperation of the judge or another authority and after some form of procedure (Art. 10:57 BW for repudiations) from repudiations established by the unilateral decision of either spouse and lacking any form of procedure (Art. 10:58 BW). It follows from the Explanatory Memorandum to the WCE that the legislator subjects the assessment for recognition of the first category of repudiations to mainly two requirements: (1) supervision or cooperation

190 Art. 79 MFC.

191 Arts. 83-87 MFC.

192 Arts. 94-97 MFC 2004.

193 Such as the self-repudiation (notably the Arts. $78 \& 89$ MFC 2004), the judicial divorce on other grounds than an irretrievable breakdown (Arts. 98-113 MFC 2004), the repudiation by agreement (Art. 114 MFC 2004), and the negotiated repudiation (Arts. 115-120 MFC 2004). 
of the competent judge or another authority and (2) some form of procedure in order to ensure the establishment of the repudiation under certain guarantees. When the requirement of supervision or cooperation of the competent judge or another authority cannot be met, the fulfilment of the requirement of consent of the other spouse pursuant to Article 10:58 paragraph $2 \mathrm{BW}$ can repair this lack. Four cumulative requirements govern the assessment for recognition of the second category of repudiations. The most important requirement concerns the agreement with or acquiescence in the repudiation by the other spouse.

If recognition of the repudiation in a concrete case nevertheless results in violation of the PIL public order and/or of human rights, that repudiation should be withheld recognition pursuant to Article 10:59 BW. However, the rationale behind and the content of the Dutch regulation concerning the recognition of foreign non-EU divorces in Articles 10:54, 10:57, and 10:58 BW precludes the success of objections to violation of the principles of equality based on gender and of due process. For this reason, a plea of a violation of the PIL public order and/or of human rights cannot succeed once the requirements of Articles 10:57 BW or 10:58 BW have been fulfilled.

Dutch case law, notably the decisions of the Hoge Raad of 13 July 2001 and of the Litigation Division of the Council of State of 3 March 2010, has further shaped Dutch recognition policy in relation to repudiation-based divorces. The courts specify the legislative norm of 'some form of procedure' into 'a procedure in which the wife as the other party has had the opportunity to be heard'. Unfortunately, the courts retain the original requirement of judicial divorces in Article 2 WCE concerning the establishment of the repudiation through the decision of the competent judge or another authority. In doing so, they deviate from the opinion of the legislator and fail to understand the terms 'decision' broadly as 'supervision' or 'cooperation' in respect of repudiations. Obviously, this requirement was not so clear-cut.

If the Litigation Division and the Rotterdam District Court and the Hoge Raad had applied Article 2 WCE to the assessment for recognition of the Moroccan repudiation and the negotiated repudiation, respectively, in accordance with the intention of the legislator, while also using sufficient and correct information about the legal and procedural character of the Moroccan repudiation and negotiated repudiation respectively, then these courts could and should have come to another conclusion. The conclusion that would follow would be that the (negotiated) repudiation fulfilled all the requirements of Article 2 WCE for repudiations and consequently should have been recognized pursuant to this article. Submitting the Moroccan repudiation-based divorce to assessment for recognition pursuant to Article 3 WCE is a result of misunderstanding its legal and procedural character, notably the procedure including the reconciliation attempt(-s) and the supervision of the Moroccan judge. Moreover, it shows a misunderstanding of the essence of the Moroccan khul ${ }^{\text {}}$. The initiative of the wife and the mutual consent of the spouses to the divorce are constitutive 
elements of the khul', next to the pronouncement of the repudiation by the husband and the judicial permission thereto, the latter two being constitutive elements of the repudiation in general. For these reasons, the Moroccan repudiation-based divorce can be characterized as a procedure under the supervision of a (competent) judge in which the parties are heard, and that thus is established under certain guarantees. The Moroccan repudiation, khul', or another repudiation-based divorce modality should not be characterized as a 'unilateral declaration of either spouse', especially not since the reforms in Moroccan family law in 1993 and even more so following the 2004 Moroccan family law reforms.

Although lower or other courts tended and still tend to pursue the same line, that is, the recognition of repudiation-based divorces pursuant to Article 3 WCE and at present Article 10:58 BW, the legal practice of the registrar shows a division in opinion since 2007/2008. Some registrars assessed and still assess repudiation-based divorces for recognition pursuant to Article $3 \mathrm{WCE}$, at present Article 10:58 BW, others pursuant to Article 2 WCE, at present Article 10:57 BW.

Finally, it can be concluded that Dutch recognition policy is based on an approach in concreto as it enables an assessment for recognition of the (repudiation-based) divorce in its concrete circumstances. Dutch legislation offers tools for recognition of a wide range of modalities of repudiation-based divorces, while seeking to respect human rights as well as the principle of favor divortii. However, Dutch case law, being essential for the Dutch legal practice, reveals two major shortcomings: an incorrect application of the legislative norms to the assessment for recognition of repudiation-based divorces and a lack of sufficient and correct understanding of these divorces, resulting in their incorrect characterization and subsequently in a wrongful (non-)recognition or recognition under conditions that are too strict. 


\section{ENGLAND}

\subsection{General Legal Framework}

Mainly two regimes govern the recognition of the validity of foreign (overseas) divorces, legal separations, and annulments by the English courts today: domestic and European law. ${ }^{1}$ England has also ratified the 'Hague Convention on the recognition of divorces and legal separations' of 1970 (hereinafter the 1970 Hague Convention). ${ }^{2}$

Articles 21-22, 24-27, and 46 of the supranational legal instrument Brussels II-bis Regulation $^{3}$ govern the recognition of foreign judgments on the dissolution of marriage, including legal separations and annulments, that have been established by a court or another competent authority in another EU Member State, except for Denmark (hereinafter EU divorces), and for which the legal proceedings were instituted after 1 March 2005; these Articles also govern the recognition of authentic documents concerning the same subjects that were drawn up after 1 March $2005 .{ }^{4}$

1 Throughout the remainder of this section, 'England' is used to signify the countries 'England' and 'Wales'. Accordingly 'English courts' denotes the courts of 'England and Wales' and 'English law' the laws of 'England and Wales'.

2 'The Hague Convention on the recognition of divorces and legal separations' of 1 June 1970; entry into force in England on 24 August 1975. This Convention applies to the recognition in one Contracting State of divorces and legal separations (excluding annulments) obtained in another Contracting State pursuant to Art. 1.

3 Council Regulation (EC) No. 2201/2003 of 27 November 2003 Concerning Jurisdiction and the Recognition and Enforcement of Judgments in Matrimonial Matters and the Matters of Parental Responsibility, O.J. (L 338/1-29); entry into force on 1 March 2005 (except for Denmark; see Recital 31; this instrument is in force in England (the United Kingdom); see Recital 30). See for background information Practice Guide for the application of the new Brussels II Regulation, drawn up by the Commission services in consultation with the European Judicial Network in civil and commercial matters (updated version of 1 June 2005) available at $<$ http://ec.europa.eu/civiljustice/divorce/parental_resp_ec_vdm_en.pdf $>$. The Brussels II-bis Regulation replaced its predecessor the Brussel II Regulation, Council Regulation (EG) No. 1347/2000 of 29 May 2000 Concerning Jurisdiction and the Recognition and Enforcement of Judgments in Matrimonial Matters and Matters of Parental Responsibility for mutual children, PbEG 2000 L 160/19, entry into force on 1 March 2001 (except for Denmark). See also for background information the 'Explanatory Report on the Convention on Jurisdiction and the Recognition and Enforcement of Judgments in Matrimonial Matters' by Dr. A. Borrás, Doc. 98/C 221/04, published in: O.J. (C 221/27) available at <http://eur-lex.europa.eu/LexUriServ/LexUriServ.do?uri=OJ:C:1998:221:0027:0064:EN:PDF>.

4 Pursuant to the substantive, formal, and temporal scopes in, successively, Arts. 1-2, 21, 46, and 64 in connection with Art. 72 Brussels II-bis Regulation. With regard to decisions that have been established after 1 March 2005, but of which its legal proceedings were instituted before 1 March 2005 as well as with regard to decisions that were established before 1 March 2005, see the transitional arrangement in Art. 64 paragraphs 2, 3, and 4 of the Brussels II-bis Regulation. Brussels II-bis Regulation may apply to these decisions if the requirements that are mentioned in Art. 64 have been met. 
Recognition of overseas (EU non-judicial, non-EU, as well as Danish) divorces, annulments, and legal separations in England is exclusively governed by part II of the Family Law Act 1986 (hereinafter FLA 1986) that has been based on the abovementioned 1970 Hague Convention. ${ }^{5}$ Accordingly, recognition of foreign or overseas divorces is mandatory if the requirements of part II FLA 1986 are met and no obstacles to recognition have occurred. ${ }^{6}$ Case law has traditionally influenced matters of recognition of divorces in England. ${ }^{7}$

The FLA 1986 employs the notion of overseas that refers to 'outside the British Isles'. Case law has clarified the definition of 'overseas' divorces as divorces that emanate from a non-English (even a non-British) jurisdiction and that have been established in accordance with the applicable law of the foreign state. ${ }^{9}$ Throughout the remainder of this section about England, the notions 'overseas' and 'foreign' will be used as synonyms. The FLA 1986 makes a fundamental distinction between overseas divorces obtained by proceedings and those obtained other than by means of proceedings in section 46 (1) and section 46 (2) FLA 1986, respectively. Case law has also clarified this distinction, as shall be addressed in the next subsections. It appears that foreign extra-judicial divorces may fall within the scope of either section 46 (1) FLA 1986 or section 46 (2) FLA 1986.

Section 44 (1) FLA 1986 contains a ban on the recognition of extra-judicial divorces obtained in the United Kingdom itself. But any divorce, annulment, or legal separation

5 Family Law Act 1986 (1986 chapter 55), entry into force on 4 April 1988, available at <www.legislation.gov.uk/ukpga/1986/55/contents $>$. This statutory regime applies retrospectively to foreign divorces (and annulments and legal separations), irrespective of whether the divorce was obtained before or after the Act came into force (Section 52 (1) FLA 1986). By virtue of section 45 (1) (b) FLA 1986, other Acts than part II of the FLA 1986 may govern the recognition of overseas divorces, annulments, and legal separations while at the same time, by virtue of section 68 (2), most legislation concerning the same issues has been repealed, and by virtue of section 52 (4) and (5), the validity of divorces shall be recognized under that repealed legislation. The FLA 1986 sought to consolidate the law relating to the recognition of divorces, annulments, and legal separations by replacing and repealing the Recognition of Divorces and Legal Separations Act 1971 (hereinafter the 1971 Recognition Act) that did not include recognition rules about nullity decrees, as well as various provisions of the Domicile and Matrimonial Proceedings Act 1973 (hereinafter Matrimonial Proceedings Act 1973). The 1971 Recognition Act was passed to implement the 1970 Hague Convention (came into force on 1 January 1972), so the FLA 1986 is still based on this Convention. The English court decides whether the foreign proceedings can be understood as divorce, annulment, or legal separation within the meaning of the FLA 1986. Cheshire et al. 2008, p. 986-987, 998, 999; Clarkson \& Hill 2011, p. 432-433; Reed 1996, p. 318-319.

6 The obstacles that are meant here are, for example, procedural deficits or one or more of the statutory grounds for denying recognition in Section 51 FLA 1986.

7 Until 1972, this issue was governed by common law rules, and since then, case law has been complementary to the statutory regulation of the 1971 Recognition Act, the predecessor of the FLA 1986, which was to implement the Convention on the Recognition of Divorces and Legal Separations adopted in 1970 by the Hague Conference on Private International Law. Cheshire et al. 2008, p. 986, 993.

8 Clarkson \& Hill 2011, p. 436.

9 See the cases of $R$ v. Registrar General of Births, Deaths and Marriages, ex parte Minhas [1977] QB 1; $R \mathrm{v}$. Secretary of State for the Home Department, ex parte Fatima [1985] QB 190, [1986] AC 527; Berkovits v. Grinberg [1995] Fam 142; and see Aldeeb Abu-Sahlieh \& Bonomi 1999, p. 193. 
granted by a court or civil jurisdiction in the United Kingdom shall be recognized in the United Kingdom pursuant to section 44(2) FLA 1986.

Section 44 (1) FLA 1986 implies that it is not allowed to establish repudiation-based divorces on English territory because of the exclusive right of the English judge to grant a divorce in England. ${ }^{10}$ Examples include repudiation-based divorces that have been obtained in one of the Sharia Councils or Tribunals in England. The validity of such repudiationbased divorces can also not be recognized under English law. Religious courts can grant religious divorces, but they cannot grant valid legal divorces under English law. ${ }^{11}$ Because of the demand for the application of Islamic family law to Muslims in England from within the Muslim communities themselves, which was triggered by the phenomenon of limping legal relationships, a complex informal network of Muslim dispute settlement fora such as Sharia Councils and Tribunals emerged in England from the early 1980s. ${ }^{12}$ It was found that at least 85 of these Sharia Councils and Tribunals were operating and, inter alia, dealing with divorce in the United Kingdom in 2009. ${ }^{13}$ Confusingly, some media suggested that divorce decisions from Islamic Sharia courts in Britain were 'legally binding' and 'that the Arbitration Act 1996 permitted binding arbitration in family matters' ${ }^{14}$ But most family matters cannot be subject to binding religious arbitration in England. ${ }^{15}$ English law considers divorce to be a matter of family law and a matter of public order as it creates a status in rem affecting third parties, and thus, it is not suitable for arbitration.

\subsection{Recognition of Overseas Divorces Obtained by Proceedings}

The recognition of the validity of the overseas or foreign (EU non-judicial, non-EU, or Danish) divorce (annulment or legal separation) after proceedings is governed by section 46 (1) FLA 1986. Section 46 (1) FLA 1986 must be read in connection with section 54 (1) FLA 1986 as the latter explains that 'proceedings' must be understood as meaning 'judicial or other proceedings'. There is no further definition of 'judicial and other proceedings' in the FLA 1986. Section 46 (3) FLA 1986 explains that the wording 'at the relevant date' in

10 Section 44(1) FLA 1986.

11 Butler-Sloss \& Hill 2013, p. 109; Douglas et al. 2011, p. 18.

12 Nielsen 2013, p. 79-96; Pearl \& Menski 1998, p. 77-80.

13 See the report Sharia law or 'one law for all? of Civitas, the Institute for the study of Civil Society, p. 69, available at <www.civitas.org.uk/pdf/ShariaLawOrOneLawForAll.pdf $>$.

14 Edge 2013, p. 123; see, e.g. 'Islamic sharia courts in Britain are now "legally binding”', in: Mail Online, Daily Mail of 15 September 2008; 'Revealed: UK’s first official sharia courts' in: Times Online, The Sunday Times of 14 September 2008.

15 Edge 2013, p. 121-131. 
section 46 (1) FLA 1986 should be read as 'the date of the commencement of the proceedings. ${ }^{16}$

Sections 46 (1) and 54 (1) FLA 1986 read as follows:

46 Grounds for recognition.

(1) The validity of an overseas divorce, annulment or legal separation obtained by means of proceedings shall be recognized if-

(a) the divorce, annulment or legal separation is effective under the law of the country in which it was obtained; and

(b) at the relevant date either party to the marriage-

(i) was habitually resident in the country in which the divorce, annulment or legal separation was obtained; or

(ii) was domiciled in that country; or

(iii) was a national of that country.

(2) $[\ldots]$

(3) In this section "the relevant date" means-

(a) in the case of an overseas divorce, annulment or legal separation obtained by means of proceedings, the date of the commencement of the proceedings;

(b) $[\ldots]$

(4) Where in the case of an overseas annulment, the relevant date fell after the death of either party to the marriage, any reference in subsection (1) or (2) above to that date shall be construed in relation to that party as a reference to the date of death.

(5) For the purpose of this section, a party to a marriage shall be treated as domiciled in a country if he was domiciled in that country either according to the law of that country in family matters or according to the law of the part of the United Kingdom in which the question of recognition arises.

54 Interpretation of Part II.

(1) In this Part-

[...]

"part of the United Kingdom" means England and Wales, Scotland or Northern Ireland;

"proceedings" means judicial or other proceedings.

16 See also section 47(1) FLA 1986 that requires, in the case of cross-proceedings, that the jurisdictional connection must be satisfied at the date of commencement of either the original proceedings or of the crossproceedings. 
The requirements for the recognition of the validity of overseas divorces after proceedings are the following: the overseas divorce must be effective in the country in which it was obtained and either spouse must be, at the date of the commencement of the proceedings, habitually resident in, domiciled in, or a national of that country. ${ }^{17}$

Section 46 (1) FLA thus provides the following jurisdictional grounds: domicile, habitual residence, or nationality. The notion of domicile in (the entire) section 46 FLA 1986 has to be understood in either the English (common law) sense of that notion or in the sense intended in the foreign law, when it is used in family matters pursuant to section 46(5) FLA $1986 .^{18}$ The notion 'habitual residence' must be interpreted according to English law; it does not have to last for any set period of time. ${ }^{19}$ In the case of a person with dual nationality, the divorce obtained in either country of nationality may qualify for recognition. $^{20}$

It is relevant for deciding about the recognition of the divorce that the foreign court had competence based on one of these jurisdictional grounds. For this reason, the English court has to check and decide whether either party indeed had a connection with the foreign country through habitual residence, domicile (in either the English or the foreign sense of the word), or nationality. Section 48 FLA 1986 deals with providing proof in the case that the foreign court has assumed its jurisdiction in order to prevent English courts from reopening this issue when it has already been decided in a foreign court. ${ }^{21}$ The foreign factfinding is conclusive evidence of the connection, if both parties took part in the proceedings. ${ }^{22}$ If both parties did not take part in the proceedings, the foreign fact-finding is suffi-

17 The notion of 'country' must be understood as the law district counting as country, if recognition of the divorce is sought on the jurisdictional grounds of habitual residence or domicile (Section 49 (1) and (3) FLA 1986); the notion 'country' must be understood as the political state, if recognition of the divorce is sought on the jurisdictional grounds of nationality (Section 49 (1) and (2) FLA 1986); see Cheshire et al. 2008, p. 996-997; Clarkson \& Hill 2011, p. 438.

18 Cheshire et al. 2008, p. 993-994. The concept of domicile used in common law jurisdictions must be distinguished from: (a) the concept of domicile used in civil law jurisdictions; (b) that concept used in EU regulations and international treaties (where the concept of domicile may override the common law sense of 'domicile'); and (c) that concept used in ordinary English usage, respectively. 'Domicile' in common law jurisdictions refers to the place of residence of someone who has the firm intention to live there permanently (equivalent of the permanent home). The concept of domicile in civil law jurisdictions means someone's habitual residence. All UK jurisdictions distinguish between three kinds of domicile: domicile of origin (communicated by operation of law to each person at his or her birth), domicile of choice (when a person has exercised a legal option to change his or her domicile as can be done when attaining majority), and domicile of dependence (applicable to those legally dependent on another person such as some incapable persons, children, or women married before 1974). A person can only have one domicile at any one time, so a person cannot have two or more domiciles. See Cheshire et al. 2008, p. 154-182; Clarkson \& Hill 2011, p. 305-327.

19 Cheshire et al. 2008, p. 994; Clarkson \& Hill 2011, p. 437.

20 Cheshire et al. 2008, p. 995.

21 Cheshire et al. 2008, p. 998; Clarkson \& Hill 2011, p. 439-440.

22 Section 48 (1 sub a), (2), and (3) FLA 1986. 
cient proof of evidence of the connection, unless the other party shows evidence to the contrary. ${ }^{23}$

The notion 'effective' does not necessarily mean 'valid'; it refers to a less strict standard. ${ }^{24}$ Cheshire et al. enumerate various examples of ineffectiveness of a divorce under a foreign law. For example, where the divorce does not 'dissolve a marriage until a specified period has elapsed, or whilst an appeal is pending, or until a decree absolute is pronounced' or where the foreign rules as to serving documents upon the parties or as to the jurisdiction of the court have not been met. ${ }^{25}$

\subsubsection{Extra-Judicial Divorces Obtained by Proceedings}

Section 46 (1) not only deals with overseas divorces obtained by judicial proceedings but also with overseas divorces obtained by other proceedings, more specifically overseas extrajudicial divorces obtained by proceedings. The latter also have to fulfil the requirements of section 46(1) in order to be recognized.

After having originally been very reluctant, England has long accepted the validity of extra-judicial divorces. ${ }^{26}$ The recognition of their validity was not thought to contravene public policy as long as the traditional grounds of recognition under common law were satisfied. These traditional grounds include that the divorce was obtained in the country of domicile of the parties or that the recognition of the divorce is considered to be valid by the law of that country. The Qureshi v. Qureshi case is illustrative of this point. ${ }^{27}$ The case concerned an Indian/Pakistani Muslim couple that had been married in England. The couple was residing in England, while the court held that its domicile was in Pakistan. The husband pronounced the repudiation in England and a reconciliation attempt was made in accordance with the MFLO 1961 at the Pakistan High Commission in Pakistan. The repudiation became effective after 90 days. The English Court of Appeal held that the repudiation should be recognized in England, despite its pronouncement on English territory, as it was valid under the law of the couple's domicile (being Pakistan). The court refused to use its discretion to invoke the public policy exception as the court was of the opinion that this discretion should be used rarely since the reformed English divorce law allowed no-fault divorce without agreement. These grounds even applied in the case of a

3 Sections 48 (1 sub b) and (2) FLA 1986.

4 Clarkson \& Hill 2011, p. 439.

25 Cheshire et al. 2008, p. 996.

26 Carroll 2008, p. 191; Cheshire et al. 2008, p. 1000; Clarkson \& Hill 2011, p. 440-441.

27 Qureshiv. Qureshi [1972] Fam 173, All ER 325; see also Pearl \& Menski 1998, p. 92. 
non-judicial divorce established without proceedings, such as the bare repudiation. ${ }^{28}$ Recognition was refused if either party was domiciled in England. ${ }^{29}$

The common law grounds continued to exist in section 6 of the Recognition of Divorces and Legal Separations Act 1971 (hereinafter the 1971 Recognition Act), the predecessor of the FLA $1986 .{ }^{30}$ In addition, a liberal regime of recognition of extra-judicial divorces obtained after proceedings abroad was introduced in sections 2 and 3 of the 1971 Recognition Act. This regime was based upon the jurisdictional grounds of domicile, habitual residence, or nationality of either spouse in the foreign country and the effectiveness of the divorce under the law of that country. Recognition could be refused because of lack of notice to the other spouse, no reasonable involvement of the other spouse in the proceedings, or a manifest violation of the public order pursuant to section 8 of the 1971 Recognition Act.

However, since 1973, divorces that were obtained out of court anywhere in the British Isles can no longer be recognized in England pursuant to section 16(1) of the Domicile and Matrimonial Proceedings Act 1973 (hereinafter Matrimonial Proceedings Act 1973). ${ }^{31}$ This also concerns repudiation-based divorces, whether or not they were established with proceedings. In this respect, the Matrimonial Proceedings Act 1973 reversed the effect of the Qureshiv. Qureshi case. ${ }^{32}$ Furthermore, a divorce that was obtained abroad by proceedings other than judicial proceedings and that does not meet the requirements of the liberal regime of the sections 2 to 5 in the 1971 Recognition Act also cannot be recognized if both parties have been habitually resident in the United Kingdom pursuant to Article 2 of the Matrimonial Proceedings Act 1973. The aim of these statutory regimes of the 1970s was to prevent husbands from relying on the repudiation (talaq) in their country of origin, instead of on an English divorce, in order to evade the financial consequences of the English divorce, as well as to deny 'the legal effects of any form of extra-judicial divorce executed in Britain'. ${ }^{33}$

Since 1986 extra-judicial divorces have to satisfy the jurisdictional grounds of part II of the FLA 1986 that is still very much based on the 1971 Act. For this reason, it pursues the same policy of denying recognition for extra-judicial divorces executed in England and restricting the recognition of extra-judicial divorces especially of the bare talaq. ${ }^{34} \mathrm{~A}$ proposal by the Law Commission that recommended including acts such as the bare talaq

28 Chaudhary v. Chaudhary [1985] Fam 19.

29 Pearl \& Menski 1998, p. 90.

30 Cheshire et al. 2008, p. 1001; Clarkson \& Hill 2011, p. 441, Pearl \& Menski 1998, p. 87-88.

31 Later re-enacted in section 44 (1) FLA 1986. The Domicile and Matrimonial Proceedings Act 1973 amended the 1971 Recognition Act.

32 Pearl \& Menski 1998, p. 96.

33 Pearl \& Menski 1998, p. 89, 96.

34 Pearl \& Menski 1998, p. 96-99. 
under 'other proceedings' was finally not implemented in the FLA $1986 .{ }^{35}$ Another critique was that the continuation of the jurisdictional grounds of 'domicile' and 'nationality' privileges wealthy long-term residents, allowing them to obtain an extra-judicial divorce in their country of origin and subsequently claim its recognition, thus still circumventing the English courts and laws and their (financial) consequences. ${ }^{36}$ Already before the enactment of the FLA 1986, case law clarified the issue of what could be considered to be (other) proceedings and what not in the context of extra-judicial divorces. ${ }^{37}$

In the Quazi v. Quazi case, the House of Lords found the Pakistani repudiation at issue in that case, which had been obtained under the Muslim Family Law Ordinance 1961 (MFLO 1961), to have been carried out by proceedings. ${ }^{38}$ The pronouncement of the talaq by the husband, the notice thereof to the chairman of the Union Council, and the copy thereof to the wife were the decisive criteria in this respect. For this reason, the repudiation met the requirements of the 1971 Recognition Act and could be recognized. A bare talaq was not considered to constitute proceedings. ${ }^{39}$ They could only be recognized if the common law grounds in section 6 of the 1971 Recognition Act were met. If either party was domiciled in England, the talaq could not be recognized.

The Court of Appeal followed this view and held in Chaudhary v. Chaudhary that a private act, thus an act or 'proceedings' 'conducted entirely by parties inter se or by one party alone', even if there are witnesses, without the intervention of any competent authority, such as the bare talaq, does not constitute 'proceedings ${ }^{40}$ The Family Law Act 1986 nevertheless stipulates a provision in section 46(2) for those types of divorce obtained 'otherwise than by means of proceedings' to enable its recognition. However, such an act or 'proceedings' fall within the ambit of 'proceedings' and thus of section 46(1), since 1986, if it has 'a degree of formality and at least the involvement of some agency, whether lay or religious, or recognized by the state as having a function that is more than simply probative. ${ }^{41}$ One of the judges of the Court of Appeal stated that there must be 'the intervention of some other body or person with a specific function to fulfil'. ${ }^{42}$

The Pakistani repudiation at issue was not recognized under the Divorce Act 1971. It did not meet the requirements of being constituted by means of proceedings since it had been pronounced by the Pakistani husband in a mosque before two witnesses in Kashmir

35 Law commission No. 137, Recognition of Foreign Nullity Decrees and Related Matters (1984) para 6.11, available at <www.scotlawcom.gov.uk/download_file/view/369/>.

36 Pearl \& Menski 1998, p. 98.

37 Cheshire et al. 2008, p. 1005-1007; Clarkson \& Hill 2011, p. 441-444; Pearl \& Menski 1998, p. 90; Reed 1996, p. 322-323.

38 Quazi v. Quazi [1980] AC 744; see also H v. H [2008] 2 F.L.R. 857 in: Arshad 2010, p. 131.

39 Pearl \& Menski 1998, p. 90.

40 Chaudhary v. Chaudhary [1985] Fam 19 at 41; Pearl \& Menski 1998, p. 90-91.

41 Chaudhary v. Chaudhary [1985] Fam 19 at 41.

42 Balcombe J in Chaudhary v. Chaudhary [1985] Fam 19 at 46. 
where the MFLO 1961 was not in force. The presence of the two witnesses was irrelevant since the law did not require the presence of witnesses. Hence, it was a bare talaq.

In $\mathrm{El} \mathrm{Fadl} \mathrm{v.} \mathrm{El} \mathrm{Fadl,} \mathrm{the} \mathrm{Family} \mathrm{Division} \mathrm{of} \mathrm{the} \mathrm{English} \mathrm{court} \mathrm{found} \mathrm{the} \mathrm{Lebanese}$ repudiation at issue in that case to amount to a divorce with proceedings within the meaning of section 46(1) FLA $1986{ }^{43}$ The decisive criteria in this case were the fact that Lebanese Law requires the husband to pronounce the talaq in the presence of two witnesses, the fact that the husband had to register the talaq in the Sharia court, that the Sharia court has formally assembled to identify the (ir-)revocability of the repudiation, and that the court made formal declarations. A judgment of a foreign court that is necessary to validate and confirm a previous bare talaq in accordance with the applicable law can also be considered to constitute 'proceedings'. ${ }^{44}$

The requirements of section 46(1) FLA 1986 allow a person domiciled in England to obtain an extra-judicial divorce in their country of nationality, habitual residence, or domicile (domicile in the sense of the law in the foreign country). Yet in Chaudhary v. Chaudhary, it was found to violate public policy if either spouse went abroad to pronounce the repudiation while both spouses are domiciled in England. ${ }^{45}$ The background was that it should be prevented that those domiciled in England could evade English law by going abroad in order to obtain a divorce, thus avoiding financial consequences. Since the entry into force of part III of the Matrimonial and Family Proceedings Act 1984, this problem has been solved. Now, when recognizing foreign divorces, the English court can make financial relief orders.

From the previous paragraphs, it follows that overseas extra-judicial divorces are governed by section 46(1) FLA 1986 if they are obtained by 'other proceedings'. Overseas extra-judicial divorces that are not obtained by 'other proceedings', but that are obtained 'otherwise than by means of proceedings', may fall within the scope of section 46(2) FLA 1986. The requirements and particularities for these divorces are discussed in the next subsection. Yet Pearl and Menski are critical about allowing this distinction between overseas divorces 'obtained by means of judicial and other proceedings' and overseas divorces obtained 'otherwise than by means of proceedings' in the FLA $1986 .{ }^{46}$ They warn that the distinction has been based upon 'a certain understanding of what the Pakistani and Bangladeshi law on talaq divorces actually' was, but that these laws themselves have changed considerably since then and that 'these changes have not been reflected in the English legislation of $1986{ }^{3}{ }^{47}$

43 El Fadl v. El Fadl [2000] 1 FLR 175.

44 A v. $L$ [2010] 2 FLR 1418.

45 Chaudhary v. Chaudhary [1985] Fam 19 at 39-40, 43-45, 48.

46 Pearl \& Menski 1998, p. 98.

47 Pearl \& Menski 1998, p. 98. 


\subsection{Recognition of Foreign Divorces Obtained without Proceedings}

The requirements for recognition of the validity of the foreign (EU non-judicial and nonEU) divorce obtained 'otherwise than by means of proceedings' appear to be narrower than the requirements for the recognition of foreign divorces obtained by proceedings. ${ }^{48}$

The relevant parts of section 46 read as follows:

46 Grounds for recognition.

(1) $[\ldots]$

2. The validity of an overseas divorce, annulment or legal separation obtained otherwise than by means of proceedings shall be recognized if-

(a) the divorce, annulment or legal separation is effective under the law of the country in which it was obtained;

(b) at the relevant date-

(i) each party to the marriage was domiciled in that country; or

(ii) either party to the marriage was domiciled in that country and the other party was domiciled in a country under whose law the divorce, annulment or legal separation is recognized as valid; and

(c) neither party to the marriage was habitually resident in the United Kingdom throughout the period of one year immediately preceding that date.

(3) In this section "the relevant date" means-

(a) $[\ldots]$

(b) in the case of an overseas divorce, annulment or legal separation obtained otherwise than by means of proceedings, the date on which it was obtained.

(4) $[\ldots]$

(5) For the purpose of this section, a party to a marriage shall be treated as domiciled in a country if he was domiciled in that country either according to the law of that country in family matters or according to the law of the part of the United Kingdom in which the question of recognition arises.

48 The notion 'obtained' in this context differs from the same notion that is used in the context of proceedings and that has to be understood as 'being granted or approved by a third party'. In this context, 'obtained' has to be understood as 'being obtained by reason of legal provision made for it'; Cheshire et al. 2008, p. 10101011. 


\subsubsection{Requirements}

From section 46(2) FLA 1986, it follows that the requirements are the following: the divorce must be effective in the country in which it was obtained, and at the date the divorce was obtained, each party had to be domiciled in that country or either party had to be domiciled in that country, while the other had to be domiciled in a country that recognizes the divorce as valid, and neither spouse should be habitually resident in the United Kingdom for one year preceding that date. ${ }^{49}$ The jurisdictional ground is domicile. The divorce will not be recognized when neither party was domiciled in the country where that divorce was obtained or pronounced. ${ }^{50}$

According to section 46(5) FLA 1986, domicile means domicile in the English sense or in the sense of the law of the foreign country in family matters. The last requirement in section 46(2) FLA 1986 is an 'anti-evasion' criterion in order to prevent circumvention of the ban on obtaining an extra-judicial divorce on English territory. ${ }^{51}$ It responds to the aim of the Family Law Act to restrict access to extra-judicial divorces abroad. This is reinforced by the procedural hurdle of the requirement of documentary evidence of the foreign divorce pursuant to section 51(3)(b) that reads as follows:

51 Refusal of recognition.

(1) $[\ldots]$

(2) $[\ldots]$

(3) $[\ldots]$

(b) in the case of a divorce, annulment or legal separation obtained otherwise than by means of proceedings-

(i) there is no official document certifying that the divorce, annulment or legal separation is effective under the law of the country in which it was obtained; or

(ii) where either party to the marriage was domiciled in another country at the relevant date, there is no official document certifying that the divorce, annulment or legal separation is recognized as valid under the law of that other country;

(4) $[\ldots]$

(5) $[\ldots]$

The court may thus refuse to recognize an overseas divorce without proceedings if there is no official document that certifies either the effectiveness of that divorce under the law

49 Section 46(2) FLA 1986; Cheshire et al. 2008, p. 1010-1012.

50 Arshad 2010, p. 130.

51 Pearl \& Menski 1998, p. 99; Reed 1996, p. 321. 


\section{ISLAMIC DIVORCES IN EUROPE}

of the country in which it was obtained or that certifies that the divorce is recognized as valid under the law of another country, being the country of domicile of either party at the date of commencement of the proceedings.

\subsection{Recognition of Transnational Divorces}

Judge David Pearl already stated in his 'Noel Coulson Memorial Lecture' in 1995: 'In a population accompanied by patterns of migration, people do not arrange their affairs within one country. ${ }^{52}$ It sometimes occurs that some parts of the divorce (proceedings) occur in one country, whereas other parts, often the more formal one(s), occur in another state. ${ }^{53}$ This concerns what is termed transnational divorce. Notably, legal scholars pay explicit attention to this phenomenon in relation to England in the literature extensively. This attention is absent in the Netherlands and in France. For this reason, I will discuss the transnational divorce more in detail in this chapter.

Since extra-judicial divorces obtained in any part of the British Isles cannot be recognized by virtue of section 44(1) FLA $1986,{ }^{54}$ and only overseas extra-judicial divorces can be recognized pursuant to section 46(1) and (2) FLA 1986, it is crucial to determine where the divorce is obtained both in relation to extra-judicial divorces obtained by proceedings and divorces obtained without proceedings. In this context, it is relevant to explain that divorces that are obtained in an embassy or consulate are to be taken as being obtained in the country where that embassy or consulate is located. ${ }^{55}$ But when the main parts or proceedings of the divorce have taken place in the country of origin and the consulate or embassy merely functioned as a registry office that issues the divorce document, the divorce may qualify for recognition as having taken place abroad.

\subsubsection{Transnational Divorces with Proceedings}

An example of a transnational divorce with proceedings is the Fatima case in which the Pakistani husband pronounced the repudiation in England and sent the written notices thereof to the chairman of the local Union Council and his wife in Pakistan where the

52 David Pearl in the 1995 Noel Coulson Memorial lecture The application of Islamic law in the English Courts, available at $<$ www.soas.ac.uk/cimel/materials/coulson-pearl.html $>$.

53 Clarkson \& Hill 2011, p. 446.

54 Except for the exceptions enumerated in subsections 52 (4) and (5) FLA 1986, for example, under common law rules recognized extra-judicial divorces obtained in the British Isles before 1974.

55 Radwan v. Radwan [1973] Fam 24, [1972] 3 All ER 967, [1972] 3 WLR 735, (1972) 116 SJ 424; Cheshire et al. 2008, p. 1004-1005. 
divorce was obtained. ${ }^{56}$ The House of Lords construed the notion of proceedings in section 2(a) and section 3 of the 1971 Recognition Act as meaning 'a single set of proceedings that had to be instituted in the same country as that in which the divorce was ultimately obtained'.$^{57}$ The facts of the case were not in line with this requirement, as the pronouncement of the talaq, part of the proceedings, had taken place in England and the divorce took effect in Pakistan, and thus the entire proceedings had not taken place in the same country. Moreover, as the divorce had partly taken place within the British Isles, the requirement of section 2 of the 1971 Recognition Act that the divorce had to be obtained outside the British Isles had not been met. Consequently, the repudiation was not recognized.

However, as stated above, section 46(1) FLA requires in the case of extra-judicial divorces obtained by proceedings that one of the spouses is habitually resident in, domiciles in, or is a national of the overseas country at the date of commencement of the proceedings and that the divorce must be effective under the law of the country in which it was obtained. The wording of these requirements is slightly different. Under these requirements, the Fatima case could have been entitled to recognition. But it follows from the interpretation of section 46(1) FLA 1986, in the Berkovits v. Grinberg case, that an act or proceedings of an extra-judicial divorce such as the get (Jewish divorce) proceedings at issue in that case, which partly take place in England and partly abroad in Israel, cannot be recognized in England as the 'proceedings must begin and end in the same place'. ${ }^{58}$ In the Berkovits case, the husband had written the get in England and then delivered it to his wife at the Rabbinical Court in Israel, the country of their common nationality, in 1988. Expert evidence showed that the divorce was final upon receipt of the get by the wife, and consequently the divorce was obtained in Israel.

Wall J. of the Family Division of the High Court in London:

Held, dismissing the petition, that a divorce obtained by means of a get was obtained "by means of proceedings" within section 46(1) of the Family Law Act 1986; that the wording of the get was an important part of the proceedings by which the divorce was ultimately obtained; that on the true construction of section 46(1) an overseas divorce would only be recognized if the divorce pro-

$56 R$ v. Secretary of State for the Home Department ex parte Ghulam Fatima [1985] QB 190; [1986] AC 527; 2 WLR 793; 2 FLR 294; see also Cheshire et al. 2008, p. 1002-1004, 1008-1009; Clarkson \& Hill 2011, p. 446447, Hodson 2008, p. 16; Pearl \& Menski 1998, p. 93-94; Reed 1996, p. 324-325. Another case concerns R v. Registrar General ex parte Minhas [1977] Q.B. 1; see Pearl \& Menski 1998, p. 92-92.

$57 R$ v. Secretary of State for the Home Department ex parte Ghulam Fatima, available at <www.religare-database.eu/component/content/article/267>.

58 Berkovits v. Grinberg [1995] Fam 142 (at 142 G-H; 143 A-B ); see also Cheshire et al. 2008, p. 1004 and p. 1007; Clarkson \& Hill 2012, p. 446-447; Hodson 2008, p. 16; Pearl \& Menski 1998, p. 101; Reed 1996, p. 326328. 
ceedings had been instituted in the country where the divorce was obtained, and the mere fact that a divorce was obtained in the sense of "finalised" or "pronounced" in one country could not dissociate the process of obtaining it from the proceedings in which it was obtained; and that, accordingly, since the get had been written in England but delivered in Israel, the English court could not recognise the divorce notwithstanding that it was effective under the law of Israel.

However, the FLA 1986 does not, in so many words, require that the proceedings must have commenced in the country where the divorce was obtained. ${ }^{59}$ Nevertheless, the Judge accepted the argument that it could not have been the intention of parliament to change the law through the FLA 1986, thus allowing the recognition of transnational divorces in England. ${ }^{60}$

The Judge concluded his judgment in Berkovits v. Grinberg by making the following remarks:

I have also come to the conclusion that policy considerations such as those discussed here are properly a matter for Parliament and not for the courts. If, for example, there is a distinction to be drawn between a talaq and a get it is a distinction which Parliament must draw after the full public debate on all the questions of policy which arise. Accordingly, the question as to whether or not in an increasingly multiracial and multi-ethnic society the refusal to recognise the transnational divorce can or should continue is a matter for Parliament, and should not influence my interpretation of the statute. ${ }^{61}$

The position that transnational divorces in which any element of the proceedings takes place in England have to be denied recognition has found support but has also met criticism from legal scholars and in literature. ${ }^{62}$ The main point of criticism in respect of denying recognition to all transnational extra-judicial divorces is that it creates limping legal relationships - being validly divorced in an overseas country but not in England - with all its implications such as having to go abroad to establish a divorce in accordance with one's religion, a hurdle which can only be realized by wealthy spouses and not by financially debilitated spouses. The implication of having to have recourse to the English court and

59 Cheshire et al. 2008, p. 1004; Clarkson \& Hill 2011, p. 447.

60 Berkovits v. Grinberg [1995] Fam 142 (at 156 D-H; 157; 158 A-B).

61 Berkovits v. Grinberg [1995] Fam 142 (at 160 A-B).

62 See, e.g. Cheshire et al. 2008, p. 1004; Pearl 1995, p. 5; but see for the opinion that transnational divorces should be (partly) recognized Cheshire et al. 2008, p. 1004; Clarkson \& Hill 2011, p. 447, Pearl \& Menski 1998, p. 97, 100; Reed 1996, p. 329-337. 
its law in order to obtain a divorce was also suggested as a most preferable remedy by judge Wall in Berkovits v. Grinberg. ${ }^{63}$

\subsubsection{Transnational Divorces without Proceedings}

It follows from the requirements for the recognition of extra-judicial proceedings obtained without proceedings that the issue is where the divorce has been obtained. As a reminder, it is required that each spouse was domiciled in the country where the divorce was obtained on the date on which it is obtained, or that either spouse was domiciled in that country, while the other party was domiciled in a country under whose law the divorce was recognized as valid, and that neither party was habitually resident in the United Kingdom in the year preceding that date. In the case of a bare repudiation, the place where the divorce has been obtained is most likely where the husband has pronounced the repudiation. Accordingly, such divorces are not genuine transnational divorces and can be recognized if the requirements of section 46(2) FLA 1986 have been met.

In Sulaiman v. Juffali, the husband pronounced a triple talaq in England and had registered it at the Sharia court in Saudi Arabia three days later. ${ }^{64}$ This repudiation was held to be obtained in England without court proceedings and thus to be invalid there by virtue of section 44(1) FLA 1986. After all, the effect of the repudiation was to dissolve the marriage upon its pronouncement, and its validity was not dependent upon intervention of judicial authorities.

\subsection{Refusal of Recognition}

The FLA 1986 contains several grounds for the refusal of recognition of foreign non-EU divorces, of which most are discretionary instead of mandatory. ${ }^{65}$ The recognition of foreign non-EU divorces can only be refused on the following grounds.

\subsubsection{Mandatory Grounds for Refusal}

It follows from section 46(1) and (2) that recognition of an overseas divorce, whether or not obtained by means of proceedings, must be refused if the jurisdictional grounds for

63 Berkovits v. Grinberg [1995] Fam 142 (at 160 C).

64 Sulaiman v. Juffali [2002] 2 FCR 427. Cheshire et al. 2008, p. 1003; Clarkson \& Hill 2011, p. 448; Thompson \& Yunus 2009, p. 14-15.

65 Clarkson \& Hill 2011, p. 448. 
recognition have not been met and/or if the divorce is not effective under the law of the country in which it was obtained.

\subsubsection{Discretionary Grounds for Refusal}

Recognition may be refused based on an exclusive number of grounds that are listed in section 51 FLA 1986. This article reads as follows:

51 Refusal of recognition.

(1) Subject to section 52 of this Act, recognition of the validity of-

(a) a divorce, annulment or judicial separation granted by a court of civil jurisdiction in any part of the British Islands, or

(b) an overseas divorce, annulment or legal separation, may be refused in any part of the United Kingdom if the divorce, annulment or separation was granted or obtained at a time when it was irreconcilable with a decision determining the question of the subsistence or validity of the marriage of the parties previously given (whether before or after the commencement of this Part) by a court of civil jurisdiction in that part of the United Kingdom or by a court elsewhere and recognized or entitled to be recognized in that part of the United Kingdom.

(2) Subject to section 52 of this Act, recognition of the validity of-

(a) a divorce or judicial separation granted by a court of civil jurisdiction in any part of the British Islands, or

(b) an overseas divorce or legal separation,

may be refused in any part of the United Kingdom if the divorce or separation was granted or obtained at a time when, according to the law of that part of the United Kingdom (including its rules of private international law and the provisions of this Part), there was no subsisting marriage between the parties.

(3) Subject to section 52 of this Act, recognition by virtue of section 45 of this Act of the validity of an overseas divorce, annulment or legal separation may be refused if-

(a) in the case of a divorce, annulment or legal separation obtained by means of proceedings, it was obtained-

(i) without such steps having been taken for giving notice of the proceedings to a party to the marriage as, having regard to the nature of the proceedings and all the circumstances, should reasonably have been taken; or 
(ii) without a party to the marriage having been given (for any reason other than lack of notice) such opportunity to take part in the proceedings as, having regard to those matters, he should reasonably have been given; or

(b) in the case of a divorce, annulment or legal separation obtained otherwise than by means of proceedings-

(i) there is no official document certifying that the divorce, annulment or legal separation is effective under the law of the country in which it was obtained; or

(ii) where either party to the marriage was domiciled in another country at the relevant date, there is no official document certifying that the divorce, annulment or legal separation is recognized as valid under the law of that other country; or

(c) in either case, recognition of the divorce, annulment or legal separation would be manifestly contrary to public policy.

(4) In this section

"official", in relation to a document certifying that a divorce, annulment or legal separation is effective, or is recognized as valid, under the law of any country, means issued by a person or body appointed or recognized for the purpose under that law;

"the relevant date" has the same meaning as in section 46 of this Act; and subsection (5) of that section shall apply for the purposes of this section as it applies for the purposes of that section.

(5) Nothing in this Part shall be construed as requiring the recognition of any finding of fault made in any proceedings for divorce, annulment or separation or of any maintenance, custody or other ancillary order made in any such proceedings.

These grounds need be considered more in detail. First, some attention has to be paid to the discretion of the court to exercise its right to refuse recognition to an overseas divorce, legal separation, or annulment by virtue of section 51 FLA 1986. This discretion entails that the court may use its discretion not only to refuse recognition but also to recognize such dissolution of marriage. The grounds for refusal in subsection 3 of section 51 demand from the court to have regard for the nature of the proceedings and all relevant circumstances and events of the case at issue in deciding whether or not to refuse recognition. ${ }^{66}$ Not only relevant circumstances and events at the time of the divorce itself but also sub-

66 Clarkson \& Hill 2011, p. 453-454. 
sequent relevant circumstances and events of perhaps even later years can be taken into account.

The first discretionary ground for refusal of recognition in section 51(1) FLA 1986 concerns irreconcilability of the divorce (or annulment or legal separation) with an earlier given judicial decision about the subsistence or validity of the marriage of the parties, or res judicata. ${ }^{67}$ This provision only comes into play because of an earlier decision that was obtained after judicial or other proceedings in England or abroad and that, in the latter case, was recognized or entitled to recognition in England. This provision does not come into play in the case of an earlier extra-judicial decision obtained without proceedings that was recognized in England.

The second ground for refusal of recognition, as mentioned in section 51(2) FLA 1986, concerns the absence of a subsisting marriage at the time that the divorce or the legal separation under recognition (not the annulment) was obtained. ${ }^{68}$ Although there is some overlap with the first ground in section 51(1) FLA 1986, this provision may apply in the case that the marriage is regarded by English law, including its conflicts of law rules, as void ab initio and in the case that the marriage is dissolved by an extra-judicial annulment that is recognized in England.

The third discretionary ground addresses the need for notice of the proceedings to be provided as mentioned in section 51(3)(a)(i) FLA 1986. ${ }^{69}$ The issue here is whether the petitioner spouse has taken reasonable steps to notify the other party about the proceedings concerning the divorce, legal separation, or annulment, taking into account 'the nature of the proceedings and all the relevant circumstances. ${ }^{70}$ This has to be examined according to English standards and has to include a variety of factors such as the issue whether the other party has decided not to take part in the proceedings. There has to be a fundamental breach of natural justice. It is not required that the notice should actually have been received. The recognition should, for example, be refused in the case of fraud of the petitioner. But a decision may be recognized 'if the interests of the spouse denied notice are met by other means ${ }^{71}$ The meagre nature of the proceedings in the case of an extra-judicial divorce does not necessarily result in the refusal of its recognition based on this ground.

The fourth discretionary ground mentioned in section 51(3)(a)(ii) FLA 1986 addresses the requirement of providing an opportunity to take part in the proceedings, taking into account 'the nature of the proceedings and all the relevant circumstances' ${ }^{72}$ The opportunity is not restricted to merely taking part in the proceedings; it has to be an effective opportunity

67 Cheshire et al. 2008, p. 1013-1015; Clarkson \& Hill 2011, p. 448.

68 Cheshire et al. 2008, p. 1015; Clarkson \& Hill 2011, p. 448.

69 Cheshire et al. 2008, p. 1015-1017; Clarkson \& Hill 2011, p. 448-449.

70 Section 51 (3) (a) (i) FLA 1986.

71 Clarkson \& Hill 2011, p. 452-453.

72 Section 51 (3) (a) (ii) FLA 1986; Cheshire et al. 2008, p. 1017-1018; Clarkson \& Hill 2011, p. 449-450. 
that enables a party 'to place views before the court'. ${ }^{73}$ Each party should have this opportunity, but it does not necessarily entail each party's attendance at the proceedings. The fact that a party cannot afford to travel to a foreign country to defend proceedings without his or her own fault is relevant in view of determining whether that party had a reasonable opportunity to take part in the proceedings. Again, the meagre nature of the proceedings in the case of an extra-judicial divorce does not necessarily result in a refusal of its recognition based on this ground.

In the context of the requirements of section 51(3)(a sub i and ii), the $H$ v. $H$ case provides a good example in which the English court recognized the Pakistani repudiation at issue, despite the fact that the wife was domiciled in England and that she had not been notified and neither did she have an opportunity to take part in the proceedings. ${ }^{74}$ In this case, a Pakistani wife petitioned for divorce and wanted ancillary relief in England. This was 17 years after her separation from her husband who had returned to Pakistan and was remarried there. The husband produced various documents, inter alia, a divorce deed of 3 March 1986, a divorce statement certificate from the Chairman of the local Union Council, and a photocopy of a page from a register of cases in the Union Council, in order to obtain recognition of the repudiation from the court, but he did not provide a copy of the notice to the Chairman. ${ }^{75}$ In his decision, the judge relied on passages from the judgment in the El Fadl v. El Fadl case about comity between the nations that required mutual recognition and about the talaq being the prevailing form of divorce in the country of both parties. ${ }^{76}$ The judge exercised his discretion 'to recognise the divorce obtained by the husband in Pakistan in 1987 which was valid from 1 April 1988 ${ }^{77}$ The judge saw no good reasons not to recognize the repudiation especially since: 1) the wife, although being domiciled in England, 'was born, brought up, and married in Pakistan to someone of the same background', and both have family there; 2 ) 'neither party wishes the marriage to continue'; and 3) 'the husband had expressly accepted that the wife has a valid financial claim under Part III of the Matrimonial and Family Proceedings Act 1984 ${ }^{78}$

Section 51(3)(c) provides for the fifth and last discretionary ground upon which recognition can be refused, which is that the recognition of the divorce, legal separation, or annulment would be manifestly contrary to the public order. ${ }^{79}$ 'Manifestly' in this context refers to the fact that the judicial discretion to deny recognition should be exercised

3 Cheshire et al. 2008, p. 1017-1018.

74 H v. H, 12/12/2007, case No. FD05P01494; [2007] EWHC 2945; [2008] 2 FLR 857.

7 v. $H, 12 / 12 / 2007$, case No. FD05P01494 at No. 32.

$6 H$ v. $H, 12 / 12 / 2007$, case No. FD05P01494 at No. 83.

$H$ v. $H, 12 / 12 / 2007$, case No. FD05P01494 at No. 87.

$78 H$ v. $H, 12 / 12 / 2007$, case No. FD05P01494 at Nos. 84 and 86.

79 Cheshire et al. 2008, p. 1018-1023; Clarkson \& Hill 2011, p. 450-454, 455-456. 
'sparingly' ${ }^{80}$ A close or definitive list of issues that can adversely affect the public order does not exist. Already under the common law rules, recognition can be denied on the ground that application of the foreign rule is, in the particular circumstances, contrary to 'the judicial sense of "substantial justice"' ${ }^{81}$ Another example according to the FLA 1986 is fraud, in the sense that one party deceived the other and the foreign court, or institution of the proceedings as the result of duress. Recognition would, for example, be refused in the case that a husband claims recognition of a judgment confirming the pronouncement of repudiation, but the judgment was based on a dishonest statement that the husband had pronounced the repudiation. ${ }^{82}$

Although the older case of Meyer was decided under common law rules and not under the FLA 1986, it is a good example of the refusal of recognition based on a manifest violation of the public order because of proceedings that had been instituted as the result of duress. ${ }^{83}$ In this case, the non-Jewish German wife divorced her Jewish German husband after he had escaped to England during World War II, in order to ensure the survival of the wife and their child in Nazi Germany. After the war, the wife joined her husband in England and they continued to live as husband and wife. Upon the husband's death, the wife was only then entitled to his pension, upon the condition that she was still married to him at the time of his death. The English court declared that the German divorce had been obtained by proceedings instituted under duress and thus could not be recognized because of a violation of the public order.

The court should 'have regard to all surrounding circumstances which would include a full investigation of the facts relied upon to support a refusal of recognition', including, inter alia, an investigation into 'what the likely consequences to the spouses and any children of the family would be if recognition were refused ${ }^{84}$ Also relevant considerations for the exercise of this statutory discretion are the principle of comity, the conduct of the parties leading up to the divorce, and motivation. ${ }^{85}$ Refusal of recognition cannot be based on the fact that the effect of the foreign decision differs from the effect of an English decision.

The situation may occur that one spouse obtains a (extra-judicial) divorce abroad while both spouses are domiciled in England. That spouse may do so to evade English law and its effects and, thus, to deprive the other spouse of her (financial) rights under English law. This cannot be done in relation to the divorce that has been established without proceedings,

80 The notion 'manifest' is used in the FLA 1986 to conform to Art. 10 of the 'the Hague Convention on the recognition of divorces and legal separations' of 1970; the notion 'sparingly' is borrowed from common law.

81 Cheshire et al. 2008, p. 1018, 1021.

82 See $A$ v. $L$ [2010] EWHC 460 Fam); 2 FLR 1418.

83 Res Meyer [1971] P 298.

84 In: Newmarch v. Newmarch [1978] Fam 79 at 95; see Cheshire et al. 2008, p. 1021 and, in the same vein, Clarkson \& Hill 2011, p. 452.

85 Cheshire et al. 2008, p. 1021. 
as the requirements to section 46(2) FLA 1986 prevent its recognition. ${ }^{86}$ It has been suggested that recognition of the divorce obtained after proceedings and under such circumstances should be refused on public order grounds. ${ }^{87}$ In Chaudhary v. Chaudhary, it was indicated that the practice of one spouse going abroad for a divorce, while both spouses are domiciled in England, would be contrary to the public order. ${ }^{88}$ Cheshire et al. states that refusing recognition to all such divorces 'seems to run counter to the policy of parliament, for the legislator does not in terms preclude their recognition nor could it under the 1970 Hague Convention on which the 1986 Act is still based ${ }^{89}$ Moreover, the harmful effect of the other spouse being deprived of her financial rights has been countered by the entry into force of part III of the Matrimonial and Family Proceedings Act 1984, since the English court can make financial relief orders under this Act when recognizing foreign divorces. ${ }^{90}$

The aforementioned grounds are all grounds for refusing to recognize a divorce that has been obtained after judicial and other proceedings, including extra-judicial divorces that were obtained after proceedings. The first two grounds and the latter, as well as the impossibility to certify the legal validity of the divorce by official documents, as mentioned in section $51(3)$ (b sub i or ii), ${ }^{91}$ are grounds for refusing to recognize an extra-judicial divorce obtained without proceedings. ${ }^{92}$

Extra-judicial divorces cannot be refused recognition on public policy grounds merely because of the fact that they have been obtained without judicial proceedings. ${ }^{93}$ As to the unilateral repudiation, as such, the court cannot deny its recognition on public policy grounds because of the mere absence of proceedings as the legislator has provided for its recognition in subsection $46(2)$ FLA. ${ }^{94}$ Its recognition has been restricted by the requirement(s) of domicile of each or either party in the country in which the divorce was obtained and of the domicile of the other party in a country under whose law the divorce is recognized as valid, and the requirement of non-residency of either party in England for one year preceding the date of the repudiation. A possible difficulty may be the lack of an official document to certify that the unilateral repudiation is effective or valid under the foreign law. Several legal scholars suggest that the court will not refuse to recognize the repudiation 'if it is satisfied as to the effectiveness' of the repudiation without any official

86 However, before the enactment of the 1971 Recognition Act, their recognition was not thought to be contrary to the public order. The 1971 Recognition Act was only relevant in relation to divorces obtained by proceedings and did not yet prevent their recognition; see Clarkson \& Hill 2011, p. 441.

87 Cheshire et al. 2008, p. 1022-1023.

88 Chaudhary v. Chaudhary [1985] 2 W.L.R. 350.

89 Cheshire et al. 2008, p. 1023, Clarkson \& Hill 2011, p. 444.

90 Clarkson \& Hill 2011, p. 444; Pearl \& Menski 1998, p. 102.

91 Cheshire et al. 2008, p. 1023-1024; Clarkson \& Hill 2011, p. 456

92 Section 51(3)(b) read with section 46(2) FLA 1986.

93 Cheshire et al. 2008, p. 1022.

94 Clarkson \& Hill 2011, p. 455. 
document, for example, by means of expert evidence. ${ }^{95}$ The court may however refuse recognition on public policy grounds because of the particular circumstances of the case. ${ }^{96}$

\subsection{Closing Remarks}

English law has long accepted foreign extra-judicial divorces, including foreign repudiationbased divorces based on comity under the common law regime. Because of gender-focused and financial considerations, the statutory regimes of the 1970s and the courts since the mid-1970s aimed at preventing husbands from evading the English legal system and its financial consequences by having recourse to a talaq in their country of origin or in England.

The fairly restrictive regime of the FLA 1986 continues this policy of discouragement up until today. It enables the recognition of overseas repudiation-based divorces but upon the fulfilment of specific requirements in section 46 of the Family Law Act 1986. Section 46(1) of the Family Law Act 1986 governs the recognition of the validity of repudiationbased divorces that are obtained after judicial or other proceedings abroad, whereas section 46(2) FLA 1986 governs the recognition of divorces obtained abroad without any proceedings (section 46(2) FLA 1986).

The legislator employs a more liberal regime of recognition for the first group of repudiation-based divorces in section 46(1) FLA 1986 as it is based on the effectiveness of the repudiation under the law of the country in which the divorce was obtained and on the jurisdictional grounds of domicile, habitual residence, and nationality at the time of commencement of the proceedings. At the same time, the legislator has restricted access to the repudiation that lacks proceedings, the bare talaq, because of social and legal concerns about husbands domiciled or residing in England who seek to evade English law and avoid financial orders in favour of the wife. 'Islamic' law does not provide for alimony or division of matrimonial assets upon divorce. Section 46(2) FLA 1986 requires the fulfilment of only one jurisdictional ground, that of domicile of each spouse in the foreign country in which the repudiation was obtained or domicile of either spouse in the foreign country in which the repudiation was obtained, while the other spouse was domiciled in the country under whose law the divorce is recognized as valid at the date the foreign repudiation was obtained.

In addition section 46(2) FLA 1986 requires the effectiveness of the repudiation under the law of that country. It also requires that neither spouse was habitually resident in the United Kingdom in the year preceding the date that the repudiation was obtained. Furthermore, the lack of documentary evidence may lead to a refusal of recognition of the extrajudicial divorce without proceedings pursuant to section 51(3)(b). And it follows from section 44(1), in connection with Article 46(2) FLA 1986, that bare repudiation-based

95 Cheshire et al. 2008, p. 1023-1024; Clarkson \& Hill 2011, p. 456.

96 Cheshire et al. 2008, p. 1022-1023. 
divorces obtained within the English territory cannot be recognized in England. In this respect, the use of the transnational repudiation obtained after proceedings has also been restricted. The Berkovits v. Grinberg case clarified that proceedings must begin and end in the same country in order to qualify for recognition in England. If the proceedings are considered to have taken place in England, they fall foul of the requirements of section 44(1) FLA. Since the place where the transnational bare repudiation has been obtained is usually the place of its pronouncement, this repudiation is not a genuine transnational repudiation. If the bare repudiation was not pronounced in England, it qualifies for recognition pursuant to section 46(2) FLA 1986. Clarkson and Hill rightly note that it is odd 'that such "bare" repudiations involving, if anything, less protection for the rights of wives, should so easily be entitled to recognition' 'given the present denial of recognition to extra-judicial transnational divorces obtained by proceedings' ${ }^{97}$

Denial of recognition of transnational divorces may result in limping legal relationships when the divorce is valid in the foreign country. The argument made in support of allowing the recognition of transnational divorces is to thus avoid this consequence of limping legal relationships. The other argument for allowing recognition is to prevent wealthy husbands from having recourse to the repudiation in their country of origin. Pearl and Menski point out that 'this should happen not in explicit reaction to Muslim demand for separate legal regulation but as a matter of uniform legal policy, i.e. under an umbrella of uniform family law' in order to protect 'members of different communities [...] by one and the same law rather than different legal regimes'. ${ }^{98}$

It follows from the above that recognition of the validity of the repudiation-based divorce must be refused if the requirements for its recognition pursuant to section 46 FLA 1986 and/or case law have not been met. But even if these requirements have been met, the English judge still has the discretion to refuse recognition on a limited number of grounds pursuant to section 51 FLA 1986. This discretion also allows the judge not to refuse recognition. The grounds such as the lack of notice of the proceedings, the requirement of an opportunity to take part in the proceedings, the impossibility to certify the validity of the repudiation with official documents and the manifest violation of the public order are the expression of the desire to protect the position of the Muslim wife in divorce.

The English legal order is in particular confronted with the Pakistani repudiation because of the large number of Pakistanis in England. These repudiations are often recognized as divorces obtained by other proceedings because of the mandatory nature of the notification procedure of section 7 MFLO. However, the developments in Pakistani law have been overlooked, in that not all Pakistani repudiations have been established in

97 Clarkson \& Hill 2011, p. 448.

98 Pearl \& Menski 1998, p. 103. 
accordance with this procedure and the mandatory nature of this notification procedure has not always been upheld. ${ }^{99}$ Hence, such repudiation does not meet the requirements of section 46(1) FLA, and it is nevertheless wrongly recognized, although it may be religiously valid in Pakistan.

In conclusion, it can be said that English recognition policy is based on an approach in concreto as it enables the assessment for the recognition of the (repudiation-based) divorce in its concrete circumstances. As is the case with Dutch legislation, English legislation also offers tools for the recognition of a wide range of modalities of repudiationbased divorces while seeking to respect human rights and in particular seeking to protect the position of (Muslim) women. The protection of the position of Muslim women is sought, inter alia, by a policy of denying repudiation-based divorces, including the transnational variants obtained on English soil, thus preventing the husband from having recourse to repudiation in his country of origin, in order to evade the English legal system and its financial consequences at the expense of his wife, and by providing for financial relief for the wife based on part III of the Matrimonial and Family Proceedings Act 1984, after the recognition of her repudiation-based divorce.

Exploration of the English recognition policy reveals that, inter alia, the Pakistani repudiation is not sufficiently or correctly understood. This shortcoming results in the incorrect characterization of the Pakistani repudiation as a divorce obtained by other proceedings, and subsequently, it results in a wrongful recognition of the divorce under section 46(1) FLA1986.

The denial of recognition of transnational repudiation-based divorces, from the perspective of preventing husbands from having recourse to a repudiation abroad or in England in order to evade the English legal system and its financial consequences and thus to protect the position of women, is paradoxal in two respects. It may result in limping legal relationships that encourage wealthy husbands to still have recourse to repudiation abroad. Furthermore, bare repudiations involving, if anything, less protection for the rights of wives may qualify for recognition, whereas extra-judicial transnational divorces obtained by proceedings are denied recognition.

99 See also Pearl \& Menski 1998, p. 387. 


\section{France}

The French Supreme Court, la Cour de Cassation, in Paris, of which its case law plays a decisive role on the French recognition policy towards repudiation-based divorces.

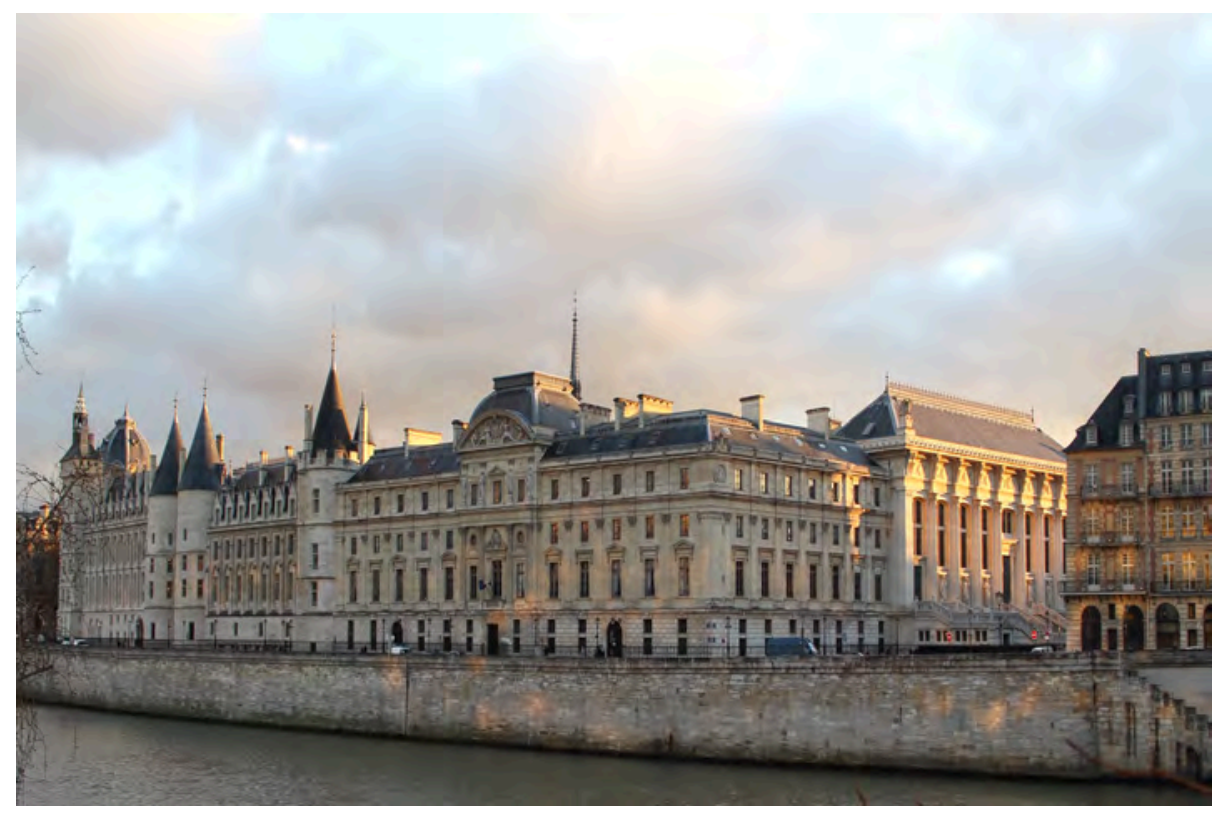

The history of French PIL is characterized by an increasing liberalization of the requirements for the recognition of foreign judicial decisions. Although this statement certainly holds true for foreign judicial decisions concerning the dissolution of marriage, it does not apply to foreign repudiation(-based divorces). This chapter will demonstrate a development in relation to repudiation-based divorces that is rather the opposite of the liberalization of their requirements for recognition. The section below first sets out the general legal framework in relation to recognition of foreign divorce decisions. 


\subsection{General Legal Framework}

Recognition of foreign divorce decisions is framed in domestic, European, as well as international law in France. French domestic private international law governs the recognition of divorce decisions that originate in states outside the European Union (third-state decisions). Not only the influence of French case law but also the influence of numerous bilateral conventions concerning the recognition and execution of judicial decisions and family law in general that France has signed over the years are significant in this respect. Of all these conventions, the Convention d'aide mutuelle judiciaire, d'exequatur des jugements et d'extradition of 1957 between France and Morocco (hereinafter the 1957 FranceMorocco Convention), the Convention relative au statut des personnes et de la famille et $\grave{a}$ la cooperation judiciaire of 1981 between France and Morocco (hereinafter the 1981 FranceMorocco Convention), and the Convention de cooperation judiciaire en matière civile, $y$ compris le statut personnel of 1982 between France and Egypt (hereinafter the 1982 FranceEgypt Convention) are relevant in the context of this study. ${ }^{1}$ This chapter will demonstrate that French authorities apply these bilateral conventions in relation to the recognition of Egyptian and Moroccan divorce judgments and of Moroccan repudiation-based divorces. But it appears that the Moroccan courts in their turn do not always observe these Conventions. ${ }^{2}$ They circumvent their application by invoking the Moroccan public policy exception whenever they consider the provisions in the Conventions to infringe upon Shari' $a$ law as it is codified in Moroccan law.

Articles 21-22, 24-27, and 46 of the supranational legal instrument Brussels II-bis Regulation $^{3}$ govern the recognition of foreign decisions on the dissolution of marriage,

1 Convention d'aide mutuelle judiciaire, d'exequatur des jugements et d'extradition entre le gouvernement de la République Française et le Royaume du Maroc of 5 October 1957, entry into force on 16 December 1959 (1957 France-Morocco Convention on judicial aid); Convention entre la République Française et le Royaume du Maroc relative au statut des personnes et de la famille et a la cooperation judiciaire of 10 August 1981, entry into force on 13 May 1983 (1981 France-Morocco Convention on judicial cooperation); Convention entre la République Française et la République Arabe d’Egypte sur la cooperation judiciaire en matière civile, y compris le statut personnel, et en matière sociale, commerciale et administrative of 15 March 1982, entry into force on 7 August 1983 (1982 France-Egypt Convention).

2 Oral information obtained from Prof. F. van der Velden and confirmed by his e-mail on 3 March 2014 (the e-mail is in the archives of the author).

3 Council Regulation (EC) No. 2201/2003 of 27 November 2003 Concerning Jurisdiction and the Recognition and Enforcement of Judgments in Matrimonial Matters and the Matters of Parental Responsibility, O.J. (L 338/1-29); entry into force on 1 March 2005 (except for Denmark). See for background information Practice Guide for the application of the new Brussels II Regulation, drawn up by the Commission services in consultation with the European Judicial Network in civil and commercial matters (updated version of 1 June 2005) available at $\langle\mathrm{http} / / /$ ec.europa.eu/civiljustice/divorce/parental_resp_ec_vdm_en.pdf $>$. The Brussels II-bis Regulation replaced its predecessor the Brussels II Regulation, Council Regulation (EG) No. 1347/2000 of 29 May 2000 Concerning Jurisdiction and the Recognition and Enforcement of Judgments in Matrimonial Matters and Matters of Parental Responsibility for mutual children, PbEG 2000 L 160/19, entry into force on 1 March 2001 (except for Denmark). See also for background information the Explanatory 
including legal separations and annulments, that have been established by a court or another competent authority in another EU Member State, except for Denmark (hereinafter EU divorces), and of which the legal proceedings were instituted after 1 March 2005, and the recognition of authentic documents concerning the same subjects were drawn up after the aforementioned date. ${ }^{4}$ France has not ratified the 'Hague Convention on the recognition of divorces and legal separations' of $1970 .^{5}$

Before discussing the issues of recognition of foreign judicial divorces and repudiationbased divorces, the notion 'decision' and the French PIL public order need further clarification. The notion 'decision' is being used in a broad sense in this chapter: the decision does not necessarily emanate from a judicial or public authority, but comes at least from an authority that has been given the prerogative to dissolve or to establish the dissolution of a marriage by the foreign state involved. ${ }^{6}$ Any kind of dissolution of marriage established abroad, even without the intervention of an authority, is usually considered to be a public act, even a decision, in France. These are constitutive decisions concerning the status of a person.

In the context of this chapter, it is also important to discuss the French PIL public order. It may manifest itself in different forms dependent on the extent of proximity with the French legal order, so dependent on the links between the legal situation and the French legal order. ${ }^{7}$ The closer these links are, the stronger the demands of French public order may be, according to the requirement of a connection to the forum (ordre public de proximité). The doctrine of the mitigated effect of public policy (effet atténué de l'ordre public), namely, that a distinction is to be made between the reaction of public policy to the effects in France of a right already acquired abroad compared to the reaction of public policy to the effects in France of a right acquired in France, entails that the reaction of French public policy will be weaker and that it does not sanction the violation of fundamental norms and values if the legal situation has no or few links with France because it has regularly

Report on the Convention on Jurisdiction and the Recognition and Enforcement of Judgments in Matrimonial Matters, by A. Borrás, Doc. 98/C 221/04, published in O.J. (C 221/27) available at <http://eurlex.europa.eu/LexUriServ/LexUriServ.do?uri=OJ:C:1998:221:0027:0064:EN:PDF>.

4 Pursuant to the substantive, formal, and temporal scopes in, successively, Arts. 1-2, 21, 46, and 64 in connection with Art. 72 Brussels II-bis Regulation. With regard to decisions that have been established after 1 March 2005, but of which its legal proceedings were instituted before 1 March 2005, as well as with regard to decisions that were established before 1 March 2005, see the transitional arrangement in Art. 64 paras 2, 3, and 4 of the Brussels II-bis Regulation. Brussels II-bis Regulation may apply to these decisions if the requirements that are mentioned in Art. 64 have been met.

5 'The Hague Convention on the recognition of divorces and legal separations' of 1 June 1970, Trb. 1979 No. 131; entry into force in the Netherlands on 22 August 1981. This Convention applies to the recognition in one Contracting State of divorces and legal separations (excluding annulments) obtained in another Contracting State pursuant to Art. 1.

6 Audit 2010, Nos. 454-456; Clavel 2010, No. 700.

7 Clavel 2010, No. 271-283; Joubert \& Gallant 2012, p. 308-309. 
been established abroad. ${ }^{8}$ This doctrine is based on the idea that certain norms and values that are considered to be essential in the French legal order may not legitimately be considered as such in a foreign legal order. In the context of legal diversity and respect for the 'otherness', it is therefore justified to treat foreign cultures with some tolerance.

\subsection{Recognition of Divorce Judgments and Public Acts}

\subsubsection{Automatic Recognition}

French case law sets the general requirements for foreign divorce judgments and public acts to be recognized in France. As an exception to all other foreign judgments and public acts, these decisions concerning the status of a person no longer need an exequatur in order to be recognized, if they meet the requirement of their regularity, since judgment Bulkley of the French Supreme Court (Cour de Cassation). ${ }^{9}$ After all, Article 509 of the French Code of Civil Procedure (Nouveau Code de Procédure Civile, hereinafter NCPC), in the chapter on trans-frontier recognition, stipulates that foreign judgments and public acts are enforceable on the territory of the French Republic in the manner and in the cases provided by law. Hence, French case law has substituted the exequatur requirement for foreign divorce decisions with the mechanism of automatic recognition or recognition $d e$ plano of their most important effects. ${ }^{10}$ This implies that these decisions immediately have legal effect and are considered as res judicata in France, without any legal procedure being required, if they have been regularly established abroad. A legal procedure for recognition may nevertheless be relevant whenever doubts arise about the (ir-)regularity of the divorce decision or to contest the (ir-)regularity of the foreign divorce decision involved. ${ }^{11}$ In France, three different procedures exist in order to confirm or exclude the recognition of a foreign decision: (1) the action en inopposabilité in order to establish that a foreign decision cannot produce any effect in France because it does not meet the requirements for its recognition; (2) the action en opposabilité, a declaratory action, in order to confirm that the foreign decision produces legal effect and has res judicata in France since it meets

8 Judgment Rivière, Cass. lère civ., 17 April 1954, GADIP No. 26, Rev. Crit. DIP 1953, p. 412 (annotated by Battifol); JDI 1953, p. 860 (annotated by R. Plaisant).

9 Judgment Bulkley, Cass. civ., 28 February 1860, DP 1860, 1, p. 57; GADIP, No. 4; S. 1861, 1, p. 210, with conclusion by Dupin. See, in particular for divorce and annulment of marriage, judgment De Wrède, Cass. civ., 9 May 1900, JDI 1900, p. 613; GADIP, No. 10; Clavel 2010, Nos. 391-392, 701. Other types of decisions that are in principle also automatically recognized or recognized de plano are the decisions concerning capacity and constitutive property law decisions. An exequatur is the procedure by which a national court or judge decides whether a judgment originating in another state may be enforced in its or his domestic territory.

10 Clavel 2010, Nos. 391, 292, 411, 412.

11 Clavel 2010, Nos. 413-416. 
all the requirements for its recognition; and (3) the reconnaissance incidente or incidental recognition is the process through which any French judge in a main dispute can establish the recognition of a foreign decision since this decision meets the requirements for its recognition. The exequatur procedure, in order to grant executory force, still remains relevant for foreign judgments and public acts that also include decisions about goods or coercion of persons. ${ }^{12}$ An example in this respect is the foreign divorce judgment that includes a pecuniary sentence against one of the spouses. The other spouse has to go through the exequatur procedure in order for that foreign decision to be recognized in the receiving French legal order.

\subsubsection{Requirements of International Regularity}

The mechanism of automatic recognition presumes that foreign divorce decisions have met the requirements of international regularity unless the irregularity of the foreign decision has been established. ${ }^{13}$ The requirements are the international competence of the foreign court, absence of violation of the public order of the recognizing state, and an absence of evasion of the law. This presumption of regularity enables these divorce decisions, judgments, and public acts to be recognized automatically, thus to have legal effect and to be considered as res judicata. The last requirement for recognition is that the decision must not be irreconcilable with a decision that is already in effect in the French legal order. ${ }^{14}$ In its judgments, De Wrede, Munzer, and Cornelissen, the French Cour de Cassation abolished the requirements of the substantive review of the case (révision au fond) and the

12 Clavel 2010, Nos. 391, 418-424.

13 In its judgment Munzer (Cass. civ. 1ère ch., 7 January 1964, JDI 1964, p. 302, annotated by Goldman; JCP 1964, éd. G, II, 13590, annotated by M. Ancel; Rev. crit. DIP 1964, p. 344, annotated by Battifol), the French Cour de Cassation indirectly confirmed the abolishment of the révision au fond test since its De Wrède judgment in 1900 (Cass. civ., 9 May 1900, JDI 1900, p. 613; GADIP, No. 10) and developed five requirements for regularity. At the outset, these requirements also included the requirements of regularity of the foreign procedure and of the applicable law being in accordance with French conflict rules. The Cour de Cassation had integrated the requirement of regularity of the foreign procedure into the requirement of the foreign procedure to be in conformity with the French procedural public order in its judgment Bachir (Cass. civ. lère 4 October 1967, D. 1968, p. 95, annotated by Mezger; Rev. Crit DIP 1968, p. 98, annotated by P. Lagarde; JDI 1969, p. 102; GADIP, no. 45). The requirement of the test to determine whether the law applicable to the foreign judgment was in accordance with the French conflict rules has been renounced in the Cornelissen judgment from the Cour de Cassation in 2007; that judgment confirms that the foreign judgment should meet three requirements in order to be regular: international competence of the foreign judge, being in conformity with the French international public order, and the absence of fraud (Cass. civ. 1ère ch., 20 February 2007, Rev. Crit. DIP 2007, p. 420, annotated by B. Ancel \& H. Muir Watt; JDI 2007, 1195, annotated by F.-X. Train; D. 2007, 1115, annotated by S. Bollee \& L. D'Avout; JCP G 2007, Act. 107, annotated by C. Bruneau); see also Weltzer, J., Actualité du divorce en droit commun et conventions bilatérales, available at <www-cdpf.u-strasbg.fr/Actualit\%C3\%A9\%20du\%20divorce\%20en\%2 0droit\%20commun.htm>; Clavel 2010, Nos. 396-404, 406, 409, 703; Pertegas 2008, p. 163-164.

14 Clavel 2010, Nos. 417, 703. 
review as to whether the applicable law is in accordance with the French conflict rules. ${ }^{15}$ The first three requirements need further discussion.

The French Cour de Cassation replaced the révision au fond test by an objective assessment of the foreign decision in order to verify its jurisdiction. For this reason, it has specified in its judgment Simitch that a foreign court has international competence from the point of view of the forum (the so-called indirect competence) if three requirements have been met. ${ }^{16}$ First, if the dispute is characteristically connected to the foreign state, for example, through the domicile of the parties, their nationality, the place of execution of the decision, etcetera, or, most preferably, through a combination of such (strong) leads. Second, it is required that the French courts do not have exclusive competence according to their rules of international competence (the so-called direct competence). If the French courts have exclusive international competence, this would imply the non-recognition of decisions emanating from foreign courts. Third, it is required that the choice for the foreign court was not made for fraudulent motives to evade the consequences of a French judgment. Examples of such fraudulent choices would be the situation in which a person deliberately 'creates' the competence of the foreign court through a fictitious domicile in that jurisdiction in order to obtain a divorce that would not have been available under the same circumstances in a French court.

The assessment of the compatibility of the foreign divorce decision with the French international public policy, the second requirement of international regularity, includes two criteria. ${ }^{17}$ The subject matter of that foreign decision must not infringe upon the French international public order, and the foreign decision, in its making, has to respect the requirements of the French procedural public order. ${ }^{18}$ The assessment of the first criterion concerns an in concreto assessment that should not result in a revision au fond test. The judge is only allowed to set aside the foreign decision if its result is really inadmissible from the perspective of the French court (forum) and not if the result simply differs from any result that which the French court would have achieved itself.

15 Judgment De Wrède, Cass. civ., 9 May 1900, JDI 1900, p. 613; GADIP, No. 10; judgment Munzer, Cass. civ. lère ch., 7 January 1964, JDI 1964, p. 302, annotated by Goldman; JCP 1964, éd. G, II, 13590, annotated by M. Ancel; Rev. crit. DIP 1964, p. 344, annotated by Battifol; judgment Cornelissen, Cass. civ. 1ère ch., 20 February 2007, Rev. Crit. DIP 2007, p. 420, annotated by B. Ancel \& H. Muir Watt; JDI 2007, 1195, annotated by F.-X. Train; D. 2007, 1115, annotated by S. Bollee \& L. D’Avout; JCP G 2007, Act. 107, annotated by C. Bruneau.

16 Judgment Simitch, Cass. civ. 1ère ch., 6 February 1980, JDI 1985, p. 460, annotated by Huet; Rev. Crit. DIP 1985, p. 369 annotated by Francescakis; GADIP, No. 42, 66. Clavel 2010, Nos. 397-400.

17 Clavel 2010, Nos. 401-403.

18 The latter criterion is the former separate requirement of international regularity, the requirement of regularity of the foreign procedure, as formulated in judgment Munzer by the Cour the Cassation. In its judgment Bachir, the Cour de Cassation has integrated this criterion in the requirement of the foreign procedure to be in conformity with the French procedural public order. 
Although the separate requirement of the regularity of the foreign procedure has been abandoned, minimum requirements must be met in order not to violate the French procedural public order. ${ }^{19}$ This entails respect for the rights of the respondent such as the respondent's rights to be duly and properly informed about the foreign proceedings and to have had the opportunity to assert his rights before the foreign court, respect for the principle of contradiction, and that grounds were given in the judgment. It follows from the ECHR case Pellegrini v. Italy that any judge in an ECHR member state should examine ex officio whether or not the internationally accepted standards of a sound legal procedure, including human rights, have been observed in the foreign procedure. This is also required in the case of a foreign procedure in a non-member state to the ECHR in the case of recognition of a foreign decision concerning matrimonial matters. ${ }^{20}$

The third requirement of regularity is that there is no evasion of the law. In this sense, evasion of the law is not limited to but rather is broader than a fraudulent choice of a foreign competent court. ${ }^{21}$ It also concerns the evasion of the applicable law through manipulation of the connecting factor in order to change the applicable law.

The foreign decision that does not meet (one of) the requirements of regularity, will not have legal effect, and will not be considered to be res judicata in France. Yet such a decision produces certain effects. It can have probative force and it can also affect a title since the decision concerns a formal finding by a public authority; it can have persuasive effect, as the French judge may take into consideration the foreign decision when giving his own judgment, and it can have de facto effect. ${ }^{22}$

\subsubsection{Recognition of Egyptian and Moroccan Divorce Judgments}

The bilateral 1982 France-Egypt Convention inter alia regulates the recognition of Egyptian divorce judgments in France. The Convention stipulates in Article 25 that Egyptian divorce judgments have ex lege legal effect in France if: (1) the divorce judgment concerns a final and enforceable decision in its state of origin, Egypt; (2) the decision emanates from either an Egyptian court that has jurisdiction in accordance with the French jurisdictional rules or an Egyptian court that is considered to have jurisdiction within the meaning of Article 26 of this Convention; (3) the parties have been notified, represented, or declared to be in default of appearance in a correct way; (4) the decision does not violate the French public order or other French essential interests; and (5) proceedings between the same litigants,

19 Judgment Bachir, Cass. civ. 1ère 4 October 1967, D. 1968, p. 95, annotated by Mezger; Rev. Crit DIP 1968, p. 98, annotated by P. Lagarde; JDI 1969, p. 102; GADIP, No. 45.

20 ECHR 20 July 2001, case 30882/96, RJङD ECHR 2001-VIII; Rev. Crit. DIP 2004, 106, annotated by L.-L Christians.

21 Clavel 2010, No. 404.

22 Clavel 2010, Nos. 425-429. 
based on the same facts and having the same object, are not pending in a French court that was first seized; did not result in a decision made by a French court (and that satisfy the necessary conditions for its recognition); and did not result in a decision made by a court of a third state and that satisfy the necessary conditions for its recognition. ${ }^{23}$ Article 26 of the 1982 France-Egypt Convention indeed specifies the grounds for indirect jurisdiction of the Egyptian court. The most relevant in the context of this study are the grounds of: (1) domicile or habitual residence of the respondent in Egypt at the start of the proceedings or (2) domicile of the respondent in Egypt as a result of a choice in order to expressly submit oneself to the jurisdiction of the Egyptian court. Article 27 stipulates that recognition cannot be denied when application of the law that would have been designated by French conflict rules had the same result as the law that has actually been applied to the divorce by the Egyptian court (not being the law that would have been designated by the French conflict rules). Article 28 prescribes the documents that the party seeking recognition has to produce. The Egyptian divorce judgments that are final (are res judicata) can be registered in the French register of births, deaths, and marriages if French law does not oppose its registration, pursuant to Article 29 of the 1982 France-Egypt Convention.

The bilateral France-Morocco Conventions of 1957 and 1981 regulates the recognition of Moroccan divorce judgments. ${ }^{24}$ These judgments have ex lege legal effect in France if the following requirements have been met: a decision emanating from a competent Moroccan court; a summons to appear served on both spouses, their proper representation, or proper declaration of their non-appearance in court; a final and enforceable decision; and the decision does not infringe the French public order or contradict a former French judgment. ${ }^{25}$ Such judgments can be published or registered at the registrar's office without exequatur. These judgments still need an exequatur when they are used for other purposes, such as the attribution of alimony. ${ }^{26}$

23 Convention entre la République Française et la République Arabe d'Egypte sur la cooperation judiciaire en matière civile, $y$ compris le statut personnel, et en matière sociale, commerciale et administrative of 15 March 1982, entry into force on 7 August 1983 (1982 France-Egypt Convention).

24 Convention d'aide mutuelle judiciaire, d'exequatur des jugements et d'extradition entre le gouvernement de la République Française et le Royaume du Maroc of 5 October 1957, entry into force on 16 December 1959 (1957 France-Morocco Convention); Convention entre la République Française et le Royaume du Maroc relative au statut des personnes et de la famille et a la cooperation judiciaire of 10 August 1981, entry into force on 13 May 1983 (1981 France-Morocco Convention).

25 Art. 16 of the 1957 France-Morocco Convention.

26 Art. 14 of the 1981 France-Morocco Convention in connection with Art. 17 of the 1957 France-Morocco Convention; see also Decroux 1985, p. 74. 


\subsection{Recognition of Repudiation-Based Divorces}

Case law of the Cour de Cassation has played the key role in developing French recognition policy towards repudiation-based divorces over the years. The 1957 France-Morocco Convention and the 1981 France-Morocco Convention are also relevant with regard to the assessment for recognition of homologated (approved) repudiation-based divorces of Moroccan origin. The 1982 France-Egypt Convention does not include any provision concerning the recognition of repudiation-based divorces.

The 1981 France-Morocco Convention includes a specific provision about the recognition of homologated repudiations concerning spouses who both have the Moroccan nationality or concerning a Moroccan husband and a French wife (being the person who demands the recognition). These repudiations will have legal effect in France under the same conditions as foreign divorce judgments if they have been drawn up according to the requirements of Moroccan law. ${ }^{27}$ One should bear in mind that the role of the judge in Morocco since 1993 until 2004 encompasses more than just the passive act of homologation. He has to give permission for the repudiation to the husband but only upon the husband has fulfilled his (financial) duties towards the wife and children. Article 13 of the 1981 France-Morocco Convention does not explicitly or implicitly refer to Article 16 of the 1957 France-Morocco Convention that stipulates the requirements for recognition of Moroccan divorce judgments. The article refers to jugements de divorce prononcés à l'étranger (divorce judgments pronounced abroad). However, the 1981 France-Morocco Convention undoubtedly builds upon the 1957 France-Morocco Convention. For these reasons, the requirements for the recognition of approved repudiation(-based divorces) are probably a combination of the general requirements for recognition of foreign divorce judgments and requirements specific to Moroccan divorce judgments pursuant to Article 16 of the 1957 France-Morocco Convention, as adapted for homologated repudiation(based divorces). These requirements are as follows: (1) a repudiation act drawn up by competent authorities and its homologation by a competent judge; (2) a summons to appear served on both spouses, their proper representation, or proper declaration of their non-appearance in court; (3) a final repudiation(-based divorce); (4) the absence of evasion of law; and (5) no infringement of the French public order or incompatibility with a previous French divorce decision.

Recognition cannot be denied to repudiation as such based on the public policy exception. Decroux, however, is of the opinion that homologated acts of repudiations cannot - as divorce judgments can - be published or registered at the registrar's office

27 Art. 13 of the 1981 France-Morocco Convention. In the case of the mixed couple, this is only possible on the explicit demand of the French wife. See also Decroux 1985, p. 73-74. 
without exequatur, as an exception to Article 14 of the 1981 France-Morocco Convention. ${ }^{28}$ Nevertheless, the French judge has recognized the Moroccan repudiation pursuant to Article 13 of the 1981 France-Morocco Convention, at least until $2004 .{ }^{29}$ In this context, the correctness of the applicable law is also important. Moroccan law has to be considered to be the applicable law if both spouses have the Moroccan nationality. In case the couple is a mixed-nationality couple, Moroccan-French, at the moment of the divorce request, Moroccan law applies if both spouses are domiciled or had their last common domicile in Morocco. ${ }^{30}$

According to French doctrinal opinion, a repudiation that lacks the consent of the wife violates the principle of equality between the spouses upon divorce and thus in principle the French public order. However, the modalities of repudiations based on mutual consent of the spouses or on acquiescence of the wife were assimilated into two forms of divorce by mutual consent acknowledged in French law, at least until $2004 .{ }^{31}$ Consequently, these two modalities of repudiation were recognized through application of the doctrine of the mitigated effect of public policy (l'effet attenué de l'ordre public). It appears to be a different story in the case of the unilateral repudiations established through the mere will of the husband.

\subsubsection{A Variety of Approaches}

Case law of the Cour de Cassation shows a variety of approaches to the unilateral repudiation established through the mere will of the husband, ranging from acceptance to rejection over the years. Before the mid-1970s, an intolerant approach towards repudiations characterized this case law in order to protect fundamental values of French society and in particular to ensure at least a relative equality of men and women during marriage. ${ }^{32}$

During the late 1970s and the 1980s, and inspired by the reform of the French divorce laws, French case law showed a more tolerant and rather liberal approach towards the recognition of repudiations even without consent of the wife. ${ }^{33}$ Invoking the doctrine of the mitigated effect of public policy (l'effet attenué de l'ordre public) could result in recognition of the repudiation that was pronounced in a regular way. ${ }^{34}$ The tolerance, however,

28 Decroux 1985, p. 74.

29 Rude-Antoine 2009, p. 189.

30 Art. 9 of the 1981 France-Morocco Convention.

31 Aldeeb Abu Sahlieh \& Bonomi 1999, p. 199; Audit 2010, No. 689.

32 Clavel 2010, No. 704.

33 Aldeeb Abu Sahlieh \& Bonomi 1999, p. 199; Audit 2010, No. 689; Clavel 2010, No. 704; Joubert \& Gallant 2012, p. 319; Lemontey 2008, 64-65.

34 Judgment Rohbi, Cass. 1ere civ. 3 November 1983, GADIP No. 63, Rev. Crit. DIP 1984, 325 (annotated by I. Fadlallah); JDI 1984, 329 (annotated by Ph. Kahn); Cass. 1ère civ., 8 December 1987, Rev. crit. DIP 1989, p. 733 (annotated by Niboyet-Hoegy); Cass. 1ère civ., 6 July 1988, JDI 1989, p. 63. The latter two cases concern 
depended on the circumstances in which the repudiation had been pronounced. The repudiation was recognized when the choice for the foreign court had not been made with fraudulent motives; when the spouses, and in particular the wife, had been enabled to assert their rights and claims in a form of procedure; when the wife could enjoy sufficient financial guarantees; ${ }^{35}$ and when the wife herself had demanded for recognition of the repudiation. ${ }^{36}$ Recognition was refused when the case had been closely connected to the French legal order, for example, because of the French nationality of the husband or both spouses, and/or in the case of fraud, where the recognition was deemed to violate French public order. ${ }^{37}$

The more tolerant and liberal approach through invoking the doctrine of the mitigated effect of public policy (l'effet attenué de l'ordre public) evoked criticism in the legal doctrine. ${ }^{38}$ It was stated that this doctrine should only be invoked in those cases in which it served to protect vested rights of foreigners upon their arrival in France. On the contrary, the doctrine of international public order should be fully applied and preclude France from recognizing repudiations within its borders that were established in the country of origin by husbands who had already been settled in France.

The Cour de Cassation reconsidered its approach in particular to opposing the acceptance of repudiations of Muslim women residing in France. ${ }^{39}$ For this reason, the Cour de Cassation invoked the grounds of fraud related to the jurisdiction, the violation of the principle of equality between the spouses and/or of the right of defence, absence of financial guarantees, and requirement of a connection to the forum (Inlandbeziehung) in successive judgments, to be discussed more in detail below. The doctrine of the mitigated effect of public policy (effet atténué de l'ordre public) was not under discussion.

The Cour de Cassation was often confronted with the situation of husbands invoking a repudiation before the French court that had been established abroad by them after their

the recognition of and thus tolerance towards repudiations that have been pronounced in Morocco after the wife instituted proceedings for alimony and legal separation, respectively, in France.

35 This requirement has been particularly imposed on the revocable repudiation in order to enable its recognition in those years. In its judgment in Ferroudji of 20 June 1978, the Cour de Cassation still held the repudiation to be contrary to the public order because of its revocable nature (Cass. Civ. 1ere, 20 June 1978, Rev. Crit. DIP 1981, 88). Later, the characteristic of revocability again allowed the public policy exception to be invoked against a recognition of the repudiation, as it stresses that the repudiation is the prerogative of the husband (Joubert \& Gallant 2012, p. 323-324).

36 See, e.g. judgment Douibi, Cass. 1ère civ., 3 July 2001, Rev. Crit. DIP 2001, 704 (annotated by L. Gannagé); Judgment Dahar, Cass. 1ere civ. 18 December 1979, Rev. Crit. DIP 1981, 88 (annotated by I. Fadlallah); judgment Rohbi, Cass. 1ere civ. 3 November 1983, GADIP no. 63; Rev. Crit. DIP 1984, 325 (annotated by I. Fadlallah); JDI 1984, No. 329 (annotated by Ph. Kahn); Cass. lere civ. 1 March 1988, D. 1988, p. 486 (annotated by Massip); Rev. Crit. DIP 1989, p. 721 (annotated by Sinay-Citermann).

37 See, e.g. Cass. 1ere civ. 22 April 1986, Rev. Crit. DIP 1987, 374 (annotated by Courbe); Cass. 1ere civ. 17 May 1993, D. 1993, p. 349; JDI 1994, 115 (annotated by Y. Lequette).

38 Aldeeb Abu Sahlieh \& Bonomi 1999, p. 200.

39 Aldeeb Abu Sahlieh \& Bonomi 1999, p. 200-204. 
wife had instituted proceedings for divorce, alimony, or otherwise in France ${ }^{40}$ Recognition of such repudiations resulted in the non-admissibility of the requests by the wives or the evasion of the consequences of French judgments that had already been passed. Such situations are facilitated for Moroccans by the second paragraph of Article 11 of the 1981 France-Morocco Convention that offers either Moroccan spouse the option to determine the Moroccan court as a competent court to pronounce the divorce - rather than the French court as the court of the common domicile pursuant to the first paragraph - if both spouses have the Moroccan nationality, irrespective of their domicile at the moment of instituting the proceedings. In 1994 the Cour de Cassation 'amended' that option by requiring that the choice for the specific jurisdiction should not have been made out of fraudulent motives. ${ }^{41}$ If this requirement is not met, the court can refuse to recognize the repudiation on the ground of fraud related to the jurisdiction or judgment, or evasion of jurisdiction. Audit questions the merits of the use of the concept of fraud related to the jurisdiction, inter alia, by referring to the availability of the jurisdiction of the Moroccan court being based on the common nationality of the spouses as stated in Article 11 of the 1981 France-Morocco Convention. ${ }^{42} \mathrm{He}$ argues that these husbands finally seek to evade the French international public order, even though the intervention of this public order is justified because of the proximity of the situation with the French legal order.

From the 1990s on, the Cour de Cassation started to invoke two human rights in particular - the right to defence as well as the right of equal access to divorce - against recognition of the repudiation. ${ }^{43}$ Disrespecting these rights would violate the international procedural and public order. This approach of the Cour de Cassation conflicts with Article 13 of the 1981 France-Morocco Convention. ${ }^{44}$ Nevertheless, in 2001 the Cour de Cassation ruled that an Algerian repudiation was admissible, based on the non-fraudulent choice of court, the respect of the right to defence, the pecuniary guarantees for the spouse, but without invoking the principle of gender equality pursuant to Article 5 of the 7 th Protocol

40 See, e.g. judgment Senoussi, Cass. 1ere civ., 1 March 1988, Rev. crit. DIP 1989, p. 721 (annotated by SinayCytermann); judgment Akla, Cass. 1ere civ., 6 June 1990, Rev. crit. DIP 1991, p. 553 (annotated by Courbe); Cass. 1ere civ., 26 June 1990, Rev. Crit. DIP 1991, p. 593 annotated by Courbe); Cass. 1ere civ., 4 May 1994, Rev. crit. DIP 1995 (annotated by Déprez).

41 Cass. 1ere civ., 4 May 1994, Rev. crit. DIP 1995 (annotated by Déprez); see also later judgments in which the Cour de Cassation upheld the requirement of a non-fraudulent choice of jurisdiction: Cass. 1ere civ., 13 December 1994, JDI 1995, p. 343 (annotated by Kahn); Cass. lere civ., 9 July 2003, JDI 2004, p. 182 (annotated by Monéger); Cass. 1ere civ., 30 September 2009, No. 08-16883.

42 Audit 2010, No. 687.

43 See, e.g.: Cass. 1ere civ., 6 June 1990, D 1990, p. 263; Rev. Crit. DIP 1991, p. 593; Cass. 1ere civ., 1 June 1994, Rev. Crit. DIP 1995, 103 (annotated by Déprez); Cass. 1ere civ. 31 January 1995, Rev. Crit. DIP 1995, 569 (annotated by Déprez); Cass. 1ere Civ. 11 March 1997, JDI 1998, 110 (annotated by Kahn); Cass. 1ere civ., 5 January 1999, D 1999, p. 671; Audit 2010, No. 689; Lemontey 2008, p. 65-69.

44 Rude-Antoine 2009, p. 190. 
to the ECHR. ${ }^{45}$ However, in the same year, the Paris Cour d'Appel refused to recognize the repudiations at issue, as it considered the repudiation to be a discretionary power of the husband, violating the principle of gender equality under Article 5 of the 7th protocol to the ECHR. ${ }^{46}$

The Cour d'Appel in Versailles found that the lack of pecuniary guarantees for the wife is another ground for repudiations to be considered contrary to public policy and thus to refuse their recognition. ${ }^{47}$ The background to this reasoning was that women without resources would become dependent on the French social services.

On several occasions, the Cour de Cassation ruled the repudiation at issue inadmissible because of the proximity of the case to the French legal order. Proximity of the case with the French territory is presumed in the case of the French nationality of both spouses or of the wife, or in the case that the wife or both spouses are domiciled in France, or in the case of both spouses being habitual resident in France. ${ }^{48}$ In a case in 1993, the Moroccan spouses had already obtained the French nationality and were domiciled in France before the husband pronounced the repudiation in his country of origin. ${ }^{49}$ The Cour de Cassation held that recognition of the repudiation would violate the public order of France, the state of which the spouses had chosen to become nationals. For this reason, their marriage could only be dissolved by French law. In 2002, the Cour de Cassation ruled that this repudiation could not be recognized because of the close connection of the case to the French legal order and the court considered the repudiation to be a violation of the French public order due to a violation of Article 5 of the 7 th Protocol to the ECHR. ${ }^{50}$ By contrast, the Tribunal de grande instance of Paris ruled that a repudiation that had been established under the same circumstances - common French nationality and residence in France of the spouses before pronouncement of the repudiation - was admissible by applying Article 13 of the 1981 France-Morocco Convention, since the wife did not contest its recognition..$^{51}$ The same court had already recognized the repudiation of a French woman, originally nonMuslim, who requested the recognition of the repudiation in $1979 .{ }^{52}$

One can conclude that the approach of the Cour de Cassation has been unstable and is characterized by frequent changes of direction until 2004, although the prelude to the

45 Judgment Douibi, Cass. 1ère civ., 3 July 2001, Rev. Crit. DIP 2001, 704 (annotated by L. Gannagé); Audit 2010, No. 689.

46 Cour d'appel de Paris 22 March 2001, Rev. Crit. DIP 2002, 848; Cour d'appel de Paris 13 December 2001, Rev. Crit. DIP 2002, 730-746.

47 Cour d'Appel de Versailles, 9 October 1989; Aldeeb Abu Sahlieh \& Bonomi 1999, p. 202-203.

48 See, respectively, Cass. civ. 1ère 17 February 2004; Cass. civ. 1ère 14 March 2006; Cass. civ. 1ère 10 May 2006; Cass. civ. 1ère 20 September 2006.

49 Cass. lere civ. 17 May 1993, D 1993, p. 349; JDI 1994, 115 (annotated by Y. Lequette).

50 Cass. 2me civ. 14 March 2002, D 2002, p. 1177.

51 Tribunal de Grande Instance de Paris, 27 September 1990, Rev. crit. DIP 1992 p. 91 (annotated by Y. Lequette).

52 Tribunal de Grande Instance de Paris, 5 December 1979, Rev. Crit. DIP 1981, p. 88. 
2004 final turning point has already been visible. Recognition of the repudiations was assessed in concreto.

\subsubsection{The 2004 Turning Point}

This approach was abandoned in 2004: the Cour de Cassation rejected the recognition of the repudiation because of the violation of the French ordre public de proximité (public order of proximity) and the European public order in four out of five of its judgments. ${ }^{53}$ It considered the legal institution of repudiation that as such by its nature implies inequality, to infringe upon the principle of gender equality under Article 5 of the 7th protocol to the ECHR, irrespective of whatever guarantees of financial or a procedural nature were offered to the wife. Moreover, it considered the PIL public order to be violated because of this reason as soon as there was sufficient proximity with the French legal order, for example, through the domicile of the wife or of both spouses in France. A divorce which is in principle only accessible by men is discriminatory, as France is bound to guarantee ECHR rights to all persons within French jurisdiction. Furthermore, case law shows that the foreign judge has been considered to be a person who merely registers the divorce or who has to give permission or pronounce the repudiation on the request of the husband; he has no other authority than to allow for the settlement of the financial arrangements for the wife, which is considered to be entirely insignificant.

According to the Cour de Cassation in the first of the five judgments of 17 February 2004 (No. 01-11.549):

\section{$[\ldots]$}

Mais attendu que l'arrêt retient que le divorce des époux Ait X... a été prononcé par les juges algériens, malgré l'opposition de la femme, au seul motif, admis par la loi algérienne, que le pouvoir conjugal reste entre les mains de l'époux et que le divorce doit être prononcé sur la seule volonté de celui-ci; que la cour d'appel en a exactement déduit que, même si elle résultait d'une procédure loyale et contradictoire, cette décision constatant une répudiation unilatérale du mari

53 Cass. 1ère civ., 17 February 2004, arrêts No. 01-11.549; 02-11.618; 02-15.766; 02-17.479 en 02-10.755, D. 2004, p. 824 (conc. F. Cavarroz) and p. 815 (note P. Courbe); GADIP, No. 64; Rev. Crit. DIP 2004, 424, note P. Hammje; JDI 2004, p. 1200, note L. Gannagé; Audit 2010, No. 689; Clavel 2010, no. 704; Joubert \& Gallant 2012, p. 320; Lemontey 2008, p. 69-71. See for an extensive discussion of these landmark decisions in the first edition of the Revue Internationale de Droit Comparé in 2006: Hugues Fulchiron, 'Ne répudiez point ...: pour une interprétation raisonnée des arrêts du 17 Février 2004'; Marie-Laure Niboyet, 'Regard Français sur la reconnaissance en France des répudiations musulmanes'; Fatna Sarehane, 'La répudiation, quels obstacles pour les marocains résidents en France? (Exercice au Maroc et reconnaissance en France)'; Ali Mezghani, 'Quelle tolérance pour les répudiations?'; Léna Gannagé, 'Le relativisme des droits de l'homme dans l'espace méditerranéen'. 
sans donner d'effet juridique à l'opposition éventuelle de la femme et en privant l'autorité compétente de tout pouvoir autre que celui d'aménager les conséquences financières de cette rupture du lien matrimonial, était contraire au principe d'égalité des époux lors de la dissolution du mariage reconnu par l'article $5 \mathrm{du}$ protocole du 22 novembre 1984, $\mathrm{n}^{\circ} 7$, additionnel à la convention européenne des droits de l'homme, que la France s'est engagée à garantir à toute personne relevant de sa juridiction, et donc à l'ordre public international réservé par l'article 1er d de la Convention franco-algérienne du 27 août 1964, dès lors que, comme en l'espèce, les deux époux étaient domiciliés sur le territoire français; $[\ldots]^{54}$ (emphasis added)

and in its second judgment (No. 02-11.618):

$[\ldots]$

Mais attendu que l'arrêt retient que le jugement du Tribunal de Biskra avait été prononcé sur demande de M. X... au motif que "la puissance maritale est entre les mains de l'époux selon la Charia et le Code" et que "le Tribunal ne peut qu'accéder à sa requête"; qu'il en résulte que cette décision constatant une répudiation unilatérale du mari sans donner d'effet juridique à l'opposition éventuelle de la femme et en privant l'autorité compétente de tout pouvoir autre que celui d'aménager les conséquences financières de cette rupture du lien matrimonial, est contraire au principe d'égalité des époux lors de la dissolution du mariage, reconnu par l'article 5 du protocole du 22 novembre 1984, $n^{\circ} 7$, additionnel à la Convention européenne des droits de l'homme, que la France s'est engagée à garantir à toute personne relevant de sa juridiction, et à l'ordre public international réservé par l'article 1er d) de la Convention franco-algérienne du 27 août 1964, dès lors que, comme en l'espèce, la femme, sinon même les deux époux, étaient domiciliés sur le territoire français; qu'ainsi, la cour d'appel a légalement justifié sa décision au regard des textes susvisés;

[...]. (emphasis added)

In its fifth judgment of 17 February 2004, the Cour de Cassation rejected the recognition of the repudiation at issue based on the lack of competence of the foreign judge. ${ }^{55}$ Yet, the foreign judge, being the judge of the common nationality of the spouses who were domiciled in France, had acquired indirect competence in accordance with the criteria of the Simitch

54 Cass. 1ère civ., 17 février 2004, arrêt no. 01-11.549.

55 Clavel 2010, No. 704. 
judgment. ${ }^{56}$ In 2006 the Cour de Cassation confirmed the competence of the judge of the common nationality to pronounce the dissolution of two spouses who are domiciled in France. ${ }^{57}$ According to the Cour de Cassation, it was not the incompetence of the judge of the common nationality of the spouses but the violation of the public order that justified the refusal of the recognition of the repudiation. The public order of proximity requires the protection of the wife as soon as she is domiciled in France. This implies that the repudiation of the wife who lives abroad qualifies for recognition.

The Cour de Cassation has affirmed the denial of recognition to the repudiation on the principles of the ECHR and proximity with the French legal order by either upholding judgments or (partly) quashing and annulling dissenting judgments, so-called arrêts de rebellion, of the Cours d'Appel in question on several occasions. ${ }^{58}$

The facts of the five cases in 2007 were more or less similar. All the cases concerned an Algerian or Moroccan repudiation by the unilateral will of the husband while both spouses were residing in France, or either spouse or both spouses had the French nationality. While their wives had instituted proceedings for divorce, alimony, or otherwise in France, the husband sought a quick divorce in Algeria or in Morocco in order to avoid the French court, the French (divorce) laws, and thus the consequences of the French judgment. In all these cases, the Cour de Cassation reiterated its two arguments, as also employed in 2004, to clarify the violation of the principle of equality between the spouses upon divorce pursuant to Article 5 of the 7 th Protocol to the ECHR. The reasoning also addressed the violation of the PIL public order pursuant to the public policy clause of the relevant bilateral convention. The reasoning addressed, on the one hand, the lacking of any legal effect of the possible opposition by the wife and of any power of the competent authority, other than that of arranging the financial consequences of the divorce, and, on the other hand, the divorce being based on the unilateral will of the husband in the foreign repudiation.

The Cour de Cassation held on 22 May 2007:

\section{$[\ldots]$}

Attendu que la décision d'une juridiction étrangère constatant une répudiation unilatérale du mari sans donner d'effet juridique à l'opposition éventuelle de la

56 Simitch judgment, Cass. civ., 6 February 1985, Rev. crit. DIP 1985, p. 369.

57 Cass. 1ère civ., 20 September 2006, Bull. 2006, I. no. 407.

58 See, e.g. Cass. 1ère civ. 3 January 2006, Rev. Crit. DIP 2006, p. 627, note M.-C. Najm; Cass. 1ère civ. 10 May 2006; Cass. 1ère civ. 7 June 2006; Cass. 1ère civ. 20 September 2006; Cass. 1ère civ. 22 May 2007; Cass. lère civ., 10 July 2007; Cass. 1ère civ., 19 September 2007, Bull. Civ. No. 280; Cass. 1ère civ., 17 October 2007; Cass. 1ère civ., 31 October 2007; see also more recently, e.g. Cass. 1ère civ., 14 March 2012, No. 11-11.896; Cass 1ère civ., 20 June 2012 (on the ground of fraud!); in the same sense, e.g. Cour d'Appel d'Amiens 14 April 2004; Cour d'Appel de Douai 23 June 2005, available at <www.legifrance.gouv.fr $>$. In most of these cases in which a Moroccan repudiation was involved, the Cour de Cassation had to judge on the recognition of repudiations established under the Moroccan Mudawwana of 1993, the predecessor of the Moroccan Family Code of 2004. 
femme et privant l'autorité compétente de tout pouvoir autre que celui d'aménager les conséquences financières de cette rupture du lien matrimonial, est contraire au principe d'égalité des époux lors de la dissolution du mariage, que la France s'est engagée à garantir à toute personne relevant de sa juridiction, et donc à l'ordre public international, spécialement lorsque les deux époux sont de nationalité française;

$[\ldots]^{59}$ (emphasis added)

on 17 October 2007:

\section{$[\ldots]$}

Or attendu que la décision d'une juridiction étrangère constatant une répudiation unilatérale du mari sans donner d'effet juridique à l'opposition éventuelle de la fermme et en privant l'autorité compétente de tout pouvoir autre que celui d'aménager les conséquences financières de cette rupture du lien matrimonial, est contraire au principe d'égalité des époux lors de la dissolution du mariage reconnu par l'article 5 du protocole du 22 novembre $1984 \mathrm{n}^{\circ} \mathrm{VII}$, additionnel à la Convention européenne des droits de l'homme, que la France s'est engagée à garantir à toute personne relevant de sa juridiction, et donc à l'ordre public international, réservé par l'article ler d) de la convention franco-algérienne du 27 août 1964, dans la mesure où l'un au moins des deux époux est domicilié sur le territoire français;

$[\ldots]^{60}$ (emphasis added)

on 10 July 2007:

\section{$[\ldots]$}

Mais attendu que l'arrêt relève que le divorce a été prononcé en Algérie sur le fondement de l'article 48 du code de la famille algérien par la seule volonté du mari; qu'il en résulte que cette décision est contraire au principe d'égalité entre les époux lors de la dissolution du mariage reconnu par l'article 5 du protocole $\mathrm{n}^{\circ} 7 \mathrm{du} 22$ novembre 1984 additionnel à la Convention européenne des droits de l'homme que la France s'est engagée à garantir à toute personne relevant de sa juridiction, et à l'ordre public international réservé par l'article 1er d) de la Convention franco-algérienne du 27 août 1964, dès que comme, en l'espèce, les époux étaient de nationalité française et que la résidence de la famille était

59 Cass. 1ère civ., 22 May 2007.

60 Cass. 1ère civ., 17 October 2007. 
en France; que par ce seul motif, la cour d'appel a légalement justifié sa décision au regard des textes susvisés;

$[\ldots]^{61}$ (emphasis added)

on 19 September 2007:

\section{$[\ldots]$}

Mais attendu que la cour d'appel constate, d'abord, que le divorce des époux a été prononcé définitivement en Algérie, de sorte qu'aucune instance n'était pendante en Algérie, et que les conditions de la litispendance faisaient défaut; qu'elle relève, ensuite, que les deux époux étaient domiciliés en France et que le divorce prononcé en Algérie sur le fondement de l'article 48 du code algérien, l'a été sur la seule volonté $d u$ mari; qu'il en résulte que cette décision est contraire au principe d'égalité des époux lors de la dissolution du mariage telle qu'il est reconnu par la loi française et l'article 5 du Protocole $n^{\circ} 7$ additionnel à la Convention de sauvegarde des droits de l'homme et des libertés fondamentales, que la France s'est engagée à garantir à toute personne relevant de sa juridiction, et à l'ordre public international réservé par l'article 1er d) de la Convention franco-algérienne du 27 août 1964, dès lors que, comme en l'espèce, les époux étaient domiciliés en France, qu'elle a pu en déduire que les décisions algériennes n'étaient pas susceptibles d'être reconnues en France;

$[\ldots]^{62}$ (emphasis added)

and on 31 October 2007:

\section{$[\ldots]$}

Attendu d'abord que l'arrêt relève, par motifs adoptés, que les deux époux vivaient en France et que préalablement à sa demande en divorce, M. X... avait sollicité sa réintégration dans la nationalité française ; puis, par motifs propres, que le jugement algérien a prononcé le divorce des époux malgré l'opposition de la femme au seul motif admis par la loi algérienne que le pouvoir conjugal restait entre les mains du mari et que le divorce devait être prononcé sur sa seule volonté, de sorte que la cour d'appel en a justement déduit que la décision était contraire au principe d'égalité des époux reconnu par l'article $5 \mathrm{du}$ protocole du 22 novembre $1984 \mathrm{n}^{\circ} 7$ additionnel à la Convention européenne des droits de l'homme que la France s'est engagée à garantir à toute personne relevant de

61 Cass. 1ère civ., 10 July 2007.

62 Cass. 1ère civ., 19 September 2007, Bull. Civ. No. 280. 
sa juridiction et donc à l'ordre public international réservé par l'article 1 d) de la Convention franco-algérienne du 27 août 1964;

$[\ldots]^{63}$ (emphasis added)

The European Court of Human Rights has approved of the strict approach of the Cour de Cassation in 2005. ${ }^{64}$ Joubert and Gallant found that lower courts seem to follow this strict approach. ${ }^{65}$ According to them, the judges of these courts do not verify in concreto whether there are circumstances that allow for the recognition of the repudiation, such as the demand for its recognition by the wife, the occurrence of an adequate check by the foreign judge, or the consent of the wife or agreement of both spouses for the repudiation. Nor do they check the exact wordings of the content of the foreign law, whether financial compensation has been accorded to the wife, or whether the wife also has the possibility to obtain a divorce.

The rigid French in abstracto approach inevitably results in limping legal relationships, and in an unnecessary number of limping legal relationships. These limping legal relationships, because of denial of recognition based on Article 5 of the 7th Protocol to the ECHR, may paradoxically result in a contradiction of human rights: the non-discrimination principle based on gender (upon divorce) and the right to defence of the wife versus the right to marry or to the family life of the husband. ${ }^{66}$

In the late 1990s, El-Husseini Begdache had already advocated 'splitting the issue of recognition of the dissolution of marriage from the issue of recognition of its effects and distributively submitting them to distinct regimes of control while taking into account their respective legal natures'. ${ }^{67}$ The exception of public policy should then only be invoked on the level of the latter issue of the effects. The aim was, inter alia, to avoid limping legal relationships.

\subsubsection{The 2004 Moroccan Divorce Law in the Cour de Cassation}

The reforms of the new Moroccan Family Code in 2004 have apparently not affected the strict approach as adopted by the Cour de Cassation. In this respect, one should think of the reforms of the repudiation and its procedure, notably the prior authorization for the repudiation by the family court, the improvement of financial guarantees for the wife, and

63 Cass. 1ère civ., 31 October 2007.

64 ECHR 8 November 2005, GP 25 February 2006, No. 56, p. 16.

65 Joubert \& Gallant 2012, p. 320-321, referring to two legal cases: TGI St. Etienne, 25 Mars 2008 (unpublished); TGI St. Etienne, 1 September 2009 (unpublished).

66 Foblets \& Rutten 2006, p. 197.

67 El-Husseini 1999, p. 446-468; El-Husseini Begdache 2002, p. 90-104, 250-262. 
the introduction of the divorce on the ground of an irretrievable breakdown that is accessible to both spouses that enables equal access to divorce by the spouses.

The judgment of the Cour de Cassation in 2009 is illustrative as it upheld the decision of the Cour d'Appel de Caen not to recognize the Moroccan repudiation at issue. ${ }^{68}$ The husband had invoked the decision of the tribunal de première instance of Khemisset (Morocco) of 4 October 2007 concerning the repudiation in order to contest the request for divorce in France by his wife. Both spouses had the Moroccan nationality and were domiciled in France. The arguments for the non-recognition of the repudiation by the Cour d'Appel de Caen concerned, in line with the case law of the Cour de Cassation since 2004, the fact that it is impossible for the wife to contest the demand for repudiation by the husband, the fact that the intervention of the Moroccan judge is restricted to the consequences of the divorce in view of the Articles 83 and 84 of the Moroccan Family Code of 2004, the fact that the wife cannot demand the same from the Moroccan court unless upon the authorization of the husband, and, moreover, the fact that both spouses were domiciled in France.

The Cour de Cassation rejected the appeal in cassation on the grounds that the decision is contrary to the principle of equality between the spouses upon divorce as articulated in Article 5 of the 7th protocol to the ECHR to which France has committed itself to guarantee to all residents within its jurisdiction, and, for this reason, that it is contrary to the international public order. The court considered the fact that the wife does not have the right to contest the demand for repudiation by the husband and that the role of the judge is restricted to settling the financial consequences of the dissolution of marriage as decisive arguments for these violations.

The Cour de Cassation held:

\section{$[\ldots]$}

... la décision d'une juridiction étrangère constatant une répudiation unilatérale par le mari sans donner d'effet juridique à l'opposition éventuelle de la femme et privant l'autorité compétente de tout pouvoir autre que celui d'aménager les conséquences financières de cette rupture du lien matrimonial, est contraire au principe d'égalité des époux lors de la dissolution du mariage énoncé par l'article $5 \mathrm{du}$ protocole du 22 novembre $1984 \mathrm{n}^{\circ}$ VII, additionnel à la Convention européenne des droits de l'homme, que la France s'est engagée à garantir à toute personne relevant de sa juridiction, et donc à l'ordre public international

68 Cass. 1ère civ., 4 November 2009, Bull. 2009, I, no. 217, D 2010, p. 1243; D 2010, p. 543; Rev. Crit. DIP 2010, p. 313, Droit de la famille 2010, No. 1, comment 13, note L. Abadie. See also Cass. 1ère civ., 20 October 2010, no. 09-15.379; Cass. lère civ., 18 May 2011, No. 10-1.750; Cour d'appel de Limoges, 7 March 2011, No. 0900956. 


\section{$[\ldots] .{ }^{69}$ (emphasis added)}

The grounds for the appeal however included the complaint for the lack of an assessment in concreto, notably:

$3 \%$ que la contrariété éventuelle d'une loi ou d'une décision étrangère à l'ordre public international français s'apprécie en fonction du résultat concret qu'entraîne l'application de cette loi ou cette décision étrangère et non au regard d'une appréciation abstraite des dispositions de cette loi ou de cette décision ${ }^{70}$

and

qu'en statuant ainsi, sans rechercher si les différentes procédures de divorce prévues par le code de la famille marocain du 5 février 2004 et ouvertes, selon les cas, à l'époux ou à l'épouse, n'assurent pas, globalement, une égalité des époux lors de la dissolution du mariage, les juges du fond ont privé leur décision de base légale au regard de l'article 16 de la convention franco-marocaine d'aide mutuelle judiciaire d'exequatur du 5 octobre 1957, de l'article 3 du code civil et des principes généraux du droit international privé. ${ }^{71}$

Not applying an in concreto approach, but strictly adhering to the in abstracto approach, results in the denial of recognition of the reformed Moroccan repudiation. Yet the legal nature of the reformed Moroccan repudiation, in connection with the total Moroccan divorce system in which it is embedded, does not contradict the requirements of Article 5 of the 7 th Protocol to the ECHR.

Furthermore, not only does France not allow for the recognition of any repudiationbased divorce because of its rigid in abstracto approach, it also does not allow the establishment of repudiation-based divorces on French soil because of the exclusive right of the French judge to grant a divorce. ${ }^{72}$

69 Cass. 1ère civ., 4 November 2009, No. 08-20.574.

70 Cass. 1ère civ., 4 November 2009, No. 08-20.574.

71 Cass. 1ère civ., 4 November 2009, No. 08-20.574.

72 Cour d'appel Paris 7 July 1959, Rev. Crit. DIP 1960, p. 354, annotated by Y. Loussouarn; Tribunal de Grande Instance Paris, 26 January 1978, Rev. Crit. DIP 1979, p. 855, annotated by Khan; Cour d'appel Paris 4 November 1992, Dr. et patrimoine 1993, p. 42; Cour d'appel Versailles 23 Mars 1995, Rev. Crit. DIP 1996, p. 699 , annotated by H. Gaudemet-Tallon. 


\subsection{Closing Remarks}

An increasing liberalization of the requirements for recognition of foreign (third-state) divorce judgments and public acts characterizes French PIL resulting in their recognition de plano under the reservation of their regularity. But the opposite holds true for the recognition of foreign repudiations. French case law dominates their recognition, notably since 2004. Three periods of approaches can be discerned: first a liberal and tolerant approach towards the recognition of repudiations through invoking the doctrine of l'effet attenué de l'ordre public in the 1970s and 1980s, followed by a stricter approach through invoking the rights to defence and to equal access to divorce from the 1990s until 2004, culminating in the third approach, which has been a severe one since 2004. An immediate cause for the more restrictive approach, already since the 1990s, was to prevent husbands from evading the French legal system and its (financial) consequences. These husbands sought to frustrate their wives' access to the French divorce legal system and/or its provisions through establishing a quick repudiation in their country of origin. French case law, at least since 2004, even supersedes the 1957 and 1981 France-Morocco Conventions, the latter providing for the possibility of recognition of the Moroccan homologated repudiation(-based divorce) under the same conditions as for divorce judgments in its Article 13. Until 2004, recognition of repudiations was assessed in concreto.

The year 2004 represents the final turning point: the French Cour de Cassation denied the recognition of the repudiation established by the unilateral will of the husband through invoking the European public order exception and the French public order of proximity (ordre public de proximité). The Cour de Cassation considers the repudiation to violate the principle of equality between the spouses upon divorce pursuant to Article 5 of the 7th Protocol to the ECHR. For this reason, the Cour de Cassation considers the repudiation also to violate the PIL public order as soon as there is sufficient proximity with the French legal order and irrespective of the occurrence of a fair and adversarial procedure. The Cour de Cassation puts forward the following grounds for the violation: first, the dissolution of the marriage is established by the unilateral will of the husband; second, the wife cannot contest the repudiation; and third, the very limited role of the judge, which is restricted to arranging the financial consequences of the divorce. There is sufficient proximity with the French legal order if both spouses or the wife is domiciled in France or if either or both spouses (also) have the French nationality. It is essential to realize that the background to this rigorous approach is to avoid the use of repudiations pronounced in the country of origin by husbands residing in an EU Member State in order to frustrate the wife's access to the court in an EU Member State.

In the years that follow, the Cour de Cassation confirmed this ruling by issuing similar rulings. The European Court of Human Rights approved of this severe approach in 2005. It appears that lower French courts follow this approach as well without verifying in concreto 
whether there are circumstances that would permit the recognition of the repudiation. Examples of such circumstances would be the demand for the recognition of the repudiation by the wife or the consent of the wife or agreement of both spouses to the repudiation. And although the modalities of repudiation that are based on the mutual consent of the spouses to or on acquiescence of the wife in the repudiation were assimilated to two forms of divorce by mutual consent acknowledged in France, at least until 2004, one may question their classification and the consequences thereof for their recognition since the rigorous 2004 rulings of the Cour de Cassation. What are the implications of the rulings of the Cour de Cassation for the negotiated repudiation, $k h u l$ '; the repudiation by agreement, mubara' $a$; or the self-repudiation? The findings as a result of an analysis of French lower courts' judgments by Joubert and Gallant suggest that these modalities also do not qualify for recognition in line with the severe approach adopted by the Cour de Cassation since 2004.

Reforms in the divorce laws of Muslim-majority countries improving the legal status of women apparently do not affect the likelihood of recognition either. The denial of recognition of a Moroccan repudiation obtained under the reformed Moroccan Family Code of 2004, by the Cour d'Appel de Caen, which was subsequently upheld by the Cour de Cassation, clearly demonstrates this. Reforms such as the prior authorization to the repudiation by the family court, the improvement of procedural and financial guarantees for the wife, and the introduction of the divorce on the ground of an irretrievable breakdown were not found to be sufficient to counter the arguments of the Cour d'Appel and the Cour de Cassation. To remind the reader, these arguments were as follows: the fact that the repudiation is a unilateral act, that the wife cannot contest the demand for repudiation by the husband, that the intervention of the Moroccan family judge is restricted to arranging the financial consequences of the divorce, and that the wife cannot make the demand for repudiation but after being authorized thereto by her husband.

In the court's enthusiasm to prevent the practice by husbands of abusing the repudiation in order to frustrate the wife's access to the French court, laws and their provisions, the French judiciary overlooks several essential matters and consequences of these reforms. First, the mandatory judicial prior authorization to the repudiation, although it cannot be refused if the husband has fulfilled his financial obligations, deprives the husband of his discretion to repudiate and is a constitutive requirement for the valid establishment of the repudiation according to Moroccan law. The authorization is given after a procedure and (a) reconciliation attempt(-s) before the family judge, in order to guarantee the rights of the wife and children. Second, it should not be overlooked that in many EU Member States, divorce may be granted on the request of one of the spouses, while the other spouse does not want to divorce. The purpose of the intervention of the judicial or administrative authority is to guarantee the rights of the other spouse (and children). In this respect, the role of the authorities in Islamic and EU Member States does not diverge, but is similar. Third, even if the husband did not hand over the power to repudiate to his wife, she still 
has the possibility to address the court for a divorce on the ground of an irretrievable breakdown, the shiqaq procedure. This modality of divorce, one of the reforms of divorce law introduced in the Moroccan Family Code in 2004, is equally accessible to both spouses and provides for a judicially monitored procedure that guarantees the rights of the spouses and children.

I conclude that the French in abstracto approach cannot be so much explained by objections to the institute of repudiation as an expression of the unilateral will of the husband, but as a legal instrument to prevent the practice in which the husband employs the repudiation in order to frustrate his wife's access to the French court, its laws and their provisions. The justification of PIL public order has become a political instrument that results in a rigorous denial of recognition to all repudiation-based divorces with proximity to the French legal order while not taking into account the relevant circumstances of the case and legal reforms in the country of origin of the repudiation. Yet, such legal reforms and the relevant circumstances of the case may favour recognition and, moreover, do not always contradict the requirements of Article 5 of the 7th Protocol to the ECHR. This rigid approach unnecessarily results in a number of avoidable limping legal relationships and their consequences and, paradoxically, in a situation of conflicting human rights: the nondiscrimination principle based on gender (upon divorce) and the right to defence of the wife versus the right to marry or the family life of the husband and/or of the wife. 


\section{Evaluation and Conclusion}

\subsection{INTRODUCTION}

The previous chapters have set out the features of the recognition policies in the Netherlands, England, and France, respectively. Every state has its own discretion to regulate its private law, and more specifically its private international law matters, and thus its recognition policies, based on that state's sovereignty. Moreover, notably socially and culturally influenced views have moulded these recognition policies. This chapter provides for an evaluation of these recognition policies through a legal comparative analysis. The analysis focuses on comparing: (1) their respective frameworks for assessment in respect of their criteria and the application of these criteria, (2) the understanding and subsequently classification of the various repudiation-based divorce modalities, and (3) their approaches towards repudiation-based divorce modalities. Hence, this chapter provides the basis for the answer to the main question of this part of the study: how do these European countries manage the legal diversity at hand by means of their PIL? This question will be answered in the conclusion of this chapter. It will also provide indispensable information for proposals for the improvement of the distinct recognition policies in part III of this study. Repudiation-based divorces are the focus of this chapter. As previously explained, recognition of Islamic judicial divorces is in general not problematic.

\subsection{Evaluation}

The evaluation in this section consists of a legal comparative analysis of the recognition policies of the Netherlands, England, and France. Its aim is to provide an answer to the question how these European countries manage the legal diversity at hand. For this reason, the following three subsections include a comparative analysis of subsequently: (1) the countries' frameworks of assessment including its criteria, (2) the countries' understanding and classification of repudiation-based divorces, and (3) their approaches towards these modalities.

\subsubsection{Frameworks for Assessment Compared}

The comparative analysis of the Dutch, English, and French frameworks for assessment aims to clarify, on a macro level, whether these frameworks provide for (specific) criteria for repudiation-based divorces and the rationale behind these criteria and, on a micro 
level, the (specific) criteria for repudiation-based divorces, notably its functioning and significance in legal practice, the role of the PIL public order in these frameworks, the significant similarities or differences in criteria, and the consequences of the distinct recognition policies, more specifically, whether the distinct recognition policy considers the consequence of non-recognition, the limping legal relationship.

\subsubsection{Comparison at the Macro Level}

A comparison of Dutch, English, and French recognition policies towards Islamic divorces reveals the following at the macro level: the Dutch and English legislators and (in addition) their judiciary have shaped their respective recognition policies towards Islamic divorce modalities.

Today, the Dutch statutory regime makes a distinction between ex lege recognition of foreign divorces established by the decision from a competent judge or another authority after a sound procedure in Article 10:57 BW and foreign divorces established by the unilateral declaration of either spouse in Article 10:58 BW. The English statutory regime distinguishes between ex lege recognition of foreign dissolutions of marriage obtained after judicial or other proceedings in section 46(1) FLA and those obtained otherwise than by means of proceedings in section 46(2) FLA.

In France the various bilateral conventions that used to govern the de plano recognition of all types of divorces still govern the de plano recognition of the judicial, non-repudiationbased divorce modalities and of those ( $\mathrm{few}$ ) homologated repudiation-based divorces without proximity between the case and the French legal order. It is French case law that dominates French recognition policy towards repudiation-based divorces since 2004 if there is proximity between the case and the French legal order.

Both sets of statutory provisions now - the Dutch Articles 10:57 and 10:58 BW and the English sections 46(1) and 46(2) FLA 1986 - may govern and provide criteria for the recognition of foreign repudiation-based divorces. They distinguish between repudiationbased divorces established or obtained after proceedings abroad and those established or obtained without any proceedings abroad. The analysis of the case law of the French Cour de Cassation since 2004 demonstrates that it provides for criteria for the non-recognition of repudiation-based divorces. But there is no differentiation between repudiation-based divorces with or without proceedings at all: repudiations are repudiations. They are considered to be established by the unilateral will of the husband, irrespective of the presence of a procedure, the request for the repudiation by the wife, or reforms in the divorce laws of Muslim-majority countries improving the legal status of women.

Hence in France, repudiation-based divorces do not qualify for recognition because of a violation of the right to equality upon divorce between the spouses, and for this reason, a violation of the PIL public order if there is sufficient proximity with the French legal order, because both spouses or the wife is domiciled in France or either or both spouses 
have (also) the French nationality. It appears that the French intolerant attitude towards repudiation-based divorces since 2004 and the tightening of the English recognition policy over the years find their explanation in the same goal: to prevent husbands from evading the French or English legal order and its financial consequences in order to frustrate their wives' access to the French or English legal divorce system and its provisions by having recourse to a quick repudiation in the country of origin. In the Netherlands, this rationale played a part as a prominent argument in the discussion in the mid-1990s whether or not to abolish the requirement for recognition of an explicit or implicit agreement to or acquiescence in the repudiation by the wife in the mid-1990s. The requirement was not abolished. The principle of favor divortii and the interests of the wife in recognition of the repudiation, in order to, inter alia, prevent limping legal relationships, provide the rationale behind the Dutch attitude towards repudiation-based divorces. Because of this principle, Dutch recognition policy not only enables recognition of any repudiation-based divorce established after proceedings as equivalent to judicial divorces (under conditions). It also allows for the recognition of repudiation-based divorces established without proceedings (upon fulfilment of specific, cumulative requirements), as is emphasized by the positive formulation of the article governing these divorces.

However, there is a remarkable difference between France and England in the consequences of their stricter attitude towards repudiation-based divorces. France has adopted a rigorous intolerant attitude, whereas England pursues a less strict intolerant attitude. The French attitude results in the denial of recognition of any repudiation-based divorce, whether or not it was established after proceedings in the case of sufficient proximity of the spouses involved with the French legal order. Hence, women retain the ability to seek a divorce and/or financial relief before the French court. The English attitude still allows for recognition of repudiation-based divorces under conditions, but it refuses recognition for repudiation-based divorces obtained without proceedings, pursuant to section 46(2) sub c FLA 1986, if either spouse had their habitual residence in the United Kingdom in the year preceding the date the repudiation was obtained. Recognition is in any case denied to transnational divorces obtained on English soil. In order not to disadvantage women because of the recognition of a repudiation-based divorce, the English legislator created the possibility for women to apply for financial relief pursuant to part III of the Matrimonial and Family Proceedings Act 1984. The English measures, the more nuanced and limited 'no proximity of either spouse' requirement of section 46(2) sub c FLA 1986 and the abovementioned possibility for financial relief, are more directly aimed at preventing the harmful consequences of husbands going abroad for a quick divorce, and thus they aim to avoid the consequence of limping legal relationships, more so than the French measures do.

The Netherlands does not have such a 'no proximity' requirement. On the contrary, even in the case of proximity with the Dutch legal order at the moment of the establishment 
of the repudiation-based divorce, the repudiation can be recognized upon fulfilment of a number of requirements. The most important requirement in the case of a repudiationbased divorce established without proceedings is the explicit or implicit consent of the wife.

The fact that repudiation-based divorces may lack proceedings is obviously not considered to be contrary to the public order, at least not if the requirements of the Dutch Article 10:58 BW and the English section 46(1) FLA 1986 have been satisfied.

Now that it has been presented that all legal systems under review provide criteria for the (non-)recognition of foreign repudiation-based divorces, let us take a closer look at the specific criteria that these European countries apply in legal practice today.

\subsubsection{Comparison at the Micro Level}

The following paragraphs recapitulate the specific criteria within the respective frameworks for assessment, as they are applied and function in legal practice in the Netherlands, England, and France.

\subsection{Criteria in the Netherlands}

In order to qualify for recognition as a repudiation-based divorce established after proceedings, Article 10:57 paragraph $1 \mathrm{BW}$, as understood and applied by the Dutch judiciary, requires that the repudiation-based divorce (1) has been established abroad, outside the Kingdom of the Netherlands; (2) has been established by the decision of a judge or another (civil or religious) authority; (3) has been established by such an authority that had competence to do so; and (4) has been established after some form of procedure in which the wife had the opportunity to be heard. In the Netherlands, failure to fulfil the requirement of the decision by the competent authority can be repaired by means of the implicit or explicit agreement with the repudiation of the other spouse during or after the proceedings pursuant to Article 10:57 paragraph $2 \mathrm{BW}$.

Four cumulative requirements in Article 10:58 BW govern the assessment for recognition of the repudiation-based divorce established by a unilateral declaration of either spouse, without proceedings: (1) its establishment abroad; (2) its establishment in accordance with any national law of the spouse who has unilaterally dissolved the marriage, so that law has to acknowledge and allow the repudiation; (3) its legal effect in the state of its establishment; and the most important requirement, (4) the explicit or implicit agreement to or acquiescence in the repudiation by the other spouse irrespective of that spouse's nationality or place of residence. The latter may become apparent from facts or circumstances such as the demand for divorce by both spouses, the remarriage of the other spouse, his or her request to register the divorce, etcetera, but it should not be assumed too quickly but assessed on a case-by-case basis. 
If recognition of the repudiation in a concrete case nevertheless results in a violation of the PIL public order, Article 10:59 BW allows for withholding recognition of that repudiation by invoking the public policy exception.

Legal scholars also defend the recognition of the extra-judicial, administrative divorces based on mutual consent as result of a teleological interpretation of Article 10:57 paragraph $2 \mathrm{BW}$. This article could be relevant for the recognition of those extra-judicial repudiationbased divorces that are based on mutual consent of the spouses, such as the Egyptian modalities of the traditional out-of-court khul' or talaq al-ibra, or the delegated repudiation, or the Pakistani out-of-court khul', the Pakistani mubara'a, or Pakistani modalities of the delegated repudiation. Requirements for their recognition are as follows: (1) being acquired abroad; (2) having legal effect in its country of establishment; and possibly, in addition, (3) being legally valid in form and in relation to substantive requirements according to the law of the state of its establishment. The administrative authority such as the registrar, notary, or chairman of the Union Council has the duty to check the fulfilment of the formal requirements in relation to the establishment of the divorce and to draw up the act of divorce that has the same legal effect as the judicial dissolution of marriage.

\subsection{Criteria in England}

The repudiation-based divorce has to fulfil the following requirements in order to qualify for recognition in the United Kingdom pursuant to section 46(1) FLA 1986: (1) being obtained by judicial or other proceedings that must begin and end in the same country, other proceedings meaning that the wife has received notice or a copy of such divorce, or that there was intervention of an authority with some degree of formality or the involvement of some agency, or registration of such a divorce before the court or a judgment that validates the repudiation; (2) being established overseas, which means emanating from a nonBritish jurisdiction and being in accordance with the law of the foreign state; (3) being effective under the law of the country in which it was obtained; (4) either party having their habitual residence or domicile (in the English or in the foreign family law's sense) in or the nationality of the country in which the divorce is obtained at the date of commencement of the proceedings. However, the repudiation-based divorce, after proceedings between spouses, either of which is domiciled in England, cannot be recognized as it constitutes an infringement upon the public order as was held in Chaudhary v. Chaudhary.

The repudiation-based divorce that does not fulfil the abovementioned requirements can still qualify for recognition pursuant to the more strict section 46(2) FLA 1986 if it fulfils the following requirements: (1) it was obtained otherwise than by means of proceedings; (2) it is effective under the law of the country of origin; (3) each party is domiciled in the country of origin at the date the repudiation-based divorce was obtained, or either party is domiciled there, while the other party is domiciled in the country under whose law the repudiation is recognized as valid at that time; and (4) neither spouse has their 
habitual residence in the United Kingdom in the year preceding the date the repudiation was obtained.

However, even if the repudiation-based divorce has fulfilled the aforementioned requirements, the English judge still has the discretion to refuse the recognition (or not) on an exclusive number of grounds pursuant to section 51 FLA 1986. These grounds, some of which concern the repudiation-based divorce after judicial or other proceedings, are as follows: irreconcilability of the repudiation-based divorce with a decision about the subsistence or validity of the marriage of the parties that has been previously given in the United Kingdom or has been recognized in the United Kingdom; lack of a subsisting marriage according to English law, including English PIL at the time the repudiation-based divorce is obtained; lack of a notice of the proceedings; a lack of an opportunity to take part in the proceedings that it is impossible to certify the effectiveness or validity of the repudiation by official documents; and the manifest violation of the public order, including fraud and duress.

\subsection{Criteria in France}

In French case law, there is no distinction between repudiation-based divorces after judicial or other proceedings and those without proceedings. Since 2004, the French Cour de Cassation and lower courts deny the recognition of repudiation-based divorces, based on an argument of the violation of the principle of gender equality upon divorce pursuant to Article 5 of the 7 th Protocol to the ECHR, if there is sufficient proximity with the French legal order.

The first requirement for the recognition of repudiation-based divorces is that there is no sufficient proximity with the French legal order. This is the case if both spouses, or at least the wife, are not domiciled in France and/or if both spouses, or at least the husband, do not have French nationality. An example of this situation could be a Moroccan husband domiciled in France with a Moroccan wife who is domiciled in Morocco.

Furthermore, the requirements of the various bilateral Conventions, if they allow for recognition of repudiation-based divorces, have to be met. The France-Egypt Convention does not allow for the recognition of repudiation-based divorces, as discussed in chapter 15. Article 13 of the 1981 France-Morocco Convention allows for the recognition of homologated repudiation-based divorces concerning spouses who both have the Moroccan nationality or concerning a Moroccan husband and a French wife (being the person who demands for recognition). These repudiation-based divorces will have legal effect in France under the same conditions as a foreign divorce judgment if they have been drawn up according to the requirements of Moroccan law. These requirements, in the context of homologated repudiation-based divorces, are (1) an act of repudiation drawn up by competent authorities and homologation of that act emanating from a competent judge; (2) a summons served on both spouses, or their proper representation or proper declaration of 
their non-appearance in court; (3) a final repudiation(-based divorce); (4) the absence of evasion of law; and (5) no infringement upon the French public order or irreconcilability with a previous French divorce decision.

The public order exception is applied as public order of proximity (ordre public de proximité) in the case of repudiation-based divorces that are deemed to have proximity to the French legal order. The closer the links between the case and the French legal order are, the stronger the exception of the PIL public order will be. If there is no proximity of the case with the French legal order, the doctrine of the mitigated effect of public policy (effet atténué de l'ordre public) is applied, meaning that the public order exception will be weaker and the violation of fundamental norms and values is not sanctioned if the legal situation has no or few links with the French legal order while the divorce has been regularly established abroad.

\subsubsection{Comparison Criteria Repudiation-Based Divorces}

A comparison of the criteria for repudiation-based divorces shows the following significant similarity: all legal systems under review require the establishment of the repudiationbased divorce abroad, whether or not it was established after proceedings. Repudiationbased divorces established on Dutch, English, or French soil cannot be recognized. The Dutch, English, and French judges, respectively, have the exclusive right to grant a divorce because of the far-reaching consequences of the divorce and, thus, to ensure the protection of the interests of the spouses and third parties and to guarantee that post-divorce arrangements are made. ${ }^{1}$

For that reason, the requirement of establishment abroad also affects transnational repudiation-based divorces. Transnational divorces are divorces of which some parts of the divorce (proceedings) occur in one country, such as in England, France, or the Netherlands, while other parts of the divorce, often the more formal one(s), occur in another state, such as the country of origin of either spouse. In France, repudiation-based divorces are denied recognition in any case if proximity with the French legal order is established, which is the case in respect of transnational divorces. In England and the Netherlands, the requirement of establishment abroad of the repudiation-based divorce results in the denial of the recognition of transnational repudiation-based divorces obtained or established after proceedings. However, the Netherlands and England both allow the recognition of bare repudiation-based divorces, at the same time. Bare repudiation-based divorces involve, if anything, less protection for women than the repudiation-based divorces obtained or

1 See in relation to the Netherlands Art. 10:55 BW; for England section 44(1) FLA 1986; and for France Cour d'appel Paris 7 July 1959, Rev. Crit. DIP 1960, p. 354, annotated by Y. Loussouarn; Tribunal de Grande Instance Paris, 26 January 1978, Rev. Crit. DIP 1979, p. 855, annotated by Khan; Cour d'appel Paris 4 November 1992, Dr. et patrimoine 1993, p. 42; Cour d'appel Versailles 23 March 1995, Rev. Crit. DIP 1996, p. 699 , annotated by H. Gaudemet-Tallon. 
established after proceedings. However, the principle of not allowing repudiations on Dutch or English soil prevails. In England and the Netherlands, it also results in limping legal relationships when the repudiation-based divorce is considered to be legally valid in the country of origin. And that may still encourage the wealthy man to go abroad for a quick divorce, which is completely in contrast with the rationale behind the English policy of discouraging recognition.

\subsection{Comparison Criteria Repudiation-Based Divorces after Proceedings}

Comparison of the criteria for repudiation-based divorces established or obtained after proceedings shows the following significant differences.

\section{Intervention of the Competent Authority}

The Dutch and English legal systems consider the intervention of an (competent) authority to be a relevant requirement for the recognition of repudiation-based divorces established by proceedings. The Dutch legal system requires this intervention to be that the judge, or any other authority, grants the divorce with a decision, whereas the English legal system requires any intervention of an authority that has a degree of formality or the involvement of some agency.

The Dutch legal system thus applies a more narrowly-defined definition of intervention of an authority than the English legal system does. The English system refers to any decision that involves the dissolution of a marriage such as its establishment, registration, or validation. The Dutch system narrows that intervention to the decision that dissolves the marriage. On the other hand, it should be realized that non-compliance with the requirement of the intervention of an (competent) authority can be remedied by the implicit or explicit agreement with or acquiescence in the repudiation-based divorce by the other spouse in accordance with the Dutch system. The English legal system does not provide for such a remedy in the case of non-compliance with that requirement. The English interpretation of 'intervention of an authority' comes close to or corresponds with the nature of intervention in repudiation(-based divorces) by authorities in the four Islamic states under review.

A closer look reveals a distinction between the two types of intervention: the intervention being constitutive for the dissolution of marriage and the intervention having a declaratory nature. In my opinion, the intervention being constitutive for the dissolution of marriage should not only concern the authority's judgment that brings about the dissolution of marriage but also the permission or fiat of the judge that is indispensable for bringing about the dissolution of marriage. Examples of the latter are the interventions in repudiation-based divorces by Moroccan and Iranian judges. The declaratory intervention just confirms the dissolution of marriage that has already been brought about, such as the act of homologation or the registration. An example is the intervention of the ma'zun in Egypt. The intervention being constitutive for the dissolution of the marriage requires an active 
role of the intervening authority, who actually checks whether the rights of the wife and children have been guaranteed. The declaratory intervention requires a (more) passive role from the authority.

Concerning the requirement of 'intervention of a (competent) authority' for the recognition of repudiation-based divorces established by proceedings, it should be stressed that Dutch courts still retain and apply the original requirement for judicial divorces of the 'establishment through the decision of a judge or another authority' to the repudiationbased divorce. Apart from the fact that this requirement is at odds with the characteristic of the repudiation that the repudiation is established by means of its pronouncement by the husband, it also does not correspond with the Dutch legislator's intention. The intention of the legislator was to explain this requirement broadly as 'under supervision' or 'with cooperation' of the judge or another (civil or religious) authority in the case of repudiationbased divorces. Chapter 13 on the Dutch recognition policy provides examples of such intervention of an authority in the sense of Article 10:57 paragraph $1 \mathrm{BW}$ being the authority that tests whether or not the statutory regulations have been met, attempts of reconciliation between the spouses have been made, that checks whether or not certain financial conditions have been met, or that checks whether the dissolution of marriage took place under the supervision of the Court. In the landmark case of 13 July 2001, Strikwerda, the Advocate-General, specified the requirement of a 'decision for divorce by the judge' as the decision by the judge that allows the husband to repudiate or that grants legal effect to the repudiation. This interpretation is in line with the Dutch legislator's intention concerning the requirement that the repudiation-based divorce should be established 'under supervision' or 'with cooperation' of the judge or another (civil or religious) authority. However, also Strikwerda's interpretation has not been adopted. By applying the original requirement of a 'decision (of a judge or another authority)', the Dutch judiciary unnecessarily frustrates and precludes the recognition of repudiationbased divorces that are established by the intervention of any competent authority. That situation results in a limping legal relationship and all its consequences.

\section{Some Form of Proceedings}

Recognition of any repudiation-based divorce under the 'light' regimes of the Dutch Article 10:57 BW or the English section 46(1) FLA requires the repudiation to have been established or obtained after some form of proceedings. This requirement aims to protect the rights of women. In accordance with its interpretation in Dutch case law, the proceedings must at least offer the wife the possibility of being heard at the occasion of which the wife can provide information about and defend the post-divorce provisions. It follows from English case law that 'other proceedings' may encompass a notice of the repudiation(-based divorce) to the Chairman of the Union Council and a copy thereof to the wife or registration of the repudiation(-based divorce) before the court. By allowing for such a broad interpretation 
of the notion 'proceedings', the English legal system offers less protection for the rights of women than the Dutch legal system does. After all, 'proceedings' in the English interpretation may only consist of some sort of guarantee that the wife has been informed about the divorce.

\subsection{Comparison Criteria Repudiation-Based Divorces without Proceedings}

When comparing the requirements for the recognition of repudiation-based divorces without proceedings in the Dutch and English regimes, both appear to require the effectiveness of the repudiation-based divorce in the state in which it was obtained or established and a link to that country through nationality or domicile. Two other requirements are most striking: the unequivocal consent of the wife (Art. 10:58 BW) and the 'habitual residence at the moment of the repudiation' criterion (section 46 (2 sub c) FLA 1986).

\section{Consent of the Wife}

The Dutch criterion of the unequivocal consent of the wife, or more specifically of her explicit or implicit agreement with or acquiescence in the repudiation-based divorce, is meant to 'repair' the violation of the right of equal access to divorce and of the right to equality of procedural rights. Hence, it not only allows the recognition of bare repudiations, but also the recognition of repudiation-based divorces that do not comply with the requirement of the decision for divorce or supervision or cooperation by a competent authority. Consequently, it prevents limping legal relationships. But this requirement is at odds with the legal nature of the repudiation. Islamic law does not require the consent of the wife for the repudiation.

\section{Proximity to the Domestic Legal Order}

As mentioned in the previous subsection about the comparison of the frameworks for assessment at the macro level, French case law imposes a rather strict 'no sufficient proximity' requirement, while the Dutch regime hardly imposes such a requirement. The rationale behind these recognition policies explains this difference: to prevent husbands from evading the French legal system and its (financial) provisions (French rationale) or favor divortii (Dutch rationale). The English regime applies a more nuanced version of the 'no proximity' criterion, for the same reason as the French. It requires that neither spouse may have had habitual residence in the United Kingdom throughout a period of one year preceding the date the repudiation-based divorce was obtained. As previously stated, this requirement is more directly aimed at preventing the harmful consequences of husbands going abroad for a quick divorce and avoids the consequence of limping legal relationships to a greater extent than the French absolute 'no proximity' requirement. 


\subsection{Public Order}

Both the Dutch and English statutory regime provides for a separate public policy clause in Article 10:59 BW and section 51(3 sub c) FLA 1986, respectively. However, the content of the Dutch and English regimes in Articles 10:54, 10:57, and 10:58 BW and 46(1) and 46(2) FLA 1986 and the rationale behind the Dutch regime for the recognition of foreign non-EU divorces should preclude the success of claims of violations of the rights to gender equality upon divorce and to due process. For this reason, a plea of a violation of the PIL public order because of these human rights should not succeed once the requirements of the aforementioned articles have been fulfilled. The same, in principle, held true for the French situation in respect of Article 13 of the 1981 France-Morocco Convention. But French case law since 2004 has overruled that article.

It appears that the functioning of the French PIL public order adapts itself to the extent of proximity with the French legal order: the effet atténué is applied if there is no proximity; the public order of proximity (ordre public de proximité) is applied if there is proximity.

\subsubsection{Issues of Understanding and Classification}

It appears that local authorities in European states such as judges, registrars, etcetera, are often faced with problems of understanding and subsequently of the classification of the numerous modalities of repudiation-based divorces. This part of the analysis aims to provide more insight into the understanding and subsequently the classification of repudiation-based divorces in the European states under review. As previously stated, a 'superficial' view of Islamic divorces may lead to misunderstanding and a wrongful appreciation of the foreign divorce at issue, leading consequently to its wrong classification and thus to a wrongful (non-)recognition or a recognition under too strict conditions and all the harmful effects arising from that. Do the authorities of the European states concerned have a sound knowledge and understanding of the foreign legal institution, its procedure, and the entire divorce system in which it is embedded? If not, (how) does this affect the assessment for recognition of a specific divorce modality? To what extent is the understanding and subsequently the classification of the repudiation-based divorce influenced by the rationale of a specific recognition policy?

Examples of difficulties in understanding and classifying repudiation-based divorces are the decisions by the Dutch Hoge Raad of 13 July 2001, concerning the issue of recognition of a Moroccan khul' established under the MFC 1993, and the Dutch Council of State of 3 March 2010, concerning the issue of recognition of a Moroccan repudiation established under MFC 2004. The explanation thereof in the relevant subsections in the chapter on the Dutch recognition policy above demonstrates that misunderstanding these Moroccan modalities due to unsound knowledge about their legal and procedural character resulted 
in their incorrect classification. Consequently, the respective courts wrongfully assessed the divorces for recognition under Article 3 WCE instead of Article 2 WCE. The incorrect classification resulted in their recognition under the wrong regime leading to wrongful non-recognition. This, apart from the fact that they also incorrectly understood and applied a legislative norm in relation to repudiation-based divorces. They applied the norm 'decision for divorce by the judge' that is meant for judicial divorces instead of understanding this norm as 'supervision' or 'cooperation of the judge' and applying it as such to the repudiation-based divorces.

To summarize, the respective courts misunderstood the legal and procedural character of the negotiated repudiation, $k h u l$ ', established under the MFC 1993 and of the repudiation established under the MFC 2004, respectively, and in particular their procedural requirements, including the summons to appear before the court, the reconciliation attempt(-s) by the court, the determination of the mandatory deposit by the husband in order to guarantee his compliance with his financial duties towards wife and children, the court's permission to the repudiation, and, in the case of the repudiation established under the MFC 2004, the court's decision about the provisions for the wife and children. Moreover, the Dutch Hoge Raad misunderstood the essence of the Moroccan khul': the initiative of the wife in a repudiation that, together with the husband's agreement thereto, expresses the mutual consent of the spouses to the repudiation; the wife's initiative is its constitutive element next to the pronouncement of the repudiation by the husband and the judicial permission thereto, the latter two being constitutive elements of the repudiation in general. Consequently, the Moroccan repudiation-based divorce can be classified as a procedure under the supervision of a (competent) judge in which the parties are heard and that, for that reason, is established under certain guarantees, thus as 'divorce'. The Moroccan repudiation, $k h u l$ ', or other repudiation-based divorce modality should not be classified as a 'unilateral declaration of either spouse' since the reforms in Moroccan family law in 1993 and especially not since the 2004 Moroccan family law reforms.

A further example of these difficulties is the issue of recognition of Pakistani repudiations that are often classified in England as divorces obtained by other proceedings because of the mandatory nature of the notification procedure of section 7 MFLO and are, as such, recognized. However, the English judiciary seems to have overlooked developments in Pakistani law in that not all Pakistani repudiations have been established in accordance with this procedure and that the mandatory nature of this notification procedure has not always been upheld. Hence, a repudiation in such a situation does not meet the requirements of section 46(1) FLA and is nevertheless wrongly recognized as a repudiation obtained after 'other' (than judicial) proceedings, although it may be religiously valid in Pakistan.

Arguments for the denial of recognition of repudiation-based divorces in France are that they are considered to be established by the unilateral will of the husband, that the wife cannot contest the repudiation, and that the role of the judge is restricted to arranging 
the financial consequences of the divorce. These arguments can be criticized, partly depending on the origin of the repudiation. Apart from the fact that the wife may demand her husband to repudiate her, the Iranian and Moroccan repudiation(-based divorce) are no longer at the sole discretion of the husband because of the mandatory intervention of the judge. In Egypt and Pakistan, the wife can obtain a khul' through judicial intervention without the consent of her husband. The wife can indeed not contest the repudiation (but she can contest its revocation in Morocco), but this is also the case for the other spouse in a divorce procedure before the French court on request of either spouse. The intervention of the Iranian and Moroccan judge is not 'restricted' to arranging the financial consequences of the divorce. He also seeks to reconcile the spouses before giving his authorization or permission to repudiate to the husband. His intervention guarantees that the husband observes the (financial) rights of the wife and children.

A difficult aspect of classification concerns the question whether emphasis is put on classifying the dissolution as a repudiation or on the principle of gender equality upon divorce, hence as divorce. An illustrative example in this context is the discussion about the recognition of the Moroccan negotiated repudiation, $k h u l$ ', in legal practice and legal doctrine in the Netherlands in the mid-1990s, as described in chapter 13 on the Dutch recognition policy: should the recognition of the negotiated repudiation be assessed according to Article 2 or Article 3 WCE? In other words, is the negotiated repudiation, $\mathrm{khul}^{\mathrm{l}}$, to be considered to be equivalent to a repudiation established by means of proceedings, a divorce, or to a bare repudiation, thus established without any proceedings? The answer follows from an adequate assessment of the documents involved in the context of these laws and practices, thus requiring a sound knowledge of the Moroccan divorce laws and practices.

The embedding of a repudiation-based divorce in the entire foreign legal system may be relevant in this respect as well. How should we classify the Moroccan repudiation, apart from its procedural features, in the context of the entire Moroccan legal system that includes the shiqaq offering women (and men) an independent access to divorce? And how should a repudiation that the wife has been authorized to carry out (a self-repudiation) be classified? And how should we classify the Egyptian or Pakistani repudiation in the context of the entire Egyptian or Pakistani legal system, respectively, that grants the wife the right to a judicial $\mathrm{khul}^{\text {' }}$ without the consent of the husband? If we take into account the entire foreign Islamic legal system involved, we may come to the conclusion that, for example, in the Moroccan legal system, the parties involved do not have 'identical arms' at their disposal, but they have at least 'equally effective arms'. We must keep in mind two issues: first, the repudiation is often the only accessible mode of dissolution of marriage for men in many Muslim-majority countries, and second, it is also possible to obtain a divorce against the will of the other spouse in European legal systems. 


\subsubsection{Different Terminology}

The use of different terms in foreign legislations, in source documents or acts, or in translations thereof may complicate the understanding of the (legal and procedural nature of a) specific repudiation-based divorce modality. ${ }^{2}$ An example is the Moroccan legislator who employs the term 'divorce' (par consentement mutuel) in order to refer to the mubara'a pursuant to Article 114 MFC 2004 in its French explanatory 'Guide Pratique' while using the term talaq in the Arabic version of the legislation. ${ }^{3}$ The Dutch translator of the MFC 2004, Berger, mainly uses the term verstoting (repudiation), but sometimes also the term echtscheiding (divorce) is used. The Moroccan consulate in Amsterdam issued a document that is called Attestation de divorce and that includes terms such as acte de divorce, [a] divorce de sa femme and [c] e divorce a été fait as proof of the establishment of a repudiation before the consummation of the marriage. ${ }^{4}$ Another example is the Moroccan legal translator who employed the wording [p] ar un divorce avant la consummation de marriage and [s] faire instrumenter l'acte de divorce, thus referring to the same repudiation before the consummation of the marriage as mentioned above. ${ }^{5}$

Verhellen also refers to the use of what she aptly defines as an amalgam of documents: various definitions for one and the same modality of repudiation or divorce. ${ }^{6}$ She gives as illustrations of acts of the Moroccan khul' and mubara'a:

"[a]cte de divorce avant consommation du mariage consensuel", "divorce par consentement mutuel avant consommation du mariage", "acte de divorce moyennant compensation [khol'e]", "acte de répudiation", "acte de répudiation par consentement mutuel avant consommation du mariage", "acte de divorce à l'amiable", "divorce judiciaire par jugement consensuel", "acte de témoignage justifiant le divorce".

This causes even more confusion. Part II of this study about Islamic divorce laws and practices has already pointed out that the notion 'divorce' does not necessarily refer to a judicial divorce, but it may also encompass a modality of a repudiation-based divorce, whether or not that divorce was established after proceedings.

See also Verhellen 2012, Nos. 685-686.

Kruiniger 2008, p. 118 footnote 64.

Attestation de divorce No. 5/2008 issued by the Moroccan Consulate in Amsterdam on 3 January 2008 (in the possession of the author).

5 Translation of 'Jugement No. 301 rendu le 04/03/09' by Jamal Yassir, licensed legal translator in Nador (in possession of the author).

6 Verhellen 2012, No. 687. 


\title{
16.2.2.2 Discretion of Each Authority
}

Another problematic aspect that complicates the process of assessment concerns not only the fact that various authorities within one country each have their own responsibility and discretion regarding this process but also the fact that different entities within one and the same authority may have their own discretion. Examples are the distinct discretions of the 'Immigration and Naturalization Service' (IND) and the registrar representing the municipality, but also the distinct discretion of each individual registrar in the Netherlands, as described in chapter 13. The following example of a Belgian case, which was presented in the introduction of this study, clearly illustrates this for Belgium: ${ }^{7}$

\begin{abstract}
A Dutch-Moroccan woman was repudiated in Morocco. Later, she remarried a Moroccan man. Then she moved from the Netherlands to Belgium. Although her repudiation had been recognized in the Netherlands, Belgian authorities refused to recognize her repudiation. As a result she is still seen as being married to her former husband in Belgium and she cannot bring her latest husband from Morocco to Belgium. There is a limping legal relationship.
\end{abstract}

It appeared that the Belgian authority that refused to recognize the repudiation was the Immigration Service (Dienst Vreemdelingenzaken (DVZ)). But the woman's municipality of residence in Belgium had registered and thus recognized the repudiation! Although Belgium is not one of the EU states being reviewed in this study, this example demonstrates perfectly the harmful effects of various authorities within one country having their own discretion, such as contradictory outcomes of the process of assessment in respect of the same repudiation and, as consequence of one of these outcomes, limping legal relationships. Another consequence was that the wife had to institute two legal procedures in order to have the repudiation recognized.

Verhellen rightly opened the discussion whether a hierarchy among the (decisions for recognition from the) various authorities or one central authority having discretion or decisive competence would solve this problem. ${ }^{8}$ An additional advantage would be combining all the expertise available that, in turn, would be more efficient and economical. A round-table discussion in which, inter alia, Belgian registrars, magistrates, public servants, lawyers, professors, and researchers participated resulted in the conclusion that introducing such a hierarchy in the Belgian situation would meet with institutional and practical objections. These objections may also be relevant for other countries such as those being reviewed in this study. Such a hierarchy is considered to be incompatible with the philosophy behind the recognition that every authority has the responsibility and discretion to

Verhellen 2012, No. 700.

Verhellen 2012, p. 2013, p. 5-9, 38, 43-44. 
assess the recognition or not of a foreign decision or act without the requirement of a judicial procedure. Not all authorities have all, or the same, relevant information as they are confronted with the foreign decision or act in the context of different procedures and at different moments. For this reason, it should remain possible to take into account new information and, thus, for another authority to take an incidental decision.

Verhellen proposed another solution that may also be of interest for the countries under review: the establishment of one central and common register in order to further the unequivocal application of the requirements for recognition.

This section has shown that a correct understanding and classification of repudiationbased divorces requires a sound knowledge of the divorce laws and practices of the Muslimmajority country involved and a consistent use of terminology in respect of repudiationbased divorces. Unsound knowledge, complicated by varying terminology and an 'amalgam' of documents, may result in an incorrect understanding of the repudiation-based divorce modality involved and/or its incorrect classification. This section also illustrated that the problematic issue that each authority within a country (and even each entity within one and the same authority) has its own discretion in respect of the process of assessment may result in different outcomes of this process and, as a consequence, in limping legal relationships. Examples in this section have shown that an incorrect understanding and classification may result in wrongful non-recognition, recognition under wrong or too strict requirements, or a wrongful recognition.

The next section will demonstrate that the approach which a country follows is also relevant for the result of the assessment for recognition and its consequences.

\subsubsection{Approach}

The third aim of the evaluation is to identify the approaches towards repudiation-based divorces that the European states under review have adopted in their recognition policies. Apart from the commonly used format of the approaches in abstracto and in concreto, this study employs the format that is based on the extent of openness towards the various modalities. Whenever the state accepts the 'otherness', there will be harmony of decisions and limping legal relationships will not occur.

To what extent do the states under research accept the 'otherness' of the repudiationbased divorces? And to what extent is this PIL interest of respect for the 'otherness' influenced by other interests, such the protection principle, the right of the wife to equal access to divorce and to equal procedural rights, and the PIL interest of preventing limping legal relationships? Are these states, in comparison, less or more open towards these divorce modalities? 
Both Dutch and English PIL in principle take into account the specific legal nature of the foreign institution at hand as well as the circumstances of the case involved, by following an approach in concreto. While thus expressing their respect for the 'otherness' of the Islamic repudiation, the Dutch and English recognition policies do justice to the intrinsic values of PIL and to legal diversity. Hence, Dutch and English PIL have a more open approach towards the acceptance of the repudiation-based divorces. This conclusion is supported by the fact that both Dutch and English PIL have included provisions in their laws, allowing for the recognition of the bare repudiation-based divorce as well as for repudiation-based divorces established or obtained after proceedings.

Although the 1981 France-Morocco Convention provides for a specific provision on the recognition of Moroccan homologated repudiations as well, this provision is not applied since the 2004 ruling of the French Cour de Cassation that the repudiation, and therefore all repudiation-based modalities, is inadmissible unless there is no proximity between the case at hand and the French legal order. The 2004 Cour de Cassation judgments are still landmark decisions for the recognition of repudiations. These decisions are considered to represent an approach in abstracto, as the repudiation is being assessed as a legal institution as such which results in its non-recognition based on violation of the ECHR right of gender equality. ${ }^{9}$ However, they rather represent a 'mitigated' approach in abstracto as it appears that the repudiation may be recognized if there is no proximity between the case and the French legal order. ${ }^{10}$ The essence of French recognition policy towards repudiations can thus be summed up as its endeavour to guarantee gender equality to all persons within French jurisdiction, at the expense of favor divortii in order to prevent limping legal relationships.

The choice for this 'mitigated' approach in abstracto implies that the French judiciary is not willing to take into consideration the characteristics of the specific legal and procedural nature of the repudiation-based divorce involved or to look at the specific circumstances of the case involved apart from its proximity with the French legal order. It has previously been shown in part I of this study that various modalities of repudiation-based divorces are subjected to judicial intervention, as in Iran and Morocco, or to a notification procedure, as in Pakistan. Furthermore, the specific circumstances of the case may reveal that the wife had obtained the right to self-repudiation from her husband (tafwid) or that she herself had initiated the negotiated repudiation $(\mathrm{khul})$. In Morocco the judge can intervene, if the spouses cannot reach an agreement about the compensation. Moreover, the divorce

9 See for the characterization of the approach of the French Cour de Cassation in 2004 as approach in abstracto Foblets 2007, p. 153.

10 Discussion with Prof. De Vareilles Sommiëres on 10 July 2009 at The Hague Academy of International Law in The Hague revealed that the 2004 Cour de Cassation judgments do not represent a genuine approach in abstracto, but it has features of an approach in concreto as the repudiation will be recognized, if there is no proximity of the case with the French legal order. 
laws of Morocco, Egypt, and Pakistan provide the wife with an independent access to judicial divorce through the shiqaq procedure (Morocco) and the judicial khul' (Egypt and Pakistan, respectively).

These characteristics and circumstances are of paramount importance for the assessment as to the issue whether or not the repudiation violates the right of equal access to divorce and/or the right to defence. The fact that the specific characteristic of the judicial intervention or specific relevant circumstances of the case are not taken into account will inevitably result in the prejudiced conclusion that the Moroccan repudiation, for example, violates human rights and can, therefore, not be recognized. Hence, the French approach does not live up to the basic principle of PIL of respect for the 'otherness' of the Islamic legal institution of repudiation or to the demands of the reality of legal diversity. In addition, French case law supersedes the 1981 France-Morocco Convention that provides for recognition of the Moroccan homologated repudiation under certain conditions.

For these reasons, it can be concluded that the approach of French recognition policy is less open, or rather not open, towards Islamic repudiation-based divorces. This approach unnecessarily results in limping legal relationships at least in those cases in which the repudiation had not been invoked in order to contest the request for divorce by the wife or in which the wife has initiated or has agreed with or acquiesced in the repudiation. It seems that France has extended the rationale of the approach to not allowing the establishment of repudiations on French soil to its approach to recognition. However, one should bear in mind that the French authority involved has to assess the status of a person that has already been decided and established abroad in the process of assessment for recognition. That authority does not have to create a new status.

Contrary to English and French PIL, Dutch PIL tends to neglect the proximity of the case with its own legal order. It can thus be concluded that among the European countries under review, the Netherlands, in its recognition policy, displays the most open approach towards repudiation-based divorces. It even accepts the 'otherness' of repudiation-based divorces established without proceedings but upon the fulfilment of the requirement of the unequivocal consent of the wife to that repudiation in order to repair the inequality of the spouses upon divorce.

\subsection{Conclusion}

The issue of how the various European countries, the Netherlands, England, and France, by means of their PIL, manage the legal diversity at hand was at the centre of study in this part. How can rights and legal status established abroad have effect in their legal orders? Do these recognition policies respect 'the otherness' of the Islamic divorce laws under study? To what extent do other interests than PIL interests play a part? In sum, do the 
recognition policies of these three countries offer an efficient and fair solution for the possible conflict between their norms and values and the norms and values of Islamic divorce laws?

This part demonstrated that the point of departure underlying recognition policies towards repudiation-based divorces, recognition or non-recognition, differs in the European states under review. Dutch policy departs from the assumption that both repudiationbased divorces established with and those established without proceedings may be eligible for recognition, upon the fulfilment of certain requirements. The point of departure of the French policy is the opposite: the non-recognition of any repudiation-based divorce, if there is sufficient proximity with the French legal order. This results in practice in denying recognition to almost all repudiation-based divorces and thus in limping legal relationships and its consequences. English recognition policy takes an in-between stance: in principle there is recognition of all repudiation-based divorces upon fulfilment of certain requirements, except for one category, the repudiation-based divorce that is not obtained after proceedings and where either party had habitual residence in the United Kingdom throughout during the period of one year preceding the date it was obtained.

Furthermore, this part showed that the English and French points of departure stem from the intention to prevent husbands from circumventing their legal systems through obtaining a quick divorce in their country of origin in order to frustrate their wives' access to the English or French legal system. But a recognition policy such as the French policy that bans all repudiation-based divorces as soon as there is sufficient proximity with the French legal order, without taking into account the concrete circumstances of the case, is too rigid and disproportionate in view of its consequences. It resolves the abstract problem of the detrimental repudiation by the fraudulent husband, but it also inevitably results in the situation of limping legal relationship in the concrete case. This is unnecessary and wrongful in those cases where the concrete circumstances could have allowed for recognition, and it is in particular harmful to those women who pursue recognition. It obviously hampers rights and legal status from having legal effect in the French legal order. The French policy also shows no respect for the 'otherness' of the repudiation-based divorces by lumping them all together and not taking into account their specific characteristics and concrete circumstances. For these reasons, the French legal system does not offer a fair and effective solution.

In comparison to the French recognition policy, the English policy offers a far better and fairer solution for the same abstract problem. First, it only denies recognition to those repudiation-based divorces that are obtained without proceedings if either party has been a habitual resident in the United Kingdom during the period of one year preceding the date it was obtained. For this reason, it limits the risk of unnecessary limping legal relationships. Second, it provides for financial relief to the wife after the recognition of her repudiation-based divorce according to part III of the Matrimonial and Family Proceedings Act 
1984. For these reasons, the English legal system in principle offers a fair and effective solution for conflicts between the domestic legal system and the Islamic legal systems. As said, in principle, since English judicial practice has shown shortcomings in the understanding and classification of the Pakistani repudiation that resulted in their wrongful recognition as repudiation obtained after 'other' (than judicial) proceedings. English recognition policy respects the 'otherness' of the repudiation-based divorces, but only to the extent that it does not allow husbands actually residing in the United Kingdom to go abroad for a quick repudiation in order to evade the domestic legal system. In this way, rights and legal status come to have legal effect in the English legal order.

The background to the Dutch stance is favor divortii and the interests of the wife in the recognition of the repudiation, in order to avoid limping legal relationships. Dutch recognition policy is notably concerned with the fundamental objections to repudiationbased divorces without any form of proceedings, but it enables their recognition nevertheless upon fulfilment of a number of cumulative requirements. The most important requirement is the unequivocal consent of the wife aimed at repairing the inequality between the spouses upon divorce. To that extent, Dutch recognition policy does respect the 'otherness' of repudiation-based divorces and offers a fair and effective solution for any apparent conflict. At the same time, legal practice has displayed shortcomings in the understanding and classification of various repudiation-based divorce modalities and in the understanding and application of its own legal norms. This hampers and may even prevent rights and legal status from having legal effect in the Netherlands. Moreover, the shortcomings with regard to understanding and classification fail to show respect for the otherness of repudiation-based divorces.

The legal comparative analysis of the Dutch, English, and French recognition policies has demonstrated major shortcomings in the management of the legal diversity at stake. First, there are problems related to the process for assessment, such as misunderstanding the various repudiation-based divorce modalities, classification problems, the variety of authorities being responsible for and having discretion for assessment, but also problems as a result of the approach to which a specific country abides. This comparative analysis also demonstrates the advantages of and need for a functional and open approach. That approach concerns an assessment in concreto of repudiation-based divorces while at the same time it balances respect for the 'otherness' of the foreign law at stake and the fundamental principle of gender equality upon divorce. Such an approach is most advisable in order to provide for an efficient and fair solution.

Second, the role and functioning of PIL is often affected by and put in the shade of other interests. Interests other than the PIL interests of respect for the 'otherness' or tolerance, international harmony of decisions, and avoidance of limping legal relationships appear to play a part to a greater or lesser extent. They appear to even dominate or supersede PIL interests and influence recognition policies. Migration interests, for example, are 
invoked in order to deny recognition to repudiation-based divorces, as was the case in the example of the Dutch-Moroccan woman. The Belgian Immigration Affairs Services (Dienst Vreemdelingenzaken) refused to recognize her second marriage because they denied recognition to her previous divorce through repudiation, although the Belgian municipality had registered and thus recognized her second marriage. These are migration interests in their negative dimension. But migration interests also have a positive dimension such as the protection of migrating persons in their legitimate expectation of respect for their fundamental rights. These rights aim to protect their identity and legal status. This dimension does not conflict with the role and functioning of PIL and should prevail.

All the above mentioned shortcomings may result in recognition under too strict conditions or wrongful (non-)recognition and its harmful consequences such as limping legal relationships. Avoiding limping legal relationships implies recognition; however, recognizing all divorces enables spouses to shop for the most attractive court and law in order to obtain a divorce which would allow the spouse to evade the requirements of the jurisdiction and laws of the country with which they are connected. Thus, fair and effective recognition rules intend to strike a fair balance between being too restrictive, which may result in limping legal relationships and being too generous by sanctioning divorces of convenience.

Third, the states under study use different policies regarding the recognition of repudiation-based divorces. There is evidently diversity in the recognition policies in Europe. This diversity has already resulted or may result in adverse consequences for Muslims migrating to or in Europe. Their diversity, the consequences, as well as possible solutions for these shortcomings are the subject of discussion in the next part of this study. 



\author{
PART III \\ Managing Legal Diversity: \\ EXPLORING SOLUTIONS FOR ITS \\ ShORTCOMINGS AND Restrictions
}





\section{INTRODUCTION}

Managing legal diversity, PIL's core business, is easy to approach on an abstract level. However, in practice, it turns out to be much more complicated and problematic, as the exploration of the recognition policies towards repudiation-based divorces in England, France, and the Netherlands in the preceding part demonstrated. That part revealed major shortcomings in the management of legal diversity at the national level. As discussed, the shortcomings concern those related to problems in the process for assessment, such as misunderstanding Islamic divorce modalities and classification issues. Shortcomings may also occur as a result of the approach to which a specific country abides. Interests other than PIL interests, such as migration, may also play a part in a specific recognition policy, among others things by 'influencing the choice for' a specific approach. As part II demonstrated, these shortcomings may lead to wrongful recognition, to recognition under too strict or under the wrong conditions, or to non-recognition and its consequences such as limping legal relationships or non-continuity of personal status. It is not alleged that a repudiation-based divorce should be recognized under all circumstances and at all times. It may be justified to deny recognition to a repudiation-based divorce in a concrete situation.

Moreover, part II revealed a diversity of national recognition policies in Europe. A disparate treatment towards recognition of repudiation-based divorces occurs in Europe due to the differing recognition policies of the European states and the absence of specific instruments dealing with recognition of third-state divorces on a supranational level. A further examination of this phenomenon in chapter 19 will show that this diversity of national recognition policies is a shortcoming on the supranational level, in particular regarding the continuity of someone's personal status after movement or migration within Europe. The question arises as to how to deal with this legal diversity in such a concrete, day-to-day situation. It is about finding solutions to concrete problems of people, not to abstract problems. Chapter 20 explores a number of such possible solutions to the shortcomings of (the diversity of) recognition policies, either on the national or EU level, or on both levels. These solutions vary from soft to hard law instruments.

But first, chapter 18 will further explain some context-related topics to the extent that it is in particular relevant for this part of the study. Individuals of whom their marriage was dissolved by means of an Islamic, in particular repudiation-based divorce and who reside in and move within Europe may fall within the scope of the EU and EU law. They may have the status of an EU citizen or of a third-country national (TCN) seen from an EU perspective. Depending on their status within the EU, these individuals can or cannot rely on specific provisions in EU law such as the (secondary) right to free movement of 
persons, one of the fundamental freedoms of the EU. ${ }^{1}$ And depending on that status, they can or cannot rely on specific solutions that will be presented in chapter 20 . For these reasons, chapter 18 sets forth the distinction of the population in the EU into EU citizens and TCNs, the relevant rights that can be derived from a specific status within the $\mathrm{EU}$, and the competences of the EU in PIL matters.

A last remark concerns the words 'decision' or 'divorce decision'. In this part, these words are used in a broad sense unless otherwise stated. It means any decision pronounced by a judicial, public, or other authority that has competence in matters related to the dissolution of marriage in the state involved. That decision may be filed in a judgment, authentic act, or any other document.

1 Art. 21 Treaty on the Functioning of the European Union (TFEU) (Art. 21 concerns free movement of EU citizens) or Arts. 45 et seq. TFEU (free movement of workers). Treaty on the Functioning of the European Union (TFEU), O.J. (C 115/47), entry into force on 1 December 2009. The TFEU amends the Treaty Establishing the European Economic Community that was originally signed in Rome. 


\section{The EU Context}

\subsection{INTRODUCTION}

Individuals who reside in and move within Europe and of whom their marriage was dissolved by means of an Islamic, in particular repudiation-based divorce, may fall within the scope of the EU and EU law. This chapter sets forth which status they may have under EU law, the status of an EU citizen or of a TCN, and their rights that can be derived from that status, such as the important right to freedom of movement enshrined in Articles 21 TFEU and 45 ChFREU (or a secondary right to free movement). This part will demonstrate that that article may be particularly relevant for those individuals of whom the marriage was dissolved by a repudiation-based divorce and who can rely on this article, because of the link between the right to freedom of movement and the continuity of their personal status within the EU. If exercising that right results in the non-continuity of someone's personal status due to recognition of that repudiation-based divorce in the one Member State and non-recognition of that divorce in another Member State as a consequence of the diversity of national recognition policies within the EU, that result may be considered as a restriction of that individual's right to freedom of movement. Chapter 20, inter alia, explores whether and to what extent EU law can offer solutions to remedy that result. For this reason, this chapter also sets forth the competences of the EU in PIL matters.

\subsection{EU Citizen or Third-Country National?}

The population within the European Union consists of EU (or Union) citizens but also of non-EU nationals who are originating from third countries. ${ }^{1}$ Individuals of whom their marriage was dissolved by means an Islamic, repudiation-based divorce and who reside in the EU may thus have the status of an EU citizen or of a third-country national (TCN). The status of an EU citizen can differ from the status of a non-EU, third-country national. TCNs have a different legal status in the EU according to whether the TCN is a family member of, and accompanying or joining an, EU citizen the TCN has a long-term residence permit, a residence permit or whether he or she is an illegal or irregular TCN. The sections

1 According to Eurostat, 20.1 million out of the 501 million inhabitants of the EU-27 were third-country nationals, so $4 \%$ of the total population in the EU-27 in 2010 (European Commission Communication, $\operatorname{COM}(2011), 291,24$ May 2011, p. 1-2). On 1 March 2014 the EU consists of 28 Member States since the accession of Croatia on 1 July 2013. 
below set out the different statuses and the rights that can be derived from these statuses and that are relevant in the context of this study.

\subsubsection{EU Citizens}

Any person who has the nationality of an EU Member State also enjoys being a citizen of the EU or Union citizenship pursuant to Article 20 TFEU. ${ }^{2}$ This concept was introduced at the occasion of the Maastricht Treaty in its Article $8 .{ }^{3} \mathrm{EU}$ citizens enjoy important rights (and duties) under EU law, such as the primary right to move and reside freely within the territory of the EU pursuant to Article 21 (1) TFEU (formerly Art. 18(1) EC Treaty, hereinafter TEC) and protected by Article 45 ChFREU also in the case that they are not economically active individuals. ${ }^{4}$ They also have the right to equal treatment pursuant to Article 18 TFEU (formerly Art. 12 TEC) that prohibits any discrimination on grounds of nationality. This right includes equal treatment with citizens of the host Member State in the case of migration. ${ }^{5}$ Case law of the European Court of Justice has further shaped the rights of citizens, notably the right of free movement, as this part will demonstrate below. It is important to realize, first, that EU citizens are not always original nationals of a Member State but may have been a TCN before their naturalization and, second, that EU citizens may have a link with a third country and/or a TCN.

\subsubsection{Distinctions among Third-Country Nationals (TCNs)}

As far as TCNs are concerned, the domestic (national) immigration law of a Member State in principle determines whether or not, and if so under what conditions, a TCN can enter the territory of a Member State either coming directly from a third country or indirectly from another Member State. ${ }^{6}$ One of the ambitious objectives of the European Council in

2 In this study, the notions of EU citizen and Union citizen, being synonyms, are used interchangeably. For a detailed discussion on Union Citizens and TCNs being family members who accompany or join EU citizens and their rights and duties, see Barnard 2013, p. 431-495.

3 Treaty on European Union (TEU) signed on 7 February 1992 and entered into force on 1 November 1993, 1992 O.J. (C 191/01).

4 According to Barnard (2013, p. 437), the European Court of Justice in Baumbast severed 'the link between migration and being economically active' (Baumbast and $R$. v. Secretary of State for the Home Department (Baumbast), Case C413/99 2002, ECR I-7091), but see also Eisele (2013, p. 2) who refers to Martinez Sala, Case C-85/96 1998, ERC I-2691 in the same context.

5 Also enshrined in Art. 24, the cornerstone of the Citizens' Rights Directive (Directive 2004/38/EC of the European Parliament and the Council of 29 April 2004 on the right of citizens of the Union and their family members to move and reside freely within the territory of the Member States).

6 Barnard 2013, p. 538. 
its Tampere Conclusions of 1999 and confirmed in the Stockholm Programme in 2009 was fair treatment of TCNs. ${ }^{7}$ The Tampere Conclusions of 1999 read as follows:

\begin{abstract}
18. The European Union must ensure fair treatment of third country nationals who reside legally on the territory of its Member States. A more vigorous integration policy should aim at granting them rights and obligations comparable to those of EU citizens. It should also enhance non-discrimination in economic, social and cultural life and develop measures against racism and xenophobia.
\end{abstract}

And moreover

21. The legal status of third country nationals should be approximated to that of Member States' nationals. A person, who has resided legally in a Member State for a period of time to be determined and who holds a long-term residence permit, should be granted in that Member State a set of uniform rights which are as near as possible to those enjoyed by EU citizens; e.g. the right to reside, receive education, and work as an employee or self-employed person, as well as the principle of non-discrimination vis-à-vis the citizens of the State of residence. The European Council endorses the objective that long-term legally resident third country nationals be offered the opportunity to obtain the nationality of the Member State in which they are resident.

As a result, the Treaty of Lisbon, Article 79 under Title V TFEU on the area of freedom, security, and justice, reflects these principles by stating that:

1. The Union shall develop a common immigration policy aimed at ensuring, at all stages, the efficient management of migration flows, fair treatment of third-country nationals residing legally in Member States, and the preven-

7 Tampere European Council 15 and 16 October 1999, Presidency Conclusions, notably paras. 18 and 21. The Tampere and Stockholm Programmes are the first and third five-year programmes that have been adopted by the European Council in order to create an 'Area of Freedom, Security and Justice' (AFSJ). The idea of an AFSJ was introduced in the Treaty of Amsterdam in May 1999. The AFSJ include a collection of home affairs and justice policies and covers areas such as the harmonization of PIL, a common European immigration policy, and police and judicial cooperation. The AFSJ and the subsequent five-year multi-annual programmes are discussed more in detail in chapter 20. EU law applicable to TCNs appears to be rather fragmented which may result in legal uncertainty, unclearness, etcetera. Eisele (2013, p. 2-3) even questions whether the 'differing legal positions are compatible with the principle of non-discrimination under the EU legal framework'. 
tion of, and enhanced measures to combat, illegal immigration and trafficking in human beings.

2. For the purposes of paragraph 1, the European Parliament and the Council, acting in accordance with the ordinary legislative procedure, shall adopt measures in the following areas:

(a) the conditions of entry and residence, and standards on the issue by Member States of long-term visas and residence permits, including those for the purpose of family reunification;

(b) the definition of the rights of third-country nationals residing legally in a Member State, including the conditions governing freedom of movement and of residence in other Member States; [...].

Article 21 (1) TFEU states that the right to residence and free movement are 'subject to the limitations and conditions laid down in the Treaties and by the measures adopted to give them effect' such as the Citizens' Rights Directive (hereinafter CRD), an instrument of secondary EU law. ${ }^{8}$

\subsubsection{Family Members of EU Citizens}

The CRD not only applies to Union citizens but also to their TCN family members, irrespective of their nationality, who 'accompany or join' the Union citizen, who moves or resides in a Member State other than that which they are a national. ${ }^{9}$ These family members concern those who must be admitted to another state, being spouses, registered partners recognized as such in both home and host state, descendants under the age of 21 , and

8 Directive 2004/38 on the right of citizens of the Union and their family members to move and reside freely within the territory of the Member States [2004] O.J. (L 158/77), entry into force on 30 April 2004. The Citizens' Rights Directive amended Regulation (EEC) No. 1612/68 and repealed nine already existing directives concerning the entry and residence for Union citizens. Art. 1 states that it lays down the conditions under which the Union citizens and their family members may move and reside freely within the EU Member States, the right to permanent residence, and the restrictions of these rights based on grounds of public policy, public security, or public health. The field of application has been extended to EEA nationals, being nationals of the European Economic Area which includes the EU and of three European Free Trade Association (EFTA) members: Iceland, Norway, and Liechtenstein; see Decision of the EEA Joint Committee No. 158/2007 of 7 December 2007, O.J. (L124), 8 May 2008, p. 20-23, that concerns, inter alia, the incorporation of the CRD into the EEA Agreement. Accordingly, the provisions of the Directive shall, for the purposes of the Agreement, be read with the following adaptations: 'the Agreement applies to nationals of the Contracting Parties. However, members of their family within the meaning of the Directive possessing the nationality of a third country shall derive certain rights according to the Directive'. The EU/Swiss Agreement on the free movement of persons between the EU and its Member States on the one hand and the Swiss Confederation on the other hand (O.J. (L 114/6) of 30 April 2002) also provides for the right to move between one EU state and another.

9 Recital 5 to the CRD; for the definition of family members, see Art. 2(2) CRD. 
dependent descendants and ascendants. ${ }^{10}$ Second, it may also concern those for whom the host state must merely facilitate their entry and residence, being other family members than those of the mandatory category who either, first, depend on the EU citizen; second, are a member of the household of the EU citizen; or, third, have serious health conditions requiring personal care by the EU citizen; and being the partner of whom it has been duly attested that the EU citizen has a durable relationship with him or her. ${ }^{11}$ The basic idea enshrined in the Directive is that 'the rights enjoyed by the migrant citizen and their family members increase the longer a person is resident in another Member State'. ${ }^{12}$

\subsubsection{Other Categories of TCNs}

Whereas EU citizens and the above-mentioned categories of TCN family members enjoy free movement between the Member States, other TCNs in general do not enjoy free movement except for the categories that enjoy what is termed as secondary movement, which will be addressed next. ${ }^{13}$

First of all, the category of long-term resident TCNs and the family members who are allowed to join them will be addressed. ${ }^{14}$ TCNs who have legally resided in the territory of a specific EU Member State continuously for five years will be granted a long-term residence permit that is valid for at least five years, if the TCN has adequate resources and health insurance. They may, inter alia, enjoy secondary free movement and reside in the territory of another Member State for more than three months if they exercise an economic activity either as an employed or self-employed person, or study there and have adequate resources and health insurance or if they have adequate resources and health insurance.

The second category to be addressed is the category of TCNs that are admitted to an EU Member State for the purposes of scientific research and their family members who are allowed to join them. ${ }^{15}$ These TCNs are entitled to a residence permit for a period of

10 Art. 3(1) CRD; see Barnard 2013, p. 440-446, for a more detailed explanation of the meaning of the various terms to describe family members under Art. 3(1) CRD.

11 Art. 3(2) CRD.

12 Barnard 2013, p. 438.

13 For a detailed discussion of TCNs being not family members of an EU citizen and the EU, see Barnard 2013, p. 538-576.

14 Under Council Directive 2003/109/EC of 25 November 2003 concerning the status of third-country nationals who are long-term residents, L 16/44 as adopted under Arts. 63(3)(a) and (4) TEC; this Directive does not apply to the United Kingdom, Ireland, and Denmark; Art. 3(2) states a long list of categories of TCNs with lawful residence that are excluded from entitlement to the status of long-term resident such as students, refugees, and au pairs. See for the list of family members who must or may be allowed to join the TCN in the context of family reunification, The Family Reunification Directive 2003/86, Council Directive 2003/86/EC of 22 September 2003 on the right to family reunification, O.J. (L 251), 3 October 2003, p. 00120018. See for a more detailed account of the rights of long-term residents: Barnard 2013, p. 560-561; Eisele 2013, p. 71-72.

15 Under Council Directive 2005/71/EC of 12 October 2005 on a specific procedure for admitting third-country nationals for the purposes of scientific research, O.J. (L 289/15) adopted under Art. 63(3)(a) and (4) TEC; the Directive does not apply to the United Kingdom and Denmark; Ireland has notified an intention to 
at least a year, inter alia, under the condition that they work with an approved research organization in the Member State and that they demonstrate that they have sufficient resources and health insurance.

The third category of TCNs is the category of highly qualified workers and their family members who are allowed to join them. ${ }^{16} \mathrm{~A}$ TCN who has an offer for a job that requires higher education qualifications or, if national law permits so, equivalent professional experience for at least five years is entitled to an EU blue card, if the person has health insurance and is not considered to be a threat to public policy, security, or health. These TCNs and their family members are allowed for secondary mobility to another Member State in order to undertake highly qualified work after a period of 18 months of legal residence in the first Member State. ${ }^{17}$

Furthermore, the following categories of TCNs, who have legally entered the territory of a Contracting State, are entitled to secondary movement for a short period pursuant to the Convention implementing the Schengen Agreement (CISA): ${ }^{18}$

- Aliens holding uniform visas are allowed to move freely within the territories of all Contracting Parties during the period of validity of their visas (Art. 19 CISA).

- Aliens being not subject to visa requirements are allowed to move freely within the territories of all Contracting Parties for a maximum period of three months during the six months following the date of first entry (Art. 20 CISA).

- Aliens having a valid residence permit issued by one of the Contracting Parties are allowed to travel to another Member State for up to three months (Art. 21 CISA).

Finally, it is of paramount importance to realize that not only EU citizens but also TCNs can claim protection under the EU Charter of Fundamental Rights, e.g. under its Article 45 that guarantees and protects the freedom of movement and of residence. Both EU citizens and TCNs can also rely on international human rights instruments to which Member States or the EU are party, such as the European Convention on Human Rights (ECHR).

participate. See for the list of family members who must or may be allowed to join the TCN in the context of family reunification, The Family Reunification Directive 2003/86. See also Barnard 2013, p. 563; Eisele 2013, p. 73.

16 Under Council Directive 2009/50/EC of 25 May 2009 on the conditions of entry and residence of thirdcountry nationals for the purposes of highly-qualified employment, O.J. (L 155/17) adopted under Art. 63(3)(a) and (4) TEC; the United Kingdom, Ireland, and Denmark do not participate in the Directive. See for the list of family members who must or may be allowed to join the TCN in the context of family reunification, The Family Reunification Directive 2003/86. See also Barnard 2013, p. 563; Eisele 2013, p. 73.

17 Arts. 18-19 Directive 2009/50.

18 The Schengen acquis - Convention implementing the Schengen Agreement of 14 June 1985 between the Governments of the States of the Benelux Economic Union, the Federal Republic of Germany, and the French Republic on the gradual abolition of checks at their common borders 2000, O.J (L 239), 22 September 2000, p. 0019-0062. 


\subsection{EU Legislative Competences in PIL Matters}

Chapter 20, inter alia, explores whether and to what extent EU law can offer solutions to remedy problems of continuity of the personal status of an EU citizen or a TCN residing in the EU and of whom the marriage was dissolved by a repudiation-based divorce. These problems may arise due to the situation of recognition of the repudiation-based divorce of that person in the one Member State and non-recognition of that divorce in another Member State. This situation may be a consequence of the diversity of national recognition policies within the EU.

The diversity stems from the fact that traditionally each Member State, or each state in general, has the discretion to make its own laws including PIL rules, based on its sovereignty. For this reason, national laws or rules (may) differ. Usually, rules of two or more national legal systems are applicable in cross-border cases. A situation of conflicting (differing) national rules results in disparate treatment in a cross-border case. However, that is in principle inherent to the coexistence of various national legal systems.

The sovereignty of (Member) States appears to be relative in that states must take into account instruments of supranational legal orders by which they are bound, such as instruments of the European Union, the Charter of Fundamental Rights of the European Union, and the European Convention on Human Rights. The EU, in principle, respects the sovereignty of its Member States, as Article 67(1) TFEU underlines by commanding ' $[\mathrm{r}$ ]espect for fundamental rights and the different legal systems and traditions of the Member States'. Furthermore, Article 4(2) of the Treaty on European Union (hereinafter TEU) states: ${ }^{19}$

The Union shall respect the equality of Member States before the Treaties as well as their national identities, inherent in their fundamental structures, political and constitutional, inclusive of regional and local self-government[...].

EU law may have primacy if a specific matter falls within the competence of the EU. The EU has no legislative competence in substantive family and personal law. The analysis of case law, in particular on names, in chapter 20 will show that the EU can step in and may restrict national sovereignty even in matters that are within the competence of Member States, if two or more legal systems conflict in regulating a cross-border case and this affects fundamental rights of EU citizens and objectives of the EU (law) ${ }^{20}$ When a person, for

19 The Treaty on European Union, O.J. (C 115/13) of 9 May 2008.

20 See, by way of analogy, Dafeki v. Landesversicherugsanstalt Württemberg, ECJ 2 December 1997, C336/94, ECR 1997, p. I-06761, paras. 16-20; see also Carlos Garcia Avello v. Etat Belge, ECJ 2 October 2003, Case 148/02, ECR 2003, I-11613, paras. 25-26; Grunkin and Paul, ECJ 14 October 2008, Case C-353/06, ECR I-0000, para. 16; Sayn-Wittgenstein ECJ 22 December 2010, Case C-208/09, ECR 2010, p. I-13693, para. 38. 
example, exercises her or his right to free movement and exercising this right results in a situation of recognition of her or his name in the one Member State but non-recognition of that name in another Member State, that result may be considered as a restriction of that individual's right to freedom of movement. In those situations of disparate treatment, Member States must nevertheless comply with EU law when exercising their competence. The analysis will further show that in this context not only national legal rules, policies, or measures that are discriminatory based on nationality but also those that restrict any of the rights to free movement are in principle prohibited under EU law. These discriminatory or restricting legal rules, measures, or policies are not prohibited if they can be justified either through express provisions in EU law or if they are based on objective considerations and are proportionate to the legitimate objective pursued by the national rules. ${ }^{21}$ Discrimination or restrictions that cannot be justified have to be resolved.

This section sets forth the legislative competences of the EU in PIL matters. EU solutions as actions of the EU require a legal basis. Articles 5(1) and (2) TEU stipulate that the Union legislator has only the competences that are conferred upon it by the Member States in the Treaties; competences that are not conferred upon the Union legislator in the Treaties remain with the Member States.

\subsubsection{Internal Legislative Competence}

\subsubsection{Situation prior to the Treaty of Amsterdam}

The involvement and development of PIL in the EU context is of a rather recent date. ${ }^{22}$ In order to create a common internal market based on the four freedoms of movement for goods, persons, services, and capital, the predecessor of the EU, the European Economic Community, almost exclusively used rules of administrative law and of other areas of public law such as rules regarding residence and labour permits and qualitative and quantitative import restrictions. Not much attention was paid to PIL matters. There was only one relevant provision in this respect that provided for a framework to conclude treaties of public international law, Article 220 of the EEC Treaty of $1958 .{ }^{23}$ This article encouraged Member States 'so far as necessary' to enter into negotiation with each other with a view to the simplification of formalities governing the reciprocal recognition and enforcement of judgments of courts or tribunals and of arbitration awards. ${ }^{24}$ This article,

21 See, e.g., Grunkin and Paul, para. 29; Sayn-Wittgenstein, para. 81.

22 Bogdan 2012, p. 6; Baarsma 2010, p. 65.

23 Baarsma 2010, p. 67. This Art. 220 of the EEC Treaty of 1958 has been abolished when the TFEU entered into force on 1 December 2009.

24 De Groot \& Kuipers 2008, p. 109; Baarsma 2010, p. 67; this article was repealed by the Lisbon Treaty. 
inter alia, resulted in the conclusion of the 'Brussels Convention on Jurisdiction and Enforcement of Foreign Judgments in Civil and Commercial Matters', in $1968 .{ }^{25}$

However, it is obvious that differences in the area of private law may also result in obstacles that hamper the achievement of a common internal market. For this reason, attempts were undertaken to harmonize substantive rules of Member States in limited sub-areas of private law such as rules related to the companies or the protection of consumers. However, harmonization or unification of the private law of the Member States appeared to be difficult because of differences in the substantive laws, differences in legal techniques used in the Member States, and the principle of subsidiarity as now enshrined in Article 5(3) TEU. ${ }^{26}$ For this reason, the importance of the harmonization or unification of the PIL of the Member States became increasingly clear.

A first turning point in the development of PIL in the EU was the introduction of the Articles K1 and K3 into Title VI on cooperation in the field of Justice and Home Affairs of the Treaty of Maastricht of $1992 .^{27}$ Article 220 EEC Treaty was maintained. Article K1 placed judicial cooperation in civil matters under the 'third pillar' of the EU. Hence, this Treaty created the legal base for negotiating and adopting EU conventions in the area of PIL resulting, inter alia, in the Brussels Convention on Jurisdiction and the Recognition and Enforcement of Judgments in Matrimonial Matters. ${ }^{28}$ The Treaty of Maastricht did not confer the competence to enact measures such as Regulations and Directives in the area of PIL upon the European Community.

\subsubsection{Situation since the Treaty of Amsterdam}

The 1999 Treaty of Amsterdam was a significant turning point in the development of PIL in the EU. ${ }^{29}$ Its amendments transferred 'judicial cooperation in civil matters' from the 'third pillar' to the 'first pillar' of European integration. Hence, Article 61(c) EC Treaty conferred the competence upon the Council to enact measures in these matters as provided for in its Article 65 in order to progressively establish progressively 'an area of freedom, security and justice'. Article 65 EC Treaty stipulated the following:

25 1972, O.J. (L 299/32).

26 The principle of subsidiarity that is enshrined in Art. 5(3) TEU requires that the EU shall only act in areas which do not fall within its exclusive competence, if the objectives of the proposed action cannot be sufficiently achieved by the Member States at the national level but can be better achieved at Union level.

27 Treaty of Maastricht or formally the Treaty on European Union, O.J. (C 191), 29 July 1992, entry into force on 1 November 1993.

28 1998, O.J. (C 221); this Convention never entered into force.

29 Treaty of Amsterdam amending the Treaty of the European Union, the Treaties establishing the European Communities and certain related acts, O.J. (C 340), 10 November 1997, entry into force on 1 May 1999. Art. 61(c) read with the Arts. 65 and 67 EC Treaty resulted in among others the Regulations Brussels I and Brussels II-bis. 
Measures in the field of judicial cooperation in civil matters having cross-border implications, to be taken in accordance with Article 67 and in so far as necessary for the proper functioning of the internal market, shall include:

(a) improving and simplifying:

- the system for cross-border service of judicial and extrajudicial documents,

- cooperation in the taking of evidence,

- the recognition and enforcement of decisions in civil and commercial cases, including decisions in extrajudicial cases;

(b) promoting the compatibility of the rules applicable in the Member States concerning the conflict of laws and of jurisdiction;

(c) eliminating obstacles to the good functioning of civil proceedings, if necessary by promoting the compatibility of the rules on civil procedure applicable in the Member States.

From the formulation of Article 65 EC Treaty, it follows that the competence to enact measures encompassed all the areas of PIL, jurisdiction, applicable law, and recognition and enforcement and that it was not limited to matters concerning the free movement of persons. ${ }^{30}$ The legislative competence of the Council was limited to measures to be taken 'insofar as necessary for the proper functioning of the internal market'. Furthermore, that competence was limited by the above-mentioned general principle of subsidiarity in Article 5 TEU.

Because of the entry into force of the Treaty on the Functioning of the European Union (TFEU) on 1 December 2009, Article 81 TFEU replaced Article 65 of the EC Treaty. This article stipulates:

1. The Union shall develop judicial cooperation in civil matters having crossborder implications, based on the principle of mutual recognition of judgments and of decisions in extrajudicial cases. Such cooperation may include the adoption of measures for the approximation of the laws and regulations of the Member States.

2. For the purposes of paragraph 1, the European Parliament and the Council, acting in accordance with the ordinary legislative procedure, shall adopt measures, particularly when necessary for the proper functioning of the internal market, aimed at ensuring:

(a) the mutual recognition and enforcement between Member States of judgments and of decisions in extrajudicial cases;

30 Baarsma 2010, p. 70-72; Bogdan 2012, p. 9. 
(b) the cross-border service of judicial and extrajudicial documents;

(c) the compatibility of the rules applicable in the Member States concerning conflict of laws and of jurisdiction;

(d) cooperation in the taking of evidence;

(e) effective access to justice;

(f) the elimination of obstacles to the proper functioning of civil proceedings, if necessary by promoting the compatibility of the rules on civil procedure applicable in the Member States;

(g) the development of alternative methods of dispute settlement;

(h) support for the training of the judiciary and judicial staff.

3. Notwithstanding paragraph 2, measures concerning family law with crossborder implications shall be established by the Council, acting in accordance with a special legislative procedure. The Council shall act unanimously after consulting the European Parliament.

The Council, on a proposal from the Commission, may adopt a decision determining those aspects of family law with cross-border implications which may be the subject of acts adopted by the ordinary legislative procedure. The Council shall act unanimously after consulting the European Parliament.

The proposal referred to in the second subparagraph shall be notified to the national Parliaments. If a national Parliament makes known its opposition within six months of the date of such notification, the decision shall not be adopted. In the absence of opposition, the Council may adopt the decision.

The following changes in Article 81 TFEU compared to its predecessor Article 65 EC Treaty are relevant. First, Article 81 TFEU shows a broader concept of 'judicial cooperation in civil matters' compared to its predecessor Article 65 EC Treaty. Second, replacing the wordings 'insofar as necessary' in Article 65 EC Treaty by the wordings 'particular when necessary' in Article 81 TFEU means that the adoption of measures thus no longer depends on the internal market requirement. This has expanded the legal basis of the Union action in the field of 'judicial cooperation in civil matters'. ${ }^{31}$ The removal of the necessary link with the internal market also clarifies the existence of competence of the EU in particular regarding the adoption of measures in the field of international family law and the issue of its external competence that will be discussed below. ${ }^{32}$ Third, the TFEU provides for a separate chapter that deals with 'judicial cooperation in civil matters' within Title V on

31 De Groot \& Kuipers 2008, p. 110-111; Baarsma 2010, p. 77.

32 Baarsma 2010, p. 78. 
'the area of freedom, security and justice' that replaced Title IV on 'Visas, asylum, immigration and other policies related to the free movement of persons' in the EC Treaty. Finally, where Article 65 EC Treaty used the wordings 'improving and simplifying the recognition and enforcement of decisions in civil and commercial cases, including decisions in extrajudicial cases', Article 81 TFEU more firmly aims at 'ensuring [...] the mutual recognition and enforcement between Member States of judgments and of decisions in extrajudicial cases'.

Article 81 TFEU is part of Title V on 'the area of freedom, security and justice' and should therefore be read in connection with Article 4(2)(j) TFEU. Article 4(2)(j) TFEU confers a shared competence between the Union and the Member States in the 'area of freedom, security and justice'. From Article 81 TFEU it follows that the EU has a (shared) competence to adopt measures that, first, must concern 'judicial cooperation in civil matters' and, second, have cross-border effects. The last requirement implies that the competence of the EU is restricted to PIL matters and does not extend to purely internal situations. For this reason, the EU has no competence to adopt measures on substantive law matters. Furthermore, the EU has in general to respect the principle of subsidiarity pursuant to Article 5(3) TEU and the principle of proportionality pursuant to Article 5(4) TEU when exercising its non-exclusive competences. ${ }^{33}$ Baarsma mentions that the European Court of Justice has confirmed that the limitations of the principles, in particular of the principle of subsidiarity, are primarily political and that the EU legislator has a broad discretion in these matters. ${ }^{34}$ The principle of proportionality relates to the legal nature of the 'measures' in Article 81 TFEU that are used to achieve the objectives.

It can be argued that the internal competence of the EU in the area of PIL regarding civil including family matters also extends to the regulation of extra-European cases since 2009. ${ }^{35}$ As Article 81 TFEU no longer imperatively demands fulfilment of the internal market requirement, the EU competence pursuant to Article 81 TFEU does no longer depend on the necessity of the measure to be taken for the proper functioning of the internal market. Moreover, Article 81 TFEU forms part of the framework that aims to establish an area of freedom, security, and justice, the common European judicial area. Consequently, the competence is no longer restricted to intra-European PIL cases as Article

33 See for the application of these principles Protocol No. 2 on the application of the principles of subsidiarity and proportionality that is an annex to the TEU and the TFEU [2008], O.J. (C 115/206). The principle of subsidiarity pursuant to Art. 5(3) TEU requires that the EU shall only act in areas which do not fall within its exclusive competence, if and in so far as the objectives of the proposed action cannot be sufficiently achieved by the Member States at the national level but can be better achieved at Union level. The principle of proportionality pursuant to Art. 5(4) requires that 'the content and form of Union action shall not exceed what is necessary to achieve the objectives of the Treaties'.

34 Baarsma 2010, p. 98.

35 See also Baarsma 2010, p. 97, who uses the same line of argumentation in the context of choice of law rules. In the situation of an extended internal competence, the conflict rule may not only refer to the law of a Member State but also to the law of a non-Member State. 
81 TFEU offers a broader legal basis for the European legislator. Article 81 TFEU thus grants the EU the competence not only to, for example, enact or amend recognition rules related to intra-European divorce decisions but also to enact or amend recognition rules related to extra-European, third-state divorce decisions.

The 'measures' to be taken can be all the legal instruments as provided for by Article 288 TFEU leaving the EU legislator a wide margin of discretion to choose the instrument that is best suited to regulate a certain topic. Article 288 TFEU more specifically stipulates:

To exercise the Union's competences, the institutions shall adopt regulations, directives, decisions, recommendations and opinions.

A regulation shall have general application. It shall be binding in its entirety and directly applicable in all Member States.

A directive shall be binding, as to the result to be achieved, upon each Member State to which it is addressed, but shall leave to the national authorities the choice of form and methods [...].

Regulations appear to be the most preferred instrument in practice. They offer legal certainty, predictability, and consistency. Regulations as compared to directives (and also to treaties) offer the advantages of being directly applicable in the Member States and having primacy over national law. Regulations do not need to be transposed into national law in contrast with directives whereby the Member States are free to choose the means and the wording of their transposition. Furthermore, Regulations are part of the acquis communautaire, the body of common rights and obligations which bind all the Member States together within the EU. ${ }^{36}$

\subsubsection{Special Position Denmark, United Kingdom, and Ireland}

Already since the Treaty of Amsterdam, the United Kingdom, Ireland, and Denmark enjoy a privileged position in relation to the former Title IV on visa, immigration, and asylum policy under the EC Treaty and now in relation to Title V on the area of freedom, security, and justice in the TFEU. ${ }^{37}$ The United Kingdom and Ireland are not obliged to participate in the preparation and adoption of a specific instrument pursuant to a special protocol. ${ }^{38}$ These Member States may opt in or opt out and thus decide on an ad hoc basis whether or not they want to participate. Denmark is not bound by the instruments that are made on the basis of the former Article 65 EC Treaty or on the basis of the current Article 81

$36<\mathrm{http} / /$ europa.eu/legislation_summaries/glossary/community_acquis_en.htm>.

37 Bogdan 2012, p. 13. Art. 69 EC Treaty.

38 Protocol No. 21 on the position of the United Kingdom and Ireland in respect of the area of freedom, security, and justice, annexed to the EU Treaty and the Treaty on the Functioning of the European Union, 2008, O.J. (C 115/295). 
TFEU pursuant to a special protocol. ${ }^{39}$ It is, however, connected to some of these instruments by means of separate agreements. ${ }^{40}$ Since the Treaty of Lisbon, a separate annex is added to this protocol that reproduces the terms of the Protocol on the position of the United Kingdom and Ireland and opens the possibility that Denmark's opt-out regarding the judicial cooperation in civil matters can be changed, subject to approval by referendum. This referendum has not yet taken place.

\subsubsection{Legislative Procedures}

Article 81(2) and (3) TFEU prescribes the legislative procedure for the adoption of PIL measures. Article 82(2) TFEU provides for the general procedure, which means that the Council enacts PIL measures in accordance with the ordinary legislative procedure. This procedure is the co-decision procedure for measures relating to judicial cooperation in civil matters pursuant to Article 289 in connection with Article 294 TFEU. Article 82 (3) TFEU, excluding international family law from this general procedure, provides for a special legislative procedure for the enactment of family law measures with cross-border implications. The Council can only act unanimously after consulting the European Parliament. Consequently, each Member State has a 'right of veto' that may restrict the exercise of the legislative competence of the $\mathrm{EU}$ in the area of international family law. The very strict legislative procedure can be explained by the sensitiveness of the area of family law 'particularly since it touches upon the very socio-political, cultural and religious heart of a nation'. ${ }^{41}$ For this reason, Member States wish to keep as many controls as possible over and proved to be reluctant to give up their national sovereignty in this area of law. However, the TFEU does introduce a passerelle clause in Article 81(3) TFEU. The Council may adopt by unanimity a decision after consultation of the European Parliament and on a proposal from the Commission that certain aspects of family law with cross-border implications may be subject of acts adopted by the ordinary legislative procedure. Although Article 67(2) EC Treaty already provided for such a passerelle clause, the passerelle clause of Article 81(3) TFEU also requires that the proposal of the Commission shall be notified to the national parliaments. If a national parliament announces its opposition to the proposed decision within six months after the notification and thus vetoes the proposed decision, the Council shall not adopt it. In the absence of any such opposition, the Council may adopt the decision. However, it is questionable whether this passerelle clause will be used in relation to the politically, culturally, religiously, and morally sensitive matters of family

39 Protocol No. 22 on the position of Denmark, annexed to the EU Treaty and the Treaty on the Functioning of the European Union, 2008, O.J. (C 115/299).

40 See, e.g., the Council Decision of 20 September 2005 on the Signing, on behalf of the Community, of the Agreement between the European Community and the Kingdom of Denmark on Jurisdiction and the Recognition and Enforcement of Judgments in Civil and Commercial Matters, 2005, O.J. (L 299), p. 61.

41 Baarsma 2010, p. 103. 
law. According to De Groot and Kuipers, the passerelle may be used in three different situations. ${ }^{42}$ One of these situations concerns family matters that are less sensitive and therefore do not require a special legislative procedure based on unanimity. Another situation concerns family matters for which ECJ has developed leading principles in its case law.

\subsubsection{External Legislative Competence}

The EU also has an implied exclusive external legislative competence in the area of PIL pursuant to Article 216 in connection with Article 3(2) TFEU. ${ }^{43}$ Article 216 TFEU stipulates that the EU may conclude international agreements if, first, the Treaties so provide; second, the conclusion of such an agreement is necessary in order to achieve an objective that is referred to in the Treaties or is provided for in a legally binding Union act; or, third, the conclusion of such an agreement is likely to affect common rules or alter their scope. Article 216 TFEU does not clarify whether the EU has an exclusive or shared exclusive competence. This article has therefore to be read in connection with Article 3(2) TFEU which entails that when the conclusion of an international agreement is required by a legislative act of the Union or is necessary to enable the Union to exercise its internal competence or in so far as conclusion of such an international agreement may affect common rules or alter their scope, the Union shall have exclusive competence for the conclusion of such an agreement. When the EU negotiates and concludes international agreements, it has to comply with the procedure as stipulated in Article 218 TFEU. The exclusive external competence of the EU means that Member States are in principle not allowed anymore to undertake, for example, new obligations under the Hague Conventions. ${ }^{44}$ It appears from Regulation 664/2009 of 7 July 2009 (hereinafter the Regulation on External Agreements in specific Family Matters $)^{45}$ that, although the EU has exclusive external competence related to these matters, the EU Commission may authorize a Member State to negotiate amendments to or the conclusion of bilateral or regional agreements with a third state concerning matters falling within the scope of the Brussels

42 De Groot \& Kuipers 2008, p. 113-114.

43 Baarsma 2010, p. 97-98; Bogdan 2012, p. 12-13.

44 Bogdan 2012, p. 12.

45 Council Regulation (EC) No. 664/2009 of 7 July 2009 establishing a procedure for the negotiation and conclusion of agreements between Member States and third countries concerning jurisdiction, recognition, and enforcement of judgments and decisions in matrimonial matters, matters of parental responsibility, and matters relating to maintenance obligations and the law applicable to matters relating to maintenance obligations (Regulation on External Agreements in Family Matters), O.J. (L 220/46) of 31 July 2009, legally based in the Arts. 61(c), 65, 67(2), and 67(5) TEC. 
II-bis Regulation and the Maintenance Regulation, ${ }^{46}$ under its control. That Regulation will be discussed in detail in chapter 20 .

Prior to the Lisbon Treaty and thus the entry into force of the TFEU, the EU's external competence could be inferred from the ERTA principle that was formulated by the European Court of Justice in the case of Commission v. Council regarding the European Agreement concerning the Work of Crews of Vehicles Engaged in International Road Transport (ERTA). ${ }^{47}$ This was confirmed in Opinion 1/03 of the European Court of Justice concerning the competence of the, at that time, Community to conclude a new Lugano Convention on jurisdiction and the enforcement of judgments in civil and commercial matters. ${ }^{48}$ This implies that Member States 'no longer have the right $[\ldots]$ to undertake obligations with non-Member State countries which affect' common rules adopted by the EU. ${ }^{49}$ The EU thus has an exclusive external competence regarding, inter alia, family matters which are already governed by Union acts in force.

46 Council Regulation (EC) No. 4/2009 of 18 December 2008 on Jurisdiction, Applicable Law, Recognition and Enforcement of Decisions and Cooperation in Matters Relating to Maintenance Obligations (Maintenance Regulation), O.J. (L 7/1-79) of 10 January 2009 and O.J. (L 131/26) of 18 May 2011, entry into force on 30 January 2009 (twentieth day following its publication in the Official Journal of the European Union; see Art. 76 Maintenance Regulation).

47 Case 22/70 [1971] ECR 263.

48 See Pertegas 2008, p. 175-187; Baratta 2008, p. 189-193; Malatesta 2008, p. 388-389.

49 Opinion 1/03 of 7 February 2006, ECR 2006, I-1145, para. 116. 


\section{Diversity of Recognition Policies within EUROPE}

\subsection{Why Diversity?}

The analysis of the Dutch, English, and French recognition policies in part II of this study clearly demonstrated a disparate treatment towards the recognition of third-state, repudiation-based divorces within Europe. These recognition policies can differ since every state has, in principle, its own discretion to regulate its private international law matters based on that state's sovereignty and since specific instruments dealing with recognition of thirdstate divorces on a supranational level lack. More specifically, every state has its own discretion towards the issue of recognition and the grounds for non-recognition such as the public policy, fraud, and irreconcilability with an earlier judgment etcetera. Moreover, the diversity of recognition policies reflects the differing, notably socially and culturally influenced, views that have moulded them. But this diversity of recognition policies may result in harmful consequences, as the two cases in the next section illustrate.

\subsection{Harmful Consequences of the Diversity Illustrated}

In the introduction to this study, the example of the Dutch-Moroccan woman, an EU citizen, was provided. She experienced difficulties after having moved to Belgium. The Belgian Immigration Affairs Service (Dienst Vreemdelingenzaken, DVZ) refused to issue a family reunification visa to her second Moroccan husband because of bigamy. The DVZ did not recognize the repudiation that had been pronounced by her first Moroccan husband in Morocco in 2005, although this repudiation had been recognized earlier in the Netherlands. The result was a multiple limping legal relationship. The woman was considered to be not divorced, and consequently she was considered to be not married to her second husband by the Belgian Immigration Affairs Service. Remarkably, the Belgian municipality of her place of residence had registered the second marriage. Hence, a discrepancy occurred between her personal status of being considered divorced from her first husband and being remarried to her second husband in Morocco; her personal status of being considered divorced from her first husband in the Netherlands and her personal status of being considered married to her second husband according to the Belgian municipality; and finally being considered not divorced from her first husband and not remarried to her second husband according to the DVZ in Belgium. She could not seek to obtain a divorce in her 
country of origin, Morocco, since she had already been divorced there. She could not seek to obtain a divorce in the Member State of recognition, the Netherlands, since her request would be declared inadmissible due to the recognition of the repudiation in the Netherlands. She could not even seek a divorce in the Member State of non-recognition of the repudiation, Belgium, due to the fact that she had no connection with Belgium at the time of repudiation. ${ }^{1}$ Furthermore, if she could have sought a divorce in either the Netherlands or Belgium, she would have been confronted with two differing dates of the dissolution of the marriage. Moreover, this situation affected her right to free movement.

Likewise, a case about the recognition of marriages can also be cited to provide an other example. In this case, a Dutch male citizen married a Nigerian woman in Nigeria. ${ }^{2}$ They moved to the United Kingdom where the marriage was recognized. Subsequently they moved to the Netherlands where the marriage was not recognized due to the application of the Dutch rules on the legalization of certificates. Consequently, the wife was refused entrance to the Netherlands by the Dutch Immigration Service, although she would normally, as a non-EU, third-country national (TCN), have been entitled to join her husband under, at the time, EC law as her marriage had been recognized in the United Kingdom. ${ }^{3}$ And the non-recognition resulted in a limping legal relationship. She was considered as not married by the Dutch authorities. ${ }^{4}$ It also restricted the right of free movement of her husband, as he would be discouraged from moving to the Netherlands if his wife could not accompany him. It was the latter that the European Court of Justice put forward as an argument in the Metock case, which addressed the rights to entry and residence of a TCN as the spouse of an EU citizen:

The refusal of the host Member State to grant rights of entry and residence to the family members of a Union citizen is as such as to discourage that citizen from moving to or residing in that Member State, even if his family members are not already lawfully resident in the territory of another Member State. ${ }^{5}$

1 Verhellen 2012, p. 456. A divorce in Belgium 'repairing' the non-recognition of the repudiation in Belgium in order to be considered in Belgium as being divorced from her first husband could only have been a solution if the wife could have obtained that divorce before her marriage to her second Moroccan husband. However, the Belgian court would not have had international jurisdiction to hear the divorce case, since at the time of the repudiation the woman neither had been habitual resident in Belgium for a specific period of time nor had the Belgian nationality as required by Art. 3 Brussels II-bis Regulation.

2 Rechtbank Amsterdam 23 January 2001, Jurisprudentie Vreemdelingenrecht 2001, 190 (with comment by G.R. de Groot).

3 Arts. 39 et seq. EC Treaty or Arts. 45 et seq. TFEU.

4 Initially also by the registrar's office.

5 Metock and others v. Minister for Justice, Equality and Law Reform, ECJ 25 July 2008, case C-127/08 Rec. 2008, p. I-6241, para. 64 . 


\subsection{Continuity of Personal Status at Stake}

Apart from situations of evasion of law or fraud, one would like to assume, especially within the socio-economic context of an increasingly globalizing world today, that one can expect to rely on the validity of the arrangements that are made regarding personal status in accordance with a specific legal system while crossing borders and notably exercising their (secondary) freedom of movement. ${ }^{6}$ Name, descent, marital status, etcetera, are an inherent part of every individual human being and follow that person wherever he or she goes. Baratta articulates that the unity, stability, and continuity of one's personal status in space are a social interest. ${ }^{7}$ In the context of the European Union, it even emerges as a socio-economic interest. The personal status should be maintained when moving across borders.

But continuity of a person's legal status appears not to be self-evident, although the official recognition of someone's personal status belongs to the sphere of one's private and family life, that is protected by, inter alia, Article 8 ECHR or Article 7 of the Charter of Fundamental Rights of the European Union (CFREU). These articles do not impose the recognition of (a change in) personal status acquired abroad, but they impose a balancing of public and private interests. ${ }^{8}$ According to Baratta, recognition of the legal status as established by foreign decisions essentially meets the primary interests of individuals as to certainty about, as well as to stability of, their personal and family legal relationships. ${ }^{9}$ He continues that instruments dealing with recognition offer a flexible solution for meeting the social need of individuals with regard to the indivisibility of their personal status. Furthermore, he defends that the primary justification for recognition can no longer only be found in the international harmony of decisions or solutions, but also in the fact that recognition tends to enforce the fundamental rights of persons.

The European Court of Justice had to decide about issues concerning the personal status of a person on a number of occasions, as the next chapter will demonstrate. In this respect, Advocate General La Pergola very strongly argued in the Dafeki case about the refusal to accept a Greek-rectified birth certificate by German social security authorities:

It cannot be accepted that an individual's status, in the sense of his legal position within the legal system in question - in this instance the Community legal system - should be evaluated differently depending on the law of the State in which he is residing or working within the territory of the Community. Were that to be the case, the way in which the competent national authorities treat

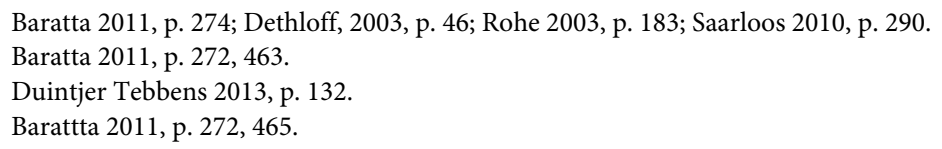


the events which are relevant for the purpose of defining the status of the person concerned would determine whether that right of the individual was recognized or denied. That is incompatible with the basic concept underlying the Treaty according to which subjective legal positions under Community law must enjoy equal recognition, that is to say it must be possible to invoke them in the same way in every Member State of the Community. In other words, the immutability of status - whenever, of course, it constitutes an element of or prerequisite for a right of the individual - derives from the necessity to guarantee in a uniform manner the actual form of subjective legal positions under Community law and their protection. It would be contrary to the very idea of integration were a right to exist and be enforceable in one Member State but not in another because the civil status of the person concerned - and more specifically his age, upon which that right depends - is assessed differently within the Community, though the Community itself is conceived, also for the purposes under consideration here, as being a single area without internal frontiers. ${ }^{10}$

La Pergola further argued that the ECJ had already confirmed the principle of 'uniformity' of the status of Community citizens (italics added) in a case concerning civil status, the Micheletti case, ${ }^{11}$ and continued by drawing the following conclusion from that case:

[o]nce it has thus been established that a person's status is determined by the law of the State to which he belongs and, consequently, that it is the authorities of that State which have the power to certify that status, the determinations made by those authorities must be accepted uniformly in all the Member States and cannot be the subject of differing assessments. ${ }^{12}$

Of course, it should be kept in mind that the Advocate General's arguments and conclusion concern the, at that time, Community context. For this reason, they cannot just be transferred to a context outside the Union.

In addition to the lack of legal certainty and predictability, the breach of the parties' legitimate expectations and arising confusion, the situation of discontinuity of personal status also has other legal, social, and financial consequences. In the context of the nonrecognition of Islamic divorces, these consequences are, in terms of impediments to a new relationship or marriage, costs for additional procedures, inaccessibility to certain social benefits, etcetera. In that respect, people may be doubly victimized, first because of the

10 Opinion of Advocate General La Pergola of 3 December 1996, case C-336/94 (Eftalia Dafeki v. Landesversicherugnsanstalt Württemberg) Rec. 1997, I-6761, para. 1.

11 Micheletti and Others v. Delegación del Gobierno en Cantabria Case C-369/90 [1992] ECR I-4239.

12 Opinion of Advocate General La Pergola of 3 December 1996 in Dafeki, para. 7. 
non-continuity of their personal status and second because of consequences such as being obliged to go through another procedure. In order to be able to reside with her current husband in Belgium, the aforementioned Dutch-Moroccan woman instituted two proceedings, one in Belgium for the recognition of her second marriage and one in the Netherlands to obtain a declaratory judgment concerning the recognition in the Netherlands of the repudiation by her first husband. ${ }^{13}$ As a result, the Belgian Court of First Instance in Turnhout delivered a judgment concerning the recognition of her second marriage without any motivation. ${ }^{14}$ The second procedure resulted in a judgment in which the Breda District Court declared that the Moroccan repudiation was recognized in the Netherlands. ${ }^{15}$

How should the recognition of a repudiation-based divorce in one Member State and its non-recognition in another Member State - apart from situations of non-recognition due to fraud or evasion of law - as a consequence of the differing recognition policies due to every Member State's own discretion to regulate its PIL matters be reconciled with fundamental rights and the rights enshrined in EU law? In the context of fundamental rights, such a situation infringes upon the right to family life and the right to marry pursuant to Articles 8 and 12 ECHR and Articles 7 and 9 ChFREU. In the context of the European Union, it hampers integration and restricts the freedom of movement of persons as, for example, enshrined in Articles 21 TFEU and 45 ChFREU. A variety of solutions for a better management of legal diversity shall be proposed and examined in the next chapter.

13 Rechtbank Turnhout 22 September 2011, AR 10/2062/B (unpublished) and Rechtbank Breda 11 October 2011, No. 232607 FA RK 11-1237, in: Verhellen 2012, p. 455.

14 Rechtbank Turnhout 22 September 2011, AR 10/2062/B (unpublished).

15 Rechtbank Breda 11 October 2011, No. 232607 FA RK 11-1237. 



\section{How Can Legal Diversity Be Managed?}

This chapter explores a number of possible solutions to remedy the shortcomings of (the diversity of) national recognition policies and their harmful effects. These solutions may be effective either on the national level, on the supranational, European level, or on both levels. This number is not exhaustive; other solutions are also conceivable. The solutions explored vary from soft to hard law instruments, being legal-technical instruments or more 'supportive' or instruments that may serve as a precondition for and further the operation of the legal-technical instruments.

\subsection{Legal Education, Trainings, Guidelines, and Manuals}

The following proposed soft law solutions are 'supportive' of character as they are a precondition to a sound and efficient functioning of legal(-technical) instruments in the context of the management of legal diversity. Their main function is to provide for sound knowledge for legal professionals who deal with the recognition of Islamic divorces. Hence, these solutions benefit all the persons who reside in Europe and whose marriages have been dissolved by means of an Islamic, in particular repudiation-based, divorce irrespective of whether they are EU citizens or TCNs.

It all starts with proper legal education. Apart from being a means to gain knowledge of law in general and of a specific national legal system in particular, legal education by means of gaining knowledge of more than one national legal system and comparing those legal systems increases the sensitivity of legal students to legal diversity. The example of the Maastricht European Law School demonstrates that students who are trained in comparative law are well prepared and equipped to manage legal diversity. ${ }^{1}$ Smits claims that for this reason 'students should be exposed to alternative ways of achieving justice, thus creating a dialogue with otherness'.

Other soft law solutions such as guidelines, manuals, or textbooks ${ }^{3}$ or trainings, formulated or provided for by experts in the field of Islamic (family) law and international family law, aim at increasing the expertise and sensitivity to legal diversity of legal professionals, such as lawyers, notaries, judges, registrars, etcetera. An example is 'The Equal Treatment Benchbook' that has been published by the Judicial Studies Board in the United Kingdom. Ballard et al. quote a statement that "The Benchbook is about "judgecraft", "the ability to

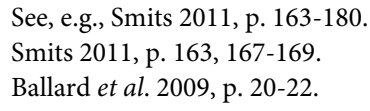


deal with all types of case and all types of litigant with fairness, humanity and courtesy in such a way that they leave the court feeling they have received justice"'. Another example may be the 'E-book on EU civil and commercial law' that could serve as a model for an online book (E-book) on the personal status laws of Muslim-majority countries or an Ebook on international family law. The 'E-book on EU civil and commercial law' includes a compilation of 17 instruments relating to civil and commercial law and a commentary explaining the content of each of these instruments. ${ }^{4}$ Another example are the specialized trainings for judges organized by the Studiecentrum Rechtspleging (known as SSR), the training institute for the judiciary in the Netherlands, or by the Judicial Studies Board in the United Kingdom. As far as specialized trainings in international family law and Islamic Law are not yet compulsory, it is recommended that they should be implemented in the various trainings for legal professionals.

These proposed instruments are simple and obvious, but their significance should not be underestimated. Trainings, guidelines, and manuals further the proper understanding and, consequently, classification of Islamic divorce modalities. For this reason, they help to foster a more consistent application of the recognition policies in order to avoid ambiguous and incorrect decisions. Hence, they are capable of enhancing legal certainty and predictability.

Moreover, regular and consistent application of guidelines may result in 'best practices' that may lead to the development of protocols or even morph into hard law. ${ }^{5}$ Guidelines are a flexible instrument because of the possibility of fast adaptation. It can be made available and easily accessible through the Internet. Although the use of guidelines is voluntary, their strength lies in their power of persuasion.

\subsection{Principles, Model Rules, or Model Law}

Principles, model rules, and model law are types of 'guidelines' on the supranational level. ${ }^{6}$ Principles drafted as a frame of reference could be considered as model or recommendations or serve as a toolbox to, for example, the European legislator to harmonize or unify national (PIL) laws or rules.

4 The 'E-book on civil and commercial law' was presented on 9 October 2013 by the General Secretariat of the Council of the EU.

5 See, for example, what is termed as 'formula of the Cantonal Judge' concerning compensation for dismissal in labour law cases (Art. 7:685 paragraph 8 Dutch Civil Code) and medical protocols which are part of the professional standard of physicians in the Netherlands (Art. 7:453 Dutch Civil Code).

6 Principles, model rules, or model law may differ regarding their level of elaboration in detail. 
The 'Principles of European Family Law regarding Divorce' drafted by the Commission on European Family Law (CEFL) in $2004{ }^{7}$ and intended 'to establish the most suitable means for the harmonization of family law within Europe', could be a model to follow. ${ }^{8}$ By way of an academic activity, a group of scholars from as many different European jurisdictions as possible performed comparative research and, as a result, drafted these principles based on the 'common core' and 'better law' approaches. By means of the 'common core approach', the CEFL tries 'to propose rules which are functionally common to a significant majority of the legal systems involved'. 'The 'better law' approach seeks 'to move forward' and 'to achieve positive results that represent the highest standard of modernity' through evaluating the national systems. ${ }^{10}$ The same working method could be undertaken by PIL scholars in order to draft principles about the recognition of third-state divorces, notably extra-judicial divorces.

According to the CEFL scholars, the time for this exercise seemed ripe. There was growing convergence in Europe and 'rapid legislative developments in the field of European private international law', such as the enactment of European legislation on the jurisdiction and recognition and enforcement of judgments in matrimonial matters, Brussels II-bis Regulation which provides for, inter alia, the recognition of divorce judgments from the one EU Member State within another EU Member State without any special procedure being required. ${ }^{11}$ The same exercise could be undertaken in order to identify the common core or better law of the national recognition policies towards third-state (divorce) decisions and acts within Europe, as a first step to harmonization.

\subsubsection{Towards Principles on the Recognition of Third-State Divorces}

It would be challenging to give the initial impetus to an outline of a draft of 'Principles of European Family Law on the Recognition of Third-State Divorces'. To remind the reader,

7 Its full title is 'Principles of European Family Law regarding Divorce and Maintenance between Former Spouses' (Boele-Woelki et al. 2004). It comprises the following principles: permitting divorce by law (1:1), determining the divorce procedure by law and granting divorce by a competent authority either being a judicial or an administrative body (1:2), permitting divorce by mutual consent as well as divorce without consent of one of the spouses in principle after a factual separation of one year $(1: 3 ; 1: 8)$, and encouraging the spouses to reach an agreement upon the consequences related to the children and economic matters but where necessary a decision on these issues by the competent authority $(1: 6 ; 1: 7 ; 1: 10)$.

8 Boele-Woelki 2005, p. 160, 164.

9 Mair 2007, p. 213.

10 Mair 2007, p. 213; Boele-Woelki 2005, p. 166.

11 Boele-Woelki 2005, p. 161 and 163; Council Regulation (EC) No. 2201/2003 of 27 November 2003 concerning jurisdiction and the recognition and enforcement of judgments in matrimonial matters and the matters of parental responsibility, O.J. (L 338/1); entry into force on 1 March 2005. 
Brussels II-bis Regulation provides for the harmonization of the recognition of divorces granted within Europe. It just concerns an initial impetus for the outline of such draft of 'Principles of European Family Law on the Recognition of Third-State Divorces'. It should be kept in mind that not just one person could take up this endeavour. The final draft should be the result of comparative research undertaken by a group of scholars from as many different European jurisdictions as possible. Nevertheless, the analysis of the recognition policies of the three European states under review in this study provides some inspiration for the formulation of basic principles that ideally should underlie a draft on 'Principles of European Family Law on Recognition of Third State Divorces'.

This analysis also highlights complex and sensitive issues to be agreed upon, such as the approach to be taken towards the repudiation-based divorce, the issue whether or not a special procedure should be required for the recognition, the extent of intervention of the competent authority and the concrete requirements for proceedings in respect of the repudiation-based divorce, the extent of proximity of the case with the domestic legal order, the extent of connection between the spouse(-s), and the legal order of establishment of the repudiation-based divorce and the public order. Considering these issues and the analysis of the aforementioned recognition policies, a tentative outline could be drafted as follows:

1. The draft Principles on the recognition of non-EU divorces should be formulated in a general manner addressing not merely repudiation-based divorces but all kinds of third-state divorces.

2. One part within these Principles should deal with the issue of recognition of repudiationbased divorces in order to do justice to their 'otherness', their specific legal nature.

3. For this reason, that part should include two specific Principles. One Principle should concern the recognition of repudiation-based divorces obtained after proceedings, whereas the other Principle should deal with the recognition of repudiation-based divorces obtained without proceedings. Hence, this distinction expresses and acknowledges the reforms within and existing diversity of the divorce laws of Muslimmajority countries. At the same time, it sets specific requirements for either type of repudiation-based divorces in order to protect in particular women. The Dutch and English statutory regimes are characterized by a similar distinction regarding the recognition of repudiation-based divorces.

4. Both Principles should be formulated in a positive way. Starting point is the recognition of repudiation-based divorces - both those obtained after and those obtained without proceedings - if specific requirements have been fulfilled. Such a formulation does justice to the pragmatic, basic principle of PIL to respect the 'otherness' of the foreign law in principle on an equal footing with domestic law by the receiving legal order.

5. The two Principles should preferably provide for the recognition of repudiation-based divorces without any special procedure being required, so an ex lege recognition. At 
least, none of the three European states under review in this study require any special procedure for the recognition of repudiation-based divorces irrespective of whether these were or were not obtained after proceedings. Although it provides for the mutual recognition of divorce judgments granted in the EU and of documents formally drawn up or registered as authentic instruments in the EU, Brussels II-bis Regulation also includes an arrangement for their recognition without any special procedure being required.

6. These two Principles should idealiter be based on an approach in concreto. Hence, assessing the repudiation-based divorce under the circumstances of the concrete case may result in its recognition, thus avoiding the (needless) occurrence of a limping legal relationship and guaranteeing continuity of the status of the person(-s) involved while doing justice to the 'otherness' of and the diversity in repudiation-based divorces. Furthermore, an approach in concreto guarantees that a possible outcome of nonrecognition is a justified outcome.

7. These specific Principles for repudiation-based divorces should idealiter be based on and reconcile the protection principle, the favor divortii principle and the pursuit of decisional harmony, the aim to prevent from fraud, and the principle of respect for the 'otherness' of Islamic divorce laws. Taking into account these principles and aims would do justice to the diversity in repudiation-based divorces, while at the same time it would guarantee the rights of women at and after divorce, preventing (needless) limping legal relationships and preventing men from pursuing a repudiation abroad in order to frustrate their wives' requests for divorce or post-divorce provisions in the European country of residence. The third and fourth considerations would also serve the more general principles of legal certainty and predictability and protect the legitimate expectations of the parties involved.

8. Interests other than PIL or the above-mentioned interests and issues should not play a part in these two Principles. Migration issues, for example, should be regulated and achieved by migration law.

9. The recognition of repudiation-based divorces in these Principles should be restricted to recognition of the effect that the repudiation-based divorce has dissolved the marriage; it should not imply recognition of other effects and consequences of and in relation to the dissolution of marriage. ${ }^{12}$

12 An example in this respect is the recognition of the negotiated repudiation or khul', which is the divorce through repudiation by the husband on the initiative of the wife in exchange for financial return. The question is whether the recognition should only entail the dissolution of marriage through the repudiation or also the obligation of the wife to pay the compensation to her husband. The above-mentioned principle advocates restricting the recognition to the effect that the repudiation-based divorce has dissolved the marriage. 
10. The section on the recognition of repudiation-based divorces should include an additional Principle that enables a spouse, in particular the wife, to claim financial provisions, such as alimony if needed, in the state of recognition, notwithstanding the issue of the recognition of the repudiation-based divorce. Hence, this additional Principle will prevent fraud; it deprives a husband of any reason for fraud by seeking to obtain a divorce by a quick repudiation abroad in order to avoid financial consequences that may result from a divorce in the European state of residence.

11. The Principle concerning repudiation-based divorces obtained after proceedings should at least depart from the following basic principles:

a. The repudiation-based divorce should be completely established abroad; this requirement shows respect for those European legal orders in which the judge has the exclusive right to grant a divorce and will discourage the establishment of transnational divorces of which some formalities have been fulfilled in the European state of residence and thus prevent fraud by the husband who seeks to obtain a divorce by a quick repudiation in order to circumvent financial consequences.

b. The repudiation-based divorce should be established in accordance with the law of the country of establishment (being legally valid).

c. The repudiation-based divorce should be legally effective in the country of establishment.

d. The repudiating party should have habitual residence, domicile (in the English or foreign family law's sense) in or the nationality of the country in which the divorce is obtained at the date of commencement of the proceedings.

e. The repudiation-based divorce should be established by means of the intervention of a judge or another authority who should have an active and constitutive role. In determining that role, the legal nature of the repudiation, being the dissolution of marriage through the pronouncement of the husband, should be taken into account. For this reason, the Principle should not impose the requirement of having a 'decision by the judge or another authority that dissolves the marriage', but instead it should rather have a requirement such as a 'decision that allows for the repudiation' or a 'decision that grants legal effect to the repudiation'. The intervention thus comes close to or corresponds to the nature of an intervention in repudiationbased divorces by the authorities in the four Islamic states under review.

f. The judge or authority should be competent to intervene.

g. The repudiation-based divorce should be established after some form of judicial or other procedure in order to meet the protection principle as much as possible; that form should provide for a check whether the procedural and substantive rights of the wife and children have been guaranteed. For this reason, it should not be restricted to informing the wife about the repudiation, but it should at least include a summons for both spouses to appear and their appearance or proper representation 
in order to be heard by the competent authority and provide information concerning and to defend the post-divorce provisions. The validity and effectiveness of the repudiation should be certified by official documents.

12. The Principle regarding repudiation-based divorces obtained without proceedings should depart from the following basic principles:

a. The repudiation-based divorce should be established abroad; this requirement shows respect for those European legal orders in which the judge has the exclusive right to grant a divorce.

b. The repudiation-based divorce should be established in accordance with any national law (or the law of the domicile) of the spouse who has unilaterally dissolved the marriage; that law has to acknowledge and allow for the repudiation.

c. The repudiation-based divorce should be legally effective in the state of its establishment, certified by an official document.

d. The wife, irrespective of her nationality or place of residence, should explicitly or implicitly agree with or acquiesce in the repudiation-based divorce. Hence, her consent implies that both spouses have agreed with the repudiation-based divorce and it 'repairs' the violations of the right to equal access to divorce and of the procedural rights upon divorce. This requirement may be at odds with the legal nature of the repudiation, as Islamic law does not require the wife's consent to the repudiation; it nevertheless pays respect to the 'otherness' of the repudiation-based divorce as it enables its recognition. Fulfilment of the requirement prevents limping legal relationships and thus provides for decisional harmony.

e. Neither spouse should have had their habitual residence in the receiving European state for a specific period of time, for example, a period of one year, preceding the date of establishment of the repudiation-based divorce; the time period has still to be agreed upon; this basic principle meets the demand for preventing from fraud.

13. The section should also include a Principle that provides grounds for the non-recognition of repudiation-based divorces at the discretion of the competent authority who assesses the request for recognition. After all, the preference for ex lege recognition of repudiation-based divorces does not necessarily entail the removal of any ground for the refusal of recognition. The grounds for the non-recognition of the repudiationbased divorces may be the following:

a. A manifest violation of the public policy of the European state in which recognition is sought. However, it should not be allowed to invoke the public policy exception, once the requirements of the two Principles on the recognition of repudiation-based divorces have been fulfilled. Fulfilment of these requirements precludes the success of a claim of the violation of the rights to gender equality upon divorce and to due process. 
b. Failure to appear; lack of reasonable steps for giving notice of the proceedings (in sufficient time) to enable the respondent to arrange for his or her defence; lack of (sufficient) intervention of any authority; lack of competence of the authority; and lack of an opportunity to take part in the proceedings, and the impossibility to certify the effectiveness or validity of the repudiation by official documents, unless it is determined that the respondent, in particular the wife, has accepted the repudiation-based divorce unequivocally (the explicit or implicit agreement with or acquiescence in the repudiation); ${ }^{13}$ the latter element expresses the consent of both spouses to the repudiation-based divorce and thus 'repairs' the violations of the right to equal access to divorce and of the procedural rights upon divorce. Although the requirement may be at odds with the legal nature of the repudiation, as Islamic law does not require the consent of the wife to the repudiation, it nevertheless pays respect to the 'otherness' of the repudiation-based divorce as it enables its recognition. Fulfilment of the requirement prevents limping legal relationships and thus provides for decisional harmony.

c. Incompatibility of the repudiation-based divorce 'with a judgment given in proceedings between the same parties in the' European state 'in which recognition is sought.'. ${ }^{14}$

d. Incompatibility 'with an earlier judgment given in another' European state or in a non-European state 'between the same parties, provided that the earlier judgment fulfils the requirements necessary for its recognition in the' European state 'in which recognition is sought'. ${ }^{15}$

As mentioned, Principles on recognition of repudiation-based divorces as species of thirdstate divorces need to be drafted by a group of scholars from as many different European jurisdictions as possible and not just by one person. This initial impetus to an outline of a draft of such Principles is not exhaustive. It can be argued, for example, to draft a separate Principle on the recognition of specific modalities of the repudiation-based divorce that require the agreement to the repudiation of both spouses such as the negotiated repudiation, $k h u l$ ', and the repudiation by agreement, mubara'a.

Dissenting opinions vis-à-vis the harmonization of national divorce laws are also voiced. Antokolskaia argues that while a general movement towards the modernization of divorce laws in European states exists, there is no spontaneous convergence ${ }^{16}$ and that, hence, no

13 Formulation partly derived from Art. 22 sub b Brussels II-bis Regulation and section 51 (3a subs i and ii) and section 51 (3b subs i and ii) FLA 1986.

14 Formulation partly derived from Art. 22 sub c Brussels II-bis Regulation.

15 Formulation partly derived from Art. 22 sub d Brussels II-bis Regulation.

16 Antokolskaia 2006, p. 307-330; p. 329-330. She holds that modernization of divorce laws and convergence of divorce laws should not be mixed up. 
'sound indication that the level of similarity of divorce laws will greatly increase in the near future' can be foreseen. In other words, harmonization of national divorce laws within Europe is not yet feasible.

Private international law answers become therefore all the more essential. And while indeed nine years after the drafting of the Principles on divorce (signs of) such harmonization still remains forthcoming, harmonization of conflict of law rules regarding divorce, although not completely, has become a (legal) reality.

An initial attempt to achieve complete harmonization concerning the applicable law to divorce through the proposal for a regulation (termed as Brussels II ter) amending Brussels II-bis Regulation (Council Regulation (EC) No. 2201/2203) failed in 2008 because of a lack of unanimity on the proposal. ${ }^{17}$ Disagreement on the methodology underlying the harmonized choice of law rules - a lex fori approach or a lex causae approach - appeared to be the most insurmountable difficulty that made unanimity impossible. The lex causae approach may result in the application of foreign law. It may be more restrictive or more liberal than and deviate from the favor matrimonii or the favor divortii principle underlying the law of the Member State involved. This is unacceptable for the Member States that adhere to a lex fori approach because of their more liberal or restrictive views on divorce and their choice for one of these approaches as represented in their substantive laws.

Council Regulation (EU) No. 1259/2010 implementing enhanced cooperation in the area of the law applicable to divorce and legal separation (termed as Rome III) has entered into force on 21 June 2012 for fourteen EU Member States. ${ }^{18}$ Could harmonizing PIL as an answer to the problematic issue of recognition of third-state divorces in Europe be a next step? This will be the subject of following sections of this chapter.

\subsection{Towards Mutual Recognition of Decisions of EU Member States on the Recognition of Third-State Divorces}

\subsubsection{Introduction}

Change or loss of personal status and its consequences after migration or movement within Europe, due to the diversity of recognition policies in Europe, could be countered by

17 See Baarsma 2009, p. 9-14.

18 Council Regulation (EU) No. $1259 / 2010$ of 20 December 2010 implementing enhanced cooperation in the area of the law applicable to divorce and legal separation (Rome III), O.J. (L 343) of 29 December 2010, p. 0010-0016, has entered into force on 21 June 2012. For the enhanced cooperation procedure, see Arts. 326334 TFEU. 
applying the principle of mutual recognition to decisions of EU Member States on the recognition of third-state divorces. ${ }^{19}$ The Commission formulated this principle as follows:

Mutual recognition is a principle that is widely understood as being based on the thought that while another state may not deal with a certain matter in the same or even a similar way as one's own state, the results will be such that they are accepted as equivalent to decisions by one's own state. Mutual trust is an important element, not only trust in the adequacy of one's partners rules, but also trust that these rules are correctly applied.

Based on this idea of equivalence and the trust it is based on, the results the other state has reached are allowed to take effect in one's own sphere of legal influence. On this basis, a decision taken by an authority in one state could be accepted as such in another state, even though a comparable authority may not even exist in that state, or could not take such decisions, or would have taken an entirely different decision in a comparable case. ${ }^{20}$

This principle is based on mutual trust between authorities of (Member) States. It is quite logical that the EU, and more specifically one European Area of Freedom, Security, and Justice, requires the recognition of a decision or document that has been taken or drawn up by a competent authority in one Member State, in the rest of the territory of the EU, that is to say in the other Member States. For this reason, Articles 21 and 46 Brussels II-bis Regulation, an EU instrument, provide in principle for mutual recognition of decisions of courts or other competent authorities in the EU and their documents concerning divorce established in an EU Member State.

It is of paramount importance that the principle of mutual recognition has found a solid legal basis in PIL in Articles 67 (4) and Article 81 (1) and (2 under a) TFEU.

Article 67 (4) TFEU states:

The Union shall facilitate access to justice, in particular through the principle of mutual recognition of judicial and extra-judicial decisions in civil matters.

Article 81 (1) TFEU states:

The Union shall develop judicial cooperation in civil matters having crossborder implications, based on the principle of mutual recognition of judgments

19 See also Baratta 2007, p. 4-11; De Groot 2007, p. 63-73; Dethloff 2003, p. 50-51; Gardeñes Santiago 2011, p. 91.

20 Communication from the Commission to the Council and the European Parliament, 'Mutual Recognition of Final Decisions in Criminal Matters', $\operatorname{COM}(2000) 495$ final, p. 4. 
and of decisions in extrajudicial cases. Such cooperation may include the adoption of measures for the approximation of the laws and regulations of the Member States.

\section{Article 81 ( 2 under a) TFEU states:}

2. For the purposes of paragraph 1, the European Parliament and the Council, acting in accordance with the ordinary legislative procedure, shall adopt measures, particularly when necessary for the proper functioning of the internal market, aimed at ensuring: [...] (a) the mutual recognition and enforcement between Member States of judgments and of decisions in extrajudicial cases.

Decisions of courts or other competent authorities in the EU and their documents concerning recognition of third-state divorces are in general not (yet) mutually recognized or accepted within the EU. This is well illustrated in the case of the Dutch-Moroccan woman in Belgium: the Netherlands had recognized her repudiation, whereas the Belgian Immigration Affairs Service had not taken over this decision nor recognized the repudiation. The Nigerian marriage case is also a good example. Yet, these are decisions or documents concerning an EU citizen and the spouse of an EU citizen, respectively, issued by a competent authority of an EU Member State after a thorough assessment of the recognition of the third-state divorce. The latter was the main argument for the Dutch District Court in the Nigerian marriage case in 2001. ${ }^{21}$ The Amsterdam court held that EC law had been violated because of the application of Dutch rules on the legalization of certificates that led to the Nigerian wife being refused entry into the Netherlands, while the certificate had already been accepted in the United Kingdom.

This section aims to examine the feasibility and mode of applying the principle of mutual recognition to the content of the decisions for recognition of third-state divorces in order to solve the problem of change or loss of personal status and its consequences after migration or movement within Europe. For this reason, this section first analyses more in general whether that principle can be implemented in matters of civil or personal status. Several developments in relation to the principle of mutual recognition appear to be relevant. To that end, developments in case law of the European Court of Justice, concerning the creation of an Area of Freedom, Security, and Justice and the adoption of specific legal instruments by the EU legislator, will be analysed. The EU context imposes its restrictions on this principle in relation to national decisions on the recognition of third-state divorces. The meaning and significance of mutual recognition should be con-

21 Rechtbank Amsterdam 23 Januari 2001, Jurisprudentie Vreemdelingenrecht 2001, 190 (annotated by G.R. de Groot). 
sidered in the context of the rights of EU citizens and of the various categories of TCNs as conferred upon them by EU law, notably the (secondary) right of free movement, as was addressed in chapter 18. EU law primarily applies to EU citizens, those persons who hold the nationality of one of the Member States. However, chapter 18 also demonstrated that not only EU citizens (including those who have been naturalized but who originally were TCNs) and specific TCN family members can rely on EU law and its rights and duties. Also a number of other categories of TCNs, such as long-term residents and those admitted for purposes of scientific research or being highly qualified workers, or certain categories of TCNs pursuant to the Convention implementing the Schengen Agreement (CISA) can, under conditions and to varying degrees, rely on EU law and its rights and duties.

\subsubsection{The Principle of Mutual Recognition in ECJ Case Law}

Case law of the European Court of Justice (hereinafter ECJ or the Court) appears to be relevant for the development and implementation of the principle of mutual recognition in EU law, not only in the context of the internal market but also in that of matters of civil status. That case law has moulded fundamental rights of EU citizens (Art. 20 TFEU; formerly Art. 17 TEC), such as the rights to non-discrimination (or equal treatment; Art. 18 TFEU; formerly Art. 12 TEC) and to move and reside freely within the territory of the Union (Art. 21 TFEU; formerly Art. 18 TEC), as this section will demonstrate. 
The European Court of Justice in Luxembourg.

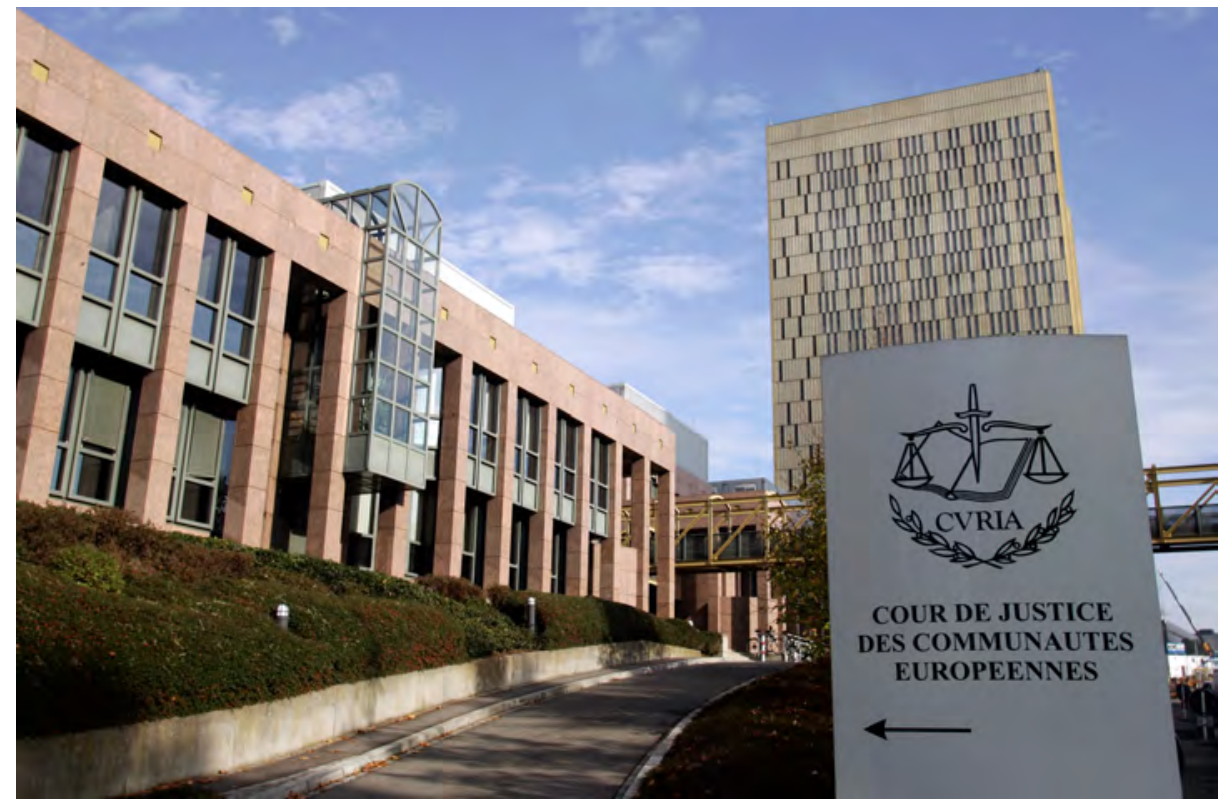

\subsubsection{Cassis de Dijon: Its Origin}

The ECJ articulated the principle of mutual recognition for the first time in the Cassis de Dijon case in relation to the free movement of goods. ${ }^{22}$ It was used for the purpose of furthering the European integration in the context of the internal market.

The relevant facts in this case were as follows: ${ }^{23}$ company Rewe-Zentral AG (Rewe) requested authorization from the Federal Monopoly Administration for Spirits (Bundesmonopolverwaltung für Branntwein) to import some spirits from France, including Cassis de Dijon, a blackcurrant liqueur containing 15 to $20 \%$ alcohol. The Administration informed Rewe that this liqueur could not be sold in Germany because of the low percentage of alcohol. Only spirits having a wine-spirit content of at least $25 \%$ were allowed to be marketed. Rewe brought an action against that decision before the Verwaltungsgericht Darmstadt which referred the case to the Hessisches Finanzgericht. That court stayed its proceedings and referred the case to the ECJ for a preliminary ruling:

[T] hereby asking for assistance in the matter of interpretation in order to enable it to assess whether the requirement of a minimum alcohol content may be

22 Rewe-Zentral AGv. Bundesmonopolverwaltung für Branntwein (Cassis de Dijon) ECJ 20 February 1979, case 120/78, REC 1979, p. 649; see notably para. 14 (4).

23 Cassis de Dijon, paras. 1-6. 
covered either by the prohibition on all measures having an effect equivalent to quantitative restrictions in trade between member states contained in article 30 of the treaty or by prohibition on all discrimination regarding the conditions under which goods are procured and marketed between nationals of Member States within the meaning of Article 37.

The ECJ started by stating that 'in the absence of common rules relating to the production and marketing of alcohol', Member States themselves may 'regulate all matters relating to the production and marketing of alcohol and alcoholic beverages on their own territory'. ${ }^{24}$ This is an affirmation of the right of states to regulate all matters that are not yet subject of community harmonization. Then the ECJ provided criteria under which exceptions to the free movement of goods should be accepted by stating that:

[O]bstacles to movement within the Community resulting from disparities between the national laws relating to the marketing of the products in question must be accepted in so far as those provisions may be recognized as being necessary in order to satisfy mandatory requirements relating in particular to the effectiveness of fiscal supervision, the protection of public health, the fairness of commercial transactions and the defence of the consumer.

In this statement, the ECJ reminds that Community law at the time (now Union law) in principle accepts disparate treatment as a result of conflicting national rules. After all, that situation is an effect that is inherent to the coexistence of national legal systems whereby each system has the sovereignty to regulate its own matters.

The court found no evidence for such mandatory requirements and thus held that legislation on 'fixing of a minimum alcohol content' for potable spirits must be understood to mean a measure 'having an effect equivalent to quantitative restrictions on imports'. Such measures and restrictions are prohibited in Article 30 EEC treaty (former Art. 28 TEC, now Art. 34 TFEU) where the importation of alcoholic beverages lawfully produced and marketed in another Member State is concerned. ${ }^{25}$

The ECJ articulated the principle of mutual recognition by stating the following:

There is therefore no valid reason why, provided that they have been lawfully produced and marketed in one of the Member States, alcoholic beverages should not be introduced into any other Member State; the sale of such products may

24 Cassis de Dijon, para. 8.

25 Cassis de Dijon, para. 15 
not be subject to a legal prohibition on the marketing of beverages with an alcohol content lower than the limit set by the national rules. ${ }^{26}$

But as stated above, the ECJ formulated four mandatory requirements that may be accepted as being necessary for restricting the free movement of goods: the effectiveness of fiscal supervision, the protection of public health, the fairness of commercial transactions, and the defence of the consumer.

Gardeñes Santiago concluded that the principle of mutual recognition essentially seeks to prevent from double regulation or unjustified double charges. ${ }^{27}$ Barnard stated in the same vein: ${ }^{28}$

The result of Cassis is to replace dual regulation of a product (by both the home and host states) with single regulation (home state) which, under the principle of mutual recognition, the host state is required to respect. Thus, Cassis introduces the principle of home state control and, in doing so, gives extra-territorial effect to the laws and standards laid down by the home state.

Saarloos points out that the principle of mutual recognition by coordinating the application of regulations of Member States has the same coordinating function in relation to goods as it has in private international law for the different national systems of private law. ${ }^{29} \mathrm{By}$ comparing a person's civil status to blackcurrant liqueur, in view of the coordinating function of the principle of mutual recognition, he shows that requiring respect from the host state for the regulation of the civil status of a person by the home state will prevent limping legal relationships that result from the dual regulation of the person's civil status by different national PIL systems.

It is challenging to apply this comparison to decisions concerning the recognition of third-state divorces as a concretization of the civil status of a person. It would imply that the limping legal relationship in the case of the Dutch-Moroccan woman resulting from the dual regulation of the recognition of third-state divorces by two different national PIL systems could have been prevented if the host state had been required to respect the regulation of the decision for recognition of the third-state divorce, i.e. her repudiation by the home state. But is it that straightforward?

Saarloos signals a first problem of how to determine the home state in the case of a person's civil status. Saarloos wonders whether that state may be the state of the person's nationality, his domicile, his habitual residence, and so forth. That problem does not occur

26 Cassis de Dijon, para. 14 (4).

27 Gardeñes Santiago 2011, p. 92.

28 Barnard 2013, p. 93.

29 Saarloos 2010, p. 291. 
in the case of decisions for the recognition of the third-state divorce; one should not overlook that that decision does not concern the establishment or creation of (a new element) or change of the civil status of a person. That decision only concerns a confirmation of that person's civil status, which has been established or created (in most cases) in the home state. And the home state is the (foreign) state to which that person belongs, according to the conclusion of Advocate General La Pergola in Dafeki. ${ }^{30}$ Advocate General La Pergola drew this conclusion from the Micheletti case, which nota bene concerned civil status.

In respect of the decision on recognition of the third-state divorce, it is not the (place of the) home state, for the purposes of civil status, that is required, but the (place of the) home state of the decision on recognition. The home state of the decision is the state where that decision was taken. As argued by Saarloos in the same way that it is obvious in the case of goods that the home state is 'the state where the goods are produced and marketed for the first time', it is also obvious in the case of the decision for recognition of a thirdstate divorce that the home state is the state where that decision was taken for the first time. ${ }^{31}$ This can be demonstrated by the example of the Dutch-Moroccan woman that was stated in the introduction of this study and in chapter 19. Her first marriage had been dissolved by a repudiation in Morocco (being a third-state divorce). That repudiation was recognized in the Netherlands for the first time but was subsequently not recognized in Belgium. So the home state of the decision on recognition in this case is the Netherlands.

However, Saarloos signals a second problem concerning what is termed as the 'race to the bottom' that may also be relevant in relation to the issue of recognition of third-state divorces. ${ }^{32}$ The German government raised this issue in Cassis de Dijon: if it is allowed to put alcoholic products with a low(-er) alcohol percentage 'into free circulation wherever', as long as these products comply with the rules of the state of production regarding their alcohol content, it would have the effect of becoming a common standard within the European Union, which would lead to lowering standards for alcoholic products in other Member States, and ultimately it would result in a convergence instead of a diversity of standards. ${ }^{33}$ Saarloos illustrates this same idea for civil status: 'if one Member State allows' for same sex marriage and same sex parenthood - and I would like to add recognition of repudiation-based divorces - 'in the end all Member States would have to accept it'. ${ }^{34}$ However, Saarloos, referring to Barnard, states that 'mandatory requirements recognized by the ECJ in Cassis' or, as Saarloos adds, 'objective justifications' as recognized by the ECJ in case law related to the free movement of persons 'are intended to place a break on any

30 Opinion of Advocate General La Pergola of 3 December 1996 in Dafeki, para. 7.

31 Saarloos 2010, p. 291.

32 Saarloos 2010, p. 292.

33 Cassis de Dijon, para. 12

34 Saarloos 2010, p. 292. 
such race to the bottom..$^{35}$ They allow for (residual) host state control where an important interest of the host state is at issue'. The following will point out that public policy may be an objective justification that indeed places a break on 'the race to the bottom'.

\subsubsection{The Principle of Mutual Recognition and Free Movement of Persons in Matters of Civil Status}

Gradually, the EU applied the principle of mutual recognition also in cases concerning the other freedoms such as the free movement of persons, among others, in the fields of competition, social security, and contract and family law. Although, according to Gardeñes Santiago, the principle of mutual recognition has other meanings in the domain of the internal market than in the domain of recognition of judicial and extra- judicial decisions in civil matters, such as decisions concerning names, it serves the same purpose of avoiding unjustified obstacles to or restrictions of the freedom of movement and shares the same basis of mutual trust. ${ }^{36}$

It should be stressed from the outset that discussion of this case law in order to demonstrate the significance of the principle of mutual recognition should be considered in relation to the status of an individual in the EU, notably being an EU citizen, a TCN family member of an EU citizen, a long-term resident TCN or family member, or a TCN or family member belonging to one of the categories as discussed above and their respective rights, in particular the right of free movement.

\subsection{Dafeki: Acceptance of Probative Value of Documents of Other Member States}

The Dafeki case concerned a claim by Mrs. Dafeki, a Greek migrant worker, for an early retirement pension from a German pension fund, on 19 December 1988. She had been working in Germany since 1966. Women who had reached the age of 60 could apply for such early retirement pension. To that end, Mrs. Dafeki presented a birth certificate that was the result of a rectification of her birth date to 20 February 1929 by a Greek court in 1986. Her former Greek civil status documents stated 3 December 1933 as her date of birth, thus indicating that she had not yet reached the age of 60 . The pension fund rejected her application and based its decision on her date of birth stated in her original civil status documents that had not yet been rectified. Mrs. Dafeki therefore instituted proceedings before a German court, the Sozialgericht Hamburg. That court questioned whether the

35 Barnard 2013, p. 94.

36 Gardeñes Santiago 2011 (p. 91-94, 105) points out that the meaning of the principle of mutual recognition in the domain of the internal market differs from its meaning in the domain of recognition of decisions in civil matters. The meaning of the principle in civil matters goes far beyond its meaning in the internal market. In the internal market, the application of the principle depends on the condition of equivalence of the norms, whereas in civil matters the principle may be applied irrespective of the equivalence of the legislative norms. The absence of the 'revision au fond' test in civil matters enables the recognition of a decision to which norms have been applied that are not equivalent to those of the recognizing state. 
application of a national rule that accords different probative value to certificates of civil status depending on whether they are of national or foreign origin is compatible with Community law, in particular with Articles 48 and 51 of the EC Treaty, as it would amount to indirect discrimination on grounds of nationality.

That court decided to stay proceedings and referred the following question to the ECJ for a preliminary ruling:

Are German social security authorities and courts bound, and if so to what extent, by the rule of Community law to the effect that foreign certificates of civil status, and judgments of foreign courts determining or rectifying data concerning matters of civil status, have binding force in proceedings concerning entitlement to social security benefit?

First, the court came to the conclusion that Community law does not require administrative and judicial authorities of a Member State to treat as equivalent rectifications of certificates of civil status made by the competent authorities of their own state and those made by these authorities of another Member State. ${ }^{37}$ The Court, inter alia, pointed out that account should be taken of 'the considerable differences that exist between the national legal orders' regarding conditions and procedures for rectifications of a date of birth and of the fact that Member States have neither harmonized this matter nor established a system for the mutual recognition of such decisions. Then the ECJ held that:

\begin{abstract}
Nevertheless, exercise of the rights arising from freedom of movement for workers is not possible without production of documents relative to personal status, which are generally issued by the worker's State of origin. It follows that the administrative and judicial authorities of a Member State must accept certificates and analogous documents relative to personal status issued by the competent authorities of the other Member States, unless their accuracy is seriously undermined by concrete evidence relating to the individual case in question. $^{38}$
\end{abstract}

It should be realized that Mrs. Dafeki did not seek to have the Greek judgment recognized in Germany, for example, in order to have her rectified age entered in the German civil status records. Hence, it does not concern an issue of mutual recognition in the strict sense. It concerns the issue that a Member State and its authorities and institutions have to take

37 Dafeki v. Landesversicherugsanstalt Württemberg ECJ 2 December 1997, C336/94, ECR 1997, p. I-06761, paras. 16-18.

38 Dafeki, para. 19. 
into account the facts as stated in the certificate or document and their appreciation by the authorities of the state that has issued the certificate. In short, they have to take into account or to accept the probative value of foreign documents. The receiving state has in principle to presume the veracity of the content of these documents emanating from other Member States based on the principle of mutual trust, unless there are reasons to suspect irregularity or inaccuracy. ${ }^{39}$ In 2010, the Commission returned to this issue in its Green Paper on promoting the free movement of public documents and recognition of the effects of civil status records, followed by the Proposal for a Regulation of the European Parliament and the Council 'on promoting the free movement of citizens and business by simplifying the acceptance of certain public documents in the EU' that will be discussed below. ${ }^{40}$

\subsection{Garcia Avello et al.: Mutual Recognition and Limping Names}

All cases to be discussed below have in common that they concern the issue of a limping (sur-)name. A limping (sur-)name concerns the situation that a person has a name in the one state that differs from that person's name in another state. Such a situation may cause serious inconveniences to someone's private and public, including professional, life. Different surnames in passports, on acts, diplomas, attestations, certificates, or other documents may raise doubts about the identity of a person, the authenticity of the document involved, and the veracity of its contents. Discussion in greater detail of these cases follows below.

\section{Garcia Avello: An Unjustified Discriminatory Restriction of Free Movement}

The Garcia Avello case concerned the request for the modification of the surname of two children born from a Spanish father, Mr. Garcia Avello, and a Belgian mother, Mrs. Weber, in Belgium in 1988 and 1992, respectively. ${ }^{41}$ The parents were married. Both children had the Belgian and the Spanish nationality and resided in Belgium. The Belgian municipality registered the children under the patronymic surname of their father in accordance with Belgian law. That law was applicable because of the Belgian preference for the Belgian nationality of the children. But the parents wanted their children to bear the surname of Garcia Weber, a double-barrelled surname that consists of the first surname of the father followed by that of the mother in accordance with well-established usage in Spanish law and tradition concerning surnames. The Spanish embassy in Belgium had indeed registered the children under this double-barrelled surname in $1993 .{ }^{42}$ The parents first requested a modification of the surname at the Belgian FOD Justitie (Federal Public Service of Justice), but their application was rejected on 1 December 1997. There were 'insufficient grounds'

39 Gardeñes Santiago 2011, p. 103-104.

$40 \operatorname{COM}(2010), 747$ final; $\operatorname{COM}(2013) 228$ final.

41 Garcia Avello, para. 13-19.

42 See Saarloos 2010, p. 267 in footnote 1352 for the source, Mr. P Kileste, the lawyer of the parents, for the year of registration at the consular section of the Spanish Embassy in Belgium. 
that would justify the modification of the surname of the children into Garcia Weber. Moreover, any request for such a double-barrelled surname is habitually refused on the ground that children bear the surname of the father in Belgium. On the occasion of their subsequent application for annulment of that decision at the Belgian Conseil d'Etat (Council of State) on 29 January 1998, the Conseil d'Etat decided to stay its proceedings and to refer the case to the ECJ for a preliminary ruling:

Are the principles of Community law relating to European citizenship and to the freedom of movement of persons, enshrined particularly in Articles 17 [EC] and $18[\mathrm{EC}]$, to be interpreted as precluding the Belgian administrative authority, to which an application to change the surname of minor children residing in Belgium who have dual Belgian and Spanish nationality has been made on the ground, without other special circumstances, that those children should bear the surname to which they are entitled according to Spanish law and tradition, from refusing that change by stating that that type of application is habitually rejected on the ground that, in Belgium, children bear their father's surname $[\ldots]$.

Articles 17 and $18 \mathrm{EC}$ as mentioned in the text are the equivalent to the present Articles 20 and 21 TFEU that provide for the right to citizenship of the Union for every person holding the nationality of a Member State and to the right of EU citizens to move freely and reside in the territory of other Member States.

The ECJ concluded in Garcia Avello that the refusal to modify the surname of the children indeed constituted discrimination without any objective justification and it was disproportionate. ${ }^{43}$ First, the Court established that the case came within the material scope of, at that time, Community law (now Union law) and thus within the Treaty provisions on citizenship of the Union. ${ }^{44}$ The children involved have the nationality of and reside in one Member State, being Belgium, whereas they also have the nationality of another Member State, being Spain. Because of the fact that the children are thus EU citizens and the case falls within the scope of Community law, the children 'may rely on the right set out in Article $12 \mathrm{EC}$ not to suffer discrimination on grounds of nationality in regard to the rules governing their surname ${ }^{35}$ The court came to its conclusion by comparing the situation of these children having dual nationality to the situation of children having only the Belgian nationality. ${ }^{46}$ The court found that their situations differed as the children with dual nationality would have different surnames in either state of their nationality resulting

43 Garcia Avello, paras. 39-44.

44 Garcia Avello, paras. 20-29.

45 Garcia Avello, para. 29.

46 Garcia Avello (judgment), paras. 34-38. 
in a 'serious inconvenience' for their private and public, including professional, lives, whereas children with only the Belgian nationality would not be in such situation. ${ }^{47}$ The case thus concerns discrimination caused by similar treatment of differently situated groups. ${ }^{48}$ The situation of the children with dual nationality was the result of disparate treatment of surnames by two national legal systems, the Belgian and the Spanish legal systems.

In their observations, the Belgian respectively Danish government put forward as justifications the immutability of surnames as a founding principle of the social order respectively as facilitating integration of nationals from other Member States in Belgium. But the ECJ did not accept these grounds. ${ }^{49}$ Furthermore, the ECJ found 'the refusal by the Belgian authorities to accede to requests for a modification of surnames such as that in issue in the main proceedings', having a disproportionate nature. ${ }^{50}$ The court put forward that 'the practice in issue already allows derogations from application of the Belgian system of handing down surnames in situations similar to that of the children of the applicant'.

For these reasons, the Court held that:

[2]. Articles $12 \mathrm{EC}$ and $17 \mathrm{EC}$ must be construed as precluding the administrative authority of a Member State from refusing to grant an application for a change of surname made on behalf of minor children resident in that State and having dual nationality of that State and of another Member State, in the case where the purpose of that application is to enable those children to bear the surname to which they are entitled according to the law and tradition of the second Member State [...]. ${ }^{51}$

\section{Grunkin and Paul: An Unjustified, Non-Discriminatory Restriction of Free Movement}

In Grunkin and Paul, the recognition of the surname of the child Leonhard Matthias was being litigated..$^{52}$ The child was of German nationality and born from German parents in Denmark in 1998. In accordance with Danish PIL, the surname Grunkin-Paul, composed of the surnames of both his father and mother, was entered on the child's birth certificate in Denmark. Upon the parents' request to register the child, the German Registry Office in Niebüll refused to recognize the double-barrelled surname of the child. The Register argued that pursuant to Article 10 EGBGB the surname of a person is determined by the

47 Garcia Avello (judgment), para. 36; Opinion Advocate General Jacobs of 22 May 2003, case C 148/02 (Garcia Avello), para. 56.

48 De Groot en Rutten 2004, p. 274; Barnard 2010, p. 447; Saarloos 2010, p. 268.

49 Garcia Avello (judgment), para. 39-43.

50 Garcia Avello (judgment), para. 44.

51 Garcia Avello, Summary of the Judgment.

52 Grunkin and Paul, para. 5-13. 
law of the state of his or her nationality and that German law does not allow such a doublebarrelled surname.

After various appeals and procedures, including a previous reference to the ECJ, for a preliminary ruling, the parents finally applied to the Amtsgericht Flensburg (cantonal court Flensburg) for an order that the Standesamt Niebüll (Register Office Niebüll) must recognize and register the surname Grunkin-Paul, as had been determined in Denmark. The court held that it could not order the Standesamt to register a surname that is not allowed under German law. The court also decided to stay its proceedings and to refer to the ECJ for a preliminary ruling: does the German PIL Article 10 EGBGB violate the right to non-discrimination pursuant to Article $12 \mathrm{EC}$ (at present: Art. 18 TFEU) and the right to freedom of movement pursuant to Article 18 EC (at present: Art. 21 TFEU) in so far as it provides that the law relating to names is governed by nationality alone? The ECJ understood this preliminary ruling as follows:

By its question, the national court asks essentially whether Articles $12 \mathrm{EC}$ and 18 EC preclude the competent authorities of a Member State from refusing to recognize a child's surname, as determined and registered in a second Member State in which the child - who, like his parents, has only the nationality of the first Member State - was born and has been resident since birth. ${ }^{53}$

The ECJ first established that the:

situation of the child Leonhard Matthias falls within the scope of the EC Treaty, under reference to the Garcia Avello case, since the child is a national of one Member State and lawfully resident in another Member State. ${ }^{54}$

The Court held that the child can therefore:

rely, in principle, as regards the Member State of which he is a national, on the right conferred by Article $12 \mathrm{EC}$ not to be discriminated against on grounds of nationality and on the right, established in Article $18 \mathrm{EC}$, to move and reside freely within the territory of the Member States. ${ }^{55}$

53 Grunkin and Paul, para. 14.

54 Grunkin and Paul, paras. 15-16.

55 Grunkin and Paul, para. 18. 
The Court applied an approach based on restrictions in this case instead of the approach based on non-discrimination as in Garcia Avello. ${ }^{56}$ In respect of Article 12 EC, the Court held that 'the determination of that child's surname in Germany in accordance with German legislation cannot constitute discrimination on grounds of nationality'. The child and his parents are German nationals, and the German conflict rule on surnames refers to the German substantive law on surnames.

However, in respect of Article 18 EC (now Art. 21 TFEU), the Court concluded that the refusal of the Member State of nationality of the child to recognize the surname that was established in the Member State of birth and residence constituted a restriction on the right to move and reside freely within the territory of the Member States.

The Court was rather clear by holding:

[A]rticle 18 EC precludes the authorities of a Member State, in applying national law which uses nationality as the sole connecting factor for the determination of surnames, from refusing to recognise a child's surname, as determined and registered in a second Member State in which the child - who, like his parents, has only the nationality of the first Member State - was born and has been resident since birth. Having to use a surname, in the Member State of which the person concerned is a national, that is different from that conferred and registered in the Member State of birth and residence is liable to hamper the exercise of the right, established in Article 18 EC, to move and reside freely within the territory of the Member States. In that regard, a discrepancy in surnames is liable to cause serious inconvenience for the person concerned, inter alia, in both the public and the private spheres on account of the fact that, as he has only one nationality, he will be issued with a passport by the State of which he is a national and which alone has the competence to do so, in a name that is different from the name he was given in the State of birth and residence. ${ }^{57}$

In fact, the situation of the limping surname (discrepancy in surnames) is the result of disparate treatment of surnames by two national legal systems, thus causing a restriction of the right to move and reside freely within the territory of the Member States of the EU citizen. The Court, by referring to the Garcia Avello case (point 36), points out that such a situation of a discrepancy in surnames 'is liable to cause serious inconvenience for those

56 Barnard 2013, p. 462-466; Barnard describes that the ECJ initially decided most of the landmark citizenship cases under the non-discrimination or equal treatment model, i.e. that the ECJ assesses whether or not discrimination based on nationality affects the right to move and reside freely within the territory of the Member States pursuant to Art. 21(1) TFEU. But then the ECJ shifts towards a restrictions- or market access approach, i.e. that the ECJ assesses whether other non-discriminatory restrictions affect the freedom of movement pursuant to Art. 21(1) TFEU.

57 Grunkin and Paul, Summary of the Judgment (see paras. 22-23, 25-28, operative part). 
concerned at both professional and private levels' through giving 'rise to doubts as to the person's identity and the authenticity of the documents submitted, or the veracity of their content ${ }^{58}$ In order to prevent this situation and its consequences of serious inconvenience, the ECJ imposes an obligation to recognize the surname as established by the first Member State based on Article 18 EC (at present: Art. 21 TFEU), thus implementing the principle of mutual recognition.

The ECJ rejected the grounds for using nationality as the sole connecting factor for the determination of surnames that the German and some other governments had put forward in order to justify the refusal to recognize the surname in question. These grounds were, inter alia, that the connecting factor 'nationality' is 'an objective criterion' that enables one to determine their surname 'with certainty and continuity', that it provides siblings with the same surname and preserves 'relationships between members of an extended family', that it ensures equal treatment to 'all persons of a particular nationality', and that it ensures the determination of 'the surnames of persons of the same nationality' in an identical manner. ${ }^{59}$ The Court showed that the use of nationality as a connecting factor in circumstances as those in the proceedings does not at all provide for certainty and continuity in respect of the determination of the surname of the child. ${ }^{60}$ The child will bear another surname as soon as he crosses the German-Danish border and vice versa. The Court rejected the ground of nationality as the connecting factor providing siblings with the same surname by simply pointing out that the issue of siblings does not arise in this case. ${ }^{61}$ The Court also pointed out that the German conflict rules relating to surnames do not only permit nationality as a connecting factor, but they also 'permit the connecting factor of the habitual residence of one of the parents where that habitual residence is in Germany' ${ }^{62}$ And finally the Court rejected the German argument of not allowing double-barrelled surnames for administrative convenience as being insufficient to justify an obstacle to freedom of movement. ${ }^{63}$ Moreover, the ECJ demonstrated that German law does not totally preclude the use of double-barrelled surnames for children of German nationality in the case 'where one of the parents has the nationality of another State'. In that case, 'the parents may choose to form the child's surname in accordance with the law of that State'.

In paragraph 38, the ECJ indicated a possible justification for the restriction of the right to free movement by precluding recognition of a child's surname that was determined and registered in Denmark if the name is contrary to public policy in Germany. ${ }^{64}$ The ECJ

58 Grunkin and Paul, paras. 23-28.

59 Grunkin and Paul, para 30.

60 Grunkin and Paul, para 32.

61 Grunkin and Paul, para. 33.

62 Grunkin and Paul, para. 34.

63 Grunkin and Paul, paras. 35-37.

64 Grunkin and Paul, para. 38. 
could not assess whether this ground indeed was a justification for precluding the recognition of the name since 'no specific reason was cited before the court'. ${ }^{65}$

The ECJ held in the Garcia Avello, Grunkin, and Paul cases, respectively, that a limping surname as result of differing national rules for determining surnames in Member States is, in principle, irreconcilable with the right of EU citizens (formerly Art. 17 TEC; now: Art. $20 \mathrm{TFEU}$ ) to non-discrimination (prohibition of discrimination on grounds of nationality; former Art. 12 TEC; now: Art. 18 TFEU) and the right of EU citizens 'to move and freely reside within the territory of the Member States' (former Art. 18 TEC; now: Art. $21 \mathrm{TFEU}) .{ }^{66}$ In these cases, the refusal to modify or to recognize the surname constituted discrimination and a restriction on the right to freedom of movement, without any justification that was based on objective considerations and was proportionate to the legitimate aim pursued by the national law.

\section{Sayn-Wittgenstein: Justified Restriction of Free Movement}

The ECJ held in the Sayn-Wittgenstein case that it may be justified to restrict the right to move and reside freely within the territory of other Member States, if this can be based on objective considerations and/or criteria in relation to the public order (or public security or public health) and if this is proportionate to the legitimate aim pursued by the national law.

The facts of this case were the following: ${ }^{67}$ in 1991, the German citizen Mr. Lothar Fürst von Sayn-Wittgenstein adopted an Austrian female adult citizen who was born in Austria in 1944 but resided in Germany at the time of adoption and proceedings. One year later, the woman acquired the surname of her adoptive father being 'Fürstin von Sayn-Wittgenstein'. She works in the real estate sector (mainly sales of castles and stately homes), principally in Germany, but also elsewhere under the name Ilonka Fürstin von Sayn-Wittgenstein. Apparently, the Austrian authorities registered that surname in the Austrian register of civil status, her passport had been renewed in that name in 2001, and the Austrian consular authorities in Germany issued two certificates of nationality in that name. However, the Verfassungsgerichtshof, the Austrian Constitutional Court, held in a case concerning a similar situation that the Austrian law on the abolition of nobility, the Adelsauf-

65 Grunkin and Paul, para. 38.

66 Carlos Garcia Avello v. Etat Belge, ECJ 2 October 2003, Case 148/02, ECR 2003, I-11613; Standesamt Niebüll, ECJ 27 April 2006, Case 96/04, ECR I-3561 and Grunkin and Paul, ECJ 14 October 2008, Case C-353/06, ECR I-0000. See also Konstantinides, ECJ 30 March 1993, Case 168/91, ECR 1993, I-1991 in which the ECJ held that the surprising transliteration of the Greek name of the litigant involved from Greek into Latin characters violates his right to free movement. See also a more detailed discussion of the Garcia Avello case and/or the Grunkin and Paul case, inter alia: De Groot 2004, p. 115-119; De Groot \& Rutten 2004, p. 273 282; Saarloos 2010, p. 267-269, 272-281, 286-287, 289-298; Verhellen 2012, p. 30-31, 381-383.

67 Sayn-Wittgenstein ECJ 22 December 2010, Case C-208/09, ECR 2010, p. I-13693, paras. 19-33; Mansel 2010, p. 305 . 
hebungsgesetz, being of constitutional status and implementing the principle of equal treatment, 'precludes an Austrian citizen from acquiring a surname' that includes the title of nobility 'von' and the title of standing Fürst, also one of foreign origin. ${ }^{68}$ As a result of that judgment, the Landeshauptmann von Wien (the Prime Minister of the federal state of Vienna) issued a decision to correct the surname of Ilonka Fürstin von Sayn-Wittgenstein in the register of civil status to 'Sayn-Wittgenstein'. In her objections and appeals, Ilonka Fürstin von Sayn-Wittgenstein referred 'to her right, based on European Union law, to travel within the Member States without having to change her name', 'on her rights to freedom of movement and to provide services, as guaranteed by the Treaties', and to the fact that 'non-recognition of the effects of the adoption with regard to the law governing names amounts to an obstacle to the freedom of movement of persons because she would have to use different surnames in different Member States'. She also argued that an amendment of her surname, which 'she has used continuously for 15 years, constitutes interference with the right to respect for family life' pursuant to Article 8 ECHR.

The Verwaltungsgerichtshof (Higher Administrative Court) stayed its proceedings and referred a preliminary question to the ECJ to inquire:

whether, in the present case, a restriction on freedom of movement liable to result from a change to the surname of the applicant in the main proceedings could nevertheless be justified in the light of the prohibition, which has constitutional status, of the use of titles of nobility, to the extent that that rule precludes Austrian citizens from using those titles, even if there is a basis in German law for their use. ${ }^{69}$

The Court first established that the situation of this case falls within the material scope of EU law. ${ }^{70}$ The applicant Mrs. Sayn-Wittgenstein is a national of a Member State and has, in her capacity as an EU citizen, used her freedom to move and to reside in another Member State; moreover, she is professionally active in the luxury real estate sector in Germany and other Member States. The Court concludes that the applicant is entitled to rely on the freedom to move and reside freely within the territory of the Member States pursuant to Article 21 TFEU.

The Court subsequently examined whether ' $\mathrm{t}]$ he refusal by the authorities of a Member State to recognize all the elements of a surname of a national of that State obtained by means of adoption in another Member State, in which that national resides', constitutes a restriction on the freedom of movement and residence, pursuant to Article 21 TFEU. ${ }^{71}$

68 Adelsaufhebungsgesetz, StGBl. (Staatsgesetzblatt) 211/1919.

69 Sayn-Wittgenstein, paras. 34-35.

70 Sayn-Wittgenstein, paras. 37-40.

71 Sayn-Wittgenstein, para. 42. 
The governments that had submitted observations argued that there was no obstacle to the freedom of movement and residence of the applicant. ${ }^{72}$ In the first place, there would be no divergence in forms of her surname entered in the registers in Germany and Austria as there was no entry in the German register of civil status; moreover, as she was an Austrian national who was born in Austria, 'she could prove her identity only on the basis of papers and documents issued by the Austrian authorities. ${ }^{73}$ Second, the governments pleaded that there was 'no inconvenience of the type' as in the case in Grunkin and Paul and more specifically that 'the correction of the name entered in the Austrian register of civil status' did not cause any risk of doubt about the identity of the applicant. ${ }^{74}$ Even if 'the title of nobility Fürst and the nobiliary particle von are removed', the essential elements characterizing the surname remain. Furthermore, there was no discrepancy in surnames, 'but rather the presence or absence' of a title of nobility as complementary to the surname. ${ }^{75}$ It is the surname that has an identifying function, whereas a title gives information about someone's social status.

But the Court concluded the opposite: the refusal by the Member State of nationality to recognize all the elements of the surname 'as entered for 15 years in the register of civil status' of the Member State of residence 'is a restriction of the freedoms conferred by Article 21 TFEU'. ${ }^{76}$ Mrs. Sayn-Wittgenstein had lived under the single name of 'Fürstin von Sayn-Wittgenstein' in Germany for 15 years that 'will have left many traces of a formal nature in both the public and the private sphere'. ${ }^{77}$ Under German law, the words Fürstin and von are considered to be constituent elements of the name that has been lawfully acquired in Germany. Her passport and driving license were issued, and her company was registered under that name in Germany, and she had opened bank accounts and concluded contracts in that name. By reference to its judgment in Grunkin and Paul, the Court stated that the divergence between the two names used for one person may lead to confusion and serious inconvenience due to having to alter all those traces of the name 'Fürstin von Sayn-Wittgenstein', 'given that her official identity documents currently refer to her by a different name ${ }^{78}$ Even if the alteration will prevent future divergences, it will be probable that Mrs. Sayn-Wittgenstein has to produce documents from before the alteration that show a different surname from that which is in her new identity documents. Every situation of difference in surnames 'is liable to give rise to doubts as to the person's identity and the authenticity of the documents submitted, or the veracity of the content'. For these reasons,

72 Mansel 2010 (p. 305-309), when commenting on the case before the ECJ had ruled in the case, also argued that there were no factual nor legal restrictions of Art. 21 TFEU.

73 Sayn-Wittgenstein, para. 45.

74 Sayn-Wittgenstein, paras. 46-47.

75 Sayn-Wittgenstein, paras. 48-49.

76 Sayn-Wittgenstein, para. 71.

77 Sayn-Wittgenstein, paras. 61-65.

78 Sayn-Wittgenstein, paras. 66-71. 
the Court held that the risk 'of being obliged because of the discrepancy in names to dispel doubts as to one's identity, is such as to hinder the exercise of the right which flows from Article $21 \mathrm{TFEU}{ }^{\prime 79}$ Interestingly, the Court started its answer by emphasizing that 'a person's name is a constituent element of his identity and private life', the latter being protected by Article 7 ChFREU and Article 8 ECHR. ${ }^{80}$

The Court then examined whether the restriction could be justified and repeated that such a restriction can only be justified if 'it is based on objective considerations and is proportionate to the legitimate objective of the national provisions ${ }^{\prime}{ }^{81}$ First, the Court established that the constitutional law on the abolition of nobility that the Austrian government invoked as an objective consideration is to be interpreted as a reliance on public policy. ${ }^{82}$ According to the Court, such an objective consideration relating to public policy may justify the refusal to recognize the surname of one of the nationals of that Member State that was given in another Member State, but the concept of public policy must be strictly interpreted. ${ }^{83}$ This means on the one hand that the scope of public policy 'cannot be determined unilaterally by each Member State without any control by the European Union institutions'. On the other hand it means that the competent national authorities have a margin of discretion within the limits that the Treaty imposes since the specific circumstances that justify the reliance on public policy may differ among Member States and over time.

The Court concluded that the objective of the law on the abolition of the nobility, i.e. to implement and observe the principle of equality before the law of all Austrian citizens as declared by the Austrian government, is compatible with EU law. ${ }^{84}$ The latter seeks to guarantee the observance of that principle as a general principle of law and has also been enshrined in Article 20 ChFREU. Upon checking whether Austria has observed the principle of proportionality, the Court concluded that the Austrian authorities did not 'appear to have gone further than is necessary in order to ensure the attainment of the fundamental constitutional objective pursued by them' by the refusal to recognize the noble elements of the name of the applicant. ${ }^{85}$ Under those circumstances, the court came to the final conclusion that that refusal 'cannot be regarded as a measure unjustifiably undermining the freedom to move and reside enjoyed by citizens of the Union'. ${ }^{86}$

The ECJ ruled: ${ }^{87}$

\footnotetext{
79 Sayn-Wittgenstein, para. 70.

80 Sayn-Wittgenstein, para. 52.

81 Sayn-Wittgenstein, para. 81.

82 Sayn-Wittgenstein, paras. 82-84.

83 Sayn-Wittgenstein, paras. 85-87.

84 Sayn-Wittgenstein, paras. 88-89.

85 Sayn-Wittgenstein, paras. 90-93.

86 Sayn-Wittgenstein, para. 94.

87 Sayn-Wittgenstein, para. 95.
} 
[A]rticle 21 TFEU must be interpreted as not precluding the authorities of a Member State, in circumstances such as those in the main proceedings, from refusing to recognise all the elements of the surname of a national of that State, as determined in another Member State - in which that national resides - at the time of his or her adoption as an adult by a national of that other Member State, where that surname includes a title of nobility which is not permitted in the first Member State under its constitutional law, provided that the measures adopted by those authorities in that context are justified on public policy grounds, that is to say, they are necessary for the protection of the interests which they are intended to secure and are proportionate to the legitimate aim pursued $[\ldots]$.

\section{Runevič-Vardyn and Wardyn}

The last relevant case to discuss in this context, because of its interesting nuances, concerns the ECJ Runevič-Vardyn and Wardyn case. ${ }^{88}$ The case concerns the refusal of the Civil Registry Division of the Municipal Administration in Vilnius (Lithuania) to amend, and more specifically to modify, the transcription of the surnames and forenames of Mrs. Malgožata Runevič-Vardyn, a Lithuanian national born in Lithuania but belonging to a Polish minority, and her husband Łukasz Paweł Wardyn, a Polish national, as they appear on the civil status certificates that were issued to them. ${ }^{89}$ According to Mrs. Runevič-Vardyn, her parents gave her the name 'Małgorzata Runiewicz'. Various documents, such as birth certificates and a passport, that were issued over the course of time by Lithuanian authorities stated her name in the Lithuanian form 'Malgožata Runevič'. A Polish birth certificate that was issued by the Civil Registry Office in Warsaw in 2006 stated her name in the Polish form as 'Małgorzata Runiewicz'. The couple's marriage certificate, issued by the Vilnius' Civil Registry Division, stated her full new name in the Lithuanian form as 'Malgožata Runevič-Vardyn' and her husband's name transcribed as 'Lukasz Pawel Wardyn' in Roman characters instead of the Cyrillic alphabet and without diacritical marks. The husband's name, as added to the wife's name, was written as 'Vardyn' since the letter 'W' does not officially exist in the Lithuanian alphabet.

Upon her request to change her forename and surname as they appear on her birth certificates and her marriage certificate into the Polish forms of her name, being 'Małgorzata Runiewicz-Wardyn', the Vilnius Civil Registry Division replied that that change was impossible under the applicable national rules such as Article 3.282 of the Lithuanian Civil Code. That article stipulates that entries on certificates of civil status must be made in Lithuanian and that forenames, surnames, and place names must be written in accordance

88 Runevič-Vardyn and Wardyn, 12 May 2011, Case C-391/09, ECR 2011, I-03787.

89 Runevič-Vardyn and Wardyn, paras. 2, 15-27. 
with the rules of the Lithuanian language. The couple brought an action before the national court that eventually resulted in a decision from the Constitutional Court on 21 October 1999 and a stay of proceedings and reference for a preliminary ruling to the ECJ among others based on Articles 18 and 21 TFEU. The Constitutional Court confirmed the constitutionality of a decision of the Supreme Council in 1991 that declared that forenames and surnames had to be entered in a passport in accordance with the rules about the spelling of the official national language in order not to undermine the constitutional status of the official national language. Article 14 of the Lithuanian Constitution declares the national language to be Lithuanian.

The questions put forward to the ECJ cover the following three aspects of the case. The first aspect of the case related to the request of Mrs. Runevič-Vardyn 'for her maiden name and her forename to be entered on her birth certificate and marriage certificate in a form which complies with the rules governing Polish spelling, which involves the use of the diacritical marks used in that language'. The second aspect related to the requests of both Mr. Wardyn and Mrs. Runevič-Vardyn that the surname of Mr. Wardyn 'joined to the maiden name of Mrs. Runevič-Vardyn 'and appearing on the marriage certificate, should be entered in a form which complies with the rules governing Polish spelling'. The third aspect was the request of Mr. Wardyn 'for his forenames to be entered on that certificate in a form which complies with the rules governing Polish spelling. ${ }^{90}$

The ECJ first established that the case falls within the scope of EU law, ratione temporis and ratione materiae, and thus within the scope of Article 21 TFEU that guarantees the right to move and reside freely within the territory of the Member States. ${ }^{91}$ In respect of the scope of this case ratione temporis, the Court, under reference to D'Hoop, reiterated that this case concerns 'an allegation of current discriminatory treatment or a current restriction in respect of a citizen of the Union' ${ }^{92}$ It reminds that provisions on EU citizenship are applicable as soon as they enter into force and that for that reason they must be applied to the present effects of situations that arose in the past. ${ }^{93}$ The Court stressed once more in this case that Member States must comply with EU law when exercising competence in matters in which they only have competence such as, as EU law stands then, the rules that govern the way in which surnames and forenames are entered on certificates of civil status. ${ }^{94}$

Then the Court assessed whether restrictions on the freedom of movement existed. As a preliminary point, the Court again noted 'that a person's forename and surname are a constituent element of his identity and of his private life' as protected by Articles 7 ChFREU

90 Runevič-Vardyn and Wardyn, para. 50.

91 Runevič-Vardyn and Wardyn, paras. 51-62.

92 Runevič-Vardyn and Wardyn, paras. 53; D'Hoop, case C-224/98, 2002, ECR I-6191, para. 24.

93 Runevič-Vardyn and Wardyn, paras. 55; D'Hoop, case C-224/98, 2002, ECR I-6191, para. 25.

94 Runevič-Vardyn and Wardyn, para. 63. 
and 8 TFEU..$^{95}$ The court emphasized that 'a person's forename and surname, as a means of personal identification and a link to a family, none the less concern his private and family life', although Article 8 ECHR does not expressly refer to it. ${ }^{96}$ The Court also reiterated two of its previous statements from previous cases. ${ }^{97}$ First, by reference to the D'Hoop case, the fact that an EU citizen receives less favourable treatment in the Member State of his nationality than he would have received if he had not exercised his right to free movement is incompatible with the right to free movement. ${ }^{98}$ Second, by reference to Grunkin and Paul and Sayn-Wittgenstein, the fact that national legislation puts some of its nationals in a disadvantaged position because they have exercised their freedom of movement constitutes a restriction of the rights pursuant to Article 21 TFEU.99

With regard to the first request, the Court concluded that in the context of moving to and marrying a national from another Member State, the absence of the right to change and enter the surname and forename that a citizen had prior to marriage in civil status documents issued by the Member State of origin, except by using the spelling of the national language of that Member State, will probably not discourage an EU citizen from exercising the right to free movement pursuant to Article 21 TFEU and, for that reason, does not constitute a restriction to free movement. ${ }^{100}$ Article 21 TFEU therefore does not 'preclude the competent authorities of a Member State from refusing', under the national law that stipulates that surnames and forenames cannot be changed and entered in documents concerning civil status than in a form respecting the rules of spelling of the national language, 'to amend' the names that a person had prior to marriage, 'where those names were registered at birth in accordance with those rules'. ${ }^{101}$ With regard to the third request, the Court held that the refusal of the competent authorities of a Member State, based on its national law, to amend the forenames of an EU citizen of another Member State in a marriage certificate with the effect that the forenames are entered in that certificate in the same form as in the certificate of the Member State of origin, i.e. in compliance with the spelling of the official national language of the latter state, thus with diacritical marks, does not constitute a restriction of the freedom to movement pursuant to Article 21 TFEU. ${ }^{102}$ With reference to the Garcia Avello, Grunkin, and Paul and Sayn-Wittgenstein cases, the Court held that the omission of diacritical marks is not likely to cause serious inconvenience for the person involved such as to give rise to doubts about the person's identity, the

95 Runevič-Vardyn and Wardyn, para. 66.

96 Runevič-Vardyn and Wardyn, para. 66.

97 Runevič-Vardyn and Wardyn, paras. 67-68.

98 Marie-Nathalie D'Hoop v. Office national d'emploi (D'Hoop) ECJ 11 July 2002, case C-224/98, Rec. 2002, I-6192, para. 30.

99 Grunkin and Paul, para. 21; Sayn-Wittgenstein, para. 53.

100 Runevič-Vardyn and Wardyn, paras. 69-70.

101 Runevič-Vardyn and Wardyn, para. 71.

102 Runevič-Vardyn and Wardyn, paras. 79-82. 
authenticity of the documents submitted by that person, and the truthfulness of those document's contents. ${ }^{103}$

But with regard to the second request, the Court concluded that if the refusal to amend the joint surname of husband and wife in their marriage certificate, in that it is entered uniformly and in accordance with the official spelling of the Member State of origin of the husband, 'is liable to cause serious inconvenience to' the couple at 'administrative, professional and private levels', then the refusal constitutes a restriction of the freedoms to move and reside freely in the territory of the Member States pursuant to Article 21 TFEU. ${ }^{104}$ The Court left it to the national court to decide whether that refusal is liable to cause 'serious inconvenience' and thus constitutes a restriction to the rights of Article 21 TFEU in that there is 'a real risk' that the family members involved will have 'to dispel doubts' about their identity and the documents submitted by them as to the 'truthfulness of the information' in those documents and the identity of and the relationship between the family members involved will be questioned. ${ }^{105}$

The court also left it to the national court to determine whether a restriction as a result of the refusal to make the amendment, if established by the court, can be justified by objective considerations and is proportionate to the legitimate aim pursued. ${ }^{106}$ More specifically, it left to 'that court to determine whether the refusal to make the amendment is necessary for the protection of the interests', i.e. the national language 'which the national rules are designed to secure' and 'cannot be attained by less restrictive measures'. ${ }^{107}$ The court herewith seems to refer to the public order justification to protect the constitutional status of the national language at issue. ${ }^{108}$ In this context, the Court reiterates that the person's surname is a constituent element of his identity and private life that is protected by Article 7 ChFREU and Article 8 ECHR. ${ }^{109}$ The Court, by reference to the joined cases Orfanopoulos and Oliveri, also reminds of the recognition under EU law of 'the importance of ensuring the protection of family life of citizens of the Union in order to eliminate obstacles to the exercise of the fundamental freedoms guaranteed by' EU law. ${ }^{110}$

\subsubsection{Lessons to Be Learned from This Case Law}

The main issue is whether this case law provides a solid basis for a general application of the principle of mutual recognition to other civil status affairs. The last four ECJ cases

\footnotetext{
103 Garcia Avello, para. 36; Grunkin and Paul, paras. 23-28; Sayn-Wittgenstein, paras. 67, 69-70.

104 Runevič-Vardyn and Wardyn, paras. 72-78.

105 Runevič-Vardyn and Wardyn, paras. 76-78.

106 Runevič-Vardyn and Wardyn, paras. 83-94.

107 Runevič-Vardyn and Wardyn, paras. 87, 88, 94

108 Runevič-Vardyn and Wardyn, paras. 84-87.

109 Runevič-Vardyn and Wardyn, para. 89.

110 Runevič-Vardyn and Wardyn, para. 90., joint cases C-482/01 and C-493/01 Orfanopoulos and Oliveri [2004] ECR I-5257, para. 98.
} 
discussed above concern the specific issue of limping names and their problematic consequences due to disparate treatment as the result of a conflict between two differing national legal systems within the EU. The area of law on names in principle falls within the competence of the Member States. The cases, although relating to the issue of (limping) surnames, are diverse and casuistic. The Garcia Avello and Runevič-Vardyn and Wardyn cases concerned requests for the modification of the surnames and of the transcription of the surnames and forenames involved, respectively, whereas the Grunkin and Paul and Sayn-Wittgenstein cases concerned the request for recognition of the surname and the elements of the surname involved, respectively.

The issue concerning a double-barrelled name (Garcia Avello and Grunkin and Paul) differs from the issue concerning a name including a title of nobility (Sayn-Wittgenstein), and both of these issues differ from the issue of the spelling of a name (Runevič-Vardyn and Wardyn). Apart from these differences, the situation in each case is sometimes very specific. For example, in Sayn-Wittgenstein, the Court had to deal with the issue of the name in the context of the extraordinary situation of the adoption of an adult woman. Analysis of this case law therefore entails that one should be realistic and exercise restraint in connecting far-reaching conclusions from this case law to the principle of mutual recognition in relation to other personal status issues.

The case law examined above shows the start of implementing the principle of mutual recognition in law on civil status affairs. Mansel argues that one cannot deduce from Articles 18 and/or 21 TFEU a general right or duty to mutual recognition. ${ }^{111}$ In this specific issue of limping names, the ECJ takes a more nuanced view as will be explained below. One could thus ask what the scope of these articles, and notably of Article 21 TFEU, is while taking into account that the EU lacks competence in and has not communitarized areas of substantive family and personal status law, such as in relation to names. The last four cases under review in this study show that situations related to names fall within the scope of EU law if those involved have lawful ties to at least two Member States, by being a national of a Member State and thus being an EU citizen and a lawful resident or professionally active in a Member State, or if they exercise their fundamental freedoms. ${ }^{112}$ If a situation falls within the scope of EU law, Member States must nevertheless comply with EU law when exercising their competence in matters in which only they have competence. ${ }^{113}$

111 Mansel 2010, p. 301.

112 Runevič-Vardyn and Wardyn, paras. 58-62; Grzelczyk v. Centre Public d'aide sociale d'Ottignies-Louvain la Neuve (Grzelczyk), ECJ 20 September 2001, case C-184/99, Rec. 2001, I-6193, para. 33; D’Hoop, para. 27, 29; it follows from the case Ruiz Zambrano that a purely internal situation may also fall within the scope of EU law, Gerardo Ruiz Zambrano v. Office national de l'emploi (ONEm) (Ruiz Zambrano), ECJ 8 March 2011, case C-34/09, 2011, I-0000, para. 40.

113 Garcia Avello, paras. 25-26; Grunkin and Paul, para. 16; Sayn-Wittgenstein, paras. 38-39; Runevič-Vardyn and Wardyn, paras. 63. 
In all of these cases, it was the party or parties involved who sought the modification or recognition of a name in respect of its composition, elements, or spelling. The name bearers had serious links with both the country of origin of the name and the country where the modification or recognition was required. The parents in Garcia Avello wanted to modify the surname of their children into the double-barrelled surname Garcia Weber, as established in accordance with the well-established usage in Spanish law which was one of the laws of nationality of the children, so in fact in order to have the Spanish name recognized in Belgium. The parents in Grunkin and Paul wanted Germany, the country of nationality of their son Leonhard Matthias, to recognize the double-barrelled surname Grunkin-Paul as determined and registered in Denmark, their son's place of birth and residence. Mrs. Sayn-Wittgenstein wanted to have her full name 'Fürstin von SaynWittgenstein', as obtained at her adoption in her country of residence Germany, recognized in Austria, the country of her nationality. Finally, the Lithuanian wife belonging to a Polish minority in Lithuania and her Polish husband in Runevič-Vardyn and Wardyn wanted the Lithuanian authorities to amend their forenames and surnames in accordance with the original Polish spelling.

The analysis above reveals that in an individual case, disparate treatment as result of a conflict between two differing national legal systems within the EU can result in discrimination (Garcia Avello) or a restriction of the right to move and reside freely within the territory of the Member States (Grunkin and Paul, Sayn-Wittgenstein, Runevič-Vardyn and Wardyn). Moreover, a situation of a discrepancy in names is liable to result in serious inconvenience in both the private and public spheres, including the professional life of the person(-s) concerned, by giving rise to doubts as to the person's identity, the authenticity of the documents submitted, or the veracity of their content. However, the omission of diacritical marks in a name is not likely to cause serious inconvenience (Runevič-Vardyn and Wardyn).

Two situations are considered not to constitute a restriction of the freedom of movement pursuant to Article 21 TFEU (Runevič-Vardyn and Wardyn). First is the fact that a person has no right to change the names that he or she had prior to marriage and to enter those names in civil status documents issued by the Member State of origin, except by using the spelling of the national language of that Member State, when that person moves to and marries a national from another Member State. The absence of such a right will probably not discourage an EU citizen from exercising the right to free movement pursuant to Article 21 TFEU. Second, the refusal of a Member State to amend the names of an EU citizen of another Member State in a marriage certificate in accordance with the spelling of that citizen's names in a certificate of the Member State of origin does not constitute a restriction of the freedom of movement pursuant to Article 21 TFEU.

But the refusal to amend, more specifically to enter uniformly and in accordance with the official spelling of the Member State of origin of the husband, the joint surname of 
spouses in their marriage certificate constitutes a restriction to the rights pursuant to Article 21 TFEU if it is liable to cause serious inconvenience (Runevič-Vardyn and Wardyn). In contrast to the other cases, the Court does not ascertain that the refusal results in serious inconvenience and thus in such a restriction but the Court leaves it to the court of the Member State to decide whether that is indeed the case.

In the context of the assessment of the existence of a restriction on the freedom of movement and of the justification for such a restriction, the Court puts forward some preliminary points: first, a person's forename and surname are a constituent element of his identity and of his private life, which is protected by Articles 7 ChFREU and 8 ECHR (Sayn-Wittgenstein, Runevič-Vardyn and Wardyn). EU law recognizes 'the importance of ensuring the protection of the family life of citizens of the Union in order to eliminate obstacles to the exercise of the fundamental freedoms guaranteed by the Treaty'. Second, national legislation that places certain of its nationals at a disadvantage because they have exercised their right to freely move and reside in the territory of other Member States is a restriction of these rights pursuant to Article 21(1) TFEU (Grunkin and Paul, SaynWittgenstein, and Runevič-Vardyn and Wardyn).

A restriction (by the refusal to recognize a name) of the rights to move and reside freely within the territory of other Member States (or to non-discrimination) can be justified on the basis of objective considerations relating to the public order (or public security or public health) and by being proportionate to the legitimate aim pursued by the national law (Sayn-Wittgenstein). The restriction in Sayn-Wittgenstein was found to be proportionate as the refusal to recognize the noble elements of the name of the applicant, as based on the 'Law on the abolition of nobility', did not go further than necessary in order to ensure the attainment of the fundamental constitutional objective of equality before the law of all Austrian citizens, as pursued by the Austrian authorities. It follows from Sayn-Wittgenstein that the concept of public order has to be interpreted strictly. This means on the one hand that its scope cannot be determined unilaterally by each Member State without any control by the EU institutions; on the other hand, the Member States have a margin of discretion within the limits that the Treaty imposes since the specific circumstances that justify the reliance upon public policy may differ among Member States and in time.

However, Article 21 TFEU can establish in individual cases that a particular result from the application of a national law appears to be an unjustified restriction of Article 21 TFEU. However, not all disparity in treatment of EU citizens, as result of differing legal systems, is consequently a restriction of the right to move and reside freely pursuant to Article 21 TFEU. According to Mansel, only 'the indirect inconveniences caused in relation to the entering, leaving or residing in a Member State of a Union Citizen' is such a restriction. ${ }^{114}$ Furthermore, Mansel states that:

114 Mansel 2010, p. 302. 
only indirect restrictions that when based on objective considerations bring about divergent legal results and particularly serious inconveniences, will be considered to represent an infringement of the right to freedom of movement as guaranteed by Article 21 TFEU.

Otherwise, there is the danger that the EU will use Article 21 TFEU 'as a lever', thus 'substituting the lack of competence' to 'intruding in' the substantive areas of, for example, family and personal law. On the other hand, serious legal consequences have to be accepted if otherwise a breach of the ChFREU or ECHR would be the result. Articles 7 ChFREU and $8 \mathrm{ECHR}$ concerning the right to respect for private and family life also have to be taken into account when interpreting Article 21 TFEU if one argues that (the right to) a name as an expression of a person's identity forms part of the right to protection of private and family life.

The fact that the ECJ left it to the national court to decide whether or not there was a restriction of the rights pursuant to Article 21 TFEU and whether or not that restriction could be justified in Runevič-Vardyn and Wardyn does not necessarily mean that the Court reconsiders the principle of mutual recognition. According to Gardeñes Santiago, the explanation can be found in the function of the ECJ when interpreting EU primary law: the Court can only pronounce whether or not there is a restriction of the freedom of movement in the sense of the provisions of the Treaty. ${ }^{115}$ His second explanation is more convincing, in my opinion: the Court left these decisions to the national court because of considerations of public policy in relation to the constitutional status of the national language.

It follows from the analysis that a Member State is required to recognize the legal status that has been determined in another Member State, if non-recognition results in a restriction of the right to free movement guaranteed by Article 21 TFEU that causes serious inconveniences and that cannot be justified on the basis of objective considerations, e.g. by invoking the public order justification and by being proportionate to the legitimate aim pursued by the national provisions (Grunkin and Paul). A Member State is not required to recognize a legal status that has been determined in another Member State, if nonrecognition does not result in a restriction or if the restriction does not cause serious inconvenience (Runevič-Vardyn and Wardyn) and/or if the restriction can be justified by objective considerations and if it is proportionate to the legitimate aim pursued by the national provisions (Sayn-Wittgenstein, Runevič-Vardyn and Wardyn).

The analysis shows that the scope of application of the principle of mutual recognition can be limited by, first, the lack of a restriction that causes serious inconveniences (RunevičVardyn and Wardyn) and, second, the public order justification (or public health or public

115 Gardeñes Santiago 2011, p. 101. 
security as objective considerations that justify the restriction) of the state that is required to recognize, notably, that state's constitutional principles. Advocate General Sharpston, in her opinion in Grunkin and Paul, already indicated that the public order could be an objective consideration that justifies the restriction. In Sayn-Wittgenstein, the Austrian law on the abolition of the nobility has a constitutional status, and in Runevič-Vardyn and Wardyn, the protection of the official language was based on the Lithuanian Constitution. It follows from Sayn-Wittgenstein that the concept of public order has to be interpreted strictly. This means on the one hand that its scope cannot be determined unilaterally by each Member State without any control by the EU institutions; on the other hand, the Member States have a margin of discretion within the limits that the Treaty imposes since the specific circumstances that justify reliance upon public policy may differ among Member States and in time.

Third, the scope of application of the principle of mutual recognition can be limited by the extent of involvement of the situation with the state of origin or the crystallization of the situation and the state of recognition. There must be a sufficient or serious link between the situation and the state of its origin/crystallization and between the situation and the state where recognition is sought in order to avoid fraud, abuse of law, or forum shopping. Although the nature and the intensity of the link may vary according to the domain concerned, the requirement of a sufficient link should be stricter in the domain of personal status in respect of reasons of fraud, abuse of law, or forum shopping. ${ }^{116}$ Gardeñes Santiago advocates that a specific criterion or link, for example, the nationality of the person involved, should not be systematically preferred over others. An example is provided in the Grunkin and Paul case in which the Court held that the German authorities had to recognize the name of the child involved as that name had been established in the state of birth of the child and where the child resided since then, despite the fact that the child (also) had the German nationality.

It also follows from this case law that Article 21 TFEU can have an impact on national laws, even in areas such as substantive family law where the EU does not (yet) have legislative competence.

The analysis also shows that some issues are still unresolved. As the Court ruled in cases in which the parties themselves requested a modification or recognition of their names, it is yet unclear whether a Member State is required to recognize, if parties themselves do not want a name (or another matter of personal status) to be recognized. For the Court, it is in any case decisive whether or not non-recognition results in an unjustified restriction of the right to free movement that causes serious inconveniences.

Another unresolved issue concerns the question of which legal status is to be recognized by which Member State. To state it differently, how will potential conflicts concerning the

116 Gardeñes Santiago 2011, p. 101-102. 
mutual recognition of decisions be resolved? One wonders whether the Spanish authorities in the Garcia Avello case did not have the obligation to recognize the surname of the children as it had been previously established in Belgium. The children were born and resided in Belgium. However, both states were allowed to determine the surname of the children. In cases such as Garcia Avello where the parties themselves request for a modification (or recognition) of the name, the legitimate expectations of the parties (or party autonomy) should play a decisive part. By their request, they express their preference for either of the lawfully established surnames in order to avoid serious inconveniences.

The question arises whether or not these judgments can be applied by analogy to decisions of (non-)recognition of third-state divorces established in another EU Member State. Some scholars, inter alia, De Groot and Rutten advocated the application of these decisions to other domains of civil status. ${ }^{117}$ Other scholars like Mansel question whether these judgments should be extrapolated to other disciplines within family law. ${ }^{118}$ Advocate General Sharpston was rather clear by stating the following opinion in the Grunkin and Paul case:

Finally, I would point out that, whilst the determination of a person's name falls within the scope of laws on personal status, it is a rather specific matter within that field. It involves identification, which is a separate matter from legal status or capacity. Consequently, I do not consider that it would necessarily follow that a ruling with regard to names should be extrapolated to such other matters. ${ }^{119}$

In my opinion, the case law that concerns issues that fall within the scope of competence of the Member States is too casuistic to conclude that they contain a solid principle of mutual recognition for cases of loss of other issues of personal status due to migration within the EU. However, the case law can be regarded as guideline. A Member State is required to recognize the legal status that has been determined in another Member State, if non-recognition results in an unjustified restriction of the right to free movement guaranteed by Article 21 TFEU, which causes serious inconveniences. But the scope of application of the principle of mutual recognition can be limited by, first of all, the lack of a restriction that causes serious inconveniences and, second, the public order (or public health or public security as objective considerations that justify the restriction) of the state that is required to recognize that has to be strictly interpreted. Furthermore, the application of the principle of mutual recognition requires a sufficient or serious link between the

117 De Groot \& Rutten 2004, p. 282.

118 For example, Mansel 2010, p. 303; Mansel 2006, p. 651, 710.

119 Opinion Advocate General Sharpston of 24 April 2008, C-454/06 (Grunkin-Paul), para. 93; see also, e.g., Mansel 2010, p. 303. 
situation and the state of its origin/crystallization and between the situation and the state where recognition is sought in order to avoid fraud, abuse of law, or forum shopping. In general, one could conclude that the analysis demonstrates that the Court searched carefully for a nuanced balance between an unrestricted freedom of movement while maintaining the personal status on the one hand (Grunkin and Paul) and leaving room to the Member States for their choices and policies (concerning issues of name in the cases at issue), thus respecting their competence on the other hand (Sayn-Wittgenstein, Runevič-Vardyn and Wardyn).

Sooner or later, the ECJ will have to deal with the issue of non-recognition of a foreign third-state divorce in relation to the right of free movement (or other issues of nonrecognition of personal status affairs in relation to the rights of free movement). Verhellen rightly notes that national courts do not have to wait for judgments by the ECJ in order to apply EU law. ${ }^{120}$ She illustrated her view by means of a judgment from the Belgian Court of Appeal in Liège concerning the non-recognition of a Danish marriage act by the Belgian registrar and the Court of First Instance, although it had been previously recognized in Germany. ${ }^{121}$ The Belgian Court of Appeal held with reference to the right to free movement of persons that the marriage act should be registered in order to give a useful effect to Community law and to render it effective.

There could be another solution that may restrict the occurrence of the harmful consequences of limping legal relationships: harmonization of recognition policies within the EU Member States. Harmonization of recognition policies within the EU does not necessarily mean full recognition of every single foreign, non-EU divorce. Unilateral repudiations, without any involvement of the wife and/or without some form of judicial or administrative control, should and will most likely not be recognized in the EU. In those situations, limping relationships are unavoidable and will still occur.

\subsubsection{The Principle of Mutual Recognition: A Cornerstone of the Area of Freedom, Security, and Justice}

\subsubsection{The Tampere, the Hague, and the Stockholm Programmes}

The Treaty of Amsterdam introduced the establishment of an area of freedom, security, and justice, a common judicial European area. ${ }^{122}$ Article 1(5) of the Treaty of Amsterdam stated that the EU must 'maintain and develop the Union as an area of freedom, security

120 Verhellen 2012, p. 334

121 Cour d'appel de Liège 14 May 2007, no. decision 2006/RQ/72, T.Vreemdelingenrecht. 2008, 55.

122 Treaty of Amsterdam amending the Treaty of the European Union, the Treaties establishing the European Communities, and certain related acts, O.J. (C 340), 10 November 1997, signed on 2 October 1997 and entry into force on 1 May 1999. 
and justice, in which the free movement of persons is assured in conjunction with appropriate measures with respect to external border controls, asylum, immigration and the prevention and combating of crime'. That idea is now enshrined in Article 3(2) TEU that states more determinedly that the Union shall offer its citizen such an area.

In order to establish that area progressively, the Union developed several policy plans and programmes, in which the principle of mutual recognition plays a pivotal part.

The European Council already made the principle of mutual recognition of judgments and other decisions of judicial authorities a true cornerstone of judicial cooperation in civil and criminal matters within the European Union at its Tampere meeting of October 1999. ${ }^{123}$ The Commission stressed the importance of 'facilitating the recognition of various types of documents' and 'mutual recognition in new fields such as the civil status of individuals, family or civil relations [...] in 2004' ${ }^{124}$ The resulting programme was followed by the adoption of legislation, such as the Brussels I- and Brussels II-bis Regulations that will be discussed more in detail below. ${ }^{125}$

The second multi-annual Hague Programme mentioned as one of its objectives:

to carry further the mutual recognition of judicial decisions and certificates both in civil and in criminal matters, and to eliminate legal and judicial obstacles in litigation in civil and family matters with cross-border implications. ${ }^{126}$

The Communication by the Commission in respect of the Hague Programme stated that in the context of the completion of the Programme on mutual recognition in civil and commercial matters, inter alia, the fundamental aspect of mutual recognition of public and private documents should be addressed. ${ }^{127}$

The next relevant steps to implement the principle of mutual recognition further resulted from the third multi-annual Stockholm Programme. It referred to An open and

123 Tampere European Council: Presidency Conclusions 15 and 16 October 1999, $\$ 33$ (Presidency Conclusions, No. 200/1/99, 16 October 1999), available at <www.consilium.europa.eu/uedocs/cms_data/docs/pressdata/en/ec/00200-r1.en9.htm>.

124 Communication from the Commission to the Council and the European Parliament, 'Area of Freedom, Security and Justice: assessment of the Tampere Programme and future orientations', $\operatorname{COM}(2004) 401$ final, p. 11, available at $<\mathrm{http} / /$ ec.europa.eu/councils/bx20040617/tampere_en.pdf $>$. According to the Green Paper (COM(2010) 747 final of 14 December 2010), public documents 'cover all the official records drawn up by a Member State authority' in order 'to establish evidence of facts recorded by an authority'. Examples of this are administrative documents such as diplomas; notarial acts such as marriage contracts; civil status records such as birth, marriage, or death certificates; certificates issued by diplomatic or consular officials; and judicial documents issued by a court or court rulings.

125 Gardeñes Santiago 2011, p. 94.

126 Council of the European Union, The Hague Programme: strengthening freedom, security, and justice in the European Union, 16054/04, JAI 559, p. 3.

127 Communication from the Commission to the Council and the European Parliament of 10 May 2005, The Hague Programme: Ten priorities for the next five years, $\operatorname{COM}(2005) 184$ final. 
secure Europe serving and protecting citizens of which its actions focus on 'building a citizens' Europe', inter alia, through the promotion of citizens' rights, in particular the right to freedom of movement. ${ }^{128}$ It, inter alia, states:

In spite of the achievements in the area of judicial cooperation in civil matters, efforts will be needed to reduce the legal constraints that still remain at transnational level regarding for example marriages, divorces, successions, matrimonial property regimes, certification of authentic acts, etc. ${ }^{129}$

The European Commission foresaw in its action plan related to the Stockholm Programme 'the adoption of a legislative proposal for dispensing with the formalities for the legalization of public documents between the Member States' and of a legislative proposal that concerns 'the recognition of the effects of certain civil status records (for instance) relating to filiation, adoption, names), so that legal status granted in one Member State can be recognized and have the same legal consequences in another'. ${ }^{130}$ The European Parliament called for a simple and autonomous European system for 'the abolition of requirements for legalization of documents [...]' and 'detailed consideration to be given [...] to the whole question of the mutual recognition of national civil status documents' and 'a definitive solution to the problem of bilateral agreements dealing with jurisdiction and the recognition and enforcement of judgments, if necessary by means of a Protocol to the next accession Treaty to be concluded' in its Resolution on the Stockholm Programme. ${ }^{131}$ But it also called for:

consideration to be given in addition to a proposal for an international instrument permitting a thorough check of all judgments from third countries before they may be recognized and enforced in a Member State. (emphasis added)

128 The Stockholm Programme - An open and secure Europe serving and protecting citizens. O.J. (C 115/8), 4 May 2010.

129 The Stockholm Programme, p. 1.

130 Action Plan Implementing the Stockholm Programme COM(2010) 171 final, available via <http://eurlex.europa.eu/LexUriServ/LexUriServ.do?uri=CELEX:52010DC0171:EN:HTML>. See also the Green paper Less bureaucracy for citizens, $\operatorname{COM}(2010) 747$ final, p. 2.

131 EP Resolution of 25 November 2009 on the Communication of the Commission to the European Parliament and the Council - An area of freedom, security and justice serving the citizen - Stockholm Programme, point 95; via <www.europarl.europa.eu/sides/getDoc.do?pubRef=-//EP//TEXT+TA+P7-TA-20090090+0+DOC+XML+V0//EN>; see also the report of the European Parliament on 'civil law, commercial law, family law and private international law components of the action plan implementing the Stockholm Programme of 22 November 2010, via <www.europarl.europa.eu/sides/getDoc.do?pubRef=//EP//TEXT+REPORT+A7-2010-0252+0+DOC+XML+V0//EN $>$ in which the European Parliament not only underlines that it is in favour of the recognition of public documents and civil status records but also that 'private international law is the means par excellence of achieving mutual recognition of, and respect for, each others' legal systems'. 
EU authorities thus strive to reduce the legal constraints for the use and acceptance within the EU of public documents originating from an EU Member State, inter alia, through abolishing the requirement of legalization. However, judgments from third countries are required to be submitted to 'a thorough check', implying that these judgments should at least still remain subjected to that requirement of legalization. In my opinion, also other decisions or documents emanating from competent third-state authorities should be submitted to such a 'thorough check'. The realization of this proposal may imply that once such a judgment (or other decision of document) has passed that assessment, any public document with respect to that judgment (or other decision of document) drawn up in an EU Member State must then benefit from the simplified system of use and acceptance of public documents between the Member States.

\subsubsection{The Green Paper 2010}

Preceding the presentation of the first legislative proposal, the European Commission launched a consultation on the possible means of facilitating the free movement of public documents between Member States by means of the Green Paper 'on promoting free movement of public documents and recognition of the effects of civil status records' on 14 December 2010. ${ }^{132}$ The results of the Special Eurobarometer 351 Civil Justice of October 2010 demonstrated that the fulfilment of all types of formalities discourages and can even prevent European citizens from exercising their citizens' rights, in particular the right to freedom of movement. ${ }^{133} 60 \%$ of those surveyed had to fulfil several formalities, such as translation (26\%), legalization (24\%), and producing an apostil (16\%) or a certified copy (19\%) when presenting a document in a Member State other than the one that had issued the document. ${ }^{134}$ Moreover, people may be confronted with requirements for documents, such as a certificate of no impediment to marriage, that do not always exist in the Member State of origin. ${ }^{135}$ These arguments underline the necessity of a simplification of the crossborder use of public documents.

The Green Paper provides an overview of the legal framework concerning the administrative formalities. That framework is characterized by fragmentation as it is based on several sources, such as national laws that differ considerably from one another, a number of international bi- and multilateral conventions and fragmented EU law. ${ }^{136}$ The framework

132 Green Paper 'Less bureaucracy for citizens; promoting free movement of public documents and recognition of the effects of civil status records', $\operatorname{COM}(2010) 747$ final, p. 16.

133 Special Eurobarometer 351 Civil Justice of October 2010, available via <http://ec.europa.eu/public_opinion/archives/ebs/ebs_351_en.pdf>.

134 Special Eurobarometer 351 Civil Justice, October 2010, p. 70.

135 Green Paper COM(2010) 747 final of 14 December 2010.

136 Examples are the 1961 Hague Convention that abolishes the requirement of legalization and replaces it with the apostil for various foreign public documents, but not for documents executed by diplomatic and consular authorities; this convention has been signed by all EU Member States and a number of non-EU countries; 
thus lacks clarity and does not provide legal certainty. The consultation included 11 questions, among others, about the abolition of administrative formalities such as legalization and the apostil and closer cooperation between Member States in particular regarding civil status records, etcetera.

At the same time, the Commission adopted the Single Market Act and the Single Market Act II. ${ }^{137}$ These acts aim to bring about an EU Single Market where citizens and businesses are free to cross borders without any limits, such as disproportionate barriers and unjustified restrictions caused by diverging national rules. ${ }^{138}$

\subsubsection{The Proposal for a Regulation 2013}

The Green Paper resulted in the 'Proposal for a Regulation on promoting the free movement of citizens and business by simplifying the acceptance of certain public documents in the European Union, and amending Regulation (EU) No. 1024/2012' (hereinafter 'Proposal EU Regulation on free movement of public documents' or 'the Proposal'). ${ }^{139}$ As such, the Proposal only deals with the first part of the Green Paper. Its overall objective is to simplify administrative formalities by abolishing the requirements of legalization and similar formalities, such as the apostil, simplifying the use of copies and translations and by establishing Union multilingual standard forms. ${ }^{140}$ The Proposal also introduced adminis-

the 1968 Council of Europe Convention that abolishes the legalization of documents issued by a diplomatic or consular authority but that is signed by only $15 \mathrm{EU}$ Member States; several conventions of the International Commission on Civil Status (CIEC): the 1957 Convention on the issue free of charge and exemption from legalization of copies of civil status records, the 1976 Convention on the issue of multilingual extracts from civil status records, and the 1977 Convention on the exemption from legalization of certain records and documents; the Brussels Convention of 25 May 1987 abolishing the legalization of documents in the Member States of the European Communities that has been ratified by only a very small number of Member States and has not entered into force except with regard to Belgium, Denmark, France, Italy, Ireland, and Latvia that apply it provisionally in relation to each other.

$137 \operatorname{COM}(2011) 206$ final and $\operatorname{COM}(2012) 573$ final.

$138 \operatorname{COM}(2013) 228$ final, Explanatory Memorandum, p. 2.

139 Proposal for a Regulation on promoting the free movement of citizens and business by simplifying the acceptance of certain public documents in the European Union and amending Regulation (EU) No. 1024/2012 (hereinafter Proposal EU Regulation on free movement of public documents), $\operatorname{COM}(2013) 228$ final of 24 March 2013, 2013/0119 (COD). It is striking that its legal basis is grounded in Art. 21(2) (the right to move and reside freely in territories of EU Member States of EU citizens) in connection with Art. 114 TFEU (adoption of measures in the context of the internal market). Its legal basis is thus not grounded in Art. 81 TFEU, the article that usually offers the legal basis for PIL measures. Art. 114 TFEU provides for the adoption of measures for the approximation of the provisions laid down by law in the context of the internal market in accordance with the ordinary legislative procedure pursuant to Art. 294 TFEU. Art. 294 TFEU requires a qualified majority for decision making. And although Art. 81(1) also provides for the adoption of measures in accordance with the ordinary legislative procedure and thus requires a qualified majority for decision making, Art. 81(3) TFEU requires decision making by unanimity regarding family law measures. It should be realized that the Proposal not only deals with public documents concerning personal status but also with public documents regarding business issues, both in relation to the internal market.

$140 \operatorname{COM}(2013) 228$ final, Explanatory Memorandum, p. 5, 7, 9; Art. 1, 4, 5, 6, 11, 12, 13, 14, 15 and Recital 16 Proposal EU Regulation on free movement of public documents; the Proposal envisages the establishment 
trative cooperation based on the Internal Market Information System (the IMI), as established by EU Regulation 1024/2012. ${ }^{141}$ In the case of reasonable doubts about the authenticity of public documents or about their certified copies, a Member State, through its central authority, should use that system for requests for information. The system also includes a possibility to maintain a repository of model public documents used within the EU that can serve to assess unfamiliar public documents. Thus, it facilitates and enhances the exercise by citizens and businesses of their Union rights to free movement and freedom of establishment and providing services within the Single Market, while it also seeks to prevent the fraud and forgery of public documents more effectively and eliminate risks of discrimination. Although the proposal aims to remedy the above-mentioned (consequences of the) fragmentation of the legal framework concerning administrative formalities, the Proposal means to complement and not to prejudice the application of Union Law about legalization, similar and other formalities, on electronic signatures and identification and the use of other systems of administrative cooperation for exchange of information between Member States in specific areas. ${ }^{142}$

Article 3(1) of the Proposal covers, inter alia, public documents that are issued by authorities of a Member State and have formal evidentiary value and that relate to the following personal status: birth, death, name, marriage and registered partnership, parenthood, adoption, residence, citizenship, and nationality. The Proposal does not cover public documents relating to divorce as such.

The model EU multilingual standard form concerning marriage seems to offer the possibility to make a note of any divorce (or annulment of marriage, legal separation, or death of a spouse) in box No. 13 concerning 'other particulars of the registration'. However, Brussels II-bis Regulation covers judgments and documents relating to divorce (or legal separation or marriage annulment) pronounced or issued in a Member State. ${ }^{143}$ Article 21 of the Brussels II-bis Regulation provides for mutual recognition of judgments relating to divorce in a Member State and in particular for updating civil status records of a Member State on the basis of such a judgment, without any special procedure being required. 'Judgment' in this context means any decision pronounced by a competent judicial or

of Union multilingual standard forms related to birth, death, marriage, registered partnership in the context of civil status in all official languages of the Union.

141 Regulation (EU) No. 1024/2012 of the European Parliament and of the Council of 25 October 2012, O.J. (L 316), 14 November 2012; $\operatorname{COM(2013)~} 228$ final, Explanatory Memorandum, p. 7, 8; Arts. 7, 8, 9, and 10 Proposal EU Regulation on free movement of public documents.

142 Art. 16 Proposal EU Regulation on free movement of public documents $\operatorname{COM}(2013) 228$ final, Explanatory Memorandum, p. 9.

143 Council Regulation (EC) No. 2201/2003 of 27 November 2003 concerning Jurisdiction and the Recognition and Enforcement of Judgments in Matrimonial Matters and the Matters of Parental Responsibility, O.J. (L 338), entry into force on 1 August 2004, applicable as from 1 March 2005. 
non-judicial authority. ${ }^{144}$ Article 46 of the Brussels II-bis Regulation requires the recognition and enforceability of documents relating to divorce that have formally been drawn up or registered as authentic instruments and are enforceable in a Member State, under the same conditions as judgments. By providing for the recognition of these divorce judgments or documents, the Brussels II-bis Regulation goes beyond the Proposal that provides for mutual acceptance of the formal evidentiary value of specific personal status documents in EU Member States. The Proposal excludes from its scope documents drawn up by private persons and documents issued by authorities of third states. ${ }^{145}$

The Proposal envisages that it would apply to the acceptance and not to the recognition of the content of public documents issued by authorities of other Member States. ${ }^{146}$ The Union multilingual standard forms will also not produce legal effects regarding the recognition of their content, but they have the same formal evidentiary value regarding their authenticity as the national public documents. ${ }^{147}$ The citizen (or company) may use these forms as an alternative to their national equivalents on a voluntary basis, but the Member State must issue the form on the request of a citizen in case an equivalent public document exists in that state. The Commission will develop detailed guidance on the use of these forms as well as an electronic format of these forms.

Article 21 of the Proposal provides for an evaluation of the application of the Regulation at the latest every three years, among others in relation to the question whether its scope should be extended to further categories of documents. Its Explanatory Memorandum underlines the compliance of the Proposal with fundamental rights as set out in the ChFREU and the promotion of their application. ${ }^{148}$ The Proposal would in particular comply with the right of protection of personal data (Art. 8 ChFREU); address the prohibition of (indirect) discrimination (Art. $18 \mathrm{TFEU}$ ); promote the right to move and reside freely within the territory of the Member States (Arts. 45, 15, and 16 ChFREU); and, inter alia, positively impact on the right to respect for private and family life and the right to marry and start a family (Arts. 7 and 9 ChFREU).

This Proposal in its actual state has very little meaning for decisions on the recognition of third-state divorces by competent authorities of Member States yet. If the Regulation would enter into force in this state, it may only indirectly apply to public documents related

144 See 'Practice Guide for the Application of the New Brussels II Regulation' drawn up by the Commission services in consultation with the European Judicial Network in civil and commercial matters, p. 10 (hereinafter 'the Practice Guide Brussels II-bis'); available at <www.ec.europa.eu/civiljustice/divorce/parental_resp_ec_ vdm_en.pdf $>$.

$145 \operatorname{COM}(2013) 228$ final, Explanatory Memorandum, p. 6.

146 Art. 2 Proposal EU Regulation on free movement of public documents; $\operatorname{COM(2013)} 228$ final, Explanatory Memorandum, p. 6, 7.

147 Arts. 11, 12, 13, 14, and 15 Proposal EU Regulation on free movement of public documents; COM(2013) 228 final, Explanatory Memorandum, p. 9; see also the legal note in the models of the various European Union Multilingual Standard Forms.

$148 \operatorname{COM}(2013) 228$ final, Explanatory Memorandum, p. 11. 
to one of the subjects that it covers (not being divorce) issued by competent authorities of a Member State, in so far as it includes a note on a decision concerning a third-state divorce by a Member State. And even then, the proposed Regulation does not provide for the recognition of its content and/or legal effects, but it only provides for the acceptance of its formal evidentiary value. If its scope will be extended to divorce in the future, it may have more significance in this respect, in so far as it concerns public documents that have been issued by a competent authority of a Member State and that have been based on a decision concerning a third-state divorce by a Member State. However, the meaning of the proposed Regulation is that it is a follow-up of the ECJ ruling in the Dafeki case.

\subsubsection{Brussels I, Brussels I Recast, and Brussels II-bis}

Furthermore, reference should be made to Brussels I Regulation, its successor that is applicable as from 10 January 2015 Brussels I Recast and notably Brussels II-bis Regulation. ${ }^{149}$ All these Regulations have incorporated the principle of mutual recognition. Brussels I Regulation and Brussels I Recast provide rules on jurisdiction and on recognition and enforcement of judgments in civil and commercial matters, but they exclude, inter alia, the subject of status of natural persons from their scope of application in their Article 1 ( 2 sub a). Brussels II-bis partly fills that gap by regulating the jurisdiction, and recognition and enforcement of judgments and authentic documents in matrimonial matters relating to divorce, legal separation and annulment of marriage, and matters of parental responsibility.

These instruments and also the incorporation of this principle in these instruments should be seen in the light of their background, being the background of their predecessors: the Brussels Conventions and the Brussels II Regulation. ${ }^{150}$ That background was to facilitate the 'free movement of court decisions on matters related to the functioning of

149 Council Regulation (EC) No. 44/2001 of 22 December 2000 on Jurisdiction and the Recognition and Enforcement of Judgments in Civil and Commercial matters (Brussels I Regulation), 2001 O.J. (L 012), entry into force on and applicable as from 1 March 2002; Regulation (EU) No 1215/2012 of the European Parliament and of the Council of 12 December 2012 on Jurisdiction and the Recognition and Enforcement of Judgments in Civil and Commercial matters (Recast), O.J. (L 351), entry into force on 9 January 2013, but applicable as from 10 January 2015; Council Regulation (EC) No. 2201/2003 of 27 November 2003 concerning Jurisdiction and the Recognition and Enforcement of Judgments in Matrimonial Matters and the Matters of Parental Responsibility, O.J. (L 338), entry into force on 1 August 2004, but applicable as from 1 March 2005.

150 Brussels Convention on Jurisdiction and the Enforcement of Judgments in Civil and Commercial Matters, 1990 O.J. (C 189); Brussels Convention on Jurisdiction and the Recognition and Enforcement of Judgments in Matrimonial Matters as approved by the Council on 28 May 1998, O.J. (C 221), p. 1, but that never entered into force; this Convention was commented on in an explanatory report prepared by Alegría Borrás, 1998 O.J. (C 221), p. 27 (hereinafter the Borrás report); EC Regulation No. 1347/2000 of 29 May 2000 concerning Jurisdiction and the Recognition and Enforcement of Judgments in Matrimonial Matters of 29 May 2000, 2000 O.J. (L 160). 
the common market' or 'a common market for judgments' as originally based on Article 220 of the EEC Treaty of 1957. This article did not directly oblige Member States to mutually recognize and enforce their judgments, but it stipulated that Member States should negotiate, so far as necessary, 'the simplification of formalities governing the reciprocal recognition and enforcement of judgments' ${ }^{151}$ However, both Brussels Conventions already went far beyond that instruction. They are what is termed a 'double instrument', as they coordinate both jurisdiction and recognition and enforcement of the Member States.

By coordinating jurisdiction and providing for rules on lis pendens, the successors the Brussels I, the Brussels I Recast, and the Brussels II-bis Regulations also aim at having not more than one decision in the same case, since contradictory decisions seriously hamper the free movement or circulation of decisions. Moreover, Recital 16 of the Brussels I Regulation states that 'Mutual trust in the administration of justice in the Community justifies judgments given in a Member State being recognized automatically without the need for any procedure except in cases of dispute'. Recital 26 of the Brussels I Recast reiterates this statement and adds:

[t] he aim of making cross-border litigation less time-consuming and costly justifies the abolition of the declaration of enforceability prior to enforcement in the Member State addressed. As a result, a judgment given by the courts of a Member State should be treated as if it had been given in the Member State addressed'. Recital 2 of the Brussels II-bis Regulation states that '[T]he Tampere European Council endorsed the principle of mutual recognition of judicial decisions as the cornerstone for the creation of a genuine judicial area [...].

The implementation of the principle of mutual recognition in the Brussels I Regulation, its successor the Brussels I Recast Regulation, and the Brussels II-bis Regulation had a double objective. ${ }^{152}$ First of all, there was the objective of attenuation and simplification of the procedures of exequatur that guided the transformation of the Brussels Convention into the Brussels I Regulation. Second, a step further, there was also the objective of abolition or suppression of the procedures of exequatur among the Member States and the adoption of a system of "full faith and credit" for judgments in the EU'. ${ }^{153}$ The intended implementation of the principle of mutual recognition and its objectives resulted for the Brussels I, Brussels I Recast, and Brussels II-bis Regulations in an automatic recognition of judgments (without any special procedure being required; recognition by operation of law or ex lege

151 Baratta 2011, p. 313; Bogdan 2012, p. 31.

152 Gardeñes Santiago 2011, p. 94-96.

153 Zilinsky 2014, p. 9. 
recognition) and a limited number of grounds for non-recognition of these judgments. ${ }^{154}$ These grounds concern inter alia a manifest violation of the public order of the recognizing state; the issue is that the respondent was not served with the document that instituted the proceedings in due time, in the case of failure to appear; or the judgment is irreconcilable with another or earlier judgment in proceedings between the same parties. Furthermore, a review of the jurisdiction of the court of the Member State of origin is in principle not allowed but to a limited extent under the Brussels I and the Brussels I Recast Regulations, and it is prohibited under the Brussels II-bis Regulation. ${ }^{155}$ All these Regulations prohibit any review as to the substance of the foreign judgment. ${ }^{156}$ The above-mentioned, second objective first led to the abolition of the exequatur for certain judgments concerning the rights of access or certain judgments requiring the return of a child in the Brussels II-bis Regulation. ${ }^{157}$ Then the applicability of the Brussels I Recast will result in the abolition of the exequatur for all judgments, authentic instruments (meaning documents), and court settlements in civil and commercial matters that fall within the scope of this Regulation. ${ }^{158}$ So, the Brussels I Recast introduces the recognition and the enforcement of enforceable judgments without any special procedure being required. ${ }^{159}$

The ECJ confirmed and reinforced the principle of mutual recognition and the abolition of the exequatur for certified judgments requiring the return of a child in the Aguirre Zarraga v. Simone Pelz case of 22 December $2010 .{ }^{160}$ The facts of this case concerned the return of a child of a divorced German-Spanish couple that was wrongfully retained by the mother in Germany, while the Spanish father had custody rights over the child. ${ }^{161} \mathrm{~A}$ Spanish court had ordered the return of the child in a certified judgment that was immediately enforceable without the need for an exequatur pursuant to Article 42 Brussels II-bis Regulation. The mother contested the enforceability of the judgment in a German court on the ground that the Spanish court had handed down the judgment in violation of Article 24 ChFREU, since the court had not heard the child. The German court stayed its proceedings and referred the case to the ECJ for a preliminary ruling.

The German court asked 1) whether the court of the Member State of enforcement may 'exceptionally itself enjoy a power of review' pursuant to Article 42 of the Brussels II-bis Regulation in conformity with the ChFREU and 2) whether the court of the Member

154 Art. 33 and Art. 34, respectively, Brussels I Regulation; Art. 36 and Art. 45, respectively, Brussels I Recast Regulation; Art. 21 in connection with Art. 46 and Art. 22, respectively, of the Brussels II-bis Regulation.

155 Art. 35 Brussels I Regulation; Art. 45 Brussels I Recast Regulation; Art. 24 Brussels II-bis Regulation.

156 Art. 36 Brussels I Regulation; Art. 52 Brussels I Recast Regulation; Art. 26 Brussels II-bis Regulation.

157 Art. 41 and Art. 42 Brussels II-bis Regulation.

158 Art. 39, Art. 58, and Art. 59 Brussels I Recast Regulation. See for an overview of instruments that have so far abolished the exequatur: Kramer 2011, p. 634-635.

159 Zilinsky 2014, p. 10.

160 Joseba Andoni Aguirre Zarraga v. Simone Pelz (Aguirre v. Simone Pelz) ECJ 22 December 2010 Case C-491/10 PPU, ECR 2010, I-14247.

161 Aguirre v. Simone Pelz, paras. 15-36. 
State of enforcement is 'obliged to enforce' that judgment although the certificate issued by the Member State of origin contains a manifestly inaccurate declaration. ${ }^{162}$ The ECJ held that the court of the Member State of enforcement 'cannot oppose the enforcement of a certified judgment' that orders the return of a wrongfully removed child, 'on the ground that the court of the Member State of origin' of the judgment may have violated Article 42 Brussels II-bis Regulation 'interpreted in accordance with' Article 24 ChFREU, as the assessment for such a violation exclusively belongs to the competence of the court of the Member State of origin. ${ }^{163}$

A closer look at the term 'judgment' in the Brussels II-bis Regulation reveals that 'judgment' is not only confined to judicial but also to non-judicial decisions concerning divorce, legal separation, and annulment of marriage (and parental responsibility), such as decisions emanating from competent administrative authorities. ${ }^{164}$ Article 2(4) of the Brussels II-bis Regulation defines the term 'judgment' as meaning divorce, etcetera, 'pronounced by a court of a Member State, whatever the judgment may be called, including a decree, order or decision'. Article 2(1) of the Brussels II-bis Regulation subsequently defines the term 'court' as covering 'all the authorities in the Member States with jurisdiction in the matters falling within the scope of this Regulation pursuant to Article 1'.

The implementation of the principle of mutual recognition and its objectives has also been extended to public and private documents in Article 57 of the Brussels I Regulation, Article 58 of the Brussels I Recast, and Article 46 of the Brussels II-bis Regulation. Article 57 of the Brussels I Regulation stipulates that a document that has been formally drawn up or registered as an authentic instrument and that is enforceable in one Member State shall be declared enforceable on application in another Member State, unless its enforcement is manifestly contrary to public policy in the Member State where enforcement is sought. Article 58 Brussels I Recast says that an authentic instrument that is enforceable in the Member State of origin shall be enforceable in another Member State without any declaration of enforceability being required; however, its enforcement may be refused but only if such enforcement is manifestly contrary to public policy in the Member State addressed. Article 46 of the Brussels II-bis Regulation provides for the recognition and declaration of enforceability of documents that have been formally drawn up or registered as authentic instruments and of agreements between the parties and that are enforceable in one Member State under the same conditions as judgments in other Member States. Since Article 21 of the Brussels II-bis Regulation also covers non-judicial decisions concerning divorce,

162 Aguirre v. Simone Pelz, para. 37.

163 Aguirre v. Simone Pelz, paras. 75-76.

164 See also Practice Guide for the Application of the New Brussels II Regulation drawn up by the Commission services in consultation with the European Judicial Network in civil and commercial matters, p. 10 (hereinafter the Practice Guide; available at <www.ec.europa.eu/civiljustice/divorce/parent al_resp_ec_vdm_en.pdf $>$. 
etcetera, such as decisions emanating from competent administrative authorities, it remains unclear what documents exactly fall within the scope of Article 46. The Practice Guide on Brussels II-bis refers to documents drawn up by notaries. ${ }^{165}$

By thus facilitating the recognition of positive divorce decisions, Brussels II-bis Regulation clearly aims to realize favor recognitionis and favor divortii and also the right to remarry as enshrined in Article 12 of the ECHR and Article 9 of the ChFREU. ${ }^{166}$

Extending the scope of relevant definitions and articles, notably 'decision' in Articles 2, 21, and 22 and 'document' in Article 46, in the Brussels II-bis Regulation in the sense of also covering the positive judicial and extra-judicial decisions and documents concerning recognition of a third-state divorce by a competent authority of a Member State, or a corresponding extensive interpretation by the ECJ, is therefore the most obvious. Hence, a regulation amending Brussels II-bis Regulation is the first and most feasible solution for harmonizing PIL in this field. Alternatively, the draft of a separate Council regulation on mutual recognition of positive, judicial, and extra-judicial decisions and documents of recognition of third-state divorces could be considered. The recognition of these recognition decisions or documents should then be done ex lege or automatically. Striving for a common European judicial area implies that Member States mutually recognize their decisions and documents without any special procedure being required. Especially in view of the intended continuity of personal status, the public policy exception should be construed as a very restricted exception, which only relates to the core values of the forum, as in Article 22 of the Brussels II-bis Regulation. After all, the compatibility of the decision with the public order has already been evaluated in the first state of recognition. Furthermore, the realization of the above-mentioned international instrument permitting a thorough check including legalization of all judgments from third countries before they may be recognized and enforced in a Member State' should imply that once such a judgment has passed that assessment, any public document with respect to that judgment drawn up in an EU Member State must then benefit from the simplified system of use and acceptance of public documents between the Member States. The legislative competence of the EU for either such an amendment of the Brussels II-bis Regulation or the draft of a separate Council Regulation can be based on Article 81 TFEU as explained more in detail in chapter 18.

165 The Practice Guide on Brussels II-bis, p. 10.

166 Baratta 2011, p. 467. Brussels II-bis Regulation excludes what is termed as negative divorce decisions that refuse to grant a divorce (or separation or annulment) from its scope; the term 'judgment' in Art. 2(4) of Brussels II-bis Regulation only refers to positive decisions that do grant a divorce (or separation or annulment); see the Borrás Report, para. 60. 


\subsection{Towards Harmonization of Recognition of Non-EU Third-State Divorces?}

Apart from divergent national PIL regimes on recognition, no other relevant, hard law instruments on recognition and enforcement of third-state divorces ${ }^{167}$ are available yet in Europe. $^{168}$

The Hague Conference's last attempt to negotiate such convention on recognition failed in 2004. The European Council stresses, as a result of its the Hague Programme adopted in November 2004, the cooperation with third countries, especially concerning recognition and enforcement of decisions, in view of the development of a coherent external dimension of the Union policy of freedom, security, and justice. ${ }^{169}$

There are sound arguments to advocate for a common EU policy on the recognition of third-state divorces. First and foremost, such a common EU policy would remedy the adverse consequences of separate and divergent recognition policies, such as legal uncertainty, unpredictability, and additional economic, administrative, social, and other burdens. ${ }^{170}$ Second, it would further the development of harmonized concepts of divorce and repudiation. ${ }^{171}$ These concepts should be based on a common core and better law approaches by taking into account the Islamic divorce laws and the human rights standards. Hence, these concepts may prevent an incorrect characterization of Islamic divorces by

167 The notions of 'third-state' and 'foreign, non-EU' are used as synonyms.

168 Yet several instruments exist but are not relevant for the recognition of third-state, Islamic divorces by European states: 1 . The (ICCS) Luxemburg Convention on the recognition of decisions relating to the matrimonial bond of 8 September 1967 is not relevant for the recognition of Islamic divorces as none of the contracting states are Muslim-majority countries (except for Turkey that is, however, a secular state and has a secular family law, although it is a Muslim-majority country in respect of its habitants; entry into force on 20 June 1980; see <www.ciec1.org/ListeConventions.htm>); 2. the Hague Convention on recognition and enforcement of foreign judgments in civil and commercial matters of 1 February 1971 and its Supplementary Protocol excludes family matters from its scope in Art. 1 (entry into force on 20 August 1979); 3. the Hague Convention of 1 June 1970 on the recognition of divorces and legal separations applies to 18 contracting states, but it only has relevance for the recognition of Egyptian judicial divorces in one of the European contracting states (entry into force on 24 August 1975, see <www.hcch.net> for the provisions of these conventions); and 4. the European instrument, Council Regulation (EC) No. 2201/2003 of 27 November 2003 concerning jurisdiction and the recognition and enforcement of judgments in matrimonial matters and matters of parental responsibility, O.J. (L 338) of 23 December 2003 (entry into force 1 March 2005) or Brussels II-bis Regulation provides for the mutual recognition of divorce decisions granted in the one EU Member State by the other EU Member State (except for Denmark).

169 Note from the Presidency of the Council aspects of judicial cooperation in civil matters in the framework of the Strategy for the External Dimension of JHA: Global Freedom, Security and Justice, doc. 8140/06 JUSTCIV 93, RELEX 228, JAI 177; The Hague Programme: strengthening freedom, security, and justice in the European Union, doc, 16054/04 JAI 559; A Strategy for External Dimension of JHA: Global Freedom, Security and Justice, doc. 5003/1/06 REV 1 JAI 1 RELEX 1 . The Hague Judgments Project aims to bring about a multilateral convention on recognition and enforcement of judgments in all civil and commercial matters, except for family law matters; see <www.hcch.net>.

170 See also Gonzalez Beilfuss 2007, p. 428 and 434-435.

171 See Gonzalez Beilfuss 2007, p. 428-430. 
the Member States and, consequently, wrongful non-recognition resulting in limping legal relationships.

Traditionally, Member States had their own competence to negotiate and conclude treaties with third states on divorce matters. However, it is not desirable that Member States conclude bilateral treaties on the recognition of Islamic divorces. When every Member State separately concludes a bilateral treaty on the same subject matter, this may result in differing treaties and, consequently, increase the diversity of and within recognition policies.

The EU has an implied exclusive external competence in the area of PIL pursuant to Article 216 in connection with Article 3(2) TFEU: when the conclusion of an international agreement is required by a legislative act of the Union, is necessary to enable the Union to exercise its internal competence, or in so far as conclusion of such an international agreement may affect common rules or alter their scope, the Union shall have exclusive competence for the conclusion of such an agreement. The EU thus has an exclusive external competence regarding, inter alia, family matters which are already governed by Union acts in force. When the EU negotiates and concludes international agreements, it has to comply with the procedure as stipulated in Article 218 TFEU. The exclusive external legislative competence of the EU means that Member States are in principle not allowed anymore to undertake, for example, new obligations under the Hague Conventions. ${ }^{172}$ Prior to the Lisbon Treaty and thus the entry into force of the TFEU, the EU's external competence could be inferred from the ERTA principle formulated by the European Court of Justice in the case of Commission v. Council, and that was confirmed in its Opinion $1 / 03 .{ }^{173}$ This implies that Member States 'no longer have the right $[\ldots]$ to undertake obligations with non-member state countries which affect' common rules adopted by the EU.

This is endorsed in the Recitals 5 and 6 of Council Regulation 664/2009 of 7 July 2009 (hereinafter the Regulation on External Agreements in specific Family Matters) that reads: ${ }^{174}$

172 Bogdan 2012, p. 12.

173 Case 22/70, [1971] ECR 263; Opinion 1/03 of 7 February 2006, ECR 2006, I-1145, para. 116.

174 Council Regulation (EC) No. 664/2009 of 7 July 2009 establishing a procedure for the negotiation and conclusion of agreements between Member States and third countries concerning jurisdiction, recognition, and enforcement of judgments and decisions in matrimonial matters, matters of parental responsibility, and matters relating to maintenance obligations and the law applicable to matters relating to maintenance obligations (Regulation on External Agreements in Family Matters), O.J. (L 220/46) of 31 July 2009, legally based in Arts. 61(c), 65, 67(2), and 67(5) TEC. The United Kingdom and Ireland take part in its adoption and application; Denmark does not (see Recitals 24 and 25 of its preamble). The Regulation 'should be regarded as an exceptional measure and should be limited in scope and time'; accordingly, it will remain in force at least until August 2020, and it will be examined whether it should be replaced by a new Regulation; see Recitals 8 and 21 of the preamble and Arts. 13 and 14 of the Regulation on External Agreements in Family Matters. 
(5) In its Opinion 1/03 of 7 February 2006 relating to the conclusion of the new Lugano Convention, the Court of Justice of the European Communities confirmed that the Community has acquired exclusive competence to conclude an international agreement like the Lugano Convention with third countries on matters affecting the rules laid down in Council Regulation (EC) No. 44/2001 of 22 December 2000 on jurisdiction and the recognition and enforcement of judgments in civil and commercial matters $[\ldots]$ (Brussels I).

(6) It is for the Community to conclude, pursuant to Article 300 of the Treaty [article 218 TFEU], agreements between the Community and a third country on matters falling within the exclusive competence of the Community.

It appears from this Regulation that, although the EU has exclusive external competence related to these matters, the EU Commission may authorize a Member State to negotiate amendments to or the conclusion of bilateral or regional agreements with a third state concerning matters falling within the scope of the Brussels II-bis Regulation and the Maintenance Regulation, ${ }^{175}$ under its control. These matters include, inter alia, recognition of judgments and decisions in matrimonial matters such as divorce. Member States should 'facilitate the achievement of the Community's tasks' (now: Union tasks) and 'abstain from any measure which could jeopardise the attainment of the objectives of the Treaty' (now: TFEU) based on their duty of loyal cooperation as mentioned in Article 10 EC Treaty. ${ }^{176}$

The Regulation primarily applies to bilateral agreements between a Member State and a third country. ${ }^{177}$

The Regulation shall not apply in two situations which underlines the exclusive external competence of the Union in these matters: first of all, when the EU has already concluded an agreement that regulates in substance the same specific legal issues with a third state ${ }^{178}$ and, second, when it appears that 'a negotiating mandate with a view to the conclusion of an agreement' between the EU and the third state concerned is specifically envisaged within the next 24 months. ${ }^{179}$ Such a mandate may be the result of consultations between the Commission and Member States following the notification of a Member State that seeks

175 Council Regulation (EC) No. 4/2009 of 18 December 2008 on Jurisdiction, Applicable Law, Recognition and Enforcement of Decisions and Cooperation in Matters Relating to Maintenance Obligations (Maintenance Regulation), O.J. (L 7/1-79) of 10 January 2009 and O.J. (L 131/26) of 18 May 2011, entry into force on 30 January 2009 (twentieth day following its publication in the Official Journal of the European Union; see Art. 76 Maintenance Regulation.)

176 Recital 7 of the preamble of the Regulation on External Agreements in Family Matters.

177 Art. 2(1)(a) Regulation on External Agreements in Family Matters.

178 Art. 1(3) and Recital 9 Regulation on External Agreements in Family Matters.

179 Art. 4(2), Art. 11, and Recital 12 Regulation on External Agreements in Family Matters; Stone 2010, p. 422. 
authorization to amend or conclude an agreement with a specific third state. The Commission informs all Member States about any such notification in order to allow them to express their interest in joining the initiative of the Member State. Hence, it can be assessed whether there is sufficient Union interest in concluding a new bilateral agreement between the Union and the third state or replacing an existing agreement between a Member State and a third state by a Union agreement.

The Regulation imposes three important requirements to a Member State before the Commission may grant an authorization to that Member State initially to open formal negotiations and eventually to conclude a negotiated agreement. ${ }^{180}$ First, the Member State concerned must notify the Commission of its intentions concerning amending or concluding an agreement with a third country and provide information that shows its 'specific interest' in amending or concluding such an agreement because of 'economic, geographic, cultural, historical, social or political ties' between the third country concerned and the state itself. Second, the Member State concerned must provide information that 'the envisaged agreement' would not render EU law ineffective nor would undermine the proper functioning of the system established by that law. Third, 'the envisaged agreement would not undermine the object and purpose' of the EU's external relations policy as decided by the EU.

When the Commission decides to authorize a Member State to open formal negotiations with a third country on an envisaged agreement, the Commission 'may propose negotiating guidelines and may request the inclusion of particular clauses' in that agreement. ${ }^{181} \mathrm{How}$ ever, the agreement must include a clause that provides for either the 'full or partial denunciation' or the 'direct replacement' of the agreement 'in the event of the conclusion of a subsequent agreement' between the Union or the Union and the Member States and the same third country on the same subject matter. ${ }^{182}$ Furthermore, the 'Commission may participate as an observer in the negotiations' or should be kept informed of the progress and results of the negotiations. ${ }^{183}$ Before the Member State concerned is allowed to sign the agreement, it must 'notify the outcome of the negotiations' and transmit the text of the agreement to the Commission. ${ }^{184}$ The Commission gives 'a reasoned decision' on authorizing the Member State to conclude the agreement if that agreement meets the conditions and fulfils the requirements as set out in Articles 4(2)(b) and (c) and 5(2).

Having an exclusive external competence in the area of recognition, the EU legislator can negotiate a bi- or even multilateral treaty with third states. However, the significance of these treaties should not be overestimated as the example of the bilateral 1957 and 1981

180 Arts. 3, 4(2)(a), (b), and (c) and Recital 11 Regulation on External Agreements in Family Matters.

181 Art. 5(1) and Recital 11Regulation on External Agreements in Family Matters.

182 Art. 5(2)(a) and (b) and Recital 19 Regulation on External Agreements in Family Matters.

183 Art. 7 and Recital 14 Regulation on External Agreements in Family Matters.

184 Art. 8 Regulation on External Agreements in Family Matters. 
France-Morocco Conventions that was discussed in section 15.1 demonstrates. To remind the reader, it appears that the Moroccan courts do not always comply with these conventions. They circumvent their application by invoking the Moroccan public policy exception whenever they consider the provisions in the conventions to infringe upon Shari' $a$ law as it is codified in Moroccan law. In other words, the courts use the public policy exception as an excuse or escape to comply with the conventions, thus undermining their purpose of facilitating the recognition of third-state divorces.

In the more distant future, it could also be considered, however, to draft an EU Regulation on the recognition of third-state divorces, including the various repudiation-based divorce modalities. Contrary to a treaty that only extends to the divorces of those third states that are treaty partners, the scope of such a regulation would cover the divorce modalities of all third states. Because of its remedying effects as mentioned above, this harmonizing instrument could be the answer to both the problematic issues of misunderstanding and incorrect classification of Islamic divorces and the divergence of national recognition policies, in particular with regard to their harmful consequence of limping legal relationships.

It can be argued that the internal competence of the EU also extends to the regulation of extra-European cases such as the regulation of recognition of third-state divorces since $2009 .{ }^{185}$ Since the 1999 Treaty of Amsterdam, the European legislator has acquired internal competence in the area of PIL regarding civil including family matters and thus also in the area of the recognition and enforcement of judgments and decisions in these matters. ${ }^{186}$ As Article 81 TFEU no longer imperatively demands the fulfilment of the internal market requirement, the EU competence pursuant to Article 81 TFEU does no longer depend on the necessity of the measure to be taken for the proper functioning of the internal market. Moreover, Article 81 forms part of the framework that aims to establish an area of freedom, security, and justice, the common European judicial area. Consequently, this competence is no longer restricted to intra-European cases as Article 81 offers a broader legal basis for enacting measures to the European legislator. Article 81 TFEU thus grants the EU the competence not only to enact or amend recognition rules related to intra-European divorce decisions but also to enact or amend recognition rules related to extra-European, thirdstate divorce decisions.

Whether this instrument and complete harmonization are feasible at the moment is questionable however. In view of the fact that complete harmonization of the national conflict rules on divorce appeared not to be feasible, the EU legislator may expect even more difficulties in drafting a Regulation on the recognition of third-state divorces, an

185 See also Baarsma 2010, p. 97, who uses the same line of argumentation in the context of choice of law rules. 186 Then based on Art. 61(c) read with Arts. 65 and 67 EC treaty, resulting in among others the Regulations Brussels I and Brussels II-bis. Now Art. 81 TFEU provides the legal basis for, inter alia, the adoption of Regulations. 
even more sensible issue, especially because of the divergent approaches towards the recognition of repudiation-based divorces. The drafting of the regulation on the basis of enhanced cooperation possibly offers an opening but is less desirable. ${ }^{187}$

Harmonization of recognition policies within the EU does and should not necessarily mean full recognition of every single foreign, non-EU divorce. Unilateral repudiations without any involvement of the wife and/or without some form of judicial or administrative control should and will most likely not be recognized in the EU. In those situations, limping relationships will still occur.

187 Based on Arts. 326-334 TFEU. 


\section{Conclusion}

\subsection{Shortcomings of the Differing National Recognition Policies}

This part of the study, in particular chapter 20, focused on exploring a number of possible solutions for the shortcomings of the differing national recognition policies regarding repudiation-based divorces in Europe.

The analysis of the Dutch, English, and French recognition policies in part II of this study revealed major shortcomings in the management of recognition of Islamic, in particular repudiation-based divorces in Europe. They vary from misunderstanding Islamic divorce modalities and problems of classification to problems as a result of the approach to which a specific country abides or as a result of the influence of other interests than PIL interests. They may result in wrongful non-recognition, recognition under too strict or under the wrong conditions, or wrongful recognition. Moreover, chapter 19 demonstrated that the differing recognition policies at the national level and the lack of a specific legal instrument dealing with recognition of third-state divorces on the supranational level may result in a situation that someone's repudiation-based divorce is recognized in the one state but not recognized in another state after that person's movement or migration within Europe. The consequence of the non-recognition is the non-continuity of someone's personal status and thus a (multiple) limping legal relationship with all kinds of harmful effects.

In particular within the socio-economic context of an increasing globalizing world today, one would like to assume that one can rely on the validity of the arrangements that are made regarding personal status in accordance with a specific legal system, such as divorce arrangements, while crossing borders. But continuity of a person's legal status appears not to be self-evident although the official recognition of someone's personal status belongs to the sphere of one's private and family life that is protected by, inter alia, Article 8 ECHR or Article 7 ChFREU. The examples and case law in chapters 19 and 20 demonstrated that non-recognition resulting in non-continuity of someone's personal status affects the interests of a person in legal certainty and predictability, breaches that person's legitimate expectations, and thereby creates confusion. Furthermore, it results in all kinds of other legal, social, and economic consequences in terms of impediments to a new relationship thus affecting someone's right to remarriage and a new family life as embedded in Articles 8 and 12 ECHR and Articles 7 and 9 ChFREU, costs for additional procedures, inaccessibility to certain social benefits, etcetera. Moreover, it may hamper the integration and restrict the freedom of movement of persons as, for example, enshrined in Article 21 TFEU and Article 45 ChFREU at least if they are entitled to the (secondary) right to free 
movement. This right is of the utmost importance for the realization of one common judicial area that aims at furthering the internal market, the main objective of the EU.

\subsection{Relevance of THE EU Context}

Whether or not a person who resides in Europe and whose marriage was dissolved by a repudiation-based divorce can rely on specific provisions in EU law such as the (secondary) right to free movement depends on the status of that person in Europe. For this reason, chapter 18 distinguishes between persons being an EU citizen (an authentic citizen of a Member State or former TCN who has been naturalized into a citizen of a Member State) or belonging to one of the categories of TCNs. TCNs have a different legal status in the $\mathrm{EU}$ according to whether the TCN is a family member of, and accompanying or joining an, EU citizen; has a long-term residence permit; a residence permit; or whether it concerns an illegal or irregular TCN.

EU citizens and specific categories of TCN family members who are allowed to accompany or join them such as spouses, recognized registered partners, dependent children, etcetera are entitled to the right to move and reside freely within the territory of the Member States of the EU pursuant to Article 21 TFEU and Article 45 ChFREU. Specific categories of TCNs and their family members who are allowed to join them, such as longterm TCNs, TCNs admitted for purposes of scientific research, and TCNs being highly qualified workers and their family members enjoy a secondary right to free movement. If exercising the (secondary) right to free movement results in the non-continuity of someone's personal status due to recognition of his or her repudiation-based divorce in the one Member State and non-recognition of that divorce in another Member State as a consequence of the diversity of national recognition policies within the EU, that result may be considered as a restriction of that person's right to free movement.

Whether or not the EU can offer solutions for the shortcomings of the diverging national recognition policies, in other words remedy situations of non-continuity of personal status, depends on their legislative competences. Chapter 18 demonstrated that the EU has a shared internal competence in the area of PIL based on Article 81 TFEU in connection with Article 4(2)(j) TFEU. It has been argued that this internal competence can be extended to extra-European cases. Article 81 TFEU offers a broader legal basis than for intraEuropean cases only, since it no longer imperatively demands fulfilment of the internal market requirement and because it forms part of the area of freedom, security, and justice. Based on this internal competence, the European legislator can adopt various kinds of measures of which the Regulation appears to be the most preferable for reasons of legal certainty, predictability, consistency, being part of the acquis communautaire and directly applicable in the Member States and having primacy over national law. Furthermore, 
chapter 18 demonstrated that the EU has an implied exclusive external legislative competence to negotiate and conclude international agreements in the area of PIL based on Article 216 in connection with Article 3(2) TFEU. Member States are only allowed to amend or to negotiate and conclude bilateral agreements in the area of specific international family law matters if they comply with the requirements of Regulation 664/2009, the Regulation on External Agreements in specific Family Matters.

The question arose of how a situation of recognition of a repudiation-based divorce in the one Member State and its non-recognition in another Member State as a consequence of the differing recognition policies due to every Member State's own discretion to regulate its PIL matters should be reconciled with the abovementioned fundamental rights and the rights enshrined in EU law?

\subsection{Solutions}

Chapter 20 therefore proposed and explored a number of soft and hard law solutions for a better management of the legal diversity at stake. The chapter in particular focused on the following solutions: the Principles on the Recognition of Third-State Divorces, the application of the principle of mutual recognition to decisions of EU Member States on the recognition of third-state divorces, and a common EU policy on recognition of thirdstate divorces.

\subsubsection{Soft Law Solutions}

The proposed soft law solutions - legal education, trainings on Islamic divorces, guidelines, and manuals - aim at increasing the legal students' or professionals' knowledge of and sensitivity to the legal diversity. Hence, they further the proper understanding and classification of Islamic divorce modalities and, consequently, help to foster a more consistent application of the recognition policies. These solutions may thus prevent incorrect decisions on recognition and their possible legal, social, and financial consequences. Hence, they may enhance legal certainty and predictability and meet the legitimate expectations of the persons involved. It has been argued that the significance of guidelines should not be underestimated because of its persuasive power and its potential to morph into hard law.

Another soft law solution, the Principles-project on European Family Law, can be seen as an example of an instrument to further harmonization in Europe. Even while no sound indication for the feasibility of harmonization of divorce laws in Europe can be seen yet, harmonizing PIL answers must be kept in mind as an option to tackle the problems. For this reason, the endeavour was undertaken to give the initial impetus to an outline of a 
draft of 'Principles of European Family Law on the Recognition of Third-State Divorces', inspired by the analysis of the three national recognition policies in Europe under review. It was argued and emphasized however that such an endeavour should be the result of comparative research done by a group of scholars from as many different European jurisdictions as possible and not by just one researcher. This exercise led to proposing four Principles: two Principles on the recognition of repudiation-based divorces either obtained abroad after proceedings or obtained abroad without proceedings, and upon fulfilment of specific requirements: one Principle that includes grounds for non-recognition and one Principle that enables a spouse, in particular the wife, to claim financial relief such as alimony, if needed, in the state of recognition notwithstanding the recognition of the repudiation-based divorce.

Their main aim is to enable in principle the recognition of repudiation-based divorces, even those obtained without any proceedings, in order to avoid unnecessary limping legal relationships while seeking to protect the rights and interests of women. For these reasons, the proposed starting points that should underlie both Principles concerning the recognition of repudiation-based divorces regard their positive formulation (recognition as starting point), an approach in concreto, ex lege recognition, the favor divortii principle, the pursuit of decisional harmony, the PIL principle of respect for the 'otherness' of Islamic divorce laws, the protection principle, the aim to prevent from fraud, and restriction of the recognition to the effect that the repudiation-based divorce has dissolved the marriage. The main requirements to the recognition of the repudiation-based divorce obtained abroad after proceedings concern the intervention of a competent judge or other authority and some form of (judicial or other) procedure in order to protect the procedural and substantfive rights of the wife and children. The main requirement to the recognition of the repudiation-based divorce obtained without proceedings concerns the wife's explicit or implicit agreement with or acquiescence in the repudiation-based divorce. Her consent implies that both spouses have agreed with the repudiation and 'repairs' the violations of the right to equal access to divorce and of the procedural rights due to the repudiation. Although this requirement is at odds with the legal nature of the repudiation as Islamic law does not require the consent of the wife, it pays respect to the 'otherness' of the repudiation-based divorce by enabling its recognition, thus also preventing limping legal relationships.

The soft law solutions that have been discussed above benefit all those persons who reside in Europe and whose marriages have been dissolved by means of an Islamic, in particular repudiation-based divorce irrespective of whether or not they are EU citizens or TCNs and can rely on EU law. This is in contrast with the proposed hard law solutions. These solutions are only beneficial to those categories of persons who can rely on EU law as discussed in chapter 18 . 


\subsubsection{Mutual Recognition of Decisions of EU Member States on the Recognition of Third-State Divorces}

As far as hard law solutions are concerned, the problem of non-continuity in personal status matters due to the migration within the EU of persons whose marriage is dissolved by a repudiation-based divorce can be countered by applying the EU mutual recognition principle to decisions of recognition of third-state divorces. To that end, developments concerning case law of the ECJ, the creation of 'an area of freedom, security, and justice', and the adoption of specific legal instruments by the EU legislator such as the Proposal EU Regulation on free movement of public documents of 2013, the Brussels I, Brussels I Recast and the Brussels II-bis Regulation, were analysed in relation to the implementation of the principle of mutual recognition in matters of civil or personal status.

First of all, case law of the ECJ appears to be relevant for the development and implementation of the principle of mutual recognition in EU law. The ECJ articulated this principle for the first time in the Cassis de Dijon case in relation to the freedom of movement of goods for the purpose of furthering European integration. Later the ECJ applied this principle also in the scope of the other freedoms of movement that are protected by EU law such as the freedom of movement of persons, also in matters of civil status.

I concluded that the analysed case law concerning names, an issue that falls within the competence of the Member States, is too casuistic - i.e. that it is based on the specific details of the case - to conclude that they contain a solid principle of mutual recognition for cases of loss of other issues of personal status due to migration within the EU. However, the case law can be regarded as guideline. The analysis demonstrated that a Member State is required to recognize the legal status that has been determined in another Member State, if nonrecognition results in an unjustified restriction of the right to free movement guaranteed by Article 21 TFEU, which causes serious inconveniences. But the scope of application of the principle of mutual recognition can be limited by, first of all, the lack of a restriction that causes serious inconveniences and, second, the public order (or public health or public security as objective considerations that justify the restriction) of the state that is required to recognize, although the public policy exception has to be strictly interpreted. Furthermore, the analysis demonstrated that the application of the principle of mutual recognition requires a sufficient or serious link between the situation and the state of its origin/crystallization and between the situation and the state where recognition is sought in order to avoid fraud, abuse of law, or forum shopping. In general, one could conclude that the analysis demonstrated that the Court searched carefully for a nuanced balance between an unrestricted freedom of movement while maintaining the personal status on the one hand (Grunkin and Paul) and leaving room to the Member States for their choices and policies (concerning issues of name in the cases at issue), thus respecting their compe- 
tence on the other hand (Sayn-Wittgenstein, Runevič-Vardyn, and Wardyn). Although the ECJ has not yet dealt with the issue of non-recognition of a foreign third-state divorce in relation to the right of free movement, national courts or other authorities do not have to wait for judgments by the ECJ in order to apply EU law and thus to give a useful effect to Union Law and to render it effective.

The analysis of the subsequent Programmes, the policy plans concerning the establishment of 'an area of freedom, security, and justice' demonstrated that the principle of mutual recognition plays a pivotal role in establishing that order progressively. It was made the cornerstone of judicial cooperation in civil matters in particular in relation to the development of common rules on recognition and enforcement in civil matters. The Stockholm Programme resulted, via a consultation on the possible means of facilitating the free movement of public documents between Member States by means of a Green Paper in 2010, in the Proposal EU Regulation on free movement of public documents in March 2013. The analysis of this Proposal demonstrated that it is a follow-up of the ECJ ruling in the Dafeki case. It appears to have in its actual state very little meaning for decisions on the recognition of third-state divorces by competent authorities of Member States yet. First of all, its scope does not directly cover the subject matter of divorce. Second, the proposal only provides for the acceptance of the evidentiary value of a public document on a subject matter that is covered by the proposal.

As a result of the 1999 Treaty of Amsterdam, the European legislator enacted, inter alia, the Brussels I and the Brussels II-bis Regulations based on Article 65 EC Treaty, and in 2012, the Brussels I Recast based on Articles 67(4) and 81(2) TFEU. All Regulations incorporate the principle of mutual recognition in order to facilitate a free movement of judgments or 'a common market for judgments' (or judicial and extra-judicial decisions according to Brussels II-bis). The incorporation of this principle into these instruments resulted in ex lege recognition of judgments or judicial or extra-judicial decisions, in a limited number of grounds for non-recognition of these judgments or decisions, and in the abolition of the exequatur in the Brussels II-bis Regulation (although partially, only for certain judgments concerning the rights of access or certain judgments requiring the return of a child) and in the Brussels I Recast Regulation. So, the Brussels I Recast introduces the recognition and the enforcement of enforceable judgments without any special procedure being required. The implementation of the principle of mutual recognition and its objectives has also been extended to public and private documents in Article 57 of the Brussels I Regulation, Article 58 of the Brussels I Recast, and Article 46 of the Brussels II-bis Regulation. Both Brussels I Regulations stipulate that an authentic instrument that is enforceable in the Member State of origin shall be enforceable in another Member State without any declaration of enforceability being required; however, its enforcement may be refused but only if such enforcement is manifestly contrary to public policy in the Member State addressed. Article 46 of the Brussels II-bis Regulation provides for the 
recognition and declaration of enforceability of documents that have been formally drawn up or registered as authentic instruments (such as documents drawn up by notaries) and of agreements between the parties and that are enforceable in one Member State under the same conditions as judgments in other Member States. By thus facilitating the recognition of positive divorce decisions, Brussels II-bis Regulation clearly aims to realize favor recognitionis and favor divortii and also the right to remarry as enshrined in Article 12 of the ECHR and Article 9 of the ChFREU.

Today the principle of mutual recognition concerning recognition of judicial and extrajudicial decisions has found a solid legal basis in PIL in Articles 67(4), 81(1), and 81(2) TFEU. Article 81 TFEU provides the legal basis for a Regulation amending Brussels II-bis Regulation or a separate Regulation on the mutual recognition of (positive) decisions and documents or certificates of recognition of third-state divorces in line with the regime of the Brussels II-bis Regulation. The realization of the proposal for an international instrument permitting a thorough check of all judgments from third countries before their recognition in a Member State may imply that once such a judgment has passed that assessment, any public document with respect to that judgment drawn up in an EU Member State must then benefit from the simplified system of use and acceptance of public documents between the Member States. Striving for a common judicial area implies that Member States mutually recognize their decisions and documents without any special procedure being required, thus implementing a system of 'full faith and credit' for these decisions and documents in the EU. This solution is most effective as well as most preferable and feasible at this moment, and it seems therefore to be the first and most suitable hard law instrument to manage this specific legal diversity.

Applying the mutual recognition principle via an amended Brussels II-bis or a separate Regulation to judicial and extra-judicial decisions of recognition of third-state divorces guarantees the continuity of the personal status of a person at migration within the EU. This would result in legal certainty, predictability, doing justice to the legitimate expectations of the person involved and avoidance of additional economic, administrative, and other burdens. For example, it may avoid instituting a second divorce procedure in such a situation in order to enable remarriage in the second Member State. Or it may avoid that a person is considered a 'bigamist' in the Member State where the divorce appears not to be recognized as result of remarriage, while the divorce was initially recognized in another EU Member State, as in the aforementioned case of the Dutch-Moroccan woman.

\subsubsection{Harmonization of Recognition of Third-State Divorces in the EU}

Furthermore, it is proposed to consider the possibilities of a multi- or bilateral treaty on the recognition of third-state divorces including repudiation-based divorces. Such a treaty should preferably be concluded by the EU that has exclusive external competence regarding, inter alia, family matters which are already governed by Union acts in force such as divorce 
pursuant to Article 216 TFEU in connection with Article 3(2) TFEU. EU Member States could also negotiate and conclude such bilateral treaties, but they are only allowed to do so today after authorization by the EU Commission and after fulfilment of other requirements set by the Regulation 664/2009, the Regulation on External Agreements in Family Matters. Bilateral agreements concluded by Member States are not desirable, because they will even increase the diversity of and within recognition policies. However, it was pointed out that the significance of multi- or bilateral treaties for the purpose of facilitating the recognition of third-state divorces should not be overestimated. The example of the 1957 and 1981 France-Morocco Conventions demonstrates that courts or authorities do not always observe the provisions of the conventions. Hence, facilitating the recognition of third-state divorces by means of bi- or multilateral treaties becomes illusory.

For the more distant future, it is also proposed to consider the possibilities of an EU Regulation on the recognition of third-state divorces including repudiation-based divorces based on the extended internal legislative competence of Article 81 TFEU. The scope of such a Regulation would cover the divorce modalities of all third states, contrary to a treaty that only extends to the divorces of those third states that are treaty partners. Such a Regulation, alternatively on the basis of the enhanced cooperation procedure, could be the answer to all shortcomings in the management of legal diversity, thus preventing limping legal relationships and other financial, administrative, and social burdens and providing for legal certainty and predictability and thereby doing justice to the legitimate expectations of the person(-s) involved. 


\section{Conclusions And Recommendations}

\subsection{Diversity in Islamic Divorce Laws and Practices}

The overview of the Islamic divorce modalities illustrated by contemporary Egyptian, Iranian, Moroccan, and Pakistani examples in part I of this study demonstrates the legal diversity within the divorce laws and practices of Muslim-majority countries.

In all the legal systems under review, women and men still have formally unequal access to divorce despite the reforms in these legal systems over the years. However, they may partially enjoy equal access where it concerns the common modality of the unconditional delegated repudiation and, only in Morocco, the judicial divorce on the ground of irretrievable breakdown. In the legal systems that provide for mandatory judicial intervention in the case of repudiation-based divorces, those of Iran and Morocco, the procedural and substantive rights of women are more and far better guaranteed than in the legal systems of Egypt and Pakistan that only provide for a mandatory registration and notification procedure respectively. All legal systems require reconciliation attempts. However, the Iranian and Moroccan legal systems provide for the judicial intervention including (an) reconciliation attempt(s) from the outset of the procedure, whereas the Pakistani notification procedure including the reconciliation attempt(s) takes place after the repudiation has been pronounced. The registration procedure in Egypt may include the pronouncement of the repudiation in the presence of the ma'zun, but may also take place at the ma'zun after the pronouncement of the repudiation. The judicial intervention in Iran and Morocco is needed for the authorization to (the pronouncement of) the repudiation (and its registration) and the respective courts settle the post-divorce provisions such as payment of the dower and maintenance, custody and visiting rights. In Egypt and Pakistan the wife has to file a separate lawsuit to claim and have settled her post-divorce rights and provisions.

Generally, women's access to divorce and possibilities to realize their substantive rights are often seriously restrained by all kinds of financial, procedural/evidential, and social drawbacks. The inequality in access to divorce is based on the principle of Islamic divorce laws that provides for individual gender-based divorce grounds for the spouses. Full equality would require the elimination of this Islamic principle.

Hence, it is to be considered whether full or a formalistic type of equality should be pursued. It may be a better option to strive for enhancing the position of women by reconciling the respect for the 'otherness' of the foreign law and the respect for fundamental values. This implies a more nuanced and step-by-step approach towards equality. Substantive equality in the access to divorce can be reached if either spouse can effectively obtain a divorce with procedural guarantees and without financial obstacles. Under these circum- 
stances, the fact that each spouse has his/her own divorce modalities is not per se discriminatory and, therefore, not incompatible with Western standards. Moreover, a step-bystep approach may pave the road to full equality.

In order to achieve such a balanced system of divorce modalities, Muslim-majority countries have to further reform their domestic divorce laws. Morocco is a good example in this respect as the government of Morocco has established an independent accessible judicial divorce for both spouses next to the other types of divorces: the judicial divorce on the ground of irretrievable breakdown.

Equally, the judicially monitored repudiation-based divorces in Iran and Morocco, the Egyptian judicial khul', and the possibility of an unconditional self-repudiation must be highlighted. As regards unilateral forms of divorce, a distinction should be made between the different modes of repudiation: from the 'bare' repudiation without any procedural guarantees to the repudiation subjected to a registration or notification procedure afterwards, as in Egypt and Pakistan, to the repudiation with judicial interference from the outset, as in Iran and Morocco. As far as the repudiation encompasses a procedure by a competent authority that guarantees the rights of the wife, it should not be considered to be incompatible with European standards. The same holds true for divorce by agreement of both spouses.

Finally, two issues should be kept in mind. First of all, the repudiation is often the only accessible type of divorce for men in many Muslim-majority countries. Second, it is also possible to obtain a divorce against the will of the other spouse in European legal systems. As long as the law and legal practice provide either spouse with the opportunity to obtain a divorce while guaranteeing the procedural position of the other spouse, there is no unbridgeable incompatibility between Islamic and Western principles regarding divorce. However, correctly understanding these divorce modalities and their detailed specifics is of great importance as it affects their assessment for recognition within the European legal orders.

\subsection{Diversity in National Recognition Policies in Europe}

The issue of how the various European countries, the Netherlands, England, and France, by means of their PIL, manage the legal diversity at hand was at the centre of study in part II. How can rights and legal status established abroad have effect in their legal orders? Do these recognition policies respect 'the otherness' of the Islamic divorce laws under study? To what extent do other interests than PIL interests play a part? In sum, do the recognition policies of these three countries offer an efficient and fair solution for the possible conflict between their norms and values and the norms and values of Islamic divorce laws? 
PIL's pragmatic, basic principle is respect for the foreign law, in that the receiving legal order accepts the 'otherness' of that law, independent of its origin, on an equal footing with domestic law. This also implies that even decisions that are alien to the own (national) legal system are in principle to be accepted. The acceptance of foreign law may, although exceptionally, only be restricted if it conflicts with fundamental norms and values, thus with the PIL public order of the receiving legal order. Hence, Private International Law is also called the Law of Tolerance (Derecho de Tolerancia).

However, this is easily said on an abstract level. In reality, it turns out to be much more complicated as the examination of the recognition policies towards repudiation-based divorces in England, France, and the Netherlands showed in part II. That part revealed major shortcomings in the management of the legal diversity at issue: misunderstanding the Islamic divorce and classification problems, other interests dominating or superseding PIL interests, and diverging European recognition policies. The issue is how legal diversity should be dealt with in concrete, day-to-day situations.

It has been demonstrated that the point of departure underlying recognition policies towards repudiation-based divorces, recognition or non-recognition, differs in the European states under review. Dutch policy departs from the assumption that both repudiationbased divorces established with and those established without proceedings may be eligible for recognition, upon the fulfilment of specific requirements. The point of departure of the French policy is the opposite: the non-recognition of any repudiation-based divorce as soon as there is sufficient proximity with the French legal order. This results in practice in denying recognition to almost all repudiation-based divorces and thus in limping legal relationships and its consequences. English recognition policy takes an in-between stance: in principle, there is recognition of all repudiation-based divorces upon fulfilment of specific requirements, except for one category, the repudiation-based divorce that is not obtained after proceedings and where either party had habitual residence in the United Kingdom during the period of one year preceding the date it was obtained.

Furthermore, it was found that the English and French points of departure stem from the intention to prevent husbands from circumventing their legal systems through obtaining a quick divorce in their country of origin in order to frustrate their wives' access to the English or French legal system. But a recognition policy such as the French policy that bans all repudiation-based divorces as soon as there is sufficient proximity with the French legal order, without taking into account the concrete circumstances of the case, is too rigid and disproportionate in view of its consequences. It resolves the abstract problem of the detrimental repudiation by the fraudulent husband, but it also inevitably results in the situation of limping legal relationship in the concrete case. This is unnecessary and results in wrongful non-recognition in those cases where the concrete circumstances could have allowed for recognition, and it is in particular harmful to those women who pursue recognition. It obviously hampers rights and legal status from having legal effect in the 
French legal order. The French policy also shows no respect for the otherness of the repudiation-based divorces by lumping them all together and not taking into account their specific characteristics and concrete circumstances and the important differences between the various Islamic states. For these reasons, the French legal system does not offer an effective and fair solution.

In comparison to the French recognition policy, the English policy offers a far more effective and fairer solution for the same abstract problem. First, it only denies recognition to those repudiation-based divorces that are obtained without proceedings if either party has been habitual resident in the United Kingdom during the period of one year preceding the date it was obtained. For this reason, it limits the risk of unnecessary limping legal relationships. Second, it provides for financial relief to the wife after the recognition of her repudiation-based divorce according to part III of the Matrimonial and Family Proceedings Act 1984. For these reasons, the English legal system in principle offers a fair and effective solution for conflicts between the domestic legal system and the Islamic legal systems. As said, the English legal system in principle offers a fair and effective solution, since judicial practice has shown shortcomings in the understanding and classification of the Pakistani repudiation wrongfully resulting in their recognition as repudiation obtained after 'other' (than judicial) proceedings. English recognition policy respects the 'otherness' of the repudiation-based divorces but only to the extent that it does not allow husbands actually residing in the United Kingdom to go abroad for a quick repudiation in order to evade the domestic legal system. In this way, rights and legal status come to have legal effect in the English legal order.

The background to the Dutch stance is favor divortii and the interests of the wife in the recognition of the repudiation in order to avoid limping legal relationships. Dutch recognition policy notably concerns the fundamental objections to repudiation-based divorces without any form of proceedings, but it enables their recognition nevertheless upon fulfilment of a number of cumulative requirements. The most important requirement is the unequivocal consent of the wife aimed at remedying the inequality between the spouses upon divorce. To that extent, Dutch recognition policy does respect the otherness of repudiation-based divorces and offers a fair and effective solution for any apparent conflict. At the same time, legal practice has displayed shortcomings in the understanding and classification of various repudiation-based divorce modalities and in the interpretation and application of its own legal norms. This hampers and may even prevent rights and legal status from having legal effect in the Netherlands. Moreover, the shortcomings with regard to understanding and classification fail to show respect for the 'otherness' of repudiation-based divorces.

The legal comparative analysis of the Dutch, English, and French recognition policies revealed major shortcomings in the management of recognition of Islamic, in particular repudiation-based, divorces in Europe. First, there are problems related to the process for 
assessment, such as misunderstanding the various repudiation-based divorce modalities, classification problems, the variety of authorities being responsible for and having discretion for assessment, but also problems as result of the approach to which a specific country abides. The comparative analysis demonstrated the advantages of and need for a functional and open approach. That approach concerns an assessment in concreto of repudiationbased divorces while at the same time it balances respect for the 'otherness' of the foreign law at stake and the fundamental principle of gender equality upon divorce. Such an approach is most advisable in order to provide for an efficient and fair solution.

Second, the role and functioning of PIL is often affected by and put in the shade of other interests. Interests other than the PIL interests of respect for the otherness or tolerance, international harmony of decisions, and avoidance of limping legal relationships appear to play a part to a greater or lesser extent. They may dominate or supersede PIL interests and may even 'influence the choice for' a specific approach. Migration interests, for example, are invoked in order to deny recognition to repudiation-based divorces, as was the case in the example of the Dutch-Moroccan woman. The Belgian Immigration Affairs Services (Dienst Vreemdelingenzaken) refused to recognize her second marriage because they denied recognition to her previous divorce through repudiation, although the Belgian municipality had registered and thus recognized her second marriage. These are migration interests in their negative dimension. But migration interests also have a positive dimension such as the protection of migrating persons in their legitimate expectation of respect for their fundamental rights. These rights aim to protect their identity and legal status. This dimension does not conflict with the role and functioning of PIL and should therefore prevail.

Third, the states under study use different policies regarding the recognition of repudiation-based divorces. There is evidently diversity in the recognition policies in Europe. The diversity, its consequences, as well as possible solutions for all the above-mentioned shortcomings were the subject of discussion in part III of this study.

All the above-mentioned shortcomings may result in wrongful (non-)recognition and its harmful consequences such as limping legal relationships. Avoiding limping legal relationships implies recognition; however, recognizing all divorces enables spouses to shop for the most attractive court and law in order to obtain a divorce which would allow the spouse to evade the requirements of the jurisdiction and laws of the country with which they are connected. Thus, fair and effective recognition rules intend to strike a fair balance between being too restrictive, which may result in limping legal relationships, and being too generous by sanctioning divorces of convenience. 


\subsection{Solutions for a Better Management of Legal Diversity in Europe}

The diversity in recognition policies in Europe has already resulted or may continue to result in adverse consequences for Muslims migrating to or within Europe. Because of the lack of a specific legal instrument dealing with recognition of third-state divorces on the supranational level, the diversity may result in a situation that someone's repudiationbased divorce is recognized in the one state, but not recognized in another state after that person's movement or migration within Europe. The consequence of the non-recognition is the non-continuity of someone's personal status and thus a (multiple) limping legal relationship with all kinds of harmful effects.

In particular, within the socio-economic context of an increasing globalizing world today, people may rightfully expect that one can rely on the validity of the arrangements that have been made regarding personal status in accordance with a specific legal system, such as divorce arrangements, while crossing borders. But continuity of a person's legal status appears not to be self-evident although the official recognition of someone's personal status belongs to the sphere of one's private and family life that is protected by, inter alia, Article 8 ECHR or Article 7 ChFREU. The examples and case law in chapters 19 and 20 demonstrated that non-recognition resulting in non-continuity of someone's personal status affects the interests of a person in legal certainty and predictability, breaches that person's legitimate expectations, and arises confusion. Furthermore, it results in all kinds of other legal, social, and economic consequences in terms of impediments to a new relationship, thus affecting someone's right to remarriage and a new family life as embedded in the Articles 8 and 12 ECHR and the Articles 7 and 9 ChFREU, costs for additional procedures, inaccessibility to certain social benefits, etcetera. Moreover, it may hamper the integration and restrict the freedom of movement as, for example, enshrined in Articles 21 TFEU and 45 ChFREU, of persons, at least if they are entitled to the (secondary) right to free movement. This right is of the utmost importance for the realization of one common judicial area, which aims at furthering the internal market, the main objective of the EU.

Whether or not a person who resides in Europe and whose marriage was dissolved by a repudiation-based divorce can rely on specific provisions in EU law such as the (secondary) right to free movement depends on the status of that person in Europe. For this reason, one should distinguish between persons being an EU citizen (an original citizen of a Member State or former TCN who has been naturalized into a citizen of a Member State) or belonging to one of the categories of TCNs. TCNs have a different legal status in the EU according to whether the TCN is a family member of, and accompanying or joining an, EU citizen; has a long-term residence permit; and has a residence permit or whether it concerns an illegal or irregular TCN.

EU citizens and specific categories of TCN family members who are allowed to accompany or join them such as spouses, recognized registered partners, dependent chil- 
dren, etcetera, are entitled to the right to move and reside freely within the territory of the Member States of the EU pursuant to Articles 21 TFEU and 45 ChFREU. Specific categories of TCNs and their family members who are allowed to join them, such as long-term TCNs, TCNs admitted for purposes of scientific research, and TCNs being highly qualified workers and their family members, enjoy a secondary right to free movement. If exercising the (secondary) right to free movement results in the non-continuity of someone's personal status due to recognition of his or her repudiation-based divorce in the one Member State and non-recognition of that divorce in another Member State as a consequence of the diversity of national recognition policies within the EU, that result may be considered as a restriction of that person's right to free movement.

Whether or not the EU can offer solutions for the shortcomings of the diverging national recognition policies, in other words remedy situations of non-continuity of personal status, depends on their legislative competences. It was demonstrated that the EU has a shared internal competence in the area of PIL based on Article 81 TFEU in connection with Article 4(2)(j) TFEU. It has been argued that this internal competence can be extended to extraEuropean cases. Article 81 TFEU offers a broader legal basis than for intra-European cases only, since it no longer imperatively demands fulfilment of the internal market requirement and because it forms part of the area of freedom, security, and justice. Based on this internal competence, the European legislator can adopt various kinds of measures of which the Regulation appears to be the most preferable for reasons of legal certainty, predictability, and consistency, being part of the acquis communautaire and directly applicable in the Member States and having primacy over national law. Furthermore, it was demonstrated that the EU has an implied exclusive external legislative competence to negotiate and conclude international agreements in the area of PIL based on Article 216 in connection with Article 3(2) TFEU. Member States are only allowed to amend or to negotiate and conclude bilateral agreements in the area of specific international family law matters, if they comply with the requirements of Regulation 664/2009, the Regulation on External Agreements in specific Family Matters.

The question arose of how a situation of recognition of a repudiation-based divorce in the one Member State and its non-recognition in another Member State as a consequence of the differing recognition policies due to every Member State's own discretion to regulate its PIL matters should be reconciled with the above-mentioned fundamental rights and the rights enshrined in EU law.

A number of soft and hard law solutions for a better management of the legal diversity at stake were proposed and explored, in particular the following solutions: the Principles on the recognition of third-state divorces, the application of the principle of mutual recognition to decisions of EU Member States on the recognition of third-state divorces, and a common EU policy on recognition of third-state divorces. 
The proposed soft law solutions - legal education, trainings on Islamic divorces, guidelines, and manuals - aim at increasing the legal students' or professionals' knowledge of and sensitivity to the legal diversity. Hence, they further the proper understanding and classification of Islamic divorce modalities and, consequently, help to foster a more consistent application of the recognition policies. These solutions may thus prevent incorrect decisions on recognition and their possible legal, social, and financial consequences. Hence, they may enhance legal certainty and predictability and meet the legitimate expectations of the persons involved. It has been argued that the significance of guidelines should not be underestimated because of its persuasive power and its potential to morph into hard law.

Another soft law solution, the Principles-project on European Family Law, can be seen as an example of an instrument to further harmonization in Europe. Even while no sound indication for the feasibility of harmonization of divorce laws in Europe can be seen yet, harmonizing PIL answers must be kept in mind as an option to tackle the problems. For this reason, the endeavour was undertaken to give the initial impetus to an outline of a draft of 'Principles of European Family Law on the Recognition of Third-State Divorces', inspired by the analysis of the three national recognition policies in Europe under review. It was argued however that such an endeavour should be the result of comparative research done by a group of scholars from as many different European jurisdictions as possible and not by just one researcher. This exercise led to proposing four Principles: two Principles on the recognition of repudiation-based divorces either obtained abroad after proceedings or obtained abroad without proceedings and upon fulfilment of specific requirements; one Principle that includes grounds for non-recognition; and one Principle that enables a spouse, in particular the wife, to claim financial relief such as alimony, if needed, in the state of recognition notwithstanding the recognition of the repudiation-based divorce.

Their main aim is to enable in principle the recognition of repudiation-based divorces even those obtained without any proceedings in order to avoid unnecessary limping legal relationships while seeking to protect the rights and interests of women. For these reasons, the proposed starting points that should underlie both Principles concerning the recognition of repudiation-based divorces regard their positive formulation (recognition as starting point), an approach in concreto, ex lege recognition, the favor divortii principle, the pursuit of decisional harmony, the PIL principle of respect for the 'otherness' of Islamic divorce laws, the protection principle, the aim to prevent from fraud, and restriction of the recognition to the effect that the repudiation-based divorce has dissolved the marriage. The main requirements to the recognition of the repudiation-based divorce obtained abroad after proceedings concern the intervention of a competent judge or other authority and some form of (judicial or other) procedure in order to protect the procedural and substantive rights of the wife and children. The main requirement to the recognition of the repudiation-based divorce obtained without proceedings concerns the wife's explicit or implicit 
agreement with or acquiescence in the repudiation-based divorce. Her consent implies that both spouses have agreed with the repudiation and 'repairs' the violations of the right to equal access to divorce and of the procedural rights due to the repudiation. Although this requirement is at odds with the legal nature of the repudiation as Islamic law does not require the consent of the wife, it pays respect to the 'otherness' of the repudiation-based divorce by enabling its recognition, thus also preventing limping legal relationships.

The soft law solutions that have been discussed above benefit all those persons who reside in Europe and whose marriages have been dissolved by means of an Islamic, in particular repudiation-based, divorce irrespective of whether they are EU citizens or TCNs and can rely on EU law. This is in contrast with the proposed hard law solutions. These solutions are only beneficial to those categories of persons who can rely on EU law.

As far as hard law solutions are concerned, the problem of non-continuity in personal status matters because of the migration within the EU of persons whose marriage is dissolved by a repudiation-based divorce can be countered by applying the EU mutual recognition principle to decisions of recognition of third-state divorces. To that end, developments concerning case law of the ECJ, the creation of 'an area of freedom, security and justice', and the adoption of specific legal instruments by the EU legislator such as the Proposal EU Regulation on free movement of public documents of 2013, the Brussels I, the Brussels I Recast and the Brussels II-bis Regulation, were analysed in relation to the implementation of the principle of mutual recognition in matters of civil or personal status.

First of all, case law of the ECJ appears to be relevant for the development and implementation of the principle of mutual recognition in EU law. The ECJ articulated this principle for the first time in the Cassis de Dijon case in relation to the freedom of movement of goods for the purpose of furthering the European integration. Later, the ECJ applied this principle also in the scope of the other freedoms of movement that are protected by EU law such as the freedom of movement of persons, also in matters of civil status.

The case law concerning names, an issue that falls within the competence of the Member States, is too casuistic to conclude that they contain a solid principle of mutual recognition for cases of loss of other issues of personal status due to migration within the EU. However, the case law can be regarded as guideline. The analysis demonstrated that a Member State is required to recognize the legal status that has been determined in another Member State, if non-recognition results in an unjustified restriction of the right to free movement guaranteed by Article 21 TFEU, which causes serious inconveniences. But the scope of application of the principle of mutual recognition can be limited by, first of all, the lack of a restriction that causes serious inconveniences and, second, the public order (or public health or public security as objective considerations that justify the restriction) of the state that is required to recognize, although the public policy exception has to be strictly interpreted. Furthermore, the analysis demonstrated that the application of the principle of mutual recognition requires a sufficient or serious link between the situation 
and the state of its origin/crystallization and between the situation and the state where recognition is sought in order to avoid fraud, abuse of law, or forum shopping. In general, one could conclude that the analysis demonstrated that the Court searched carefully for a nuanced balance between an unrestricted freedom of movement while maintaining the personal status on the one hand (Grunkin and Paul) and leaving room to the Member States for their choices and policies (concerning issues of name in the cases at issue), thus respecting their competence on the other hand (Sayn-Wittgenstein, Runevič-Vardyn and Wardyn).

The analysis of the subsequent Programmes, the policy plans concerning the establishment of 'an area of freedom, security and justice', demonstrated that the principle of mutual recognition plays a pivotal part to establish that order progressively. It was made the cornerstone of judicial cooperation in civil matters in particular in relation to the development of common rules on recognition and enforcement in civil matters. The Stockholm Programme resulted, via a consultation on the possible means of facilitating the free movement of public documents between Member States by means of a Green Paper in 2010, in the Proposal EU Regulation on free movement of public documents in March 2013. The analysis of this Proposal demonstrated that it is a follow-up of the ECJ ruling in the Dafeki case. It appears to have in its actual state very little meaning for decisions on the recognition of third-state divorces by competent authorities of Member States yet. First of all, its scope does not directly cover the subject matter of divorce. Second, the proposal only provides for the acceptance of the evidentiary value of a public document on a subject matter that is covered by the proposal.

As a result of the 1999 Treaty of Amsterdam, the European legislator enacted, inter alia, the Brussels I and Brussels II-bis Regulations based on Article 65 EC Treaty, and later in 2012, the Brussels I Recast based on Articles 67 (4) and 81 (2) TFEU. All Regulations incorporate the principle of mutual recognition in order to facilitate a free movement of judgments or 'a common market for judgments' (and also extra-judicial decisions such as decisions emanating from competent administrative authorities according to Brussels II-bis). Consequently, the Brussels I, Brussels I Recast, and Brussels II-bis Regulations provide for an automatic recognition of judgments (without any special procedure being required; recognition by operation of law or ex lege recognition) and a limited number of grounds for non-recognition of these judgments. Furthermore, the incorporation of this principle into these instruments resulted in the abolition of the exequatur for certain judgments concerning the rights of access or certain judgments requiring the return of a child in the Brussels II-bis Regulation. The applicability of the Brussels I Recast (as from 10 January 2015) will result in the abolition of the exequatur for all judgments, authentic instruments (meaning documents), and court settlements in civil and commercial matters that fall within the scope of this Regulation. So, the Brussels I Recast introduces the 
recognition and the enforcement of enforceable judgments without any special procedure being required.

The implementation of the principle of mutual recognition and its objectives has also been extended to public and private documents in Article 57 of the Brussels I Regulation, Article 58 of the Brussels I Recast, and Article 46 of the Brussels II-bis Regulation. Article 57 of the Brussels I Regulation and Article 58 Brussels I Recast stipulate that an authentic instrument that is enforceable in the Member State of origin shall be enforceable in another Member State without any declaration of enforceability being required; however, its enforcement may be refused but only if such enforcement is manifestly contrary to public policy in the Member State addressed. Article 46 of the Brussels II-bis Regulation provides for the recognition and declaration of enforceability of documents that have been formally drawn up or registered as authentic instruments (such as documents drawn up by notaries) and of agreements between the parties and that are enforceable in one Member State under the same conditions as judgments in other Member States. By thus facilitating the recognition of positive divorce decisions, Brussels II-bis Regulation clearly aims to realize favor recognitionis and favor divortii and also the right to remarry as enshrined in Article 12 of the ECHR and Article 9 of the ChFREU.

Today, the principle of mutual recognition concerning recognition of judicial and extra-judicial decisions has found a solid legal basis in PIL in Articles 67(4), 81(1), and 81(2) TFEU. Article 81 TFEU provides the legal basis for a Regulation amending Brussels II-bis Regulation or a separate Regulation on the mutual recognition of (positive) decisions and documents or certificates of recognition of third-state divorces in line with the regime of the Brussels II-bis Regulation. The realization of the proposal for an international instrument permitting a thorough check of all judgments from third countries before their recognition in a Member State may imply that once such a judgment has passed that assessment, any public document with respect to that judgment drawn up in an EU Member State must then benefit from the simplified system of use and acceptance of public documents between the Member States. Striving for a common judicial area implies that Member States mutually recognize their decisions and documents without any special procedure being required. This solution is most effective as well as most preferable and feasible at this moment, and it seems therefore to be the first and most suitable hard law instrument to manage this specific legal diversity.

Applying the mutual recognition principle via an amended Brussels II-bis or a separate Regulation to judicial and extra-judicial decisions of recognition of third-state divorces guarantees the continuity of the personal status of a person at migration within the EU. This would result in legal certainty, predictability, doing justice to the legitimate expectations of the person involved, and avoidance of additional economic, administrative, and other burdens. For example, it may avoid instituting a second divorce procedure in such a situation in order to enable remarriage in the second Member State. Or it may avoid that 
a person is considered a 'bigamist' in the Member State where the divorce appears not to be recognized as result of remarriage, while the divorce was initially recognized in another EU Member State, as in the aforementioned case of the Dutch-Moroccan woman.

Furthermore, one could consider the possibilities of a multi- or bilateral treaty on the recognition of third-state divorces including repudiation-based divorces. Such a treaty should preferably be concluded by the EU that has exclusive external competence regarding, inter alia, family matters which are already governed by Union acts in force such as divorce pursuant to Article 216 TFEU in connection with Article 3(2) TFEU. EU Member States could also negotiate and conclude such bilateral treaties, but they are only allowed to do so today after authorization by the EU Commission and after fulfilment of other requirements set by the Regulation 664/2009, the Regulation on External Agreements in Family Matters. Bilateral agreements concluded by Member States are not desirable, because they will even increase the diversity of and within recognition policies. Moreover, the significance of multi- or bilateral treaties as means of facilitating the recognition of third-state divorces should not be overestimated. Their significance is dependent on the compliance of the Contracting States with the convention as the example of the bilateral 1957 and 1981 France-Morocco Conventions demonstrated. It appears that the Moroccan courts do not always observe these conventions, thus making the above-mentioned purpose of the treaties illusory.

For the more distant future, one should consider the possibilities of an EU Regulation on the recognition of third-state divorces including repudiation-based divorces based on the extended internal legislative competence of Article 81 TFEU. The scope of such a Regulation would cover the divorce modalities of all third states, contrary to a treaty that only extends to the divorces of those third states that are treaty partners. Such a Regulation, alternatively on the basis of the enhanced cooperation procedure, could be the answer to all shortcomings in the management of legal diversity, thus preventing limping legal relationships and other financial, administrative, and social burdens and providing for legal certainty and predictability and doing justice to the legitimate expectations of the person(-s) involved.

However, national codifications are still needed as long as this area is not yet covered by international and European legislation. They take into account the international and Communitarian obligations by referring to and incorporating international and European instruments. Thus, it is not an obstacle to the process of unification of PIL through conventions and European regulations, but it will facilitate, in the future, integration of new international and European instruments. 


\subsection{Research Questions}

Two questions were put forward in this study. First, to what extent should Western legal systems acknowledge and accommodate the legal differences emanating from Islamic legal institutions through their recognition policy? Should cultural diversity - in this context be protected or rejected? Or is there an alternative way? Second, what is the most suitable approach or instrument for the adequate management of this legal diversity? The main question in the Introduction was:

How should Europe deal with the various modalities of Islamic divorce? How should Europe manage the legal diversity at issue?

This study found that in particular two major shortcomings exist in the management of legal diversity: first, misunderstanding the Islamic divorce, in particular the repudiationbased divorce, has led or leads to an incorrect characterization of the legal nature of the Islamic divorces and thus to a wrongful recognition, recognition under too strict conditions, or (non-)recognition and its harmful consequences such as limping legal relationships. Second, the variety of national recognition policies has far-reaching consequences for the continuity of the personal status of Muslim migrants moving from one EU Member State to another. Both shortcomings may lead to legal inequality, legal uncertainty, unpredictability, and breach of people's legitimate expectations, thereby creating confusion and economic, administrative, and other burdens such as limping legal relationships with all their harmful consequences.

The overview of Egyptian, Iranian, Moroccan, and Pakistani divorce laws has demonstrated legal diversity within Islamic divorce laws: the Moroccan, judicially monitored repudiation, for example, is not the equivalent of the Pakistani repudiation subject to the notification procedure, so 'the' repudiation does not exist. Nevertheless, these foreign institutions have to fit within the framework of European legal orders. Hence, they have to comply with the criteria for their acceptability: the fundamental principles of the spouses' equal access to divorce and equal procedural rights upon divorce.

Islamic divorce laws can, in principle, never comply with the requirement of full equality in access to divorce, as they are conceptualized around intrinsic differences of the sexes. As full equality would imply the elimination of Islamic principles, a more nuanced and step-by-step approach towards equality must be adopted. The legal status of women can then be enhanced through reconciliation between respect for the 'otherness' of the foreign law and respect for fundamental values. No unbridgeable incompatibility exists between Islamic and Western principles regarding divorce, if Islamic legal systems and practices provide either spouse the opportunity to effectively obtain a divorce, while the procedural position of either spouse, especially the wife, is guaranteed. 
Under these conditions, I advocate that cultural diversity should be respected by Western legal systems through their recognition policies, in particular by doing justice to the complexity of the Islamic legal reality through correct characterization of the legal institution at hand. It contributes to safeguarding legal equality, legal certainty, and predictability for and legitimate interests of Muslim residents and citizens in Europe. And it does justice to the recently reformed Islamic legal diversity. Hence, it shows respect for the 'other' Islamic norms and values in accordance with the above-mentioned basic principle in PIL and the demands of cultural diversity.

To remedy the harmful consequences of the diversity in recognition policies, a number of soft and hard law solutions were proposed and explored for a better management of the legal diversity at stake. The proposed soft law solutions - guidelines, a textbook, trainings on Islamic divorces, or exchange of legal practitioners - aimed at increasing the legal actors' knowledge of and sensitivity to the legal diversity benefits all Muslim immigrants in Europe, irrespective of their status. It has been argued that its significance should not be underestimated because of its persuasive power and its potential to morph into hard law.

Another soft law solution, the Principles-project on European Family Law, can be seen as an example of an instrument to further harmonization in Europe. Even while no sound indication for the feasibility of harmonization of divorce laws in Europe can be seen yet, harmonizing PIL answers must be kept in mind as an option to tackle the problems. For this reason, the endeavour was undertaken to draft an outline of 'Principles of European Family Law on the Recognition of Third-State Divorces', inspired by the analysis of the three national recognition policies in Europe under review. This exercise led to proposing four Principles: two on the recognition of repudiation-based divorces either obtained abroad after proceedings or obtained abroad without proceedings and upon fulfilment of specific requirements; one including grounds for non-recognition; and one enabling a spouse, in particular the wife, to claim financial relief such as alimony, if needed, in the state of recognition notwithstanding the recognition of the repudiation-based divorce. Their main aim is to enable in principle the recognition of repudiation-based divorces even those obtained without any proceedings in order to avoid unnecessary limping legal relationships while seeking to protect the rights and interests of women.

As far as hard law solutions are concerned, the problem of discontinuity in personal status matters because of the migration of Muslims within the EU can be countered by applying the EU mutual recognition principle to decisions of recognition of third-state divorces. Article 81 TFEU provides the legal basis for a Regulation amending Brussels II-bis Regulation or a separate Regulation on the mutual recognition of (positive) decisions and documents or certificates of recognition of third-state divorces in line with the regime of the Brussels II-bis Regulation. Striving for a common judicial area implies that Member States mutually recognize their decisions and documents without any special procedure being required, thus implementing a system of 'full faith and credit' for these decisions 
and documents in the EU. This hard law solution is most effective as well as most preferable and feasible at this moment, and it seems therefore to be the first and most suitable hard law instrument to manage this specific legal diversity.

It is proposed to consider the possibilities of a multi- or bilateral treaty on the recognition of third-state divorces including repudiation-based divorces. Such a treaty should preferably be concluded by the EU that has exclusive external competence regarding, inter alia, family matters which are already governed by Union acts in force such as divorce pursuant to Article 216 TFEU in connection with Article 3(2) TFEU. EU Member States could also negotiate and conclude such bilateral treaties, but they are only allowed to do so today after authorization by the EU Commission and after fulfilment of other requirements set by the Regulation 664/2009, the Regulation on External Agreements in Family Matters. Bilateral agreements concluded by Member States are not desirable, because they will even increase the diversity of and within recognition policies. Moreover, the significance of multi- or bilateral treaties as means of facilitating the recognition of third-state divorces should not be overestimated. Non-compliance of Contracting States with any convention makes the above-mentioned purpose of the treaties illusory, as the example of the bilateral 1957 and 1981 France-Morocco Conventions that appeared not always to be observed by the Moroccan courts demonstrated.

For the more distant future, it is also proposed to consider the possibilities of an EU Regulation on the recognition of third-state divorces including repudiation-based divorces based on the extended internal legislative competence of Article 81 TFEU. The scope of such a Regulation would cover the divorce modalities of all third states, contrary to a treaty that only extends to the divorces of those third states that are treaty partners. Such a Regulation, alternatively on the basis of the enhanced cooperation procedure, could be the answer to all shortcomings in the management of legal diversity, thus preventing limping legal relationships and other financial, administrative, and social burdens and providing for legal certainty and predictability and doing justice to the legitimate expectations of the person(-s) involved, while Europe would not 'repudiate' its Muslim migrants (migrating) within Europe. 



\section{SAMENVATTING: ISLAMITISCHE ECHTSCHEIDINGEN IN EURopa}

Het overbruggen van de kloof tussen Europese en Islamitische rechtsordes

In dit rechtsvergelijkende onderzoek staat de erkenning in Europa van echtscheidingen uit 'islamitische' landen centraal. In de rechtspraktijk en uit de rechtspraak van Europese landen blijkt dat de erkenning van dergelijke echtscheidingen vaak problematisch is. De volgende twee problemen blijken zich met name voor te doen: (1) veelal ten gevolge van te weinig kennis van het specifieke 'islamitische' echtscheidingsrecht, en met name van het eigen-aardige rechtskarakter van de op verstoting gebaseerde echtscheidingsvormen wordt soms ten onrechte een 'islamitische' echtscheiding niet erkend of wel erkend of onder te strenge voorwaarden erkend binnen Europa; (2) het bestaan van een grote verscheidenheid aan erkenningsbeleid in Europa; dit kan resulteren in verschillende uitkomsten en dientengevolge de continuïteit van iemands personele staat beïnvloeden. Het doel van dit onderzoek is daarom te beantwoorden: (1) hoe Europese autoriteiten met de verschillende vormen van 'Islamitische' echtscheidingen kunnen en moeten omgaan; en (2) welke juridische oplossingen daarbij behulpzaam kunnen zijn.

Wanneer iemand gescheiden is in het ene land, wordt die persoon niet automatisch als gescheiden beschouwd in een ander land. De echtscheiding moet eerst erkend worden. Er wordt echter vanuit gegaan dat met name de echtscheidingsvormen die op een verstoting gebaseerd zijn, fundamentele rechten van vrouwen schenden, zoals het recht op gelijke toegang tot de echtscheiding en procedurele rechten. Om die reden worden dergelijke echtscheidingen vaak niet erkend. Maar niet-erkenning van een echtscheiding leidt tot een hinkende rechtsverhouding: een situatie waarin iemand als gescheiden wordt beschouwd in het ene land, maar als (nog) getrouwd in het andere land, met ernstige gevolgen zoals het niet opnieuw kunnen trouwen of een dubbele echtscheidingsprocedure moeten instellen, en geen aanspraak kunnen maken op bepaalde sociale voorzieningen of een verblijfsvergunning. Deze situatie schendt weer het recht op familieleven, en tast de rechtszekerheid, rechtsgelijkheid en de gerechtvaardigde verwachting van partijen over continuïteit van hun burgerlijke staat, aan.

Het eerste deel van het onderzoek laat zien dat bijvoorbeeld de Marokkaanse verstoting niet hetzelfde is als een Egyptische of Iraanse of Pakistaanse verstoting. Dit deel toont aan dat een op verstoting gebaseerde echtscheiding niet altijd als onverenigbaar met bovengenoemde fundamentele rechten in Europese landen beschouwd hoeft te worden. Het 'Islamitisch' rechtsstelsel moet dan wel iedere echtgenoot de mogelijkheid geven om een 
echtscheiding te verkrijgen waarbij de procedurele (en materiele) rechten van de andere echtgenoot, met name de vrouw, beschermd worden, bijvoorbeeld door tussenkomst van een rechter.

In het tweede deel van het onderzoek worden het erkenningsbeleid van Engeland, Frankrijk en Nederland onderzocht. Het toont ernstige problemen aan: onvoldoende kennis van het Marokkaanse, Egyptische etcetera echtscheidingsrecht; verschillende ambtenaren die ieder voor zich de erkenning van een en dezelfde op verstoting gebaseerde echtscheiding moet beoordelen met als mogelijk gevolg een verschillend oordeel; de keuze voor een bepaald beleid; een politiek gebruik van het (internationaal privaat-)recht en erkenningsbeleid dat verschilt tussen Europese landen.

Deel drie van het onderzoek toont aan dat dat laatste, de diversiteit in erkenningsbeleid binnen Europa, kan leiden tot hinder van het recht op vrij verkeer van personen. Het laatste kan weer resulteren in een hinkende rechtsverhouding, wanneer een persoon van het ene Europese land naar het andere verhuist en de landen de echtscheiding van die persoon verschillend beoordelen. In dit deel worden vervolgens diverse juridische oplossingen voor de genoemde problemen besproken. De belangrijkste zijn achtereenvolgens: 1. de 'Beginselen van Europees familierecht betreffende de erkenning van 'islamitische' echtscheidingen'; 2. een Europese verordening die de wederzijdse erkenning van besluiten van een Europees land over de erkenning van 'islamitische' echtscheidingen regelt (de meest doeltreffende en op dit moment meest haalbare oplossing); 3. een verdrag tussen de Europese en 'islamitische' landen over de erkenning van elkaars echtscheidingen; en 4. een Europese verordening over de erkenning van 'islamitische' echtscheidingen. Al deze oplossingen kunnen hinkende rechtsverhoudingen en andere financiële, juridische en sociale problemen rond de erkenning van op verstoting gebaseerde echtscheidingen voorkomen. Deze oplossingen zorgen tevens voor rechtszekerheid, rechtsgelijkheid en voorspelbaarheid, doen recht aan de gerechtvaardigde verwachtingen van de betrokkenen bij zo'n echtscheiding, en bevorderen vrij verkeer van ingezetenen binnen Europa. 


\title{
BiBLIOGRAPHY
}

\author{
Abghari 2008 \\ Abghari, A., Introduction to the Iranian Legal System and the Protection of Human Rights \\ in Iran, London: British Institute of International and Comparative Law 2008.
}

\section{Ahmed Chowdhury 2006}

Ahmed Chowdhury, J., 'Family Court A.D.R. in Egypt and Some Exemplary Provisions for Other Muslim Countries', Studies in Islam and the Middle East 2006, available at: $<$ http://majalla.org/papers/2006/02/fam-court-in-egypt.pdf $>$.

\section{Aldeeb Abu Sahlieh \& Bonomi 1999}

Aldeeb Abu Sahlieh, S. \& Bonomi, A. (eds.), Le Droit Musulman de la Famille et des Successions à l'Épreuve des Ordres Juridiques Occidentaux, Zürich: Schulthess 1999.

\section{Ali 2008}

Ali, K., 'Marriage in Classical Islamic Jurisprudence: a Survey of Doctrines', in: Quraishi, A. \& Vogel, F.E. (eds.), The Islamic Marriage Contract; Case studies in Islamic Family Law, Cambridge (MA): Harvard University Press 2008, p. 11-45.

\section{Al-Sharmani 2009}

Al-Sharmani, M., 'Egyptian Family Courts: A Pathway of Women's Empowerment?', Journal of Women of the Middle East and the Islamic World 2009, p. 89-110.

\section{Al-Sharmani 2012}

Al-Sharmani, M., 'Egyptian Khul': Legal Reform, Courtroom Practices, and Realities of Women', in: Mehdi, R., Menski, W., \& Nielsen, J.S. (eds.), Interpreting Divorce Laws in Islam, Copenhagen: DJØF Publishing 2012, p. 85-104.

\section{Al-Sharmani 2013}

Al-Sharmani, M., 'Reforming Egyptian Family Laws; The Debate about a New Substantive Code', in: Al-Sharmani, M. (ed.), Feminist Activism, Women's Rights, and Legal Reform, New York: Zed Books Ltd. 2013, p. 73-99.

\section{An-Na'im 2002}

An-Na'im, A. (ed.), Islamic Family Law in a Changing World; A Global Resource Book, London: Zed Books Ltd. 2002. 


\section{Ansari-Pour 2005-2006}

Ansari-Pour, M.A., 'Iran', Yearbook of Islamic and Middle Eastern Law 2005-2006, p. 415429.

\section{Antokolskaia 2003}

Antokolskaia, M., 'Development of Family Law in Western and Eastern Europe: Common Origins, Common Driving Forces, Common Tendencies', Journal of Family History 2003, p. 52-69.

\section{Antokolskaia 2006}

Antokolskaia, M., 'Convergence and Divergence of Divorce Laws in Europe', Child and Family Law Quarterly 2006, p. 307-330.

\section{Arabi 2001}

Arabi, O., 'The Dawning of the Third Millennium on Shari'a: Egypt's Law No. 1 of 2000, or Women May Divorce at Will', Arab Law Quarterly 2001, p. 2-21.

\section{Arshad 2010}

Arshad, R., Islamic Family Law, London: Sweet Maxwell 2010.

\section{Asser 10-II 2012}

Vonken A.P.M.J., 'Internationaal Privaatrecht, deel II Internationaal personen-, familieen erfrecht', in: Mr. C. Assers Handleiding tot de beoefening van het Nederlands Burgerlijk Recht, Deventer: Kluwer 2012.

\section{Audit 2010}

Audit, B., Droit International Privé, Paris: Ed. Economica 2010.

\section{Baarsma 2009}

Baarsma, N.A., 'European Choice of Law on Divorce (Rome III): Where Did it Go Wrong?', Nederlands Internationaal Privaatrecht 2009, p. 9-14.

\section{Baarsma 2010}

Baarsma, N.A., The Europeanisation of International Family Law. From Dutch to European Law: an Analysis on the Basis of the Choice of Law on Divorce and on the Termination of Registered Partnerships (diss. Groningen RUG), Groningen: Rijksuniversiteit Groningen Ulrik Huber Institute for Private International Law 2010. 


\section{Baderin 2005}

Baderin, M., International Human Rights and Islamic Law, Oxford: Oxford University Press 2005.

\section{Baillie 1887}

Baillie, N.B.E., A Digest of Moohummudan Law, London: Smith, Elder \& Co. 1887 (historical reproduction, Charleston, Bibliolife 2010).

\section{Balchin 1994}

Balchin, C., A Handbook on Family Law in Pakistan, Lahore: Shirkat Gah/Women living under Muslim laws (WLUML) 1994.

\section{Ballard et al. 2009}

Ballard, R. et al., 'Cultural Diversity: Challenge and Accommodation', in: Grillo, R. et al. (eds.), Legal Practice and Cultural Diversity, Farnham: Ashgate Publishing Ltd. 2009, p. 11-29.

\section{Baratta 2007}

Baratta, R., 'Problematic Elements of an Implicit Rule Providing for Mutual Recognition of Personal and Family Status in the EC', Praxis des Internationalen Privat und Verfahrensrecht 2007, p. 4-11.

\section{Baratta 2008}

Baratta, R., 'Short Remarks on EC Competence in Matters of Family Law', in: Malatesta, A. et al. (eds.), The External Dimension of EC Private International Law in Family and Succession Matters, Milan: CEDAM 2008, p. 189-193.

\section{Baratta 2011}

Baratta, R., 'La reconnaissance internationale des situations juridiques personnelles et familiales', Collected Courses of the Hague Academy of International Law (348), Leiden/Boston, Martinus Nijhoff Publishers 2011, p. 256-499.

\section{Bariklou 2011}

Bariklou, A.R., 'The Wife's Right to Divorce on the Basis of the Delegation Condition under Islamic and Iranian Law', International Journal of Law, Policy and the Family 2011, p. 184-199 (retrieved via Westlaw, p. 1-11). 


\section{Barnard 2013}

Barnard, C., The Substantive Law of the EU. The Four Freedoms, Oxford: Oxford University Press 2013.

\section{Basedow and Yassari 2004}

Basedow, J. \& Yassari, N. (eds.), Iranian Family and Succession Laws and Their Application in German Courts, Tübingen: Mohr Siebeck 2004.

\section{Benradi 2007}

Benradi, M. et al., Le Code de la Famille, Perceptions et Pratique Judiciaire, Friedrich Ebert Stiftung 2007, available at: <www.fes.org.ma/publications.html>.

\section{Berger 2006}

Berger, M., Klassieke Sharia en Vernieuwing, Amsterdam: Amsterdam University Press 2006.

\section{Berger \& Sonneveld 2006}

Berger, M. \& Sonneveld, N., 'Shari'a en Nationaal recht in Egypte', in Otto, J.M. et al. (eds.), Shari'a en national recht in twaalf moslimlanden, Amsterdam: Amsterdam University Press 2006, p. 19-39.

\section{Berger \& Sonneveld 2010}

Berger, M. \& Sonneveld, N., 'Sharia and national law in Egypt', in: Otto, J.M. (ed.), Sharia Incorporated; A Comparative Overview of the Legal Systems of Twelve Muslim Countries in Past and Present, Leiden: Leiden University Press 2010, p. 51-88.

\section{Bergmann et al. 2002}

Bergmann, A. and Ferid, M.(and republished by Henrich, D), 'Iran', Internationales Eheund Kindschaftsrecht, Frankfurt am Main: Verlag für das Standesamtswesen, Stand 2002 (loose-leaf).

\section{Bernard-Maugiron 2002}

Bernard-Maugiron, N., 'From Jihane to Susanne, Twenty Years of Personal Status Law in Egypt', in Rutten, S. (ed.), Recht van de Islam (19) 2002, p. 1-19.

\section{Bernard-Maugiron 2004}

Bernard-Maugiron, N., 'Quelques développements récentes dans le droit du statut personnel en Egypte', Revue Internationale de Droit Comparé (2) 2004, p. 355-385. 


\section{Bernard-Maugiron \& Dupret 2002}

Bernard-Maugiron, N. \& Dupret, B., 'From Jihan to Susanne, Twenty Years of Personal Status Law in Egypt', Recht van de Islam, Maastricht: RIMO 2002, p. 1-19.

\section{Bernard-Maugiron \& Dupret 2008}

Bernard-Maugiron, N \& Dupret, B., 'Breaking Up the Family: Divorce in Egyptian Law and Practice', Journal of Women of the Middle East and the Islamic World 2008, p. 52-74.

\section{Boele-Woelki 2000}

Boele-Woelki, K.,'Internationaal privaatrecht', Ars Aequi 2000, katern 77, p. 3971-3973.

\section{Boele Woelki et al. 2003}

Boele Woelki, K. et al., European Family Law in Action; Volume I: Grounds for Divorce, Antwerp: Intersentia 2003.

\section{Boele-Woelki et al. 2004}

Boele-Woelki, K. et al., Principles of European Family Law Regarding Divorce and Maintenance between Former Spouses, Antwerp: Intersentia 2004.

\section{Boele-Woelki 2005}

Boele-Woelki, K., 'The Principles of European Family Law: Its Aims and Prospects', Utrecht Law Review, 2005, p. 160-168, available at: <www.utrechtlawreview.org/>.

\section{Bogdan 2012}

Bogdan, M., Concise Introduction to EU Private International Law, Groningen: Europa Law Publishing 2012.

\section{Bolten 1987}

Bolten, J.J., 'Verstotingen in Nederland: over de grens', Nemesis 1987, p. 55-63.

\section{Boumans 1990}

Boumans, L., 'De zelfverstoting in het islamitisch familierecht van Marokko', Migrantenrecht 1990, p. 103-109.

\section{Burgerzaken en recht 1997}

Uit de Vereniging, Burgerzaken en recht 1997, p. 50-51.

\section{Buskens 1999}

Buskens, L., Islamitisch recht en familiebetrekkingen in Marokko, Amsterdam: Bulaaq 1999. 


\section{Buskens 2003}

Buskens, L., 'Recent Debates on Family Law Reform in Morocco: Islamic Law as Politics in an Emerging Public Sphere', Islamic Law and Society (1) 2003, p. 70-131.

\section{Buskens 2006}

Buskens, L., 'Sharia en nationaal recht in Marokko', in: Otto, J.M. et al. (eds.), Sharia en nationaal recht in twaalf moslimlanden, Amsterdam: Amsterdam University Press 2006, p. 43-66.

\section{Buskens 2008}

Buskens, L., 'Een nieuwe wet voor het gezin in Marokko; enkele elementen uit de Mudawwana van 2004', Actuele ontwikkelingen in het familierecht, UCERF reeks 2, Nijmegen: Ars Aequi Libri 2008, p. 31-43.

\section{Buskens 2010}

Buskens, L., 'Sharia and national law in Morocco', in: Otto, J.M. (ed.), Sharia Incorporated; A Comparative Overview of the Legal Systems of Twelve Muslim Countries in Past and Present, Leiden: Leiden University Press 2010, p. 89-138.

\section{Butler-Sloss \& Hill 2013}

Butler-Sloss, E. \& Hill, M., 'Family law: current conflicts and their resolution', in: GriffithJones, R. (ed.), Islam and English Law, Cambridge: Cambridge University Press 2013, p. 108-115.

\section{Carroll 1996}

Carroll, L., "'Qur'an 2:229: 'A Charter Granted to the Wife”? Judicial Khul' in Pakistan', Islamic Law and Society 1996, p. 91-126.

\section{Carroll 2008}

Carroll, L., 'Muslim Women and Islamic Divorce in England', in: Laquer Estin, A., The Multi-cultural Family, Aldershot: Ashgate 2008, p. 189-207.

\section{Charrad 2012}

Charrad, M.M., Family Law Reforms in the Arab World: Tunisia and Morocco, report for the United Nations Department of Economic and Social Affairs (UNDESA), Expert Group Meeting, New York, 15-17 May 2012, available at: <www.un.org/esa/socdev/family/docs/ egm12/PAPER-CHARRAD.pdf>. 


\section{Cheshire et al. 2008}

Fawcettt, J. \& Carruthers, J.M., Cheshire, North \& Fawcett Private International Law, Oxford: Oxford University Press 2008.

\section{Clarkson \& Hill 2011}

Clarkson, C.M.V. \& Hill, J., The Conflict of Laws, Oxford: Oxford University Press 2011.

\section{Clavel 2010}

Clavel S., Droit international privé, Paris: DALLOZ 2010.

\section{Coulson 1964}

Coulson, N.J., A History of Islamic Law, Edinburgh: Edinburgh University Press 1964.

\section{Damad 2004}

Damad, S.M.M., 'Legal and Civil Aspects of Marriage in Islam According to Shī ${ }^{\mathrm{C}} \mathrm{i}$ Tradition', in: Basedow, J. \& Yassari, N. (eds.), Iranian Family and Successions Laws and their Application in German Courts, Tübingen: Mohr Siebeck 2004, p. 57-68.

\section{De Boer 1988}

De Boer, Th.M., 'Internationaal privaatrecht: verstoting in Nederland', Ars Aequi 1988, p. 182-190.

\section{Decroux 1985}

Decroux, P., 'La Convention franco-marocaine du 10 août 1981 relative au statut des personnes et de la famille et à la coopération judiciaire', Journal de Droit International Clunet 1985, p. 49-103.

\section{De Groot 2003}

De Groot, G-R., Handboek Nieuw Nationaliteitsrecht, Deventer: Kluwer 2003.

\section{De Groot 2007}

De Groot, G-R., 'Towards European Rules on the Recognition of Foreign Civil Status Certificates', in: Kasprzyk, P. (ed.), Selected Problems in the Area of Family Law and Civil Status Registration, Lublin: The John Paul II Catholic University of Lublin 2007, p. 63-73.

\section{De Groot \& Kuipers 2008}

De Groot, G-R. \& Kuipers, J-J., 'The New Provisions on Private International Law in the Treaty of Lisbon', Maastricht Journal of European and Comparative Law 2008, p. 109-114. 


\section{De Groot \& Rutten 2004}

De Groot, G.R. \& Rutten, S., 'Op weg naar een Europees IPR op het gebied van personenen familierecht', Nederlands Internationaal Privaatrecht 2004, p. 273-282.

\section{Dethloff 2003}

Dethloff, N., 'Arguments for the Unification and Harmonisation of Family Law in Europe', in: Boele-Woelki, K. (ed.), Perspectives for the Unification and Harmonisation of Family Law in Europe, Antwerp: Intersentia 2003, p. 37-64.

\section{Doi 2008}

Doi, A., Shari'ah: Islamic Law, London: Ta-Ha Publishers Ltd. 2008.

\section{Douglas et al. 2011}

Douglas et al., Social Cohesion and Civil Law: Marriage, Divorce and Religious Courts, Report, Cardiff: Cardiff University 2011.

\section{Duintjer Tebbens 2013}

Duintjer Tebbens, H., 'Divorce- a Fundamental Right?', A Commitment to Private International Law: Essays in the Honour of Hans van Loon, Cambridge: Intersentia 2013, p. 123133.

\section{Edge 2013}

Edge, I., 'Islamic Finance, Alternative Dispute Resolutions and Family Law: Developments towards Legal Pluralism', in: Griffith-Jones, R. (ed.), Islam and English Law, Cambridge: Cambridge University Press 2013, p. 116-143.

\section{Eisele 2013}

Eisele, K., The External Dimension of the EU's Migration Policy. Different Legal Positions of Third-Country Nationals in the EU. A Comparative Perspective, diss. Maastricht: Maastricht University 2013.

\section{El-Ehwany 2012}

El-Ehwany, H., 'Le droit Égyptian de la famille', in: Bernard-Maugiron, N. \& Dupret, B. (eds.), Ordre public et droit musulman de la famille en Europe et en Afrique du Nord, Bruxelles: Éditions Bruylant 2012, p. 29-69.

\section{El-Husseini 1999}

El-Husseini, R., 'Le droit international privé français et la repudiation Islamique', Revue Critique de Droit International Privé 1999, p. 427-468. 


\section{El-Husseini Begdache 2002}

El-Husseini Begdache, R., Le Droit International Privé Français et la Repudiation Islamique, Paris: L.G.D.J. 2002.

\section{Esposito 2001}

Esposito, J.L., Women in Muslim Family Law, New York: Syracuse University Press 2001.

\section{Esposito 2009}

Esposito, J.L. (ed.), The Oxford Encyclopedia of the Islamic World, Oxford: Oxford University Press 2009.

\section{Evenhuis \& Van Eijk 2001}

Evenhuis W. \& Van Eijk, E., Met recht een vrouw; het VN-Vrouwenverdrag toegelicht, Amsterdam: Greber Uitgever \& Distributeur 2001.

\section{Farahat 2009}

Farahat, A., 'The Exclusiveness of Inclusion: On the Boundaries of Human Rights in Protecting Transnational and Second Generation Migrants', European Journal of Migration and Law 2009, p. 253-269.

\section{Feteris 1984}

Feteris, M.W.C., 'Erkenning in Nederland van verstotingen', Ars Aequi 1984, p. 9-14.

\section{Foblets 2007}

Foblets, M.C., 'The Admissibility of Repudiation: Requirements in Private International Law. Recent Developments in France, Belgium and The Netherlands', in: Mehdi, R. (ed.), Integration \& Retsudviking, Kopenhagen: Jurist- og Okonomforbundets Forlag 2007, p. 151-170.

\section{Foblets \& Rutten 2006}

Foblets, M-C., Rutten, S., 'De toelaatbaarheid van de verstoting: recente ontwikkelingen in Nederlands, Frans en Belgisch internationaal privaatrecht', in: Van der Grinten, P. \& Heukels, T. (eds.), Crossing Borders: Essays in European and Private International Law, Nationality Law and Islamic Law in Honour of Frans van der Velden, Deventer: Kluwer 2006.

\section{Fournier 2010}

Fournier, P., Muslim Marriage in Western Courts: Lost in Transplantation, Farnham/Burlington: Ashgate 2010. 


\section{ISLAMIC DIVORCES IN EUROPE}

\section{Fredman 2003}

Fredman, S., 'Beyond the Dichotomy of Formal and Substantive Equality: Towards a New Definition of Equal Rights', in: Boerefijn, I. et al. (eds.), Temporary Special Measures, Antwerp: Intersentia 2003, p. 111-118.

\section{Fyzee 2002}

Fyzee, A.A.A., Outlines of Muhammadan Law, New Delhi: Oxford University Press 2002.

\section{Gardeñes Santiago 2011}

Gardeñes Santiago, M., 'Les exigencies du marché interieur dans la construction d'un code européen de droit international privé, en particulier la place de la confiance et de la reconnaissance mutuelle', in: Fallon, M., Lagarde, P., \& Poillot-Peruzzetto, S. (eds.), Quelle architecture pour un code Européen de droit international privé?, Bruxelles: Peter Lang S.A. 2011.

\section{Glassé 2001}

Glassé, C., The Concise Encyclopaedia of Islam, London: Stacey International 2001.

\section{Gonzalez Beilfuss 2007}

Gonzalez Beilfuss, C., 'Islamic Family Law in the European Union', in: Meeusen, J. et al. (eds.), International Family Law for the European Union, Antwerp: Intersentia 2007, p. 425-438.

\section{Gubbels 2008}

Gubbels, E., 'Uitgelezen; gezag en verstoting', Burgerzaken en Recht (6) 2008, p. 200-201.

\section{Haeri 1989}

Haeri, S., Law of Desire; Temporary Marriage in Shi'i Iran, Syracuse NY: Syracuse University Press 1989.

\section{Hallaq 2009}

Hallaq, W., An Introduction to Islamic Law, Cambridge: Cambridge University Press 2009.

\section{Hamid 2006}

Hamid, A.G., 'Reservations to CEDAW and the Implementation of Islamic Family Law: Issues and Challenges', Asian Journal of International Law (1) 2006, p. 121-155. 


\section{Hamidian 2004}

Hamidian, H., 'Jurisdiction of Family Courts in Iran', in: Basedow, J. \& Yassari, N. (eds.), Iranian Family and Successions Laws and their Application in German Courts, Tübingen: Mohr Siebeck 2004, p. 81-96.

\section{Henricot 2011}

Henricot, C., 'L'application du Code Marocain de la famille, à la croisée des jurisprudences belge et marocaine en matière de dissolution du marriage', Journal des Tribunaux 2011, p. 641-651.

\section{Hinchcliffe 1968}

Hinchcliffe, D., 'The Iranian Family Protection Act', International and Comparative Law Quarterly 1968, p. 516-521 (retrieved via HeinOnline).

\section{Hodson 2008}

Hodson, D., 'Recognition of Foreign Marriages and Divorces', in: Hodson (ed.), A Practical Guide to International Family Law, Bristol: Jordans 2008, p. 1-18 available at: <www.davidhodson.com/assets/documents/recognition.pdf>.

\section{Human Rights Watch 2004}

Human Rights Watch, Divorced from Justice: Women's Unequal Access to Divorce in Egypt (Vol. 16, No. 8(E)) 2004, via <www.hrw.org/reports/2004/egypt1204/egypt1204.pdf>.

\section{Ibili 2010}

Ibili, F., 'Boek 10 BW (IPR): Echtscheiding (art. 10:54 t/m 59 BW)', Weekblad voor privaatrecht, notariaat, en registratie (6838) 2010, p. 273-278 (via wpnr.online p. 1-7).

\section{Ja'far al-Sadiq 2012}

Ja'far al-Sadiq, Islamic Law According to Ja'fari School of Jurisprudence (Vol. 2 Transactions), United Kingdom: Createspace Independent Publishing Platform 2012.

\section{Jahangir 1998}

Jahangir, A., 'The Origins of the MFLO: Reflections for Activism', in: Shaheed, F. et al. (eds.), Shaping Women's Lives, Lahore: Shirkat Gah, Women's Resource Centre 1998, p. 93-106.

\section{Jansen 2007}

Jansen, Y-O., 'Muslim Brides and the Ghost of the Shari'a', Northwestern Journal of International Human Rights (2) 2007, p. 181-212. 


\section{Jessurun d'Oliveira 1975}

Jessurun d'Oliveira, H.U., 'Openbare orde en rechtsvergelijking', 't Exempel Dwinght. Opstellen aangeboden aan Prof. Mr. I. Kisch, Zwolle: W.E.J. Tjeenk Willink 1975, p. 239262.

\section{Jordens-Cotran 1991}

L. Jordens-Cotran, L., 'De ontbinding van het Marokkaanse huwelijk (IV). De erkenning van Marokkaanse echtscheidingen in Nederland', Migrantenrecht 1991-5, p. 91-96.

\section{Jordens-Cotran 1995}

Jordens-Cotran, L., 'Instemming met de verstoting, naturalisatie en de erkenning van Marokkaanse verstotingen: artikel 3 of 2 WCE?', Tijdschrift voor Familie- en Jeugdrecht 1995, p. 146-151.

\section{Jordens-Cotran 1996}

Jordens-Cotran, L., 'De instemming van de vrouw met de verstoting. Kanttekeningen bij het voorstel tot wijziging van artikel 3 WCE', Migrantenrecht 1996, p. 161-167.

\section{Jordens-Cotran 2000}

Jordens-Cotran, L., Het Marokkaanse familierecht en de Nederlandse rechtspraktijk, Utrecht: Forum 2000.

\section{Jordens-Cotran 2001}

Jordens-Cotran, L.,'De Hoge Raad en de erkenning van de verstoting tegen compensatie (khoel)', Burgerzaken en Recht 2001, p. 290-294.

\section{Jordens-Cotran 2002}

Jordens-Cotran, L., 'De erkenning van de Marokkaanse khoel en andere administratieve echtscheidingen', Nederlands Internationaal Privaatrecht 2002, p. 123-141.

\section{Jordens-Cotran 2005}

Jordens-Cotran, L., 'Marokkaanse echtscheidingen en hun documenten, Migrantenrecht 2005, p. 180-183.

\section{Jordens-Cotran 2007}

Jordens-Cotran, L., Nieuw Marokkaans familierecht en Nederlands IPR (diss. Maastricht UM), Den-Haag: SDU 2007. 


\section{Joubert \& Gallant 2012}

Joubert, N. \& Gallant, E., 'Le recours à l'exception d'ordre public en droit français dans leur confrontation aux droits des pays arabes', in: Bernard-Maugiron, N. \& Dupret, B. (eds.), Ordre public et droit musulman de la famille en Europe et en Afrique du Nord, Bruxelles: Éditions Bruylant 2012, p. 307-334.

\section{Joustra 2001}

Joustra, C.,'De Hoge Raad over verstoting tegen compensatie en de effectiviteitstoets bij artikel 3 WCE', Nederlands Internationaal Privaatrecht 2001, p. 406-410.

\section{Kamali 2008}

Kamali, M., Shari'ah Law an Introduction, Oxford: One world Publications 2008.

\section{Kokkini-Iatridou 1983}

D. Kokkini-Iatridou, D., 'Internationaal Privaatrecht, jurisprudentie: Marokkaanse verstotingen', Ars Aequi 1983, katern 9, p. 335-338.

\section{Kramer 2011}

Kramer, X.E., 'Abolition of Exequatur under the Brussels I Regulation: Effecting and Protecting Rights in the European Judicial Area', Nederlands Internationaal Privaatrecht 2011, p. 633-641.

\section{Kruiniger 2008}

Kruiniger, P., Marokkaanse verstotingsvormen in de Nederlandse rechtspraktijk; een juridische beschouwing over de Marokkaanse $\mathrm{khul}^{c}$ en talaq in het kader van erkenning in Nederland, Tilburg: Celsus Juridische Uitgeverij 2008.

\section{Kruiniger 2011}

Kruiniger, P. 'Muslim Marriage in Western Courts: Lost in Transplantation' Book review, Maastricht Journal of European and Comparative Law 2011, p. 563-572.

\section{Kruiniger 2012}

Kruiniger, P., Article 16 of the Women's Convention and the Status of Muslim Women at Divorce, in: Westendorp, I. (ed.), The Women's Convention Turned 30, (Maastricht Centre for Human Rights), Antwerp: Intersentia 2012, p. 363-390.

\section{Kruiniger 2013}

Kruiniger, P., Repudiated by Husband And Europe? A Critical Re-assessment of the Policies of Recognition of Islamic Repudiations in Western Legal Sytems, in: Foblets, M.C. \& 
Yassari, N. (eds.), Legal Approaches to Cultural Diversity (The Series of The Hague Academy, Centre for Studies and Research in International Law and International Relations of the Hague Academy of International Law), Leiden/Boston: Martinus Nijhoff Publishers 2013, p. 464-520.

\section{Kulk 2013}

Kulk, F., Laverend langs grenzen; Transnationale gezinnen en Nederlands en islamitisch familie- en nationaliteitsrecht, dissertation Radboud University Nijmegen, Nijmegen 2013.

\section{Lau 2005-2006}

Lau, M., 'Country Surveys: Pakistan', Yearbook of Islamic and Middle-Eastern Law 20052006, p. 443-472.

\section{Lau 2006}

Lau, M., The Role of Islam in the Legal System of Pakistan, Leiden: Martinus Nijhoff Publishers 2006.

\section{Lau 2010}

Lau, M., 'Sharia and National Law in Pakistan', in: Otto, J.M. (ed.), Sharia Incorporated, Leiden: Leiden University Press 2010, p. 373-432.

\section{Lemontey 2008}

Lemontey, J., 'Le volontarisme en jurisprudence: l'exemple des repudiations musulmanes devant la Cour de Cassation', Droit international privé: travaux du Comité Français de Droit international privé Année 2004-2005, Paris: Editions Pedone 2008, p. 63-88.

\section{Linant de Bellefonds 1965 (vol. I)}

Linant de Bellefonds, Y., Traité de Droit Musulman comparé (Tombe I, théorie générale de l'acte juridique), La Haye: Mouton \& Co. 1965.

\section{Linant de Bellefonds 1965 (vol. II)}

Linant de Bellefonds, Y., Traité de Droit Musulman comparé (Tombe II, le marriage; la dissolution du marriage), La Haye: Mouton \& Co. 1965.

\section{Linant de Bellefonds 1973}

Linant de Bellefonds, Y., Traité de Droit Musulman comparé (Tombe III, filiation - incapacités - liberalités entre vifs), Paris/La Haye: Mouton \& Co. 1973. 


\section{Lindbekk \& Sonneveld forthcoming}

Lindbekk, M. \& Sonneveld, N., 'A Counter-Revolution in Muslim Family Law? Egypt's Pre- And Post Revolutionary Period (2011-2013) Compared', New Middle Eastern Studies forthcoming.

\section{Maghniyyah 1997}

Maghniyyah, M.J., Divorce, According to Five Schools of Islamic Law (Vol. VI), Tehran: Department of Translation and Publication, Islamic Culture and Relations Organization 1997.

\section{Mahmood 2010}

Mahmood, M., The Code of Muslim Family Laws, Lahore: Al-Qanoon Publishers 2010.

\section{Mair 2007}

Mair, J., 'The National Legal Systems Juxtaposed to the CEFL Principles: Harmonious Ideals?', in: Örücü, E. \& Mair, J. (eds.), Juxtaposing Legal Systems and the Principles of European Family Law on Divorce and Maintenance, Antwerpen: Intersentia 2007.

\section{Malatesta 2008}

Malatesta, A., 'Final Report', in: Malatesta, A. et al. (eds.), The External Dimension of EC Private International Law in Family and Succession Matters, Milan: CEDAM 2008, p. 388389.

\section{Mansel 2006}

Mansel, H.P., 'Anerkennung als Grundprinzip des Europäischen Anerkennings-Kollisionsrechts: Anerkennung statt Verweisung als neues Strukturprinzip des Europäischen internationalen Privatsrechts?', Rabels Zeitschrift für ausländisches und internationals Privatrecht 2006, p. 651-731.

\section{Mansel 2010}

Mansel, H.P., 'The Impact of the European Union's Prohibition of Discrimination and the Right of Free Movement of Persons on the Private International Law Rules of Member States - With Comments on the Sayn-Wittgenstein Case before the European Court of Justice', in: Boele-Woelki, K. et al. (eds.), Convergence and Divergence in Private International Law - Liber Amicorum Kurt Siehr, Den-Haag: Eleven International Publishing 2010, p. 291-309. 


\section{Maudoodi 2000}

Maudoodi, M.A.A., The Laws of Marriage and Divorce in Islam, Kuwait: Islamic Book Publishers 2000.

\section{Mayer 2001}

Mayer, A.E., 'Religious Reservations to the Convention on the Elimination of All Forms of Discrimination against Women: What Do They Really Mean?', in: Howland, C.W. (ed.), Religious Fundamentalism and The Human Rights Of Women, New York: Palgrave 2001, p. 105-116.

\section{Mayer 2004}

Mayer, A.E., 'Internationalizing the Conversation on Women's Rights: Arab Countries Face the CEDAW Committee', in: Haddad Y.Y. \& Freyer Stowasser, B. (eds.), Islamic Law and the Challenges of Modernity, Walnut Creek (CA): Altamira Press 2004, p 133-160.

\section{Mayer 2008}

Mayer, A.E., 'The Reformulation of Islamic Thought on Gender Rights and Roles', in: Akbarzadeh, S. \& MacQueen, B. (eds.), Islam and Human Rights in Practice, London: Routledge 2008, p. 12-32.

\section{Menski 2006}

Menski, W., Comparative Law in a Global Context; the Legal Systems of Asia and Africa, Cambridge: Cambridge University Press 2006.

\section{Mernissi 2004}

Mernissi, F., Achter de sluier. De islam en de strijd tussen de seksen, Breda: De Geus 2004.

\section{Mir-Hosseini 2000}

Mir-Hosseini, Z., Marriage on Trial; A Study of Islamic Family Law, London: I.B. Tauris Publishers 2000.

\section{Mir-Hosseini 2009}

Mir-Hosseini, Z., 'Classical Fiqh, Contemporary Ethics and Gender Justice', in: Vogt, K., Larsen, L., \& Moe, C. (eds.), New Directions in Islamic Thought, London/New York: I.B. Tauris \& Co. Ltd. 2009, p. 77-88. 


\section{Mir-Hosseini 2010}

Mir-Hosseini, Z., 'Sharia and National Law in Iran', in: Otto, J.M. (ed.), Sharia incorporated; A Comparative Overview of the Legal Systems of Twelve Muslim Countries in Past and Present, Leiden: Leiden University Press 2010, p. 319-371.

\section{Mir-Hosseini 2012}

Mir-Hosseini, Z., 'The Politics of Divorce in Iran', in: Mehdi, R., Menski, W. \& Nielsen, J.S. (eds.), Interpreting Divorce Laws in Islam, Copenhagen: DJØF Publishing 2012, p. 6583.

\section{Mohammad Hussain Patel 2003}

Mohammad Hussain Patel, R., Woman versus Man; Socio-Legal Gender Inequality in Pakistan, Karachi: Oxford University Press 2003.

\section{Mole \& Hardy 2006}

Mole, N. \& Hardy, C., The Right to a Fair Trial; A Guide to the Implementation of Article 6 of the European Convention on Human Rights, Council of Europe, 2006, available at: $<$ http://book.coe.int/sysmodules/RBS_fichier/admin/download.php?fileid=3014>.

\section{Mostermans 1999}

Mostermans, P.M.M., Echtscheiding, Deventer: Kluwer 1999.

\section{Mostermans 2003}

Mostermans, P.M.M., Echtscheiding, Deventer: Kluwer 2003.

\section{Moussa 2011}

Moussa, J., Competing Fundamentalisms and Egyptian Women's Family Rights; International Law and the Reform of Sharīa-Derived Legislation, Leiden: BRILL 2011.

\section{Munir 2005-2006}

Munir, M., 'Stipulations in a Muslim Marriage Contract with Special Reference to talaq al-tafwid Provisions in Pakistan', Yearbook of Islamic and Middle Eastern Law 2005-2006, p. 235-262.

\section{Naamane 1994}

Naamane, S., De schaamte ontsluierd, Amsterdam: Globe Pocket 1994.

\section{Nasir 2002}

Nasir, J.J., The Islamic Law of Personal Status, The Hague: Kluwer Law International 2002. 


\section{Nayyeri 2013}

Nayyeri, M.H., Gender Inequality and Discrimination: The Case of Iranian Women, Iran Human Rights Documentation Center 2013, available at: <www.iranhrdc.org/english/publications/legal-commentary/1000000261-gender-inequality-and-discrimination-the-caseof-iranian-women.html\#.UyVnQv2jlbA>.

\section{Naz \& Zia 2012}

Naz, R. \& Zia, M., Muslim Family Laws in Pakistan, Aurat Foundation, submitted by Musawah on its website on 3 July 2012, available at: $<$ www.musawah.org/sites/default/files/ Pakistan-report\%20for\%20Home\%20Truths.pdf $>$.

\section{Nielsen 2013}

Nielsen, J., 'An Early Discussion on Islamic Family Law in the English Jurisdiction', in: Berger, S. (ed.), Applying Shari'a in the West, Leiden: Leiden University Press 2013, p. 7996.

\section{Oblak Flander 2011}

Oblak Flander, A., 'Population and Social Conditions', in: Eurostat (ed.), Statistics in Focus, Issue No. 1/2011, available at: <http://epp.eurostat.ec.europa.eu/cache/ITY_OFFPUB/KSSF-11-001/EN/KS-SF-11-001-EN.PDF $>$.

\section{Oderkerk 2012}

Oderkerk, A.E., 'Ontbinding van het huwelijk', in: De Boer, Th.M. \& Ibili, F.(eds.), Nederlands internationaal personen- en familierecht, Deventer: Kluwer 2012, p. 133-152.

\section{Osanloo 2013}

Osanloo, A., 'From Status to Rights; The Shifting Dimensions of Women's Activism in Iranian Family Law Reform', in: Al-Sharmani, M. (ed.), Feminist Activism, Women's Rights, and Legal Reform, New York: Zed Books Ltd. 2013, p. 125-150.

\section{Pearl 1987}

Pearl, D., A Textbook on Muslim Personal Law, London: Croom Helm 1987.

\section{Pearl \& Menski 1998}

Pearl, D. \& Menski, W., Muslim Family Law, London: Sweet \& Maxwell 1998. 


\section{Pertegas 2008}

Pertegas, M., 'Recognition and Enforcement of Judgments in Family and Succession Matters', in: Malatesta, A. et al. (eds.), The External Dimension of EC Private International Law in Family and Succession Matters, Milan: CEDAM 2008, p. 161-187.

\section{Peters 2002}

Peters, R., 'From Jurists' Law to Statute Law or What Happens When the Shari'a is Codified', Mediterranean Politics 2002, p. 82-95.

\section{Plasschaert 2002}

Plasschaert, J.N.E., Burgerlijke Stand, Amsterdam: Register Amsterdam 2002.

\section{Qassem 2002}

Qassem, Y., 'Law of the Family (Personal Status Law)', in: Bernard-Maugiron, N, \& Dupret, B. (eds.), Egypt and its Laws, The Hague: Kluwer Law International 2002, p. 19-36.

\section{Reed 1996}

Reed, A., 'Transnational Non-Judicial Divorces: A Comparative Analysis of Recognition under English and U.S. Jurisprudence', Loyola of Los Angeles International and Comparative Law Review 1996, p. 311-337, available at: <http://digitalcommons.lmu.edu/edu/ilr/vol18/ iss $2 / 3>$.

\section{Rhissassi \& Berjaoui 2010}

Rhissassi F., \& Berjaoui, K., 'Femmes, droit de la famille et système judiciaire dans les États du Maghreb: l'exemple du Maroc', in: Saad-Zoy, S. (ed.), Femmes, droit de la famille et système judiciaire en Algérie, au Maroc et en Tunisie, Rabat: UNESCO 2010, available at: $<$ http://unesdoc.unesco.org/images/0018/001893/189399f.pdf>.

\section{Rude Antoine 2009}

Rude-Antoine, E., 'La prise en consideration et la reconnaissance du statut personnel des étrangers par l'ordre juridique français', in: Aoun, M. (ed.), Les statuts personnels en droit compare. Évolutions récentes et implications pratiques, Leuven: Peeters 2009, p. 175-195.

\section{Rutten 1996}

Rutten S., 'De realiteit van verstotingen: niet alleen een morele kwestie', Nederlands Juristenblad 1996, p. 968-969. 


\section{Rutten 2003}

Rutten, S., 'Verstotingen in de Marokkaanse rechtspraktijk', Migrantenrecht 2003, p. 220235.

\section{Rutten 2004}

Rutten, S., 'Recognition of Divorce by Repudiation (talaq) in France, Germany and the Netherlands', Maastricht Journal of European and Comparative Law, 2004, p. 263-285.

\section{Saarloos 2010}

Saarloos, K., European private international law on legal parentage? Thoughts on a European instrument implementing the principle of mutual recognition in legal parentage, dissertation Maastricht University 2010.

\section{Safa'i 2004}

Safa'i, H., 'Le marriage et le divorce en droit Iranian', in: Basedow, J. \& Yassari, N. (eds.), Iranian Family and Successions Laws and their Application in German Courts, Tübingen: Mohr Siebeck 2004, p. 69-80.

\section{Sardar Ali \& Arif 1998}

Sardar Ali, S. \& Arif, K., 'Parallel Judicial Systems in Pakistan and Consequences for Human Rights', in: Shaheed, F. et al. (eds.), Shaping Women's Lives, Lahore: Shirkat Gah, Women's Resource Centre 1998, p. 29-60.

\section{Sardar Ali \& Naz 1998}

Sardar Ali, S. \& Naz, R., 'Marriage, Dower, and Divorce: Superior Courts and Case Law in Pakistan', in: Shaheed, F. et al. (eds.), Shaping Women's Lives, Lahore: Shirkat Gah, Women's Resource Centre 1998, p. 107-142.

\section{Sarehane 2004}

Sarehane, F., 'Le nouveau code marocain de la famille', Gazette du Palais 2004, p. 2-17.

\section{Schacht 1982}

Schacht, J., An introduction to Islamic Law, Oxford: Clarendon Press 1982.

\section{Schöpp-Schilling 2007}

Schöpp-Schilling, B., 'The Nature and Scope of the Convention', in: Schöpp-Schilling, H. \& Flinterman, K. (eds.), The Circle of Empowerment: Twenty Five Years of the UN Committee on the Elimination of Discrimination against Women, New York: The Feminist Press 2007, p. 10-29. 


\section{Shid 2005}

Shid, N., 'Selected Aspects of Iranian Family Law', in: Yassari, N. (ed.), The Shari'a in the Constitutions of Afghanistan, Iran and Egypt: Implications for Private Law, Tübingen: Mohr Siebeck 2005, p. 141-152.

\section{Smits 2011}

Smits, J.M., 'European Legal Education, or: How to Prepare Students for Global Citizenship?', The Law Teacher (2) 2011, p. 163-180.

\section{Soleimani 2004}

Soleimani, A., Islamitisch personen- en familierecht conform de Sjaria, Drachten: het talenhuis 2004 .

\section{Sonneveld 2009}

Sonneveld, N., Khul' Divorce in Egypt; Public Debates, Judicial Practices and Everyday Life, Dissertation University of Amsterdam, Amsterdam 2009.

\section{Sonneveld 2012}

Sonneveld, N., Khul' Divorce in Egypt; Public Debates, Judicial Practices and Everyday Life, Cairo/New York: The American University in Cairo Press 2012.

\section{Sportel 2014}

Sportel, I., 'Maybe I'm Still His Wife'; Transnational Divorce in Dutch-Moroccan and Dutch Egyptian Families, Dissertation Radboud University Nijmegen, Nijmegen 2014.

\section{Strikwerda 2012}

Strikwerda, L., Inleiding tot het Nederlandse Internationaal Privaatrecht, Deventer: Kluwer 2012.

\section{Struycken 2009}

Struycken, A.V.M., Co-ordination and Co-operation in Respectful Disagreement, Leiden/Boston: Martinus Nijhoff Publishers 2009.

\section{Thompson \& Yunus 2007}

Thompson, E. \& Yunus, F., 'Choice of laws or Choice of Culture: How Western Nations Treat the Islamic Marriage Contract in Domestic Courts', 25 Wisconsin International Law Journal (361), 2007, p. 1-27, retrieved via Westlaw. 


\section{Tjittes \& Asser 2007}

Tjittes, R.P.J.L. \& Asser, W.D.H., Rechtsmiddelen (Studiereeks Burgerlijk Procesrecht), Deventer: Kluwer 2007.

\section{Tomson 2009}

Tomson J.C., 'Jurisprudentie; Instemming van de vrouw met de verstoting is hard', Burgerzaken en Recht (1) 2009, p. 24-25.

\section{Tomson 2010}

Tomson J.C., 'Raad van State over 'nieuw' Marokkaans echtscheidingsrecht', Jurisprudentie, Burgerzaken en Recht (3/4) 2010, p. 120-121.

\section{Van den Eeckhout 2002}

Van den Eeckhout, V., 'Internationaal privaatrecht en migratierecht', Nemesis (4) 2002, p. $75-88$.

\section{Van den Eeckhout 2002a}

Van den Eeckhout, V., 'Rechtspraak: noot bij HR 13 juli 2001 (nr. 1487) en HR 9 november 2001 (nr. 1488), Nemesis (4) 2002, p. 7-9.

\section{Van den Eeckhout 2003}

Van den Eeckhout, V., ' 'Gelijkheid' in het internationaal privaatrecht', Nemesis (5/6) 2003, p. 177-189.

\section{Van den Eeckhout 2012}

Van den Eeckhout, V., The Instrumentalisation of Private International Law: quo vadis? Rethinking the 'Neutrality' of Private International Law in an Era of Globalisation and Europeanisation of Private International Law, available at: $<$ http://ssrn.com/abstract $=$ 2148288>.

\section{Van den Eeckhout 2013}

Van den Eeckhout, V., 'Internationaal privaatrecht en fundamentele rechten. IPR als instrument ter bevordering van respect voor fundamentele rechten?', in: Gerards, J. \& Sieburgh, C., De invloed van fundamentele rechten op het materiële recht, Deventer: Kluwer 2013, p. 265-290.

\section{Van der Velden 2003}

Van der Velden, F.J.A., Talaq in de rechtszaal? Verstoting en openbare orde (oratie Amsterdam VU), Deventer: Kluwer 2003. 


\section{Van der Velden 2004a}

Van der Velden, F.J.A., 'Het Marokkaanse huwelijksontbindingsrecht en het Nederlandse IPR', Weekblad voor Privaatrecht, Notariaat en Registratie 2004a, p. 351-359.

\section{Van der Velden 2004b}

Van der Velden, F.J.A., 'Betekenis van de islam en het islamitisch recht voor het Nederlandse familie- en jeugdrecht', Tijdschrift voor Familie- en Jeugdrecht 2004b, p. 58-64.

\section{Van der Velden 2005}

Van der Velden, F., 'Het nieuwe Marokkaanse wetboek van familierecht: een schets', Nederlands Internationaal Privaatrecht (1) 2005, p. 4-10.

\section{Van der Velden 2013-2014}

Van der Velden, F., Inleiding in de Shari'a; een kennismaking met het recht van de islam en van de islam-georiënteerde wereld (reader), Maastricht: Maastricht University 20132014.

\section{Van Hoek 2012}

Van Hoek, A.H., 'Managing Legal Diversity - New Challenges for Private International Law', Tijdschrift Nederlands Internationaal Privaatrecht 2012, p. 362-370.

\section{Verhellen 2010}

Verhellen, J., 'Internationaal Familierecht en Migratiebeleid: IPR als Deus ex Machina?', Tijdschrift voor Internationaal Privaatrecht (1) 2010, p. 152-155.

\section{Verhellen 2012}

Verhellen, J., Het Belgisch Wetboek IPR in familiezaken; Wetgevende doelstellingen getoetst aan de praktijk, Brugge: die Keure 2012.

\section{Vonken 1998}

Vonken, A.P.M.J., 'De multiculturele samenleving en de bemiddelende rol van het internationaal privaatrecht en de mensenrechten. Iets over tolerantie, culturele identiteit en rechtspluralisme', in: Cliteur P.B.E.A., (red.), Sociale cohesie en het recht, Lelystad: Koninklijke Vermande 1998, p. 97-166.

\section{Vonken 2004}

Vonken, A.P.J.M., 'Titel 9, Internationaal privaatrecht. Internationale echtscheidingen', in: Wortmann, S.F.M. (ed.), Personen- en familierecht, Deventer: Kluwer (losbl.) 2004. 


\section{Von Savigny 1869}

Von Savigny, F.C., A Treatise on the Conflict of Laws, translated by Guthrie, W., Edinburgh: T\&T Clark, Law Publishers 1869.

\section{Wadud 2004}

Wadud, A., De koran en de vrouw, Amsterdam: Uitgeverij Bulaaq 2004.

\section{Warraich \& Balchin 1998}

Warraich, S. \& Balchin, C., 'Confusion Worse Confounded: A Critique of Divorce Law and Legal Practice in Pakistan', in: Shaheed, F. et al (eds.), Shaping Women's Lives: Laws, Practices and Strategies in Pakistan, Lahore: Shirkat Gah 1998, p. 181-226.

\section{Welchman 2004}

Welchman, L. (ed.), Women's Rights \& Islamic Family Law; Perspectives on Reform, London: Zedbooks 2004.

\section{Welchman 2007}

Welchman, L., Women and Muslim Family Laws in Arab States, Amsterdam: Amsterdam University Press 2007.

\section{Weltzer 2007}

Weltzer, J., Actualité du divorce en droit commun et conventions bilatérales, was available at: <www-cdpf.u-strasbg.fr/Actualit\%C3\%A9\%20du\%20divorce\%20en\%20droit\%20commun.htm>.

\section{WLUML (Women Living Under Muslim Laws) 2006}

Women Living Under Muslim Laws, Knowing Our Rights; Women, Family, Laws and Customs in the Muslim World, London: WLUML 2006.

\section{Yahyaoui Krivenko 2009}

Yahyaoui Krivenko, E., Women, Islam and International Law, Leiden: Martinus Nijhoff Publishers 2009.

\section{Yassari 2002}

Yassari, N., 'Überblick über das iranische Scheidingsrecht', Zeitschrift für das gesamte Familienrecht 2002, p. 1088-1094. 


\section{Yassari 2014}

Yassari, N., 'Iran: Das neue Gesetz zum Schutze der Familie 2013', das Standesamt (4) 2014, p. 125-127.

\section{Zilinsky 2014}

Zilinsky, M., 'De herschikte EEX-Verordening: een overzicht en de gevolgen voor de Nederlandse rechtspraktijk', Tijdschrift Nederlands Internationaal Privaatrecht 2014, p. 3-11.

\section{Zulficar 2009}

Zulficar, M., 'The Islamic Marriage Contract in Egypt', in: Quraishi, A. \& Vogel, F.E. (eds.), The Islamic Marriage Contract: Case Studies in Islamic Family Law, Cambridge, MA: Harvard University Press 2009, p. 231-255.

\section{INTERNET SOURCES (IF NOT IN FOOTNOTES)}

\section{Association Marocaine de Lutte contre la Violence à l'Égard des Femmes 2005} Association Marocaine de Lutte contre la Violence à l'Égard des Femmes, l'Application du Code de la Famille: acquis \& défis, 2005, available at: <www.amvef.org/html_fr/documentation.html>.

\section{Association Marocaine de Lutte contre la Violence à l'Égard des Femmes 2007}

Association Marocaine de Lutte contre la Violence à l'Égard des Femmes, La Perception $d u$ Code de la Famille et de son Environnement Social et Professionnel, 2007, available at: $<$ www.amvef.org/html_fr/documentation.html $>$.

\section{CEDAW shadow report coordinated by the Association Démocratique des Femmes du} Maroc 2007

NGOs shadow report to the third and fourth periodic, report coordinated by the Association Démocratique des Femmes du Maroc, 2007, available at: <www2.ohchr.org/english/bodies/cedaw/cedaws40.htm>.

\section{CEDAW shadow report 2007}

CEDAW Shadow Report on Pakistan, 2007, was available at: <www.iwrawap.org/ resources/pdf/Pakistan\%20SR\%20(NCJP).pdf>. 


\section{CEDAW Shadow Report Shirkat Gah 2013}

CEDAW Shadow Report, Obstructing Progress: Growing Talibanisation \& Poor Governance in Pakistan, submitted by Shirkat Gah on 25 January 2013, available at: <www2.ohchr. org/English/bodies/cedaw/docs/ngos/ShirkatGah_Women'sResourceCentre_FTS.pdf>.

\section{Combined initial, second and third periodic reports CEDAW Pakistan 2005}

Combined initial, second and third periodic reports of Pakistan, submitted on 3 August 2005, UN doc. CEDAW/C/PAK/1-3, available at: <http://daccess-dds-ny.un.org/doc/ UNDOC/GEN/N05/454/37/PDF/N0545437.pdf?OpenElement>.

\section{Combined third and fourth periodic report CEDAW Morocco 2006}

Combined third and fourth periodic report of Morocco of 18 September 2006, CEDAW/C/MAR/4, available at: <http://daccess-dds-ny.un.org/doc/UNDOC/GEN/N06/ 563/69/PDF/N0656369.pdf?Open Element $>$.

\section{Concluding comments of CEDAW Pakistan 2007}

Concluding comments of CEDAW, Pakistan, 2007, of 11 June 2007, CEDAW/C/PAK/CO/3, available at: $<$ www.iwraw-ap.org/committee/pdf/38_concluding_observations/pakistan. pdf $>$.

\section{Concluding comments of CEDAW Morocco 2008}

Concluding comments of CEDAW, Morocco, of 8 April 2008, CEDAW/C/MAR/CO/4, available at: $<$ www2.ohchr.org/english/bodies/cedaw/docs/CEDAW.C.MAR.CO.4_en.pdf $>$.

\section{Concluding observations of the CEDAW Egypt 2010}

Concluding observations of the Committee on the Elimination of Discrimination against Women, Egypt, of 5 February 2010, CEDAW/C/EGY/CO/7, available at: <www2.ohchr.org/ english/bodies/cedaw/docs/co/CEDAW-C-EGY-CO-7.pdf>.

\section{Concluding observations of the CEDAW Pakistan 2013}

Concluding observations of the Committee on the Elimination of Discrimination against Women, on the fourth periodic report of Pakistan of 27 March 2013, CEDAW/C/PAK/CO/4, available at: <http://daccess-dds-ny.un.org/doc/UNDOC/GEN/G13/422/89/PDF/ G1342289.pdf?OpenElement>.

\section{FIDH report 2003}

Fédération Internationale des Liques des Droits de l'Homme, Discrimination against religious minorities in Iran, Report presented by the FIDH and the Ligue de Défense des Droits 
de l'Homme en Iran, $63^{\text {rd }}$ Session of the Committee on the Elimination of Racial Discrimination, August 2003, available at: <www.fidh.org/IMG/pdf/ir0108a.pdf>.

\section{General Recommendation No. 211994}

General Recommendation No. 21, UN doc. A/49/38, $13^{\text {th }}$ Session 1994, available at: $<w w w$. un.org/womenwatch/daw/cedaw/recommendations/recomm.htm\#recom21>

\section{Guide Pratique 2004}

Guide Pratique du Code de la Famille (2004), was available via <www.ejustice.gov.ma/justice/ fr/documentation $>$; also not available via $<\mathrm{http}$ ://adala.justice.gov.ma/FR/Home.aspx $>$ retrieved via <www.tv5.org/cms/userdata/c_bloc_file/0/183/183_fichier_Guide_pratique_ du_code_de_la_famille.pdf> (on 18 March 2014).

\section{IHRDC report 2006}

Iran Human Rights Documentation Center, A Faith Denied, the Persecution of the Baha'is of Iran, New Haven (Connecticut) 2006, available at: <www.iranhrdc.org/english/publications/reports/3149-a-faith-denied-the-persecution-of-the-baha-is-of-iran.html > .

\section{La Ligue Démocratique pour les Droits des Femmes Rapport annuel 2005}

La Ligue Démocratique pour les Droits des Femmes, Rapport annuel sur l'application $d u$ code de la famille, March 2005, available at: <www.tanmia.ma/IMG/pdf/LDDF-rapportannuel.pdf>.

\section{Mahmood 2007}

Mahmood, M.S., Presentation of Pakistan's combined Initial, Second and Third Periodic Report, Geneva, 22 May 2007, p. 2, available at: <www2.ohchr.org/english/bodies/cedaw/ docs/statement/Pakistan38.pdf>.

\section{Muslims in the EU - Cities Background Research Reports 2007}

Muslims in the EU - Cities Background Research Reports: France, the Netherlands, United Kingdom, Open Society Institute, EU monitoring and advocacy program 2007, available at: $<$ www.soros.org/initiatives/home/articles_publications/publications/museucities_ 20080101>.

\section{Skalli 2008}

Skalli, N., Implementing CEDAW: Third and Fourth Periodic Reports, Geneva, 24 January 2008, presentation at the fortieth session of the CEDAW, Geneva, 24 January 2008. 
Miscellaneous

\section{El-Alami \& Hinchcliffe 1996}

El-Alami, D.S. \& Hinchcliffe, D., Islamic Marriage and Divorce Laws of the Arab World, The Netherlands: Kluwer Law International 1996.

\section{Herm 2008}

Herm, A., 'Population and Social Conditions', in: Eurostat (ed.), Statistics in Focus, Issue No. 98/2008, available at: <http://epp.eurostat.ec.europa.eu/cache/ITY_OFFPUB/KS-SF08-098/EN/KS-SF-08-098-EN.PDF>.

Mudawwanah, Marokkaans wetboek inzake personen-, familie- en erfrecht (1957/581993)

Berger, M. \& Kaldenhoven, J., De Mudawwanah. Marokkaans wetboek inzake personen-, familie- en erfrecht, Nijmegen: Ars Aequi Libri 1989.

\section{Mudawwana; Marokkaanse familiewet 2004}

Berger, M., Mudawwana; Marokaanse familiewet, Nijmegen: Ars Aequi Libri 2004.

\section{Pearl 1995}

Pearl, D., The Application of Islamic Law in the English Courts, Noel Coulson Memorial Lecture 1995, London: The School of Oriental and African Studies 1995, available at: $<$ www.soas.ac.uk/cimel/materials/coulson-pearl.html>.

\section{Sarehane 2005}

Sarehane, F., Workshop Le nouveau code Marocain de la famille: son application en Belgique, lecture, Association pour le droit des étrangers, Brussels, 2 December 2005.

\section{Sonneveld 2013}

Sonneveld, N., From the Liberation of Women to the Liberation of Men? A century of Family Law Reform in Egypt, lecture presented at the Radboud University Nijmegen Conference, 'Islamic family law in modern Europe and the Muslim world: normative, legal and empirical approaches beyond the women's rights issue', Nijmegen 21 June 2013.

\section{The Hans Wehr Dictionalry of Modern Written Arabic}

Cowan, J.M. (ed.), The Hans Wehr Dictionary of Modern Written Arabic (4th edition), Urbana, IL USA: Spoken Language Services Inc. 1994. 


\section{Wautelet 2009}

Wautelet, P., Buitenlands Familiaal Statuut en Vreemdelingenrecht: het IPR in het Verdomhoekje?, Lecture presented at the Ius Commune Conference, Maastricht, 27 November 2009. 



\section{ACKNOWLEDgements}

On the memorable day of 19 December 2008, Prof. dr. G-R. de Groot, my then envisaged promotor, received an e-mail. It conveyed the message that NWO (The Netherlands Organisation for Scientific Research) had awarded a grant to my research proposal entitled 'Repudiation or recognition of Islamic divorces in Europe?'. For this reason, my sincere gratitude goes out to NWO. The funding made this research possible in the first place and provided an enormous incentive.

It is often contended that a $\mathrm{PhD}$ research is 'a long project in solitude'. That is not my personal experience. It is a long journey indeed, but a beautiful journey full of adventures and experiences. ${ }^{1}$ Moreover, it is a journey during which many accompanied me, and that offered me the opportunity to meet many interesting people.

Prof. dr. G.-R. de Groot and Dr. S.W.E. Rutten, my promotor and co-promotor respectively, supervised me from the initial phase of the research proposal through completion of the thesis itself. I would like to express my sincere appreciation and gratitude to them for their always-enthusiastic guidance and support that provided me the indispensable motivation to successfully complete this book, for their constructive comments and valuable advices, and for their trust in me.

I am also very grateful to Prof. Léon Buskens, who inspired me to start a $\mathrm{PhD}$ research in the first place. Moreover, he always kindly offered me the opportunity to participate in the valuable Spring and Autumn schools of NISIS, the Netherlands Interuniversity School for Islamic Studies.

I am convinced that the valuable, strategic advices from Sebastiaan Huntjens and his assistant resulted in the grant from NWO. For this reason, my utmost thanks goes out to them as well as to Eric Knipschild for their help in the designing phase of the research proposal that preceded this research.

My participation in the Research Programme of the Centre for Studies and Research in International Law and International Relations of the Hague Academy of International Law in 2009 under the enthusiastic and inspiring supervision of Prof. M-C. Foblets and N. Yassari meant an enormous impetus for my research as well. I am very grateful for their guidance and valuable advice and comments.

During all these years of research, Prof. Frans van der Velden always showed great interest in this research and its progress. I would like to express my sincere appreciation

1 Afer the poem 'Ithaca' from C.P. Cavaly (1863-1933), available in various translations at <www.cavafy. com/poems/content.asp?id=204\&cat $=1>$. 
and thanks to him for his enthusiastic support, thought-provoking discussions and constructive comments on the completed thesis.

My sincere appreciation and thanks also goes out to my colleague and dear friend Dr. Rankie ten Hoopen for her unremitting support, encouragement, and valuable advice.

Prof. Cees Flinterman, one of the members of the Committee on the Elimination of Discrimination against Women at the time, provided me the opportunity to attend the meetings of the CEDAW considering the country reports of Tunisia in Geneva in 2010, a fascinating and informative experience. I would like to express my sincere gratitude and appreciation to him as well.

My stays in The Hague also offered me an opportunity to use the facilities at the Library of the Peace Palace (apart from meeting many new colleagues). My sincere thanks goes out to Mr. Vervliet, the library director, Drs. Eveline van Trigt, reference librarian, and Niels van Tol, services librarian, for their kind and practical help and advice during my stay in the Library.

I am also very grateful for my two inspiring stays in the Max Planck Institute for Comparative and International Private Law in Hamburg and my stay at the British Institute for Comparative Law and the School for Oriental and African Studies (SOAS) in London. I greatly valued my meeting with Dr. Martin Lau in London who offered me a thoughtprovoking discussion on the Pakistani $\mathrm{khul}^{\prime}$ and repudiations in general (and the occasion to meet the late Hon. Judge Eugene Cotran and Dr. Doreen Hinchcliffe during lunch). A special thanks goes out to Mrs. Halsen-Raffel and her staff for their kind and indispensable help in the Library of the Max Planck Institute.

Furthermore, I am deeply indebted to all who have contributed in some way to the successful completion and publication of this book, including, in no particular order, Mrs. Marjo Mullers for her indispensable, efficient, kind, and patient help in providing the layout of the manuscript; Carol Ní Ghiollarnáth for carefully language-editing the manuscript; Alexander Hoogenboom for critically reading and valuably commenting on the draft of part III of this book; Khalidah Ahmadi for her indispensable help in translating the Farsi version of the Iranian Family Protection Act 2013; and the director of Boom uitgevers Den Haag, Wirt Soetenhorst, and the staff of Eleven international publishing, Selma Hoedt, Mariska Duindam and Tom van der Meer for their personal and meticulous service and dedication in publishing this book.

Many, many thanks goes out to all my colleagues in the field - in the broadest sense from the colleagues of the Ius Commune Research School to the colleagues at the Faculty of Law for their valuable suggestions, thoughts, encouragements, and friendship, in particular Eric Gubbels, Kim Hoofs, Friso Kulk, Lotte Meurkens, Pia Lokin, Rianka Rijnbout, Nadia Sonneveld, Jinske Verhellen, Lars van Vliet, and Maaike Voorhoeve, and to my dear friends for their friendship, support, and care, especially Christian Drenth, Marion KoeneGorren, Katja Lubina, Marie-Lou Porta, Marie-Berthe Roemers, Inga Swane - van Gelein 
Vitringa, and Adelheid Wösten. A special word of thanks goes out to my colleagues and friends Esther van Eijk and Iris Sportel who supported me in particular during the last phase of this research, in particular on 17 December 2014. To all other persons that I did not explicitly mention but that are not forgotten: THANK YOU!

Last but not least, words of gratitude and appreciation to my family. Dorothee, Emanuel, Lou, Leila and Anna, my French family, writing the draft of the research proposal that resulted in this book went so smoothly with you at my side during our skiing holiday in Gresse en Vercors; many thanks for all your support and love.

Sofia and Gerrit, thank you for being at my side and for your unremitting love, support, trust, and patience! I could not have completed this book without it. 



\section{Curriculum Vitae}

Pauline Kruiniger (1965, Rotterdam) completed her secondary school at the Jeanne d'Arc Gymnasium in Maastricht in 1984. She had various paramedical occupations at the University Hospital Maastricht for more than 20 years before she took up a study in law. She holds a law degree from Maastricht University. In 2006, she completed her studies by specializing in Health Law and in Islamic Law at Leiden University. In October 2006, she was appointed as junior lecturer Health Law at the Faculty of Health, Medicine and Life Sciences of Maastricht University. From September 2007, she worked as researcher and junior lecturer, Private International Law, at the Faculty of Law of the same university. In 2008, she published her book on Moroccan divorce modalities in Dutch legal practice ('Marokkaanse verstotingsvormen in de Nederlandse rechtspraktijk'; Amersfoort: Celsus Juridische Uitgeverij). Due to a grant by The Netherlands Organisation for Scientific Research (NWO) in December 2008, she carried out her $\mathrm{PhD}$ research about the problematic issue of recognition of Islamic divorces in Europe, which is the subject of this book, in the period January 2009-February 2014. In August 2009, she had the opportunity to participate with a group of young researchers in 'the Hague Academy of International Law, Centre for Studies and Research' dedicated to the theme 'Cultural Diversity' under the expert direction of Prof. M-C. Foblets and Dr. N. Yassari, which resulted in the publication of the chapter 'Repudiated by Husband and Europe?' in the book Legal Approaches to Cultural Diversity (Leiden/Boston: Martinus Nijhoff Publishers 2013). In June 2014, she was appointed as postdoctoral researcher in the research project 'Marital Captivity: Bridging the Gap between Religion and Law', which is funded by NWO as well. In this research project, she investigates legal solutions for women that Dutch Law can offer to prevent or to solve situations of 'marital captivity'; she also examines legal solutions for women that aim at obtaining a lawful divorce in the country of origin in order to prevent or solve situations of marital captivity there.

Her research interests concern Islamic Law, Middle Eastern Law, Human Rights with a focus on the Rights of Women, Private International Law, Interreligious and Multicultural Society Issues, and Health Law (notably in relation to medical-ethical issues and multiculturalism). She regularly publishes and lectures related to those interests and her research projects. She is a board member of the RIMO Association (Association of the study of Islam and the Middle East) and is the editor responsible for the publication of the yearly RIMO volumes. 